UNIVERSIDAD NACIONAL DE LA PLATA

FACULTAD DE PERIODISMO Y COMUNICACIÓN SOCIAL

DOCTORADO EN COMUNICACIÓN

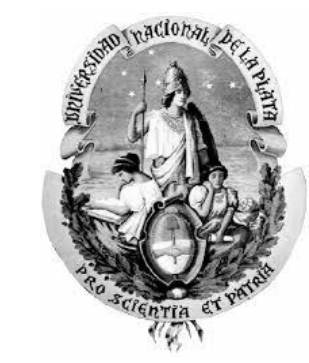

Tesis para optar por el título de

Doctor en Comunicación

\title{
Cambio de piel. Intervenciones culturales, acción colectiva y politicidad emergente en el espacio público de La Plata
}

Autor

Lic. y Prof. Matías David López

Director: Dr. Carlos J. Giordano

Co-Directora: Dra. Silvia L. Elizalde

Febrero de 2017 


\section{Entrada}

La presente tesis es un trabajo de investigación para optar por el título de Doctor en Comunicación por la UNLP. La investigación indaga, cartografía y analiza las intervenciones culturales que se desarrollaron en la ciudad La Plata, a partir de preguntas sobre la ciudad y el espacio público, la producción cultural y la dimensión política de las prácticas culturales.

Se puede reconocer al estallido popular de 2001 en Argentina como un acontecimiento que abrió nuevos umbrales de posibilidad en los modos de hacer, ver, decir y mirar y cambios en la subjetividad. Las experiencias de intervención cultural que aquí se indagan forman parte de las diversas construcciones colectivas que, como parte de esa situación novedosa, plantearon nuevos interrogantes sobre la política, la cultura, el arte y la sociedad y desplegaron formas creativas de organización y acción colectiva.

Las experiencias culturales locales tomadas para este trabajo son: Sienvolando, Unidad Muralista Hermanos Tello, Arte al Ataque, La Muestra Ambulante -organizada por el Grupo La Grieta-, Colectivo Siempre y Luxor.

El principal período de análisis es el que corresponde a los años 2006-2011. Otra temporalidad, que va de los años 2012 a 2015, es tomada como un período complementario de indagación de estas formas culturales. De conjunto, ambas conforman una década que plantea una densidad temporal interesante para la investigación social -en cuanto recorte y universo-; y a su vez, puede reconocerse como un momento de surgimiento y potenciación de estas formas y prácticas culturales en dicha ciudad.

La propuesta es comprender a las intervenciones culturales como formas de "producir" la ciudad, que juegan en la esfera de la "politicidad" de las prácticas sociales. Es decir, en tanto prácticas y experiencias que se inscriben en las tramas de sentido y disputas por el espacio urbano y lo público. De este modo, se indaga y analiza la articulación entre dichas prácticas y los sentidos y las apropiaciones sobre la ciudad y los espacios de lo público construidos desde las experiencias culturales.

El documento está integrado por la introducción, ocho capítulos de desarrollo, las palabras finales, la bibliografía general de la tesis y los anexos.

Palabras clave: intervención cultural - ciudad - espacio urbano - espacio público producción cultural - acción colectiva - La Plata 


\section{Agradecimientos}

Esta investigación ha sido posible gracias al otorgamiento de una Beca Doctoral del Consejo Nacional de Investigaciones Científicas y Técnicas (CONICET) entre los años 20122017.

Junto a ello, considero importante reconocer a personas y espacios concretos. En tal sentido, quiero agradecer a los/as que han colaborado en mi trayectoria por la Universidad Pública con una palabra, una recomendación, un diálogo o la apertura de espacios. Seguro me olvide de varios/as pero no quiero dejar de mencionar a Esteban Rodríguez, Daniel Badenes, Jerónimo Pinedo y Fabián Viegas. También a Constanza Erbetta, Lucas Demarco y Valeria Lacerra del Liceo "Víctor Mercante" (UNLP), espacio que siento como uno de mis hogares. Constanza y Lucas además me permitieron ensayar muchas de las preguntas e hipótesis que se trabajan en esta tesis en un taller para estudiantes de $6^{\circ}$ año titulado "Nuevas tecnologías y espacio público: territorios de intervenciones culturales", espacio que coordinamos junto con Pilar Placzek en el Liceo entre los años 2011 y 2013. A Nancy Díaz Larrañaga de la FPyCS (UNLP), directora de los Proyectos de Investigación en los que participo, por abrir uno de mis caminos en la investigación social. A Magalí Catino, también profesora de la Facultad, que fue la primera persona que leyó el borrador del proyecto de investigación y realizó importantes sugerencias. A Carlos Giordano, Director de Instituto de Investigaciones en Comunicación (IICom) de la Facultad, por abrir ese espacio cuando esta investigación comenzaba desplegarse.

A los/as compañeros/as becarios/as de la Facultad y de otros espacios académicos, a los/as compañeros/as de la Cohorte 2012 del Doctorado en Comunicación.

A los/as compañeros/as de la Secretaría de Posgrado y del Doctorado por su ayuda en el trayecto de este espacio formativo y especialmente, en el último tiempo mientras esta tesis se escribía y entregaba, reconocer la dedicación de Lía, Emilia y Germán.

Muchas veces se reconoce que en una investigación existen co-autorías que suelen quedar en un segundo plano. En mi caso particular, he tenido interlocutores que me han ayudado a pensar desde el accionar colectivo que detona prácticas compartidas y saberes comunes. En este sentido quiero destacar principalmente a Chempes, Dani, Dani, Pili, Fede y Lucas que son parte importante de esta tesis y con quienes -junto con muchos/as otros y otrashe compartido militancias, escritos, diálogos, lecturas, intercambios, proyectos y prácticas y hemos reflexionado en conjunto muchas de las ideas que en esta tesis se presentan. También 
quiero mencionar en este punto y agradecer a La Grieta, Indymedia La Plata, el Galpón de Tolosa, Luli, Luxor, Carlos “el pulpo”, Magdalena, Iconoclasistas, Volver a habitar, Síntoma curadores y a boba por los diálogos e intercambios enriquecedores y llenos de aprendizajes.

Agradecer a Ulises, estudiante de la carrera de Comunicación Social, que colaboró conmigo en ardua tarea de desgrabación de las entrevistas, a Gonza por el préstamo de la computadora y al "Flaco" Vimercati de Beart 64 por el diseño del sitio web de la tesis.

A Silvia Elizalde y Carlos Giordano por su acompañamiento en estos años de producción de la investigación y en el arduo ejercicio de escritura de la tesis.

A mis viejos Esther y Hugo y mi hermana Verónica por el apoyo que siempre me brindan.

A Ana y Ema por su amor, compañía y aguante. 


\section{ÍNDICE}

\section{Introducción.}

\section{La piel de la ciudad: Mutaciones del espacio público}

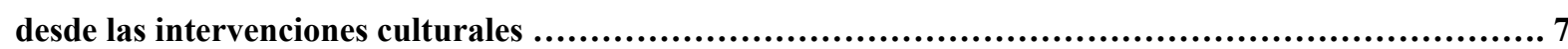

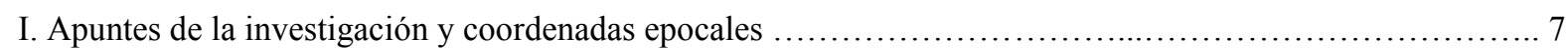

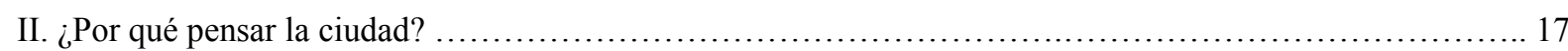

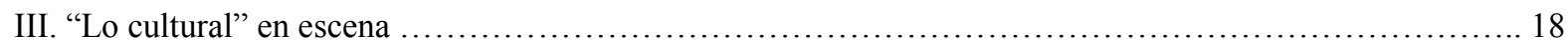

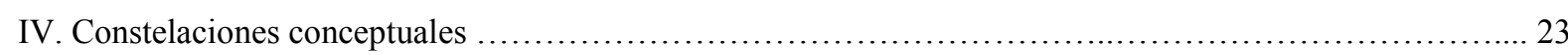

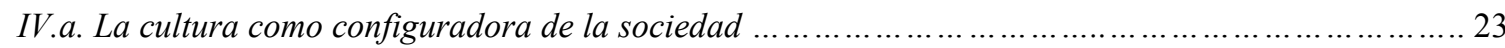

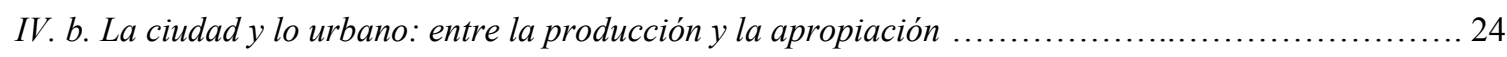

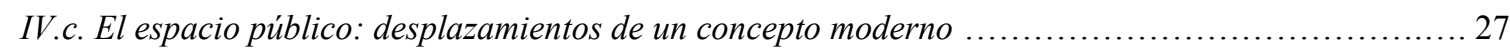

IV.d. La política, lo político y lo social: una constelación tensa ............................................. 31

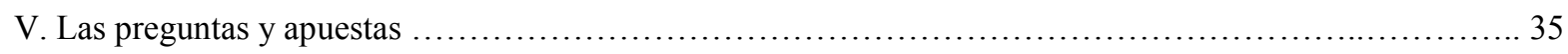

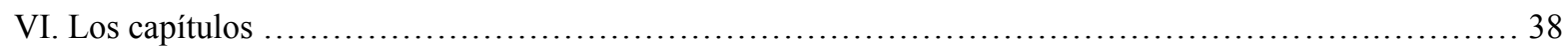

\section{Capítulo 1.}

La trama de los debates: producción cultural, ciudad y acción colectiva $\ldots \ldots \ldots \ldots \ldots \ldots \ldots \ldots \ldots \ldots \ldots \ldots . . . \ldots 1$

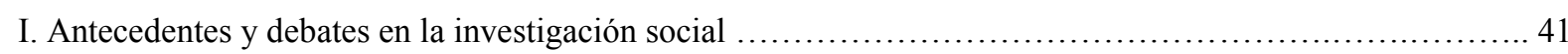

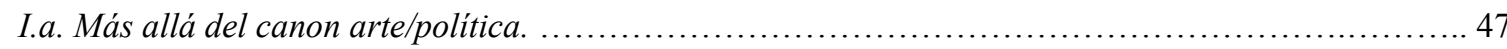

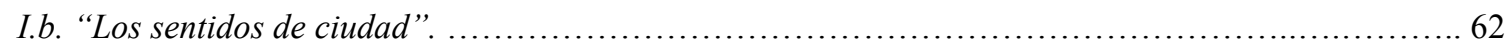

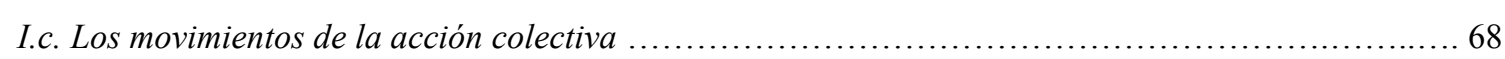

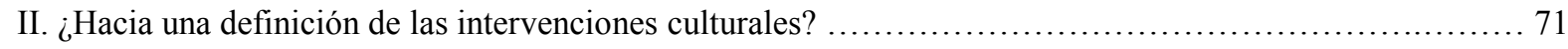

\section{Capítulo 2.}

Apuestas y derivas metodológicas para la indagación de prácticas culturales ….........................77

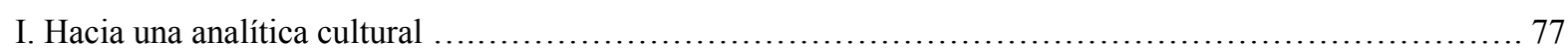

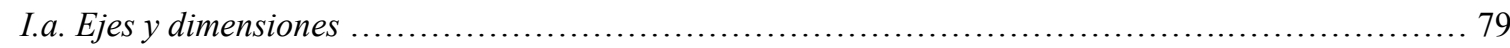

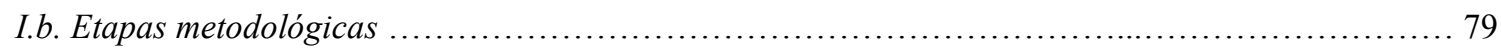

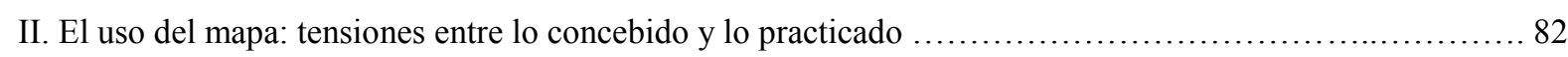

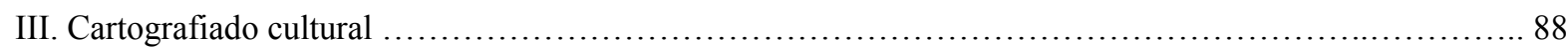

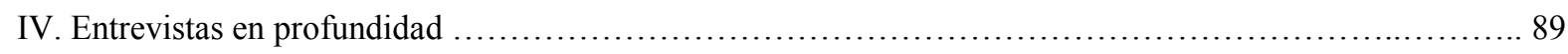

V. Otras técnicas de análisis y modulaciones sobre el lugar del investigador .................................. 92

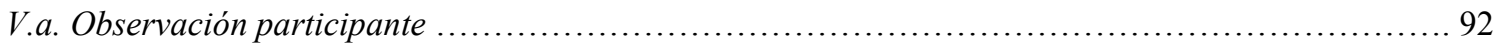

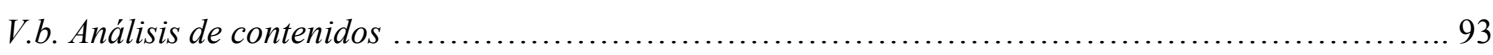

V.c. Sobre el lugar del investigador y su implicación con el objeto de estudio ............................... 95

\section{Capítulo 3.}

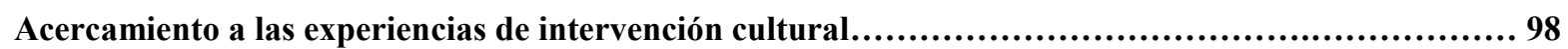

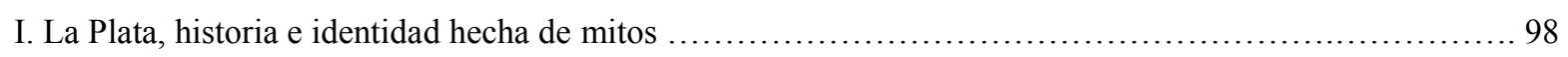




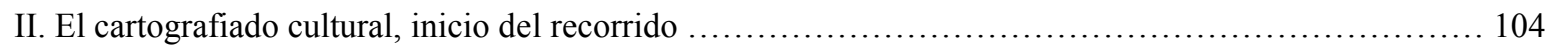

III. Delimitación de las experiencias de intervención cultural ..................................... 107

III.a. La Grieta, el contrapunto permanente .................................................... 107

III.b. Sienvolando, cambiar la piel de la ciudad .......................................... 112

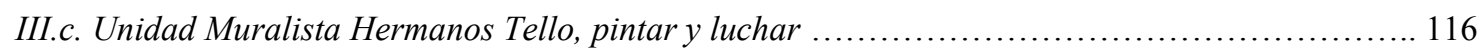

III.d. Colectivo Siempre, entre el arte y la acción política ...................................... 119

III.e. Arte al Ataque, la cultura como frente de lucha ......................................... 122

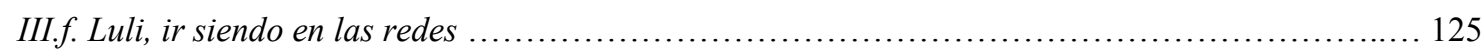

III.g. Luxor, pintar relaciones del mundo nuevo .......................................... 130

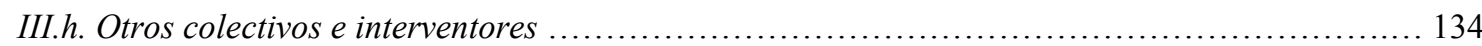

\section{Capítulo 4.}

"Estar en la avalancha". Ampliación del cartografiado ................................................. 138

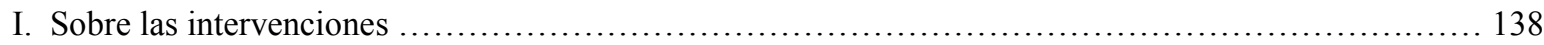

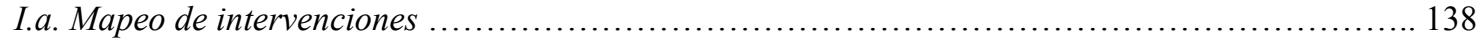

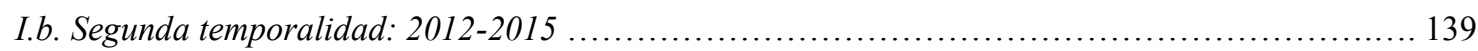

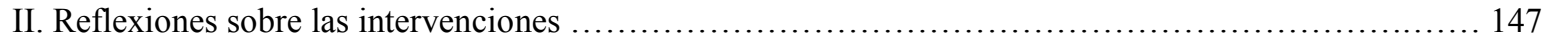

II.a. Dispositivos de comunicación en la ciudad ................................................. 147

II. b. Potencia performática de los cuerpos ............................................ 150

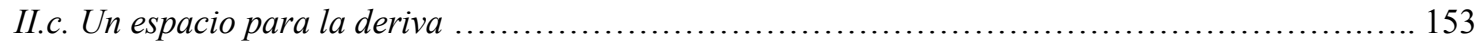

II.d. El estallido del color, la insistencia del encuentro ......................................... 155

II.e. Figuras de una nueva esfera pública .............................................. 156

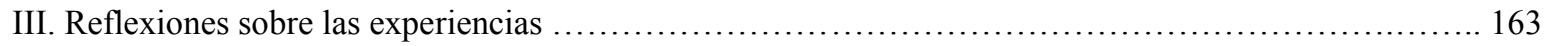

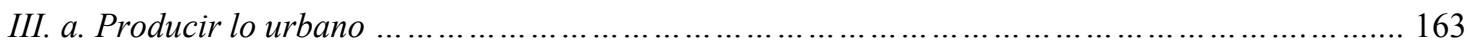

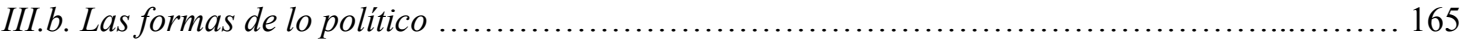

III.c. Tiempo de cambios ................................................................... 166

\section{Capítulo 5.}

“Mover todo de lugar". Conceptos, saberes y prácticas de las experiencias ............................. 169

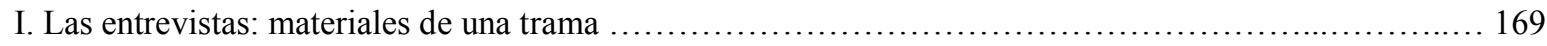

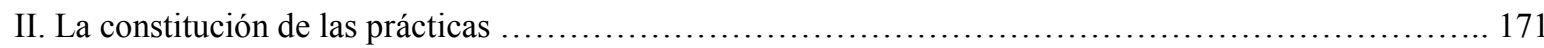

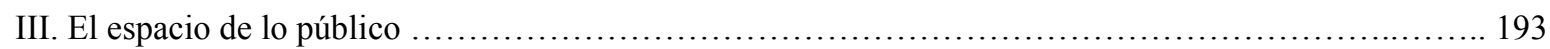

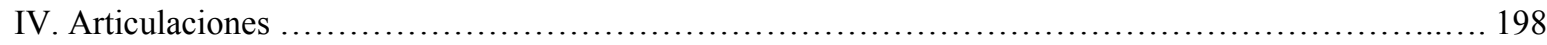

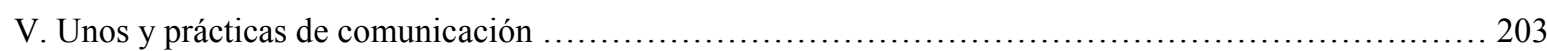

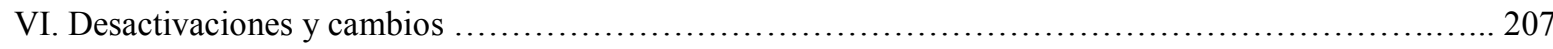

VII. Repensar el espacio de lo público desde las intervenciones culturales ........................... 215

\section{Capítulo 6.}

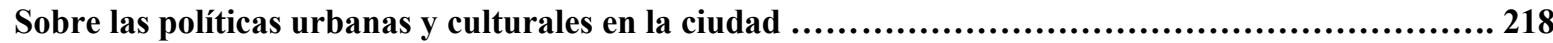

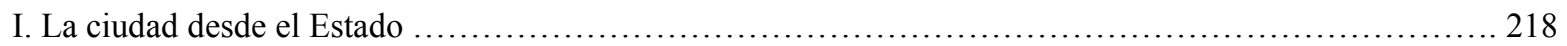


I.b. Una ciudad "bella, limpia e iluminada" .................................................. 221

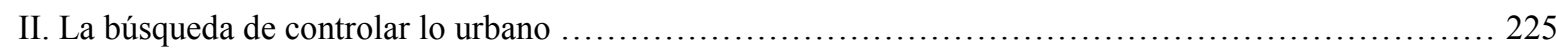

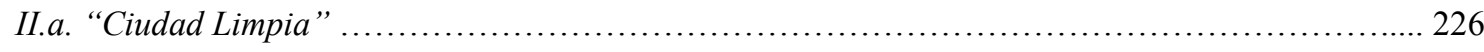

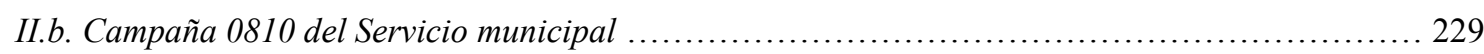

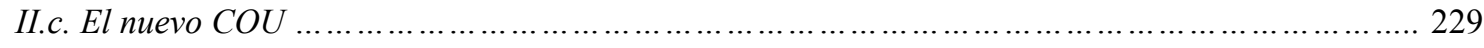

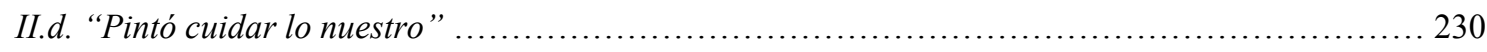

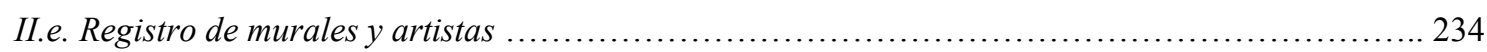

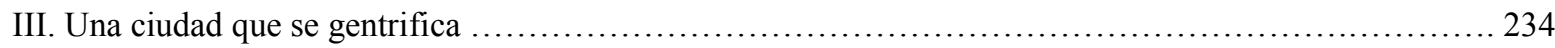

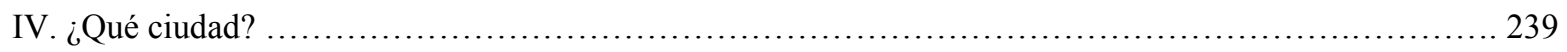

\section{Capítulo 7.}

Artistas vs. vándalos: construcciones binarias desde la prensa comercial ............................. 242

I. La ciudad en los medios, los medios en la trama urbana ..................................... 242

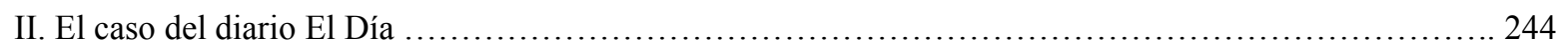

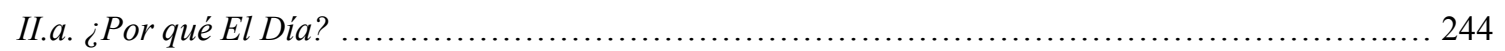

II.b. Los materiales y la propuesta de análisis .............................................. 246

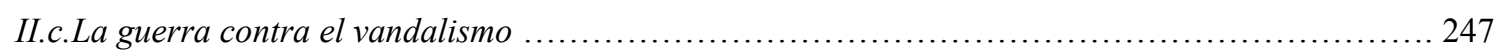

II.d. Una ciudad para contemplar ...................................................... 251

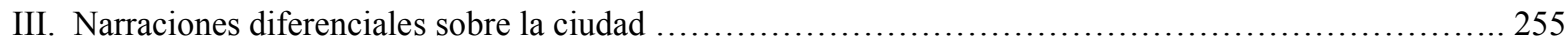

\section{Capítulo 8.}

¿De la calle a la galería? Desplazamientos y derivas de las prácticas culturales .......................... 258

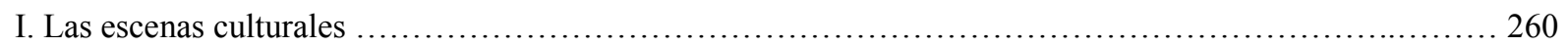

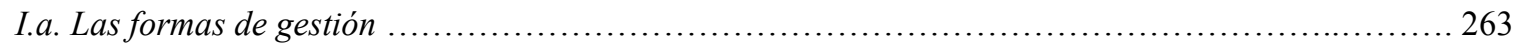

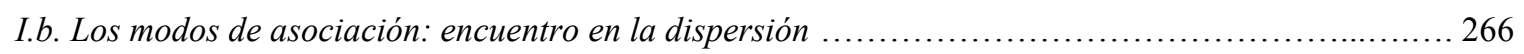

I.c. ¿Políticas estéticas en la escena local de artes visuales? ...................................... 267

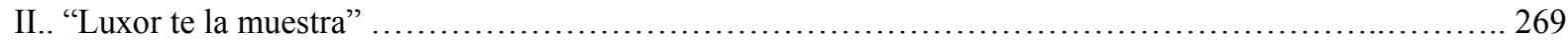

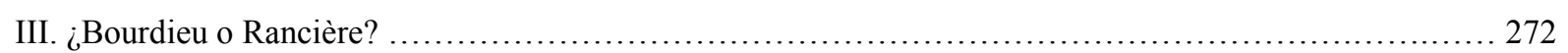

IV.. "Pensar y potenciar la escena local": La experiencia de Síntoma .................................. 275

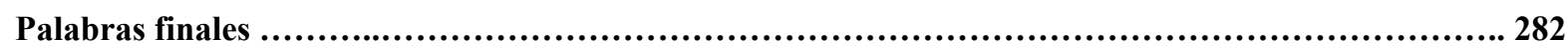

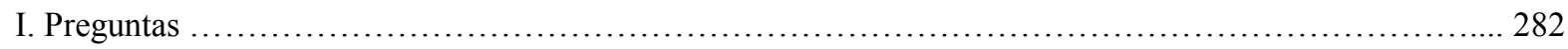

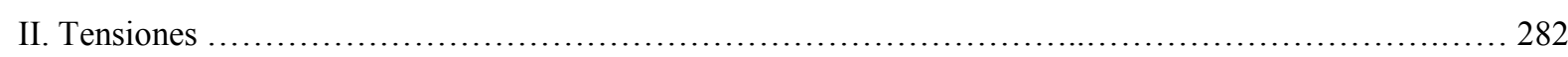

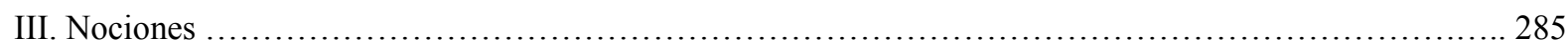

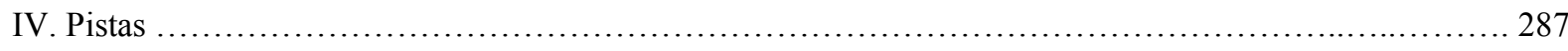

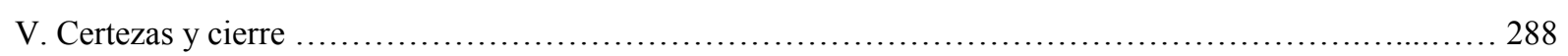

Bibliografía.......................................................................................... 297

Anexos 


\title{
Introducción
}

\section{La piel de la ciudad: Mutaciones del espacio público desde las intervenciones culturales}

\begin{abstract}
"Por las historias los lugares se tornan habitables. Habitar es narrativizar. Fomentar o restaurar esta narratividad es, por tanto, una forma de rehabilitación. Hay que despertar a las historias que duermen en las calles y que yacen a veces en un simple nombre, replegadas en ese dedal como las sedas del hada. Son las llaves de la ciudad: dan acceso a lo que ésta es, una visión mítica, una mitología."

Michel De Certeau y Luce Girad. La invención de lo cotidiano, 1980.
\end{abstract}

"Puesto que las clases populares son muy sensibles a los símbolos de la hegemonía, el campo de lo simbólico, tanto o más que el de la acción directa, se convierte en espacio precioso para investigar las formas de protesta popular."

Jesús Martín-Barbero. De los medios a las medicaciones, 1987.

"Concebimos la ciudad como un ser vivo que va perdiendo y cambiando la piel. Justamente trabajamos sobre esa piel y en ese proceso contemplamos la posibilidad de que la ciudad se exprese." Sienvolando, revista La Pulseada N$^{\circ}$ 55, 2007.

\section{Apuntes de la investigación y coordenadas epocales}

El objetivo de esta investigación es cartografiar y analizar las experiencias de intervención cultural que se desarrollaron en la ciudad de La Plata (Buenos Aires, Argentina) entre los años 2006-2011, para reconocer los procesos de disputas y apropiaciones de la ciudad que se pusieron en juego en dicho periodo. Se busca de este modo identificar e indagar las dinámicas de "producción" de la ciudad y las formas de politicidad emergente de/desde las prácticas culturales y repensar las nuevas configuraciones del espacio público en la situación contemporánea. Una situación marcada por procesos de retraimiento de lo público y apuestas por forjar lazos comunes, constituida por flujos globales y desencuentros locales, caracterizada por lógicas de fragmentación social y mass-mediatización de la cultura. Pero también constituida por cuestionamientos a las formas tradicionales de la política y por búsquedas de formas otras de organización y participación colectiva. En este contexto en la 
ciudad se visualizan y debaten las frustraciones y los deseos colectivos, es donde se desenvuelven los dramas del presente pero también donde se traman los proyectos de cambio.

En la investigación se toma como universo de análisis empírico a los colectivos Sienvolando, Arte al ataque, Unidad Muralista Hermanos Tello, Colectivo Siempre, Luli, a las últimas tres ediciones de la Muestra Ambulante organizada por el Grupo La Grieta y al interventor Luxor. Secundariamente también se relevan otros grupos, interventores y acciones que se hayan realizado durante los años 2012 y 2015 (período de complementación y ampliación del trabajo de campo), es decir, se indaga en las intervenciones culturales que en situación surgieron en la ciudad de La Plata durante el curso de la investigación ${ }^{1}$.

El sentido de tomar ambos cortes temporales, que refieren a una década, se debe a que puede reconocerse un período de profundas transformaciones sociales y políticas en el país durante estos años, que conforman, respecto de las intervenciones culturales en La Plata en particular, un momento específico y especialmente fructífero. En la investigación se pone principal foco en el primer recorte (2006-2011), coincidente con cierto momento de emergencia, alza y "reflujo" de este tipo de prácticas en relación a situaciones sociales y políticas, movimientos colectivos y reclamos callejeros que sucedieron en la ciudad en ese mismo lapso. A su vez, en ese período ampliado, se desarrollaron diferentes emprendimientos urbanos y culturales que modificaron la ciudad.

Como parte de la contextualización de las intervenciones culturales y para complejizar un escenario de transformaciones y debates en el período seleccionado, además 1) se explora en la discursividad producida por parte de medios locales, con el propósito de reconocer resonancias $\mathrm{u}$ omisiones y reconstruir complejamente el mapa de sentidos asociados a las intervenciones (sobre "la ciudad", "la calle", "la cultura", "el arte", "lo político", "lo legítimo/ilegítimo", etc.) y, 2) se indaga en las políticas públicas culturales y urbanas que se plantearon desde los gobiernos municipales, ya que pueden ser sintomáticas de lo que se entiende por espacio público y por cultura desde el Estado. Estas dos derivas, complementarias al núcleo de la investigación, permitirán a su vez entender que se trata de relatos, políticas "concretas" y sentidos sociales que disputan y "construyen" la ciudad y lo urbano $^{2}$.

\footnotetext{
${ }^{1}$ Sobre las prácticas culturales de esta segunda temporalidad, de los años 2012-2015, marcada por otro contexto social, político y cultural se trabaja en parte del capítulo 4 y especialmente en el capítulo 8 con los desplazamientos producidos en la práctica de Luxor y en la experiencia del colectivo Síntoma que reflexiona sobre la "escena local de las artes visuales".

${ }^{2}$ En julio de 2016, en momentos en los que se escribía esta tesis, el actual gobierno municipal -liderado por Julio Garro (PRO/Cambiamos)- "tapó" algunos murales que fueron realizados en el centro de la ciudad por iniciativas colectivas, lo que moviliza a pensar en lo inquietante de este tipo de intervenciones para los relatos oficiales.
} 
Para alcanzar los objetivos de la investigación se recuperan diversos estudios y perspectivas que aportan a la constitución de una analítica cultural desde la complejidad del escenario contemporáneo y propenden a la formulación de una mirada crítica de los procesos sociales. La perspectiva teórico-metodológica entonces es construida desde una mirada plural, que toma principalmente como herramientas de indagación cualitativas al cartografiado cultural -esto es, la reconstrucción etnográfica del mapa de actores, prácticas y territorios que integran el material empírico central de la tesis-, la entrevista en profundidad, la observación y la técnica del análisis de contenidos. La tesis se inscribe así en el campo de los estudios socioculturales, con especial foco en los estudios de comunicación, ciudad y espacio público. Pero se reconoce los puntales que hacen que la investigación teja una trama con los debates y aportes de otros campos de saber y disciplinas. Su inscripción en el Doctorado en Comunicación de la Universidad Nacional de La Plata, se debe a que este espacio académicoformativo reconoce a las prácticas culturales, la construcción de la ciudad y de la vida urbana como objetos-problema relevantes para la indagación, interpretación y producción de conocimiento sobre los procesos sociales y políticos de las sociedades contemporáneas desde su dimensión comunicacional, simbólica y material, de formulación de sentidos en la cultura.

Se retoma el trabajo de Carlos Giordano para entender a la tesis como una construcción discursiva e histórica, "un texto que sostiene un discurso" y en el que se debate el poder. A su vez, puede ser tomado como “un 'informe de situación' del 'estado presente' de un proceso en tránsito" (Souza, Giordano y Migliorati, 2012: 11-12). Se trata por lo tanto, de una producción / objeto académico específico en el que se ponen en juego determinados procedimientos, estrategias y operaciones (conceptuales, metodológicas, epistemológicas, escriturales) en donde la centralidad del sujeto cobra importancia en la constitución del objeto de estudio y en los límites discretos del género.

Hace veinte años Néstor García Canclini se preguntaba “¿Se acuerdan de que hubo épocas en que lo público era un espacio?” (1996: 5). Sin embargo, la premisa analítica que se abría (lo público es más que un espacio) no ha sido sencilla de desandar desde entonces y

Dos murales en el marco de la campaña nacional impulsada por diferentes organizaciones sociales y políticas titulada "Macri para la mano"; lo particular de este mural es que fue tapado las dos veces que se pintó en la esquina de 1 y 58. Además, unas pintadas y un mural alusivos a la seccional La Plata de la UOCRA, liderada por el dirigente "Pata" Medina, taparon un mural que se realizó como parte de una jornada de protesta nacional por la libertad de la dirigente social Milagro Sala, realizado en la esquina de 4 y 44 por el Comité de Solidaridad de La Plata, integrantes de la Facultad de Periodismo y Comunicación Social de la UNLP y el interventor Lumpenbola. Ver: http://www.diariocontexto.com.ar/2016/07/21/taparon-en-la-plata-un-mural-por-la-libertadde-milagro-sala/ y https://www.facebook.com/Macri-par\%C3\%A1-la-mano-La-Plata-Berisso-y-Ensenada$\underline{1237529929594545 /}$ 
hasta ahora. Al mismo tiempo, se conformó con insistencia una idea sobre la desaparición o "agotamiento" del espacio público -visión que cobró fuerza en las ciencias sociales-, que parecía hacer evidente la "nostalgia por un lugar perdido" (Rabotnikof, 2005: 11). Se puede comprender actualmente que lo público no se reduce a un espacio (físico, material o simbólico), ni a ciertos sitios de la ciudad, ni a territorios delimitados -sean por los estados o los mercados ${ }^{3}$. Con la pretensión de generar una definición, se puede afirmar que los procesos sociales, económicos, políticos, urbanos y culturales contemporáneos han producido un estallido de la noción de territorio ${ }^{4}$, lo que invita a pensar, no en el fin del espacio público sino, en su reconceptualización y redefinición, en pensar un "otro territorio" (Ortiz, 1998).

En esta complejización de lo público, los procesos de mediatización de la cultura y de las prácticas sociales, así como la incorporación de las tecnologías digitales y virtuales en las mutaciones de los modos de vivir en la ciudad y en las formas de subjetivación contemporánea han operado como condiciones clave para su reconfiguración actual. Pese a ello, el campo de las acciones culturales que se realizan en el espacio público permanece como un objeto estudiado en menor medida, al menos en comparación con otras dinámicas de la matriz público-urbana-territorial como algunas las recién mencionadas. Este menor desarrollo de análisis sistemáticos es, a la vez, un terreno abierto que resulta fructífero para la investigación social y cobra relevancia sobre todo en la ciudad de La Plata, donde estas dinámicas y prácticas culturales han tenido un creciente desarrollo en la última década. Principalmente en la "pos-crisis" -económica, social y política de 2001-2002 acontecida en la Argentina ${ }^{5}$-, con la creación de muchos "colectivos", la activación de productores e

\footnotetext{
${ }^{3}$ Tampoco se puede reconocer hoy al espacio público solamente con la comunidad política o con el Estado, como se lo identificó durante mucho tiempo. Pero tampoco -luego de las crisis del Estado moderno o en las situaciones en que este se identificó como un Estado autoritario- se puede identificar a lo público con cierto desplazamiento que operó hacia una "sociedad civil", que se articuló con la "cruzada antiestatal" impulsada por las fuerzas del mercado y "con la defensa de lo estrictamente privado" (Rabotnikof. 2005: 11-12).

${ }^{4}$ Procesos contradictorios que comúnmente se denominan "globalización" y que se vienen discutiendo en las Ciencias Sociales desde hace cuatro décadas, vinculados tanto al debate y la problemática de la modernidadposmodernidad como a las transformaciones (y varias catástrofes) económicas, sociales, comunicacionales, urbanísticas y ambientales de nuestro tiempo (Giddens, 2000; Beck, 2001; Wallerstein, 2002; Bauman, 2000; Sassen, 1999, 2012; Harvey, 1998, 2005; Castells, 1995, 2001, 2009; Jameson, 2012; Guattari, 2004, 2013; Ortiz, 1998; Mattelart, 2001; Canclini, 2008). Félix Guattari es uno de los críticos de la utilización del concepto de «globalización», por considerarlo demasiado genérico y porque omite un elemento central para entender esos procesos: la economía capitalista mundializada y neoliberal. El autor propone como alternativa el concepto de "Capitalismo Mundial Integrado" (CMI) para dar cuenta de la instalación de un nuevo régimen social y económico. "El capitalismo es mundial e integrado porque potencialmente ha colonizado el conjunto del planeta, porque actualmente vive en simbiosis con países que históricamente parecían habérsele escapado (los países del bloque soviético, China) y porque tiende a hacer que ninguna actividad humana, ningún sector de producción escape de su control" (Guattari, 2004: 57).

${ }^{5}$ La crisis de 2001 en la Argentina puede ser interpretada no solamente como una crisis por la inviabilidad -para las mayorías populares- del modelo económico neoliberal y el agotamiento de la legitimidad de la "clase política", sino además como un espacio abierto a formas de hacer y una mutación en la subjetividad que produce
} 
interventores culturales y el desarrollo de diversas acciones públicas que se presentaron tanto en el espacio urbano como en la web, y que articuló -en algunos casos- ambos territorios como superficies de intervención cultural.

Con el interés de ampliar la caracterización sobre los contornos de la época contemporánea, se puede afirmar que en las últimas cuatro décadas las modificaciones en los modos de producción, no solo económicos (lo que algunos dieron en llamar "postfordismo", "capitalismo cognitivo" o "semiocapitalismo", combinado con una profundización de la "biopolítica") 6 , junto con el avance de la lógica de mercado y las políticas estatales neoliberales -que conllevaron la salida del Estado de Bienestar, la desindustrialización, la desocupación estructural, la flexibilización y precarización laboral-, marcaron los procesos de producción social, las prácticas sociales, los modos de pensar, así como la emergencia de nuevas formas de subjetivación ${ }^{7}$. Estos procesos adquieren connotaciones importantes

nuevos desplazamientos y correlaciones de fuerza articuladas con nuevas formas de organización colectiva (Colectivo Situaciones, 2002). Para este grupo dedicado a la "investigación militante": "La hipótesis que aquí trabajamos se constituye como un lugar de polé-micas, rupturas y continuidades respecto de las luchas de los 70 y del período de la posdictadura. Afirmamos la emergencia de un conjunto de prácticas y lenguajes que dan lugar a un nuevo tipo de intervención en el ámbito político y social. Un protagonismo social que opera reuniendo el conjunto de las dimensiones de la existencia y es consecuencia de una ruptura histórica mayor respecto de los mitos del determinismo y del progreso característicos de la modernidad." (Colectivo Situaciones, 2002: 10). Se volverá sobre estas cuestiones en el capítulo 1.

${ }^{6}$ Pensamos en varios autores ligados a la corriente filosófica-política autonomista que plantean, aún con sus diferencias, estas reflexiones: Hardt y Negri (2002), Virno (1993, 2003), Lazzarato (2006), Berardi (2007), Mezzadra (2005). A su vez, algunas publicaciones que han planteado y actualizado estos debates han sido Futuro Anterior y Multitudes. El postfordismo se puede entender como un modo de producción que, a diferencia del fordismo -en el cual los trabajadores se encontraban en una estructura de producción en línea y realizaban tareas repetitivas especializadas-, se caracteriza por el uso de nuevas tecnologías de información, la explotación de capacidades lingüísticas y afectivas de los trabajadores, la formación permanente, la rotación y la polivalencia de tareas, así como un régimen de flexibilización laboral acompañado de una pérdida de condiciones de seguridad social. Se trata de una mutación del trabajo en el capitalismo, iniciada luego de los conflictos laborales y sociales de finales de los años 60 del siglo XX. Otros pensadores posicionados desde una corriente filosófica e histórica -representada por Agamben (2005) y Espósito (2012)- se apoyan en las reflexiones de Foucault sobre la proliferación de las estrategias "biopolíticas". El primero para indagar sobre el "estado de excepción": como ese momento del Derecho en el que este se suspende para garantizar su continuidad; una forma legal de lo que no puede ser legal. Se trata -para Agamben- de la forma permanente y paradigmática de gobierno de las sociedades occidentales durante el siglo XX. El segundo para reflexionar sobre las formas de la comunidad y su relación con la política moderna: relación marcada por una tensión irresoluble entre una tendencia a la nada de lo común y otra tendencia inmunizadora que garantiza la vida individual.

${ }^{7}$ Félix Guattari propone -frente a la idea de "sujeto" de una tradición filosófica y humanística- la idea de una "subjetividad" de naturaleza maquínica, es decir, fabricada, recibida, consumida, etc. De este modo entenderá que las transformaciones de todo tipo conciernen a la "producción de subjetividad". Esta idea de producción lo aleja de nociones como ideología, superestructura y representación. Reconoce la existencia de una "subjetividad capitalística" que es un "sistema de significación dominante" articulado con la producción capitalista, que establece un "límite" y una "reducción modelizadora" para los agenciamientos, los procesos de singularización y las relaciones de desterritorialización. "Todo lo que es producido por la subjetivación capitalística -todo lo que nos llega por el lenguaje, por la familia y por los equipamientos que nos rodean- no es sólo una cuestión de ideas o de significaciones por medio de enunciados significantes. Tampoco se reduce a modelos de identidad o a identificaciones con polos maternos y paternos. Se trata de sistemas de conexión directa entre las grandes máquinas productivas, las grandes máquinas de control social y las instancias psíquicas que definen la manera de 
especialmente en los países de América Latina, donde se combinan el modelo de producción postfordista y modelos productivos anteriores, las condiciones de vida precarias de las mayorías y la segregación de amplios sectores de la población, sobre todo de pobres urbanos. Para algunos, la vida humana pasó a ser entendida como mercancía, un recurso humano disponible (de ser ajustado, precarizado, explotado, etc.) y a la vez, como un desecho, recurso prescindible (para ser "excluido", "marginado", "estigmatizado", "reprimido"). Estos procesos -combinados y desiguales en distintas regiones del planeta- modelaron todas las relaciones sociales y tomaron la vida por entero. Para la mayoría de la bibliografía crítica disponible el punto de inflexión de esta cuestión se da a mediados de los años 70 del siglo XX con los procesos de reestructuración capitalista: impulsados principalmente por la "nueva economía" neoliberal (primacía de la acumulación financiera), así como por una nueva forma estatal que reemplaza al Estado de bienestar ${ }^{8}$.

En este sentido, en el campo de la gobernabilidad estatal las políticas públicas económicas, sociales, culturales, urbanísticas- comenzaron a operar desde una nueva racionalidad signada por la segregación y la exclusión: el "estado de excepción" se ha convertido en paradigma de gobierno en la política contemporánea (Agamben, 2005); una acción gubernamental ejercida como "gestión diferencial de desigualdades" (Lazzarato, 2006); o la constitución de un "nuevo orden interior" donde el Estado realiza una cierta “desinversión” de las cuestiones en las que se ocupaba y se presentará, al mismo tiempo, “desentendido y condescendiente" (Foucault, 1979) ${ }^{9}$. Esa racionalidad excluyente se tradujo en una política urbana específica, signada por una planificación urbana y una distribución del suelo urbano y el ingreso que produjeron desigualdad social (Harvey, 1977); así como por la marginalidad y "guetización" de zonas de las ciudades y de sectores sociales vulnerables y estigmatizados (Wacquant, 2007); y por los procesos de "gentrificación" en tanto reapropiación de ciertas áreas estratégicas de la ciudad que son "destinadas a los negocios, a los sectores sociales más privilegiados y a las fuerzas del mercado en general" (Contested Cities, 2016), que muchas veces implica el desplazamiento de los sectores populares y

percibir el mundo. (...) La producción de subjetividad constituye la materia prima de toda y cualquier producción" (Guattari, en Guattari y Rolnik, 2013: 37-41)

${ }^{8}$ Algunos análisis, que buscan apartarse de las miradas economicistas, incluso plantean que las mutaciones no devienen de una crisis económica (por ejemplo, de sobreproducción) sino de modificaciones en la subjetividad, atravesada por impulsos emancipatorios y de dominación (Guattari, 2013, 2015).

${ }^{9}$ En este punto es preciso mencionar que la mayoría de estos estudios sobre postfordismo y biopolítica recuperan como referencia fundamental los trabajos de Michel Foucault, especialmente algunos de sus últimos cursos en el Collège de France en los años 1976 ("Defender la sociedad"), 1978 ("Seguridad, territorio, población") y 1979 ("Nacimiento de la biopolítica"). 
sectores medios que los habitaban. Es decir, una política urbana anclada en la austeridad y en la segregación y desposesión de los sectores populares.

Se puede decir entonces que en tales procesos también tuvieron una fuerte transformación las ciudades (en los modos de habitarlas, en la organización económica y política, en las maneras de gestionarlas). Al ritmo de la globalización capitalista se configuró una otra situación que algunos han denominado como un "nuevo orden socioespacial" (Sassen, 1999, 2012) ${ }^{10}$, donde las ciudades -ahora "globales"- tienen una mayor injerencia en la medida que adquieren nuevas funciones relacionadas a la organización económica mundial $^{11}$-sin embargo, esta es una tesis que varios autores discuten y relativizan-. Esto se puede articular, en el contexto de la crisis actual, con la importancia de la política urbana para el desarrollo de la "nueva economía informacional", cuya productividad se basa en la transformación de la información en conocimiento (Castells, 2009) ${ }^{12}$.

\footnotetext{
${ }^{10}$ Para Saskia Sassen en los análisis sociológicos hay que ir más allá de las imágenes que dominan el discurso de la globalización -como la hipermovilidad, la comunicación global y la neutralización de la distancia-. Según esta autora es preciso desplazar el enfoque hacia "las prácticas" en el análisis de la globalización económica porque recupera las categorías de lugar y de procesos de trabajo. Estas "permiten observar la multiplicidad de economías y culturas de trabajo donde se inserta el sistema económico global, así como también recuperar los procesos concretos y localizados que materializan la globalización y afirmar que el multiculturalismo de las grandes urbes forma parte de ese fenómeno tanto como el mercado financiero internacional. Por último, (...) permiten describir los caracteres específicos de una geografía de territorios estratégicos a escala global." Uno de los interrogantes de ese análisis es conocer si esta nueva geografía transnacional "también constituye el espacio para una nueva política transnacional" (Sassen, 2012: 126). En ese nuevo ordenamiento socioespacial, la "ciudad global" podría constituirse en un "nexo" para nuevos alineamientos político-económicos. Para Sassen allí se destaca la "presencia" en el proceso político de los inmigrantes y las mujeres asalariadas con sus demandas de derechos, presencia que "trasciende los límites de las estructuras políticas formales" y abre "la posibilidad de una nueva política". Una política de carácter transnacional -por lo que no se subsume en lo nacional- "pero centrada en espacios locales concretos", como las diversas comunidades de pertenencia (2012: 163).

11 A inicios de los años '90 Félix Guattari también se refirió a las nuevas condiciones, interconectadas y desterritorializadas, de las "ciudades-mundo" en la producción capitalista. Con esto reconoce la alteración -desde el último tercio del siglo XX- de la concentración del poder en una metrópolis y que acentúa las desigualdades en los modos de habitar. "Desde entonces, ya no se tratará de un centro localizado, sino de la hegemonía de un 'archipiélago de ciudades' o, más exactamente, de subconjuntos de grandes ciudades conectadas por medios telemáticos e informáticos. Así pues, la ciudad-mundo de la nueva imagen del capitalismo mundial integrado se ha desterritorializado profundamente, y sus componentes se han diseminado sobre un rizoma multipolar urbano que abarca toda la superficie del planeta. Observemos que, si esta configuración en la red planetaria del poder capitalista ha homogeneizado sus equipamientos urbanos y de comunicación, así como la mentalidad de sus élites, también ha exacerbado las diferencias de nivel de vida entre las zonas de hábitat. Las desigualdades ya no se producen necesariamente entre un centro y su periferia, sino entre pequeñas mallas urbanas sobre equipadas tecnológica e informáticamente, y entre zonas de hábitat mediocre para las clases medias y zonas, en ocasiones catastróficas, de pobreza." (Guattari, 2003: 38-47).

${ }^{12}$ Se trata para Castells de "una economía que desarrolla extraordinariamente el crecimiento de la productividad económica y de la capacidad competitiva de las distintas unidades de la economía: empresas, agentes económicos, países o regiones. Ese incremento de productividad y de competitividad con respecto a parámetros históricos anteriores se desarrolla sobre la base de un nuevo modelo productivo. En ese sentido, la nueva economía es, ni más ni menos, que la economía informacional, el nuevo tipo de economía, un nuevo modelo productivo que se basa en la utilización de nuevas y poderosas tecnologías de información y, sobre todo, tecnologías basadas en la comunicación entre redes de ordenadores, incluyendo Internet." (Castells, 2009)
} 
Por su parte, en el campo de lo social puede interpretarse que se produjo un retraimiento de lo público -o como se mencionó antes, se expandió la idea de la desaparición o "agonía" del espacio público, entendido éste más allá del andamiaje estatal como una construcción colectiva, diversa y abierta de lo común (Rabotnikof, 1997, 2005)-, que fragmenta lazos comunitarios y deposita, muchas veces, las expectativas de encuentro a través de la lógica mediática y las industrias culturales.

Con todo lo expuesto se puede hablar entonces de una esfera pública/espacio público contemporáneo atravesado por:

1) las lógicas de espectacularización mediática: llevadas adelante tanto por los medios masivos de comunicación como por las expresiones políticas y culturales en el espacio público; los mass-media son erigidos como ágora democrática de los asuntos públicos y portavoces de la "verdad"13. Esto produce una mirada limitante: el humor de la "opinión pública" vendría a delimitar lo público. De ese modo, los medios llevan adelante una función legitimadora de las políticas de control.

2) Los constantes discursos sociales del "miedo" y aplicación de políticas de "seguridad": generación de zonas de exclusión en la ciudad, naturalización del control policial, ciudadano y mediático, producción de miedo y de "lo peligroso" en los discursos sociales, rechazo a lo diferente, estigmatización de sectores populares, criminalización y judicialización de la protesta social, etc. $^{14}$

3) Las lógicas de privación y privatización de lo público: que genera un achicamiento de la posibilidad de intervención social, que desanda continuos procesos de clausura y

\footnotetext{
${ }^{13}$ Más adelante describiremos algunos de los aportes de Rossana Reguillo para pensar este problema.

${ }^{14}$ Esteban Rodríguez $(2003,2014,2016)$ es uno de los investigadores que en la Argentina indaga sobre las problemáticas de la violencia institucional, las políticas estatales de seguridad y delito, así como sobre las construcciones discursivas sobre el "miedo", "seguridad" e "inseguridad" ciudadana. En la ciudad de La Plata ha sido el diario El Día uno de los principales portavoces de llevar adelante un discurso sobre el miedo y la inseguridad. Un eje permanente de ese discurso es la estigmatización de menores y jóvenes pobres, principalmente habitantes de barrios populares. Uno los puntos más extremos de esta mirada se encuentra en la gran cantidad de notas y columnas que publicó dicho medio en el año 2008 sobre la denominada "banda de la frazada" de Plaza San Martín. Solo para un ejemplo ver: http://pasado.eldia.com/edis/20080728/policiales 18.htm La complejidad del problema se presenta al reconocer que la estigmatización y la "demagogia punitiva" no se operaron solamente desde el discurso mediático, sino también desde el discurso político (por ejemplo, en el intento de bajar la edad de imputabilidad de los menores impulsada desde el entonces gobernador Daniel Scioli) y la aplicación de políticas de estado "policiales" que socaban los derechos de los menores (por ejemplo, el Municipio liderado por Pablo Bruera al utilizar a la Dirección de Control Urbano como agente de resolución de problemas sociales en la vía pública en los que niños y jóvenes menores de edad son participes). Para un análisis del tratamiento mediático de este caso ver Badenes, 2009. También una reciente e interesantísima investigación analiza el discurso policial y mediático sobre esta problemática y recupera la voz de los chicxs involucrados en aquellos hechos (Calligo, 2016).
} 
fragmentación de la ciudad. Controles cotidianos en espacios públicos ${ }^{15}$, enrejamiento de lugares públicos ${ }^{16}$, aplicación de códigos contravencionales y de políticas urbanas segregadoras (que castigan a las personas que viven en "situación de calle", el merodeo, la venta callejera, las pintadas y graffitis en la "vía pública") ${ }^{17}$, lógicas estatales que posibilitan el uso privado de espacios públicos, brindar servicios de transporte público "deficientes" y organizados de una mirada excluyente de los barrios y zonas "periféricas", entre otras cuestiones $^{18}$.

Asimismo estos tres puntos mencionados dan cuenta de una "atmósfera", es decir, de cierto "clima de época" o del momento, que puede ser relevado desde el análisis al tomar algunos parámetros culturales. Esto lo desarrollaremos a lo largo de toda la tesis, pero especialmente en los capítulos 6 y 7 al indagar en las políticas urbanas y culturales y en el discurso mediático sobre las acciones que suceden en la ciudad.

Aquí resulta pertinente observar e indagar en los contrastes, discontinuidades y continuidades entre esos procesos sociales globales y el giro "nacional-popular" que en la

\footnotetext{
${ }^{15}$ En La Plata se ha vuelto, lamentablemente, parte del paisaje cotidiano los controles a pibes y jóvenes de sectores populares que buscan acceder y circulan por el centro de la ciudad: interrogatorios, cacheos, pedidos de documentos y hostigamientos en la vía pública. El Estado -al presentarse con ropaje policial- los convierte así en sospechosos de un posible delito o infracción ante la mirada de los otros transeúntes. Si una ciudad se predispone para el consumo de bienes materiales y culturales como principal lógica de circulación, se abre el campo para una pregunta que opera directamente en el sentido común: “¿Qué tienen que hacer en el centro de la ciudad estos jóvenes que no tienen recursos para consumir?"

${ }_{16}$ Desde el 2010 ha habido en la ciudad una proliferación de "enrejamientos" de edificios y espacios públicos que tenían usos cotidianos diversos, por mencionar algunos: la Catedral, el Rectorado y varias facultades y colegios de la UNLP, las sedes del Poder Judicial (provincial y federal), los edificios provinciales como la Gobernación, el Palacio Legislativo, la Dirección General de Cultura y Educación y el Teatro Argentino a los que en breve se les sumará el Palacio Municipal). Estas iniciativas poco originales para el "cuidado, mantenimiento y protección" de esos espacios fueron promovidas por actores institucionales diferentes, lo que no implica pensarlas como una lógica y una política común de privación que atraviesa a espacios políticos muchas veces adversarios- y sectores sociales. Se sostiene aquí que ese tipo de política urbana potencia la degradación del patrimonio, priva a los habitantes de la ciudad de utilizar y construir el espacio público al regular sus accesos y desplazamientos, y refuerza la criminalización de prácticas culturales diversas (que van desde el estigmatizado graffiti a los reclamos sindicales y sociales). Sobre esto se volverá en el capítulo 6.

${ }^{17}$ Desde hace varios años que existen conflictos entre los vendedores ambulantes o manteros y el Municipio platense. Hacia fines de 2016, un funcionario municipal de "convivencia y control ciudadano" lanzó -en declaraciones a la prensa- un elocuente planteo de lo que "debía" ser una política estatal sobre las prácticas de los manteros en el centro: "Tenemos que evitar que la ciudad se transforme en una feria ambulante, vamos a dar batalla a los manteros". En el mismo sentido, uno de los responsables de la Cámara de comerciantes de de la región declaró que "sobre todo el centro de la ciudad está invadido por los puesteros".

${ }^{18}$ Más adelante nos detendremos en algunos hechos significativos que sucedieron en el período central de estudio. Sintéticamente podemos mencionar que fueron -sobre todo- los gobiernos municipal y provincial quienes impulsaron medidas que causaron cuestionamientos y conflictos por parte de diversas organizaciones de la sociedad civil (movimientos sociales, organizaciones de Derechos Humanos, ONGs, organizaciones profesionales, movimientos autoconvocados). Algunas de esas acciones oficiales fueron la criminalización de niños y jóvenes que vivían en Plaza San Martín (que incluyó maltratos físicos y narraciones estigmatizantes) y la búsqueda por bajar de edad de imputabilidad de los menores, los intentos de legislar un nuevo Código Contravencional (finalmente fallido), la aprobación y aplicación de un nuevo Código de Ordenamiento Urbano en la ciudad, el aumento del boleto de micros, las irregularidades y la desidia con las que enfrentaron la brutal inundación de 2 de abril de 2013, entre otras.
} 
Argentina se llevó adelante desde el Estado con los tres gobiernos kirchneristas desde mediados de 2003 hasta 2015 -que coincidió con el surgimiento y alza de gobiernos progresistas en otros países de América del Sur-. Se trata de cambios en relación a los procesos políticos formales que se dieron en el país (por ejemplo, por el fuerte vínculo con determinadas organizaciones sociales y por la articulación regional con varios países del continente por fuera de los tratados de libre comercio bilaterales) y del impulso de ciertas políticas "compensatorias", de "inclusión social" y "ampliación de derechos" llevadas adelante desde el Estado, que interpelaron a los diversos actores y sectores sociales: principalmente, sectores del movimiento obrero, sectores populares y capas medias, determinadas organizaciones de derechos humanos y colectivos de género, parte del sector científico-tecnológico, así como al campo académico y a experiencias de comunicación popular. Es en este contexto que varios autores e intelectuales comenzaron a plantear que en la Argentina transcurrían tiempos de "restitución de lo público". A modo de hipótesis, en este trabajo, sugerimos sostener que esa nueva situación política en el país no anuló sino que se tensionó y amalgamó con los procesos globales-postfordistas del capitalismo y el neoliberalismo, caracterizados anteriormente ${ }^{19}$.

Así es que se puede reconocer cierta ambivalencia en ese proceso político que tuvo lugar en la década bajo estudio. Por ejemplo, al momento de pensar la matriz productiva del país y su modelo económico, en donde se fortaleció cierto capitalismo nacional con una recomposición industrial (que generó valor agregado en productos industriales de fabricación nacional) y el impulso del mercado interno a través del consumo, junto con la extranjerización de la explotación de los recursos nacionales no renovables y su comercialización (sojización de las tierras, megaminería a cielo abierto, explotación del petróleo por empresas internacionales), características que dan cuenta de un modelo de producción "extractivista" (Svampa, 2008, 2012).

\footnotetext{
${ }^{19}$ En este punto hay que destacar que no pocos analistas políticos -por ejemplo, Sader, Borón, Figueroacomenzaron a hablar de "posneliberalismo" como un momento de ruptura provocado -principalmente en América del Sur- por los gobiernos autodenominados como "progresistas", surgidos desde o luego de las luchas sociales contra el neoliberalismo. Dos de las cuestiones que tomaban estos autores para construir esta idea que evidenciaba un nuevo tiempo histórico era la distancia que tomaban de aquellos gobiernos -anteriores y simultáneos- que adherían al Consenso de Washington y el rol del Estado como un agente dinamizador de la vida social y la economía (por ejemplo, políticas públicas con sentido inclusivo). Ver: Sader, Emir. (2008) Posneoliberalismo en América Latina, Buenos Aires, Clacso / CTA Ediciones. Disponible en: http://bibliotecavirtual.clacso.org.ar/ar/libros/coedicion/sader/ Para una revisión de estos postulados ver: Dávalos, Pablo. (2016) "Posneoliberalismo, apuntes para una discusión”. Rebelión. Disponible en: http://www.rebelion.org/noticia.php?id=212580
} 


\section{II. ¿Por qué pensar la ciudad?}

"Hoy en día, en el comienzo de un nuevo siglo, la ciudad resurge como espacio estratégico para entender tendencias críticas en la reconfiguración del orden social."

Saskia Sassen. Una sociología de la globalización, 2012

Desde hace tiempo algunos estudios dentro de las ciencias sociales sostienen que las ciudades son espacios destacados para mirar y analizar la aplicación de diferentes políticas, que en la sociedad contemporánea acentúan segregaciones y profundizan antagonismos, al ritmo de lo que algunos consideran el "neoliberalismo urbano" o la "ciudad neoliberal" (Theodore, Peck y Brenner, 2009; Hidalgo y Janoschka, 2014) -en un sentido similar juega también el concepto de "arreglo espacial" (spatial fix) con el que Harvey $(1998,2005)$ entiende que la acumulación del capital construye un espacio y una geografía urbana a medida de sus necesidades-. También se plantea que las ciudades son un ámbito fructífero para observar las disputas, reinterpretaciones y reapropiaciones que se producen desde el campo de lo popular y desde los usos e itinerarios de los habitantes ${ }^{20}$. Pero, además se ha comenzado a entender la interconexión de la ciudad con los procesos económicos y sociales "globales", que en muchos casos entiende que la ciudad es un subsistema de producción (y explotación) económica. Las imágenes preponderantes de este último discurso han sido la hipermovilidad, la comunicación y control global, el poderío de las empresas multinacionales, la economía informacional.

Estas miradas sirven para comprender y densificar los análisis sobre la ciudad y los diferentes procesos y entramado de relaciones en los que ésta se halla inserta. Colaboran, a su vez, con el entendimiento de que la ciudad no se construye de manera igual ni unívoca en sus significados para los distintos sectores, grupos o clases. Existirán entonces formas diversas (y muchas veces contrapuestas) de nombrarla, distinguirla y caracterizarla, lo que le exige a los estudios sobre las ciudades una atención particular en sus complejas configuraciones históricas y contemporáneas.

Lo que interesa aquí es pensar que la ciudad, y en particular en esta tesis a la ciudad de La Plata, se configura desde una "trama sociocultural heterogénea" -según la definición

\footnotetext{
${ }^{20}$ En el campo de los estudios socioculturales en América Latina "la ciudad" ha sido objeto de análisis y propuestas de intervención desde la investigación: como un lugar privilegiado de la cultura para comprender los sentidos y las dinámicas de la hegemonía, es decir como un campo de fuerza de negociaciones y conflictos (pensamos en autores como J. Martín-Barbero, N. García Canclini, J. González o R. Reguillo) o la ciudad "imaginada" como escenario de las cartografías culturales y los imaginarios urbanos, es decir, con la preocupación centrada en indagar en las formas perceptivas y cognitivas de la vida urbana (A. Silva, N. García Canclini). En el próximo capítulo se vuelve sobre estos trabajos.
} 
propuesta por Martín-Barbero (2004)-, conformada de prácticas y discursos, acontecimientos y narraciones diferentes. La ciudad se cruza con lo político y lo estético, se construye en la vida cotidiana de sus habitantes y en las políticas que se aplican desde el Estado. En ella se amasan expectativas y se refuerzan desigualdades; se movilizan encuentros y modos de hacer colectivos pero también acciones que, en el día a día de la ciudad, sostienen los desencuentros y las exclusiones. Asimismo, al entender, con Michel De Certeau (2000), que los espacios configuran modos posibles de habitarlos, se reconoce a la ciudad como un "lugar practicado", producido por recorridos transversales y una pluralidad de intersecciones. De este modo, las percepciones y sensibilidades del desplazamiento se convierten en la materia prima de la experiencia urbana (Delgado, 2007a: 61$)^{21}$. Con especial énfasis en próximos apartados de este capítulo se trabaja con algunas nociones que acercan y diferencian a la ciudad del espacio urbano y estas con las concepciones de espacio público. En el siguiente capítulo se amplía la indagación sobre los estudios que piensan a la ciudad como objeto de análisis desde las ciencias sociales. Por su parte, en el capítulo 3 se ahonda en la caracterización de la ciudad de La Plata en relación a los relatos que la denominan y a las transformaciones que en ella han suscitado en los últimos tiempos. En el capítulo 5 se trabajan los sentidos sobre la ciudad y lo público en las experiencias de intervención cultural. Mientras que en el capítulo 6 y 7 respectivamente se analizan las construcciones de sentido sobre la ciudad y el espacio público en los discursos del Estado local y en los medios de comunicación comerciales de La Plata.

\title{
III. "Lo cultural" en escena
}

\begin{abstract}
"La cultura se confunde con el ocio programado; es una grilla para llenar el fin de semana. Mirada a través del espectáculo se dispone para la mera recreación. (...) Con las intervenciones en la vereda y la calle, con las exposiciones en los locales comerciales y la muestra de oficios en los garajes de los vecinos, la Muestra Ambulante le devuelve la cultura a la vida cotidiana"

Grupo La Grieta, La muestra ambulante, 2009.
\end{abstract}

En este punto interesa destacar la propuesta abierta por los Estudios Culturales, tanto en su raigambre anglosajona como en su especificidad latinoamericana. Primero son relevantes los aportes producidos por Raymond Williams (1994, 1997, 2000, 2009) para pensar los fenómenos y procesos sociales desde una perspectiva inscripta en el denominado

\footnotetext{
${ }^{21}$ Para este entendimiento también son importantes los aportes de Henri Lefebvre $(1970,1974)$, al comprender a lo urbano como un espacio para la práctica y la representación: un espacio vivido y percibido, una producción que se hace desde el intercambio generalizado.
} 
"materialismo cultural". Una mirada que focaliza no sólo en el doble e inseparable carácter material/simbólico de todas las prácticas sociales, sino que avanza en el análisis del estatuto históricamente específico, siempre en el marco de la especificación de las dinámicas ideológicas que participan en los procesos de producción de hegemonía desde el campo de la cultura. Por lo tanto, se trata de una perspectiva de análisis cultural que reconoce el poder configurador de la cultura y observa las implicancias de ésta en los procesos históricos y los cambios sociales $^{22}$. (Más adelante en este capítulo, cuando se presentan las constelaciones conceptuales de la tesis, se vuelve sobre los aportes de esta perspectiva abierta por los Estudios culturales).

De este modo, esta perspectiva servirá, en parte, para comprender -como se planteó al describir las características de "semiocapitalismo"- el peso de "lo cultural" en la producción social contemporánea. A la vez, entender que la cultura se inserta en el centro de la reproducción material y simbólica de la vida. Es decir, releva la importancia de la cultura en la configuración e incidencia en "lo real". En este sentido, se puede reconocer que en los procesos sociales contemporáneos, las diversas experiencias culturales cobran una importancia central en la producción y disputas de sentidos, en la construcción de imaginarios sociales y en su inserción en movimientos colectivos que plantean resistencias y críticas así como prácticas creativas.

Principalmente en los años 80 del siglo XX se realizaron gran parte de los análisis sobre la importancia de la cultura en las transformaciones de las sociedades occidentales. Insertos en los debates sobre modernismo y posmodernismo -pero también sobre el postestructuralismo y las problemáticas del neoliberalismo y conservadurismo del momentoestos estudios indagaron complejamente sobre continuidades y discontinuidades, dicotomías y articulaciones de esos procesos (Jameson, 2012; Huyssen, 2006; Foster, 2001a, 2001b; Harvey, 1998).

A mediados de esa década, Hal Foster daba cuenta de parte de esta nueva situación y del protagonismo de lo cultural en lo social -y en los intereses del autor de la posición del arte político en el capitalismo de nuevo tipo-. Reconocía una "dislocación" que cuestionaba la correlación entre lo social y lo económico, que producía dentro de las fuerzas progresistas y de izquierda dos desplazamientos en los postulados del marxismo: en relación al sujeto de la historia en términos de clase y a la centralidad de los medios de producción.

\footnotetext{
${ }^{22}$ En este punto fueron importantes las lecturas y reflexiones que se realizaron lo largo de la cursada del seminario en Estudios Culturales, así como la elaboración del trabajo final. Este seminario fue dictado por la profesora Silvia Elizalde y cursado en 2013 (Doctorado en Comunicación - UNLP).
} 
"El campo de batalla de estas fuerzas políticas no es tanto los medios de producción como el código cultural de representación, no tanto el homo economicus como el homo significans (...) Puesto que el aparato productivo ha cambiado de un modo claro bajo el capitalismo multinacional, es posible que la intervención en el consumo de imágenes mediáticas pueda tener ahora un mayor valor crítico que la creación de otras nuevas." (Foster, 2001a: 99-100).

En este sentido, en la caracterización propuesta por Foster, se produce un pasaje de implicancias políticas y de posicionamiento: de la "trasgresión" de la vanguardia artística del siglo XX a la "resistencia" cultural del arte político actual.

Ya en los inicios del siglo XXI, diferentes autores han reflexionado sobre el lugar destacado de la cultura (y las artes) en las sociedades contemporáneas. En sus análisis consideran las modificaciones que la cultura realiza en la producción social y económica (Brea, 2004; Harvey, 2005; Yúdice, 2002, 2008; García Canclini, 2010; Benzecry, 2012). George Yúdice fue uno de los autores que conceptualizó ese proceso en el que el capitalismo contemporáneo incorpora a la cultura como fuerza constitutiva. Es decir, no sólo como una mercancía sino que es tomada desde varias dimensiones y usos en términos de rendimiento: las transformaciones operadas por la globalización han realzado el valor de la cultura como recurso (Yúdice, 2002). A su vez, entenderá que la relación entre globalización y cultura es de conveniencia porque la reproducción del sistema de relaciones capitalistas "se culturaliza" ${ }^{23}$. Plantea entonces que se está en presencia de una lógica cultural transterritorial que pone en cuestión a las soberanías nacionales. Con la idea de la "cultura como recurso" intenta dar cuenta del valor asignado a la cultura tanto por los agentes económicos, por el campo de la política (resolución de conflictos, desarrollo económico, procurar la justicia social, acciones que llevan al fortalecimiento de la sociedad civil), como así también por los movimientos sociales. Al entender que los proyectos políticos se juegan no solo en la producción de sentido sino en la circulación, el autor delinea un aporte interesante para

\footnotetext{
23 “Se invoca la cultura cada vez más no solo como un motor del desarrollo capitalista (...). Hay quienes aducen incluso que la cultura se ha transformado en la lógica misma del capitalismo contemporáneo (...).Esta culturalización de la economía no ocurrió naturalmente, por cierto, sino que fue cuidadosamente coordinada mediante acuerdos sobre el comercio y la propiedad intelectual, tales como el GATT y el OMC, y mediante leyes que controlan el movimiento del trabajo intelectual y manual (por ejemplo, las leyes de inmigración). En otras palabras, la nueva fase del crecimiento económico, la economía cultural, es también economía política." (Yúdice, 2002: 31)
} 
comprender la relación entre cultura y política ${ }^{24}$. A su vez, adopta una mirada prudente en relación a la "agencia cultural" de los movimientos sociales -y los cambios que esta puede generar-.

Asimismo es importante reconocer que este lugar destacado que ocupa la cultura en los procesos sociales, juega decididamente en la reconfiguración de las ciudades contemporáneas donde lo cultural adquiere un valor significativo Una "cualidad" con la que una ciudad se presenta. Se trata de una singularidad cultural que no es producida por el Estado sino por "el conjunto de las prácticas culturales que caracterizan la cotidianidad de la vida" de una ciudad (Mezzadra, 2008: 47) o lo que algunos estudios denominan como la "clase creativa" -productores, artistas, gestores, “emprendedores" ${ }^{25}$. El Estado será el encargado de "capturar" esas innovaciones, atraer inversiones de las "industrias creativas" y fomentar circuitos culturales y turísticos. Para Mezzadra, este tipo de política cultural debe ponerse en relación con los "nuevos circuitos de producción y circulación que definen realmente lo que es hoy el capitalismo" (Mezzadra: 2008: 47).

En esta situación contemporánea de redefiniciones las experiencias culturales adquieren, para algunos autores, un carácter reparador y renovador del tejido social -donde por ejemplo, ciertas prácticas artísticas ocuparían el lugar que tenían las utopías políticas y toman los espacios que "dejan" o desatienden las políticas neoliberales (Bourriaud, 2006, 2009a, 2009b; Ardenne, 2006; Laddaga, 2006)-. Para otros autores se trata de apuestas en tanto construcción "disensual” -en el discurso público y en la cultura mediática (MartínBarbero, 2001, 2009); en la estética y en la política y en el campo de lo que tienen en común y las emparenta (Rancière, 2005, 2011, 2014) ${ }^{26}$-, que introduce ruido, dislocaciones e

\footnotetext{
${ }^{24}$ Una mirada similar -pero particularmente para la esfera del arte contemporáneo- es la que propone N. García Canclini (2010) para analizar el lugar que ocupa la práctica artística y los proyectos artísticos, en su condición "postautónoma", como "alternativa" o respuesta, luego de la caída de diversas utopías y en momentos de globalización económica.

${ }^{25}$ En un volumen colectivo el proyecto transform (2008) repone, desde un sentido crítico, las actuales discusiones sobre las "industrias creativas", "nueva economía", culturalización de la economía, "clase creativa", productores culturales y prácticas instituyentes.

${ }^{26}$ Este autor emprende un intenso trabajo para establecer el debate y aclarar el sentido sobre lo que se designa por "estética". Para él, fue principalmente el pensamiento posmoderno (por ejemplo, en los textos de Lyotard) el que realizó una inversión de los principios kantianos de lo sublime al trasladar la estética al arte. Para Rancière, la palabra estética no designa "la teoría del arte en general o una teoría del arte que lo remitiría a sus efectos sobre la sensibilidad, sino un régimen específico de identificación y de pensamiento de las artes: un modo de articulación entre formas de hacer, formas de visibilidad de esas maneras de hacer y de los modos de pensar sus relaciones, implicando una cierta idea de la efectividad del pensamiento." (Rancière, 2014: 15) En la definición más repetida y reproducida del autor la estética "no es el pensamiento de la 'sensibilidad': es el pensamiento del sensorium paradójico que permite definir las cosas del arte" (Rancière, 2011: 21-22). Dicho de otro modo, es el "pensamiento del nuevo desorden" ya que actualmente no hay pruebas de "jerarquía alguna de la inteligencia activa por sobre la pasividad sensible", lo que abre un espacio para una "igualdad inédita" (por ejemplo, entre artistas y espectadores). Entiende así que la estética en tanto "régimen de identificación del arte, conlleva una
} 
irrupciones en los relatos hegemónicos, en las formas de visibilidad y en los modos de mirar. Además de una apuesta por el disenso en relación a los relatos y las visibilidades, otros autores entienden que las experiencias culturales colaboran en la indagación de los modos de transitar la ciudad y usar el espacio virtual, al buscar interrogar y movilizar la vida cotidiana y mostrar/hacer otras realidades (Sager y López, 2009; López, 2009, 2011, 2014; López, Badenes y Saurio, 2014; Pérez Balbi, 2012a y 2012b). Al considerar los aportes de Jacques Rancière (2006, 2007, 2014), que plantea que el "régimen policial" se diferencia de la política al modelar y organizar los repartos de tiempos, espacios y actividades -y voces-; se puede decir que en una sociedad que marca quién puede hablar/hacer y quién queda excluido del reparto de la palabra y los espacios, las experiencias culturales proponen trastocar y distorsionar ese orden de los repartos para producir otro ordenamiento. Ante la prédica de la política formal y estatal de construir consenso (y esperas), estas acciones parten del disenso (y la urgencia). ${ }^{27}$ Para otros, quizá más "prudentes", se corre el riesgo de creer que con el impulso de una expresión o de una identidad, el agenciamiento cultural conduciría a cambios (Yúdice, 2002), un cuestionamiento crítico principalmente hacia ciertos estudios culturales que se comparten en esta indagación. En próximos capítulos, se continúa con la reflexión sobre la importancia que juega la producción cultural en los procesos sociales contemporáneos.

En este sentido, aquí resulta interesante interrogarse sobre cuáles de estos puntos y dimensiones (la restitución de lazos sociales, la configuración de un disenso político, la profusión de esferas públicas, las limitaciones de las prácticas que activan desde lo cultural) operan en las experiencias "platenses" que son tomadas en la investigación. En todo caso, se puede responder -provisoriamente- que se trata de una pregunta permanente que abren las intervenciones culturales al reflexionar sobre las motivaciones que las ponen a andar y los resultados y cambios que pueden generar, es decir, en su intervención en "lo real". En tal sentido, siempre alguna de esas dimensiones prima en las propuestas previas y los balances posteriores de las intervenciones.

política", o sea, se vincula a la promesa de un arte "que sería más que un arte o que no sería más un arte", es decir, una práctica más allá del arte (2011:23-24-25). En el capítulo 8 se vuelva sobre estas discusiones.

${ }^{27}$ En sentido similar Jesús Martín-Barbero entiende que los discursos, prácticas y acontecimientos desatan "una multiplicidad de dinámicas sociales que [hacen] emerger el conflicto entre la política formal y la que tejen las demandas y los proyectos ciudadanos, la conquista de espacios de enunciación y configuración de grupalidades nuevas que sí aparecen como 'políticamente irrelevantes' constituyen sin embargo la red de socialidades que mantiene viva la sociedad" (Martín-Barbero en Reguillo, 2005: 13-14). 


\section{Constelaciones conceptuales}

La mirada desde la que aquí exploramos a las intervenciones culturales entiende a la comunicación imbricada con la cultura, las prácticas sociales y la producción de sentido. Esta perspectiva permite observar e interpretar procesos sociales y disputas por el sentido en múltiples escenarios y elementos. A continuación se presenta el comúnmente denominado marco teórico-conceptual de la tesis, a partir de tres constelaciones de objetos-materiales: cultura, ciudad y espacio público. Por su parte, las discusiones sobre la política, lo político y la politicidad de las prácticas, problemática candente en el debate contemporáneo, será abordado en una última constelación.

\section{IV.a. La cultura como configuradora de la sociedad}

Los Cultural Studies británicos aportaron una interesante perspectiva para comprender la cultura. Se desmarcaron tanto de los planteos idealistas que la definían como un conjunto de ideas como de la perspectiva tradicional que -al tomar de manera rígida la metáfora de la base/superestructura- entendía a lo cultural como un epifenómeno de las relaciones de producción económicas. Pero asimismo se distanciaron, en parte, de la postura asumida por la "Teoría crítica" que pensaba a los hechos culturales como subordinados a la "industria cultural" y devueltos a la sociedad en tanto mercancías culturales que se insertaban así en las formas de producción y reproducción capitalistas. De este modo, los Cultural Studies construyeron sus propuestas teóricas recuperando por un lado, elementos del marxismo heterodoxo -sobre todo en la relectura de la obra de Antonio Gramsci en relación a la hegemonía y a la cultura- y teniendo presente sus propias trayectorias (de clase, formativas y experienciales). Desde esta revisión entendieron a la cultura como "práctica social” y "formas de vida" ${ }^{28}$. Esta noción activa de la cultura implica comprender su carácter productor -y no sólo reproductor- de sociedad: "como un proceso constituyente de lo social, creador de diferentes y específicas "formas de vida"” (Williams, 2009: 29). Así, al interpretar el rol constitutivo de la cultura, comprendieron sus implicaciones en los procesos históricos, sus tensiones y sus cambios. De esta perspectiva también cobra importancia la dimensión de los usos y las reinterpretaciones que los sectores populares y subalternos pueden hacer de los discursos y las producciones culturales hegemónicas, masivas y mediáticas; por tanto, que pueden, en el marco de condiciones específicas e históricamente situadas, construir sus

\footnotetext{
${ }^{28}$ Stuart Hall (2010) sintetiza y analiza los posicionamientos de los Cultural studies sobre la cultura en un texto fundamental para indagar en esta cuestión "Estudios culturales: dos paradigmas", escrito original de 1980.
} 
propios agenciamientos y re-elaboraciones de sentido y no sólo ser portadores de reproducción social.

Desde esta perspectiva Raymond Williams (1994, 1997, 2000, 2009) contribuyó a una sociología de la cultura que pretende entender las "interrelaciones dinámicas" de los procesos culturales. En ese camino resalta la especificidad de tres aspectos -tradiciones, instituciones y formaciones-, que operan articuladamente con tres dimensiones claves de la dinámica cultural: lo dominante, lo residual y lo emergente. Elementos todos ellos que complejizan una analítica de los procesos culturales contemporáneos y sirven para pensar los procesos de incorporación, subordinación, resistencia y emergencia de significados y prácticas alternativas o de oposición a lo hegemónico. Para este trabajo sobre intervenciones culturales entonces es fundamental comprender el campo de acción productivo que abren los Cultural Studies, al plantearse cómo lo cultural "hace" sociedad, cómo las prácticas culturales además de ser productos sociales generan efectos sociales y cómo forman parte de los procesos de cambio social.

A su vez, dentro del campo latinoamericano de estudios culturales, se rescata que la dimensión simbólica tiene relevancia en la cotidianeidad, en los modos de grupalidad y en las luchas sociales y políticas (Martín-Barbero, 2003), perspectiva que reconoce el lugar que tienen los públicos, los usuarios y los sectores populares en la re-elaboración de sentidos, insertos de la trama hegemónica. Es decir, que los sujetos pueden configurar sus “agenciamientos" colectivos para librar las luchas del presente, en el que la comunicación y la cultura constituyen "un campo primordial de la batalla política: el estratégico escenario que le exige a la política recuperar su dimensión simbólica" (Martín-Barbero, 2003: XV).

En el sentido de lo expuesto hasta aquí es que se preferirá, antes que hablar desde un concepto genérico de cultura, tomar una noción más específica de "producción cultural" porque liga a un "hacer" e incorpora esa dimensión "productiva" y "práctica" que nos interesa especialmente destacar a la hora de indagar en las intervenciones culturales que se describen $\mathrm{y}$ analizan en la tesis.

\section{IV. b. La ciudad y lo urbano: entre la producción y la apropiación}

Como se mencionó anteriormente, uno de los aportes que interesan aquí para pensar a la ciudad es el de Michel De Certeau (2000), porque concibe al "espacio como un lugar practicado". Para este autor, existen: 
“algunas prácticas ajenas al espacio 'geométrico' o 'geográfico' de las construcciones visuales, panópticas o teóricas. Estas prácticas del espacio remiten a una forma específica de operaciones (de "maneras de hacer"), a "otra espacialidad"' (una experiencia "antropológica", poética y mítica del espacio), y a una esfera de influencia opaca y ciega de la ciudad habitada." (De Certeau, 2000: 105)

Podemos comprender así a la ciudad como un lugar "practicado" o, siguiendo a este autor, desplazar el concepto de ciudad para ir hacia las "prácticas de espacio" o "prácticas urbanas". Para De Certeau, a su vez, la ciudad es un espacio en conflicto, por lo que será el terreno de lo imprevisto en donde prácticas y acciones cotidianas de quienes la habitan, subvierten y alteran el poder en su narración y significado. En las artes de hacer -plantea el autor- "se crea un espacio de juego para maneras de utilizar el orden imperante en el lugar o respecto de la lengua (...) [que] instaura algo de la pluralidad y la creatividad. Gracias a un arte del intervalo, obtiene efectos imprevistos" (De Certeau, 2000: 36). Se abre entonces un posible espacio de resistencia y creación no subordinado al orden dominante desde prácticas astutas, testarudas y cotidianas que buscan insertar e introducir cuestionamientos a las divisiones de espacios y las gramáticas hegemónicas. Entonces, si bien la cuadrícula de vigilancia y control de ese orden dominante opera y tiene una fuerza que no hay que descartar, para De Certeau existen tácticas que no se reducen a esa cuadrícula, se le escapan y se diseminan por los intersticios de la sociedad capitalista ${ }^{29}$, así entre los "huecos" de la

\footnotetext{
${ }^{29}$ En este punto se vuelve a insistir sobre lo fundamental de pensar las coordenadas de la sociedad contemporánea marcada por las lógicas de producción / acumulación / circulación del "postfordismo" donde se hace imprescindible generar signos, bienes inmateriales y habilidades lingüísticas, discursivas y afectivas para habitar y producir la sociedad -por ende también el espacio y la ciudad-. El análisis de estas tendencias y lógicas "recombinantes" de la sociedad se encuentra en las estudios críticos de Negri (2002), Virno (2003), Lazzarato (2006), Berardi (2007) y Mezzadra (2005). A su vez, en el nivel de la producción de la ciudad, es importante destacar los estudios de los procesos de "urbanización", las lógicas de "exclusión/inclusión", la relación entre "nuevo urbanismo" y desigualdad social, así como las apuestas democráticas y participativas por el "derecho a la ciudad". Todas esas tendencias se aportaron desde finales de la década del 60' en Europa, con lo que se puede genéricamente, el "urbanismo crítico" (Castells, 1974; Lefebvre, 1970, 1974; Harvey, 1977, 2013) del cual se ha realizado una sintética descripción en el capítulo 1. Pero también se reconoce que esos análisis que fueron complejizados por los estudios urbanos contemporáneos sobre los debates y conflictos por el "acceso diferencial" a la ciudad y al espacio público (ver por ejemplo, para el caso de la ciudad de La Plata los trabajos de Ramiro Segura 2010, 2013, 2014, 2015); así como por los estudios de los procesos de "las metamorfosis de lo urbano" (o posciudad): las lógicas de la ciudad de las "tres velocidades", los procesos de "metropolización" y las tendencias a la "gentrificación" de ciertas zonas y espacios valorizados de las ciudades. Para un análisis de algunas de estas tendencias y procesos sobre la ciudad ver el estudio panorámico de O. Mongin, que parte de entender que "la ciudad ha cedido su lugar a una dinámica metropolitana y que la fragmentación de los territorios crea una jerarquía entre los espacios urbanos, lo cual no se condice con el espíritu igualitario de la ley republicana. Hemos entrado en el mundo de la 'posciudad', una etapa en la que entidades ayer circunscritas en lugares autónomos, ahora dependen de factores exógenos, principalmente los flujos tecnológicos, las telecomunicaciones y el transporte... El equilibrio ideal entre los lugares y los flujos se ha vuelto completamente ilusorio." (Mongin, 2006: 16)
} 
producción y el consumo habita un espacio de realización heterogéneo y conflictivo de modos de hacer que desvían y reconfiguran las propuestas y los discursos del orden hegemónico ${ }^{30}$.

Por su parte, siguiendo con la dimensión de "lo practicado", pero profundizando la distinción lefebvriana entre la ciudad y lo urbano, el antropólogo Manuel Delgado se pregunta si la antropología urbana es una antropología de o en la ciudad -en tanto realidad delimitable compuesta por estructuras e instituciones sociales, etc.- o si se debe establecer como una antropología de lo urbano -es decir de las sociedades urbanizadas o en los procesos de urbanización-. Sostiene que, lo que queda claro, es que "la ciudad no es lo mismo que lo urbano". "Si la ciudad es un gran asentamiento de construcciones estables, habitado por una población numerosa y densa, la urbanidad es un tipo de sociedad que puede darse en la ciudad... o no. Lo urbano tiene lugar en otros muchos contextos que trascienden los límites de la ciudad en tanto que territorio" (Delgado, 1999: 11). Y agregar:

\begin{abstract}
"La ciudad no es lo urbano. La ciudad es una composición espacial definida por la alta densidad poblacional y el asentamiento de un amplio conjunto de construcciones estables, una colonia humana densa y heterogénea conformada esencialmente por extraños entre sí. (...) Lo urbano consiste en una labor, un trabajo de lo social sobre sí: la sociedad «manos a la obra», produciéndose, haciéndose y luego deshaciéndose una y otra vez, empleando para ello materiales siempre perecederos. Lo urbano está constituido por todo lo que se opone a cualquier cristalización estructural, puesto que es fluctuante, aleatorio, fortuito..., es decir reuniendo lo que hace posible la vida social, pero antes de que haya cerrado del todo tal tarea, como si hubiéramos sorprendido a la materia prima societaria en estado ya no crudo, sino en un proceso de cocción que nunca nos será dado ver concluido.” (Delgado, 1999: 23 y 25).
\end{abstract}

De este modo, se puede observar que pensar "lo situado" en el espacio-tiempo de las prácticas sociales, abre en parte el camino para comprender la dimensión política de las intervenciones culturales. Pero su vez, plantear que el espacio de la ciudad -sus calles, paredes, plazas y veredas, pero fundamentalmente las relaciones y experiencias que allí se producen- es tomado, apropiado como un recurso para poner de manifiesto tensiones,

\footnotetext{
${ }^{30}$ Como ya se mencionó Martín-Barbero también plantea que la ciudad tiene que pensarse desde las formas del "habitar" y no desde la regularidad de los modelos urbanísticos, lo que conecta directamente con los planteos de De Certeau y Delgado. Pero Martín-Barbero, a diferencia de estos, atiende al lugar que ocupa la comunicación y los elementos contemporáneos del fragmento y la fluidez. De este modo, entiende que en el territorio de la ciudad (territorio-ciudad) "se configuran nuevos escenarios de comunicación de los que emerge un sensorium nuevo, cuyos dispositivos clave son la fragmentación -no sólo de los relatos sino de la experiencia, de la desagregación social- y el flujo ininterrumpido de las imágenes" (Martín-Barbero, 2004: 34).
} 
reclamos y discursos sobre diferentes acontecimientos sociales y políticos que atraviesan y construyen la realidad, lo que reconfigura parte de las narraciones de la trama urbana. Estas prácticas generan un desplazamiento de la ciudad concebida a la ciudad practicada (Delgado, 1999, 2007a). Es decir, de la ciudad pensada y construida como cuadrícula, como ámbito cerrado, se pasa a una ciudad vivida y ejercida desde las relaciones y apropiaciones -dispares, contradictorias, disruptivas, conflictivas-. Para esta conceptualización, la ciudad practicada, o lo urbano, por sus cualidades emergentes, no puede ser concebido como cosa u objeto cristalizado. Así es que, se debe entender que los habitantes de los espacios urbanos -estén estos inmóviles o se desplacen- y las intervenciones que allí acontecen -acciones que también producen ese espacio- "tienen constantemente en cuenta las condiciones ordinarias o excepcionales de esa superficie dispuesta para la acción que es la calle y lo hacen concibiéndola y practicándola como campo de visibilidad" (Delgado, 2007a: 132). En un sentido similar, Martín-Barbero entiende que "la figura de la ciudad tiene menos que ver con la alta regularidad de los modelos expertos de edificar que con el mosaico artesanal del habitar" (2004: 275). De ahí que reconoce la existencia de una "trama sociocultural heterogénea" de la ciudad latinoamericana.

\section{IV.c. El espacio público: desplazamientos de un concepto moderno}

De Hannah Arendt a Jürgen Habermas, de Carl Schmitt a Richard Sennett, de John B. Thompson a John Keane, de Clauss Offe a Paolo Virno o Manuel Delgado, el pensamiento social -fundamentalmente desde la filosofía, la teórica política, la historia y la sociología, pero también desde la antropología, los estudios culturales y de comunicación- ha formulado y repuesto los conceptos de "esfera pública", "espacio público", "vida pública” y "opinión pública", construyendo tanto miradas consensualistas como conflictuales sobre dichos conceptos.

Estas conceptualizaciones han posado sus definiciones en los vínculos y tensiones entre la vida pública y la vida doméstica (la polis y el oikos) en vías de concertarse con los demás "para actuar de común acuerdo" (Arendt, 2009)². En los "asuntos" del Estado moderno, en la autoridad y las formas del poder político -para su legitimación y ejercicio(Schmitt, 2006). En la búsqueda de "consenso" que unifique y trascienda a las particularidades para construir una "vida social pública" que ha caído en decadencia por la

\footnotetext{
${ }^{31}$ Para esta autora, a partir de criticar la distinción entre lo social y lo político, la esfera pública es "lo común entre" sujetos: el escenario para la "libertad" y el ámbito de la "acción". Es precisamente en la esfera pública donde se sitúa la política, su alcance no se extiende más allá de esta esfera. Para Arendt la naturaleza autocreadora de la experiencia política se realiza en el ámbito público (Arendt, 2009).
} 
"re-feudalización" provocada por los medios de comunicación y sus técnicas de manipulación (Habermas, 1981) ${ }^{32}$. En la esfera de la comunidad y la vida pública considerando a las "voces excluidas" o los movimientos de oposición (Thompson, 1996; Keane, 1992) En la comprensión de que lo público y lo privado se asimilan dentro del capitalismo global, configurando tanto una "esfera pública global” como “microesferas públicas” (Keane, 1997). En el "deterioro" de esta vida pública (que se convierte en una "cuestión de obligación formal" que pierde su fuerza vinculante) por la primacía de lo personal e íntimo -la "vida privada"- (Sennett, 2011). En la "politización" de la esfera pública -la sociedad civil y sus instituciones- por medio de la emergencia de nuevos movimientos sociales como manera de emanciparse ante la crisis de gobernabilidad del Estado de Bienestar y el cuestionar su monopolio político (Offe, 1988). En el reconocimiento de las mutaciones que genera el capitalismo contemporáneo -en su fase postfordista- y la posibilidad para constituir una "esfera pública no estatal" que se aleje de las formas tradicionales de la soberanía y opere hacia una "defección" de la lógica del capital (Virno, 2003). En la comprensión de las retóricas y los usos contemporáneos (políticos-institucionales y urbanísticos) que convierten al espacio público en una "representación ideológica" para la "reapropiación capitalista de la ciudad" y el "disciplinamiento moral de los habitantes" (Delgado, 2011). Con todo lo planteado hasta aquí, se puede dar cuenta que tanto visiones normativas, históricas, revisionistas como críticas marcan la densidad y espesor de lo que se entiende y define por $l o$ público.

Anteriormente se delinearon algunas diferencias entre la ciudad y el espacio urbano. La primera, una noción cercana a una dimensión de lo concebido, la segunda ligada a una visión de lo practicado, a las "formas o modos de hacer" que escapan de la planificación urbanística y las políticas urbanas: una ciudad practicada. Ambas categorías se han puesto constantemente en juego para pensar el espacio de "lo público". Sin embargo, también se sostiene aquí que no deben ser nociones que a priori "tengan" que pensarse como sinónimos de "espacio público", ni como palabras intercambiables. Vayamos entonces ahora a profundizar la reflexión sobre eso que se llama espacio público. Según Nora Rabotnikof

\footnotetext{
${ }^{32}$ Para este autor alemán, la "esfera pública burguesa" consiguió, al menos por un tiempo, desarrollar esta idea de construir un espacio de debate racional, una "esfera de "lo público" que se ubicó entre el dominio estatal (autoridad pública) y el dominio privado (la familia, la sociedad civil económica). Luego devino su "declive" -a grosso modo- por el problema de la "refeudalización" de la esfera pública debido a la acción de los medios de comunicación y la introducción de las masas en la política (Habermas, 1981). Algunas revisiones críticas de esta teorización se encuentra en John B. Thompson (1996) y John Keane (1992). Una de las críticas más importantes a la teoría habermasiana de la "esfera pública" apunta al carácter "consensualista" y racionalista de la acción y la comunicación -concebidas de manera abstracta-, cuestión que no resultaría adecuada para describir a una sociedad altamente conflictiva como las capitalistas.
} 
(1997, 2005) las tres propiedades que constituyen la semántica de lo público son lo visible, lo abierto y lo común. Esas propiedades originarias o tradicionales, si bien parten de asociar a lo público a un "interés colectivo", pueden de algún modo ser válidas también para analizar las configuraciones de las experiencias de intervención cultural. Esto es así desde el momento en que entendemos que el espacio de lo público se encuentra siempre en tensión y disputa; de este modo “es en la propia práctica del espacio donde se definen los límites de 'lo público' (lo colectivo, lo visible, lo accesible), definición cambiante y conflictiva, no exenta de exclusiones" (Segura, 2013: 19). Parecería que en nuestras sociedades contemporáneas siempre hay que constituir o reponerlo y para ese propósito resultan relevantes las acciones de movimientos y colectivos sociales que interrogan lo público, actúan en público y construyen esfera pública.

Ampliando la caracterización de las intervenciones simbólicas y su articulación con el espacio público, se puede comprender que accionan en "lo público", ya que se plantean en temáticas y espacios que involucran deseos, malestares, sentires, imaginarios e intereses, sobre todo, sociales y colectivos. De este modo, no se trata sólo de "estar" en el espacio público urbano por parte de estas acciones sino de producirlo y "usarlo" de modo colectivo y creativo. Así "actuar en público" y "activar o practicar lo público" se vuelven parte fundamental de estas prácticas y acciones, buscando construir un "lugar común" y donde lo público sería el espacio de "lo visible o manifiesto" frente a lo oscuro o secreto, en los términos propuestos por Rabotnikof (2005). A su vez, para esta autora, en las configuraciones contemporáneas el espacio público ya no es el lugar de un sujeto soberano constituido, sino el escenario de una "pluralidad de voces" que, de manera reconocidamente desigual, pugnan por aparecer y ser reconocidas. En este sentido, las nuevas formas tecno-comunicativas y la aceleración temporal desafían a la "esfera pública moderna" como visión normativa que organizaba la temporalidad y las experiencias colectivas (Rabotnikof, 2013). Podemos resumir que el espacio público es un ámbito dinámico en permanente construcción, (ligado a idearios republicanos y democráticos) y a su vez, es parte de procesos de apropiación como objeto-espacio-territorio (donde podemos introducir allí a la noción de "ciudad practicada") de disputas materiales y simbólicas, protagonizadas por actores sociales diversos/desiguales: clases, fracciones o grupos de interés, etnias, comunidades.

Como ya se mencionó, Jacques Rancière $(2006,2007,2014)$ diferencia entre la política y el "régimen policial". Este último es el que organiza los repartos de lo sensible (tiempos, actividades, espacios, etc.), mientras que la política buscar ir más allá de los límites formales 
de "la policía" (entendida como gestión de lo social) a partir de la apertura de un "desacuerdo",33.

En tanto, el análisis de Richard Sennett sobre el "declive del hombre público" anuncia un repliegue hacia lo privado: "actualmente la vida pública se ha transformado en una cuestión de obligación formal” (Sennett, 2011: 15). Esta descripción crítica puede ser productiva para analizar los espacios que fue ganando lo privado en lo público -pensemos en los espacios públicos de "uso privado" como ocurre en la ciudad con los museos o espacios culturales estatales o en los procesos de gentrificación de las ciudades que producen transformaciones urbanas en donde sectores de mayores recursos desplazan a otros por medio de la valorización inmobiliaria y del consumo de bienes materiales y simbólicos que pasan a ser el principio de ordenamiento, apropiación y justificación para estar en determinados lugares $-{ }^{34}$. De hecho, en esta investigación sobre intervenciones culturales resulta clave reparar en estos procesos de retraimiento de lo público, ante los cuales diversas acciones colectivas buscaron desnaturalizar, cuestionar y confrontar.

Por su parte, respecto de los vínculos y tensiones entre el espacio público, la comunicación e internet y redes virtuales aquí sostenemos que el "espacio virtual" es constitutivo del espacio público contemporáneo, ya no sólo "ampliándolo" de lo urbano sino dándole una nueva configuración, plagada de usos, apropiaciones y convites entre la trama urbana, las tecnologías virtuales y las narraciones y subjetividades colectivas. Se pone el foco en estas prácticas: intervenciones de resistencia, disidencia, crítica y creación que configuran una politicidad emergente. En este sentido, resulta valioso otro de los aportes de Jesús Martín-Barbero al plantear que

\begin{abstract}
"los medios y las redes electrónicas se están constituyendo en mediadores de la trama de imaginarios que configura la identidad de las ciudades y las regiones, del espacio local y barrial (...) Ahí están los usos que de las redes hacen muchas minorías y comunidades marginadas introduciendo ruido en las redes, distorsiones en el discurso de lo global, a
\end{abstract}

\footnotetext{
${ }^{33}$ Aunque en este punto es conveniente aquí aclarar que para este autor se producen muy pocos momentos de apertura de "desacuerdos". Más adelante volveremos sobre esta conceptualización de la política.

${ }^{34}$ Como se profundizará en los capítulos 3, 5 y 6 el barrio Meridiano $\mathrm{V}^{\mathrm{o}}$ puede ser estudiado desde algunas de estas coordenadas: ha tenido importantes transformaciones en los últimos diez años de la mano de la consolidación de actividades culturales y artísticas, el desarrollo de un "circuito cultural" -con el apoyo municipal y de emprendimientos privados- integrado por bares, restaurantes, centros culturales y "actividades de agenda cultural" todos los fines de semana, y la valorización que tuvieron las propiedades inmuebles de esa zona de la ciudad. Link del circuito: http://www.meridianocultural.com.ar. El barrio Hipódromo también se puede sumar a esta tendencia, aunque en una escala más pequeña: desde finales del 2014 varios espacios culturales, bares y restaurantes han impulsado junto con el Municipio el "circuito cultura Hipódromo". En el capítulo 6 además se indaga sobre lo que ocurre en otras zonas de la ciudad.
} 
través de las cuales emerge la palabra de los otros, de muchos otros" (Martín-Barbero, 2001: 86-87).

El autor pone de relieve que la construcción de sociabilidad en las redes no es meramente virtual, sino que en ellas se generan grupos que, en muchos casos, "acaban reterritorializándose, pasando de la conexión al encuentro, y del encuentro a la acción”. Para Martín-Barbero la "reconstrucción" de la esfera pública se vincula al uso alternativo de las tecnologías informáticas e implica "profundos cambios en los mapas mentales, en los lenguajes y los diseños de políticas” (2001: 87). Por su parte, Paolo Virno (1993, 2003) plantea que en las crisis actuales y en los procesos desatados por el postfordismo (valoración de las características afectivas y lingüísticas, polivalencia de actividades) se presenta la posibilidad de constituir una esfera pública de nuevo tipo, ya no marcada por los tiempos y lógicas estatales y las demandas del capital. Para esto cobra centralidad el hacer político la "multitud" y la defección o el éxodo que puede producir. Estas discusiones y concepciones sobre lo público dan pie a la siguiente constelación conceptual.

\section{IV.d. La política, lo político y lo social: una constelación tensa ${ }^{35}$}

La distinción entre lo político, la política y lo social es una de las cuestiones que más se han abordado en la teoría social contemporánea. Desde los iniciales y decisivos aportes de Louis Althusser a los trabajos de Ernesto Laclau y Chantal Mouffe, los debates, derivas y desplazamientos entre el pensamiento estructuralista y post-estructuralista (y en estos autores específicamente entre marxismo y post-marxismo desde fines de los años 70' a la actualidad) han guiado la discusión, el desarrollo conceptual y su intervención en los procesos sociales recientes.

Laclau (1990) no distingue entre la política y lo político, sino entre lo social y lo político. En su pensamiento todo orden social es indefectiblemente precario, momentáneo, provisional y abierto. Allí lo político y lo social se conectan por un nexo paradojal: se excluyen y requieren para que exista una configuración política. En ésta lo político es la “instancia conflictiva articulatoria de lo social”, definición en la que entra en juego el antagonismo, la lucha y el poder. Cualquier intervención política efectiva tiene que tener, desde esta perspectiva, una combinación de dos lógicas contradictorias, un momento negativo: "suspensión" y uno positivo: "hegemonización”. El autor establece una nítida

\footnotetext{
${ }^{35}$ Una profundización de esta constelación conceptual, a partir de los aportes de Laclau, Mouffe y Rancière, se encuentra en el trabajo final que realicé para el seminario de doctorado "Análisis de la Política Contemporánea" dictado por el Dr. Martín Retamozo en el Doctorado en Ciencias Sociales de la FaHCE (UNLP): López, 2016b.
} 
frontera analítica entre "lo social", entendido como espacio de prácticas rutinarias recurrentes, necesarias y naturalizadas- y "lo político", definido como instancia de descubrimiento de la contingencia originaria de lo social y de institución de nuevas relaciones sociales (Laclau, 2011). La política entonces partirá -en la argumentación de Laclau- de esa escisión fundamental entre lo político como instancia conflictiva y lo social como las prácticas sedimentadas.

\footnotetext{
"Las formas sedimentadas de la 'objetividad' constituyen el campo de lo que denominaremos 'lo social'. El momento del antagonismo, en el que se hace plenamente visible el carácter indecidible de las alternativas y su resolución a través de relaciones de poder es lo que constituye el campo de 'lo político'. (...) La distinción entre lo social y lo político es pues ontológicamente constitutiva de las relaciones sociales (...). Pero la frontera entre lo que en una sociedad es social y lo que es político se desplaza constantemente." (Laclau, 2011: 51-52)
}

El pensamiento de Mouffe diferenciará "la política" y "lo político": la primera noción designa el conjunto de prácticas correspondientes a la actividad política tradicional (lo "óntico"), mientras que la segunda refiere al modo en que se instituye la sociedad (lo “ontológico”). Lo político es asumido -al igual que en Laclau- desde un carácter conflictual propio de toda sociedad:

\footnotetext{
“Concibo 'lo político' como la dimensión de antagonismo que considero constitutiva de las sociedades humanas, mientras que entiendo a 'la política' como el conjunto de prácticas e instituciones a través de las cuales se crea un determinado orden, organizando la coexistencia humana en el contexto de la conflictividad derivada de lo político.” (Mouffe, 2009: 16).
}

Si bien se pueden realizar varias observaciones críticas a las propuestas teóricas de Laclau y Mouffe y sus implicancias en el debate y la política actual, al plantear aquí solamente las distinciones sobre lo político, consideramos que estos aportes no desarrollan la potencia de la politicidad de las prácticas cotidianas, quedando éstas como un fenómeno de lo político, que sería lo único instituyente de las nuevas relaciones, luego del momento antagonista. En este sentido, en el cuadro propuesto por estos autores, muchas prácticas sociales quedarían relegadas de lo político si no consiguen ser parte de una articulación o formación hegemónica (el conjunto articulado de las diferencias). 
Por su parte, la política remitirá en Rancière a la aparición en escena de aquellos que "no tienen parte" reclamando "formar parte" del "reparto de lo sensible": "la política existe cuando el orden natural de la dominación es interrumpido por la institución de la parte de los que no tienen parte" (Rancière, 2007: 25). Sin embargo, reconocer esto no implica -en los parámetros de Rancière- asumir que siempre hay política. Por el contrario, para este autor "hay política cuando la lógica supuestamente natural de la dominación es atravesada por el efecto de esa igualdad" (2007: 31). De este modo, podemos inferir que para este autor en muy pocos momentos "hay política", lo que no implica pensar que ésta sólo se hace presente en un momento de insurrección o en acontecimientos excepcionales ${ }^{36}$. En tal sentido, la noción de política será definida como la actividad que:

"desplaza un cuerpo del lugar que le estaba asignado o cambia el destino de un lugar; hace ver lo que no tenía razón para ser visto, hace escuchar un discurso allí donde sólo el ruido tenía lugar, hace escuchar como discurso lo que no era escuchado más que como ruido. [Así] la actividad política es siempre un modo de manifestación que deshace las divisiones sensibles del orden policial mediante la puesta en acto de un supuesto que por principio le es heterogéneo, el de una parte de los que no tienen parte, la que, en última instancia manifiesta en sí misma la pura contingencia del orden, la igualdad de cualquier ser parlante con cualquier otro ser parlante" (Rancière, 2007: 45-46).

La política es lo inexacto, lo no correspondido -lo que no se reduce a las instituciones políticas, ni a las formas institucionalizadas del conflicto y sus formas de resolverlo-, acción “incorrecta" producida por los que no están "autorizados" para hablar. Para Rancière, esta noción de política habrá que diferenciarla del concepto de "policía". En otro escrito este autor articula más acabadamente la diferencia entre ambos conceptos. Así plantea que el "régimen policial" es el que organiza los repartos de lo sensible (tiempos, actividades, espacios, etc.). La "policía" impone límites, es la gestión de lo social. Pero el orden policial no se limita al aparato de Estado, sino que está pensando en la figura del "poder ejercido por hombres sobre otros hombres en nombre de una capacidad específica". Así en la empresa, la escuela o la

\footnotetext{
${ }^{36}$ En el Prólogo de Momentos políticos, Rancière realiza algunos comentarios que pueden ser aclaratorios de esta cuestión y a su vez, responde a las críticas que se le realizaron: "hablar de momentos políticos es ante todo decir que la política no se identifica con el curso ininterrumpido de los actos de los gobiernos y de las luchas por el poder (...). Un momento político ocurre cuando la temporalidad del consenso es interrumpida, cuando una fuerza es capaz de actualizar la imaginación de la comunidad que está comprometida allí y de oponerle otra configuración de la relación de cada uno con todos. La política no necesita barricadas para existir. Pero sí necesita que una manera de describir la situación común y de contar a sus participantes se oponga a otra y que se oponga significativamente. También es por ello que sólo existe en determinados momentos: esto no quiere decir que se dé mediante destellos fugitivos sino mediante la construcción de escenas de dissensus." (2010b: 10-11).
} 
iglesia "están gobernadas por aquellos a quienes la riqueza, el saber, la elección divina, les dan el título para ejercer ese gobierno". Así las sociedades serían empujadas a ser gobernadas según "esta regla de la superioridad sobre la inferioridad". El orden policial entonces se funda en una lógica de adaptación, y es -según el autor- la que tiende hoy a repartirse el mundo. Lo político es el encuentro, problemático, entre dos procesos heterogéneos: la policía (el gobierno, la distribución jerárquica de los lugares y las funciones, la gestión) y la política (la emancipación guiada por la presuposición de la igualdad). La policía daña la igualdad, la política daña el orden jerárquico de los repartos. "Lo político será el terreno del encuentro entre la política y la policía en el tratamiento de un daño.” (Rancière, 2006: 11, 17 y 18)

Entonces, lo político se puede entender como los conflictos -o microconflictos- entre la lógica del reparto y las demandas de igualdad (contingentes, "impropias"), es un más allá de los límites formales de "la policía". Se abre entonces la posibilidad de un hacer político una acción política- desde el desacuerdo, donde "los sin parte" reclaman por su lugar y un nuevo reparto de lo sensible: de este modo la política tiene como elementos fundantes la igualdad y la contingencia.

Al tener presente estas características en la investigación se indaga cómo las intervenciones que se desarrollaron y se desarrollan en la ciudad de La Plata -en los casos tomados: intervenciones colectivas, públicas y culturales- se producen en la dimensión política en dos niveles: ya que jugarían en el territorio de la politicidad de las prácticas sociales y en el espacio de lo político. Es decir, en el primer sentido, porque operan en lo cotidiano, en el orden de lo que se puede llamar micro-social y micro-político. En el segundo, por tratarse de prácticas que implican grados de organización complejos, posicionamientos y enunciados ético-políticos y, muchas veces, acciones de disputa y de conflictividad directa, por lo que se las puede entender como acción política que participa de escenarios de conflicto social. En este último sentido -y siguiendo los estudios críticos latinoamericanos en la perspectiva de comunicación/cultura-, podemos pensar que en las intervenciones culturales aquí estudiadas se gestan producciones y estrategias de transformación y de nueva configuración social, que actúan entonces en el campo de lo político. Es decir, que proponen activar en el campo de la producción de sentido, -significaciones críticas sobre diferentes situaciones y escenarios de injusticia, desigualdad, exclusiones y disputas-, "tomando" a la cultura y a la producción cultural como constitutivas de lo social y articulando sus prácticas en muchos casos- con "luchas sociales y populares" específicas. Ahí es donde la articulación política con colectivos y organizaciones sociales y políticas, de derechos humanos, de género, gremiales y de trabajadores puede dar lugar a entenderlos en el pasaje de un "movimiento 
alternativo" a un "movimiento oposicional". El análisis sobre las prácticas culturales puede ser un espacio de interés para comprender las formas de organización y participación colectiva contemporánea, los usos y apropiaciones de la ciudad, la cultura urbana y de la web como "territorios" o espacios imbricados de intervención cultural.

\section{Las preguntas y propuestas}

En continuidad con lo expuesto hasta aquí, una de las preguntas centrales de la investigación se vincula con la postulación, por parte de los colectivos y productores etnografiados en esta tesis, de la posible emergencia de un nuevo tipo de esfera pública en la que convergen cultura, comunicación y política -o mejor, producciones culturales, acciones comunicativas y acciones políticas- que configuran un nuevo tipo de práctica socio-cultural. En tal sentido, dicha esfera pública ¿se tensiona con la esfera pública tradicional? ¿Cómo disputan las narraciones y sentidos construidos sobre la ciudad y la política?

A su vez, en relación a la configuración de las prácticas y sus modalidades de acción: moviliza la sospecha de que lo colectivo y lo afectivo son elementos constitutivos de las prácticas investigadas, constituyendo sentidos de experiencia; así las preguntas que surgen son ¿cómo se constituyen dichas prácticas y cuáles son sus características? ¿Cuáles son sus modos de hacer? ¿Cómo interpretan los protagonistas a sus acciones y desde dónde las piensan?

Por último, sobre la dimensión urbana, lo cultural y lo político surgen otros interrogantes: las intervenciones en la ciudad ¿están planteando una nueva "experiencia urbana"? Estas prácticas culturales, que implican la apropiación del espacio urbano y de los recursos de la producción cultural ¿constituyen tácticas de acción o forman también parte de estrategias y posicionamientos respecto de lo social, lo político y la política? ¿Qué tipo de vinculación tienen con lo institucional y las políticas urbanas y culturales? ¿Se inscriben en tácticas cotidianas y desarticuladas o buscan también producir una política acontecicional, una acción política desde la producción de un desacuerdo $?^{37}$

Se sostiene, como propuesta interpretativa, que es constitutivo de estas prácticas culturales y artísticas locales el encuentro y cruces de aquellos tres modos de hacer

\footnotetext{
${ }^{37}$ Como ya se enunció en la tesis la idea de "acontecimiento" es trabajada desde los aportes de Lazzarato (2006) y es entendida como una mutación de la subjetividad; mientras que el "hacer político" o la acción política entendida como "desacuerdo" es planteada por Rancière (2007), como aquel que intenta trastocar el "orden de los repartos" de los lugares, espacios y actividades.
} 
entendidos de manera inseparablemente y superpuesta. De este modo se entenderá a la política, la cultura y la comunicación como divisiones de lo sensible (Rancière, 2010, 2014), por lo cual las prácticas culturales refuerzan un orden o lo impugnan ${ }^{38}$. Entendemos que las intervenciones culturales indagadas intentan "practicar la ciudad" desde producir cultura, construir discursos-enunciados públicos y disputar las narraciones y sentidos sobre cuestiones sensibles de lo real (demandas y conflictos sociales urgentes, cuestionamientos y visibilidades astutas sobre la ciudad o sobre situaciones que en ella suceden). Pero también -en algunos casos- plantean insertarse en ese otro territorio de la web y las redes virtuales, que no sólo han "ampliado" el espacio público, sino que lo reconfiguran en la situación contemporánea (López, 2014, 2016a) ${ }^{39}$.

Las experiencias de intervención cultural tomadas para indagar en estos problemas sobre lo público, la ciudad y las potencialidades de la producción cultural-comunicacional (en la construcción y disputa de sentidos, en la articulación de acciones colectivas, en la prefiguración y gestación de cambios sociales), generalmente se comprenden en la investigación social como "elementos discretos", y se sitúan en una zona "menor" de las prácticas sociales: locales, cotidianas, microsociales -y muchas veces discontinuas, "efímeras", precarias e invisibilizadas-. Sin embargo, en este trabajo consideramos que ellas tejen una red viva de socialidades y grupalidades que buscan movilizar unos otros "modos de hacer" de/desde la cultura y en muchos casos, discutir, tensionar y hacer vibrar las prácticas, los sentidos y los discursos instituidos, normativos y reglados del mundo de la vida. Forman parte así de la "vitalidad micropolítica", de las "fuerzas de resistencia y de creación" que “agitan" y movilizan políticas del deseo, subjetividades y nuevas relaciones entre los sujetos (Guattari y Rolnik, 2013).

Esta tesis pretende ser un elemento que participa de un esfuerzo colectivo llevado adelante por muchos y muchas. Se trata de búsquedas, preguntas y apuestas colectivas en las

\footnotetext{
${ }^{38}$ Preferimos pensar al arte, la estética, la política, la cultura y la comunicación en términos de "división de lo sensible" y no así en términos de "esferas" o "campos autónomos", propios de algunas tradiciones sociológicas. Esta propuesta de Rancière parte de entender que no son realidades separadas, sino que se encuentran en relación. Lo sensible constituye un espacio común que, sin embargo, se encuentra delimitado por determinadas distribuciones y particiones ("partage") de espacios, tiempos y actividades. La política, la cultura y la comunicación (los tres términos que aquí preferimos privilegiar frente a los de "estética" y "política" que pondera dicho autor francés) intervienen en la división de ese espacio común.

39 En esta nueva situación contemporánea en donde las redes digitales y virtuales promueven otras formas de producción y usos de la comunicación, podemos reconocer que en algunas acciones de estos colectivos -en Sienvolando y principalmente en Luli- se proponen cruzar tanto el espacio urbano como el espacio virtual con la intención de comprender y utilizar sus lógicas, códigos y lenguajes. Se los entiende así como dos "territorios" y superficies de y para la intervención que forman parte de la esfera pública.
} 
que -en varios casos- el autor ha sido parte ${ }^{40}$. De este modo, la investigación es el intento de reflexión sobre la práctica y de movilización de la reflexión analítica. Una tarea teóricopráctica de sistematización, análisis y reflexión crítica, que si bien tiene un objetivo de interlocución principal en el espacio académico, intenta asimismo interpelar a otros espacios, actores y prácticas sociales. En simultáneo, nos interesa remarcar que ese involucramiento con el "objeto de estudio" -incluso anterior a la idea de hacer una investigación doctoral- no habilita a dejar de lado los planteos epistemológicos de las ciencias sociales en cuanto a la construcción del objeto, las preguntas de investigación y la interrogación por la posición del propio investigador, sino que -por el contrario- representa una valiosa oportunidad para complejizar y radicalizar la propia reflexividad sobre las múltiples dimensiones movilizadas en la experiencia investigativa ${ }^{41}$.

En este sentido, este involucramiento con algunas de las prácticas culturales que aquí se indagan es una posibilidad y una tensión. En el primer término, porque permitió -en la mayoría de los casos- el "acceso al campo" y a las "fuentes de información" de un modo directo (se pudo obtener "informantes clave", entrevistados, registros y documentación de primera mano $)^{42}$. En segundo término, porque tensó las propias prenociones y las formas de mirar, lo que obligó a construir necesariamente una interpretación plural, que no se limitara a

\footnotetext{
${ }^{40}$ No es la intención aquí dar cuenta de los grados de participación, simpatía e involucramiento con algunas de las prácticas culturales que en la tesis se indagan. Por un lado, porque contrastaría con los intentos de que muchas de las acciones sean colectivas y sin figuración personal. Por otro, porque no aportaría a las coordenadas de reflexión propuestas el listar las prácticas en las que se ha participado.

${ }^{41}$ Antes de definir a la propia tarea de investigador y la perspectiva de la presente tesis como "investigación militante" o "investigación-acción participativa", preferimos sostener la tensión -no sin ambivalencia- de un sujeto que habita y participa de ambas instancias, que entra y sale de las dos redes de prácticas y saberes de la academia y de las experiencias culturales. A su vez, tomar dichas perspectivas mencionadas hubiese correspondido llevar adelante un trabajo investigativo y analítico de coproducción explícito con los actores involucrados, que ponga en discusión objetivos, categorías analíticas puestas en juego y herramientas metodológicas. Lo que sí se realizó, como parte de ese "entrar y salir de la red", fue compartir varios avances de la investigación con algunos actores integrantes de esas prácticas, así como participar -a veces como invitado, otras como organizador- en los procesos de reflexión (algunas veces textualizada) y de producción comunicacional en varias acciones que se llevaron adelante en los últimos cinco años (por ejemplo, encuentro ZigZag, Volver a habitar, Síntoma curadores, muestra Inundación y Después, Desbordes, Concreto, revista boba, entre otros), período que comprende el trabajo de campo de la tesis.

${ }^{42}$ En este punto, participar de la red de las experiencias culturales indagadas colabora para cuestionar el aspecto fuertemente positivista de la investigación social al momento de construir el objeto, ya que se utiliza a los sujetos involucrados -y sus prácticas y discursos- como "fuentes de información" -orales o documentales-, "informantes", "datos", "referente empírico". Esta formulación, aceptada corrientemente en la investigación, colabora con un modo "extractivo" hacia las prácticas indagadas, y se desentiende de la propia construcción de conocimientos que realizan. En este punto, si bien no han sido parte de las principales lecturas del proceso de tesis, se puede reconocer una convergencia con la perspectiva decolonial. En todo caso, se trata de un decolonialismo epistemológico ad hoc y propio del quehacer de esta investigación. Sobre esta cuestión del doble posicionamiento como sujeto/objeto de conocimiento se volverá en el capítulo 2.
} 
lo que "ya se conocía" y a lo "ya se tenía definido" de antemano, sino que lo desnaturalizara y pusiera en cuestión ${ }^{43}$.

\section{Los capítulos}

El primer capítulo sirve como un aporte de elementos para el despliegue de una analítica cultural en relación a las "intervenciones culturales" en particular, y a la "cultura" y a la "producción cultural" como constitutivas de la sociedad y sus cambios, en general. En este capítulo se desarrolla un detallado estado de la cuestión que se entiende como un cruce de áreas de investigación, disciplinas sociales y campos de saber. Tres son las entradas para ordenar las tramas de saberes y debates que conforman los antecedentes de investigación: la producción cultural y artística; la ciudad y lo urbano; y la acción colectiva y la política. Además, en una de esas tramas se realiza una pregunta por los conceptos en uso: ¿qué términos y nociones son adecuados para pensar las prácticas y experiencias indagadas? A partir de ahí se presentan algunas tensiones y discusiones con las nociones que han guiado y renovado los análisis del par "arte/política". Sobre el final del capítulo se bosquejan algunas coordenadas para una definición de las intervenciones culturales, como un repertorio diverso de nociones, prácticas, saberes y estrategias de enunciación.

En el segundo capítulo se desarrolla una serie de reflexiones teórico-metodológicas sobre la perspectiva cualitativa adoptada desde el análisis cultural para indagar las prácticas culturales y los procesos sociales. Se amplían y profundizan así los comentarios que se realizaron en los capítulos previos. Por un lado, sobre el cartografiado como una forma de indagación para la investigación social. También sobre el recurso del mapa, sus usos, alcances y problemáticas, así como las tensiones entre el mapa, el territorio y las prácticas culturales. Por otro lado, se trabaja sobre la entrevista en profundidad y la observación de prácticas culturales como herramientas de recolección de datos, pero también como herramientas analíticas y conceptuales (la recuperación de la palabra como posicionamiento vivo del sujeto, la conformación de una red de sentidos colectivos sobre las prácticas). Este capítulo se cierra

\footnotetext{
${ }^{43}$ Esa interpretación plural lleva también a discutir con las formas canonizadas del trabajo científico que reconoce principalmente su valor en la elaboración racional de conocimiento, y omite que las prácticas indagadas también participan en dicha producción de conocimientos. Pero, a su vez, las prácticas culturales como las que aquí se exploran- suelen no escindir entendimiento racional de sensibilidad, concepto de mito. Es decir, no separan -como suele hacer el campo científico "tradicional"- el mundo racional del mundo sensible. De ahí nuestra intencionalidad de relevar y resaltar simultáneamente en la tesis las formas racionalizadas y sensibles: los "modos de hacer" con las "sensibilidades" y "visibilidades"; las definiciones con las "formas de mirar".
} 
con algunos comentarios sobre las decisiones metodológicas, el posicionamiento del investigador y los vaivenes entre salir y entrar de la trama de prácticas colectivas, saberes y sentidos compartidos.

En el tercer y el cuarto capítulo se despliega un completo cartografiado cultural de las intervenciones culturales en La Plata, entendido como herramienta metodológica para indagar en la materialidad de la cultura y que es parte sustancial del desarrollo de la investigación. La cartografía está integrada por una presentación descriptiva de los colectivos e interventores seleccionados, un mapeo de localización de las acciones en la cuadrícula urbana (a escala ciudad) y un detallado acercamiento a cada acción a través de un cuadro descriptivocomparativo. En los últimos apartados del capítulo 4 se puntualiza el análisis sobre algunas intervenciones y se abre una reflexión sobre las experiencias. Asimismo, integra la cartografía una web propia de la tesis que funciona como síntesis de lo trabajado en este capítulo (http://cambiodepiel.com.ar). Pero también se la propone como cruce entre el documento escrito y una producción comunicacional. Allí se encuentra el mapeo de acciones en la cuadrícula urbana, las descripciones de las acciones y de los colectivos e interventores.

En el quinto capítulo se trabaja sobre las entrevistas en profundidad realizadas en la investigación. Los ejes que motorizan el análisis son los siguientes: la constitución de las prácticas y las formas de nominación de su hacer por parte de los colectivos explorados; los modos de apropiación del espacio público contemporáneo y los sentidos sobre la ciudad y lo público; las formas de organización colectiva $\mathrm{y}$ las articulaciones con grupos $\mathrm{y}$ organizaciones; los recursos y usos de la producción cultural y la comunicación (la discursividad y las formas de enunciación, la comunicabilidad de las acciones, los campos de interlocución de las prácticas) y los cambios o desactivaciones de las prácticas.

En el sexto capítulo se plantean algunos imaginarios e imágenes de la ciudad a partir de la indagación de las políticas culturales y urbanas estatales desarrolladas en el periodo de análisis. Se traza un análisis sobre la convergencia de estas políticas y se trabaja sobre cómo varias de estas acciones (campañas comunicacionales, normativas y ordenanzas, programas) tenderían hacia a) cierta homogeneización del discurso público y b) intentos de clausura hacia las prácticas sociales y hacia la producción cultural diversa, que contribuyen al fortalecimiento de una "ciudad excluyente" a partir de la confluencia con las iniciativas de construcción y reconversión urbana.

El séptimo capítulo analiza la construcción discursiva del diario El Día -en tanto medio de comunicación comercial, tradicional y hegemónico de la ciudad- sobre diversas prácticas de intervención cultural. Se reconoce que este medio produce una economía 
simbólica que va de la omisión a la negatividad, y llega a cierto reconocimiento en tanto sean prácticas leídas como "artísticas" a las que se carga con la tarea de "frenar el vandalismo" que anida en el espacio urbano. Dicha estrategia reforzaría algunos imaginarios tradicionales sobre la ciudad y el arte (limpieza, no conflictividad, belleza urbana, contemplación) y promueve la indignación y criminalización hacia otras prácticas que no encajan en esos parámetros del "arte" y de la "ciudad".

En el octavo capítulo se despliegan algunas sospechas sobre las intervenciones culturales y su vínculo con otras prácticas y búsquedas situadas en La Plata. ¿De la calle a la galería? ¿De las intervenciones situadas en el espacio urbano a pensar la escena local de artes visuales? Son las preguntas que se realizan con la intención de marcar algunas situaciones y momentos contrastantes entre las prácticas indagadas a lo largo de la tesis y otras prácticas volcadas hacia el "mundo" del arte. El objetivo del capítulo es poder leer a la "cultura emergente" desde las "escenas culturales" y los nuevos actores -productores, galeristas, curadores, gestores, comunicadores-, las inquietudes estéticas e intervenciones en el campo artístico local. Se relevan la iniciativa de Luxor como productor visual que intenta "vivir del arte" y en la propuesta de Síntoma curadores que interviene en la visualización de una escena local, la construcción de reflexiones y de políticas del "campo artístico". Se considera que en estas dos experiencias se pueden observar esos desplazamientos y contrastes en las prácticas culturales.

El último capítulo se reserva para las palabras finales de la tesis y el planteamiento de posibles nuevas preguntas y/o próximas líneas de investigación en torno del campo temático aquí abordado. 


\title{
Capítulo 1
}

\section{La trama de los debates: producción cultural, ciudad y acción colectiva}

\author{
"Utilice la práctica política como un intensificador del \\ pensamiento, y el análisis como un multiplicador de las formas y \\ los dominios de intervención de la acción política." \\ Michel Foucault. "Introducción a la vida no fascista”, 1983 \\ "El conocimiento (...) no obtiene validez de su facultad de abarcar \\ el todo, lo universal (...) sino de su capacidad de dirigirnos y \\ mostrarnos una 'inmensa red de relaciones' en busca de la \\ producción de algo nuevo y singular. El conocimiento también \\ tiene un modo de constitución pluralista, distributivo y temporal." \\ Maurizio Lazzarato. Politicas del acontecimiento, 2006
}

\section{Antecedentes y debates en la investigación social}

Al hablar de la constitución de una escena de debates se hace referencia a una trama heterogénea, productiva y conflictiva de argumentos que se inserta en experiencias colectivas de cambio, que, en esta tesis, se vinculan principalmente con experiencias desde y en las formas culturales y de producción simbólica.

Tomar esta perspectiva en el campo de la investigación social es apostar a que el quehacer investigativo no tenga que ver con la "disección" de objetos y temas entre disciplinas, sino más bien con un tipo de concepción del mundo, con la que se discute, y con los materiales -teóricos y prácticos- que se construyen y ponen en juego. Desde esta mirada, los saberes y prácticas de la comunicación cobran relevancia en tanto "articulación de los modos colectivos de interacción y producción de significaciones que afectan las prácticas políticas y sociales en los procesos actuales de globalización económica, tecnológica y cultural." (Delfino, 2013). Guía entonces a esta investigación una proposición potente: la investigación social es un modo de interpelación a la acción. Pero también a la inversa, como 
tratamos de demostrar en esta investigación: la acción colectiva interpela y "hace andar" a la investigación y a la producción de conocimiento ${ }^{44}$.

Para ampliar la metáfora de la trama podemos argumentar que ciertas situaciones, episodios y acontecimientos constituyen tramas de prácticas, saberes y performances que aportan a una producción colectiva de significaciones sociales y políticas. A su vez, las tramas permiten la aparición de una escena de debates: zona retórica de argumentos de carácter polémico y performático que pone el foco en los materiales y distribuye posiciones y acciones; y contribuyen a ciertas formas organizativas, o modos de movilización política y disputa hegemónica ${ }^{45}$.

A continuación se busca constituir una narrativa de esas tramas que la propia investigación busca interpelar, es decir, construir como parte de su campo de interlocución. Se trata de saberes, nociones y marcos interpretativos que, muchas veces anclados en ciertas particularidades disciplinares, pueden sufrir desplazamientos o producir nuevas articulaciones para constituir una trama común. En términos generales, las tramas invocadas en este análisis son tres: a) las miradas sobre la ciudad y lo urbano b) las intersecciones para indagar en la producción cultural y artística y c) los modos de pensar la acción colectiva. Para dar cuenta de cada una de ellas, así como de sus vinculaciones recíprocas, presentamos a continuación algunos de los principales debates teóricos en los que se inscriben desde distintas perspectivas y áreas de estudio, al tiempo que se plantean algunas discusiones para repensar nuevas dimensiones y formas de abordaje.

Dentro de las ciencias sociales podemos encontrar abundantes investigaciones y estudios sobre diversas prácticas sociales y culturales contemporáneas -principalmente desde la sociología de la cultura, la antropología cultural, la sociología de los movimientos sociales, los estudios de género, los estudios de juventudes-. Por su parte, las preguntas por la ciudad, lo urbano y la constitución de lo público, han tenido una presencia algo más periférica en los programas académicos y en las carreras "humanísticas". Su ubicación actual es más difusa que los objetos y campos de saber recién nombrados. Sin embargo, pese a esa condición

\footnotetext{
${ }^{44}$ Un sentido similar es trabajado por Silvia Delfino al reflexionar sobre el modo de potenciar el valor crítico de las diferencias. Es así que se pregunta "si los movimientos sociales, en tanto formas de organización colectiva, han cambiado la historia de la investigación social, ¿cuál es la relevancia de la investigación para los movimientos sociales, los grupos o los actores en las condiciones actuales de crisis de hegemonía?" De este modo, entiende que "el vínculo entre activismo político e investigación tiene como petición de principio que lo que es político no es un conjunto de conceptos predefinidos como "temas" u "objetos", sino el tipo de preguntas que se plantean en términos de formulación de problemas y posiciones." (Delfino, 2009: 37)

45 Esta metáfora de la "trama" para reflexionar sobre la dimensión polémica en la que se inserta una investigación es recuperada de los debates y las reflexiones realizadas en la cursada del mencionado seminario del Doctorado dictado por la profesora Delfino.
} 
“insular”, los debates sobre la ciudad y lo urbano han ganado -en los últimos tiempos- cierto lugar en la investigación social, principalmente desde dos problemáticas:

1. Por las modificaciones en las tramas urbanas (políticas urbanas, distribuciones de espacios e ingresos, planificación urbanística) producidas por las mutaciones del capitalismo globalizado, sintetizados en nociones como "posciudades", "megaciudades", "ciudad global”, “ciudad-mundo", "hiperciudad", "postmetrópolis", “ciudad genérica” (Mongin, 2006; Sassen, 1999, 2012; Guattari, 2003; Corboz, 2016; Soja, 2008; Koolhaas, 1995).

2. Por las transformaciones producidas por los medios de comunicación, las redes audiovisuales y las tecnologías digitales que movilizan otros vínculos de las sociedades como el espacio y otras formas de ciudades: la "ciudad informacional" y "sociedad-red" como espacio de los flujos (Castells, 1995, 2009), "sociedad global de la información" -desde un análisis crítico (Mattelart, 2001)-, la "ciudad comunicacional” (García Canclini, 1996) o como parte de la "proliferación de lo urbano sobre el tejido social" (Piccini, 1996).

La indagación de estas problemáticas ha derivado -en términos generales- en dos tipos de estudios en ciencias sociales. Por un lado, unos análisis, que ponderan a veces un punto de vista político y otras veces uno ideológico, se esfuerzan por responder cómo se modelan los "sentidos" de ciudad, y procuran indagar en los procesos de "disputa", las "apropiaciones" materiales y simbólicas del espacio urbano -llevadas adelantes principalmente por sectores populares- y los "sentidos de experiencia" que despierta la vida urbana, que -en muchos casos- se enfrentan a las políticas de clausura, segregación y de "recuperación del espacio público" 46 . La urbe, entonces, es pensada y estudiada como campo de fuerzas en el que éstas se chocan, interpelan, distancian. Hablar de disputas, apropiaciones, sentidos, da cuenta de términos-íntimamente ligadas al territorio de lo político y -en términos gramscianos- se podría entender a la ciudad como parte de la construcción de hegemonía ${ }^{47}$. Así, una definición vital de estos trabajos -sobre todo los provenientes de la antropología urbana, y los estudios culturales- sería el entendimiento de la ciudad como escenario del conflicto y la resistencia.

\footnotetext{
${ }^{46}$ En el capítulo 6 se analizan algunas políticas de "recuperación del espacio público" llevadas adelante en la ciudad de La Plata.

${ }^{47}$ La separación entre tres unidades (economía, política, ideología), y sus puntos de vista metodológicos para indagar las ciudades es tomada de Jorge A. González (1994), aunque no adherimos a la marcada escisión que el autor hace de las dos últimas porque separa las dimensiones de lo político y lo cotidiano. Para González, en el punto de vista económico "la estructura de clases que da vida a la ciudad nos aparece como una unidad geoeconómica de producción, distribución y consumo" que la perfila como "subsistema de la explotación”. El punto de vista político, que representa a la ciudad como "una unidad geopolítica de la organización, de la convivencia y la cohesión social" que la convierten en "un subsistema de dominación de clases". Por último, el punto ideológico (que es el que pondera para su análisis González) entiende a la ciudad "como una unidad geoideológica de construcción y reconstrucción de sentidos históricamente construidos entre clases delimitables a escala de la urbe" y reconoce que "la vida en la ciudad no sólo distingue, sino que también (y por el mismo hecho de la distinción) identifica" (González, 1994: 89 y 91).
} 
Por otro lado, se encuentran los estudios que observan el lugar que ocuparía la ciudad en los procesos de producción (y reproducción) económica y social en un mundo globalizado. Podemos circunscribir estos trabajos a la economía-política, la sociología y a la sociología urbana. De este modo, si bien el elemento conflictual no desaparecerá en ellos, sí lo hará cierto horizonte utópico que encuentra en las diversas prácticas asociativas y colectivas de la sociedad civil -movimientos sociales, organizaciones de trabajadores, de consumidores, vecinales, sectores populares urbanos, etc.- la posibilidad de construir otra ciudad y otra sociedad. De este modo, las maneras de representar y habitar la ciudad no forman parte sustancial de las preocupaciones de este grupo de investigaciones. En una definición genérica, allí se entiende a la ciudad como espacio de los flujos ${ }^{48}$.

Se puede reconocer que algunos estudios han intentado articular estas dos cuestiones, al interpretar a lo urbano como el territorio experimental de los "modos de estar juntos" y de nuevas formas de ciudadanía entre el caos de la ciudad y la densidad tecnológica. Esto los lleva a comprender que las ciudades, especialmente en Latinoamérica, están formadas por una “trama cultural heterogénea" en donde lo público se re-configura desde la comunicación (Martín-Barbero, 1996a, 1996b, 2001, 2004, 2009). A su vez, estas miradas se vinculan los planteos que entienden a la ciudad desde la dimensión de "lo practicado": desde los usos cotidianos de los habitantes (De Certeau, 2000), o como la actividad de los "practicantes de lo urbano" (Delgado, 1999, 2007a, 2007b). Por lo relevante de sus contribuciones, todas estas indagaciones e investigaciones sobre la ciudad forman parte de los antecedentes de esta tesis.

La intención de esta investigación no es enfocarse en indagar todas las perspectivas y definiciones sobre "lo urbano" y "la ciudad" que se produjeron en las ciencias sociales, sino abrir algunas de las miradas que son importantes para el estudio de prácticas culturales contemporáneas. En este sentido, se considera que esas dos grandes tendencias recién mencionadas, en algunos puntos tienden puentes y en otros se tensionan con los estudios que fueron denominados como "urbanismo crítico" o "estudios urbanos críticos". Una definición y recorte bastante discutido -incluso por los propios autores implicados- ya que no se trató de una escuela o corriente de pensamiento sobre la ciudad; pero sí de estudios en los que

\footnotetext{
${ }^{48}$ No se pretende aquí caer en una definición que produzca una división analítica imprecisa y dicotómica. Esto ocurriría si adhiriésemos por entero a aquella propuesta de M. Castells $(1995,2001)$ sobre la "dualidad urbana" en la que se distinguiría la ciudad como "espacio de los lugares" y como "espacio de los flujos", producto de la nueva "economía informacional". En la primera es donde quedarían limitados los sectores populares al no poder trascender las relaciones de proximidad de los lugares geográficos (experiencia fragmentada imposibilitada de salir de lo local). Mientras que en la segunda, sería el espacio que, a través de las redes y los flujos de intercambios, conecta entre sí a los sectores privilegiados del mercado (un espacio social dominante).
} 
podemos reconocer algunas preguntas y búsquedas en común que renovaron la mirada sobre la "cuestión urbana" desde la geografía, la sociología urbana y la filosofía 49 .

En tanto que los debates sobre el espacio público y lo público, ha sido principalmente un territorio de las controversias y conceptualizaciones de la teoría política y la filosofía donde generalmente la ciudad no se presenta como parte de la problemática en debate o, a lo sumo, como lugar de escenificación de lo público-. En esos campos de saber, se han ponderado visiones históricas y normativas, pero también han surgido miradas críticas y renovadoras que ponen en juego otras dimensiones para comprender lo público (Habermas, 1981; Arendt, 2009; Sennett, 2011; Thompson, 1996; Rabotnikof, 1997, 2005; Delgado, 2011). En la introducción se desplegó en profundidad esta cuestión.

Respecto de la producción cultural y artística sabido es que constituye un terreno fructífero de investigación social, con destacado desarrollo en las últimas décadas. En la región latinoamericana, tanto desde la crítica cultural y la historiografía del arte argentino y latinoamericano, como desde los estudios culturales y la sociología de la cultura, se han presentado estudios sobre prácticas que cruzan o tensan los territorios del arte y la política y cuyos objetos paradigmáticos han sido las experiencias de Tucumán Arde!, la vanguardia artística porteña de los sesenta, El Siluetazo, la Escena de avanzada en Chile y, al reflexionar sobre los últimos años, el activismo artístico de los años '90 y 2000 junto a los artistas visuales y performáticos contemporáneos. Estos estudios también se constituyen en antecedentes importantes para la propia investigación (Longoni 2005, 2006, 2007, 2009;

\footnotetext{
49 Ese mote de "estudios urbanos críticos" hace referencia a las obras teóricas y trabajos de investigación empírica desarrollados principalmente en algunos países de Europa entre finales de los años, 60 y los 70 del siglo XX, y que tuvo en el centro de su producción intelectual a autores como Manuel Castells, David Harvey y Henri Lefebvre. Lefebvre $(1970,1974)$-desde finales de los años 60- realizó aportes interesantes como, por ejemplo, los conceptos de "derecho a la ciudad", "producción del espacio" y "revolución urbana", cuestionó la tendencia generalizada hacia la urbanización y recuperó las formas de la vida cotidiana. Por su parte David Harvey (1977), realizó una crítica radical de la urbanización capitalista desde una orientación marxista, en la que conjuga elementos de la economía-política y la geografía. También durante los años 70, Manuel Castells (1974, 1976) -desde una sociología crítica con fuertes vinculaciones con el pensamiento marxista-estructuralista del momento- desarrolló un modelo teórico que podríamos identificar como una economía-política de la "cuestión urbana", en esos textos no aparece una consideración por las dimensiones culturales de la vida urbana. En la actualidad, se puede reconocer ciertas líneas de continuidad con estos planteos de la red internacional de investigadores "Contested cities", un proyecto colectivo que trabaja a partir de algunos tópicos del conflicto urbano: la segregación urbana y la gentrificación, así como sobre las resistencias y la construcción de alternativas que desarrollan movimientos sociales y grupos "contrahegemónicos" frente a -lo que consideran- la "neoliberalización de la ciudad". Link: http://contested-cities.net Por otro lado, Edward W. Soja (2008) realizó extenso trabajo sobre los estudios urbanos críticos e indagó en las formas contemporáneas de la "postmetrópolis". Harvey $(2005,2013)$ continúa el desarrollo de un trabajo de análisis crítico sobre la ciudad y las condiciones de globalización. Una revisión de los estudios urbanos críticos producidos en América Latina y Europa en los últimos años se encuentra en García Canclini (2005) y en Carman y Janoshka (2014). Una revisión sobre los estudios sobre el espacio y la antropología urbana en Segura (2010).
} 
Longoni y Bruzzone, 2008; Longoni y Mestman, 2010; Richard, 2004, 2006, 2007, 2014; García Canclini, 2010; Giunta, 2008, 2009, entre otros).

Con todo, las preguntas por el cruce entre producción cultural, ciudad y espacio público, en donde las prácticas sociales y culturales se vuelven constitutivas de lo público y de la ciudad, y a la inversa, donde la ciudad y el espacio también "performan" a las prácticas se han desplegado por caminos paralelos antes que imbricados en el ámbito de las ciencias sociales en general, si bien -cabe reconocerlo- han encontrado significativo desarrollo en los estudios socioculturales latinoamericanos. El sello mayoritario, empero, parece indicar que uno de los términos/fenómenos de estudio subordina al otro, lo que produce estudios separados: por un lado, investigaciones sobre lo urbano-público y, por el otro, indagaciones sobre lo cultural-artístico, cada uno desanclado del espesor del otro.

De este modo, pese a contar con un gran caudal de literatura crítica en estos y otros campos, que sirven como anclajes para reflexionar sobre los contextos de la producción y emergencia de las prácticas culturales, existen pocos trabajos académicos e investigaciones empíricas que hayan abordado las intervenciones culturales contemporáneas en Argentina de una forma sistemática en donde se registren, mapeen, describan y analicen dichas acciones en tanto configuradoras del espacio público y de las tramas de la ciudad.

Recientemente comenzaron a publicarse trabajos académicos (ponencias, artículos, algunas tesis de posgrado) que tienen como preocupación las configuraciones de lo urbano y la dimensión del espacio público en la constitución de prácticas sociales y culturales. Algunos de estos estudios están anclados en las preocupaciones de la apropiación y acceso diferencial a la ciudad de los sectores populares de Buenos Aires y La Plata (Carman, 2006; Chaves, 2010, 2010; Segura, 2010, 2013, 2014, 2015) o en la constitución de lazos socio-urbanos en organizaciones autoconvocadas (Cáneva, 2015).

Otras investigaciones indagan sobre la politicidad de las prácticas comunicacionales y culturales para reconocer nuevas dimensiones de lo público en vínculo con las tecnologías virtuales y los usos de la ciudad (Sager y López, 2009, 2012; López, 2011, 2014, 2016; López, Badenes y Saurio, 2014; Pérez Balbi, 2012a, 2012b, 2013).

Otros estudios indagan desde la historia cultural urbana. Algunos sobre la construcción de la historia y la memoria de La Plata en los discursos de publicaciones gráficas en la celebración del centenario de la ciudad, desde donde proponen pensar una "historia de la historia local" (Badenes, 2012, 2015). Otros sobre las miradas en relación a la conformación, ocupación y expansión urbana de la ciudad de Buenos Aires (Gorelik, 2004, 2010). 
Junto a esto, ciertas producciones se interrogan sobre las prácticas artísticas (visuales) y las "poéticas-políticas" en contextos urbanos o ancladas en los circuitos artísticos, las instituciones del arte y sus debates específicos (De Rueda, 2003, 2014; Cuello, 2014; Capasso, 2011, 2012, 2013, Bugnone, 2013).

Por último, existen investigaciones recientes que, si bien atienden a los contextos locales, no anclan la mirada sobre la ciudad y lo urbano, y centran su interés en las discusiones y dinámicas sobre la producción y circulación artística "emergente". Al pensar en los modos de profesionalización y proyección de músicos, gestores y sellos discográficos de La Plata (Boix, 2013, 2016), en procesos similares que suceden en las artes escénicas, la danza y del circo (Sáez, 2015, 2016) y en los procesos de reactivación del circo en donde se producen disputas y negociaciones entre los jóvenes artistas circenses y las agencias estatales, en sus prácticas y representaciones (Infantino, 2013, 2014). Al indagar en las renovadas formas de producción y gestión del arte con la utilización de las tecnologías digitales y redes virtuales desde la perspectiva de la "cultura libre" (Racioppe, 2015. Al reflexionar sobre los modos de (auto)gestión, las políticas estéticas y las formas de visibilidad de espacios, productores y colectivos vinculados a la cultura y las artes visuales en la ciudad de La Plata (López, 2013b, 2015a, 2015b).

Reconociendo el valor y los distintos aportes producidos por este universo amplio de investigaciones precedentes y en curso, entendemos que esta tesis recupera dicho recorrido al tiempo que aspira a contribuir, desde el campo de estudios de la comunicación y la cultura, a un área de interés donde construir nuevos conocimientos y sistematizaciones sobre experiencias culturales y reflexiones sobre la ciudad y el espacio de lo público, con la intención de articular de manera compleja la producción cultural y la producción de lo público-urbano.

En lo que sigue de este capítulo se describen y analizan los tres campos de antecedentes en la investigación social mencionados y que resultan pertinentes al horizonte de problemas abordados en la presente tesis. La división tiene la intención de hacer ordenada la presentación del estado del arte. Pero se reconoce que se trata de estudios que en muchos casos cruzan los campos temáticos, las disciplinas y las propuestas metodológicas. De este modo, los ejes de cada sub-apartado son: a) las prácticas culturales y artísticas, b) la ciudad y lo urbano y c) la acción colectiva. Por su parte, los debates sobre lo público y lo político se trabajaron en la introducción. 


\section{I.a. Más allá del canon arte/política}

En las últimas décadas se multiplicaron las interpretaciones y discusiones sobre la producción cultural, las prácticas artísticas y las cuestiones estéticas. La cultura, los problemas y las "cosas del arte" han sido objeto de numerosas reflexiones críticas; estos aportes se hicieron desde diversos campos de saber: la historia del arte, la crítica cultural, las teorías del arte, la teoría estética, así como desde la filosofía, la antropología, la sociología de la cultura y los estudios culturales. A su vez, se renovaron los debates en torno a conceptos como "vanguardia artística", "arte público", "arte político", "activismo artístico", "arte contextual" que -pese a sus diferencias- marcaron las fronteras canónicas para pensar el par arte / política en varias de esas disciplinas (principalmente en la historia y la teoría del arte).

En este escenario contemporáneo el pensamiento de Walter Benjamín (2015 [1927], [1931], [1935-36], [1938]) cobró un nuevo impulso y se produjeron relecturas diversas (Buck-Morss, 2014; Opitz y Wizisla, 2014; Martín-Barbero, 2003; Huyssen, 2006; Kohan, 2004; Follari, 2003; Sarlo, 2007; Richard, 2007; Jay, 2009; Williams, 2009; Rancière, 2011, 2014; Groys, 2016; Di Filippo, 2011) ${ }^{50}$. Así algunas revisiones producidas en los últimos veinte años lo recuperan como pensamiento productivo para indagar en el par arte / política; en la afirmación de la cultura de masas y en el potencial cognitivo y político de las experiencias culturales mediadas por lo tecnológico y como pensamiento fértil para indagar en las formas creativas de la ciudad y en las utopías urbanas. Otras lecturas realizaron observaciones críticas que discuten varios de sus análisis, entre ellos, la idea de la "politización" del arte que Benjamín reconoce en el comunismo soviético y la deducción de propiedades estéticas y políticas del arte a partir de sus aspectos técnicos.

En este renovado escenario de debates, además, se pusieron en primer plano otros pares posibles como el de "estética y política" -actualizado por Rancière (2010, 2011, 2014) en el debate contemporáneo para reelaborar ambas categorías y repensar lo que tienen en común-; y el de "poética y política" -sugerido, entre otros, por Boris Groys (2014) como

\footnotetext{
${ }^{50}$ En este punto es preciso aclarar dos cuestiones: 1) ha sido primeramente la Escuela de Frankfurt la que ha puesto en el centro de la escena de los debates filosóficos y sociológicos del siglo XX a la problemática cultural. 2) En las relecturas contemporáneas -desde los ' 80 hasta la actualidad- gran parte de las contribuciones teóricas de la Escuela de Frankfurt fueron revisitadas. Sin embargo, fue el pensamiento de Benjamín el que adquirió una nueva vitalidad, muchas veces opuesto -en las relecturas- a las concepciones de Adorno. Quizá, de forma simplificada, podríamos decir que el pensamiento benjaminiano se elevó casi a la figura de un "hit académico" póstumo y que la mirada adorniana cayó en desgracia (las críticas principales a este autor fueron a su supuesto "elitismo" para pensar la cultura). Casi todas las publicaciones recientes que refieren a cuestiones del arte y la estética y del arte y la ciudad reponen y citan la obra de Benjamín. Esta cuestión problemática de las recepciones y re-visiones académicas de los trabajos de los pensadores de Frankfurt amerita una particular investigación.
} 
modo de reconceptualización desde la producción artística y no desde la recepción estética del público- ${ }^{51}$.

Asimismo, se comenzaron a utilizar, a veces incluso como definiciones de las propias prácticas culturales, algunos juegos categoriales como "arte relacional" -popularizado por el crítico y curador Nicolás Bourriaud (2006) para analizar prácticas artísticas actuales y cierto nuevo "modelo de artista" en la posmodernidad-, "arte de acción" -trabajado, entre otros, por Rodrigo Alonso (2011)- o incluso "la cultura como recurso" -como ya mencionamos, una definición propuesta por George Yúdice (2002) para indagar la producción cultural en épocas de globalización económica-. Aquí, de forma acotada, se presentan éstas y otras reflexiones y se plantean algunas consideraciones críticas.

A mediados de la década de los años 90 -aunque la recepción en Argentina data de mediados de los 2000- Nicolás Bourriaud (2006, 2009a 2009b) buscó describir cuáles eran los problemas que se planteaban los artistas, a partir de algunos interrogantes: “¿cuáles son las apuestas reales del arte contemporáneo, sus relaciones con la sociedad, con la historia, con la cultura?" Para este autor, las relaciones humanas son cosificadas y reducidas por la mercantilización, "el lazo social se convirtió en un artefacto estandarizado." Frente a esto, "la realización artística aparece hoy como un terreno rico en experimentaciones sociales, como un espacio parcialmente preservado de la uniformidad de los comportamientos", se constituye entonces una "utopía de la proximidad" (Bourriaud, 2006: 5-6-7). El autor propuso el concepto de "estética relacional" para nombrar y orientar cierta "repolitización" del arte en el contexto contemporáneo, en la que el artista a través de sus prácticas -procesuales, comportamentales, interactivas- restituye el "lazo social". Lo complejo de esta propuesta es que si bien se trastoca el estatuto, la materialidad y producción de la "obra de arte", no pasa lo mismo con la figura del "artista", que sería el sujeto que idea, habilita y produce el "hecho estético" relacional y también el encargado de restablecer los contactos humanos, el "lazo social" resquebrajado, en un contexto de cuestionamientos y descreimiento del sistema político. Así parecería que el "artista" ocupa un rol social articulador, frente a la falta de representatividad de la política formal, un postulado que exagera la posibilidad en tanto sujeto-artista y encaja con la mirada (posmoderna) que descree de la construcción política. El

\footnotetext{
${ }^{51}$ Para Groys en la tradicional actitud estética se ha privilegiado "la actitud del espectador", que le exige al arte el goce y la experiencia estética. Pero plantea que hay que posicionarse desde otro lado, desde la actitud del productor, desde la "poética". Su hipótesis es que en la contemporaneidad de la redes virtuales e internet y en el mayor acceso a los dispositivos de producción de imágenes, hay más personas con intenciones de producir arte que de consumirlo; es decir, en llevar adelante la "producción del propio Yo público", una "autopoética". Por esto desde finales del siglo XX entramos -según el autor- en la era de la producción artística masiva (Groys, 2014: 9-19).
} 
otro punto discutible es la noción de comunicación que maneja: entendida como información, autopistas y medios electrónicos, que -según Bourriaud- impiden los vínculos, “sepulta los contactos humanos" y transforman a los usuarios en "consumidores"; de ahí que el artista se esfuerce en la tarea de restituir y habilitar esos contactos rotos por la comunicación.

La pregunta por los "contextos" de la producción artística guía a otros recientes trabajos. Por un lado, Paul Ardenne (2006) centra sus reflexiones en prácticas de "creación artística" que se implican (de manera directa) con "lo real" e "impugnan las normas", entre ellas, la mediación artística representada en sus tradiciones e instituciones (galerías, museos, etc). A partir de retomar el concepto de "arte contextual" busca analizar y "hacer valer el potencial crítico y estético de formas y prácticas artísticas enfocadas en la presentación más que en la representación” (Ardenne, 2006: 11). Desde allí destaca algunas características de este arte: en situación (como actos de presencia); en medio urbano (producen cierta apropiación del espacio público que entienden a la ciudad como "espacio práctico"), de intervención (por medio de happenings) y de participación junto con sujetos no artistas. Lo fuerte de estas prácticas, entonces, es que son creaciones colectivas, activas o participativas y que difieren de la obra de arte tradicional (2006: 10). Pero Ardenne, como se mencionó antes en Bourriaud, mantiene aún una concepción "aurática" del arte (porque sostiene una autonomía de la obra previa a su inserción en el contexto), una definición limitada del "público" (que al participar "se integra" y "completa" la obra) y sobrecarga el rol que tendría el artista "contextual": no sólo es el que "habilita" la participación del "otro" ("pulsión participativa" o "agorética" del artista como refiere el propio Ardenne) sino que es un enunciador privilegiado para enmendar o mejorar la sociedad. Parecería así que este arte contextual solamente jugaría como una nueva posición dentro del campo del arte y su historia (al tomar distancia del arte clásico, de la vanguardia del siglo XX y del arte conceptual), cuya pretensión sería relacionar de manera directa la obra y la "realidad", dejando a resguardo el $\operatorname{arte}^{52}$.

Desde un cruce entre teoría del arte y filosofía, Reinaldo Laddaga indaga en la reorientación de las artes en un escenario de crisis de la sociedad disciplinaria y de la modernidad estética (centrada en las figuras de la obra como objetivo paradigmático de la práctica artística): la “aparición de nuevas formas de subjetividad y asociación desbordaba las

\footnotetext{
${ }^{52}$ Estas observaciones se pueden articular con la crítica planteada por Williams $(1997,2009)$ a las concepciones elitistas del arte que anidan en el "modernismo", y que piensan al artista, y al crítico cultural, como guardianes de los valores y el legado estético de una época. Entre dichas concepciones, por ejemplo, los movimientos artísticos de vanguardia -como "grupos autoconscientes, designados y autodesignados"- se veían así mismo como "una brecha hacia el futuro", como los agentes de "una creatividad que reanimaría y liberaría a la humanidad" (Williams, 1997: 73)
} 
estructuras organizativas del estado social y el capitalismo de gran industria entraba en un período de turbulencia" (Laddaga, 2006: 8), momento en el que también se inicia un nuevo ciclo global de protestas. En ese contexto un número creciente de artistas "parecía interesarse menos en construir obras que en participar en la formación de ecologías culturales.” (2006: 9) En esta transición en curso, estos actores:

\footnotetext{
"reaccionan al evidente agotamiento del paradigma moderno (y a la insuficiencia de esa clase de respuestas que identificábamos como posmodernas) realizando una metabolización selectiva de algunos de sus momentos: la demanda de autonomía, la creencia en el valor interrogativo de ciertas configuraciones de imágenes y de discursos, la voluntad de articular estas configuraciones con la exploración de 'la substancia y la significación de la comunidad"” (Laddaga, 2006: 9).
}

Para el autor esto implica "abandonar la mayor parte de los gestos, las formas, las operaciones heredadas de esa cultura [moderna] de las artes" (2006: 9). Dos cuestiones importantes de estas producciones artísticas serán su carácter "colaborativo" y que ensayan modos posdisciplinarios de operar. De este modo, el autor construye una proposición: en estos "proyectos" lo que "está en juego es la invención de una cultura de las artes para una época de fin de la sociedad disciplinaria." (2006: 263) Un cuestionamiento a esta mirada crítica de la "cultura moderna" se puede dar desde su propia propuesta, ya que aún reconoce ámbitos separados de actividad (la cultura de las artes, la ciencia, la producción económica, la práctica política).

García Canclini también participa en estos debates -desde un cruce entre la sociología del arte y la antropología- y plantea que "la historia contemporánea del arte es una combinación paradójica de conductas dedicadas a afianzar la independencia del campo propio y otras empecinadas en abatir los límites que lo separan" (García Canclini, 2010: 15). La respuesta a la oscilación entre bregar por la autonomía del campo y no poder trascenderla, hay que buscarla -dice Canclini- en lo que le ocurre al "intersectarse" con otros campos y volverse "postautónomo". Con esta noción designa al actual desplazamiento en relación con las prácticas artísticas, que, en muchos casos, dejan de estar centradas en los objetos para pasar a estar insertas en los contextos -donde se involucran formas de vida social y campos extraartísticos-: "hasta llegar a insertar las obras en medios de comunicación, espacios urbanos, redes digitales y formas de participación social donde parece diluirse la diferencia estética" (2010: 17 -las cursivas aparecen en el texto-). Sin embargo, en los ejemplos que el autor 
indaga se vuelve a reforzar la idea de obra y también la figura del artista reconocido -ya que toma como casos paradigmáticos las propuesta artísticas de León Ferrari, Francis Alÿs, Cildo Meireles, Antoni Muntadas, Gabriel Orozco, Santiago Sierra, entre otros-.

Uno de los aportes destacados en el campo de estudios sobre "arte público y activista" son las reflexiones de Nina Felshin. Esta autora estadounidense destaca el carácter "procesual" de las prácticas activistas y que tienen lugar en "emplazamientos públicos": "tanto en sus formas como en sus métodos, en el sentido de que en lugar de estar orientado hacia el objeto o el producto, cobra significado a través de su proceso de realización y recepción". A su vez, apunta que el "arte activista" se distingue por el uso de métodos colaborativos de ejecución, "tomando una importancia central la investigación preliminar y la actividad organizativa y de orientación de los participantes” (Felshin, 2001: 74). En relación con esto, para la autora "el artista público es aquel cuyo trabajo es esencialmente sensible a los problemas, necesidades e intereses que definen esa entidad esquiva y difícil de definir que es el lugar [site]" (Felshin, 2001: 85).

Brian Holmes $(2002,2008)$ es otro de los autores y activistas que ha desarrollado importantes reflexiones sobre la relación entre las prácticas artísticas y la política, desde los contextos francés y estadounidense que habita. Para él, la principal problemática son las “políticas de representación” dentro del juego del arte contemporáneo. Se pregunta ¿Por qué el arte tiene necesidad de representar o volver imagen a la política de los excluidos? Holmes (2002) reconoce los vínculos entre esa búsqueda de representación del arte y el trasfondo corporativo que financia premios, muestras, museos y bienales artísticas en donde esas representaciones circularán. Por otro lado, plantea que se puede reconocer una nueva crítica de las instituciones artísticas en las búsquedas de muchos artistas por "trabajar fuera de los límites de su propia disciplina". Propone, así, el concepto de "investigaciones extradisciplinarias" para pensar en esos proyectos (Holmes, 2008).

Por su parte, Gregory Sholette también reflexiona sobre el "arte activista" e indaga en lo que considera un "espacio ganado" por "una contra-narrativa" sobre las prácticas creativas -inadvertidas y de oposición- "que están ya presentes en la sombra de la industria cultural" (Sholette, 2015: 5). Se propone así "ofrecer un mapa de una esfera creativa poco iluminada y en gran parte excluida de las estructuras económicas y discursivas del mundo del arte institucionalizado" (2015: 6). Con la metáfora de la "materia oscura" este autor estadounidense refiere a la producción creativa colectiva que "constituye el grueso de la actividad artística producida en nuestra sociedad postindustrial” (2015: 12) y que la historia del arte tradicional ha omitido. Recientemente, Boris Groys también se ha insertado en los 
debates sobre el "activismo artístico". Afirma que "las discusiones actuales sobre arte están muy centradas en la cuestión del activismo; es decir, en la capacidad que tiene el arte para funcionar como arena y medio de la protesta política del activismo social" (Groys, 2016: 55). De ahí plantea que quienes llevan adelante estas prácticas activistas no realizan solamente -a diferencia del arte crítico- una "crítica del sistema del arte o de sus condiciones políticas y sociales generales bajo las cuales funciona", sino que pretenden "cambiar estas condiciones por medio del arte", es decir, cambiar la realidad (2016: 55). Los problemas -sostiene- tanto de índole política, teórica y práctica se presentan porque estos artistas activistas, que quieren cambiar la realidad y hacer del mundo un lugar mejor, "al mismo tiempo, no quieren dejar de ser artistas". Por lo que se vuelven blanco de ataques, tanto de la tradición artística como de las perspectivas tradicionalmente activistas (Groys, 2016: 56).

Por su parte, en la trayectoria intelectual de Nelly Richard (2004, 2006, 2007, 2014) el debate por lo crítico y lo político en el arte ha estado presente entre sus principales reflexiones. Posicionada desde la crítica cultural, sostiene el cuestionamiento a la figura del "artista comprometido" que se configuró en los años 60 y a la idea de tomar a la región latinoamericana como una totalidad. Dos figuras que -para la intelectual residente en Chile han perdido su peso, lo que explica en parte que la retórica del "arte comprometido" ha caído en desuso (Richard, 2014). Al indagar en la "Escena de Avanzada", que llevó adelante sus acciones en plena dictadura en Chile a finales de los años 70 como parte de la resistencia cultural pero a distancia de las formas tradicionales de ésta, reconoce que allí se desplegaron "micro-políticas" que abrieron un campo de exploración de géneros y formatos que batalló contra el academicismo y la institucionalización cultural a la vez que contra el léxico artístico de la izquierda (Richard, 2006) ${ }^{53}$.

Todos los autores y propuestas trabajadas hasta aquí -desde Bourriaud hasta Richardaportan algunas interesantes miradas que ponen en tensión las tradiciones disciplinares desde donde se han pensado los fenómenos de la cultura; aunque también se pudo reconocer que, en varios de los casos mencionados, se encuentra un intenso pulso por pensar en y sobre lo artístico y retenerlo casi como un espacio no-contaminado de otros saberes y prácticas. En lo

\footnotetext{
53 “Quienes integraron esa escena reformularon (...) mecánicas de producción creativa que cruzaron las fronteras entre los géneros y que ampliaron los soportes técnicos del arte a las dinámicas procesuales del cuerpo vivo y de la ciudad. (...) La Escena de Avanzada -hecha de arte, de poesía y literatura, de escrituras críticas- se caracterizó por extremar su pregunta en torno a las condiciones límite de las prácticas artística en el marco totalitario de una sociedad represiva; por apostar a la imaginación crítica como fuerza disruptiva del orden administrado que vigilaba la censura; por reformular el nexo entre 'arte' y 'política' fuera de toda dependencia ilustrativa al repertorio ideológico de la izquierda, sin dejar, al mismo tiempo, de oponerse tajantemente al idealismo de lo estético como esfera desvinculada de lo social y exenta de responsabilidad crítica en la denuncia de los poderes establecidos" (Richard, 2007: 13-14).
} 
que a esta tesis interesa, se recuperan especialmente aquellas perspectivas que indagan sobre todo en prácticas "menores" y "micropolíticas" para pensar allí su articulación con la criticidad y la politicidad de las prácticas culturales, así como la idea de las dinámicas/formas procesuales de producción cultural. Asimismo, estos estudios cobran valor al producir sus reflexiones desde un conocimiento situado (que explicita sus posiciones) y encontrarse imbricadas en experiencias culturales. Este espacio de debates y de líneas convergentes es recorrido principalmente Felshin, Holmes, Richard y Sholette.

En las últimas dos décadas se encuentran varios aportes que reflexionan sobre experiencias artístico-culturales situadas en Argentina. Por medio de dos caminos de investigación inscritos en la historia del arte argentino y latinoamericano, tanto Ana Longoni como Andrea Giunta, analizan a colectivos y artistas que desarrollaron sus prácticas -sobre todo- en la ciudad de Buenos Aires en los años 90, durante la crisis social y política de los años 2001-2002, así como el reciente escenario de "pos-crisis". Estas autoras indagan las articulaciones y diferencias con las "vanguardias artísticas" de los años "60 y "70 que se vincularon con los movimientos políticos revolucionarios de su tiempo ${ }^{54}$. Estos estudios buscan insertar estas acciones dentro del campo del arte argentino y su historiografía y analizan las tensiones y convergencias en el par "arte y política" (Longoni, 2005, 2006, 2007, 2009; Longoni y Vindel, 2010; Giunta, 2009). En su línea de indagación Longoni propone, con reparos, la categoría genérica de "activismo artístico" o "arte activista" que comprendería

\footnotetext{
${ }^{54}$ Varios de los trabajos de estas autoras centran sus análisis en esos movimientos artísticos de las décadas de los años 60, 70 y 80 del siglo XX en Argentina. En su indagación sobre "arte argentino en los sesenta" Andrea Giunta busca "volver significativos pactos y disidencias: aquellos momentos en los que artistas, instituciones y críticos formaron un mismo frente organizado para el logro de una única misión (en el caso que nos ocupa, gestar un arte argentino, colocarlo en el mundo y lograr el postergado reconocimiento)." (Giunta, 2008: 13). Su universo de análisis -focalizado en el medio artístico de Buenos Aires- serán así los proyectos de internacionalización, las programas artísticos de la vanguardia, las imágenes y discursos antagónicos que desde mediados de los 50 hasta finales de los 60 constituyeron al "nuevo arte argentino", contribuyeron a su localización destacada en el mapa mundial del arte y marcaron las polémicas del período. "En ese clima se reescribió la tensión entre el arte y la política en los términos que ahora imponía el debate cultural en América latina, y se le imprimió una radicalidad que fue aumentando en el transcurso de la década" (Giunta, 2008: 17). Para la autora es allí donde se puede inscribir el surgimiento del arte contemporáneo en el país. En tanto que para Longoni y Mestman es fundamental indagar lo que denominan como el "itinerario del " 68 " en el que la vanguardia artística (porteña y rosarina) se encontró con la vanguardia política y de este modo se desbordó el campo del arte: se produjo allí una ruptura con las instituciones artísticas modernizadoras (de las que habían sido parte, en especial el Instituto Di Tella) y con las formas establecidas de concebir y practicar el arte. De este modo, destacan que en ese "68 argentino" -y en particular la más conocida de sus acciones, "Tucumán arde"varios núcleos plásticos experimentales pasan de una posición alternativa a una de oposición frente a las instituciones del arte, la dictadura militar y el sistema capitalista (Longoni y Mestman, 2010: 21). En un volumen posterior, se indagan y documentan los episodios que hacia finales de la dictadura y en los primeros años de la recuperación democrática se denominaron luego como "El Siluetazo", acciones de reapropiación del espacio público desde la performance grupal ligado a las reclamos de "aparición con vida" impulsada por los organismos de Derechos Humanos: "la más recordada de las prácticas artístico-políticas que proporcionaron una potente visualidad en el espacio público de Buenos Aires y muchas otras ciudades del país a las reivindicaciones del movimiento de derechos humanos" (Longoni y Bruzzone, 2008: 7).
} 
a "producciones y acciones, muchas veces colectivas, que abrevan en recursos artísticos con la voluntad de tomar posición e incidir de alguna forma en el territorio de lo político" (Longoni, 2009: 18) y entiende que estas prácticas producen un "desborde" de los límites de arte. La autora recupera esta categoría por tratarse de una noción que juega en la articulación de ambos términos sin subordinarlos y al mismo tiempo realiza una crítica al concepto de “arte político" por considerar que en éste la política queda como "adjetivo del arte". Es decir subsumido como una forma posible de la práctica artística. En sintonía con sus planteos, Marcelo Expósito $(2012,2014)$ y Jaime Vindel $(2010,2012)$ también forman parte de estos debates y caracterizaciones. Así entenderán al “activismo artístico” como:

“aquellos modos de producción de formas estéticas y de relacionalidad que anteponen la acción social a la tradicional exigencia de autonomía del arte que es consustancial al pensamiento de la modernidad europea. De esa exigencia de autonomía se deriva la inevitabilidad de una esfera artística separada. El activismo artístico niega de facto tal separación, no exclusivamente en el plano teórico o ideológico, sino en la práctica" (Expósito, Vindel y Vidal, 2012: 43).

Por su parte, Andrea Giunta (2009) estudia las transformaciones y los debates que se desarrollaron en el campo artístico porteño en el escenario de profunda crisis -política, económica y cultural- y de ebullición en el que surgieron prácticas artísticas renovadas y cuestionadoras, así como el posterior escenario de "pos-crisis", marcado fuertemente por el surgimiento de nuevos museos y galerías (nuevo circuito institucional), la presencia de muchas de estas prácticas artísticas en las instituciones legitimadoras del arte y cierto repliegue al trabajo individual ("vuelta al atelier"); a todo la autora lo denomina como la “escena del cambio cultural”. Para Giunta estas "dinámicas de organización artística":

\footnotetext{
"quedan como un intenso laboratorio de experimentación de formas cotidianas de invención realizadas por artistas que trabajaron, por algún tiempo, juntos. Pero esta creatividad no se circunscribió al campo del arte, también fue intensa en la escena social. Allí adquirió distintas modalidades y se gestaron formas visuales de inscribir el reclamo en el imaginario social"' (Giunta, 2009: 17).
}

Con algunas similitudes al planteo de Giunta, la idea de "arte de acción", fue trabajada en las últimas décadas en la Argentina -entre otros- por Rodrigo Alonso (1999, 2011). Con esta categoría intenta dar cuenta de cierto giro y renovación que los propios actores 
involucrados en el campo artístico buscan darle a las formas y procedimientos tradicionales del arte plástico, tanto desde una búsqueda formal, una posición política crítica o desde la experimentación. Aquí también, como ya se apuntó para otros autores, en Alonso se mantiene la idea de obra de arte (por más que ya no sea con los medios tradicionales del arte visual), así como la intención encontrarle al arte cierta particularidad. A su vez, sus planteos circunscriben más marcadamente la concepción de que el "arte de acción" es un movimiento dentro del propio campo artístico ${ }^{55}$.

Como síntesis se puede decir que tanto Longoni como Giunta destacan experiencias que principalmente sucedieron y se inscribieron en el escenario de la ciudad de Buenos Aires: Taller Popular de Serigrafía, Grupo de Arte callejero, Etcétera y Arde Arte! y encuentran además un momento de "institucionalización" y encrucijadas de estas expresiones de "arte activista" $"$. Estas indagaciones sin dudas aportaron valiosos elementos de análisis para comprender y caracterizar la configuración de estas experiencias en el país.

Como parte de un contrapunto que esta tesis invita a explorar, aquí partimos de asumir que en la ciudad de La Plata se vivenció un proceso diferente e inédito en relación a lo que acontecía en la Ciudad Autónoma de Buenos Aires. Mientras que en los estudios de aquellas prácticas culturales se describe y reconoce un momento de repliegue del llamado "activismo artístico" hacia los años 2004 y 2005 (marcado por procesos diversos que van desde las expectativas democratizadoras generadas en torno del nuevo gobierno nacional de base peronista y configurado en la transversalidad política a ciertos problemas vinculados con las dinámicas artísticas, pasando por la incorporación de algunas de estas prácticas dentro del circuito del arte institucional (fenómeno denominado por algunos como "bienalización del arte activista"), en La Plata tuvieron lugar otras situaciones y dinámicas, bien contrastantes. En la capital bonaerense ésos fueron años de surgimiento y potenciación de colectivos e intervenciones que -en varios casos- se articularon entre sí y con demandas colectivas y

\footnotetext{
55 “Su aparición está vinculada con el intento de algunos artistas de trascender los medios tradicionales (pintura, escultura, grabado, dibujo), ya sea por encontrarlos limitados en sus cualidades expresivas, por considerarlos políticamente objetables (al relacionarlos con los valores burgueses o el mercado), o simplemente, por la búsqueda de la novedad mediante la renuncia a lo ya conocido o la experimentación" (Alonso, 2011). Recientemente se han publicado algunos trabajos que, desde esta perspectiva, indagan a colectivos e interventores en la ciudad de La Plata. Principalmente se hace referencia del Proyecto de Investigación "Arte de Acción en La Plata en el Siglo XXI", dirigido por la profesora María Cristina Fukelman y radicado en la Facultad de Bellas Artes de la UNLP. Web del proyecto: http://blogs.unlp.edu.ar/arteaccionlaplataxxi

${ }^{56}$ También se pueden mencionar dos trabajos de Cecilia Vázquez $(2008,2011)$ en los que indaga en las acciones artístico-políticas "de oposición” y su vínculo con las protestas sociales en la Argentina reciente. Se trató -para la autora- de un activismo artístico que trabajó en tanto mediadores y facilitadores de construcción de sentido para poner en escena las demandas sociales a través de la utilización del recurso de "lo artístico" y sus herramientas. También reconoce la mayor visibilidad y alza de estas experiencias -en la ciudad de Buenos Aires- en diciembre de 2001 y sus reflujos entre los años 2005-2007.
} 
luchas diversas (de movimientos sociales, de derechos humanos, de trabajadores y de género) que renovaron el escenario cultural local, a la vez que contribuyeron con algunos cuestionamientos políticos, estéticos e institucionales del momento ${ }^{57}$. A su vez, otra cuestión importante es que no encontramos por aquellos años en la ciudad de La Plata un circuito del arte visual, ni visible en términos de política cultural (que promovida por el Estado y el mercado abra la posibilidad de "bienalizar" prácticas, obras y artistas), ni viable en términos financieros (como una suerte de mercado del arte local desde el cual solventarse), lo que implica que las promesas materiales y simbólicas que el arte puede ofrecer no aparecían entre las principales expectativas de los practicantes de las experiencias que aquí se indagan, un punto que marca una diferencia sustancial con las experiencias porteñas. Al seguir este razonamiento podríamos decir que sin esas condiciones -un circuito dinámico de producción/circulación/consumo, una política cultural de promoción y producción artística (con instituciones abocadas a esta tarea) y la consolidación de un mercado de arte (existencia de público-consumidor de obras, de galerías y de otros intermediarios) no se podría hablar de prácticas artísticas. En el capítulo 8 nos detendremos a reflexionar sobre estas cuestiones para pensar en el caso particular de La Plata.

Por su parte, en su tesis doctoral, Marilé Di Filippo (2015) analiza -a partir de una perspectiva inscripta en las teorías decoloniales- diferentes prácticas y experiencias "estéticopolíticas" en la ciudad de Rosario a partir de la década que abrió la insurrección popular de 2001. Para la autora, esa ciudad se convirtió en un laboratorio para la potenciación de este tipo de acciones que "conformaron una trama sensible y de sentidos en la superficie urbana". De este modo, indaga en el devenir y en el repliegue de estas prácticas y en el surgimiento de otras nuevas y propone la denominación de "una estética-en-la-calle visual y performática" para pensar esas experiencias.

\footnotetext{
${ }^{57}$ Cabe mencionar que por esos años y principalmente a partir de la segunda desaparición de Jorge Julio López en septiembre de 2006, fue desde el espacio denominado "Multisectorial La Plata, Berisso y Ensenada" donde se articularon la mayoría de los reclamos de justicia y denuncias en relación a esa desaparición. Esa coordinadora de partidos políticos, organizaciones sindicales, sociales, de derechos humanos y estudiantiles fue la principal responsable de organizar las movilizaciones callejeras en la ciudad por la aparición con vida de Julio López. Se puede plantear que las problemáticas de los derechos humanos ha sido el principal eje articulador de ese espacio, aunque también se ha manifestado sobre otras problemáticas sentidas de la región -por ejemplo, solidaridad con diferentes luchas de trabajadores-. Si bien desde el 2006 en adelante no participaron siempre las mismas organizaciones -ya que algunas abandonaron el espacio y otras nuevas surgieron- podemos mencionar al colectivo Justicia Ya!, HIJOS La Plata (el sector no ligado al kirchnerismo), Asociación de Ex Detenidosdesaparecidos, Familiares de víctimas del Gatillo Fácil, CORREPI, el Centro por los Derechos Humanos Hermanos Zaragoza, Suteba La Plata, PTS, PCR, PO, nuevo MAS, MST, Frente Popular Darío Santillán, Patria Grande, Quebracho, La Brecha, Surcos, las organizaciones estudiantiles nucleadas en la COPA y agrupaciones como CEPA, Juventud Guevarista, Insurrectos, Cauce, Agite y Frente estudiantil Liberación.
} 
Existen al menos tres escritos que han sido concebidos desde algunas prácticas de intervención cultural en la Argentina: el libro del GAC (2009) y el "manual" de mapeo colectivo de Iconoclasistas $(2013)^{58}$ de Buenos Aires y el "catálogo" de la Muestra Ambulante publicado por La Grieta $(2009)^{59}$. Se trata de textos de reflexión sobre las propias prácticas, escritos sobre y desde la experiencia de cada uno de estos colectivos. En ellos además se documentan y registran acciones y proponen recorridos visuales por las mismas.

Por su parte, dentro de los trabajos de investigación empírica que indagan en experiencias recientes en la ciudad de La Plata, encontramos los estudios ya mencionados de Pérez Balbi (2012a, 2012b, 2013), De Rueda (2003, 2014), Cuello, (2014), Capasso (2011, 2012, 2013) y Fukelman (2014). Desde el tópico “arte y ciudad”, De Rueda indaga en los proyectos del arte contemporáneo y conceptual de la Argentina -algunos llevados adelante por colectivos y artistas de La Plata- que en el siglo XX plantearon "utopías urbanas", partiendo de las características del arte de vanguardia:

\begin{abstract}
"El arte contemporáneo a partir de los postulados de la obra de vanguardia se ha expandido en variadas posibilidades conquistando y construyendo nuevos espacios, creando 'mundos posibles', alterando o modificando el espacio urbano, la ciudad, el espacio específico de lo artístico. (...) Las manifestaciones artísticas de este siglo (...) de-construyeron y reconstruyeron el estatuto del arte y el sistema artístico en su conjunto, a partir de una serie de operaciones al interior del sistema y al exterior del mismo. (...) Si pensamos en los objetivos de algunas de las vanguardias históricas, su carácter deconstructivo, la disolución del arte en lo cotidiano, la transformación de la sociedad partiendo de la transformación del ambiente (...), nos encontramos con analogías en nuestro arte. Una serie de obras y discursos artísticos dentro del arte
\end{abstract}

\footnotetext{
${ }^{58}$ El libro del GAC es un auto-estudio reflexivo sobre la totalidad del recorrido del grupo en el que también invitan a otros a prologar y comentar (Ana Longoni, Sebastián Hacher, Colectivo Situaciones), mientras que el texto de Iconoclasistas focaliza en las prácticas de mapeo colectivo. Este punto se retoma en el capítulo 2 al referirse a cartografiado cultural.

${ }^{59}$ El casi permanente ejercicio de escritura y la edición de materiales impresos (libros, cuadernillos, revistas, folletos de intervención) son dos características de La Grieta que diferencian a este colectivo del resto de las experiencias analizadas en la tesis. Aunque -como se referirá en el momento que se indague en profundidad en este grupo- en los últimos años esa producción textual y editorial ha disminuido "como colectivo", y si se han editado publicaciones específicas de varios talleres o de integrantes individuales. Como reflexión se podría decir que la pulsión editorialista se ha mantenido en La Grieta pero ha disminuido el discurso público urgente, el texto de intervención político-cultural que caracterizó a gran parte de su experiencia principalmente en los 90' y primera mitad de los años 2000. El otro colectivo local que también ha realizado abundante producción textual fue Luli -abundante teniendo en cuenta que el grupo existió solo durante dos años y medio-. Esa producción fue principalmente digital-virtual (aunque pusieron en circulación varios materiales impresos pero que eran, por lo general, piezas gráficas de sus intervenciones). Sus reflexiones se volcaron por plataformas como el blog y el perfil de Facebook, y en dispositivos comunicacionales que iban del mapa conceptual al collage visual, del gráfico al post.
} 
argentino (....) han construido sus poéticas y enunciados artísticos en el camino a una reformulación del espacio urbano" (De Rueda, 2003: 9-10)

Como observación global de estos trabajos "locales" se reconoce que se trata de un conjunto heterogéneo de trabajos inscriptos en la historia del arte que llevan adelante un ejercicio de análisis descriptivo de acciones y se interrogan sobre prácticas (principalmente visuales) denominadas desde una diversidad conceptual ("vanguardia artística", "activismo artístico", "arte de acción”, "prácticas artístico-militantes" y "poéticas-políticas”). A su vez estas son concebidas en los contextos urbanos en los que se desarrollan, aunque con diferentes profundidades para pensar la ciudad y lo público. También estos trabajos buscan el anclaje de dichas prácticas en el sistema del arte: los circuitos artísticos, las instituciones del arte y sus debates específicos que estos abren. Allí es donde se relacionan con los núcleos de investigación desarrollados en la ciudad de Buenos Aires (principalmente los de Longoni, Giunta y Alonso). En este sentido, se considera que estos trabajos no realizan una diferenciación sustancial con aquellos estudios, por lo que se puede inferir que mayormente en sus análisis no relevan ciertas particularidades y diferencias de la situación "platense" en relación a este tipo de prácticas. Los trabajos con los que se puede trazar mayor diálogo en esta investigación son los de Magdalena Pérez Balbi (2012a, 2012b, 2013). Principalmente porque reponen la dimensión de lo público (y desde allí ejercitan en el análisis de las prácticas el supuesto de pensar a la web como parte del espacio público), porque consideran algunas características particulares de las prácticas locales y por último, y porque entienden al arte y a la política no como campos autónomos, sino como divisiones de lo sensible en términos rancieranos ${ }^{60}$.

Por último, cabe mencionar que existen otros trabajos que centran sus inquietudes en las "culturas urbanas" y en las inscripciones culturales que se realizan en la ciudad, cuestión que los relaciona con la próxima trama de antecedentes. Allí se encuentran principalmente trabajos que estudian las prácticas del graffiti, el stencil callejero y otras intervenciones en grandes urbes. En ese campo, Claudia Kozak, a través de varios trabajos de investigación empírica desde líneas de investigación que cruzan arte, tecnologías y culturas urbanas,

\footnotetext{
${ }^{60}$ Asimismo, dentro de los estudios que han indagado en prácticas de intervención situadas en La Plata encontramos dos trabajos de Chempes $(2008,2009)$ que también dialogan con esta investigación. Planteados más cerca de los estudios comunicacionales y visuales que de las conceptualización de las historia del arte, en estos trabajos se documenta e indaga sobre la utilización de los recursos de la producción cultural en las movilizaciones por la aparición con vida de Julio López y en los reclamos de justicia por el femicidio de Sandra Ayala Gamboa. Se analizan las formas de visibilidad de dichos reclamos y los contrapuntos entre los discursos de los medios hegemónicos y los medios alternativos de la ciudad.
} 
construyó una categorización y clasificación -sobre todo- de las acciones de grafiteros en CABA con la intención de mostrar ciertas transformaciones en el campo de lo "verbalartístico" en el marco de la "cultura mediática" y relacionadas al campo de las subculturas juveniles. En su planteo: "se descubren como poderosos lenguajes que hablan en silencio pero con insistencia. Lenguajes empecinados, saturados, a los que no siempre se presta[n] ojos más allá de la rápida mirada distraída, no involucrada" (Kozak, 2004: 10) ${ }^{61}$. Para la autora se trata de acciones que se proponen desnaturalizar la ciudad. El contexto y superficie de estas intervenciones es lo que Kozak llama "ciudad artefacto", que lleva consigo las inscripciones simbólicas ${ }^{62}$.

Todas estas reflexiones e investigaciones que reseñamos en este apartado resultan relevantes para entender el escenario de la producción cultural y artística contemporánea. Sin embargo, en esta investigación no se tomará al arte y a las prácticas artísticas como dato previo para tipificar allí las acciones e intervenciones que sucedieron en la ciudad de La Plata, ni tampoco se tiene la intención de re-situarlas dentro del campo de arte (contemporáneo, conceptual, político, latinoamericano, local), su historia y sus narrativas. Consideramos que en las prácticas que se toman para ésta investigación, "lo artístico", la idea de "obra" y la figura del "artista" se presentan y representan de modos muy diferentes, por lo que se indaga en esas diferencias y se atiende a las modalidades de enunciación y de acción de los actores implicados. Al plantearnos aportar a una analítica de la cultura preferimos utilizar los conceptos de intervención cultural y de producción cultural, que se han problematizado en la introducción y se retoman en el capítulo 2.

\footnotetext{
${ }^{61}$ También cabe mencionar a los trabajos emprendidos por Guido Indij (2011a, 2011b; 2011c) que registran y compilan "intervenciones urbanas", como el stencil-graffiti y el street art -también en ámbito porteño- que surgieron en momentos críticos y de intensa protesta social hacia finales de 2001. Allí se plantea que en esa clase de momentos de ruptura la "producción artística se incrementa de manera directamente proporcional". A su vez, que las manifestaciones artísticas se desplazaron de las galerías a espacios más públicos, como puede ser el espacio urbano (Indij, 2011a: 15). Para el autor, en poco tiempo se ha "asistido al redescubrimiento, popularización e institucionalización del stencil graffiti, una de las formas de intervención urbana más interesantes y actualmente la más popular y creativa de la Ciudad de Buenos Aires". Es así que esta técnica y expresión popular vulnerable "por el blanqueo" ha sido cooptada por diferentes emprendimientos -políticos, corporativos, publicitarios-.

${ }^{62}$ Para esta autora "la ciudad moderna ya había nacido herida y las contemporáneas difícilmente podrían desconocer esa marca en el orillo. La ciudad artefacto lleva inscripto el graffiti como cualquier otro artefacto técnico lleva inscripto su propio accidente, su propio efecto no deseado." (Kozak, 2009). En un reciente volumen colectivo, la autora y su equipo se proponen documentar e indagar en las prácticas artísticas que introducen a las tecnologías en su producción. Por medio de una serie de entradas -de campos, géneros y conceptos- construyen un "archivo blando e incompleto" de arte y tecnologías que pone el foco a las "tecnopoéticas argentinas" (Kozak, 2012). De ese archivo son de interés la mirada de lo digital no solo como una superficie del mundo electrónico sino además del terreno del arte. También las entregadas sobre "guerrilla de la comunicación", "performance", "nuevos medios", entre otras.
} 
Al realizar una primera descripción de las experiencias culturales que se toman en la tesis, se puede observar que, en algunos casos, estas categorías de "arte", "obra", "artista", son parte de sus "conceptos nativos", es decir, de sus "repertorios" de enunciación-acción y se reconocen en las prácticas ligadas al arte. En otras experiencias se presenta una negación intencional por no inscribirse en estas formas de prácticas, al buscar desplazarse continuamente del anclaje, no sólo del campo de "lo artístico", sino de cualquier definición cerrada o delimitada sobre sus prácticas. Sin embargo, podemos plantear que la mayoría de los colectivos y productores seleccionados no se entienden o definen como "artistas" ni que conciben sus prácticas y acciones como "obra" y "arte", sino que más bien participan de un juego incesante de tensiones y desplazamientos respecto de estas nominaciones "totalizadoras", en procura de otros modos de posicionamiento en el mapa cultural local. Aunque, con varias reservas y reparos, se puede decir que varios de los grupos e interventores conocen lo que son las prácticas artísticas, sus procedimientos y algunas de las reglas del campo cultural-artístico, tanto por sus diversas trayectorias formativas -que incluyen carreras, espacios y talleres ligados a la formación artística- como a ciertos los circuitos por donde se mueven; se trata de un conocimiento desigual, no equivalente entre las experiencias analizadas. La sospecha es que -al menos en el principal período de indagación- las apuestas y búsquedas de estos colectivos no se movilizan por las preocupaciones del y hacia el arte, así como las redes de relaciones que cultivaban no son principalmente artísticas sino de otro tipo $^{63}$.

Varios de los trabajos reseñados en este apartado colaboran para afirmar algunas cuestiones que serán de utilidad para configurar analíticamente el campo de la producción

\footnotetext{
${ }^{63}$ El Grupo La Grieta y la propuesta de la Muestra Ambulante (en una constante apuesta por el cruce y el contrapunto de disciplinas artísticas y literarias con la vida cotidiana), el Colectivo Siempre (al entender la danza y la performance dentro del campo del arte) y Luxor (desde una economía discursiva que habla de "la obra" y "lo bello" que busca, como el propio interventor ha planteado, "embellecer la ciudad y los barrios" desde la idea de "obra") son las tres experiencias donde podemos encontrar explícitamente búsquedas por lo artístico-estético y por entender a sus acciones como "prácticas artísticas" ligadas a intervenciones en y con lo público, lo social y lo político. En Arte al ataque lo artístico se presenta diseminado sin encontrar una especificidad: hay principalmente una reivindicación sindical del arte (al entender a "las artistas como trabajadorxs de la cultura") y una intervención explícitamente política (en articulación con una organización política determinada, el FPDS). En Sienvolando, Unidad Muralista Hnos. Tello y Luli se encuentra sobre todo un uso permanente de recursos artísticos, estéticos, comunicacionales y visuales sin una articulación explícita por "nominar" esas prácticas como artísticas, incluso a veces se la niega ("no hacemos arte", "no nos consideramos artistas"). Las derivas de los lugares de enunciación son diversas en cada colectivo y momento de su trayectoria: desde una explicitación de la acción política colectiva (fuertemente marcada en Arte al Ataque y en Los Tello, y a veces o en menor medida en Sienvolando, Siempre, La Grieta y Luxor) hasta el juego con su reverso, pleno de tensiones, que se mueve continuamente de lugar ("no hacemos arte", "no somos artistas", "no hacemos política", "es una acción política con elementos estéticos" en Sienvolando), pasando por un devenir situacional ("vamos siendo", "somos en las redes") y la apertura de interrogantes y acciones sobre la "esfera pública" a partir de dispositivos y estrategias de comunicación (ambas en Luli). Estas cuestiones se presentan con mayor desarrollo en los capítulos 3,4 y 5 y parte del 8 .
} 
cultural contemporánea, y particularmente servirán en la indagación de intervenciones culturales que son objeto en esta tesis. Entre estas cuestiones, destacamos:

a) la importancia de la "producción colaborativa" de/en las prácticas culturales y artísticas contemporáneas. Esto no implica solo personas reunidas por un objetivo común, sino una actividad de producción común (toma de decisiones, debates, negociación, creación, puesta en acto). Una perspectiva que además lleva, en muchos casos, a proponerse e implicar efectivamente a otros sujetos ("públicos", "espectadores ocasionales", "transeúntes", "militancia", "sujetos más allá del cerco militante", "vecinos", “comunidad" etc.) en el proceso y desarrollo de acciones culturales. Se borra así la idea de un único sujeto creador de obras y prácticas.

b) las "formas experimentales" en las que se sumergen y despliegan las prácticas culturales: lo que lleva a cruzar en su hacer el trabajo intelectual y la producción cultural y artística-: una praxis de reflexión y acción compleja. Pero también, a llevar adelante a una exploración creativa, crítica y productiva con los materiales, géneros, formatos, soportes y lenguajes del arte, la comunicación, la publicidad, las tecnologías.

c) las relaciones / articulaciones / nexos imbricados entre el "arte" y la "política", “cultura” y "política". Muchos de los autores parten de idea que no se trata de una dicotomía y discuten las formas tradicionales de la historia del arte que los ha tomado como elementos a priori ajenos entre sí o que se repelen. Sin embargo, el reconocimiento de un nexo, de una imbricación -en las que muchas veces son términos que se yuxtaponen, solapan, complementan- no omite la complejidad de la relación ni los modos de análisis que se han propuesto desde las ciencias sociales -que en mayor medida operan desde la división de esferas, campos y zonas de actividad-. Lo que podemos reconocer de esa relación entre arte y política -o mejor, como pretendemos tomar aquí, entre cultura y política- es, por un lado, una "criticidad" hacia los poderes establecidos (que puede derivar en movimientos alternativos u oposionales) y, por el otro, las búsquedas por construir nuevos "modos de subjetividad" y "vitalidad" a través de formas creativas y sensibles: decibles, visibles y de pensar.

\section{I.b. "Los sentidos de ciudad"}

Lo urbano y la trama urbana, si bien tiene una presencia periférica en los programas académicos, han ganado terreno en la investigación social en los últimos tiempos. En el campo latinoamericano de la investigación -y especialmente al relevar los objetos de estudio de la investigación en comunicación y los estudios socioculturales-, la problemática de la ciudad y sus apropiaciones ha tenido un desarrollo interesante y fértil. De este modo, se han 
producido interesantes investigaciones a partir de objetos novedosos como la ciudad y sus sentidos, los imaginarios urbanos, las trayectorias y apropiaciones de los sectores populares en el espacio urbano, las nuevas grupalidades e identidades (juveniles, de género, sexualidades disidentes, etc.) que se producen en la ciudad. Algunos estudios han acentuado la mirada en la producción de sentidos y la comunicación para pensar las reformulaciones de la hegemonía y la particular modernización de América Latina (Martín-Barbero, Reguillo, García Canclini, González, Silva). Otros trabajos anclan la mirada en el estudio de las identidades que se construyen y se tensan en la vida urbana (la "ciudad letrada", pero fundamentalmente en las "infiltraciones" populares), al buscar comprender los usos, recorridos y "sentidos de experiencia de la ciudad", tanto desde la historia cultural urbana (Gorelik) como desde la antropología urbana (Carman, Chaves, Segura, Lacarrieu, García Canclini, Reguillo). Todos estos estudios atienden a las peculiaridades, particularidades y conflictos de Latinoamérica y sus ciudades, su vínculo con los “contextos” globales y su ubicación en el mundo contemporáneo. A la vez, reconocen a la ciudad como una trama socio-cultural que se construye en sus diferencias y sus desigualdades y se pondera sobre todo una "perspectiva del habitar". Así en diferentes investigaciones y escritos, la ciudad y lo urbano se encuentran -como problemática, producto sociocultural, sentidos, usos y vida cultural- atravesada por otras manifestaciones que la constituyen y que se conformen en la ciudad: las culturas populares, los imaginarios urbanos, las culturas juveniles, las identidades culturales, las formas de socialidad, grupalidad y vecindad, los movimientos sociales urbanos, las memorias, la historia, las prácticas estéticas, los conflictos sociales, étnicos, de género y de clase, etc.

Según Jesús Martín-Barbero, hablar de la ciudad latinoamericana, implica pensar en una "heterogénea trama sociocultural" (1996a, 2004). En tanto que, al repasar los objetos de estudio de la comunicación y los estudios culturales, plantea que la ciudad:

\footnotetext{
“ocupa hoy un lugar estratégico en el cruce de los debates teóricos con los proyectos políticos, de las experimentaciones estéticas y las utopías comunitarias. Lo cual nos está exigiendo un pensamiento nómada y plural, capaz de burlar los compartimentos de las disciplinas y convocar los diversos lenguajes de las ciencias y las artes, confrontar la índole de los diferentes instrumentos descriptivos e interpretativos integrando saberes y sabores, ideas y prácticas: la comunicación con el drama urbano, la música con el ambiente y el paisaje, la arquitectura con los trayectos y los relatos, el diseño con memoria y la ciudad". (Martín-Barbero, 2009: 64).
} 
Por su parte, Rossana Reguillo (1991, 1997, 2000a, 2000b, 2005, 2012) ha indagado sobre la ciudad y el espacio urbano en varios de sus trabajos. La autora encuentra que ciertos asuntos considerados "pequeños" se imponen en el debate, entre ellos:

"la investigación sobre la ciudad, sobre sus trazos, sus edificios, su historia y sus historias, sus batallas cotidianas, sus pequeñas victorias, su gente, que no es sólo un dato estadístico pues también nombra, usa, marca, se apropia de la ciudad. Ciudadanos que ante la globalización de la economía, ante la cultura-mundo, le sacan la vuelta al poder generando nuevas respuestas, conectando la experiencia local con lo universal, estableciendo nuevas redes de relaciones" (Reguillo, 2005: 22).

De este modo, Reguillo entiende que el análisis de la ciudad no se puede agotar en el estudio del espacio, ni en las cifras ni en las decisiones o discursos institucionales, pero tampoco de forma aislada en las acciones ciudadanas. En toda su opacidad y complejidad la ciudad "es estructurada por los actores sociales al tiempo que éstos, como actores históricamente situados, son estructurados por ella." (2005: 22) Es una “construcción simbólica, dinámica, conflictiva, estructurada y estructuradora de los sujetos sociales" (2005: 472). Así es que le interesará indagar en el espacio urbano los "procesos simbólicos mediante los cuales los actores entienden 'su' ciudad, la nombran, se la apropian, la transforman, la segmentan, en una palabra la construyen simbólicamente para exorcizar el peligro, reducir la incertidumbre y dotar de sentido al conjunto de sus prácticas.” (2005: 471) A su vez, la autora reconoce que en un contexto de hegemonía mediática en la construcción de sentidos sociales, los movimientos sociales deben construir estrategias de "visibilidad" en los medios de comunicación para que sus demandas tengan resonancia en la "opinión pública” por medio de la "dramatización del conflicto"; cuestión que muchas veces trae aparejado que se desdibuje el proyecto y caigan rehenes de la espectacularización creciente del drama -político, cotidiano, contemporáneo- que producen los medios (Reguillo, 2000b: 83-84) ${ }^{64}$.

\footnotetext{
${ }^{64}$ De este modo, ya no alcanza con la escenificación de un drama o conflicto en el espacio de la ciudad, sino fundamentalmente en el espacio mediático. "Nos guste o no, hoy la sobrevivencia de cualquier movimiento social pasa por su capacidad de mantenerse en el debate, en ese espacio público que como ya sabemos ha sustituido el encuentro cara a cara, la reunión en la plaza, por esa compleja red de portavoces 'autorizados' en que se han convertido los nuevos medios de comunicación. (...) Muchas críticas pueden planteársele a esta lógica que parece estar trastocando la(s) formas tradicionales de hacer política; sin embargo, en la misma medida en que resulta necesario hacer su crítica, resulta fundamental no ignorarla, en tanto distintas evidencias señalan que a mayor visibilización menor vulnerabilidad o mejores posibilidades de impulsar en una cierta dirección un acontecimiento. (...) El lenguaje de los medios (...) se constituye hoy en una herramienta necesaria para la sobrevivencia" (Reguillo, 2000b: 83).
} 
Jorge A. González desde su propuesta de los "frentes culturales" entenderá que una ciudad además de ser muchas cosas -cemento, viviendas, etc.- "significa" y se hace dos interrogantes: ¿Cómo es que se construye socialmente ese "significado”? ¿Cómo estudiar la construcción de sentidos en la ciudad?. Este autor parte del supuesto de que

\begin{abstract}
"en una ciudad con desigual distribución del poder y la riqueza, coexisten modos de construcción y reinterpretación semiótica, no sólo diferentes sino también desnivelados entre sí. Esto delimita 'usos' y 'significados' distintos de la misma unidad social y significante que se encuentran enraizados en todas partes, en todas las relaciones y en particular en la organización de la vida cotidiana 'urbana'. Pero, ¿hay algo que sea particular o específicamente urbano?, ¿algo que todas las clases sociales citadinas compartan?” (González, 1994: 88).
\end{abstract}

Para este autor, el punto de vista metodológico privilegiado será el ideológico, por sobre otras unidades de análisis como el político y el económico. Desde este recorte se puede comprender que existen estructuralmente en una ciudad distintas situaciones sociales que implican distintas representaciones sobre los significados de la ciudad, lo que funda el principio de la distinción. Parte de su propuesta de "cartografiado cultural" fue de utilidad para el planteo de la perspectiva metodológica de la tesis, que será presentado en el próximo capítulo.

Néstor García Canclini (2008) a partir de su conceptualización de las "hibridaciones" de los procesos socioculturales y al considerar la peculiar y compleja modernidad latinoamericana, entiende que, sobre todo, las grandes ciudades y las fronteras entre países son contextos y entidades sociales que auspician y condicionan la hibridación, así como los mayores conflictos sociales y la creatividad cultural (2008: 22). Así se pregunta:

“¿Cómo hablar de la ciudad moderna, que a veces está dejando de ser moderna y de ser ciudad? Lo que era un conjunto de barrios se derrama más allá de lo que podamos relacionar, nadie abarca todos los itinerarios, ni todas las ofertas materiales y simbólicas deshilvanadas que se presentan. (...) ¿Cómo estudiar las astucias con que la ciudad intenta conciliar todo lo que llega y prolifera, y trata de contener el desorden (...)?" (García Canclini, 2008: 37) ${ }^{65}$.

\footnotetext{
65 Una de las líneas de análisis culturalista que desarrolla Canclini para pensar la ciudad es en relación a los "imaginarios urbanos": es decir, sobre las formas en que los habitantes le otorgan sentido a la ciudad entre los hechos y las ficciones. Tiene como premisa que las ciudades son lugares para ser habitados y también para ser imaginados. "La ciudad se vuelve densa al cargarse con fantasías heterogéneas. La urbe programada para
} 
Este autor ha intentado describir los procesos de comunicaciones masivas que suceden en la sociedad contemporánea y que no se pueden anclar solo territorialmente. De este modo, lo urbano se ve modificado tanto por la ciudad material como por la "ciudad comunicacional" (García Canclini, 1996).

Desde los aportes de Adrián Gorelik (2004, 2007, 2010) -en su cruce entre historia de las ideas e historia cultural urbana- se puede entender al espacio urbano como objeto de disputas, protagonizadas por actores sociales diversos/desiguales, en un proceso que se ha denominado apropiación del territorio. Pero esa disputa de la ciudad no sólo se produce en una dimensión material sino que implica una dimensión simbólica; es decir que la postulación de ciertas narrativas está enredada en la disputa de la ciudad misma. Existe una dialéctica entre la ciudad representada/narrada y la ciudad vivida/practicada: "la ciudad y sus representaciones se producen mutuamente. No hay ciudad $\sin$ representaciones de ella, y las representaciones no sólo decodifican el texto urbano en conocimiento social, sino que inciden en el propio sentido de la transformación material de la ciudad." (Gorelik, 2004: 13) De este autor también cobra interés la problematización y complejización de la relación entre el espacio público y la ciudad. Una relación que -entiende- simplificaron tanto la teoría urbana al pensar al primero como mero espacio abierto de la ciudad, pero también las teorías del espacio público al dar por supuesto "la conexión entre espacio público urbano y esfera pública política" (Gorelik, 2010: 20). El autor entiende que:

\footnotetext{
“tal vez por su ambigüedad constitutiva, no existe una teoría que guíe el análisis en su producción mutua, la peculiar unidad de forma y política implícita en tal reciprocidad. (...) Vamos a considerar al espacio público como el producto de una colisión, fugaz e inestable entre forma y política." (Gorelik, 2010: 20)
}

La importancia de las narrativas en la configuración del espacio público y la disputa de las ciudades también ha sido remarcada por María Carman (2006; Carman y Janoschka, 2014). En su investigación doctoral, inscrita en el campo de la antropología cultural y urbana, plantea que

funcionar, diseñada en cuadrícula, se desborda y se multiplica en ficciones individuales y colectivas" (1997: 107). Armando Silva (2006) es uno de los que ha iniciado esta perspectiva de estudios sobre "imaginarios urbanos" dentro de los estudios culturales en América Latina. Para una discusión y crítica sobre los propósitos y las limitaciones de estos estudios, por ejemplo, en su incorporación a la política urbana ver Gorelik (2004: 259279). Este autor cuestiona a la propuesta de Silva sobre los imaginarios y recorta positivamente a los estudios emprendidos por Canclini. 
“determinados proyectos urbanos pueden comprenderse no sólo fundados y anclados únicamente en lo físico, arquitectónico y urbanístico, sino también a partir de la imposición de un relato que procura unir espacios y prácticas espaciales, exaltando algunos puntos de la ciudad en detrimento de otros, y legitimando ciertos recorridos en función de un proyecto escogido como modelo de ciudad ideal" (Carman, 2006: 139).

De este modo, la problemática urbana y los "sentidos de lugar" aparecen en constante tensión y disputa entre los proyectos urbanos (donde se define un orden sobre los sujetos dignos de "merecer la ciudad" que produce violencia simbólica) y los usos que de determinados espacios de la ciudad realizan los pobres urbanos ${ }^{66}$. A su vez, según la indagación de esta autora la referencia a la "cultura" es un activo presente para conseguir la revalorización de los barrios "obsoletos"; este proceso -muchas veces impulsado por el Estado- pone en valor los lugares y su autenticidad para que las fuerzas dominantes del mercado las gestionen en su provecho ${ }^{67}$. En sintonía con estos planteos se pueden reconocer los trabajos antropológicos que indagan en el "sentido de experiencia del lugar", principalmente en los contextos locales de las ciudades contemporáneas, marcados por disputas y tensiones entre diferentes sectores sociales urbanos. Por ejemplo, en relación a la relocalización de asentamientos en Buenos Aires y a la planificación urbana que produce procesos de segregación (Lacarrieu, 2016).

Por su parte, Ramiro Segura (2010, 2013, 2014, 2015) -desde un recorrido que incluye antropología cultural y urbana y estudios culturales- ha realizado trabajos reflexivos y de investigación empírica desde la etnografía sobre la problemática urbana. Ancla su preocupación en las formas de acceso, regulación y exclusión, así como en las representaciones, experiencias, recorridos e interacciones de los sectores populares que "habitan la periferia" (en su caso de estudio, sectores populares del barrio Altos de San Lorenzo del partido de La Plata, que el autor denomina "espacios segregados" o "sectores urbanos segregados"), que se traducen a una "apropiación diferencial de la ciudad" (Segura, 2013: 18). En su investigación doctoral, el autor se propone "indagar el lugar que el espacio

\footnotetext{
${ }^{66}$ Resulta necesario en este punto hacer mención de uno de los trabajos fundacionales en los estudios sociales sobre la ciudad y sus problemáticas, producido en la Argentina: Oszlak, Oscar. (1991) Merecer la ciudad. Los pobres y el acceso al espacio urbano. Buenos Aires, Humanitas.

${ }^{67}$ En el caso de esta investigación, se trata de ocupantes ilegales del barrio Abasto en Buenos Aires que "toman casas", en momentos en los que el Mercado deviene shopping y el tango y la figura de Gardel se constituyeron como patrimonio inmaterial de la ciudad, recursos que desde la cultura ayudan a crear al ese barrio como "un lugar fuera de lo común". Así, el Abasto forma parte, junto a otras zonas, de un recorrido y una política de lugares para incrementar el valor cultural de la ciudad (Carman, 2006).
} 
ocupa como condición de posibilidad y condicionante de la experiencia social, así como el papel de dicha experiencia en la construcción social del espacio urbano.” (Segura, 2010: 1) Para esto parte de un postulado general (lo público es la puesta en práctica de un lugar) y de una posición teórico-política (la necesidad de no idealizar el espacio público, y al mismo tiempo, de retenerlo como una herramienta de crítica del presente). En su planteo la "experiencia urbana" "remite a los modos (eventualmente diferenciales) de ver, hacer y sentir (la ciudad y la vida en la ciudad) por parte de actores situados social y espacialmente." (2010: 1) Se propone entonces analizar tres dimensiones constitutivas de la vida urbana: representar el espacio, habitarlo y transitarlo. Sus reflexiones se conectan con algunas cuestiones que se plantea en la presente investigación, principalmente por los interrogantes sobre la "experiencia urbana" como espacio en el cual indagar desde las ciencias sociales. Pero también porque trabaja con prácticas situadas en la ciudad de La Plata y porque recupera los aportes de De Certeau, Delgado y Rabotnikof para pensar el espacio público.

Estos recorridos sobre la ciudad y lo urbano colaboran a densificar y complejizar el análisis contemporáneo, al situar la mirada desde la región para tener presente las situaciones y realidades de América Latina -sus formas de modernizarse, su ubicación en la globalización, los vínculos entre la cultura mediática y la cultura urbana, los traumas ante las políticas económicas, sociales y urbanas neoliberales- así como las formas de lo "local" -los modos de "estar juntos", las formas de organización colectiva frentes a dichas políticas o ante desastres en la ciudad, los modos de producción de relatos y sentidos sociales en disputa que construyen ciudades-. En relación a las intervenciones culturales, estos trabajos aportan mayormente desde una perspectiva que indaga en las formas de habitar- a la interpretación y comprensión de la trama de sentidos, discursos, prácticas y relaciones desde la que se configuran las ciudades latinoamericanas atravesadas por desigualdades, disputas, negociaciones y conflictos sociales. En este sentido, las formas de discursividad alternativas, las maneras de habitar y practicar la ciudad y los modos de apropiación del espacio urbano que realizan diversos movimientos, colectivos sociales, organizaciones ciudadanas $\mathrm{y}$, de modo más general, los sectores populares y subalternos, son los elementos destacados de estas producciones, que aquí se retoman y complejizan a la luz de los materiales culturales explorados.

\section{I.c. Los movimientos de la acción colectiva}

Si bien la sociología de los movimientos sociales producida en la región, con un fuerte impulso en los últimos quince años, ha privilegiado el estudio de la acción colectiva en torno 
a los movimientos y organizaciones sociales de mayor notoriedad pública en este periodo de desocupados, indígenas, ambientalistas, derechos humanos, inmigrantes y movimientos de reivindicaciones locales y de luchas de género-, consideramos que muchas de sus herramientas y contribuciones analíticas son de gran valor para el estudio de los colectivos, interventores y acciones culturales que tomamos para el análisis pueden ser interpretados desde algunos de los parámetros analíticos de dicho campo de estudio ${ }^{68}$.

Una manera de abordaje de la acción colectiva es la perspectiva sociológica de análisis de la realidad social contemporánea. Desde esa posición para Massimo Modonesi (2008, 2010) estamos ante la presencia de un "cambio de época" en la región latinoamericana, en el que se puede identificar un "pasaje histórico significativo" marcado por la fractura del consenso neoliberal e invita necesariamente a tomar nuevos caminos de reflexión. Plantea una interpretación de

\begin{abstract}
"la historia del tiempo presente a partir de la caracterización de la idea de cambio de época en función de la centralidad de dos fenómenos entrelazados: la emergencia de rasgos antagonistas en los movimientos sociales y el paralelo agotamiento de la hegemonía neoliberal. Este doble acercamiento pretende asentar la imprecisa idea de "cambio" en el terreno teórico de la relación entre estructura y agencia, es decir la relación entre transformaciones estructurales de la forma de dominación y la acción transformadora que impulsa u orienta esta modificación.” (Modonesi, 2008: 116)
\end{abstract}

Este autor propone, para entender a los movimientos socio-políticos de América Latina de las últimas décadas, articular tres categorías de la tradición marxista, y

\footnotetext{
${ }^{68}$ En este punto resulta necesario hacer una mención a cierto "ciclo" de luchas y protestas a escalas local/global que se desataron desde -al menos- 1994 luego de la firma del Tratado de Libre Comercio entre EE.UU. y México y el alzamiento del movimiento zapatista en Chiapas, pasando por las fuertes protestas e interrupciones que el "movimiento antiglobalización" emprendió contra las Cumbres de la OMC, el BM, el FMI, el FEM y el G8 en ciudades como Seattle (diciembre de 1999), Davos (2000 y 2001), Québec (abril de 2001), Barcelona (junio de 2001) Génova (julio de 2001) y Cancún (2001 y 2003), hasta el surgimiento y popularización del Foro Social Mundial (lanzado en Porto Alegre bajo el lema "Otro mundo es posible" en enero de 2001) y la "Contracumbre" de las Américas en Mar del Plata (noviembre de 2005). Si bien la indagación de estos acontecimientos escapa a los propósitos de la tesis, se trata de acciones colectivas que fueron innovadoras en los modos de protesta y plantearon la articulación entre grupos diversos y el uso de medios de comunicación, recursos digitales y redes virtuales (en tanto visibilización de demandas, gestión de canales y plataformas alternativas de información y construcción de formas novedosas de participación desde la comunicación). Asimismo, es en este ciclo de luchas donde se puede inscribir cierto "momento utópico" de internet y las redes virtuales. Uno de los casos paradigmáticos en este sentido es la red global de información y comunicación alternativa Indymedia, experiencia que se ha replicado en la Argentina y que tuvo un colectivo en La Plata (activo desde 2004 hasta 2013). Link: https://www.indymedia.org
} 
particularmente gramsciana: subalternidad, antagonismo y autonomía ${ }^{69}$. Según Modonesi (2010), en todo proceso se juegan esos tres elementos y se combinan de formas distintas. Pero uno de ellos es predominante, por lo que hay que ver cuál marca cada momento. En estas configuraciones entonces hay reflujos, oscilaciones, estancamientos, desmovilización y entran nuevos pasajes.

Desde un planteo similar, Maristella Svampa $(2008,2012)$ también reflexiona sobre el "cambio de época", éste se refiere, antes que nada, a la apertura de una "nueva etapa de transición" marcada por dos tendencias: aquellas ligadas a la ruptura del modelo excluyente instalado en los 90'; por el otro, aquellas que dan cuenta de una profundización del modelo neoliberal. Se trata así de una época marcada por el par ruptura-continuidad y que abre un escenario de ambivalencias en la región. En este escenario el papel que desempeñan los movimientos sociales es importante en tanto actores colectivos plurales que han ampliado su representación discursiva en relación con la sociedad y que, insertos en un campo organizacional múltiple, asumen una actitud activa en defensa de sus demandas sociales heterogéneas. En este sentido, según Svampa, la constitución de un nuevo ethos militante -por lo general, en función de su identidad territorial y de su opción por la acción directa, la defensa de una democracia asamblearia y la demanda de autonomía- y la "multiescalaridad" de los conflictos, han otorgado a estos movimientos la posibilidad de abrir nuevos espacios de participación popular.

Esta noción de acción colectiva situada en el contexto latinoamericano se puede articular con el concepto de "nuevo protagonismo social" que ya fue referido en la introducción de la tesis ${ }^{70}$. Se trata de un concepto por el que apostaron otros investigadores

\footnotetext{
${ }^{69}$ Subalternidad, en tanto condición y experiencia de subalternación, como procesamiento de la condición material, allí inicia la construcción del sujeto. La lógica del dominado que se activa en una resistencia. Autonomía, como opuesta al "subalternismo". Es el desborde, el sujeto es en tanto experimenta la emancipación y conquista de espacios de autonomía. Antagonismo, va más allá de la resistencia, oscila entre un confrontación más estructural y objetiva -que describe la confrontación entre capital y trabajo- y una noción más subjetiva de lucha de clases, es decir, de construcción de la subjetividad en el conflicto.

${ }^{70}$ Estas propuestas de análisis contemporáneo de la acción colectiva sirven para discutir a las perspectivas más difundidas de la sociología americana (guiada por un modelo estructural-funcionalista) de los movimientos sociales (entre otros, Tilly, Tarrow), para las cuales la acción colectiva es una ecualización que requiere "recursos combinados con intereses compartidos" -en la definición de Charles Tilly-. Es decir, una movilización de demandas y recursos más la oportunidad política; perspectiva que deja por fuera la construcción de tejidos sociales y subjetividades políticas, así como de cualquier planteo político o construcción política más amplia. Esta sociología americana de la acción colectiva entiende, sin embargo, la importancia de la conflictividad y de la organización "desde abajo" como potenciadores de cambios. Asimismo, se puede reconocer que la otra perspectiva con la que discute es la sociología producida en Europa (que, con sus diferencias, podemos reconocer en autores como Giddens, Beck, Lash, Touraine, Melucci), anclada en las teorías de la "identidad" y que entiende al surgimiento de los "nuevos movimiento sociales" en un "momento post político", mirada que puede llegar a eliminar el elemento conflictual de la política y se encierra en el paradigma liberal consensualista. Melucci sería un autor que toma distancia de algunas de estas cuestiones al retener el elemento conflictivo en lo
} 
sociales -por ejemplo, el Colectivo Situaciones (2002) al reflexionar sobre diversos movimientos de Argentina, México y Bolivia principalmente-; un protagonismo de nuevo tipo que abría un proceso social inédito y producía nuevos "repertorios de la protesta social", en donde lo simbólico y lo cultural adquiere un rol fundamental para el despliegue de la acción.

$\mathrm{Al}$ recuperar todos estos aportes, se propone pensar a las intervenciones culturales que se analizan en la tesis como acciones colectivas que juegan en este "cambio de época" en América Latina. A su vez, como parte de ese amplio, heterogéneo y complejo "repertorio" de las protestas sociales, que adquirieron en Argentina diferentes formas y niveles de protagonismo y desplegaron una fuerte crítica social sobre las instancias representacionales (políticas, judiciales, mediáticas, económicas). En ese sentido, se puede reconocer al estallido social de diciembre de 2001 como un "acontecimiento", que en cuanto tal produce una "mutación de la subjetividad" y la "apertura de nuevos posibles" (Lazzarato, 2006), y que sirve como situación destacada para pensar diferentes prácticas sociales y culturales, anteriores y posteriores a esos sucesos ${ }^{71}$.

\section{II. ¿Hacia una definición de las intervenciones culturales?}

Luego de haber presentado las tramas de antecedentes y debates de la investigación, en este último apartado buscamos caracterizar lo que en este trabajo entendemos por experiencias de intervención cultural. Se realiza así una aproximación conceptual-argumental sobre las intervenciones, sin pretender hacer una definición normativa ni acabada, sino con la

social y al buscar comprender la base estructural de los conflictos, es decir, orienta sus preguntas hacia el por $q u e ́$ de la acción colectiva. El supuesto sería el siguiente: en la actual sociedad occidental habitan nuevos conflictos que permiten el surgimiento de nuevos movimientos sociales. Para la mejor comprensión de estos movimientos habría que descartar el análisis marxista, ya que desde esta perspectiva el conflicto capital-trabajo pierde centralidad. Un itinerario crítico del campo temático de los movimientos sociales dentro de las ciencias sociales se encuentra en Retamozo (2010).

${ }^{71}$ Para Lazzarato las jornadas de Seattle (1999) son las que se configuraron como verdadero "acontecimiento político" que modifica las maneras de sentir: "no se soporta más lo que se soportaba anteriormente (...) La consigna 'Otro mundo es posible' es síntoma de esta metamorfosis. (Esta consigna) se limita a anunciar que ha sido creado algo en el orden de lo posible, que se expresaron nuevas posibilidades de vida y que se trata de llevarlas a cabo. Surgió la posibilidad de otro mundo, pero queda como tarea a cumplir. De este modo hemos entrado en una nueva atmósfera intelectual, en otra constelación conceptual.” (Lazzarato, 2006: 43-44). En línea con el pensamiento de Deleuze y Guattari, el autor sostiene que "El acontecimiento muestra lo que una época tiene de intolerable, pero también hace emerger nuevas posibilidades de vida. Esta nueva distribución de los posibles y de los deseos abre a su vez un proceso de experimentación y de creación. Hay que experimentar lo que implica la mutación de la subjetividad y crear los agenciamientos, dispositivos e instituciones que sean capaces de desplegar estas nuevas posibilidades de vida, recibiendo los valores que una nueva generación (que creció después de la caída del Muro, en el curso de una fase de expansión norteamericana y del nacimiento de la nueva economía) ha sabido crear: nuevas relaciones con la economía y con la política-mundo, una manera diferente de vivir el tiempo, el cuerpo, el trabajo, la comunicación, nuevas maneras de estar juntos y de estar contra" (2006: 44). 
intención de desplegar una conceptualización dinámica que se articule con otras nociones y saberes.

Como observación crítica se puede plantear que la noción de intervenciones culturales puede resultar demasiado genérica, y por lo tanto poco específica, en comparación con el esfuerzo reflexivo y los alcances de otras nociones que se han puesto en juego para describir e interpretar a ciertas prácticas culturales como las que son "objeto" de esta tesis: las anteriormente descritas "arte de acción", "activismo artístico", "arte relacional”, "arte contextual", y las más "clásicas" como "arte político" y "arte público". Sin embargo, consideramos que todas categorías son de algún modo incompletas, a cada una de ella se les "escapa algo" de las prácticas que buscan (re)presentar y nominar, por lo tanto producir e interpelar.

De este modo, aún al reconocer esta doble situación -lo poco específica y lo incompleta de la noción- se decidió tomar para esta investigación la noción de intervenciones culturales. Por un lado, para no circunscribir el sentido de las prácticas en el campo de lo artístico ni tampoco reconocerlas de antemano jugando en el territorio político (en todo caso esto implicará una deconstrucción y no una definición apriorística). Por otro, para buscar dar cuenta de lo movedizo y, a la vez, situado de estas prácticas, que la denominación de “intervención” habilita. También es un término que nos aproxima a lo finito -en el espacio y en el tiempo, en la producción de sentido y en sus disputas- de estas acciones. La idea es dar cuenta del carácter concreto, finito y a la vez contingente -condición y producto de un hacer de orden cultural- que no puede ser del todo condensado y formateado en una categoría, pero no por ello relativizado a algo limitado o insignificante. Por último, la referencia directa a las palabras "intervención" o "intervenir" se encuentra en casi todas las retóricas y los enunciados "nativos", tanto para nombrar y describir muchas de las prácticas de los colectivos (en Sienvolando, UMHT, Luli y Arte al Ataque, La Grieta), así como al momento de hablar de experiencias de intervención específicas (Muestra Ambulante, Intervención Magenta, muestra Calle Tomada, Encuentro ZigZag, Volver a habitar, Desbordes). Las palabras que juegan con la de intervención en esos enunciados pueden ser varias, pero se puede decir que se mueven en el mismo universo conceptual: intervención urbana, intervención cultural, intervención simbólica, intervención social desde del mundo de la cultura. En las experiencias analizadas, 
estas referencias a la noción de intervención son más directas y recurrentes que a las nociones de "arte activista", "activismo artístico", "arte contextual", "arte urbano"72.

Uno de los puntos de partida es entender que las intervenciones culturales actúan "en situación”, porque se escriben en una circunstancia concreta y específica en la que, se puede entender, buscan expresar una voz, construir situaciones renovadas en la vida urbana y quizá apropiarse del espacio público e -incluso- generar un “desacuerdo" (político). En este sentido, se trata de acciones situacionales, inscriptas en temporalidades finitas, en momentos específicos y concretos -esto puede tener relación con aquellas tácticas astutas, de uso y consumo, que mapeó De Certeau (2000)-.

Articulado con esto, se puede entender a las intervenciones culturales como espacios de enunciación. Es decir, como apuestas de generación de enunciados, interrogantes y cuestionamientos sociales, a través de una amplia producción discursiva que entreteje diferentes elementos, formas, dinámicas, categorías y estrategias de diversos campos de prácticas y saberes. Es decir, las intervenciones toman para sí y movilizan los repertorios de acciones y conocimientos de la comunicación social, de las artes visuales, escénicas y performáticas, del lenguaje visual y la publicidad, de las estrategias de comunicación popular y de la militancia política y social. Entonces, podríamos interpretarlas como prácticas que en situación generan espacios de enunciación (por lo general, enunciación pública y colectiva), que intentan ocupar la palabra y el espacio en un tiempo determinado, producir encuentros, descentramientos y desnaturalizaciones, plantear preguntas, llamar la atención de algo discordante que no es atendido, cuestionar o denunciar situaciones e injusticias sociales, visibilizar reclamos y demandas sociales y políticas. Entonces, puesta de acto, situada, de diferentes sentidos a partir de constituir un "régimen de visibilidad", y quizá, desde ahí reclamar un "nuevo reparto de lo sensible" (Rancière, 2007, 2011, 2014). Como mencionamos más arriba, un propósito de estas prácticas podría ser trastocar el orden de los repartos y distorsionar los discursos hegemónicos.

También se las puede entender como prácticas urbanas, ya que su desarrollo está íntimamente ligado a las formas y los espacios que comúnmente se entienden que constituyen "la ciudad": la calle, las veredas, los muros, las plazas, los lugares estatal-institucionales. Pero también porque las intervenciones son prácticas insertas en la "cultura urbana", es decir, por jugar en el espacio de "lo practicado" que configura lo urbano, son parte de la "experiencia

\footnotetext{
${ }^{72}$ Una de las primeras aproximaciones a esta definición de las intervenciones culturales se puede encontrar en la ponencia colectiva presentada en el XII Congreso de ALAIC (López, Badenes, Saurio, 2014). Sin embargo, en la tesis se realiza una caracterización más amplia y exhaustiva.
} 
urbana". En este sentido es que tensionan las formas instituidas de circular y movilizan formas renovadas de habitar la ciudad. Al construir un enunciado con cierta interpretación analítica, las intervenciones culturales serían entonces parte de las heterogéneas prácticas que, frente a la "ciudad concebida", buscan construir una "ciudad practicada" (De Certeau, 2000; Delgado, 2007a), es decir, se mueven entre las acciones diversas que activan y practican la ciudad, unas "formas insolentes de apropiación del espacio urbano" (Delgado, 2007b). Sin embargo, se operaría una reducción si se las piensa únicamente como "intervenciones urbanas" con un anclaje únicamente territorial, en parte, por el siguiente punto que las vincula con los usos tecnológicos y de las redes virtuales ${ }^{73}$.

De este modo, en muchos casos, se presentan también como prácticas virtuales. Es decir, que implican acciones que utilizan recursos, dispositivos y elementos de internet y las tecnologías digitales para producirse o que hacen proliferar su intervención a partir de la web; lo que podríamos denominar provisoriamente "acción web" o "acción para la web" (López, 2011, 2014, 2016a; López, Badenes, Saurio, 2014; Pérez Balbi, 2012a, 2012b). Acciones que plantean "usos" novedosos y creativos de la web, apuestas que "buscan tomar y hacer de la web un espacio público virtual, espacio que amplíe las posibilidades de interacción e intervención cultural, política y comunicativa" (López, 2014: 325) ${ }^{74}$. En muchos casos, se trata de acciones que intervienen en y se apropian del espacio urbano y del espacio virtual, y producen en ese cruce un novedoso entendimiento y reconfiguración del espacio público. Varias de las experiencias que se analizan en este trabajo entienden que no alcanza con la toma u ocupación del espacio urbano para visibilizar y legitimar una demanda -el espacio de "la calle" y la plaza pública frente a los centros de poder como expresión fundamental y

\footnotetext{
${ }^{73}$ Tampoco sería conveniente denominarlas como "arte urbano" / "arte callejero" o "street art" -actualmente tres términos ya canónicos en la interpretación que los medios de comunicación tradicionales hacen de algunas prácticas culturales-, porque opera más como rótulo de segmentación (de estilo gráfico, de cierto tipo de grupalidad juvenil, de consumo de indumentaria, de circuito turístico y de marketing), antes que por densidad descriptiva. Si bien suelen ser "representativos" de algunas estéticas y formas de grupalidad (graffiti de nueva escuela, usos de varios recursos visuales, organización en $\mathrm{crew}$ ), a los efectos de esta investigación limitaría la interpretación de las prácticas que aquí se indagan, por más que se suele decir que el "street art es mucho más que graffiti", un concepto más englobador donde entrarían prácticas heterogéneas que suceden en la calle, desde los recursos visuales -el stencil, el mural, el graffiti-. Asimismo, estas categorías no serán tomadas en la investigación, porque no son denominaciones utilizadas en las prácticas analizadas y, en varios casos, son hasta nombres rechazados por los/as entrevistados/as. En el capítulo 7 se indaga sobre el modo en que los medios de información locales toman este concepto de arte urbano y street art como sinónimo de "embellecimiento de la ciudad" y como práctica de combate al "vandalismo" del graffiti o la pintada ilegal.

${ }^{74}$ Mariano Vázquez $(2013,2015)$ también amplía la caracterización de la "esfera pública virtual". Parte de entender a las tecnologías como "artefacto" o "forma cultural" -en el sentido que propone R. Williams- y plantea que: "Internet en particular, y las TIC en general, no son pensados como instrumentos neutrales, ahistóricos y aplicados a la transformación de la naturaleza; sino que son concebidos como parte de un proceso de transformación social que involucra, en mayor o menor medida, un desarrollo tecnológico donde son las condiciones histórico-sociales en las que se desenvuelven las que otorgan un sentido particular y distintivo." (Vázquez, 2013: 139)
} 
verificación de la protesta-, sino que es importante apropiarse de las diversas herramientas de la producción discursiva y simbólica contemporánea -principalmente la producción de imágenes, audiovisual y comunicacional ${ }^{75}$, así como de los espacios, los recursos y las lógicas de internet y de las redes sociales virtuales.

Además se propone entender a las intervenciones culturales -como mencionamos antes- en tanto acción colectiva, ya que involucran a personas que (se) activan por motivaciones en común y que generan participación -en las decisiones, en los recursos que eligen, en las producciones que realizan- en formas estables o flexibles de organización colectiva. Además, se inscriben en la conflictividad de una nueva situación social contemporánea, marcada por fuertes cuestionamientos de las lógicas tradicionales de representación (en la política, en la economía, en los regímenes del arte, en los medios masivos de comunicación, etc.). Con la puesta en juego de repertorios de prácticas y saberes diversos, las intervenciones culturales activan en el campo de lo político como microconflictos y ampliación de posibles, más allá de los límites formales de la política, y en muchos casos, se articula práctica cultural con demanda social ${ }^{76}$.

\footnotetext{
${ }^{75}$ El Manual de la guerrilla de la comunicación (2000) -editado por el colectivo alemán a.f.r.i.k.a.- recopila y analiza diversas experiencias de intervención simbólica y cultural. Allí se que plantea la re-apropiación, alteración y tergiversación de la "gramática cultural imperante" -y no su destrucción- como modalidad de esas prácticas que buscan realizar una crítica a las relaciones sociales de dominio en los discursos sociales y sus formas, principalmente en la comunicación cotidiana -interpersonal, publicitaria, etc.-. Mayormente en este volumen se ponderan las acciones "cara a cara" o de comunicación interpersonal en el espacio urbano como las formas de de-construir esa gramática hegemónica. La web es sobre todo pensada como forma (o dispositivo) de activar medios alternativos y contrainformación (en el sentido de agencias, centros de medios o radios populares vía streaming, prácticas que el libro no analiza). Pero casi no aparece en el sentido de usar la web para practicar otras formas de intervención desde la propia lógica de internet y sus recursos. Sin embargo, en el propio trabajo de investigación se pudo reconocer que muchas de las intervenciones seleccionadas parten de conjugar un "imaginario tecnológico" y usos concretos de las tecnologías digitales y virtuales con formas de producción cultural vinculadas a las acciones -visuales, artísticas, comunicacionales- en el espacio urbano. De este modo, varios de los grupos (principalmente Luli, pero también Sienvolando y Arte al Ataque) y las acciones indagadas complejizan y conectan los pensamientos sobre la web y la ciudad: se las entiende como recursos para la intervención y como espacios o superficies de experimentación colectiva y cultural. La utilización de los recursos y lenguajes de la comunicación permiten plantear una sospecha propositiva: ¿por qué no indagar a las intervenciones culturales como prácticas de comunicación alternativa y popular? Vilém Flusser (2015) es otra de las referencias para comprender el cambio de época respecto de la influencia y el uso de las imágenes en la producción simbólica contemporánea. Este autor plantea que se habita una nueva realidad de imágenes técnicas principalmente por la irrupción de las tecnologías digitales- en la sociedad informacional.

${ }^{76}$ Una cuestión novedosa de las experiencias culturales aquí indagadas y de ese momento de emergencia política y social en la ciudad tiene que ver con los vínculos porosos y no del todo delimitados entre las organizaciones políticas y sociales (algunos partidos políticos, la Multisectorial, colectivos autónomos y especialmente el FPDS, algunas consolidadas y otras en formación, como este último caso), y estas formas de intervención cultural. Lo que podemos barajar es que la articulación no era solamente de "adhesión" ni de subordinación (de los colectivos de intervención en las organizaciones) sino de coproducción y complementariedad, marcada, en muchos casos, por fuertes vínculos afectivos y por una posición de "tomar la iniciativa" de las experiencias de intervención. Los colectivos de intervención e interventores -principalmente Sienvolando, UMHT, Siempre, La Grieta, Luli y Luxor- no funcionaron como "brazo cultural" de grupos más amplios o de movilizaciones puntuales sino como otro actor con sus particularidades, discusiones, propuestas y formas de hacer que
} 
El siguiente capítulo se centra en las apuestas que configuraron la perspectiva de análisis cultural para indagar en las prácticas culturales contemporáneas. A su vez, se describen las etapas de la investigación, las herramientas metodológicas seleccionadas y se reflexiona sobre sus limitaciones, potencialidades y usos. Por último, también se amplía el ejercicio de reflexividad sobre la posición del investigador "implicado" en las prácticas que estudia.

interpelaron de modos crítico, afectivo y, varias veces, conflictivo a las organizaciones políticas y sociales. $\mathrm{Al}$ tomar la iniciativa, planteamos, fueron interlocutores y no meros transmisores de un discurso político o público. 


\title{
Capítulo 2
}

\section{Apuestas y derivas metodológicas para la indagación de prácticas culturales}

\author{
“"Sólo investigamos de verdad lo que nos afecta', y afectar \\ viene de afecto". \\ Jesús Martín-Barbero, citando a Antonio Gramsci, Oficio de \\ cartógrafo, 2004.
}

\section{Hacia una analítica cultural}

Como venimos señalando, esta investigación se inscribe en el amplio campo de los estudios de la cultura. Se entiende que este no es un campo disciplinario formado por un conjunto determinado de tradiciones y paradigmas teóricos y métodos, sino que se trata de "una enorme diversidad de lenguajes conceptuales, orientaciones y prácticas de investigación" (Benzecry, 2012) ${ }^{77}$. En ese marco, una de las propuestas iniciales al emprender la investigación fue plantear a la analítica cultural como una perspectiva plural que permite moverse entre disciplinas y campos de saber. Tomar prestadas categorías, nociones, modos de abordaje y construcción de objetos de la antropología cultural, la sociología de la cultura, los estudios socioculturales y el campo de estudios de la comunicación. Puede inscribirse así entre las formas plurales e "indisciplinadas" de investigar dentro de las ciencias sociales (Arias y López, 2016) ${ }^{78}$. Se entenderá a esta analítica como una perspectiva de producción de conocimientos para la comprensión de los fenómenos, las problemáticas y relaciones complejas entre cultura, política y sociedad ${ }^{79}$.

\footnotetext{
${ }^{77}$ En el texto referido Benzecry se refiere principalmente a la sociología de la cultura norteamericana. Sin embargo, en esta tesis se prefiere ampliar el ámbito de ese diagnóstico-definición a todos los estudios que indagan en la cultura.

78 "Es necesario entender lo inter-transdisciplinar en tanto constituye una apuesta por salir de los interiores disciplinares y no como un dato previo. esta mirada implica un aporte al análisis, la interpretación, la reflexión y la crítica tanto de los procesos sociales, culturales e históricos, como de las propias formas académicas e investigativas de producción de conocimiento." (Arias y López, 2016: 22-23)

79 Desde la perspectiva de análisis asumida, la cultura no puede ser entendida como un elemento "superestructural", alejado de los elementos que serían más objetivos y que comprenden la "infraestructura" de
} 
Desde allí, una de las apuestas de la perspectiva de análisis cultural propuesta es poder pasar del nivel descriptivo a la interpretación teórica de los fenómenos estudiados. Al respecto, Gilberto Giménez plantea que “un análisis puramente descriptivo que no culmine en la explicación o en la interpretación teóricamente fundada de los datos o fenómenos registrados, es un análisis que se queda corto desde el punto de vista científico." (Giménez, 1999: 129) Para entender esto recupera la propuesta de Passeron y sostiene que:

"es posible diferenciar analíticamente tres tipos de enunciados en todo lenguaje científico: a) los enunciados informativos que proporcionan datos mínimos sobre el mundo empírico; b) los enunciados que producen efectos de conocimiento, resultantes de una primera preconceptualización de la información recopilada y que permiten formular nuevas preguntas sobre la misma, y c) los enunciados que producen efectos de inteligibilidad mediante la reconstrucción sistemática de los "efectos de conocimiento" en función de una teoría. Para que una investigación alcance este último nivel, se requiere filtrar los datos a través de una interpretación teórica.” (Giménez, 1999: 129)

En este sentido, entre los objetivos de conocimiento de la perspectiva analítica asumida en este trabajo se encuentran: 1) realizar una completa descripción de las prácticas de intervención cultural acontecidas en la ciudad de La Plata a través de materiales empíricos acopiados y producidos; 2) volver operativas algunas nociones como producción cultural, ciudad, espacio público y lo político para poder analizar, interpretar y comprender las modalidades y los sentidos de las prácticas culturales (su producción discursiva, sus usos y tácticas, sus estrategias de acción, sus modos de hacer, etc.) para producir unas primeras conceptualizaciones que abran nuevas preguntas; y 3) articular esas descripciones y análisis de los materiales con una interpretación teórica -en este caso una analítica cultural- que reconozca los procesos de producción social contemporáneos, en los que la cultura es entendida como configuradora de estos.

De este modo, por ejemplo, si la ciudad no es entendida sólo como cuadrícula -si La Plata no es vista desde su "cuadrado perfecto" y las tradicionales circulaciones urbanas- sino desde las acciones que la "practican", es decir, desde las prácticas que la "habitan", se la

la sociedad. Pero tampoco puede limitarse a los sistemas de creencias, pensamientos y percepciones subjetivas, como fenómenos que se resistirían a ser operacionalizados y medidos. Estos son algunos de los "supuestos limitativos" que han inhibido el estudio de la cultura (Wuthnow et al, 1988). Para la perspectiva de análisis que se postula, la cultura es una dimensión constitutiva de la sociedad. Una de las referencias importantes al momento de plantear la construcción de una analítica cultural en la tesis, fueron los debates y las reflexiones suscitadas en el Taller de Tesis coordinado por el prof. Alejandro Kaufman en los años 2013 y 2014 (Doctorado en Comunicación - UNLP). 
“apropian" y la "hacen", tenemos allí un interesante y productivo espacio de indagación para trabajar desde las ciencias sociales, y en particular desde el análisis cultural.

En relación con lo planteado hasta aquí, la estrategia metodológica de la investigación respondió a un enfoque cualitativo orientado a la comprensión interpretativa del problema analizado. Articuló así herramientas de distintos campos de las ciencias sociales y pretendió como ya se presentó- construir una matriz de análisis cultural desde los estudios socioculturales.

\section{I.a. Ejes y dimensiones}

Partimos de asumir que toda práctica social es discursiva y que los discursos sociales también performan prácticas. Desde allí se tomaron analíticamente dos ejes de análisis: a) los discursos sociales (principalmente de los colectivos e interventores seleccionados como fuentes de primera mano, pero también de notas en los medios de comunicación locales junto con las textualidades producidas por las políticas públicas vinculadas al tema, a partir de diversas técnicas metodológicas) y b) las prácticas de los sujetos involucrados en las intervenciones simbólicas (a partir, por ejemplo, de observaciones de dichas prácticas). Ambos ejes fueron, a su vez, articulados s con dos dimensiones relacionales:

- Lo público-privado: los espacios de lo público, cómo se práctica y produce la ciudad desde las intervenciones, con qué lógicas privadas y privativas se tensionan y discuten.

- Lo institucional-emergente: Las formas de pensar y producir la ciudad desde las políticas públicas institucionales (culturales y urbanísticas) y desde las intervenciones culturales (urgencias, diálogos entre colectivos y sujetos, acción colectiva, usos del espacio urbano).

\section{I.b. Etapas metodológicas}

El proceso de investigación se llevó adelante con la combinación de etapas metodológicas tanto de trabajo de campo como de análisis. No se trató de un orden fijo de momentos sino que implicó, en algunos casos, permanentes reformulaciones y vueltas sobre los materiales y las operaciones analíticas realizadas. Una de las primeras etapas metodológicas, como parte de la perspectiva de análisis propuesta, consistió en el acopio y ordenamiento cronológico de materiales diversos: principalmente fuentes, registros y mapas. Las actividades de esta primera etapa fueron:

1) La recopilación de materiales gráficos (gran parte de ellos fueron digitalizados a través de la toma de fotografías o el escaneo) y de materiales virtuales (encontrados en la web) de los 
colectivos e interventores, que fueron valiosas fuentes de información: flyers, volantes, afiches, banner, cartillas, cuadernillos y otras publicaciones.

2) La confección de un completo archivo de registros de imágenes de las intervenciones desde el año 2006 al 2015. Para ello se realizó una base de archivos que contaba con un registro fotográfico propio (ver anexo 6), los registros realizados por los propios colectivos/interventores y un seguimiento permanente por la web (tanto en los sitios de los grupos como otras páginas que resultaron relevantes). Principalmente las imágenes de las intervenciones son de tipos referenciales y documentales. Pero también hay collages.

3) El armado de un listado con breves descripciones de las acciones, con datos de referencia y localización, ordenadas cronológicamente.

4) Se realizó una recolección de notas, entrevistas e informes periodísticos que fueron publicados en los últimos diez años (2006-2015) en diarios y revistas de tirada local, provincial o nacional que involucren a las acciones de intervención cultural (sobre todo a los diarios El Día, Hoy, Diagonales y revistas locales como La Pulseada), así como agencias de noticias y colectivos de comunicación (como Indymedia La Plata, Prensa de Frente, entre otros). También se recuperaron entrevistas previas a la investigación realizadas por el tesista (sobre todo entre los años 2009 / 2011) que fueron parte de artículos publicados en revistas y programas radiales. La principal estrategia de relevamiento de estos materiales fue vía internet a través búsquedas de "palabras clave" -tanto en buscadores de los medios mencionados como en otros buscadores web- y de algunas fechas específicas donde se tenía conocimiento de la realización de intervenciones culturales en la ciudad. Además, varias de las notas publicadas de manera impresa fueron recopiladas en un archivo personal. Los propios informantes fueron un elemento importante para construir este archivo y localizar algunas de las publicaciones en la web, ya que realizaron comentarios sobre esas notas periodísticas y aportaron materiales.

5) La búsqueda y acopio de mapas de la ciudad de La Plata confeccionados por organismos oficiales: Municipalidad de La Plata y Dirección de Geodesia e Imágenes satelitales de la Provincia de Buenos Aires.

6) La búsqueda y obtención de fuentes documentales sobre ordenanzas municipales sobre el espacio público y sobre la cultura. La búsqueda de estas normativas se realizó a partir del propio conocimiento de la existencia de varias de estas y a través de la búsqueda por medio de "palabras clave" en el sitio oficial del Digesto municipal.

Las tres primeras acciones metodológicas y la última de esta primera etapa fueron útiles para la confección del cartografiado cultural de intervenciones. A su vez, la tercera fue el primer 
paso para la producción del cuadro descriptivo de intervenciones (anexo 1). La utilización y los resultados obtenidos en estas actividades se presentan en el capítulo 3 y 4 . La cuarta actividad fue parte indispensable para la construcción del corpus de análisis de contenidos presentado en el capítulo 7. La sexta actividad fue importante para el análisis de las políticas culturales y urbanas que se despliega en el capítulo 6 .

En paralelo, pero formando parte de una segunda instancia metodológica que puede denominarse etapa de formulación del problema de investigación, consistió en la toma de decisiones sobre las definiciones y "constelaciones" conceptuales (comúnmente llamado "marco teórico") y la delimitación y alcance del trabajo (sus objetivos), presentados en la introducción de la tesis ${ }^{80}$. Así, por ejemplo, se fue constituyendo una definición abierta y compleja de "intervención cultural", atravesada con nociones sobre la producción cultural contemporánea, el espacio urbano / la ciudad y la acción colectiva con la idea de dotar a esa construcción de una perspectiva no solo conceptual sino también operativa. Algunas de estas cuestiones fueron presentadas principalmente en el capítulo 1, sintetizado en los “Antecedentes" de la investigación y corresponde a la intención de configurar una perspectiva plural y de frontera entre campos de saberes y disciplinas sociales. En este punto también fue importante la lectura y fichaje de textos y fuentes de información que abordan a la ciudad de La Plata para construir una caracterización de la misma, parte sustancial de esto se presenta en la introducción y los capítulos 3, 5, 6, 7 y 8 .

Una tercera etapa consistió en la operacionalización del problema y el diseño de la investigación. En esta etapa, por un lado, se trabajó en el desarrollo de las preguntas e interrogantes de investigación, en la delimitación de las "unidades de análisis" (las experiencias locales de intervención cultural, las políticas urbanas y culturales, las publicaciones periodísticas seleccionadas para indagar) y en la delimitación de los dos recortes temporales (2006-2011 / 2012-2015). Por otro lado, se diseñó un protocolo de entrevistas semi-estructuradas, siguiendo los núcleos de problemas de la investigación y se construyó la primera cartografía (presentada como imagen fija). Como parte del trabajo cartográfico se produjo un exhaustivo cuadro descriptivo de intervenciones culturales en el período 2006-2011, este cuadro fue una elaboración ad hoc del autor (ver anexo 1). También aquí se seleccionaron las técnicas de recolección y análisis de datos.

\footnotetext{
${ }^{80} \mathrm{La}$ "constelación conceptual" de la tesis implicó la lectura y revisión de una amplia bibliografía y literatura crítica -principalmente de corte teórico- desde campos de saber diversos. Esta constelación se encuentra sistematizada en parte de la introducción, sus referencias se encuentran en la "Bibliografía" de la tesis.
} 
Una cuarta instancia metodológica fue la etapa analítica. Se refiere al análisis de un recorte de las intervenciones culturales que resultaron más relevantes y al procesamiento y sistematización del material obtenido/producido en las entrevistas. También se terminó de diseñar la cartografía cultural, cuya versión definitiva se encuentra en un mapa virtual en la web de la investigación: http://cambiodepiel.com.ar. Asimismo, se puso a prueba y se terminó de producir el análisis de contenidos sobre publicaciones de la prensa local. La descripción y reflexión sobre esta última etapa y sobre las técnicas metodológicas utilizadas (cartografiado, entrevistas en profundidad, análisis de contenidos, etc.), se presenta en los siguientes apartados.

Si bien la presentación en etapas puede dar la idea de una investigación fuertemente estructurada y secuencial, queremos dejar en claro que la "construcción del dato y la información" correspondió a una estrategia flexible de interacción entre el investigador y el objeto de estudio. O mejor, entre el investigador y las experiencias de intervención cultural que son objeto de análisis en esta tesis.

\section{El uso del mapa: tensiones entre lo concebido y lo practicado}

\footnotetext{
"Usamos un mapa para referenciar, fijar relaciones, indicarnos dónde estamos parados, pero el paisaje se revela andando. La mirada viajera inventa coordenadas, otros rumbos. Cartografías imaginadas".

Grupo La Grieta, folleto de la Muestra Ambulante 3, 2006.
}

Se sabe que "el mapa no es el territorio". La magnitud del territorio, así como la porosidad, la movilidad y la indeterminación de las prácticas sociales en el espacio son constitutivas y renovadoras de éste. Pero también hay que comprender que el espacio no se agota en el territorio, como ya se vienen insistiendo en la tesis: el territorio es una forma del espacio. Siguiendo estos razonamientos, el espacio urbano no está concebido de antemano, es algo que no se lo puede asir de manera acabada, suturada. Lo que está concebido de antemano -siguiendo las propuestas de H. Lefebvre y M. Delgado- es la ciudad como proyección urbanística. La ciudad y lo urbano son dos cosas diferentes; si la ciudad se concibe a partir de sus límites, lo urbano son los recorridos, las formas de habitar y las apropiaciones (dispares) que no se pueden delimitar ni proyectar. Lo urbano siempre se está "haciendo".

En términos tradicionales, el mapa es una representación gráfica del territorio o de la Tierra -pequeñas extensiones de terreno para el topógrafo; grandes extensiones para el geodesta-. Es este sentido, en cuanto a una ciudad, como dispositivo cartográfico el mapa es 
una imagen fija y plana, allí no hay movimiento sino cuadrícula y lugares vacíos. Busca plasmar -aunque nunca lo consiga del todo- en una forma planoide a algo que es curvo, ondulado, movedizo, como se viene constatando en esta indagación. Este tipo de mapas es un dispositivo y una representación que corresponde a ese momento en el que se busca fijar a lo urbano en un plano, en una forma-plana, que intenta, por tanto, restringirlo en los límites y los márgenes -tanto físicos como simbólicos- de lo que es y debería ser la ciudad, así como para generar acciones (simultáneas o posteriores) para administrar y gestionar ${ }^{81}$. Por esto el mapa de una ciudad es reconocido y certificado por el Estado -pensemos en las oficinas de Catastro, en las direcciones de Geodesia o en las de Planeamiento Urbano-; éste determina cuáles son las porciones de territorios asignadas, delimita lo urbano de lo rural, certifica urbanizaciones, aprueba y regula el trazado urbanístico y los emplazamientos, dice donde existe población y donde no la hay, denomina a sus calles, caminos y avenidas, normaliza circulaciones, etc.

Sin embargo, si bien el mapa es parte de esa acción estatal que busca fijar, delimitar y gestionar la ciudad -y así también marcar los posibles recorridos que hacen sus habitantes, es decir, fijar y gestionar a lo urbano-, está continuamente puesto en cuestión, desbordado por las prácticas sociales, por sus usos y las apropiaciones diferenciales desde diferentes actores que lo emplean ${ }^{82}$. De un modo más amplio, la cartografía puede ser entendida no solo como un instrumento de una representación distorsionada.

Al rastrear la situación de la cartografía, en su objetivo de construir "mapas cognitivos", Martín-Barbero encuentra que ésta se encuentra envuelta en varias querellas actuales que la ponen en discusión. Pero también reconoce su potencial para el entendimiento de un archipiélago interconectado pero movedizo que son las experiencias y los saberes.

\footnotetext{
${ }^{81}$ Como ya se mencionó, el colectivo Iconoclasistas se dedica, entre otras acciones, al desarrollo de mapeos colectivos con organizaciones y comunidades de base. En el manual que publicó sobre "mapeo colectivo" sostiene que "los mapas son representaciones ideológicas"; su confección "es uno de los principales instrumentos que el poder dominante ha utilizado históricamente para la apropiación utilitaria de los territorios. Este modo de operar supone no sólo una forma de ordenamiento territorial sino también la demarcación de nuevas fronteras para señalar ocupamientos y planificar las estrategias de invasión, saqueo y apropiación de los bienes comunes." (Iconoclasistas, 2013: 5)

${ }^{82}$ Se asume así que la cartografía es un ejercicio que implica posiciones y usos diferentes. En tal sentido se puede dar cuanta que existen "cartografías del consumo" -las que han producido las entidades bancarias y las tarjetas de crédito y que es una forma "sutil" de control sobre las poblaciones-. Están las "cartografías de la inseguridad" -los "mapas del delito" que diariamente construyen los medios de información hegemónicos para nombrar "zonas peligrosas" y que cada tanto desvelan a algún candidato oportunista-. Existen las cartografías de Google que conjugan escala planetaria con imágenes de lugares, recorridos individuales y espacios para el ocio y el consumo. Pero también existen otras cartografías que localizan las intensidades y los propósitos de organizaciones y comunidades en resistencia. Mapeos en y para usos críticos realizados colectiva y colaborativamente.
} 
"la cartografía (...) se halla atrapada en el remolino de los apocalipsis fin de milenio que la han convertido en objeto de descalificaciones y disputas. Pues para algunos, todo mapa es en principio filtro y censura, que no sólo reduce el tamaño de lo representado sino deforma las figuras de la representación trucando, simplificando, mintiendo aunque sólo sea por omisión. Para otros, al situarse en la encrucijada de la ciencia y el arte, la cartografía se ha abierto a una ambigüedad ilimitada, ya que lo que las tecnologías aclaran en el plano de la observación y su registro es emborronado por la estetización digitalizada de su forma (...)

Y finalmente, no pocos se preguntan: ¿mapas para qué? Cuando la estabilidad del terreno, de los referentes y las medidas es socavada por el flujo de la vida urbana y la fluidez de la experiencia cosmopolita, los mapas nos impedirían hacer nuestro propio camino al andar, aventurarnos a explorar y trazar nuevos itinerarios, nos evitan el riesgo de perdernos sin el que no hay posibilidad de descubrir/nos.

Pero, ¿quién ha dicho que la cartografia sólo puede representar fronteras y no construir imágenes de las relaciones y los entrelazamientos, de los senderos en fuga y los laberintos?" (Martín-Barbero, 2004: 11).

En sentido similar, aquí se considera que el mapa en tanto recurso cartográfico puede ser algo más que un elemento de delimitación, reducción, certificación y control. Puede servir como dispositivo de conocimiento, visibilización y construcción de otras formas de experiencia y de otros relatos sobre lo urbano. En este sentido, el ejercicio del cartografiado puede contribuir para acercamiento (siempre precario, provisional, incompleto) a esas acciones movedizas que configuran y hacen lo urbano, "mapeando" prácticas inquietas que continuamente se llevan adelante en la ciudad y producen lo urbano, a esas acciones que practican la ciudad -en el sentido propuesto por De Certeau-. Entonces, el mapa puede ser útil para dar cuenta de esos desplazamientos de "la ciudad concebida a la ciudad practicada" (Delgado, 2007a) en la medida en la que:

a) se reconozcan los propios límites como recurso cartográfico -ya que muestra una cuadrícula, plantea bordes y zonas que incluso muchas veces en los hechos no pueden ser observados- que presente una imagen que no habrá que considerar "transparente" sino más bien incompleta, parcial, provisional;

b) se lo interrogue en las ponderaciones, inclusiones y exclusiones que realiza (no puede generar una sutura, un cierre: excluye y a su vez es desbordado por los modos de hacer); 
c) se lo intervenga buscando relevar y presentar dinámicas y desplazamientos de las prácticas sociales que hacen a la "cultura urbana" -y particularmente en este caso, de de las intervenciones culturales- apropiándose del territorio urbano.

Al momento de pensar y construir una cartografia cultural como parte de la investigación, uno de los obstáculos que se presentó fue el de recurrir o no a los recursos cartográficos oficiales, es decir, provistos por entes estatales. Se realizó una relevamiento de los mismos. Así, se pudo constatar que en los recursos web disponibles de la Municipalidad de La Plata se cuenta desde hace algunos años y actualmente sólo con un plano de lo que se conoce como el "casco urbano" de la ciudad". Es decir, el "cuadrado perfecto" -como también se lo llama en esa web oficial-, esa cuadrícula urbanística por la que la ciudad es conocida $^{84}$. Sin embargo, este mapa dejaba afuera (del espacio representado) a ciertas acciones que se buscan relevar en este cartografiado, ya que no contempla a los barrios y las zonas que están más allá de esa cuadrícula.

\footnotetext{
${ }^{83}$ Es llamativo cómo dicha sección del sitio web oficial se llama "Accesos y Planos" pero sólo se encuentra un plano disponible para observar y descargar que corresponde al casco urbano de la ciudad -omitiendo al resto del partido de La Plata-; y en los "accesos" se presenta un mapa de Google en el que se destaca con color rojo solamente al casco urbano. Las consultas se realizaron entre mayo de 2014 y junio 2015 sin encontrar cambios y modificaciones. En julio de 2016, con cambio de gobierno municipal mediante, la sección cartográfica oficial sigue del mismo modo. Disponible en: http://www.laciudad.laplata.gov.ar/turismo/accesos-yplanos/planodelaciudad.

En la búsqueda web se encontró otro sitio oficial, en este caso de la Dirección General de Estadística y Evaluación de Programas Especiales del Municipio, cuya última actualización es del año 2009. En esta web de "estadísticas" se encontraron tres mapas: un mapa general de todo el partido que solo muestra el casco urbano y los centros comunales (mapa que está al inicio, en el "index" de la página); otro que delimita cada centro comunal que integran el partido (Abasto, Arturo Segui, City Bell, Etcheverry, El Peligro, Gonnet, Gorina, Hernández, Lisandro Olmos, Los Hornos, Melchor Romero, Ringuelet, San Carlos, San Lorenzo, Tolosa, Villa Elisa y Villa Elvira) y lo referencia con la imagen de todo el partido; y un último mapa que detalla todo el partido con su trazado especificado, este mapa se refiere a "la construcción en La Plata" en el año 2006. Disponible en: http://www.estadistica.laplata.gov.ar/index.htm

${ }^{84}$ En la sección "Generalidades" se dice: "La Plata es reconocida por su trazado, un cuadrado perfecto con el "Eje Histórico" conservado hasta hoy en forma intacta; al igual que el diseño sobresaliente de las diagonales que lo cruzan formando rombos dentro de su contorno, bosques y plazas colocadas con exactitud cada seis cuadras." Disponible en: http://www.laciudad.laplata.gov.ar/turismo/caracteristicas/generalidades (última consulta 26/10/2016)
} 

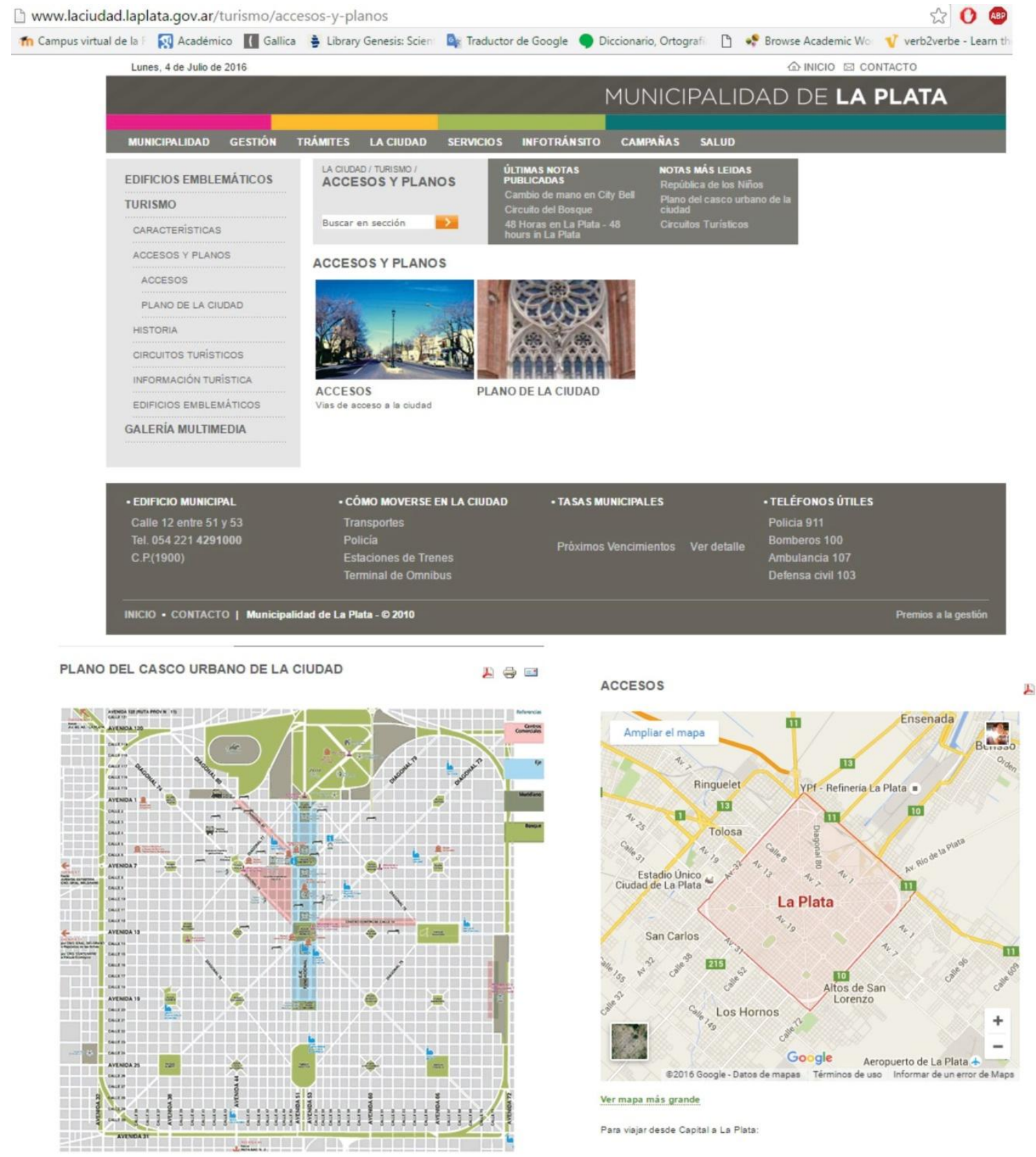

Ver mapa más orande

Para viajar desde Captal a La Plata:

Imagen 1. En el sitio web oficial del Municipio de La Plata se (re)presenta a la ciudad visualmente desde la forma-plano solamente desde el trazado y los límites urbanísticos del casco urbano. Lo que se puede objetar es que esa porción de la ciudad no es toda la ciudad. El resto de los barrios y zonas que también componente la ciudad se puede encontrar en la sección destinada a las "delegaciones". Esta manera de identificar a la ciudad desde la construcción de un plano limitado estuvo presente tanto en la gestión de Pablo Bruera (PJ-FPV) como en la actual administración municipal de Julio Garro (Pro-Cambiemos). Se trata de las mismas representaciones visuales.

En la continuación de la búsqueda de recursos cartográficos estatales se consiguieron dos mapas en Departamento Cartográfico de la Dirección de Geodesia de la Provincia de Buenos Aires, uno digital y otro en papel. Si bien eran un poco más amplios que el anterior mapa, continuaban sin mostrar de conjunto todo el partido de La Plata y presentaban sólo algunos fragmentos de la región. 


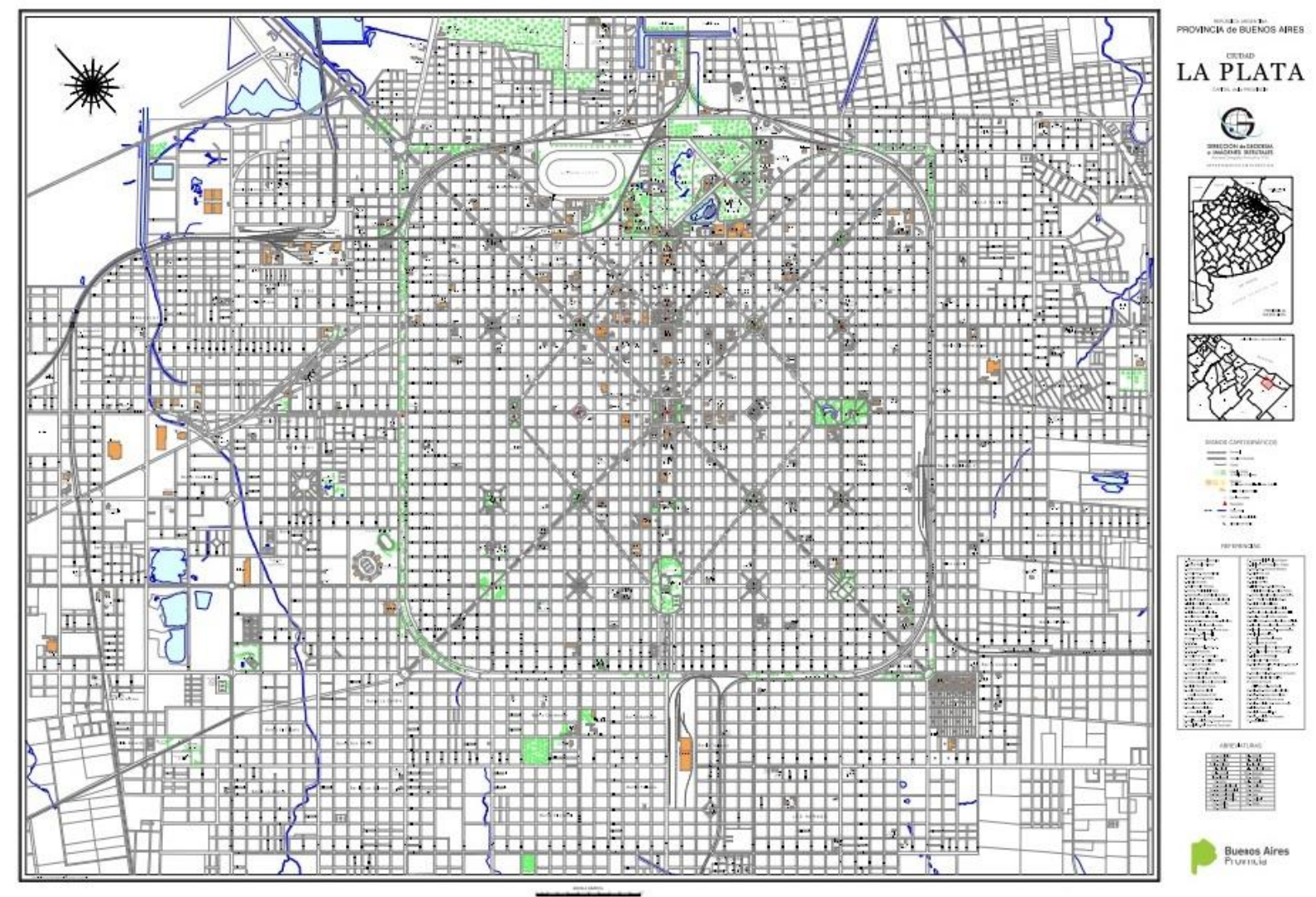

Mapa 1. Mapa del casco urbano y de los alrededores de La Plata, Departamento Cartográfico, Dirección de Geodesia e Imágenes Satelitales, Provincia de Buenos Aires.

Como se presentará de forma reducida en el siguiente capítulo, sobre el mapa "oficial" de la ciudad de La Plata, aquel que pondera el "cuadrado perfecto", se localizaron a las intervenciones realizadas entre los años 2006 y 2011 por los colectivos e interventores tomados para este trabajo (ver mapa 2). Sin embargo, finalmente se decidió producir una propia web de la investigación (http://cambiodepiel.com.ar) en la que se enlaza y utiliza la aplicación Google maps. Este programa cartográfico (online/offline) permite mayor elasticidad y dinamismo para presentar y visibilizar las acciones en el cartografiado. A su vez, es de fácil actualización, manipulación y modificación ${ }^{85}$ (por ejemplo, permite realizar cambios y mejoras; hacer desplazamientos y zoom de acercamientos o alejamientos a un mapa), que lo diferencia sustancialmente de una imagen plana con puntos de localización.

\footnotetext{
${ }^{85}$ Si bien al hablar de Google Maps se hace referencia a una aplicación que forma parte de un sistema operativo privativo (es decir, diferente a los sistemas de acceso abierto y colaborativo), Google ha tenido la capacidad de desarrollar, en su arquitectura, programas con cierta apertura y flexibilidad que permiten introducir capas, recursos gráficos y visuales, etc., todo manejados desde la nube con una cuenta básica y sin tener que bajar, instalar o comprar programas. Este punto puede hacer link con lo que ya referimos sobre el final del "momento utópico" de la web, momento que ha sido reabsorbido (¿subsumido?) a la lógica Google y de algunas redes sociales.
} 
Otra cuestión fundamental es que permite el despliegue de recursos que suman a la caracterización de un objeto, en nuestro caso de las intervenciones culturales (colocar imágenes y brindar breves textos descriptivos). Por último, es una aplicación que se puede reproducir y visualizar en múltiples dispositivos electrónicos.

\title{
III. Cartografiado cultural
}

\begin{abstract}
"Cada 'cartografía' representa una visión particular del mundo, la cual, aún cuando sea adoptada por un gran número de individuos, encierra siempre en su seno un núcleo de incertidumbre. Es, en verdad, su capital más precioso. Es a partir de él que puede constituirse una auténtica escucha del otro."

Félix Guattari, ¿Qué es la ecosofía?, 2015.
\end{abstract}

Se viene sosteniendo que la producción cartográfica está constituida por representaciones del mundo que colaboran -desde diferentes posiciones y usos- con su construcción. Elaboración de mapas, trazado de navegaciones y rumbos, la cartografía implica una conceptualización y un hacer. Es un ejercicio. Desde la perspectiva de Jorge A. González "hacer una cartografía implica necesariamente ejercer el arte de trazar un mapa" (González, 1995: 143). De este modo, el mapa:

\footnotetext{
"es un instrumento que muestra una serie de relaciones entre elementos registrados bajo un código explícito y con ello nos vuelve observable una configuración de la realidad. El mapa, objeto semiótico complejo, está hecho para significar, y en la medida que significa con precisión, nos sirve para representarnos una realidad desde un punto de vista y desde una escala" (González, 1995: 153).
}

Tomando parte de esta propuesta se buscó construir al "cartografiado cultural" como una herramienta para hacer observables las huellas de las intervenciones culturales en la morfología urbana, así como proveer materiales para fundamentar y ajustar las preguntas e hipótesis iniciales. Así se tomaron en consideración la distribución del "equipamiento cultural" de la ciudad y sus cambios, entendiéndola como espacio físico, histórico y social, para marcar la "creciente diferenciación y especialización cultural de los espacios urbanos" 
(González, 1995: 143). De esta propuesta se tomaron algunas consideraciones de las coordenadas expresivas: el campo de arte y la cultura ${ }^{86}$.

Otra referencia importante para emplear el recurso de la cartografía para la propia investigación fue la propuesta de Iconoclasistas. Para este colectivo el "mapeo" es una práctica, "una acción de reflexión en la cual el mapa es sólo una de las herramientas que facilita el abordaje y la problematización de territorios sociales, subjetivos, geográficos" (Iconoclasistas, 2013: 7) $)^{87}$.

Con estas referencias y teniendo al análisis cultural como perspectiva, emprender metodológicamente un cartografiado cultural no refiere solo a localizar territorialmente en un mapa de la ciudad (la cuadrícula urbanística) las acciones que se produjeron en determinadas coordenadas espacio-temporales. Más bien, implica construir una mirada situada en las prácticas y sus contextos de producción (comunicacional, discursiva, etc.) a fin de desplegar un exhaustivo trabajo ad hoc de mapeo y descripción de las intervenciones realizadas en la ciudad en el período indagado y, a la vez, (re)construir la trama colectiva de intensidades y flujos, apuestas y puestas en acto, subjetividades y enunciados tejida en su entorno espacial, histórico y cultural. En esta construcción se tuvieron centralmente en cuenta los enunciados, las voces y las reflexiones de los sujetos partícipes de dichas prácticas culturales -materiales construidos por medio de entrevistas en profundidad- buscando reconocer los sentidos que movilizaron y movilizan sus acciones, así como los sentidos de experiencia de apropiación de la ciudad que ellas han propiciado. De este modo, la cartografía se densifica y se vuelve herramienta propicia del análisis cultural. Al cartografiado y a las entrevistas se le sumaron otras técnicas propias del análisis cualitativo. De este modo, la observación, el análisis de documentos y de contenidos (en productos y piezas de comunicación y en publicaciones mediáticas), conforman una perspectiva de análisis apropiada, coherente y diversificada para indagar en prácticas culturales contemporáneas.

\section{Entrevistas en profundidad}

\footnotetext{
${ }^{86}$ Dentro de las investigaciones que trabajan con "cartografías culturales" cabe destacar los trabajos realizado en el proyecto de investigación dirigido por Magalí Catino "Comunicación y vecindad: memorias de la sociabilidad en barrios de La Plata" (FPyCS-UNLP).

${ }^{87}$ Para una ampliación de la propuesta del mapeo colectivo como recurso cartográfico "para procesos territoriales de creación colaborativa", así como descargar el manual y conocer parte de sus acciones, ver el sitio web del colectivo: http://www.iconoclasistas.net
} 
Juan Piovani plantea que "en las ciencias sociales la entrevista se refiere a una forma especial de encuentro: una conversación a la que se recurre con el fín de recolectar determinado tipo de información en el marco de una investigación" (Marradi, Archenti y Piovani, 2007: 215). Se trata de una de las técnicas más utilizadas en las investigaciones de carácter empírico y su objetivo primario es conocer. En particular la entrevista en profundidad puede ser definida, siguiendo a Piovani, como

\begin{abstract}
"una forma especial de conversación entre dos o más personas (...), dirigida y registrada por el investigador con el propósito de favorecer la producción de un discurso conversacional continuo con cierta línea argumental por parte del entrevistado, acerca de un tema de interés definido en el marco de la investigación" (2007: 216).
\end{abstract}

Como parte de la investigación se realizaron 30 entrevistas de tipo semi-estructuradas en profundidad a interventores culturales e integrantes de colectivos de intervención de de La Plata; de las cuales 25 entrevistas se utilizaron para la producción de la tesis (ver anexo 3$)^{88}$. El tipo de contacto para todas ellas fue personal o cara a cara. Se partía de un cuestionario con preguntas -denominado protocolo de entrevistas (ver anexo 2)-, pero con la premisa de que cada conversación tenga sus propias derivas y zonas de interés en las que se podía profundizar, sin condicionar al entrevistado/a que a que responda todas las preguntas. En la aplicación de la técnica esta propuesta abierta (con un grado de imprevisibilidad y espontaneidad propio del intercambio verbal) funcionó. Solo una de las entrevistadas pidió conocer las preguntas previamente a la entrevista pero no como una instancia de control sino para poder ir preparada con algunas respuestas, datos y materiales. Varios entrevistados pidieron que les contara brevemente -por lo general vía red social Facebook, correo electrónico, comunicación telefónica y cara a cara en alguna actividad- sobre la entrevista y sobre lo que se estaba investigando en los primeros contactos que se produjeron para concretar las entrevistas. Con otros/as esa explicación / explicitación de los objetivos de la entrevista se dieron momentos antes de concretar la conversación. Solo dos personas de las

\footnotetext{
${ }^{88}$ La mayor cantidad de entrevistas se realizaron entre mediados de 2014 y mediados de 2016. Seis entrevistas corresponden a siete integrantes de Sienvolando: Ernesto, Pili, Dani, Mariano, Lalo y Nacho y Lucía (grupal). Cuatro entrevistas a cinco integrante del colectivo Siempre: Renée, Mariana, Julia y Diana y Mariana (grupal). Seis entrevistas a integrantes de La Grieta: Fabiana, Esteban, Andrea, Daniel, Matías y Gabriela. Una entrevista a Carlos de la UMHT. Dos entrevistas a Luxor. Tres entrevistas a Luli: Ernesto, Pili y Dani. Una entrevista grupal a los/as integrantes de Arte al Ataque. Para el capítulo 8 utilizamos además dos entrevistas realizadas a Síntoma. La totalidad de las entrevistas han sido numeradas y se presentan en los siguientes capítulos con el código (E y el número correspondiente). Por ejemplo: (E 1). En varias ocasiones también se agrega el nombre del entrevistado/a para orientar al lector. Por ejemplo: (E 16, Julia).
} 
contactadas explícitamente no quisieron realizar las entrevistas (ambas integrante de la Unidad Muralista Hermanos Tello), dos más fueron contactadas pero nunca respondieron a la solicitud (integrantes de Siempre) y con dos personas se quedó en realizar las entrevistas pero finalmente no se concretaron, principalmente por cuestiones de no encontrar el espacio para juntarse (un organizador de la Muestra Ambulante y un integrante de Luli). A la mayoría de los/as entrevistados/as se los conocía previamente a la puesta en contacto para la entrevista.

Las entrevistas fueron grabadas con el consentimiento de los/as involucrados/as y duraron entre una y tres horas cada una y se buscó que se realizaran en situación de conversación. Todas fueron acordadas con tiempo con cada uno/a de los/as informantes y se realizaron en lugares donde ellos y ellas quisieron (principalmente en sus casas, también en espacios culturales y en lugares semi-públicos como bares). Solo uno de los/as entrevistados/as solicitó preservar su nombre y/o apodo y utilizar un seudónimo, con todo el resto se acordó utilizar los nombres de pila o apodos "reales" por los que son llamados/as Los/as integrantes de Arte al Ataque solicitaron ser identificados/as con el nombre genérico de grupo. La mayor cantidad de entrevistas fueron individuales, solo tres de ellas fueron entrevistas grupales, principalmente a propuesta de los/as entrevistados/as (Nacho y Lucía de Sienvolando, Mariana y Diana de Siempre y a todo el colectivo de Arte al Ataque). Varias de ellas se realizaron contando con materiales gráficos y digitales aportados tanto por el entrevistador como por el entrevistado para su discusión en el transcurso de las conversaciones. Esos momentos de revolver cajas, bolsas, carpetas y cuadernos con diferentes materiales y anotaciones o de explorar en carpetas de computadora, archivos digitales y correos electrónicos, resultaron muy productivas y despertaron recuerdos de los entrevistados así como reponer y/o plantear reflexiones situadas. Algunas entrevistas se extendieron en el tiempo e implicaron más de un encuentro, a fin de retomar cuestiones, ampliar las respuestas e incorporar nuevas preguntas ${ }^{89}$.

El análisis de los registros obtenidos buscó identificar enunciados de valor referencial y teórico-analítico vinculados con los núcleos temáticos y analíticos de la investigación. Se indagaron así en enunciados significativos brindados por los actores integrantes y partícipes de las experiencias de intervención cultural. Este análisis se presenta fundamentalmente en el capítulo 5, pero también en parte de los capítulos 3, 4, 6, 7 y 8; la totalidad de la trascripción textualizada de las entrevistas se encuentra en el "Anexo" (anexo 3).

\footnotetext{
${ }^{89}$ En otros casos, el encuentro con estos actores se ramificó en conversaciones pautadas u ocasionales, en recorridas en auto o en micro por la ciudad, en rondas de mates o cerveza, en almuerzos y cenas o mientras se desplegaban intervenciones en los últimos años, lo que corresponde principalmente a la técnica de la observación participante.
} 
Al plantearse indagar en prácticas contemporáneas y actuales pero en muchos casos también del pasado reciente (es decir, ocurridas entre 5 y 10 años atrás), la entrevista cobró una importancia clave en tanto relevamiento de lo realizado en esos años por los grupos e interventores culturales consultados, potenciando de este modo su valor de archivo. Pero también, como registro de los modos en que dichas prácticas y reflexiones del pasado se actualizaban en los relatos de sus protagonistas y testimoniantes con las marcas subjetivas, ideológicas y políticas del presente de su enunciación.

\section{Otras técnicas de análisis y modulaciones sobre el lugar del investigador}

En este apartado explicitamos y describimos otras técnicas de indagación y análisis de investigación empírica que se pusieron en juego en la presente investigación y se propone una reflexión sobre el doble perfil de investigador / participante.

\section{V.a. Observación participante}

Junto a las entrevistas se realizaron también, en todos los casos en fue factible, numerosas observaciones de campo. Se trata ésta de una estrategia que "consiste en presentar de manera directa el fenómeno estudiado en su 'ambiente natural', sin manipularlo" (Marradi, Archenti y Piovani, 2007: 195). Se puede agregar que es una técnica de investigación cualitativa que registra y describe conductas, situaciones y relaciones de una comunidad (un grupo, un colectivo, etc.) para reconstruir e interpretar el sentido que los sujetos le dan a sus prácticas. Entre algunos de sus principios, se puede mencionar que es el propio investigador quien debe recolectar los datos de primera mano y que este tiene que tener siempre una actitud observadora.

Para esta investigación se llevaron a cabo algunas observaciones de diversas acciones e intervenciones producidas entre 2012 y 2015 en la ciudad de La Plata. El carácter de las mismas fue principalmente exploratorio y con la intención de 1) conocer mayores detalles de la "cocina" de las prácticas de intervención cultural vigentes en ese momento; y 2) procurar un modo activo de participación y construcción de rapport, empatía y conocimiento microsociológico exhaustivo: compartir momentos, conversar con los sujetos. Por esto de modo general se trató de observaciones participantes que buscaron registrar "desde adentro" el fenómeno de estudio, planteando cierto involucramiento del investigador. En este sentido, dichos relevamientos se apartaron por completo de la mera contemplación que demandaría 
una actitud "externa" o "naturalista". El involucramiento aludido no se refiere de modo exclusivo al desarrollo específico de la investigación sino -como señalamos previamente- a la participación previa o en simultáneo a la investigación en prácticas culturales, lo que podemos definir conceptualmente como un "observador/investigador nativo".

Es así que, porque ejemplo, se participó en la organización y producción previa o en la realización in situ de algunas intervenciones en la ciudad, se colaboró en el registro de acciones y eventos, se aportó en las estrategias comunicacionales de algunas intervenciones y se tomaron dos talleres de "arte urbano" 90 con interventores visuales locales. En todas estas observaciones se realizaron apuntes y anotaciones de campo -en cuadernos o libretassiguiendo algunos núcleos temáticos de interés (sintetizados en formas de organizarse y moverse de los implicados; nociones sobre la ciudad y sobre lo público), pero no una descripción y sistematización pormenorizada de las situaciones observadas. Además se hicieron anotaciones de encuentros y conversaciones ocasionales con los sujetos participantes de las experiencias de intervención.

Asimismo, se puede plantear que se desarrolló una "observación virtual" a través de acciones de "rastrillaje" en profundidad por la web durante todo el período de la investigación (en blogs, páginas web, perfiles en redes sociales y comentarios expresados en esas plataformas) o el uso de la herramienta del chat como espacio de contacto e intercambio de información. Esto tiene algunas coordenadas de convergencia con la propuesta de Christine Hine (2004) sobre la "etnografía virtual", una perspectiva etnográfica del uso cotidiano de internet (entendiendo a ésta como una cultura en sí misma y como un artefacto cultural).

Es importante aclarar que, en la construcción y el ejercicio del trabajo de campo, las observaciones quedaron como una técnica complementaria del cartografiado de las intervenciones y de las entrevistas en profundidad. Esas tres herramientas, así como el análisis de contenidos, se emplearon en la investigación empírica para la búsqueda de significados de las prácticas sociales.

\section{V.b. Análisis de contenidos}

En la definición de Klaus Krippendorff se entiende al análisis de contenidos como "una técnica de investigación destinada a formular, a partir de ciertos datos, inferencias reproducibles y válidas que puedan aplicarse a su contexto" (Krippendorff, 1990: 28).

\footnotetext{
${ }^{90}$ Uno de ellos coordinado por Acra en C'est la vie y el otro dictado por Vic y Agua Helada en Cösmiko. Además, entre los años 2012 y 2015, se asistió a cerca de cien muestras y exposiciones en galerías y espacios de arte de la ciudad -alternativos e institucionales-. Algunas cuestiones y materiales de esta parte del trabajo de campo se trabajan en el capítulo 8. También forman parte de algunas publicaciones: López, 2013b 2015a, 2015b.
} 
Pueden ser textos u otro material con significado. Tomando la propuesta de esta autor consideramos que el análisis de contenidos, en tanto una técnica recurrente en el análisis clásico cuantitativo, puede ser enriquecida con procedimientos interpretativos. Es decir, desde una mirada cualitativa que dé cuenta, por ejemplo, del contexto en el que se inscriben los textos o de cuestiones latentes (Marradi, Archenti y Piovani, 2007: 291-292). Al ampliar su definición -en la orientación y aplicación que aquí nos interesa- puede ser entendido como un procedimiento sistemático ideado con el objetivo de examinar el contenido de una información publicada por los medios de comunicación (en nuestro caso, diarios) para obtener datos empíricos con los cuales trabajar sus hipótesis o preguntas de investigación. De este modo, adopta como unidad de análisis al mensaje.

Para la utilización de esta técnica interpretativa se construyó un universo amplio de textualidades periodísticas en medios gráficos y digitales: notas, notas de opinión, crónicas periodísticas y editoriales en diarios y revistas locales, provinciales y nacionales sobre las intervenciones urbanas en la Argentina y en La Plata particularmente (entre los medios comerciales: diarios El Día, Hoy, Diagonales, La Nación, Clarín, Página /12 y revista N; entre los medios alternativos: revista La Pulseada, portal Prensa de Frente, Indymedia La Plata, Diario Contexto, entre otros). Finalmente, se decidió delimitar un corpus de análisis en las publicaciones del diario de tirada local y regional El Día, tanto de su versión impresa como en su versión web ${ }^{91}$. Esta decisión se corresponde con una caracterización del lugar que ocupa ese medio en la configuración de sentidos sobre y en la ciudad de La Plata, más allá de las distancias de mirada y posición que podemos tener con ese medio. A la vez, en la contabilización de los materiales, fue el medio periodístico local de mayor cobertura, produciendo varias notas sobre cuestiones vinculadas a los intereses de la investigación, esto se puede ver en detalle en el capítulo 7. Si bien reconocemos que se trata de un medio que ejerce un tipo de periodismo tradicional y, en muchos casos, conservador y elitista, ese contraste con las prácticas de intervención cultural que se indagaban en la investigación -que de modo rápido se pueden entender como "alternativas", "no-institucionales" y "emergentes"fue podía ser productivo para indagar y confrontar diferentes enfoques miradas sobre la ciudad y la cultura.

Por último, este tipo de análisis de contenidos también fue utilizado para indagar en otros documentos, en este caso, producidos por los colectivos e interventores: afiches, volantes, flyers virtuales, post en blogs y sitios web.

\footnotetext{
${ }^{91} \mathrm{http}: / / \mathrm{www} . \mathrm{eldia.com}$
} 


\section{V.c. Sobre el lugar del investigador y su implicación con el objeto de estudio}

Por último, como se fue señalando, resulta innegable que mi participación o conocimiento, preexistente a la investigación, en y sobre varias de las prácticas indagadas ${ }^{92}$ formó no sólo parte de sus condiciones de posibilidad sino parte misma de los materiales a reflexionar. En este sentido, este doble lugar representó tanto una valiosa oportunidad como un sugerente desafío a la hora de llevar adelante el trabajo de campo. Por un lado, evitó moverse con cierta ingenuidad, gracias al acumulado de informaciones y experiencias previas vinculadas a la trayectoria de los colectivos y/o sujetos consultados, lo cual facilitó acelerar el acopio y chequeo de ciertos datos, aceitar y gestionar contactos, y alcanzar niveles interesantes de profundización de algunos aspectos estudiados. Por el otro, reforzó el reto de producir conocimiento crítico a partir de la invitación constante a desnaturalizar las propias certezas y automatismos, y a articular complejamente la información "vieja” con la nueva.

A los efectos de la producción de la tesis, se planteó no adherir -al menos no por entero- a las perspectivas de la "investigación militante" o la "investigación-acción participativa", sino mantener la tensión entre participar de las redes que constituyen y cultivan las prácticas culturales indagadas y, a la vez, participar de los espacios y debates académicos de las en ciencias sociales. La propuesta fue entonces desplazarse recursivamente entre entrar y salir de ambas redes. Una certeza relacionada con esta intención es que consideramos que los sujetos involucrados en las prácticas culturales que se analizan no precisan de ninguna tesis doctoral para hablar y conocer. En este sentido, no se pretende aquí darle la voz a ningún actor invisibilizado -ya que en sus prácticas y saberes, con sus recursos y objetivos estos actores configuran sus propios campos y formas de visibilidad-. En todo caso, se trata de complejizar y producir interpretaciones que conecten prácticas y nociones y que abran sentidos y pensamientos.

Sin embargo, emprender esta tarea no tiene el objetivo de reforzar construcciones separadas e impenetrables. Por el contrario, la intención es que esas dos miradas (y "mundos") se pueden aunar en la comprensión compleja y enriquecida de las producciones y formaciones culturales contemporáneas y del propio presente. Se sostiene que el campo de las prácticas culturales puede aportar una mirada sensible y crítica del presente, no anclada en corset disciplinarios ni en deadline de escrituras. Por su parte, el saber académico y el

\footnotetext{
${ }^{92}$ Para varios autores la observación participante es adecuada especialmente cuando se sabe poco del fenómeno de interés (Marradi, Archenti y Piovani, 2007: 198), lo que se diferencia sustantivamente de esta propuesta de investigación.
} 
quehacer investigativo -que no se guían con recetas del formulario- pueden contribuir con aportar una perspectiva mirada atenta e interpeladora de que interpela a las prácticas bajo estudio, al aportar preguntas y complejizar tanto los modos de entender la sociedad contemporánea como las maneras de hacer dichas desde las prácticas culturales.

En el quehacer de la propia investigación, el acercamiento, la escucha y el diálogo con diversos actores que fueron o son parte de las prácticas culturales -y que en muchos casos ellos/as son parte de los/as entrevistados/as de la tesis- fueron pensamos como una "interlocución". Interlocutores que tiene mucho para aportar en el entendimiento y la interpretación de sus prácticas. Estos diálogos y encuentros han sido permanentes y sostenidos a lo largo de los cinco años en los que se realizó la investigación. Fueron diálogos construidos desde lazos de confianza y afecto -en muchos casos se trató de lazos previos a la realización de la investigación-. Este es uno de los puntos que permite comprender cómo una red puede aportar a la otra.

Este propósito de darle relevancia a los/as protagonistas de las prácticas, se vincula con la propuesta de Martín-Barbero sobre el descentramiento de "la mirada del investigador hacia la de los otros" (2004: 14). De allí que se trató de un tipo de interlocución que, como el intercambio con colegas del espacio académico, ha sido productiva y fructífera. Fueron encuentros y conversaciones que hacen trama de sentidos y de saberes. Alejado, pues, de estos, se plantearon allí cuestiones para no "esencializar" a las prácticas y los sujetos. Pero tampoco se pretendió tener una posición "extractivista" de la información aportada, la consigna fue dar lugar a estos. Es decir, se realizó una interrogación permanente sobre la posición de investigador, observador y analista. ¿Es correcto el planteo sobre mi posición? ¿No inhibe a los sujetos, no coarta la conversación? ¿Hasta dónde involucrarme en el período en el que desarrolló el trabajo de campo? ¿Puedo hacer todo lo que quiero hacer? ¿Me presento como investigador social o como compañero de acción? En el día a día del trabajo de campo y en los diálogos fue imposible separar, aparecían ambos ¿“perfiles”? constantemente. El principal desafío fue procurar que primara, en proporciones equitativas, Aunque siempre se destacó más la experiencia previa y presente en las acciones, el gesto hacia el campo académico, y la investigación propiamente dicha, aparecía frecuentemente:

\footnotetext{
"Mati el investigador".

"No sé, vos sos el que investiga estas cosas, lo debés tener más fresco".

"Matías está anotando, seguro es para su tesis"

"Todo esto va a la tesis"
} 
Pero además en los encuentros y diálogos -con los sujetos partícipes de las prácticas indagadas- surgieron re-elaboraciones conceptuales, nuevas lecturas e interrogantes para pensar. ¿Es la ciudad un elemento destacado en y para las acciones? ¿No es exagerado plantear que las intervenciones culturales analizadas "hacen ciudad" y no solo la utilizan como un medio, recurso o un escenario para la acción? ¿Son prácticas oposicionales, en oposición a qué? ¿La ciudad y el espacio urbano no son lo mismo? ¿El espacio público se puede reducir a la ciudad? ¿Por qué otros colectivos y experiencias locales no ampliaron la apuesta por tomar a la web como espacio público? ¿Por qué los espacios de la ciudad y (salir a) la calle funcionan como "verificadores" de las acciones colectivas?

En todo momento se buscó una coherencia y articulación entre las preguntas construidas, los ejes de análisis, las etapas de investigación y las herramientas metodológicas. En tal sentido, la propuesta de construir una estrategia teórico-metodológica desde una analítica cultural procuró construir herramientas y formulaciones que permitan indagar en profundidad en prácticas culturales contemporáneas. En los siguientes tres capítulos se despliega la descripción y el análisis de las intervenciones culturales en la ciudad de La Plata por medio del cartografiado cultural y las otras técnicas de investigación empleadas. 


\title{
Capítulo 3
}

\section{Acercamiento a las experiencias de intervención cultural}

\author{
"No quiero ver mi ciudad / Con esa onda determinada. \\ Negros, grises y azul / Dominan calles / No valen nada. \\ Quiero ver mi ciudad / Que levante la cabeza / Que reciba el \\ rock / Que estimula ondas más nuevas. \\ Para juntos practicar / Nuevas formas de encarar / Esta densa \\ realidad, oh" \\ Virus, "Densa realidad" \\ "Variar el sistema que nos rige y cambiar las estructuras \\ clásicas en cuanto a medios que movieron el arte hasta \\ nuestros días, romper con los habitáculos, salir y ganar la calle, \\ forman en su todo la "NUEVA ACTITUD DE LOS \\ AGITADORES DEL DÍA Y DE LA NOCHE” que se \\ proponen realizar por vez primera una "revulsión" que no sea \\ únicamente formal y estética sino de CAMBIO REAL DE \\ VIDA." \\ Edgardo A. Vigo, "La calle: escenario del arte actual” (1971), \\ Hexágono ' 71 , № be, 1972.
}

\section{La Plata, historia e identidad hecha de mitos}

Antes de comenzar a desplegar la descripción de los instrumentos de indagación cartográficos y de las prácticas de intervención cultural, se hace necesario plantear algunas consideraciones sobre la ciudad de La Plata. Su mito fundacional habla de que fue una ciudad "diseñada" antes de ser habitada, lo cual le confirió -hasta la actualidad- cierta auricidad modernista y única. Luego de la definitiva "federalización” de Buenos Aires como capital nacional de la Argentina en 1880, la aristocracia bonaerense se vio urgida por la necesidad de constituir una nueva capital provincial. Soñada, o mejor pensada estratégicamente por este sector, la nueva ciudad buscaría competirle a Buenos Aires, a sus brillos y su puerto con el objetivo, en un futuro cercano, de desplazarla como capital de la República.

Una comisión de notables eligió a la localidad costera de Ensenada por su ubicación y cercanía con el ferrocarril y con Buenos Aires. Pero a diez kilómetros tierra adentro de la costa del Río de La Plata se ubicaban los terrenos pantanosos y húmedos donde se emplazaría el centro administrativo y político de la nueva capital. Se los llamaba por entonces las "Lomas 
de Ensenada". El ingeniero Pedro Benoit fue convocado para trazar los planos y diseñar la ciudad capital, que tendría como característica -lo que se denominó luego como- su "trazado perfecto": cuadras simétricas, red de calles que se cortan en ángulo recto, ordenamiento de la circulación y de los espacios públicos, eje cívico-fundacional, avenidas y diagonales que atraviesan toda la cuadrícula ${ }^{93}$. En noviembre de 1882 esta nueva ciudad, llamada La Plata por el entonces gobernador y su fundador Dardo Rocha, se convertiría en la capital de la Provincia. El derrotero de la política nacional hizo que parte sustancial de ese "sueño" de Rocha y los suyos, nunca se consumara. De este modo la ciudad -o mejor, sus instituciones y los sectores de poder económico y político- tuvo que encontrar su lugar propio, y construir su historia y su pasado. Una historia y un pasado no forjados en grandes hazañas libertadoras sino en la autocelebración de sus "mitos".

Es así que "la ciudad" -de nuevo, desde sus instituciones y el establishment local y luego también desde sus clases medias instruidas- se fue empecinando en resaltar y reforzar una identidad anclada en unas míticas características particulares (Badenes, 2012, 2015): "ciudad modelo" o "ciudad perfecta" (por su trazado urbanístico), "ciudad de los poetas y la bohemia" (lugar de la creación y la expresión literaria y artística), "ciudad universitaria” (por el lugar destacado del conocimiento y la ciencia materializado en "su" Universidad Nacional) o "ciudad joven" (idea moderna que mezcla todas las anteriores) ${ }^{94}$. Daniel Badenes al analizar la celebración del centenario de La Plata en 1982 a partir de las publicaciones gráficas aparecidas en torno a esa fecha, resume las miradas sobre la ciudad en tres grandes mitos: el trazado perfecto, la capital de la cultura y la ciudad de la conciliación.

\begin{abstract}
"Una consecuencia de esa mistificación es la pérdida del sentido de región y un olvido sobre el proyecto original para desarrollar un gran puerto. (...) La mirada centrada en el casco urbano de la ciudad deja afuera a los barrios periféricos y a los partidos autonomizados de Berisso y Ensenada, y facilita la construcción del imaginario más fuerte: el que identifica a La Plata como ciudad universitaria, capital cultural, sitio privilegiado de las ciencias y las artes.
\end{abstract}

\footnotetext{
${ }^{93}$ Se ha mencionado muchas veces y en varios lugares que la concepción urbanista en la que se proyectó a la ciudad de La Plata está ligada al "higienismo" moderno. Según André Corboz, "las teorías higienistas dictan las reglas de la vida sana: aire y luz (es decir, orientación según la exposición al sol y los vientos dominantes), separación de las funciones, especialización de las vías de comunicación). (...) Los protagonistas del movimiento moderno comparten una misma filosofía científica, el positivismo." (Corboz, 2016: 258). Es en ese movimiento donde se deben inscribir los proyectos urbanísticos y arquitectónicos de finales del siglo XIX.

${ }_{94}$ Para una profundización de estos mitos sobre La Plata se recomienda la lectura de la interesantísima tesis de Maestría en Historia y Memoria de Daniel Badenes (2012). Una reescritura de esa tesis fue recientemente publicada como libro (Badenes, 2015).
} 
Esto opera en detrimento de la posibilidad de reconocer otras actividades o actores urbanos, que aparecen sólo en algunos textos y tienden a adquirir el carácter de anécdotas o curiosidades. La significación de la ciudad universitaria aplasta a la producción industrial o frutihorticola, al movimiento obrero de la región e incluso a la función administrativa de la capital provincial. La Plata aparece, sobre todo, como un foco de cultura, y esa definición es la que filtra la atención sobre instituciones y personalidades. (...) Porque la ciudad cultural no es la capital de cualquier cultura. (...) No es tampoco cualquier ciudad universitaria, sino una que entiende el conocimiento como signo de distinción y promueve una institución académica incapaz de convivir y crecer con las expresiones de la ciudad obrera" (Badenes, 2015: 28).

Esta caracterización crítica que aporta Badenes, al construir una "historia de la historia local" -desde los estudios de historia y memoria sobre las significaciones y mistificaciones de La Plata-, es elocuente para comprender y discutir muchas de las actuales miradas y discursos sociales sobre la ciudad. Sentidos y discursos que ponderan a algunos actores urbanos por sobre otros y que están plagados de omisiones y distinciones, algunas cuestiones que ya fuimos describiendo a lo largo de la tesis.

Por otro lado, dentro de lo que se suele llamar los datos "duros", se puede mencionar que La Plata es una ciudad "intermedia", habitada actualmente por casi 700 mil personas, entre el casco urbano y el resto de las localidades y barrios que conforman el partido. ${ }^{95} \mathrm{~A}$ estos datos demográficos y poblacionales, se le pueden sumar cuestiones morfológicas: La Plata tiene una superficie de $940 \mathrm{~km} 2$ y se ubica a $56 \mathrm{~km}$ al sureste de Ciudad Autónoma de Buenos Aires. Se encuentra emplazada en el límite con las localidades de Berisso y Ensenada. Asimismo su casco urbano cuenta con una trama viaria ortogonal o en damero, conformada por una estructura cuadriculada atravesada por calles paralelas ${ }^{96}$. El interior de este cuadrilátero o cuadrícula está conformado por 42 por 42 manzanas. Otro dato de esta construcción es que cada 6 calles hay una avenida y en los cruces de las avenidas, por lo general, se cuenta emplazada una plaza o parque. El trazado de sus calles está ordenado numéricamente y va de 1 a 31 y de 32 a 72. La Plata fue concebida con un "eje fundacional" que se encuentra entre las avenidas 51 y 53, en el que se encuentran los edificios de la Casa de Gobierno, la Legislatura provincial, el Teatro Argentino, la Municipalidad, la Catedral, del

\footnotetext{
95 Datos poblacionales extraídos del Censo Nacional 2010. Disponible en: http://www.indec.gov.ar/ftp/censos/2010/CuadrosDefinitivos/P2-D_6 441.pdf

${ }^{96}$ En un plano urbano ortogonal o reticular predominan las líneas rectas en el trazado de las calles que se cortan perpendicularmente formando una cuadrícula, lo que conforma una sensación de orden.
} 
Ministerio de Seguridad y Justicia, del Ministerio de Salud y el Correo, entre los más destacados.

Por su parte, vinculada con su cultura urbana, una de las cuestiones más mencionadas sobre la ciudad es su relación con el "conocimiento". En este sentido, una de las instituciones más importantes es la Universidad Nacional de La Plata -institución pública de educación superior-, que está integrada por más 100 mil personas entre estudiantes y trabajadores ${ }^{97}$. En ella cursan estudiantes llegados desde varios puntos del país, e incluso provenientes de otros países de Latinoamérica -siendo elegidas por estos estudiantes principalmente las facultades de Bellas Artes. Ingeniería y Humanidades- ${ }^{98}$. Es interesante observar cierta sinergia entre las dinámicas de la Universidad y los movimientos de la ciudad. Sin exagerar, podemos pensar que la universidad en múltiples dimensiones es parte de muchos de los movimientos que "hacen ciudad" (principalmente en la política, en la cultura y las artes, tanto en las inscripciones hegemónicas como en las alternativas).

También, en parte vinculado que esto último, La Plata es una ciudad donde germinan abundantes experiencias ligadas al ámbito de la cultura, las artes y la comunicación. Solo por mencionar algunas iniciativas de los últimos veinte años: decenas de los centros y casas culturales (tanto colectivizados como privados), los espacios y talleres de arte, los colectivos artísticos (las murgas, las cuerdas de candombe, los ensambles de percusión, las compañías teatrales, etc.), los grupos musicales y las "movidas" ligadas a las escenas musicales (el rock indie, el folclore y el circuito de peñas, el candombe, los bailes de tango), la renovada escena de las artes visuales (conformada por productores, galerías, curadores, gestores y una gran cantidad de muestras y talleres), y la "movida" literaria y editorial (integrada por revistas culturales, nuevos grupos editoriales independientes, pequeñas librerías y muchos autores/as): se puede hablar entonces de una multiplicidad de iniciativas culturales autogestionarias que proliferan por y "hacen" a la ciudad, a las que llamaremos "escenas". Entonces, como caracterización general se entiende que en la ciudad proliferan, de modo variado y en gran cantidad, ofertas y demandas culturales que están ligadas no solo a las ideas de "realización personal" -del artista joven, del gestor cultural, del consumidor de arte y cultura alternativa,

\footnotetext{
${ }^{97}$ Según el “Anuario de estadísticas Universitarias 2013” elaborado por la Secretaría de Políticas Universitarias del Ministerio de educación de la Nación, la UNLP cuenta con 109.803 estudiantes de pregrado y grado.

${ }^{98}$ Ver algunas notas sobre esta cuestión aparecidas en los últimos años: "Se duplicó la matrícula de estudiantes extranjeros en la UNLP”, Agencia Télam. 20 de abril de 2014. Disponible en: http://www.telam.com.ar/notas/201404/60059-se-duplico-la-matricula-de-extranjeros-en-la-unlp.html y "Cada vez más extranjeros eligen a la UNLP”. Nota publicada en el Portal web de la UNLP. Disponible en: http://www.unlp.edu.ar/articulo/2013/4/24/extranjeros_en_la_unlp_abril_2013
} 
etc.- sino principalmente a las ideas de "proyectos culturales" colectivos -sobre esto se trabajará específicamente en el capítulo 8-.

Para ampliar esta mirada sobre la ciudad, se recupera lo planteado por Esteban Rodríguez -docente universitario y ex integrante de La Grieta- en un breve ensayo que integraba La Plata, ciudad inventada, un volumen colectivo sobre la cultura local:

\begin{abstract}
"Es una ciudad con el tamaño ideal para ponerse a conspirar. Carga en su mito fundacional con los masones exiliados conspirando en catacumbas, tomando distancia de Buenos Aires para desquitarse. Y la revancha llega con el paso del tiempo, ya sin ánimo de venganza, por lugares y con actores muy distintos y no precisamente masónicos. (...) La Plata es una ciudad gris pero colorida; desprolija y bullanguera que respira inocencia, inconsciencia, ingenuidad, complicidad." (Rodríguez, 2011: 30)
\end{abstract}

Esta idea sobre la posibilidad de "conspirar" en esta ciudad por sus dimensiones y formas aprehensibles y recorribles, que la hace un "caldo de cultivo" y de ebullición de prácticas culturales alternativas y autogestionadas, resulta productiva para la caracterización e indagación de las intervenciones culturales como las que son objeto de esta investigación ${ }^{99}$.

Junto a estas caracterizaciones cabe señalar, también, que La Plata es asimismo -y quizá en parte por varios de los fenómenos planteados hasta aquí- la ciudad de las demoliciones de edificios históricos y de la especulación de empresas constructoras, inmobiliarias y estudios de abogados: "una ciudad con menos sol y con más especulación inmobiliaria" (López, y Sager, 2010). La ciudad (movilizada por el) "dinero" que recorta el cielo con los edificios en altura, satura la infraestructura y los servicios públicos elementales, borra -con la fuerza de grúas y máquinas pesadas- a su patrimonio arquitectónico e histórico y dificulta el acceso a la vivienda digna, principalmente, a los sectores más vulnerables pero también a los sectores "medios" (por el aumento del precio del suelo, la falta de políticas

\footnotetext{
${ }^{99}$ Con todo, La Plata -y toda la región que comprenden con Berisso y Ensenada- es también la "ciudad de la tragedia", aquella que, lamentablemente, se destaca por gran cantidad de víctimas durante el terrorismo de Estado de la última dictadura. Al respecto Marta Vedio, abogada e integrante de la APDH y ex-Subsecretaría de Derechos Humanos del Municipio comentó en relación a densidad poblacional que La Plata era "la ciudad más castigada proporcionalmente del país" por el genocidio (ver testimonio en Leavi, 2013). Pese el terrorífico golpe de la dictadura, La Plata es también una de las principales ciudades donde se amasaron aquellos proyectos que, desde abajo, le hicieron frente a la desaparición, el secuestro y el ocultamiento de lo sucedido. En algunas conversaciones personales y en los comentarios al boceto de tesis, Ernesto, uno de los entrevistados, me recordó/recalcó que La Plata es también la ciudad donde se gestaron las Madres y Abuelas de Plaza de Mayo a finales de los años 70 -varias de sus integrantes vivían en La Plata: Hebe Pastor de Bonafini, Estela Barnes de Carlotto, María Isabel "Chica" Chorobik de Mariani, Alicia "Licha" Zubasnabar de la Cuadra y Adelina Dematti de Alaye por mencionar a algunas- y la agrupación HIJOS a mediados de los '90. Tres agrupamientos fundamentales del movimiento por Derechos Humanos en el país, pero también organizaciones importantísimas para comprender los movimientos sociales y democráticos de la Argentina reciente.
} 
democráticas de urbanización y los "negociados" de las inmobiliarias y el poder político local). ${ }^{100}$

La principal transformación urbana de la ciudad -sólida, pesada, demoledora del patrimonio- es la que impulsan los proyectos urbanísticos de la especulación constructiva e inmobiliaria para construir edificios de departamentos y oficinas en altura. Dentro de esos proyectos urbanísticos "sólidos" se deben colocar también a la proliferación de nuevos polos o "centros" para el consumo en varias propuestas, sumándose -y disputando tambiénpúblicos y consumidores a los tradicionales paseos de compras de calle 8 y calle 12 . A la vez, podemos encontrar otras situaciones que, a su modo, juegan en las mutaciones contemporáneas de la ciudad: la creación de los “circuitos culturales", allí el barrio Meridiano $\mathrm{V}^{\circ}$ puede ser el caso paradigmático en la región ${ }^{101}$.

La expansión de la construcción en altura -en una ciudad que fue pensada de planta compleja pero baja-, la demolición de gran parte de su patrimonio histórico y arquitectónico pese a contar en los últimos doce años con un área de conservación patrimonial-, el enrejamiento de casi todos los edificios públicos -utilizado como salida poco original para

\footnotetext{
${ }^{100}$ En 2010, a pedido de la revista La Pulseada ( $\mathrm{N}^{\circ} 80$ ), realicé junto con Federico Sager un detallado informe de investigación periodística sobre el armado, la aprobación y las observaciones críticas del Código de Ordenamiento Urbano y Territorial (COUT). Esa nueva normativa -la ordenanza municipal 10681- era impulsada por el oficialismo local -liderado por el entonces intendente Pablo Bruera (PJ-FPV)- y con el visto positivo de empresas inmobiliarias y constructoras, la Cámara de Comercio e industria y el Colegio de Martilleros locales. Desde el momento de su aprobación se pidió desde algunos sectores sociales derogar el Código y trabajar en una nueva normativa -pedido que se acentuó luego de la inundación del 2 de abril de 2013-. Al menos dos asociaciones civiles plantean en la ciudad demandas y cuestionamientos sobre el COUT: Defendamos La Plata y SOS La Plata. En menor medida lo hace el Colegio de Arquitectos (CAPBA 1). Links: http://defendamoslaplata.blogspot.com.ar y http://soslaplata.wixsite.com/soslp2

${ }^{101}$ La idea de proyectos urbanísticos "sólidos" es tomado de un artículo de opinión escrito por Matías Manuele en el diario El Día titulado "Las ciudades y las "cosas"” (16/03/2016). Aunque con esa noción el autor no está describiendo específicamente a los proyectos de la ciudad de La Plata sino que, al ejemplificar, se refiere a los mega-emprendimientos desarrollados en Nueva York, Bilbao o Puerto Madero. Para Manuele, el barrio Meridiano $\mathrm{V}^{\circ}$ da cuenta de otro proceso, es parte de emprendimientos urbanístico-culturales que denomina "leves". "Frente a este modelo que llamaré "sólido", por sus intervenciones pesadas, imponentes y costosas, otro modelo es posible. El arquitecto Rubén Pesci lo llama "leve". La levedad no implica la superficialidad pues no elude lo conflictivo. La levedad es radicular, moviliza las fuerzas locales, pone en relación a los vecinos (entendidos de manera compleja como comerciantes, decisores políticos, militantes barriales, artistas, niños, niñas, etc.) para que sean ellos quienes, a través de sus propias prácticas, dinamicen su espacio de vida, recreen viejas y nuevas formas de vivir y sobrevivir. Esta manera de entender el desarrollo se viene desplegando en el barrio Meridiano V desde hace ya dos décadas." Según Manuele son los primeros proyectos los que producen procesos de gentrificación, mientras que los segundos -como Meridiano V- producen desarrollo local y son llevados adelante con participación y el protagonismo de los vecinos. Sin embargo, aún reconociendo los matices y objetivos diferenciales de algunos de los proyectos que se realizan en los barrios Meridiano $\mathrm{V}$ e Hipódromo (impulsados e impulsadores de los "circuitos culturales" y con un fuerte trabajo en las iniciativas culturales y territoriales) frente a los que se gestan actualmente en el centro de la ciudad -como los mencionados, que tienen un exclusivo sesgo comercial-, se considera que todos actualmente aportan, con diferentes grados y escalas, a los procesos de gentrificación de la ciudad. En otro artículo publicado en la revista boba $\left(\mathrm{N}^{\circ} 3\right.$, diciembre de 2016), Manuele repone esta mirada de los circuitos y su relación con los procesos de gentrificación. Sobre esto se vuelve en el capítulo 6. La columna de opinión está disponible en: http://www.eldia.com/opinion/la-ciudad-y-las-cosas-122568 Una ampliación de la caracterización de las transformaciones culturales y urbanas sucedidas en Meridiano $V^{\circ}$ se encuentra en los capítulos 4, 5 y 6 .
} 
"sacarse de encima" a manteros, adolescentes, graffiteros y skaters- y contar además con servicios públicos deficitarios, son algunas de las problemáticas que dan cuenta de una ciudad que se está transformando y en la cual muchos de estos cambios atraviesan negativamente a los habitantes y van en detrimento de su calidad de vida. Para continuar y ampliar este análisis, en el capítulo 6 se indagan en detalle algunas políticas urbanas y culturas estatales que se desarrollaron en La Plata.

\section{El cartografiado cultural, inicio del recorrido}

Como mencionamos, en este trabajo se explora la propuesta de la "cartografía cultural" y se busca construir una herramienta para hacer observables las huellas de las intervenciones culturales en la morfología y geografía urbanas (ver mapa más adelante y cuadro en Anexo 1), así como proveer materiales para fundamentar y ajustar las preguntas e hipótesis iniciales sobre las apropiaciones del espacio público urbano.

En este sentido, a partir del trabajo sobre el mapa de la ciudad de La Plata se marcaron las distintas acciones de los grupos e interventores tomados para este estudio. La localización de dichas intervenciones buscó dar cuenta, en términos cuantitativos, de la densidad y la cantidad de intervenciones que sucedieron en el espacio urbano durante el período seleccionado (2006-2011) ${ }^{102}$. Pero a su vez, se hipotetiza sobre los recorridos que estas acciones hicieron y propusieron para pensar y habitar la ciudad; así como reflexionar sobre la dimensión política de las mismas, en su politicidad y en el nivel de la acción política que proponen.

Indicamos, también, que el principal recorte temporal elegido comprende el periodo que va entre 2006 y 2011, etapa que condensa un "momento" de emergencia, visualización, auge, fortaleza y cierto repliegue de estas formas de activación cultural en la ciudad de La Plata. La gran cantidad de grupos e interventores, así como algunos encuentros colectivos, sumando a las innumerables intervenciones que se produjeron en esos años constituyen cierta “formación cultural" emergente (Williams, 2009) ${ }^{103}$. De este modo, se busca indagar en esta formación cultural que, alejada de lo institucional y a distancia de las políticas estatales

\footnotetext{
${ }^{102}$ Como ya referimos en el anterior capítulo, una parte importante del cartografiado está disponible en un sitio web creado especialmente para la tesis: http://cambiodepiel.com.ar

${ }^{103}$ Siguiendo a Raymond Williams (2009), el concepto de "formación cultural" y aquello que conforma lo "emergente" dan cuenta de elementos alternativos u oposicionales y de la construcción de nuevas formas, relaciones y sentidos llevados adelantes por grupos y actores específicos de un proceso cultural, por lo tanto se producen en "interacciones dinámicas" con los elementos dominantes.
} 
destinadas a la cultura, intervino en la ciudad -en sus espacios y recursos- así como en las tramas de cultura urbana -en sus formas, escenas, articulaciones colectivas y temporalidades-. Reiteramos que la idea rectora aquí es indagar si las intervenciones culturales relevadas propusieron formas de habitar la ciudad (es decir, unos otros recorridos, diferentes a los que se producen sobre los sentidos instituidos del andar / circular / transitar por la urbe); así como preguntarnos de qué manera buscaron "tomar la palabra" (sus recursos, estrategias comunicacionales y modos de hacer) y/o procuraron constituir cierto "desacuerdo" (Rancière, 2007) alrededor de algunos reclamos, demandas y conflictos sociales y políticos mediante en muchos casos- el establecimiento de alianzas y vínculos con distintos organizaciones y movimientos sociales.

En tal sentido, para profundizar la noción de formación cultural que se pone aquí en juego, podemos describir algunas de las situaciones y acontecimientos que movilizaron las intervenciones culturales en la ciudad de La Plata en el período recortado. De modo destacado: la segunda desaparición forzada de Jorge Julio López en septiembre de $2006^{104}$ (que coincide con el periodo de alza y reflujo por el reclamo social ante el Estado de su "aparición con vida"); los juicios orales llevados adelante en la ciudad contra militares y civiles que participaron de la represión ilegal durante la última dictadura en Argentina (dos juicios emblemáticos de este período al ex policía Miguel Etchecolatz en 2006 y al capellán Christian von Wernich en 2007) ${ }^{105}$; el femicidio de Sandra Ayala Gamboa, ocurrido en febrero de 2007 en una dependencia del Estado provincial ${ }^{106}$, la baja en la edad de

\footnotetext{
104 Jorge Julio López, militante de la organización de la izquierda peronista Montoneros, fue secuestrado y estuvo desaparecido por primera vez desde el 21 de octubre de 1976 hasta el 25 de junio de 1979. Casi treinta años después López se convirtió en testigo clave en el que fue el principal juicio donde se condenó al represor y ex policía Miguel Etchecolatz -uno de los responsables de su desaparición- por delitos cometidos "en el marco de un genocidio" según define la sentencia judicial. El 18 de septiembre de 2006, en la etapa final del juicio a Etchecolatz que se desarrollaba en La Plata, López no llegó a la audiencia, constituyéndose su segunda desaparición forzada. Puede pensarse que los posteriores años de luchas en su búsqueda y por encontrar a los responsables, plantearon un punto de inflexión en relación al discurso de búsqueda de justicia por parte del Estado. La desaparición del testigo recibió de los distintos estamentos estatales municipal, provincial, y nacional un tratamiento equívoco, primero, y luego un llamativo silencio. El activismo social y de derechos humanos que había sido parte fundamental del impulso de los juicios a los represores le recriminó al Estado en su conjunto no haber esgrimido ninguno de los amplios mecanismos a su alcance para develar la verdad en el caso López (López, Badenes y Saurio, 2014)

${ }^{105}$ Para un análisis de este período de juicios por crímenes cometidos durante la última dictadura cívico-militar en relación a las "escenas de justicia" y los discursos producidos desde los actores judiciales y sociales, ver la tesis doctoral de Carlos Leavi (2013) Los sentidos de justicia: juicio por genocidio y desaparición de López en la ciudad de La Plata, Doctorado en Comunicación, FPyCS-UNLP.

${ }^{106}$ En el trabajo de Chempes (2009) se hace una sintética caracterización de lo sucedido: Sandra Ayala llegó a la ciudad de La Plata el 10 de octubre de 2006 desde su ciudad natal de Ancón en Perú. Planeaba terminar la carrera de enfermería y estudiar medicina. Vivía en una pensión en el centro de la ciudad. El 16 de febrero de 2007 fue acompañada por un inquilino de la pensión a una entrevista laboral para cuidar a dos niños. La entrevista se realizó en un edificio del entonces Rentas, hoy Arba (Agencia recaudadora de la Provincia de Buenos Aires), en pleno centro de la ciudad. El ingreso de ella, así como de la persona con quién tuvo la
} 
imputabilidad de los menores y la formulación de una nuevo "Código contravencional", propuestas ambas por el Ejecutivo provincial y apoyada por los medios de comunicación tradicionales de la región; y las luchas emprendidas por las expresiones de la diversidad de género que cobraron relevancia en la ciudad. Asimismo, entre 2006 al 2011 se potenciaron o surgieron algunas coordinaciones y espacios de confluencias -sectoriales, multisectoriales, diversos, puntuales-. Por mencionar algunos: asamblea "Justicia por Sandra" (2009-2011), asamblea "No al código de Scioli" (2010), asamblea "Contra el Tarifazo" (2009), Asamblea por los derechos de la niñez (2008-2012), Multisectorial La Plata, Berisso y Ensenada, Mesa de Escrache Popular (organización de escraches a genocidas en la ciudad), FLIA La Plata (2009-2014), las jornadas-eventos “Arde Closet” (2008-2016). Todo esto puede configurarse como “formación”, es decir, como sugiere Raymond Williams

\begin{abstract}
"las formaciones son más reconocibles como tendencias y movimientos conscientes (literarios, artísticos, filosóficos o científicos) que normalmente pueden ser distinguidos de sus producciones formativas. (...) estas son articulaciones de formaciones efectivas mucho más amplias que de ningún modo pueden ser plenamente identificadas con las instituciones formales o con sus significados y valores formales, y que pueden ser positivamente opuestas a ellas" (Williams: 2009, 158).
\end{abstract}

Esta idea de formación cultural da cuenta de un proceso en el que diferentes actores se unen para conseguir objetivos comunes y específicos. Este universo de actores,

entrevista y principal sospechoso, fueron filmados por una cámara de seguridad. El edificio se encontraba en refacción. Las llaves de acceso estaban bajo la órbita de Rentas, perteneciente al Ministerio de Economía de la Provincia de Buenos Aires. El mismo 16 de febrero, al no regresar a su domicilio, el novio de Sandra realizó la denuncia en la Comisaría de la ciudad, la cual no se aceptada bajo pretexto de no haber transcurrido 24hs de la ausencia de la mujer de su domicilio. Cuando finalmente pudo presentarla, la policía y el fiscal Tomás Morán, se negaron a ingresar al lugar del hecho, realizando únicamente un reconocimiento externo. El 21 de febrero llegó la madre de Ayala, proveniente de Perú (...) Recién al día siguiente la policía ingresó al edificio encontrando el cadáver de Sandra. Desde su desaparición concurrieron al edificio al menos seis personas, entre ellos el director de la obra, quienes declararon no haber visto nada en el lugar, a pesar de que el cuerpo se encontraba en el baño, en estado de descomposición. Debido a la demora para poder ingresar al edificio no se pudo realizar la constatación de la violación. Sin embargo otros datos como la postura y la disposición de la ropa confirman la hipótesis." En octubre de 2012, se inició el juicio por el asesinato de Sandra, y en noviembre se dio a conocer una sentencia, que fue interpretada como insuficiente teniendo en cuenta las expectativas tanto de su madre, Nelly, como de las propias organizaciones y colectivos que la acompañaron desde los primeros meses. "Dicha sentencia, emitida por el Tribunal Oral en lo Criminal $\mathrm{N}^{\circ} 5$ de La Plata, condenó a Diego José Cadícamo, único imputado por el asesinato de Sandra, a 21 años de prisión, y por la violación de 7 mujeres más, en algunos casos, inmigrantes como Sandra, y menores de edad. No obstante, más allá de la autoría material del hecho, faltó esclarecer, puntualizar y juzgar a otros actores responsables y cómplices, precisamente por tratarse de un crimen acaecido en un edificio del Estado Provincial. El abogado defensor de la familia Gamboa había solicitado ampliar la causa para investigar a quienes ingresaron al lugar durante los días que tardaron en encontrar el cadáver de Sandra." Florencia Actis. "A siete años del femicidio de Sandra Ayala Gamboa". Disponible en: http://perio.unlp.edu.ar/node/3967 
intervenciones y situaciones que aquí se indagan no se constituyeron exclusivamente en torno a reclamos, demandas y exigencias al Estado. Con frecuencia fueron también iniciativas cargadas de positividad, de intentos de prefigurar otros mundos posibles y de visibilización de modos alternativos de acción y vínculos diversos, principalmente en relación a las formas de organización y creación colectiva y al despliegue de lo afectivo en el desarrollo de las experiencias compartidas.

\section{Delimitación de las experiencias: colectivos e interventores}

A continuación se presentan de forma sintética las experiencias de intervención cultural (colectivos e interventores) que se tomaron para relevar, describir y mapear en la geografía de la ciudad de La Plata en el lapso recortado (2006 y 2011). Se trata, como indicamos al inicio, de los siguientes: La Grieta, Sienvolando, Unidad Muralista Hermanos Tello, Siempre, Arte al Ataque, Luli y Luxor ${ }^{107}$.

\section{III.a. La Grieta, el contrapunto permanente}

La Grieta es un grupo cultural que se inició en La Plata hacia fines de 1993 y que al momento de entrega de esta tesis (febrero de 2017) continúa activo. En los primeros años su actividad estuvo centrada en la realización de una revista impresa (del mismo nombre), luego también sus integrantes ampliaron su intervención en la realización de cuadernillos de debate, folletos y libros, seminarios y espacios formativos, intervenciones callejeras, talleres ligados a algunas disciplinas artísticas (pintura, literatura, etc.) y programas de radio. Como lo plantea Fabiana, una de sus hacedoras, sus actividades se caracterizan "por la creación colectiva, el cruce de lenguajes y la voluntad de encontrarse”. De hecho, el trabajo llevado adelante por el grupo estuvo desde su inicio sostenido desde la autogestión y la colaboración de amigos y vecinos (Entrevista 1, Fabiana). En relación al nombre del grupo, Esteban -otro integrante del grupo-, comenta en una entrevista para La Pulseada: "Había un graffiti que decía: 'no quiero vivir fuera del sistema sino en sus grietas'. Hay tensiones que trabajan todo el tiempo, no hay sólidos infalibles. La grieta es como un espacio de tensión, el momento antes de la

\footnotetext{
${ }^{107}$ Recordamos que para la reconstrucción de los perfiles y las trayectorias de cada uno se combinó información relevada durante el trabajo de campo con la recolectada en sitios web y blog de los colectivos e interventores y otros sitios, notas y entrevistas publicadas en medios de comunicación -tanto comerciales como alternativos de la ciudad-, y algunas conversaciones y entrevistas realizadas para la tesis con integrantes de los colectivos e interventores.
} 
ruptura"108. En este sentido, una suerte de "manifiesto" que fue publicado en el $\mathrm{N}^{\mathrm{o}} 0$ de la revista La Grieta (primavera de 1993) bajo el título "El ojo de la mosca", sirve para dar cuenta de las inquietudes que movilizan al grupo y de su posicionamiento filosófico-político, ético y estético:

“es común soñar con sólidos perfectos, esquemas rígidos y cerrados y miradas ubicuas. Pero lo cierto es que, desde los bordes que recorren el atlas de lo social, pequeñas dislocaciones coexisten en estado de microagitación. Grietas. Centros de gravedad, líneas de fuga. Todo lo sólido está sometido a presiones. Miles de procesos creativos y destructivos vibran en su interior. Lo que para el "otro" es un punto de fragilidad, una zona de peligro de derrumbe, que por tanto habrá de cercar y mantener vigilada; para nosotros es un punto de creación, de producción deseante; un respiradero. Es la zona de vitalidad donde los hombres se reconocen como una multiplicidad. Es el hábitat natural donde los cuerpos se juntan; el espacio de encuentro, de la "mezcla" liberadora de tensión. Una grieta, es aquella rajadura nómade, que escapa a toda rutina. No se deja absorber para convertirse en una institución previsible (...) La grieta es el hueco de luz, el intersticio de la calle (...) es el río en medio del mar, el panorama de los insectos, el ojo de la mosca, el ruido de la noche cuando cruje (...) Pensar ese afuera, es despertar al niño dormido, al imaginado.”

Más cerca en el tiempo, en 1010, cuando el sitio web de La Grieta estaba aún disponible, se podía leer en el apartado “¿Quiénes somos?”:

"Una grieta puede ser literatura, puede ser aventura, riesgo, movilización, comprensión de lo ruinoso, añoranza de construcción o de destrucción. Puede ser aquello que empieza a visibilizarse como quiebre. (...) En una grieta se ve la luz exterior. Queda la vista mirando hacia espacios abiertos. Pueden coexistir las dudas de lo que se desmorona, lo que está próximo a la caída, como la devoción por poner manos a la obra, no para subsanar la herida, el corte, sino para poner práctica la mezcla.”

La Muestra Ambulante: Entre fines de mayo y principios de junio 1995 realizaron la $1^{a}$ Muestra Ambulante (MA) en el barrio Meridiano V, lugar de la ciudad en el que el grupo desarrollaba parte de sus actividades de manera itinerante y residencia de varios de sus integrantes. En aquella muestra hubo 58 espacios donde se desarrollaron las actividades -

\footnotetext{
${ }^{108}$ Declaración extraída de la nota de Ramón Tarruella, "Las revistas en La Plata: Los parientes de La Pulseada", La Pulseada, $\mathrm{N}^{\circ} 19$, abril de 2004.
} 
principalmente negocios-, entre almacenes y el Banco Municipal, entre kioscos y el bar "Ocampos", entre peluquerías y ferreterías, entre la explanada de la Estación provincial y los galpones del ferrocarril. Fue una muestra que se propuso "desafiar al centro" -a las galerías y museos y a la universidad- ${ }^{109}$ y la vez comenzar a "descubrir el barrio" que ya se lo habitaba. En el folleto de la muestra -titulado “de viaje en la estación otoño" (1995)- puede leerse:

\begin{abstract}
"Desplazarse. Moverse. Cambiarse. Un río intenso que fluye y no estatiza. Un río inmenso que en las esquinas: grita, que vuelve, que va. (...) Lazos. Puentes. Urbanautas que se desplazan de un lugar a otro con los gestos adquiridos en los caminos: la debilidad, la fuerza. (...) Viajar en la ciudad. Construir el viaje en la baldosa. (...) Hay una orquesta en la cara de la luna. Hay una orquesta en la palma de la mano. Hay un concierto en la plaza. Hay un mapa que nombra. De la calle seca, áspera, con charco pero de la calle al fin es que surgen estas canciones. No son más que sentir, develar, darse ánimo. Ser solos y nuevos, pero sobre todo ser otros."
\end{abstract}

El grupo continúo produciendo la revista y realizando sus actividades de forma itinerante (por ejemplo, en La Fabriquera, Galpón Sur, facultades de la UNLP y algunos talleres en casas particulares), hasta que a inicios de 2004 recuperaron y refuncionalizaron uno de los galpones abandonados del ex Ferrocarril Provincial en el barrio Meridiano $\mathrm{V}^{\mathrm{o}}$, al que llamaron "Galpón de Encomiendas y Equipajes”, nombre que tenía cuando funcionaba el ferrocarril. En este propio y nuevo espacio es donde se volcó y transitó desde ese entonces la mayor parte de la experiencia de este colectivo, proponiendo principalmente varios espacios de taller formativos y creativos pero además se convirtió en un espacio de eventos culturales (recitales, fiestas, etc.). En el 2004 también publicaron el último número de la revista en formato impreso y plantearon que la revista -como eje articulador de la experiencia del grupocobraba una "dimensión tridimensional o en 3D" (E 5, Matías y E 4, Daniel) al incorporarse el galpón. En los años 2005, 2006, 2007 y 2009 desde La Grieta re-editaron la MA en las ediciones 2, 3, 4 y 5 siempre en Meridiano $\mathrm{V}$ y en los meses de noviembre o diciembre.

Las últimas tres muestras: Con una idea-fuerza de poner "la silla en la vereda" la Muestra Ambulante fue un espacio que convocó a artistas de distintas disciplinas, vecinos y

\footnotetext{
${ }^{109}$ En el libro de la MA La Grieta escribe sobre los propósitos de esta primer muestra: "Nos impulsaba, sobre todo, poder en discusión una idea muy difundida en el mundo académico y en el campo del arte -y también bastante arraigada entre los vecinos-: la de que el arte necesita de un ámbito particular para su contemplación" (La Grieta, 2009: 173).
} 
curiosos $^{110}$. A su vez, discutiendo el lugar central y la legitimidad que ocupan los espacios céntricos de la ciudad para visibilizar, producir y acceder a las expresiones artísticas y culturales, La Grieta convocó a pensar y producir otros lugares, recorridos, momentos y temporalidades para las experiencias estéticas, no ligadas tanto al momento programado del ocio -la salida nocturna, la visita al museo, la agenda del fin de semana- sino a la vida cotidiana del vecino o del paseante ocasional buscando provocar diálogos entre sujetos diferentes. Las Muestras Ambulantes de 2006, 2007 y 2009 tuvieron diferentes intensidades y magnitudes. Las dos últimas concentraron -según los organizadores- la participación de 700 artistas, colectivos productores culturales y llegaron a convocar a más de 10.000 personas cada una, según los cálculos del grupo gestor (La Grieta, 2009). Pero además de la propia muestra, lo que fue cambiando profundamente fue ese propio barrio que vivenció diferentes procesos sociales, urbanísticos y culturales: de ferro-barrio al cierre de la estación y el pasaje a lugar abandonado; de espacio donde comenzaron a aflorar iniciativas culturales colectivas con la recuperación por parte de los vecinos de espacios abandonados- al "circuito cultural" Meridiano V con bares, restaurantes, mega-eventos y fiestas nocturnas; del "barrio de viejos" a una zona donde los jóvenes de clase media "salen" los fines de semana, un barrio donde el consumo parece ser un eje importante que encadena las experiencias que allí suceden. La Muestra Ambulante vivió, transitó, participó y contribuyó en muchas de las modificaciones que hacen que hoy exista otro barrio. Actualmente La Grieta tiene cerrada la posibilidad de una nueva MA, al menos no con las características y magnitudes de las dos últimas ediciones. Esto se debe centralmente por las principales apuestas e intereses que actualmente guían al grupo -ligadas a un trabajo más cotidiano de prácticas formación y creación- y, en parte, por los cambios ocurridos en el barrio Meridiano $\mathrm{V}^{\circ}$.

En 2011 comenzaron a editar la revista "La Grieta digital"111, buscando en algunos casos un cruce entre ensayo político y artes visuales. Publicaron 11 números online, el último en $2013^{112}$. También produjeron su propia página web que, desde hace unos años, no está

\footnotetext{
${ }^{110}$ En el escrito "Habitar y derivar. 20 tesis sobre la muestra ambulante" de Esteban Rodríguez (2008: 68) se plantea: "La ciudad se mueve, los vecinos salen a la calle, se encuentran. ¡Otra vez la silla en la vereda! El arte está vivo. La cultura otra vez en las aceras. La Muestra Ambulante es una obra hecha con muchas obras, una obra colectiva, abierta, que se bifurca a medida que se la van apropiando los vecinos, los artistas y colectivos culturales que participan. Una muestra donde las obras se devoran entre sí, y al devorarse mutuamente, mutan, se impregnan de otros sentidos."

111 http://lagrietadigital.blogspot.com.ar

112 Daniel, que integró el grupo entre el 2007 y 2010 y no participó del proyecto de la revista digital, realiza una observación crítica de esta publicación: "hay algo ahí que se bifurca, que hasta podría tener una lectura de género, porque si vos te fijas cuando ese grupo de históricos que orbitan, deciden que aunque sea digital, vuelva a la revista La Grieta (...) básicamente es, exagerando y caricaturizando, es una revista en la que los hombres de La Grieta escribieron, mientras las mujeres sostenían el galpón y daban talleres, y consolidan el proyecto que es,
} 
disponible para visualizarse. Algunos canales virtuales que utilizan son la red social Facebook ${ }^{113}$ y un $\operatorname{blog}^{114}$ donde publicitan las actividades que ocurren en el galpón, pero ninguno funciona como una publicación sistemática.

Actualmente sus principales actividades son el desarrollo de talleres de formación, producción y creación -propuestas que van entre el teatro, la literatura infantil, la literatura para jóvenes y adultos, la construcción de objetos y la plástica- así como otras actividades culturales -recitales, presentaciones de libros y revistas, muestras de arte- todas desarrolladas en el galpón. Actividades que aportan a la consolidación y desarrollo de un proyecto educativo, creativo y territorial.

\section{CircuitoCulturalMeridianoV CentroculturalEstaciónProvincialGalpónSursiempre MuestraAmbulante centrolgavazquez AsambleabarrialMeridianoV Luli FMFuturaTormentaMedioLimón ReddeCentrosCulturales}

Imagen 2. Composición visual de las articulaciones del grupo La Grieta.

para mí, el más interesante de La Grieta. (...) Daba para un chiste, esa cosa de que los hombres escriben y las mujeres le ponen el cuerpo en la producción... una producción que, para mí, es mucho más interesante que la reedición de una revista cuyo lenguaje ya no es para la época. Lo digital me parece buena apuesta. Lo que pasa es que no hubo una producción desde lo digital. De hecho cuando me contaron el proyecto no me gusta nada que fuera un Blogspot, eran muchos blogspots enganchados, era una pedorrada en términos de tiempos... No era la revista Carapachay, no era Anfibia, ningún programador web, diseñador se puso a pensarla. La Grieta como revista papel era una revista que había que romper una faja para abrirla. En el tiempo de lo digital, hacé lo mismo con el 2.0, pero que algo te provoque. En una cosa de suma de ensayos que para mí es... La Grieta, El Ojo Mocho, Pensamientos de los confines, revistas que para mí son de los 90’ y para leer en los 90’. (...) Me cuesta pensar que vuelva a haber una revista La Grieta que tenga un sentido como tuvo la revista. Pero lo que no podés permitir es tener una revista donde el pasado se repite como farsa" (E 4, Daniel).

${ }_{114} \underline{\mathrm{https}: / / \text { www.facebook.com/lagrietaylachicharra }}$ 


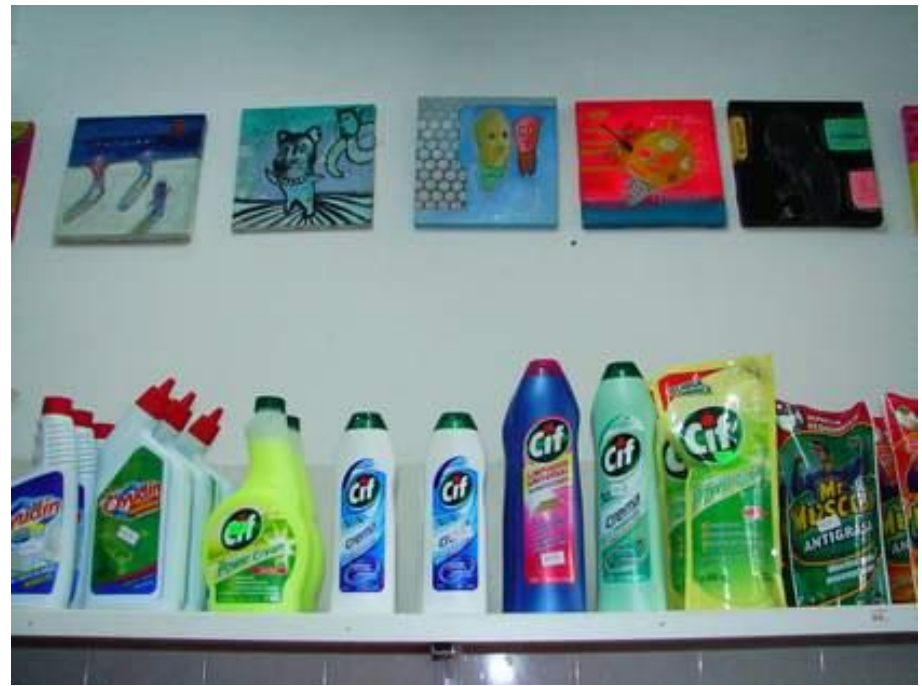

Imagen 3. "Muestra Ambulante 4", pinturas de Camilo Garbin en el local de artículos de limpieza "Todo suelto". Fecha: noviembre de 2007. Ubicación: 68 e/716 y 17. Extraída del blog del grupo.

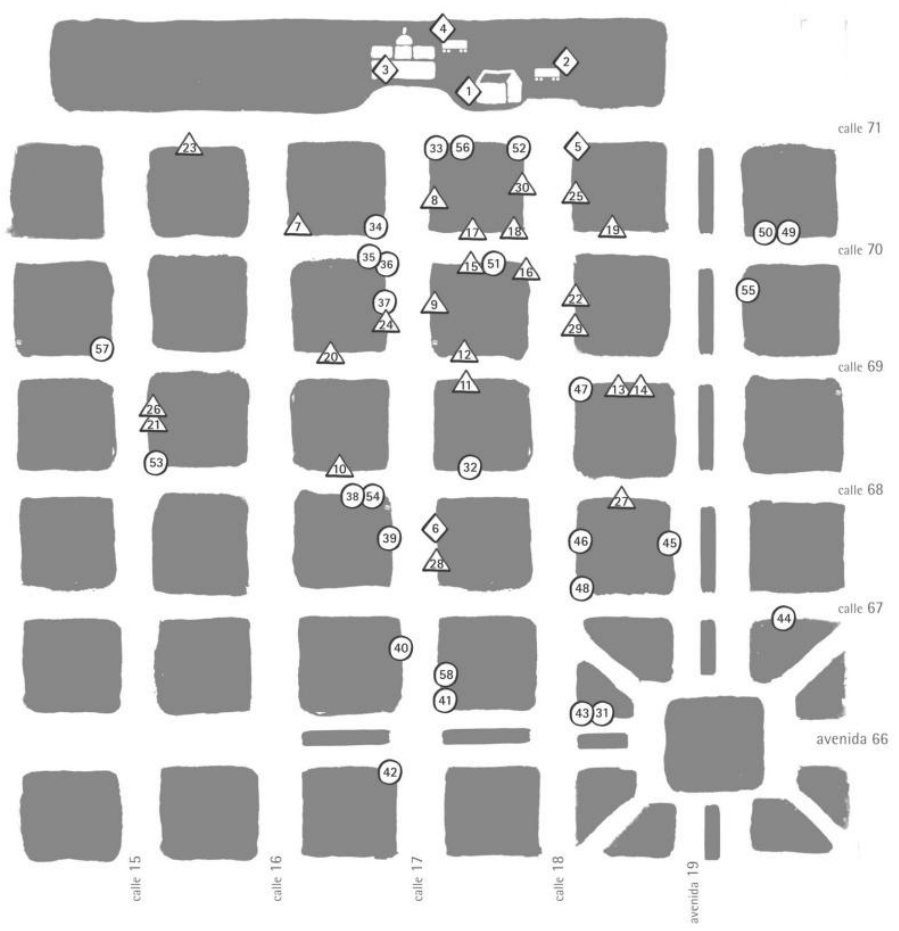

Imagen 4. "Un mapa para perderse" Muestra Ambulante 5. Fecha: noviembre de 2009. Ubicación: lugares y puntos del barrio Meridiano V en los que sucedían actividades de la muestra. Imagen extraída del blog de la Muestra Ambulante.

\section{III.b. Sienvolando, cambiar la piel de la ciudad}

Sienvolando fue un colectivo que existió entre 2002 y 2009 y que intervino principalmente en el espacio urbano de La Plata. Por las búsquedas estéticas-comunicativas y los cruces constantes se puede reconocer que no se trató sólo de un grupo muralista, ya que en 
sus acciones se propusieron combinar saberes, recursos y soportes del espacio urbano, las artes visuales, el diseño y la publicidad, la comunicación y la web. Muchas de sus intervenciones se articularon con organizaciones sociales, políticas, sindicales y de derechos humanos, así como movimientos sociales territoriales y otros grupos de intervención. Estas articulaciones generaron acciones colectivas que supusieron desde pensar las ideas-fuerza, el discurso y las estrategias comunicacionales, hasta las formas de llevarlo adelante en el espacio urbano, y su realización. Quizá no se puede reconocer a Sienvolando como una práctica artística (mural) ni como un colectivo de comunicación (que realiza una estrategia comunicacional), sino como un despliegue múltiple de un dispositivo crítico que pone en juego elementos estéticos, artísticos, comunicacionales, publicitarios y políticos: acciones en paredes y murales, acciones en veredas y calles, acciones web, cartas apócrifas y banners, murales, stencils y diseños web, cruces entre soportes y entre recursos. En una de las pocas entrevistas que se publicaron cuando el colectivo estaba activo, planteaban que Sienvolando era:

"un conjunto que personas que se fueron juntando para desarrollar acciones. La idea es no tener muchos preconceptos fuertes, sino ir viendo a través de la acción y de la experiencia concreta cómo se va plasmando ese proyecto, ese es el motor general.

(...) Primero fueron murales, después fueron surgiendo otro tipo de acciones. (...) Surgió esto de ir coordinando con otras agrupaciones, lo más rico es ir compartiendo con otros grupos. Ir laburando en red para descentralizar, usando las redes que ya están hechas, para laburar de una forma más fuerte."115

En otra entrevista, ante las preguntas de por qué pintan murales y si les preocupa lo efímero del soporte (la pared), respondieron: "Nos preocupa pero positivamente. Concebimos la ciudad como un ser vivo que va perdiendo y cambiando la piel. Justamente trabajamos sobre esa piel y en el mismo proceso contemplamos la posibilidad de que la ciudad se exprese." 116 Esa posibilidad de que "la ciudad se exprese" hace referencia a lo imprevisible del accionar de otros discursos y enunciados, a la posibilidad del "escracho" al mural y la ampliación -promovida incluso por el colectivo- de otras intervenciones allí mismo y a la apertura de nuevos sentidos. Por ende, el colectivo auspiciaba tanto el diálogo como el

\footnotetext{
115 "Usamos muchos recursos de la publicidad para emitir otro tipo de mensajes". Entrevista al grupo Sienvolando, Indymedia La Plata, junio de 2008. Disponible en: http://argentina.indymedia.org/news/2008/06/610696.php

${ }^{116}$ Entrevista en revista La Pulseada $\mathrm{N}^{\circ} 55$, noviembre de 2007.
} 
desacuerdo ${ }^{117}$. Pensar desde esa metáfora de "la piel de la ciudad" -que este mismo trabajo retoma en su título- habilita a imaginar que la ciudad va mutando y se moviliza, abriendo la posibilidad de los cambios. A su vez, esa metáfora discute con ciertos planteos de la monumentalidad y la perdurabilidad del muralismo. Al respecto, en la última entrevista como colectivo decían:

\begin{abstract}
"elegimos herramientas para comunicar una idea. Entonces el mural es una herramienta más, como puede ser un mail, una página de internet, un afiche, un personaje inventado, un cartel. Tratamos de escapar a quedar en el mural. (...) Desbaratar la idea de mural, si se quiere, para pensar más bien en una piel, en algo que es orgánico, con algo que crece, que muta, que cambia. Romper un poco con el deber ser del mural."
\end{abstract}

En Sienvolando fueron importantes tanto las intervenciones de estudio e investigación (coordinación previa con colectivos, construcción colectiva de la acción, indagación en los dispositivos, plazos medianos y largos de producción) como las acciones más "directas" realizadas en un día. Algunas de sus acciones fueron: mural "Fuera Bush" (2005), murales por la desaparición de Jorge Julio López (2006 y 2008), acciones por el femicidio de Sandra Ayala Gamboa (2008, 2009), intervención sobre "La banda de la frazada" (2008), intervención en el espacio urbano y en la web por el aniversario del asesinato de Darío Santillán y Maximiliano Kosteki "Buscar Justicia” (2008), mural junto con Autoconvocados contra el SIDA -Addhes- (2008) y la participación en la intervención "Hacé como José" (2009) sobre el aumento del boleto de colectivos locales. Junto a esto utilizaron también estrategias de comunicación para registrar detalladamente sus acciones. Así, crearon un blog, que funcionó principalmente como archivo y en menor medida como espacio de publicidad de

\footnotetext{
${ }^{117}$ Uno de los murales de Sienvolando proponía el lema "escrachelo usted mismo" ("Fuera Bush" del año 2005), otro dejaba dibujadas una mochila y unas hojas de carpeta para que sean intervenidas ("La Noche de los Lápices", 2006). A su vez, varias pintadas murales fueron tapadas por el mismo colectivo con otras acciones gráficas. Hasta llegaron a realizar un mural que a los pocos días iba a ser escrachado como parte del recorrido de una marcha, a dos años de la segunda desaparición de Jorge Julio López (“Silencio K = impunidad”, septiembre de 2008).

${ }^{118}$ En esa misma entrevista, que forma parte del documental "La rebeldía es multicolor" (2009) realizado por la editora VomitArte, desde Sienvolando agregan: "Así como creemos que no está bueno que haya en la plaza un monumento impuesto para siempre, que está ahí, que es sólido y que nadie lo puede sacar. Tampoco está bueno que seamos nosotros los que imponemos las imágenes. No solo porque no está bueno imponerlas, porque son nuestras y podrían estar otras, sino que no está bueno imponerlas para siempre porque la realidad va cambiando. Entonces, está bueno que otra gente se apropie de las paredes y que vayan cambiando con la misma realidad, que no haya como un pasado estancado, firme en las paredes que vaya contando historia para quienes que vengan después. Si no que esa misma realidad vaya cambiando, siga contando historia a futuro". Video disponible en: https://www.youtube.com/watch?v=bj3 LKWw8Ks
} 
las intervenciones realizadas ${ }^{119}$. Desde ese mismo espacio en la web anunciaron la disolución del colectivo con una imagen-placa utilizando el "Game over" del videojuego PacMan.

\section{SutebaLaPlata \\ AsambleaContraelAumentodelBoleto \\ CentroOmarFavero CentroOlgaVazquez \\ UnidadHnos. Tello ${ }^{\text {Asambleaususiciaporsandra }}$ \\ Siempre e- FPDSHIJOSLaPlata \\ ArtealAtaque Multisectorial}

Imagen 5. Composición visual sobre las experiencias con las que articuló Sienvolando.

También se pueden reconocer algunas derivas y relaciones de Sienvolando con otras prácticas posteriores: Luli, Luxor, Lumpenbola, otros/as productores/as visuales individuales y Síntoma curadores.

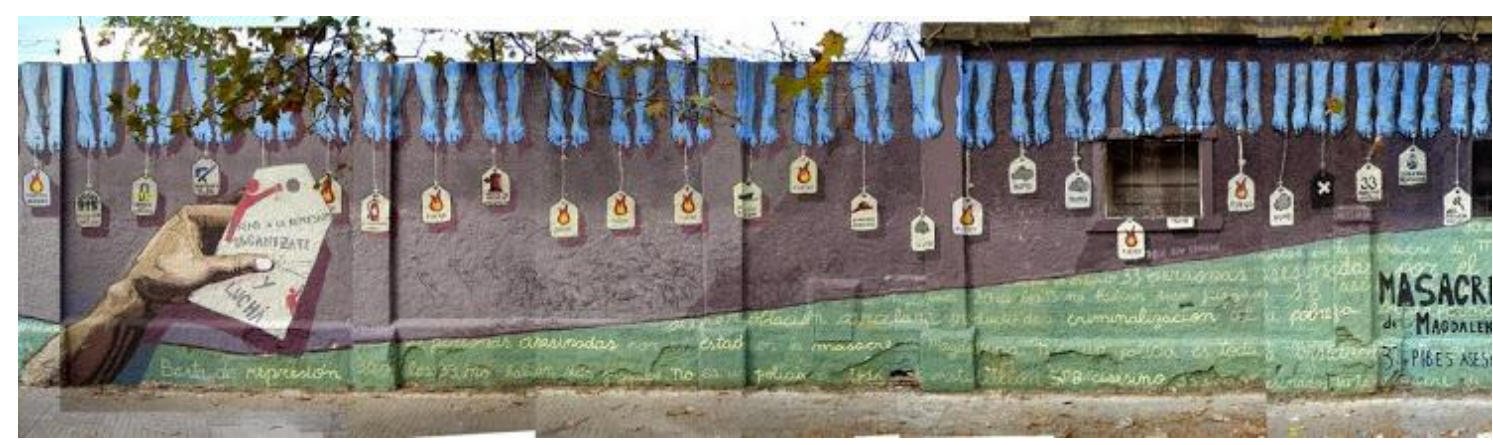

Imagen 6. Mural de Sienvolando junto a Correpi La Plata por la "masacre de Magdalena”. Fecha: mayo de 2008. Ubicación: Av. 44 esq. 3. Extraída del blog del colectivo.

\footnotetext{
${ }^{119}$ http://sienvolando.blogspot.com.ar
} 


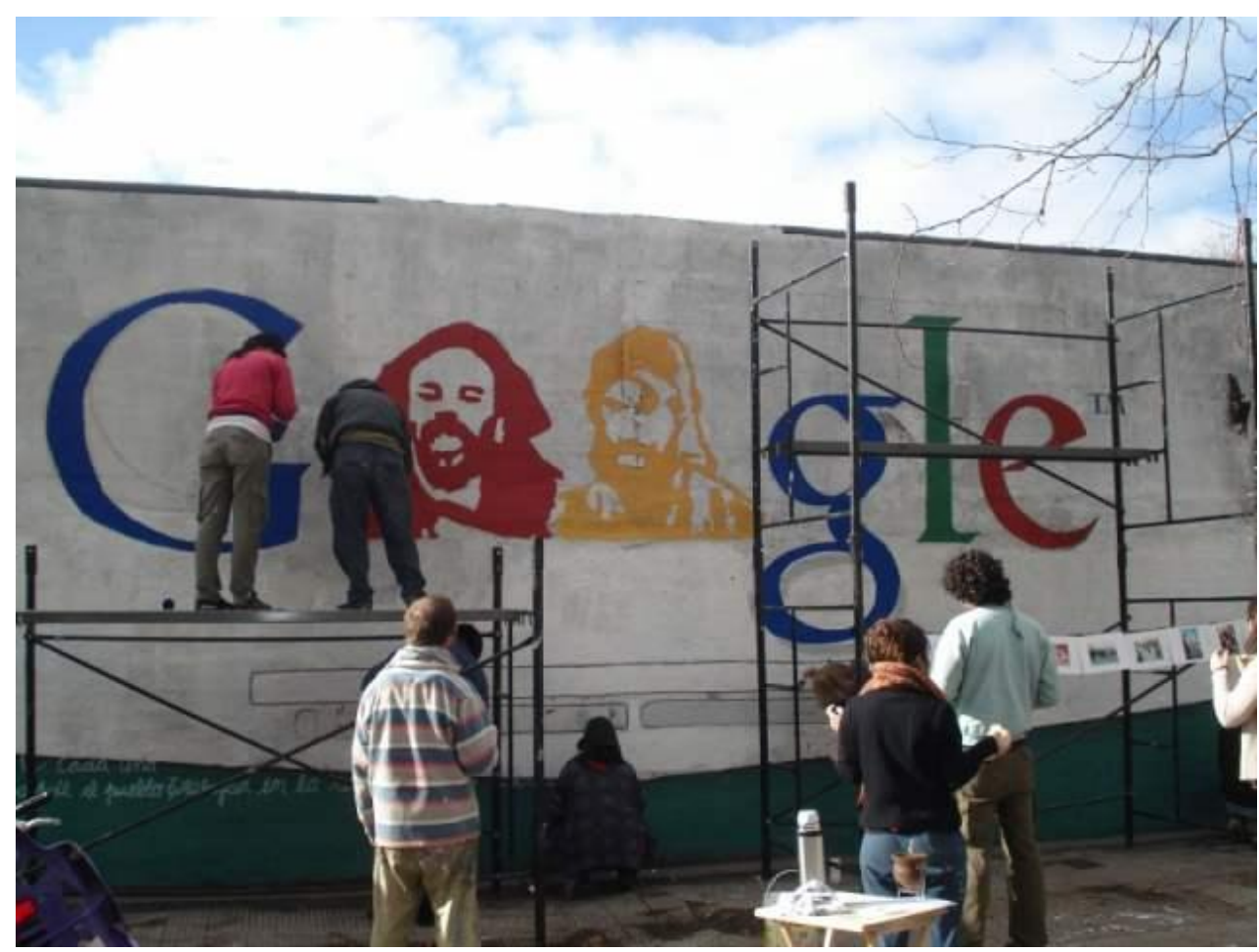

Imagen 7. Mural que fue parte de la acción "Darío y Maxi: Buscar justicia", realizada por Sienvolando junto con el espacio cultural del FPDS. Fecha: junio de 2008. Ubicación Avenida 1 e/ 56 y 57. Imagen de Federico Sager y Daniela Samponi extraída de sitio web de Indymedia La Plata.

\section{III.c. Unidad Muralista Hermanos Tello, pintar y luchar}

La Muralista Hermanos Tello, La muralista o simplemente "Los Tello", fue un grupo muralista que desplegó sus acciones en La Plata entre 2006 y 2011. Tuvo otras unidades "hermanas" en Quilmes y Capital Federal, con las cuales intervenía frecuentemente en esas y otros ciudades; también realizó intervenciones en otros países, como en Chile. El nombre de la Unidad Muralista, a la vez de construir una figura colectiva del propio grupo, remite a Marcelo, Pablo y Rafael Tello, integrantes de la organización "Resistencia Libertaria" ${ }^{20}$, los tres fueron detenidos-desaparecidos durante la última dictadura militar argentina. Se puede reconocer una presencia de elementos de una perspectiva política libertaria y una fuerte impronta de denuncia -de reclamos sociales y de derechos humanos, así como de situaciones reconocidas como injusticias. Gran parte de sus acciones se articularon con movimientos sociales, trabajadores en conflicto, coordinadoras de colectivos artísticopolíticos y con organizaciones de Derechos Humanos (sobre todo en relación a la búsqueda de justicia por la desaparición forzada de Jorge Julio López ocurrida en la ciudad de La Plata en octubre de 2006). También con organizaciones territoriales como comedores comunitarios, bachilleratos populares y centros culturales autogestionados de La Plata, Buenos Aires y

\footnotetext{
${ }^{120}$ En un número 63 de la revista Sudestada (octubre de 2007) se analiza en un informe especial esta experiencia política libertaria desarrollada en Argentina.
} 
localidades del conurbano bonaerense. "La Muralista" a través de un modo de organización horizontal, buscó extender las herramientas gráficas, para que otros se las apropien, como plantea uno de sus integrantes:

\begin{abstract}
"Nosotros no tenemos la película clara, la película iluminada como vanguardia, no tenemos esa intención. Es parte de una construcción colectiva y en ese mismo marco se basa la forma de hacer los dibujos, que sea de fácil acceso y cualquiera pueda hacerlo, (...) para formar un grupo con estas características de organización horizontal, rescatando lo que es colectivo."121
\end{abstract}

A su vez, la mayoría de sus acciones se desplegaron en los "espacios céntricos" de la ciudad, sobre todo acompañando movilizaciones y reclamos colectivos, pero también en barrios populares donde están asentadas varias de las organizaciones sociales con las que coordinaron los murales, pintadas, pegatinas y jornadas culturales. "Los Tello" utilizaron una estética con tres colores básicos -negro, rojo y blanco-, líneas, figuras humanas y textos. Sus producciones gráfico-visuales se centraron en la realización de murales, pero también tipos móviles, figurones y pancartas ${ }^{122}$. Su blog ${ }^{123}$ y perfil en fotolog ${ }^{124}$ funcionan como registro y archivo, poco sistemático, de sus acciones, desde el 2008. También tuvieron perfil de Facebook que actualmente está dado de baja. En ninguna de estas tres plataformas anunciaron la disolución de "la muralista".

\footnotetext{
${ }^{121}$ Fragmento de entrevista a un integrante de UMHT realizada para la muestra colectiva "Calle tomada" (2010) coordinada por el Centro Experimental Vigo y el Museo de Arte y Memoria (Comisión Provincial por la Memoria). La desgrabación de las entrevistas a los participantes fueron cedidas al autor por parte del Museo para ser utilizadas en una nota escrita en su momento para la revista Puentes $\mathrm{N}^{\circ} 10$ de la CPM. Para una mayor descripción de dicha muestra ver:

Blog de la muestra: http://calletomada.blogspot.com.ar

Nota en Indymedia La Plata: http://argentina.indymedia.org/news/2010/04/728061.php

Nota en revista La Pulseada, $\mathrm{N}^{\circ}$ 82, agosto de 2010 (por Magdalena Pérez Balbi). Disponible en: http://www.lapulseada.com.ar/site/?p=1461

${ }_{122}$ Algunas de sus intervenciones están registradas en videos cortos publicados en Youtube, como la realizada en la estación Avellaneda, -renombrada "Estación Darío y Maxi"- en junio de 2007 al cumplirse 5 años del asesinato de los dos militantes del movimiento piquetero, Darío Santillán y Maximiliano Kosteki. Disponible en: https://www.youtube.com/watch?v=TQ6qyzVeEME El mural que produjeron en diciembre de 2008 en el Centro "Olga Vázquez". Disponible en: https://www.youtube.com/watch?v=A6X7RtN4bzo También está publicado un video de la intervención con stencil realizada en la estación "Darío y Maxi" como parte de las jornada cultural de los días 25 y 26 de junio 2009 . Disponible en: https://www.youtube.com/watch?v=4MFR3gz452c

123 http://umht.blogspot.com.ar

$124 \underline{\text { http://www.fotolog.com/umht/mosaic }}$
} 
CalleTomada intervención Wagenta

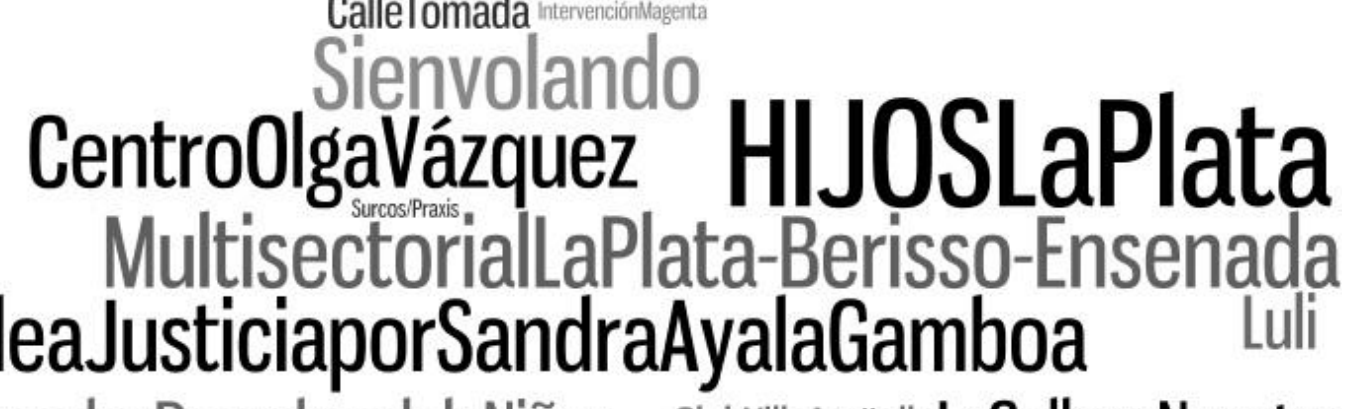
AsambleaporlosDerechosdelaNiñez ClubvillaArgüelloLaCalleesNuestra GalpóndeTolosa

\section{ArtealAtaque FlialaPlata}

Imagen 8. Composición visual de las articulaciones de la UMHT.

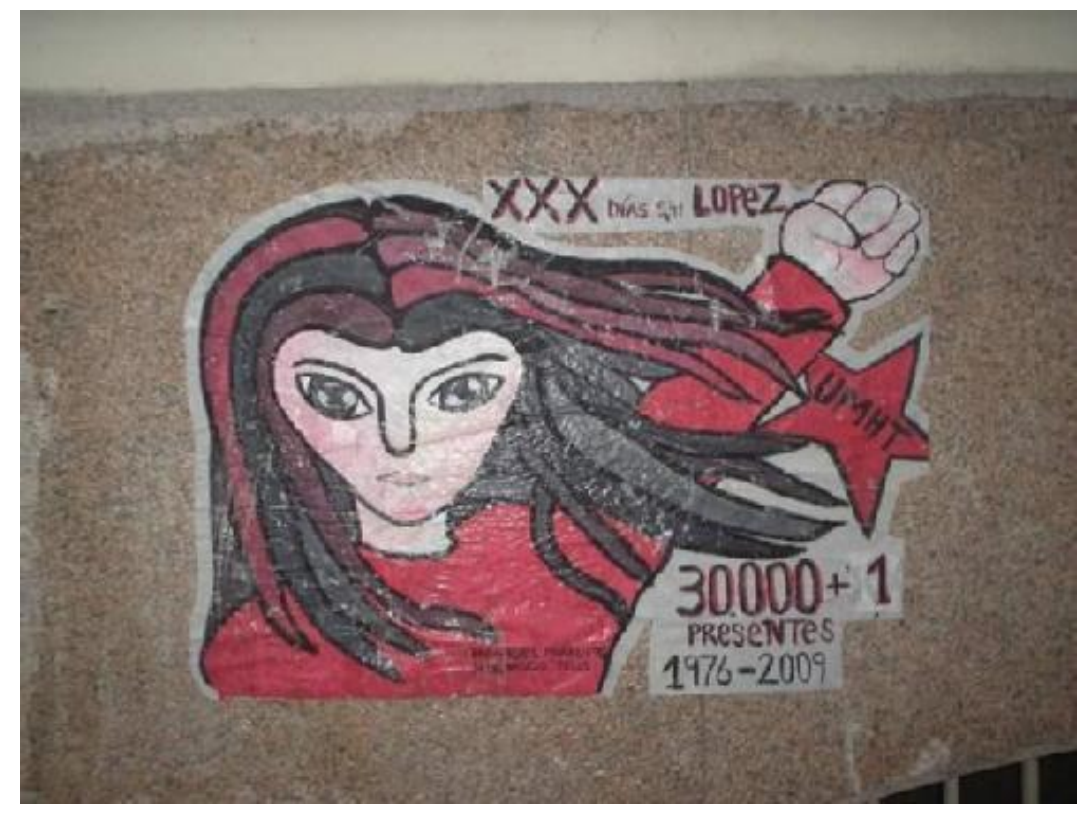

Imagen 9. Pegatina de figurones de la UMHT. Marcha en La Plata por el 24 de marzo a 33 años del golpe cívico-militar. Ubicación: edificio público en el centro de la ciudad. Año: 2009. Extraída del fotolog del grupo. 


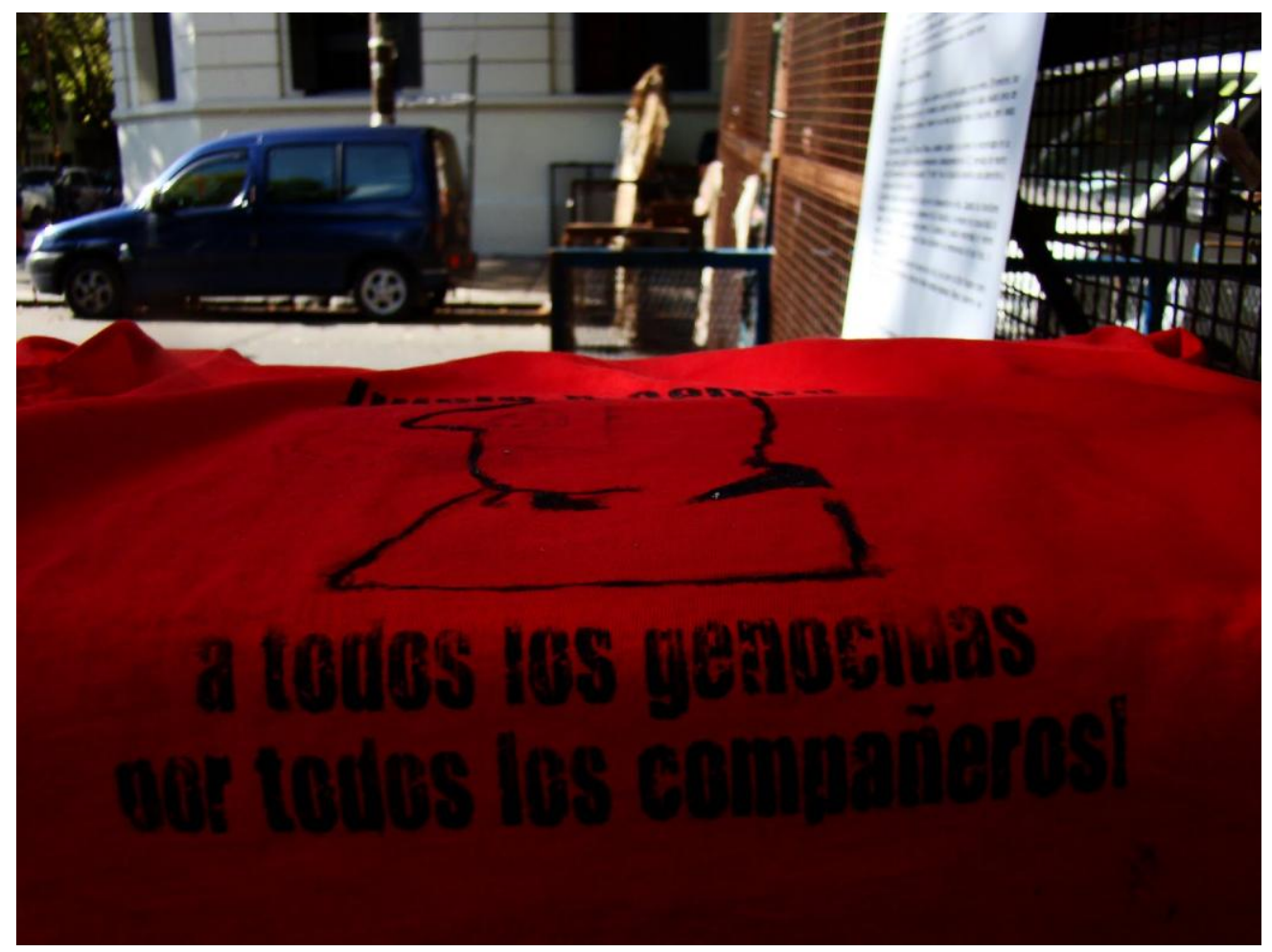

Imagen 10. "Juicio x centro. A todos los genocidas por todos los compañeros". Estampado de remeras con leyenda llevado adelante por UMHT junto con HIJOS La Plata y Arte al Ataque, en el marco del juicio a los represores de la Unidad 9. Fecha: abril de 2010. Ubicación: 4 y 51. Imagen extraída del blog de la Unidad.

\section{III.d. Colectivo Siempre, entre el arte y la acción política}

Siempre fue un colectivo conformado por mujeres que desde inicios del 2006 centró sus intervenciones en la danza, la coreografía y la performance corporal, principalmente en espacios públicos de la ciudad (como plazas, movilizaciones, jornadas y eventos culturales, facultades, centros culturales municipales y autogestionados). El primer antecedente para reconocer el surgimiento del colectivo es una obra de danza y música denominada "Siempre" producida en la Facultad de Bellas Artes de la UNLP, al conmemorarse los 30 años del golpe cívico-militar en Argentina. En su blog se presentan del siguiente modo:

"Venimos trabajando desde el año 2006. Hoy somos un grupo de mujeres que encontramos en el arte un modo para reflexionar y operar sobre nuestra realidad, tomando diversas problemáticas políticas y sociales que nos convocan y nos interesan. El discurso artístico es el medio y el cuerpo la principal herramienta de ese discurso. A veces hacemos producciones coreográficas y otras, acciones más performáticas y agitativas, 
buscando la expresión y participación colectiva. Generalmente abordamos el espacio público como escenario o lugar de manifestación." 125

Se trató de una propuesta posicionada desde un triple lugar: a partir de tomar y repensar el discurso y la práctica artística -por ejemplo, en la circulación de materiales y textos analíticos en su blog-, la articulación con acciones políticas y grupos, y el trabajo con la coyuntura. En este sentido expresan, en ese mismo texto de su blog: "como nuestro universo de acción no se limita solamente al ámbito artístico, en este espacio también informamos acerca de eventos políticos, sociales y culturales que consideramos importante divulgar y apoyar."

Julia (E 16) que fue parte de la obra de danza y del video-danza, encuentra que la conformación del colectivo se da principalmente a partir de la creación y organización de la acción por los seis meses de la desaparición de Julio López (en febrero-marzo de 2007):

\begin{abstract}
"[desde ahí] empezamos a juntarnos y a proyectar, a tener una constancia -creo que nos juntábamos una vez por semana- Teníamos una constancia de trabajo que nos fue unificando las decisiones que tomar en cuanto a lo político y lo estético. Nos empezamos a poner más de acuerdo en quiénes éramos y hacia dónde íbamos sobre un tiempo, éramos muchas mujeres, bastante intenso.” (E 16, Julia)
\end{abstract}

Renée (E 13) sintetiza los propósitos del grupo en buscar una "creación colectiva en la danza", "romper con los espacios convencionales del arte" y "cruzar el arte y lo político". Para Julia (E 16) el colectivo se propuso "repensar los modos de creación desde el lenguaje de la danza". El colectivo desarrolló varias acciones en coordinación con otros colectivos y participó en diversos eventos como las movilizaciones por la aparición con vida de Jorge Julio López (acción "rostros", "Comando tapabocas"), las actividades de colectivos feministas y queer (como "Arde Closet"), las vinculadas al pedido de justicia por el femicidio de Sandra Ayala Gamboa, en las FLIAs y en la Muestra Ambulante a través de la "Verdudanza" (2007) y el "Proyecto ligado" (2009). Entre las obras propias se encuentran la mencionada obra de danza y música "Siempre” (2006), “Cuerpo de baile” (2008-2009), el videodanza "Siempre” (2008).

El grupo se disolvió a mediados de 2011, anunciando su despedida en su blog. Ese espacio virtual funcionaba como visualización de sus acciones y eventos, lugar de expresión

\footnotetext{
${ }^{125}$ Este fragmento es parte del texto de presentación del colectivo que aparece como destacado y primera publicación cuando se accede al blog. Disponible en: http://colectivosiempre.blogspot.com.ar
} 
de pensamientos y posiciones del grupo, espacio para compartir textos sobre algunos ejes que trabajaban y actualizaciones de noticias de su interés (principalmente extraídas de medios electrónicos alternativos).

\section{MuestraAmbulante SienvolandoLaGrieta} HIJOSLaPlata TintaRoja

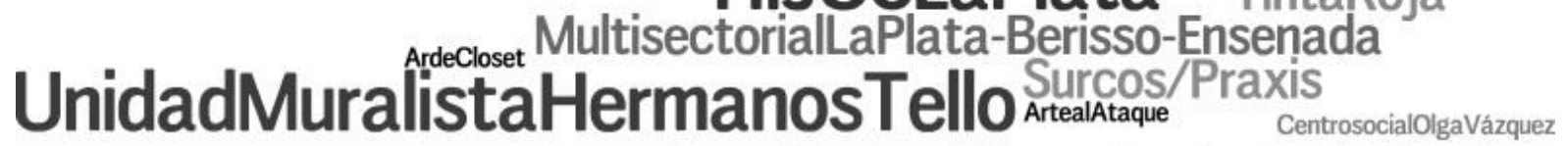
AsambleaJusticiaporSandraAyalaGamboa

Imagen 11. Composición visual de las articulaciones del colectivo Siempre.

También se puede encontrar algunas derivas y vínculos de Siempre con otras prácticas simultáneas y posteriores: Aula 20, Proyecto en Bruto, Festival DanzaAfuera, Ecart (Encuentro Platense de Investigadores sobre el Cuerpo en las Artes Escénicas y Performáticas).

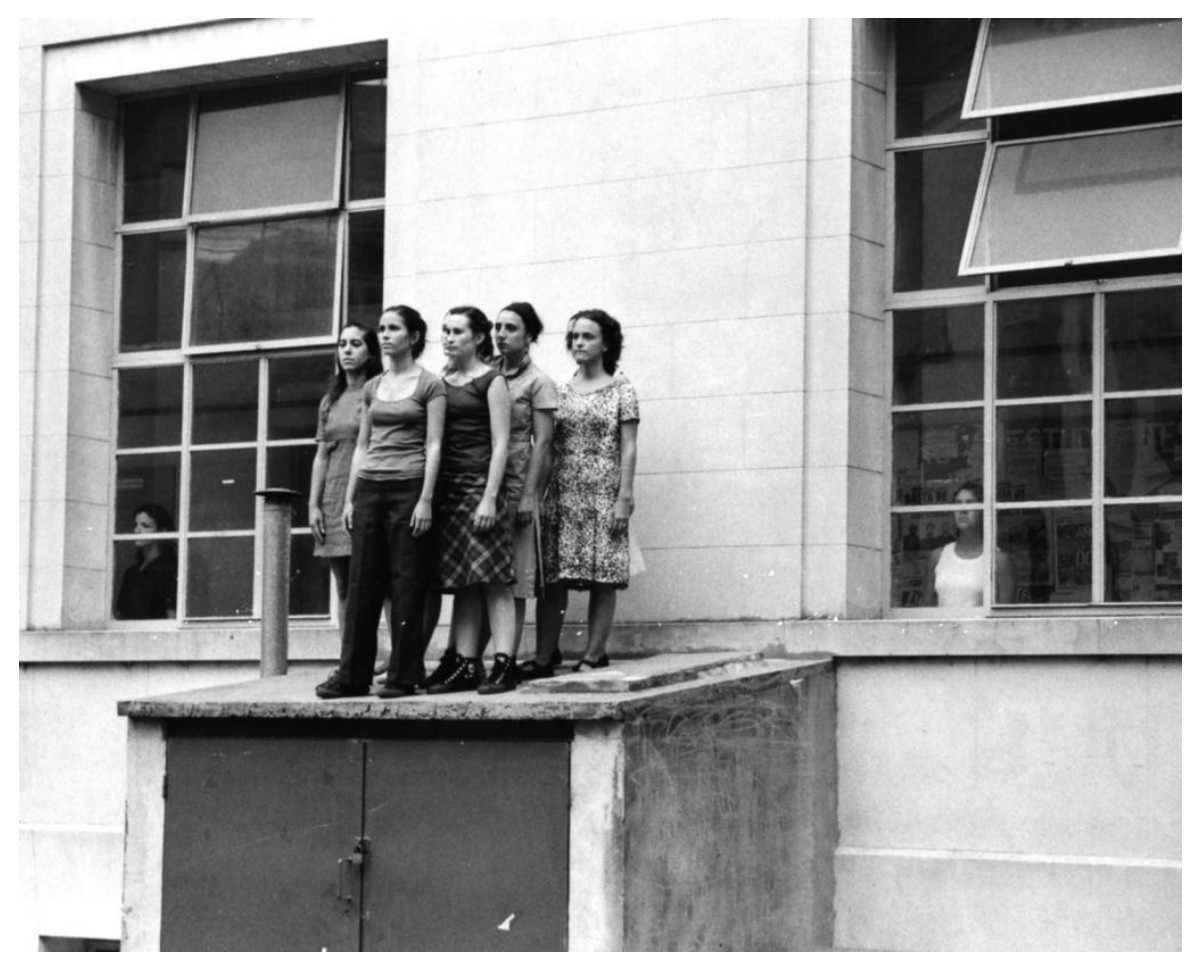

Imagen 12. Obra de danza y música "Siempre". Fecha: presentada el 24 de marzo de 2006. Ubicación: Facultad de Bellas Artes (UNLP). Extraída del blog del Colectivo Siempre. 


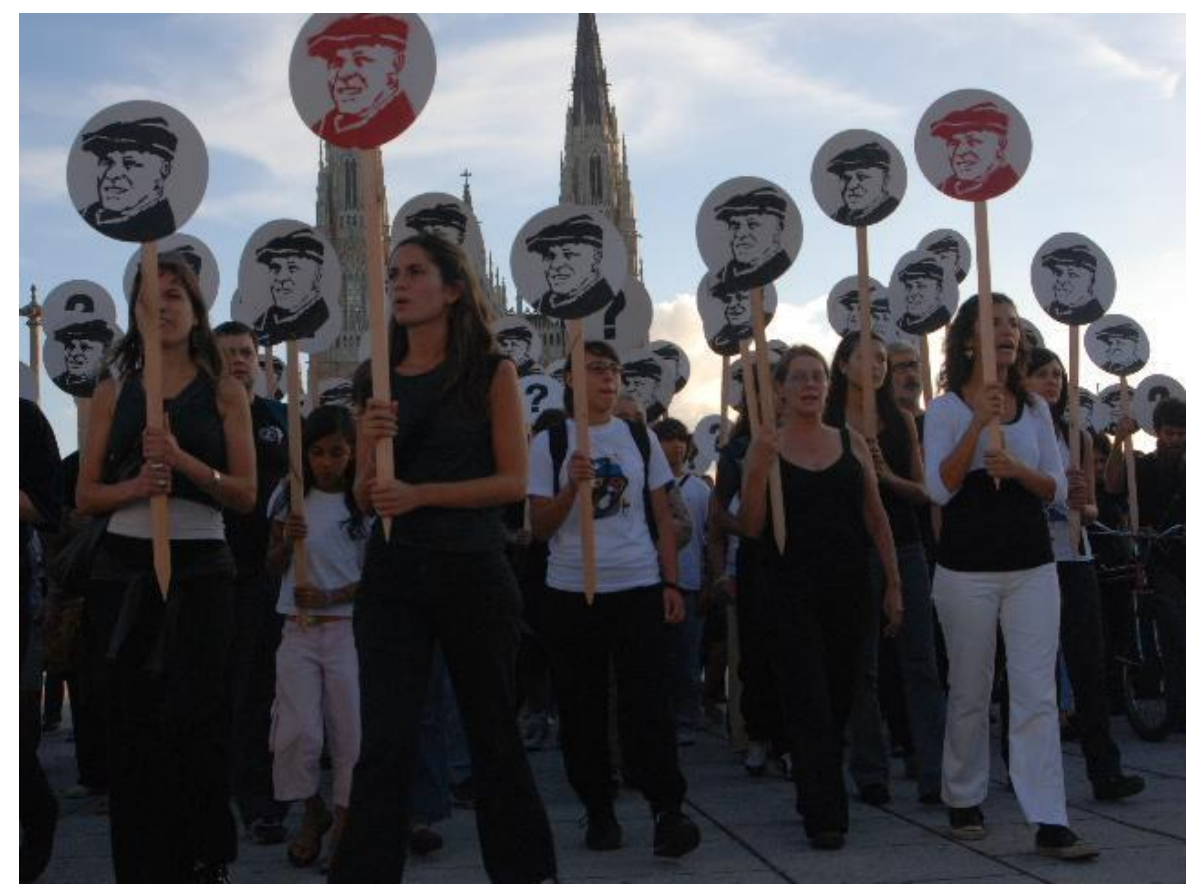

Imagen 13. Intervención participativa con pancartas, chillidos y vestimenta negra y blanca. Ubicación: Plaza Moreno y jardines del Palacio Municipal (12 e/ 51 y 53). Fecha: 23 de marzo de 2007. Extraída del blog del Colectivo Siempre.

\section{III.e. Arte al Ataque, la cultura como frente de lucha}

Arte al Ataque, es un grupo cultural vinculado el Frente Popular Darío Santillán ${ }^{126}$. Sus inicios se dieron a mediados del año 2008 y continúa activo (al momento de entrega de la tesis). Sus primeros trabajos se movieron en relación a los dispositivos visuales (acción "Buscar Justicia" junto a Sienvolando), el registro audiovisual de movilizaciones y a la performance callejera ("Bicicleteada contra la precarización laboral”). Su mayor desarrollo está centrado en la construcción de figuras gráficas y visuales (sobre todo stencils y pintadas políticas), instalaciones y performances que funcionan como marcajes de espacios de la ciudad, en la mayoría de sus acciones acompañando movilizaciones de protesta por el centro urbano (24 de marzo, Desaparición de Julio López, Día de la Soberanía Alimentaria, Día de la Mujer, Escraches a centros de detención, etc.) o en apariciones sorpresivas. Desarrolló muchas de las acciones con coordinación con otros colectivos: Sienvolando, Hermanos Tello, HIJOS La Plata, Surcos, Galpón Sur, Asamblea por los Derechos de la Niñez y agrupaciones

\footnotetext{
${ }^{126}$ Actualmente Arte al Ataque es parte del espacio que se denomina Frente Popular Darío Santillán "Corriente Nacional", distanciado de otros grupos con los que antes conformaban el FPDS unificado (como el Frente Popular Darío Santillán y Patria Grande). Esta fractura se hizo pública a inicios de 2013. En el período 20062011, el primero Espacio cultural del FPDS (La Plata) y luego Arte al Ataque integró el FPDS unido. En la ciudad de La Plata este espacio político y social ha tenido un lugar de visibilidad de sus prácticas y propuestas en el centro de la ciudad de La Plata, hablamos del Centro social y político "Olga Vázquez".
} 
vinculadas al FPDS. También participó de la Muestra Ambulante 5 con la acción "Del piquete al movimiento".

En un video que produjo el propio el colectivo se muestran algunas de sus intervenciones, al tiempo que explicitan sus concepciones en la propia voz de sus integrantes y de los compañeros de militancia. Se destacan especialmente retóricas de la militancia de izquierda independiente en las que la "lucha", el "cambio social", "lo cultural" y la "alegría" son ejes articuladores de la experiencia:

“Es intervención política pura en las calles. (...)

Acción, creatividad, mucho ingenio. (...)

Luchamos por una cultura subversiva, revolucionaria, combativa. (...)

Luchamos por cambiar esta realidad que no nos convence, no nos gusta. (...)

Creemos que el cambio social también tiene que ser cultural. (...)

Es una nueva forma de expresar la lucha, comunicar las luchas y generar luchas nuevas.

(...) Es el arte pensado desde otro lugar”. (...)

Buscamos transmitir las ideas del frente con otras herramientas más culturales (...)

Una prueba viviente de que la comunicación puede hacerse con alegría. (...)

Un lugar donde se cruzan las luchas de los pueblos y la belleza (...)

Un vuelo político y una capacidad de difusión zarpada

Es la pizca de buena onda y de cultura que necesita cualquier tipo de lucha." 127

En una serie de seis flyer-placas virtuales, publicadas en su página de Facebook en 2012, Arte al Ataque presenta otras de sus posturas en relación al espacio público y al trabajo cultural:

“Consideramos al ESPACIO PÚBLICO no como un lugar de paso sino como un lugar vivo, de formación, de producción y encuentro con la cultura. También buscamos resignificarlo como espacio de trabajo y nos manifestamos en contra de las restricciones a las expresiones culturales callejeras".

En otra de las placas dicen "Creemos fundamental el reconocimiento de lxs ARTISTAS como TRABAJADORXS de la cultura y la valorización de su rol dentro de la sociedad". Aparece en estas producciones una utilización explícita de posicionamientos

\footnotetext{
${ }^{127}$ El audiovisual cierra con un breve manifiesto que enuncia a dos voces: "No somos ilusos, sabemos que el arte por sí solo no logra la revolución. Pero no somos necios, la revolución es imposible sin el arte”. Video "¿Qué es Arte al Ataque?" (2011). Disponible en: https://www.youtube.com/watch?v=TU2_u3TvZP8
} 
ideológicos y de ciertas demandas de tipo sindical (por ejemplo, reconocer el trabajo cultural, reconocer legalmente a los centros culturales recuperados) y de tipo político (por ejemplo, sentidos críticos sobre la ciudad, la valorización del rol de artista) traducidas en consignas. Su $\operatorname{blog}^{128}$ funciona como registro sistemático y archivo completo de las acciones del colectivo desde su creación hasta la actualidad.

\section{canus

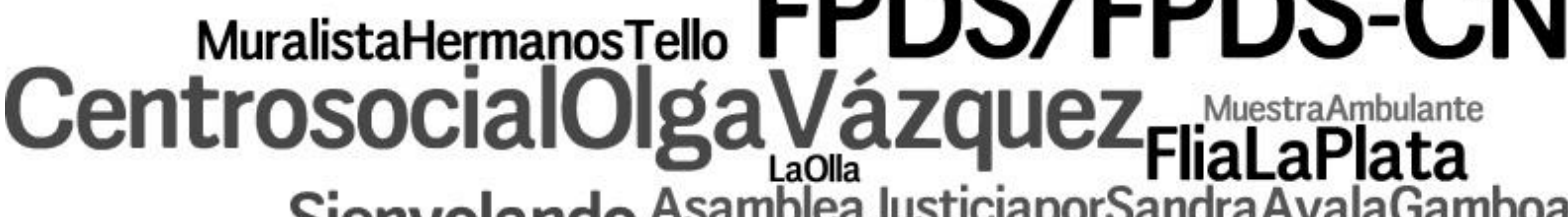 Sienvolando AsambleaJusticiaporSandraAyalaGamboa MultisectorialLaPlata-Berisso-Ensenada AsambleaporlosDerechosdelaNiñez HIJOSLaPlata
GalpónSur LaCalleesNuestra GalpónSur LaCalleesNuestra Siempre Luxor}

Imagen 14. Composición visual de las articulaciones de Arte al Ataque.

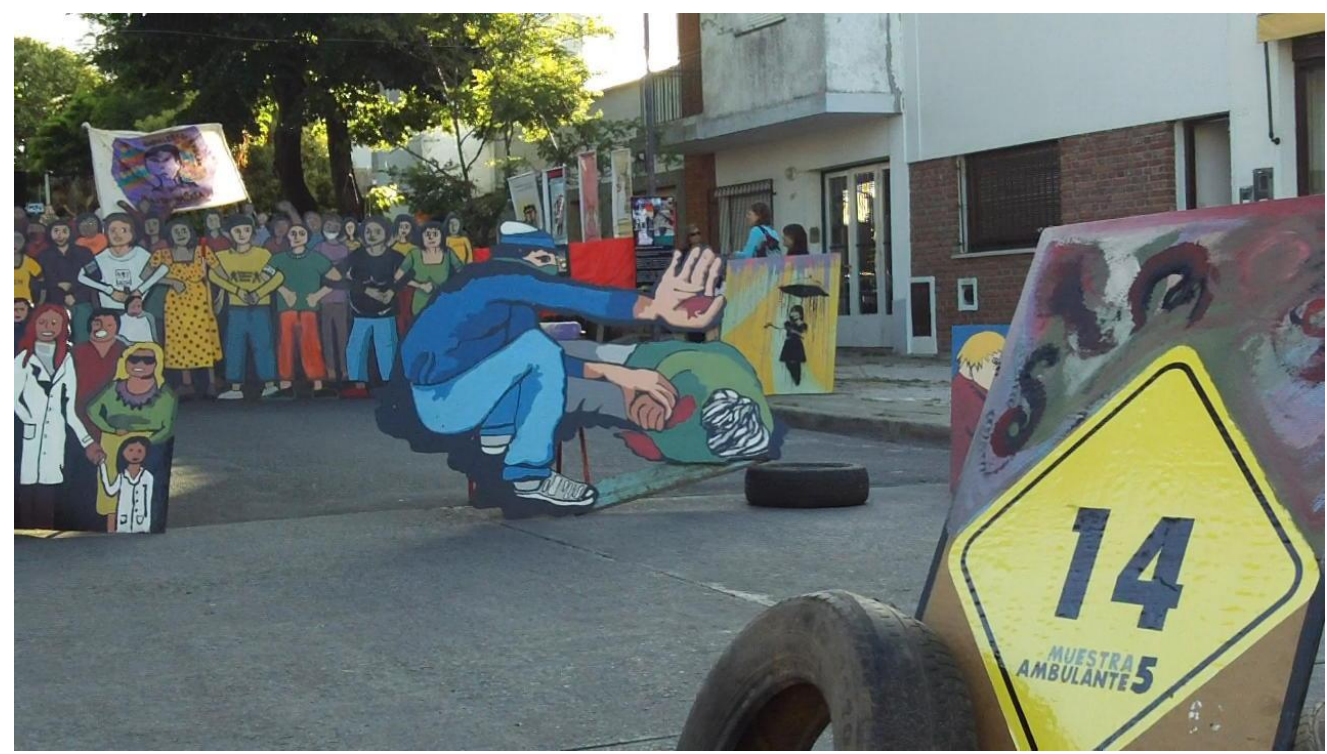

Imagen 15. "Del piquete al movimiento" intervención de Arte al Ataque en la Muestra Ambulante 5. Fecha: noviembre de 2009. Ubicación: 69 e/ 18 y 19 (barrio Meridiano V).

${ }^{128} \mathrm{http} / / /$ artealataque.blogspot.com.ar 


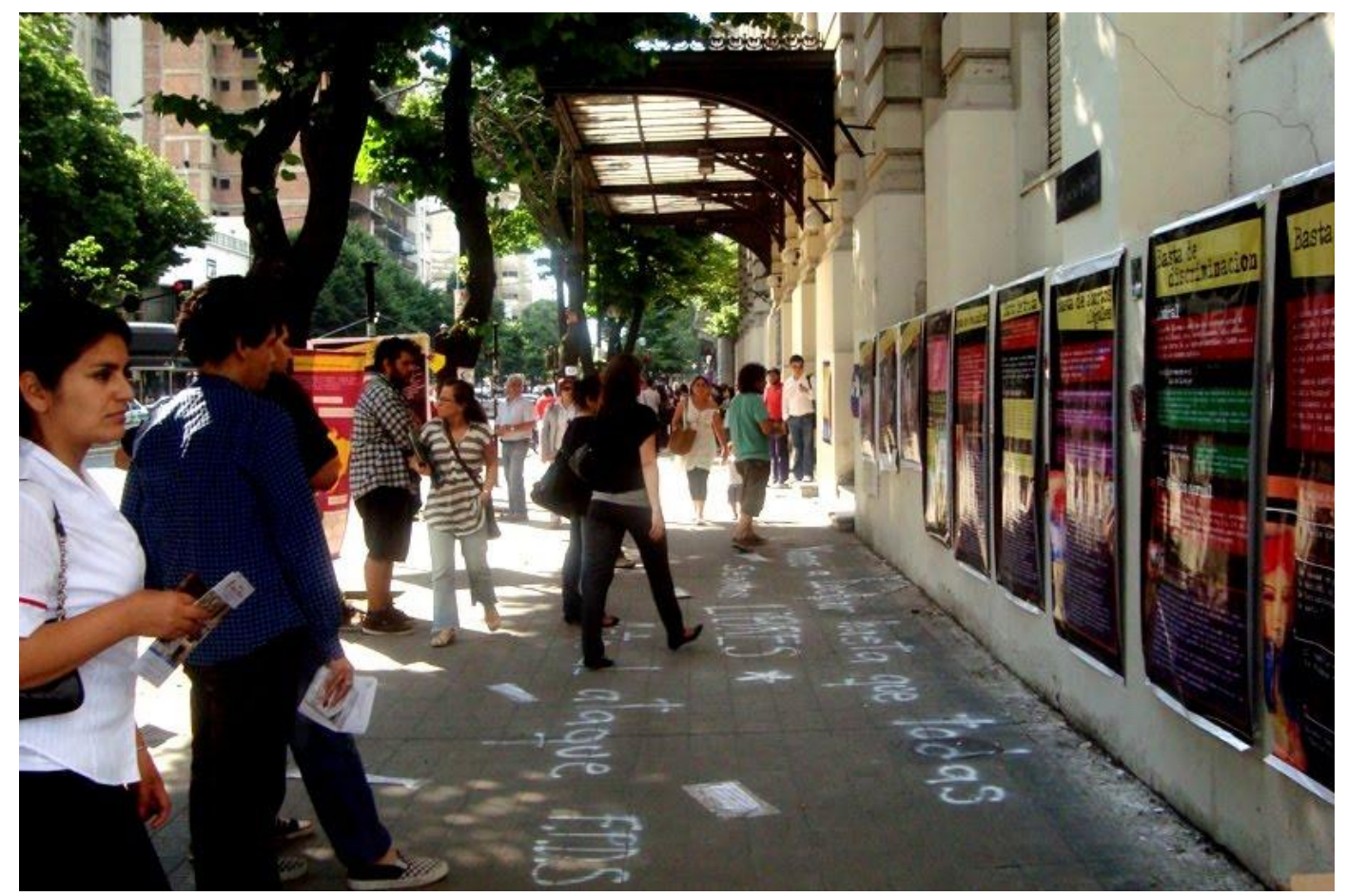

Imagen 16. Instalación callejera de la Muestra "Cuando una mujer avanza...", intervención de Arte al Ataque como parte de la Jornada por el "Día de la No violencia contra las mujeres". Fecha: 25 de noviembre de 2010. Ubicación: 7 y 50 (pared del Pasaje Dardo Rocha). De la jornada y movilización también participó Luxor con una pintada. Imagen extraída del blog del grupo.

\section{III.f. Luli, ir siendo en las redes}

Luli fue un colectivo -de nombre femenino y con muchas referencias a ese universoque intervino entre mediados de 2009 y diciembre de 2011. Buscó poner en juego dispositivos de comunicación en el espacio urbano y en el espacio de la web, buscando las tensiones, los cruces y los diálogos posibles entre diferentes registros y lenguajes (mural, estampas, gigantografías, banners y otros recursos gráficos, multimediales, diseños y dispositivos web, redes sociales), interrogando a éstos como espacios de intervención en lo público y en la esfera pública. En una entrevista, realizada al momento en que este colectivo estaba activo, Luli entendía que su práctica iba mutando:

"primero sería una práctica que buscaba no definirse de entrada, en todo caso va mutando según para qué es esa práctica. (...) Se va definiendo. Luli tiene una práctica muy fuerte de lo que viene haciendo. Pero no es una práctica que esté buscando reafirmarse, sino todo lo contrario, que muchas veces está buscando cuestionarse, está buscando tener una relación con lo que está diciendo lo más directa posible."129

\footnotetext{
${ }^{129}$ Entrevista realizada por el autor al colectivo Luli (julio de 2010).
} 
Allí también plantean la idea del uso de un nombre colectivo que no focaliza en figuras individuales y que a su vez, se reconoce múltiple. Pero sin la intención de que sea una afirmación identitaria en sentido fuerte -como se produce en otras iniciativas-: "no se busca generar una identidad que diga 'acá está Luli'"130. Sobre esto en otra entrevista también comentaban que

“- $(,,$,$) no queríamos un nombre con una carga fuerte, sino que formara parte de esa$ misma indefinición.

- Y que la carga fuerte la tuviera después, al llenarlo nosotros de sentido. Queríamos un nombre que no fuera un "gran nombre", que fuera más indefinido, más blando, que hablara de un personaje."

Asimismo, entendían que lo que unifica a sus diversas acciones es una "necesidad de retomar la palabra" desde la "urgencia" y utilizando los dispositivos existentes en la coyuntura específica, aunque sean definiciones precarias y plenas de tensiones había un objetivo, no plantear definiciones e identidades fuertes:

“- El dispositivo que se pone en marcha sobre el cual se incide, tiene que ver con algo coyuntural. A su vez, no necesariamente esa coyuntura tiene que ver con algo directamente político -como en muchas acciones de LULI- sino que intentamos repensar los dispositivos que nos atraviesan. (...) Y en esa urgencia en la que somos interpeladas todo el tiempo, retomar la palabra y atacar los dispositivos sobre los que se construye la realidad es lo que unifica nuestro discurso. O no. No queremos dar un cierre a lo que somos.

- Esta indefinición, esa cosa migrante es lo que también define a LULI." ${ }^{131}$

En un escenario diferente y cambiante desde el cual pensar la práctica, además de realizar intervenciones propias, buscó insistentemente generar articulaciones con otros colectivos de intervención (por ejemplo en la muestra colectiva "Calle Tomada" en el MAM, en el encuentro de colectivos "La calle es nuestra" y en las acciones "Papa Negra TV",

\footnotetext{
${ }^{130}$ Sobre estas decisiones de cómo nominarse hacia afuera, Dani comenta: "desde Luli tampoco nos nombrábamos mucho como artistas, ni artivistas, nos nombrábamos como Luli. No sé si es una de las discusiones más interesantes sobre eso se dieron en Luli, me parece que las discusiones sobre cómo nombrarse y eso que se construyó, tal vez sí se dieron en Sienvolando. En Luli fue replicar eso, porque estábamos adaptados desde nuestra cabeza de que más o menos era así.” (E 22)

${ }^{131}$ Este y el anterior fragmento corresponde a la entrevista a Luli en Prensa de Frente, 21/12/2010. Disponible en: https://lulitieneblog.wordpress.com/2010/12/21/nota-en-pdf
} 
"Intervención magenta" y "La expedición", en la fiesta-evento en dos galpones "Pegate un viaje" con El Galpón de Tolosa y La Grieta) y con organizaciones y coordinadores sociales (Asamblea por Sandra Ayala Gamboa, la participación en las FLIA, etc.).

Otras de sus acciones importantes fueron: "Buscando a López" (mural y juegoaplicación en Facebook que tuvo tres versiones entre 2010 y 2011), “Esto es una contravención?" (2009 y 2010) y "Plantemos flores" (2010) y "Coloreá tu ciudad" (un pequeño cuaderno de ilustraciones para colorear y aplicación-juego en Facebook en 2010). También llevaron adelante espacios formativos como los seminarios "Cambiar el mundo con un click" (2010) y "Medios alternativos y populares" (2011). Tanto su perfil en la red Facebook ${ }^{132}$ como su blog ${ }^{133}$ actualmente funcionan como "archivo" de las acciones, contando con abundante registro y materiales, aunque muchas de las páginas apócrifas y aplicaciones web que crearon están "caídas" de la nube (por ejemplo, las de "Esto no es una contravención", "Cambiar el mundo con un click" y la cronología de intervenciones que realizaron para la muestra "Calle tomada") ${ }^{134}$.

Luli anunció que dejaba de activar en diciembre de 2011 por medio de un mural en el centro de la ciudad (con la frase "Luli tiene un "in"), un breve post de despedida en su blog en el que también se documentaba la acción en el muro- y un sugerente Tweet en esa red social: "Volveré y seré ponencia". En ese último post en el blog -y replicado en Facebookhay un texto de despedida que recapitula la experiencia y la centra en sus redes de activación:

“-¿Qué es Luli? -preguntaban.

-Vamos siendo -decíamos. Sonaba a zafar la respuesta, pero era una declaración de principios. Apenas un par de veces nos arriesgamos a una definición y fue incómodo.

Luli fue paredista, programadora web, editora, expedicionaria, comunicadora en un sentido amplio, consultora de imagen, docente. Luli tejió lazos con otras. Luli intervino en el espacio público.

\footnotetext{
132 https://www.facebook.com/lulitienefb

133 http://lulitieneblog.wordpress.com

134 Por ejemplo, esta última era una web presentada unas semanas antes de la muestra y permitía a los usuarios ser parte del armado de una línea de tiempo cronológica de intervenciones en el espacio urbano de La Plata (se podían ingresar nombre de la acción, lugar y fecha, colectivo interventor, localización y una imagen), convirtiéndose en una completa acción interactiva y participativa en la web, además constructora de saberes colectivos sobre intervenciones. Conversando con los integrantes de Luli varios años después sobre la pérdida de muchas de las webs que el grupo construyó, comentaron que "eran momentos en que creíamos que lo que se generaba y se colgaba en internet duraba para siempre"; podemos agregar, un momento y sentido "utópico" de la red internet. Lo que sucedió con varias de esas webs es que se le dió de baja desde el hosting (un servidor web gratuito) en las que estaban alojadas porque el usuario ( $\mathrm{Luli}$ ) colgó un "juego virtual" (una referencia a la aplicación de Facebook "Buscando a López"), actividad que no estaba permitida por las políticas del servidor. Luli intentó recuperar la información y la base de datos de estas webs por medio de mensajes vía correo electrónico al servidor pero no lo consiguió.
} 
Ir siendo no era, como pensó alguno, una forma de descompromiso, sino una decisión consciente: que la praxis fuera su manifiesto. Luli se definió con sus acciones y en sus redes.

(...) Luli tuvo que ver con un contexto y creció con él. Hoy la época se fue complejizando. Hay colectivos que buscaron otros caminos, hay grupos pinchados, hay nuevas iniciativas que buscan su forma. Pero las redes que conocíamos ya no están, se movieron de lugar o ya no funcionan del mismo modo. Y nosotras tampoco.

Luli era en esas redes.

Sin ellas, las acciones pierden sentido. Se vuelven caprichos."

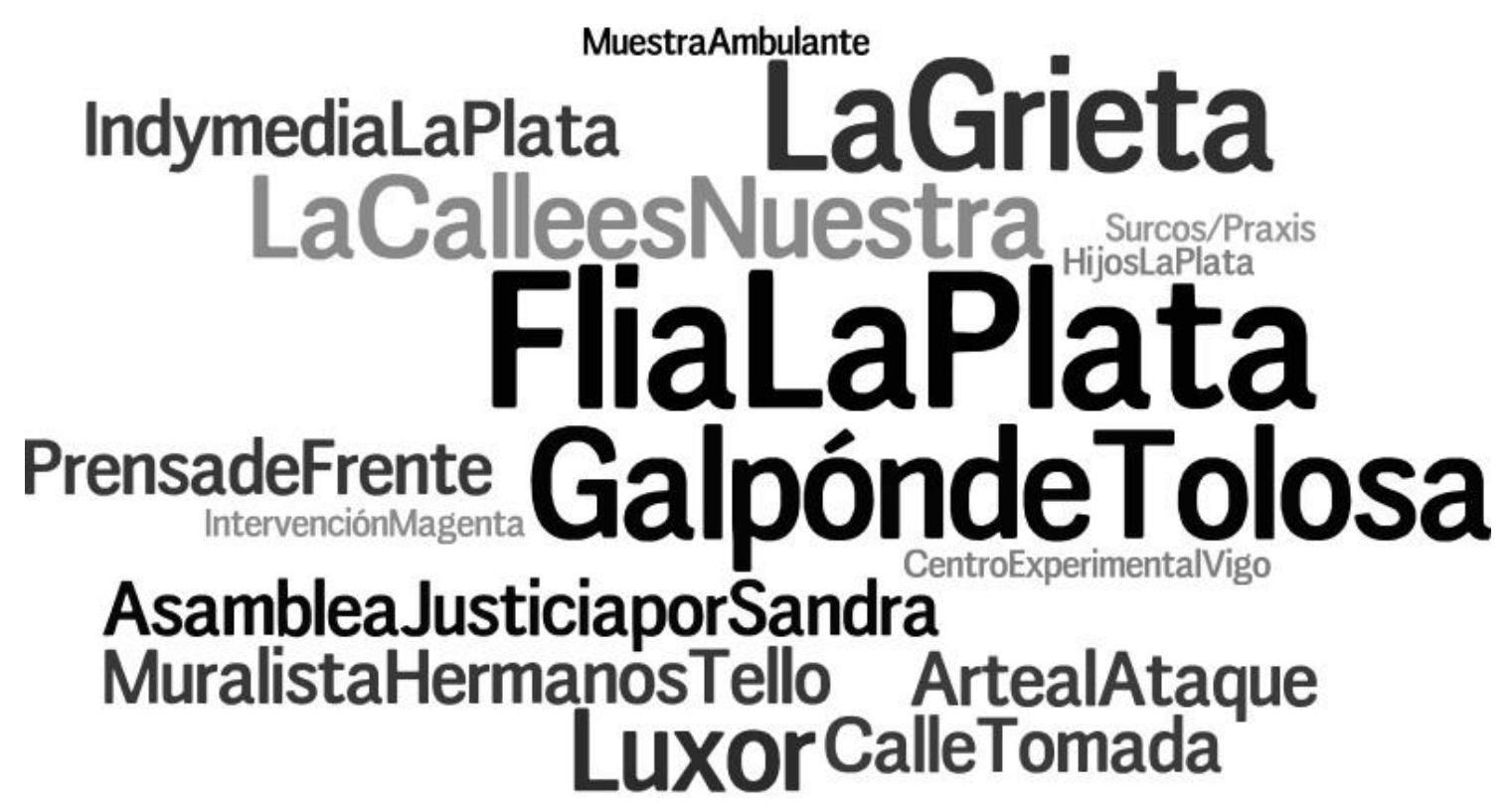

Imagen 17. Composición visual de las articulaciones del colectivo Luli.

Derivas y vínculos con prácticas posteriores: Síntoma curadores, encuentro ZigZag, Pólvora y productores/as visuales individuales. 


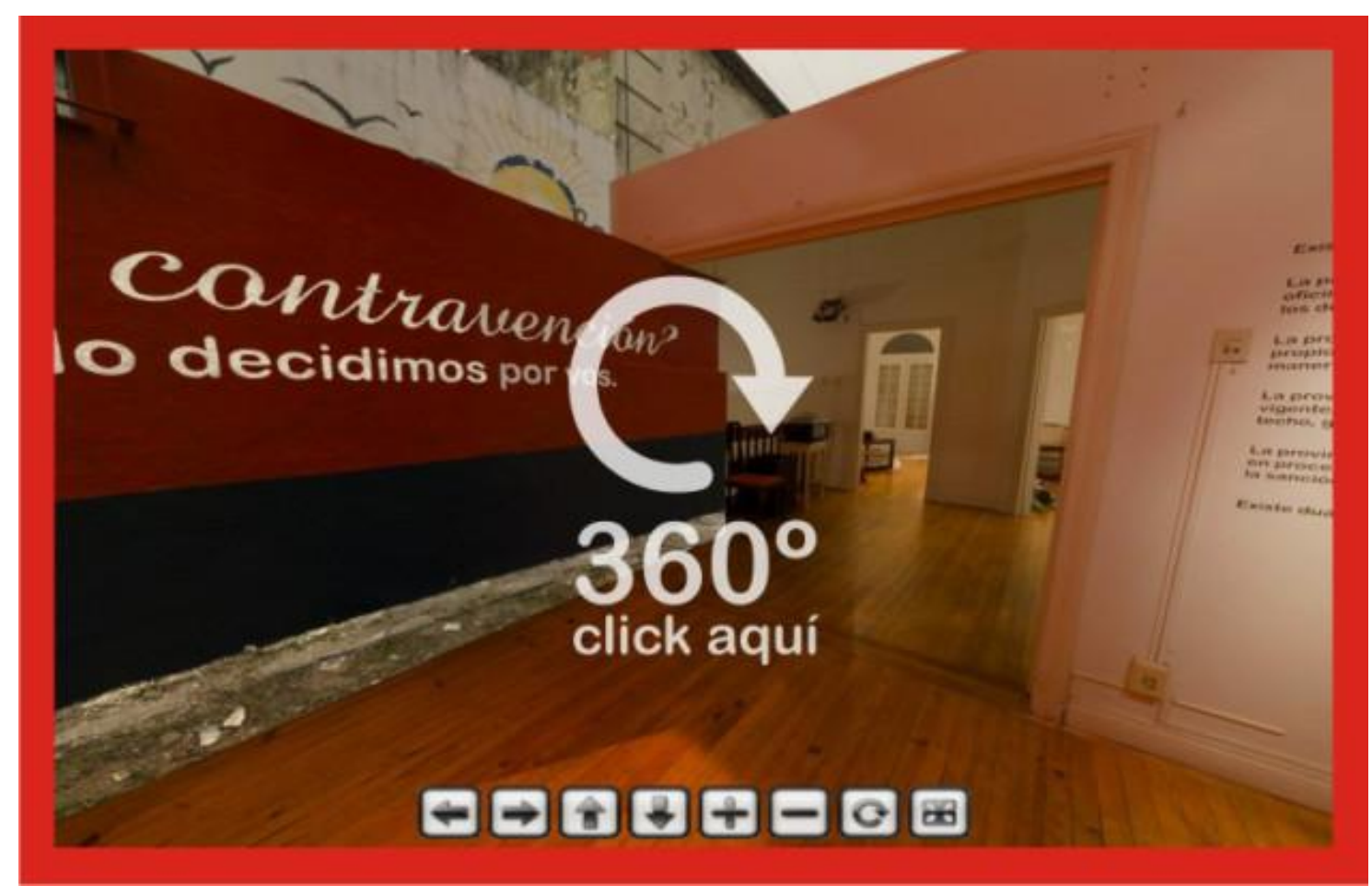

Imagen 18. "Esto es una contravención". La imagen es una captura del desarrollo virtual-visual que mostraba ambas intervenciones: en el espacio urbano y en el espacio del museo. Actualmente no está disponible para ser visualizado. Años: 2009 y 2010. Ubicaciones: Diagonal 74 casi esquina 6 y en el Museo de Arte y Memoria (9 e/ 51 y 53). Imagen extraída del blog del colectivo.

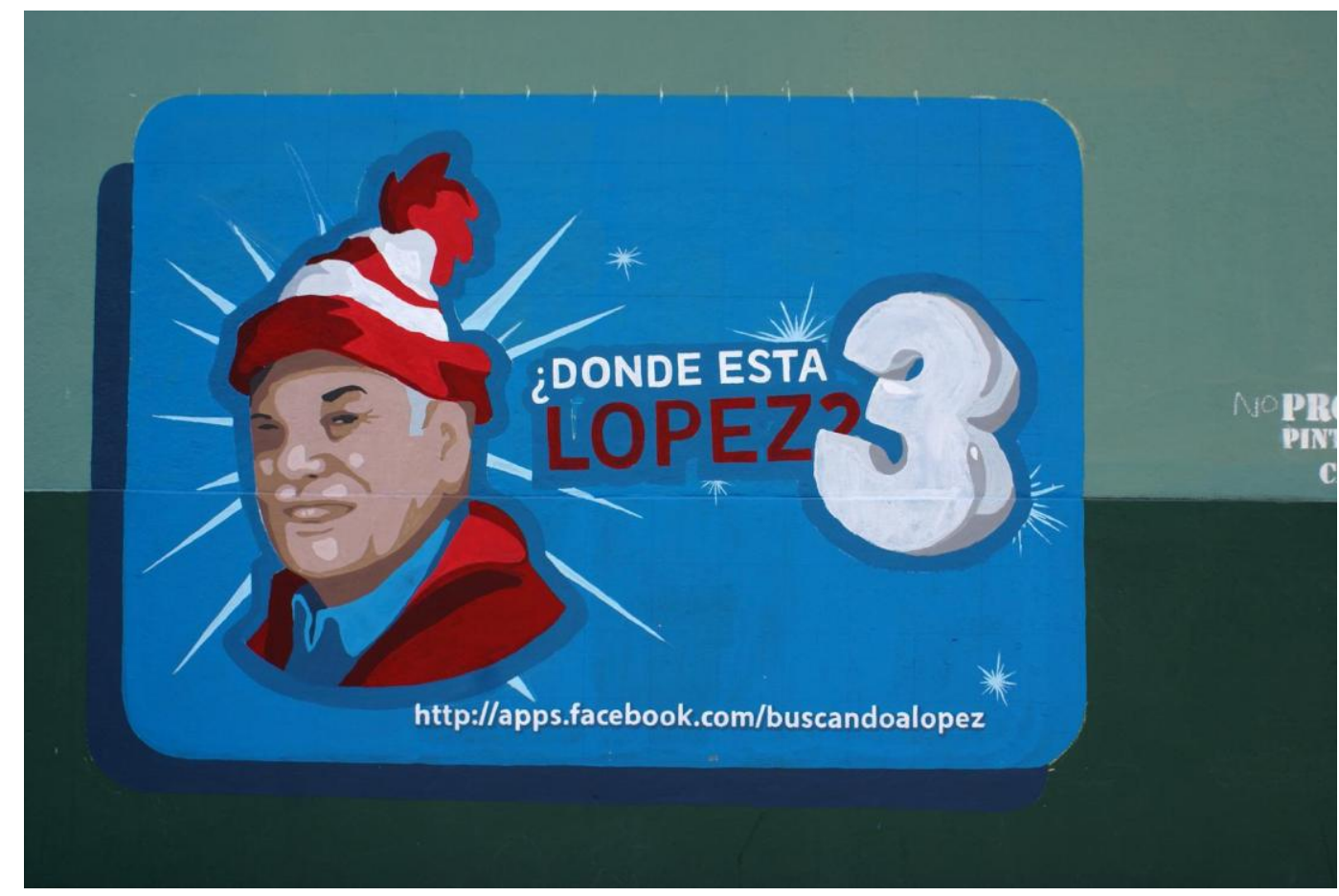

Imagen 19. Mural en la calle que linkea a la aplicación de Facebook "Buscando a López versión 3.0" desarrollada por Luli. Fecha: 18 de septiembre de 2011. Ubicación: Diagonal 73 y 62. Imagen extraída del blog del colectivo. 


\section{III.g. Luxor, pintar relaciones del mundo nuevo}

Luxor es un interventor individual callejero que activa principalmente en La Plata desde marzo de 2010 y continúa en la actualidad ${ }^{135}$. Se mueve entre formas y estéticas con cierta ligazón con el graffiti -principalmente en la utilización del aerosol y la construcción de una referencia propia-. Pero también tiene una notoria distancia de estas prácticas -no se mueve en crew, generalmente pinta de día y pidiendo permiso en los lugares, no pondera como estética su "firma" o "tag" y no utiliza solo el aerosol como única herramienta -sino también el pincel, el rodillo, el látex y otras pinturas- lo que lo acerca a los procedimientos y dinámicas tanto del street art como del muralismo. A su vez la pared no es su único recurso; también lo son el audiovisual, el formato cuadro en pequeño, mediano y gran formato, la lámina, el grabado, el diseño visual y la reproducción digital. Si bien no rechaza todas estas formas construidas del graffiti y el street art -y también del mural-, no se siente identificado con ellas, no inscribe su práctica en ninguna. Por esto entiende que para identificar una propia perspectiva denomina a su acción como "pintura callejera". Sus formas de moverse por la ciudad articulan actividades individuales (pintadas en casas, en jornadas y eventos que organiza o es invitado, la realización de muestras individuales) y en proyectos colectivos en los que se junta e involucra con otros productores: "Intervención magenta" (2010), "Proyecto Kalle” (2011), "La Pantufleta refrescante” (2011), "ZigZag” (2012), "Volver a habitar" (2013 y 2014), “Concreto" (2014), "Dos Pi” (2015). Estos proyectos tienen más relación con ciertas formaciones o grupalidades ligadas a colectivos de intervención cultural, que con una crew con su nombre y estética definidas, lo que no implica que no trabaje con compañeros-amigos con los que compartió ciertas dinámicas "de crew" -principalmente cuando articula con productores vinculados al street art y el graffiti (por ejemplo en "Intervención Magenta", "Proyecto Kalle”, “ZigZag”, “Concreto”, “2Pi”). De este modo, Luxor planea correrse del graffiti tradicional por la composición de sus producciones (que lo acercan al "graffiti de personajes"), al participar de este tipo de proyectos-evento que no solo se relacionan con el circuito grafitero sino que dialogan con otros actores (otros productores visuales, comunicadores, instituciones educativas, vecinos de los barrios populares, etc.), así como cuando realiza muestras individuales y colectivas (en las que varias veces son eventos de "venta de obra") en pequeñas galerías de arte y espacios culturales de la ciudad.

Al pretender construir esa "pintada callejera" Luxor busca posicionarla desde la “cultura popular", los sentidos "disidentes" y las realidades de "los barrios". Así es que los

\footnotetext{
${ }^{135}$ En todos estos años -de 2010 al 2016- también ha pintado en varias localidades de la provincia de Buenos Aires y de otras provincias, en la CABA, Uruguay, Perú, Brasil e Italia.
} 
ejes que movilizan y atraviesan sus obras y producciones son "las relaciones entre las personas", y “contar cosas desde lo cotidiano". En los primeros años Luxor centró el concepto de su producción desde una cierta mirada feminista -las "relaciones disidentes" miradas desde la complicidad- articulada con una idea de pintar belleza. Es así que en sus pintadas callejeras buscaba mostrar esas relaciones entre mujeres, lesbianas, homosexuales y trans, -varias veces articulando esos murales con lo que llama la "lucha feminista", en movidas y jornadas específicas de esa lucha-. Algunos fragmentos de dos entrevistas realizadas a Luxor, en su primer año de intervención en la ciudad, pueden ilustrar estas cuestiones:

\begin{abstract}
"Voy dejando relaciones disidentes, relaciones del mundo nuevo. Las relaciones entre las personas vistas desde una complicidad. Yo retrato la complicidad entre las personas, que es lo que me motivó a pintar. Pinto belleza porque la vida es una mierda. Porque la vida es desigual. Pinto belleza porque quiero un mundo bello, un mundo con otro tipo de relaciones. " 136

"Mi idea es poder charlar con ese mundo, este mundo disidente, que es el que trato de reivindicar en mis obras, que no hablan de mí, sino de una realidad de gente que tiene una complicidad entre ella, es lo que me conmueve (...) Tratar de tener, dentro de lo contrahegemónico, un discurso bonito, bello. Pensar lo bello como una herramienta, y no como algo de las Bellas Artes, no tan anticuado."137
\end{abstract}

Sin bien algunos ejes-fuerza de su producción se fueron desplazando hacia retratar las realidades de los barrios, siempre intenta conectarlos con las "relaciones del mundo nuevo". Ha realizado más de 300 murales y pintadas en la ciudad. Luego de pintar -sobre todo en los dos primeros años- en espacios céntricos, Luxor realizó un desplazamiento hacia espacios en barrios fuera del casco urbano, siempre combinando tanto lugares públicos (tanques de agua, centros culturales, edificios estatales, etc.) como lugares privados (fachadas de casas y comercios, paredes exteriores e interiores, medianeras, etc.). En cuanto a la relación entre la técnica, los recursos y el uso del espacio decía en aquella entrevista radial: "uso el aerosol porque me gusta, es rápido, efectivo y tiene una forma para soltar la línea bastante laxa. Para mí la acción tiene que ser bastante rápida y la idea mía es que el paisaje urbano cambie de un momento a otro" (E 23, Luxor). Sus composiciones visuales son construidas con saturación de colores -en los primeros años principalmente el color magenta pero luego amplió la paleta

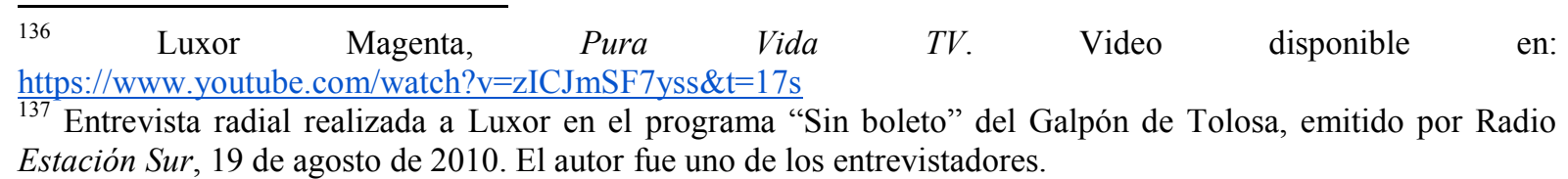


cromática- y la creación de personajes ("pajaritas", "mujeres", "lechuzas", "voladoras" “caminantes", "protectores", "soles”) que tienen una fuerte presencia en toda su producción.

"Me gusta utilizar una paleta de colores de mucha saturación para que el color te despierte, te sorprenda. Que camines así por la calle y te choques con un bloque de color. En cuanto a la textura creo que es algo que se puede tomar desde la pintura como desde las superficies de la pared. Cada superficie genera una textura diferente en cuanto al soporte lo cual también modifica la pintura." 138

De este modo, en relación con la comprensión y uso del espacio urbano y el lugar de las instituciones, podemos ampliar algunas de sus ideas-fuerza, planteadas por él en aquella entrevista radial de 2010:

"veo paredes todo el tiempo. Es el orgasmo matutino. Para mí la pared es lo mejor que hay. La pared y el color magenta (...) La idea es no pedir permiso, resignificar el medio público, realmente como medio público y sobre todo las instituciones, pintar en la institución. (...) Ya hay un montón de obras muertas en la facultad, esculturas de hace sesenta mil años llenas de mugre (...) la cuestión de la calle es generar movidas dinámicas. Para estática está la institución, que es eso, una cosa erguida ahí (...) La idea es llenar la ciudad de color".

En relación a algunas de sus formas de comunicación, en su experiencia es importante la utilización de las redes sociales virtuales, que han sido fundamentales para la proliferación de sus producciones, así como para el contacto y vinculaciones con grupos y personas. E1 recurso web clave para Luxor es su perfil en Facebook, un dispositivo de encuentro e intercambio que pasó a ser, a inicios de 2014, una página en esa misma red ${ }^{139}$. Ese pasaje posibilita que el número máximo de "amigos" que permite esa red para un perfil personal (5000 contactos) se pueda aplicar al cambiar al formato página (y pasar de "amigos" a "me gusta", lo que equivaldría a los "seguidores" en otras redes sociales). En el 2011 el perfil personal de Luxor ya saturaba en los 5.000 contactos. Actualmente, la página "Soy Luxor" en esa red social tiene más de 17.500 "me gusta"140. Además Luxor también tiene un canal de

\footnotetext{
${ }^{138}$ Nota-entrevista en el portal "Gráfica Mestiza”, enero de 2013. Disponible en: http://www.graficamestiza.com/index.php/artistas/argentina/74-luxor/

${ }_{139}$ www.facebook.com/soyluxor

140 Datos actualizados a enero de 2017. En dos ocasiones anteriores se realizó un relevamiento de estos números: Agosto de 2014 - 13.400 me gusta y Marzo de 2015 - 14.000 me gusta.
} 
$Y_{\text {Youtube }}^{141}$-en el que se pueden encontrar algunas de sus producciones audiovisuales-, un sitio web $^{142}$. También es posible hallar algunas plataformas de imágenes ${ }^{143}$ y un blog ${ }^{144}$ (plataformas virtuales que ya no actualiza).

En los últimos años Luxor ha encarando una amplia producción individual diversificada en formatos -trabajos de bastidor, obras en pequeño, mediano y gran formato, serigrafías, muestras personales y pintadas callejeras casi semanales-. Asimismo, participó en el colectivo/acción "Volver a habitar" dedicada a realizar murales en barrios inundados el 2 de abril de 2013 y a relevar historias de vecinos inundados a través de producciones audiovisuales (microdocumentales publicados en Youtube y replicados en redes sociales). También en otros proyectos colectivos puntuales como "Concreto. Museo de la calle" (en el que junto con otros productores y comunicadores planearon generan "arte público" en barrios de La Plata por fuera del casco urbano) y "2 PI" pintadas que realiza junto a Acra, otro productor visual de la ciudad. Desde inicios de 2016 gestiona un espacio y taller de arte, junto con Yapán y Justina, llamado “Obrador 45”.

\section{Acra IntervenirLP DelotroladodelArbol MalascomolasArañas Concreo IntervenciónMagenta AsambleaJusticiaporSandra
ProyectoKalle Campaña|DerechoatenerDerechos Juss ClubAlborada CentrosocialOlgaVázquez VolveraHabitar Inka Lumpenbola Pantufletarefrescante AsambleaporlosDerechosdelaNiñez GalpóndeTolosa
LuliYapánAdRian}

Imagen 20. Composición visual de las articulaciones de Luxor.

\footnotetext{
${ }^{141}$ https://www.youtube.com/user/soyluxor/videos

142 http://soyluxor.com.ar

143 http://www.flickriver.com/photos/luxormagenta y https://www.flickr.com/photos/luxormagenta

144 https://soyluxor.wordpress.com

También varios bloggers y sitios específicos de murales y graffitis han replicado a las obras de Luxor. Algunos ejemplos son:

https://sudakia.wordpress.com (varios post con referencia a Luxor y sus pintadas)

http://lacovachadelostiteres.blogspot.com.ar/2011/06/dale-luxor.html

http://malascomolasa.blogspot.com.ar/2010 $06 \quad 01$ archive.html

http://www.taringa.net/comunidades/graffiti/1055015/Intervencion-Magenta---Megaencuentro-en-La-Plata.html http://buenosairesstreetart.com/

https://elsudacarenegau.wordpress.com/tag/luxor/ (varios post)

http://www.escritosenlacalle.com (tres post)

https://loladuerme.wordpress.com

http://info.nodo50.org/La-Plata-se-interviene-en-Magenta.html

https://yiraenlp.com (tres post con referencia a luxor)
} 


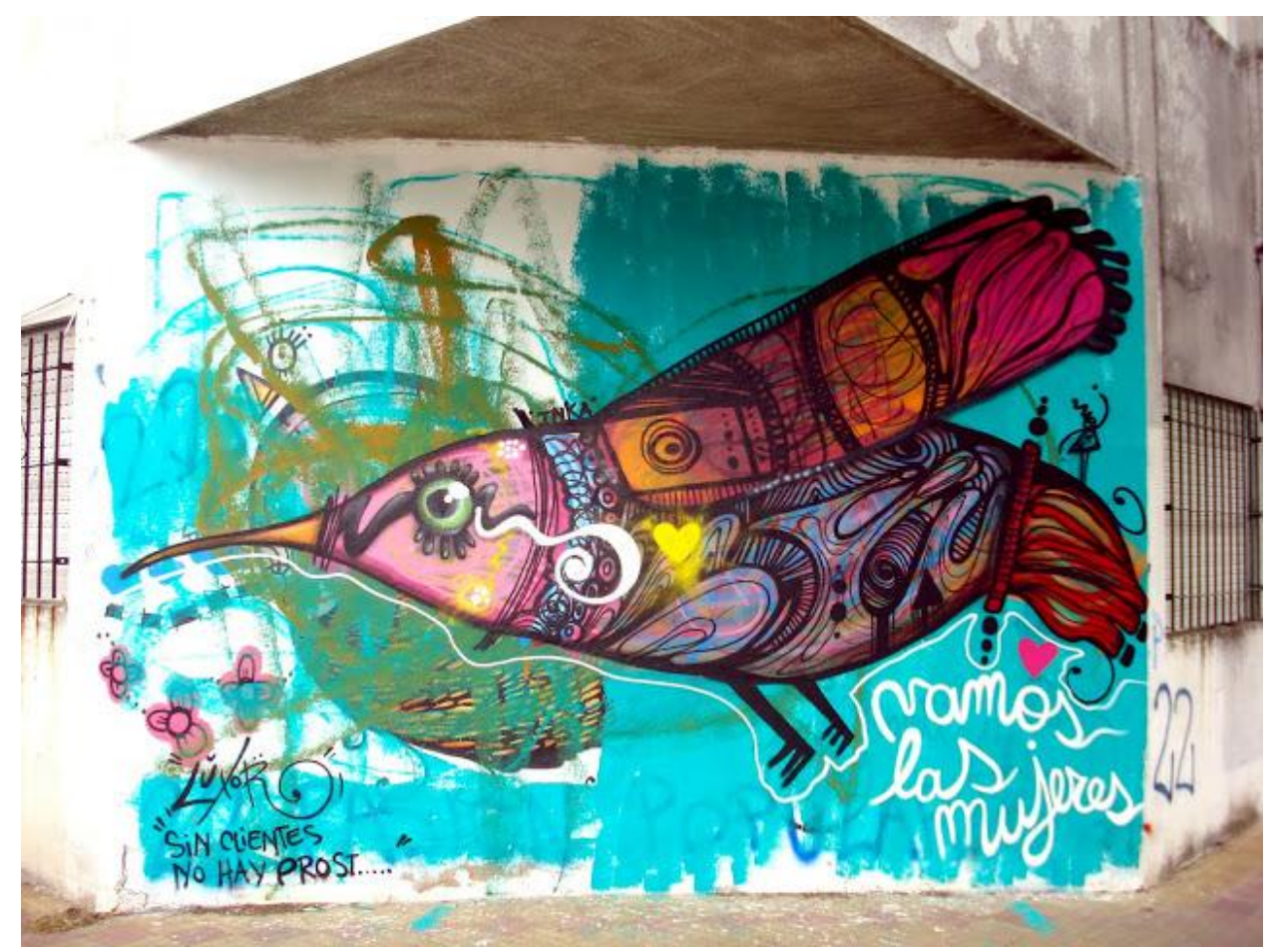

Imagen 21. Luxor. "Vamos las mujeres". Año: 2010. Ubicación: Casco urbano de La Plata. Extraída de su perfil de Facebook. Actualmente no está disponible en esa red social. En esa misma pared luego pintó dos veces más.

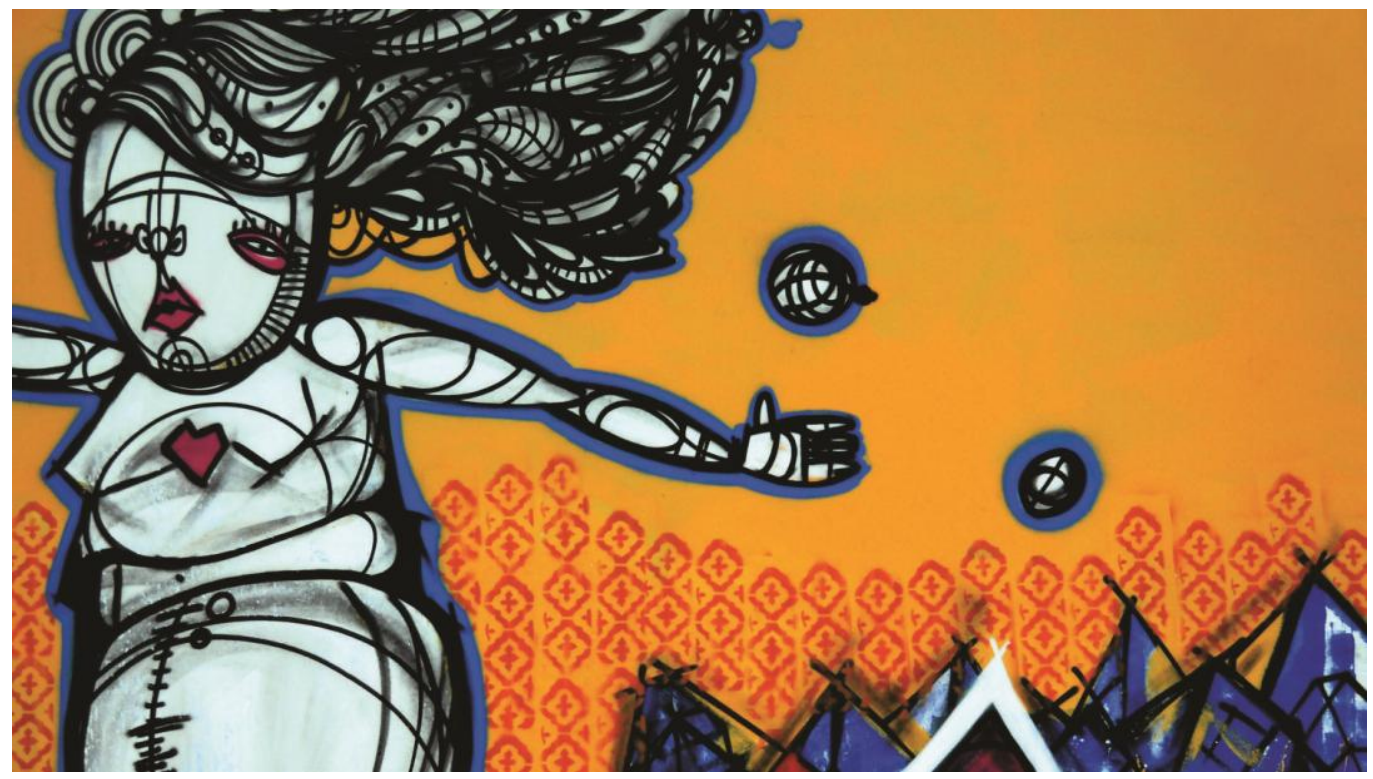

Imagen 22. Luxor. "Abrazo". Fecha: agosto de 2010. Ubicación: 13 y 68 (zona Parque Saavedra). Extraída de su perfil de Facebook, actualmente no disponible. En esa misma pared ha renovado pintadas varias veces.

III.h. Otros colectivos e interventores 
A partir de un trabajo de campo de relevamiento y seguimiento de acciones culturales y de indagación de registros web -que particularmente he realizando desde 2008-, se puede ampliar la nómina de colectivos e interventores que activaron en la ciudad en el mismo período (2006-2011) o en el inmediato posterior a ese universo temporal. Entre los colectivos mencionamos: Grupo La Olla (2005-2013) ${ }^{145}$, Arde Minga (2007-2011) ${ }^{146}$, Táctica plop $(2006-2010)^{147}$, Figurones $(2005-2011)^{148}$, Indymedia La Plata $(2004-2012)^{149}$, Surcos (2005 y continúa) ${ }^{150}$, Hijos La Plata (1995 y continúa) ${ }^{151}$, Malas como las arañas (continúa) ${ }^{152}$, Colectiva Feminista Las Furiosas ${ }^{153}$ (2009-2012), El Galpón de Tolosa (2008 y continúa) ${ }^{154}$, Del último cajón (2005-2013), Ala Plástica (1992 y continúa) ${ }^{155}$, Frente de Artistas del Partido Obrero (2010 y continúa esporádicamente), Libélula, Síntoma curadores (2012 y ${\text { continúa })^{156} \text {, Volver a habitar }}^{157}$ (2013 y 2014), Pólvora (2013 y 2014) ${ }^{158}$ y la crew MEC. Entre los y las interventores/as individuales relevamos: Acra ${ }^{159}$ (2005 a la actualidad), Lumpenbola (inicios de 2010 a la actualidad) ${ }^{160}$, Valentino Tettamanti ${ }^{161}$, Cons Kamikaze ${ }^{162}$, Marta, Doble 51, Joaquin Pantera, Jus-tina/Juss ${ }^{163}$, Yapán ${ }^{164}$, Falopapas ${ }^{165}$, AdRian, Cuore ${ }^{166}$, Leo Gauna (2007 y continúa) ${ }^{167}$ y Nelson Sosa, entre otros.

A lo largo de este capítulo se planteó un acercamiento principalmente descriptivo a las experiencias culturales seleccionadas. La hipótesis de lectura que se construyó es que si bien se trata de prácticas diferentes -algunas iniciadas en los años 90, otras generadas en los años

\footnotetext{
145 https://www.facebook.com/grupo.laolla

$146 \mathrm{http} / / /$ ardeminga.blogspot.com.ar/

147 http://tacticaplop.blogspot.com.ar y https://www.facebook.com/tactica.plop

148 http://figublog.blogspot.com.ar

$149 \mathrm{http}: / /$ argentina.indymedia.org/features/laplata

$150 \mathrm{http}$ ://agrupacionsurcos.blogspot.com.ar

151 http://hijosprensa.blogspot.com.ar

$152 \mathrm{http://malascomolasa.blogspot.com.ar}$

153 http://feministasfuriosas.blogspot.com.ar

154 http://galpondetolosa.blogspot.com.ar

$155 \mathrm{http://www.alaplastica.org} \mathrm{y} \mathrm{https://www.facebook.com/Alaplastica}$

156 https://issuu.com/sintoma

157 https://www.facebook.com/volverahabitar

158 https://blogpolvora.wordpress.com

159 https://www.facebook.com/rodrigo.acra y http://rodrigoacra.blogspot.com.ar

$160 \mathrm{http://lumpenbola.blogspot.com.ar/} \mathrm{y} \mathrm{https://www.facebook.com/pg/Lumpen-Bola.} \mathrm{Una} \mathrm{reciente} \mathrm{nota} \mathrm{sobre}$ Lumpenbola fue publicada en el diario Página /12, se encuentra en: https://www.pagina12.com.ar/2853-unpaseo-por-la-plata-en-clave-de-rock

$161 \mathrm{http}: / /$ cargocollective.com/valentinotettamanti y https://es-la.facebook.com/valentino.tettamanti

162 https://es-la.facebook.com/conskamikaze

163 https://lt-lt.facebook.com/Juss.justina

164 https://www.facebook.com/YapanFileteado

165 https://es-la.facebook.com/falo.papas

166 http://carolina-favale.blogspot.com.ar/ y una completa nota se encuentra disponible en el sitio de Buenos Aires street art : http://buenosairesstreetart.com/es/2012/07/el-circulo-de-la-vida-entrevista-con-cuore/

${ }^{167}$ http://leogauna.blogspot.com.ar
} 
tomados para el estudio, algunas con ciertas apuestas sobre el espacio del arte y otras focalizadas a un campo "más" militante, algunas reconocen que en lo cultural también anida lo político, otras que además lo cultural debe conectarse con un exterior sociopolítico- pueden encontrarse puentes que las cruzan y las ponen en diálogo. Esos vínculos no son sólo producto de por compartir una geografía específica -la ciudad de La Plata- ni una temporalidad particular -los años 2006-2011-, sino que puede pensarse como un momento específicamente intenso y productivo de debates, preguntas y acciones colectivas en las que se cruzaron prácticas y saberes heterogéneos que ponderaron y destacaron las posibilidades, las apropiaciones y los usos tanto de los recursos culturales como del espacio urbano. Como se pudo mencionar en las descripciones y observar en las composiciones visuales, elaboradas para dar cuenta de las articulaciones de cada experiencia cultural con otros grupos y organizaciones, en muchos casos esos diálogos eran cotidianos y formaban parte de un intenso hacer colectivo que se expresaba en la ciudad y fue fortaleciendo esas relaciones. Asimismo, se puede comprender que en esa red heterogénea de prácticas y saberes se conforma una experiencia urbana desde las intervenciones culturales en la que se producen tomas de posición sobre cuestiones sensibles del presente: allí la palabra, la imagen y el cuerpo se configuran como potentes dispositivos de enunciación colectiva y de intervención sobre lo real.

En los siguientes dos capítulos se amplía el cartografiado a través del mapeo, la descripción y el análisis de las intervenciones culturales realizadas por los colectivos e interventores seleccionados, lo que permitirá leer y comprender sus modos específicos de pensar, habitar y "producir" la ciudad. A su vez, las maneras de entender y experimentar lo político desde estas prácticas culturales. Por medio de una descripción y análisis denso de las intervenciones y los colectivos se busca dar cuenta de lo fructífero y destacado de estas prácticas culturales en el período de estudio. En particular en el capítulo 4, luego de mapear y localizar las acciones en un mapa a escala ciudad y presentar un cuadro descriptivo de las acciones, nos detendremos a analizar algunas de las intervenciones consideradas interesantes por algunas de las características que implicaron: formas disruptivas o novedosas de apropiación del espacio urbano, interrogantes que abrieron en relación a situaciones específicas de la ciudad, modos de realización colectivos y participativos que generaron. Por su parte, en el capítulo 5, se analiza en profundidad sobre las prácticas seleccionadas: su constitución y formas de organización, las formas de apropiación del espacio urbano y los sentidos de lo público, las prácticas de comunicación y las articulaciones con colectivos y 
organizaciones, son algunos de los ejes de análisis. Las entrevistas en profundidad producidas en el trabajo de campo son el principal recurso de indagación. 


\title{
Capítulo 4
}

\section{"Estar en la avalancha". Ampliación del cartografiado}

\author{
"Siempre hicimos hincapié en las conexiones, en las relaciones \\ entre los grupos. Porque nosotros pensamos que estamos dentro \\ de la avalancha y no intervenimos desde afuera". \\ Luli, en "Calle Tomada".
}

\section{Sobre las intervenciones}

En este capítulo se continúa el despliegue de la cartografía cultural iniciada en el anterior capítulo. La indagación se centra en las acciones e intervenciones del período 20062011 de los colectivos e interventores seleccionados. Los datos fueron construidos en el relevamiento de las prácticas tanto en las recorridas por la ciudad como navegando la web. Se sintetizan para producir un primer mapeo de localización de las intervenciones en un mapa de La Plata y un detallado cuadro descriptivo. El empleo de ambas herramientas sirve para visualizar intervenciones e interventores y trabajar sobre los recorridos urbanos y las apuestas de dichas acciones. Luego se indaga en algunas de las intervenciones y, sobre el final del capítulo, se plantean algunas cuestiones para comprender las derivas y los cambios que tuvieron las experiencias de intervención en la ciudad -una cuestión que se profundiza en el capítulo 5-. También se detallan y describen varias de las acciones de la segunda temporalidad (2012-2015) del cartografiado.

\section{I.a. Mapeo de intervenciones}

El relevamiento de colectivos, interventores y acciones se completó con una primera puesta de localización de las intervenciones en un mapa plano de la ciudad, a partir del recorte temporal propuesto y los referentes empíricos seleccionados y descritos anteriormente. Este mapeo es exhaustivo pero fue ampliado en la versión online presentada en el sitio web de la tesis. En relación a las referencias para su lectura se le designa un color para cada grupo o interventor. Por un lado se busca visibilizar en el mapa de la ciudad -una parte de "lo 
concebido"- ciertos puntos del espacio utilizados, pero también los recorridos urbanos, propuestas y reiteraciones que siguieron a las intervenciones culturales -ya que estos emplazamientos son un espacio de la "ciudad practicada", de las apropiaciones-, así como simultaneidades entre las acciones. El mapeo se completa con un exhaustivo cuadro descriptivo de las intervenciones realizadas en el periodos 2006-2011 por los colectivos e interventores seleccionados, allí se referencia a las coordenadas temporales de las acciones. El cuadro fue una elaboración ad hoc del autor (ver anexo 1).

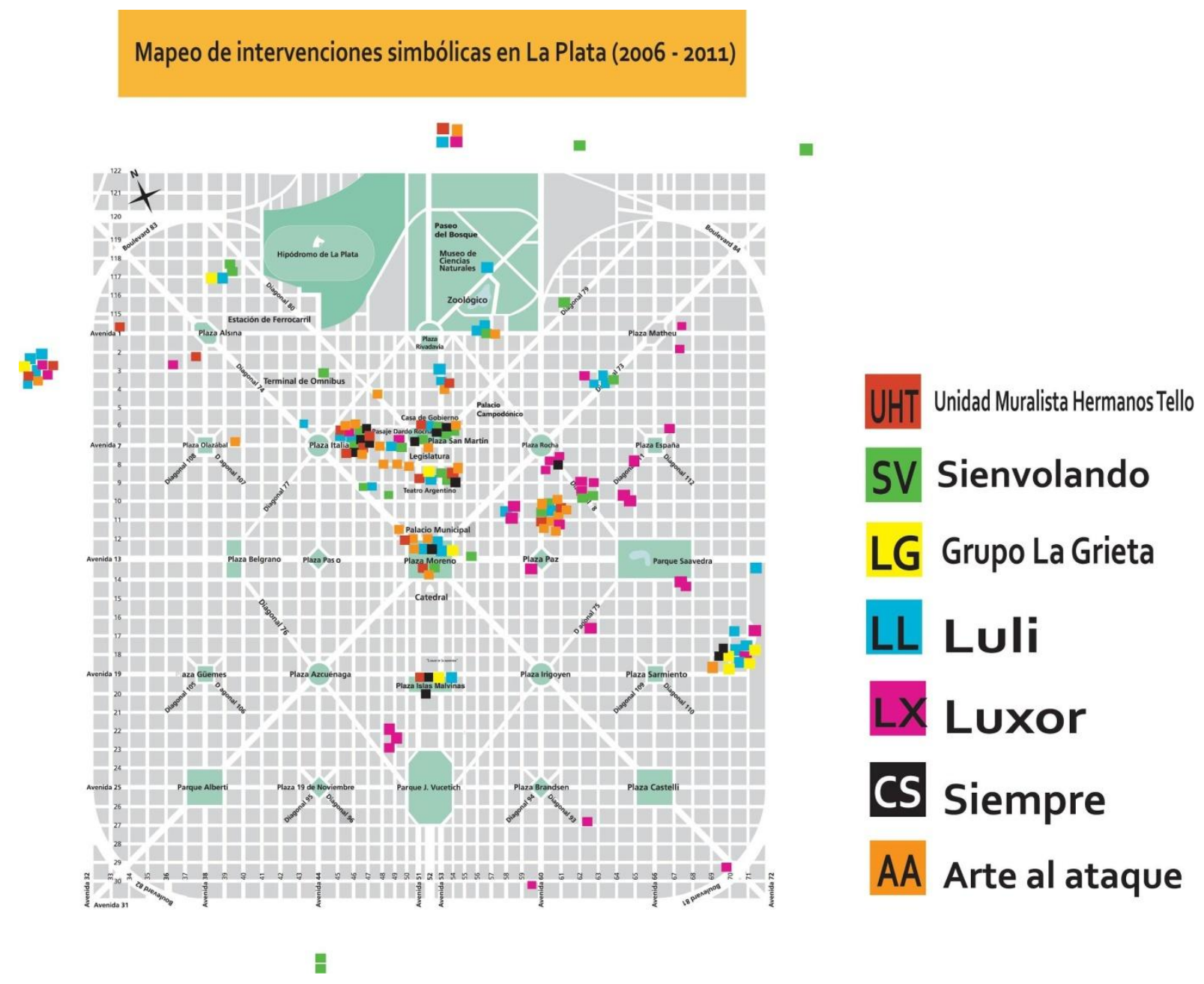

Mapa 2. Mapeo de localización de intervenciones culturales por colectivo o interventor. Período: 2006-2011.

\section{I.b. Segunda temporalidad: 2012-2015}

En los años siguientes, que van del 2012 al 2015, podemos encontrar otras acciones/intervenciones como:

- Pintadas murales sobre la "cultura rock" (2010-2015). Individual y con referencia. Luego de participar en experiencias colectivas (Sienvolando, Mutantes e Intervención Magenta) 
LumpenBola comenzó a pintar en la calle de forma individual. Su poética está centrada rostros y figuras humanas -una de sus principales serie de murales está referida a músicos y personas conocidas del mundo artístico, pero esto no es excluyente en su producción-. El barrio La Loma es una zona de la ciudad donde llevó adelante gran parte sus murales sobre personajes de la cultura rock (local, nacional e internacional): Federico Moura, Sumo, Luca Prodan, el Flaco Spinetta, Patricio Rey, Divididos, Manu Chao, Jimmy Hendrix, entre otros.

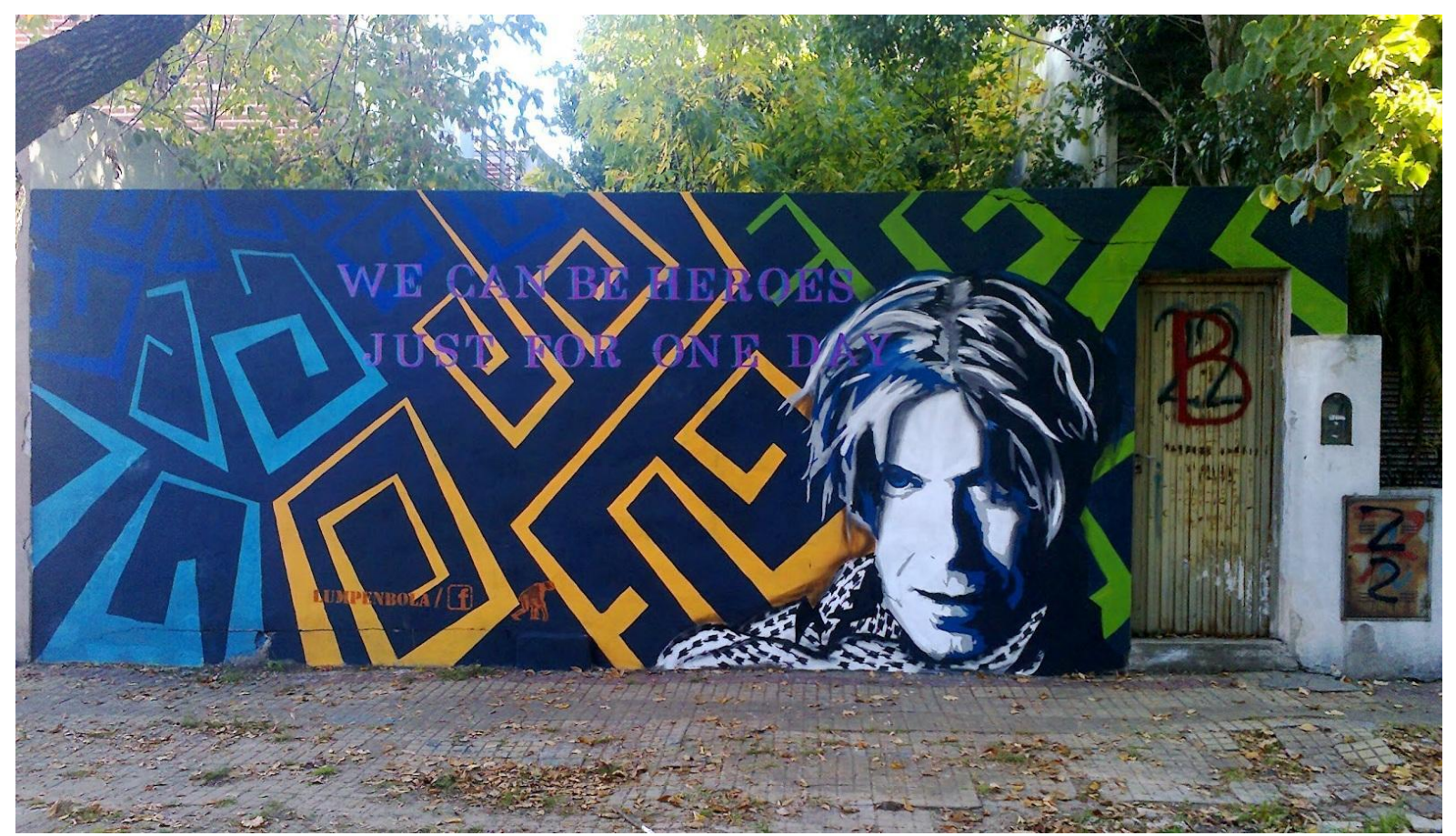

Imagen 23. Mural sobre "Héroes" de David Bowie. Fecha: abril de 2012. Imagen extraída del blog de Lumpenbola.

- Pintadas colectivas (mayo de 2012). Colectivas y con referencia. Una de ellas fue una acción durante dos días sobre una inmensa pared en calle 132 e/ 60 y 61 en el barrio de Los Hornos. Estuvo organizada por Luxor y Acra e intervinieron, además de ellos dos, Nelson Sosa, Cons Kamikaze, Sato, Manuel Rubín, Santiago Ambrosio, Ailen Lanzamidad, Juss, Cuore, Manuela Majul, Inka, Santiago Elefante, Ka Jum, Ma Pe y Ice. ${ }^{168}$ También se realizó otra jornada de pintadas en la sede la una organización sin fines de lucro gestionada por Luxor y Acra y contó con la participación de muchos de los interventores recién mencionados y otros. Invitados por el TACEC, Luxor, Acra y Leo Gauna intervinieron con sus pintadas en las paredes una de las fosas del Teatro Argentino.

- Festival "Arde Closet” (junio 2012-2015). Colectiva, participativa, con y sin referencia. Esta actividad en conmemoración de la revuelta de Stonewall (Nueva York, 1969) y como parte

${ }_{168}$ Un video de esta intervención fue realizado por Lucio Zanzio y se encuentra disponible en: https://www.youtube.com/watch?v=7h5Ca57FOTg 
del Día Internacional de Orgullo se realiza desde 2008 en la plazoleta de 8 y 61 siempre a finales de junio. Se trata de una performance colectiva con música, baile, juegos, pintadas, stencils, muestras fotográficas y otras intervenciones visuales y sonoras. Una jornada por el "placer disidente", para discutir el patriarcado, la agresión homo-lesbo-transfóbica y resistir "a la heterosexualidad impuesta como norma". Entre sus convocantes se encuentra Malas como las Arañas.

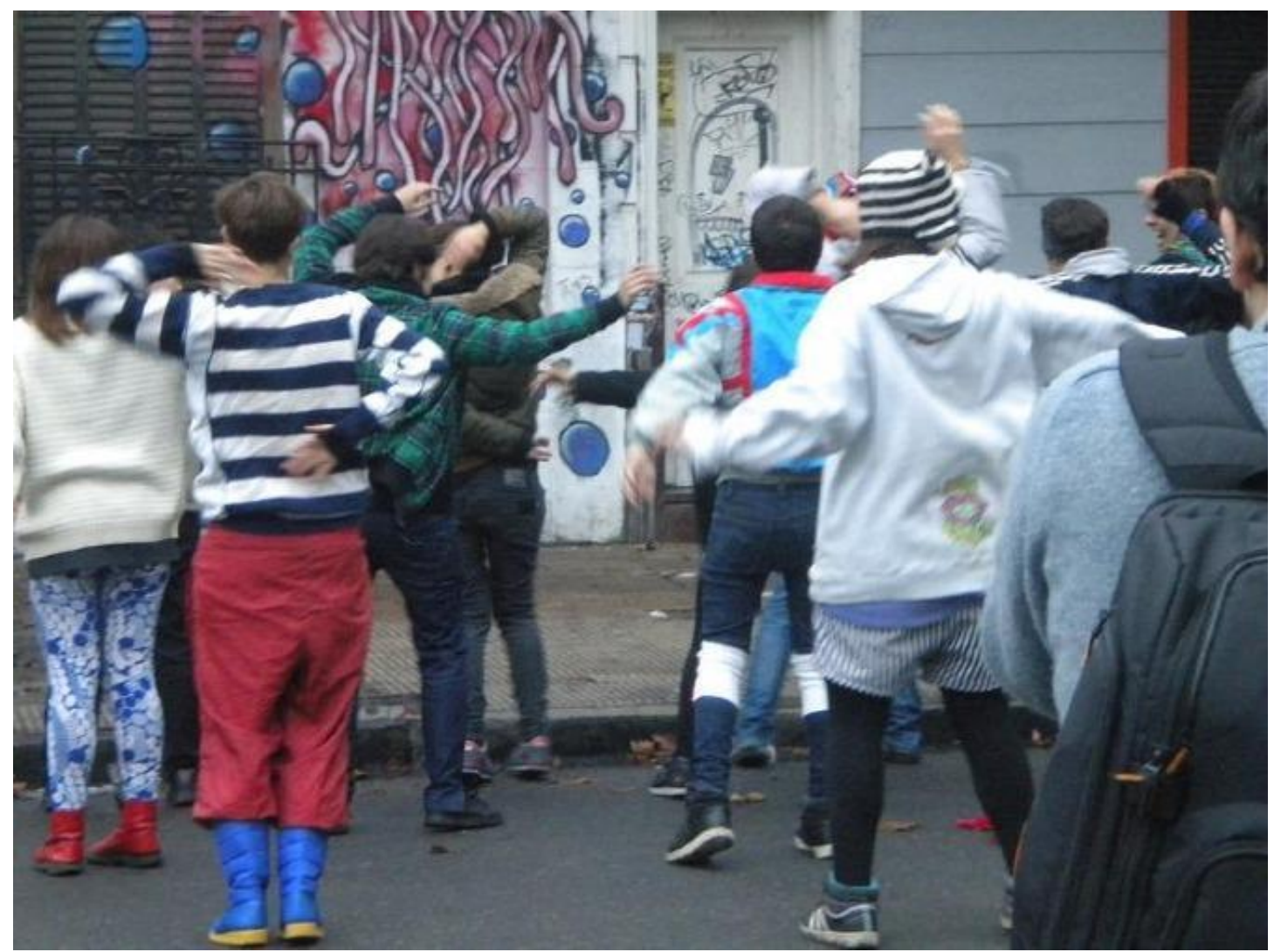

Imagen 24. Festival “Arde closet”. Fecha 28 de junio de 2012. Lugar: Plazoleta de La Noche de los Lápices (8 y 61). Imagen extraída del sitio web de Malas como las arañas.

- Encuentro "Haciendo zigzag" (octubre de 2012). Colectiva y de referencia. En su organización participaron Luxor, Acra y Síntoma curadores, entre otros interventores y productores locales. Se realizaron dos eventos previos, los "Me Gusta", en el Club Alborada (58 e/ 10 y 11), lugar que fue el espacio de referencia para los días del Encuentro junto al Centro Olga Vázquez, donde se llevó a cabo la jornada de cierre. ${ }^{169}$

169 https://www.facebook.com/haciendozigzag/ 

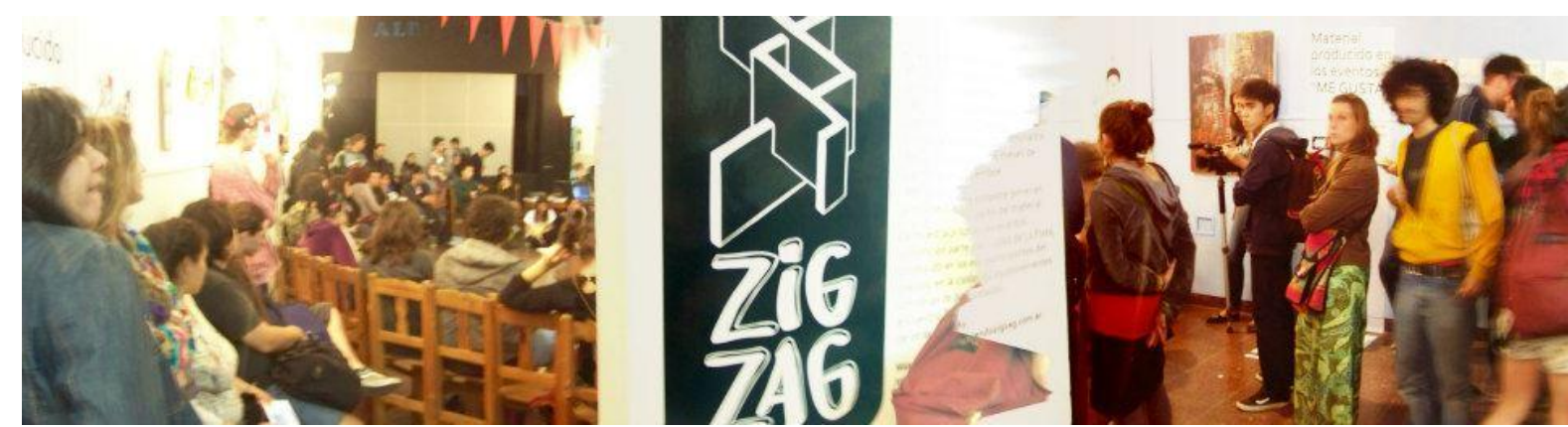

Imagen 25. "ZigZag. Encuentro latinoamericano". Fecha: Del 12 al 14 de octubre de 2012. Imagen de Carlos Godoy Baez, extraída del Facebook del evento.

- "Un amor de verano" / "Paseo de verano" (enero de 2013). Intervención conformada por una serie de dibujos en Facebook y en muros de la ciudad. Las imágenes de objetos surgieron a partir de los viajes de verano de personas que son contacto de Dani Lorenzo en esa red social. El cierre de la intervención fue con un catálogo y recorrido por la ciudad donde se encontraban los dibujos ${ }^{170}$.

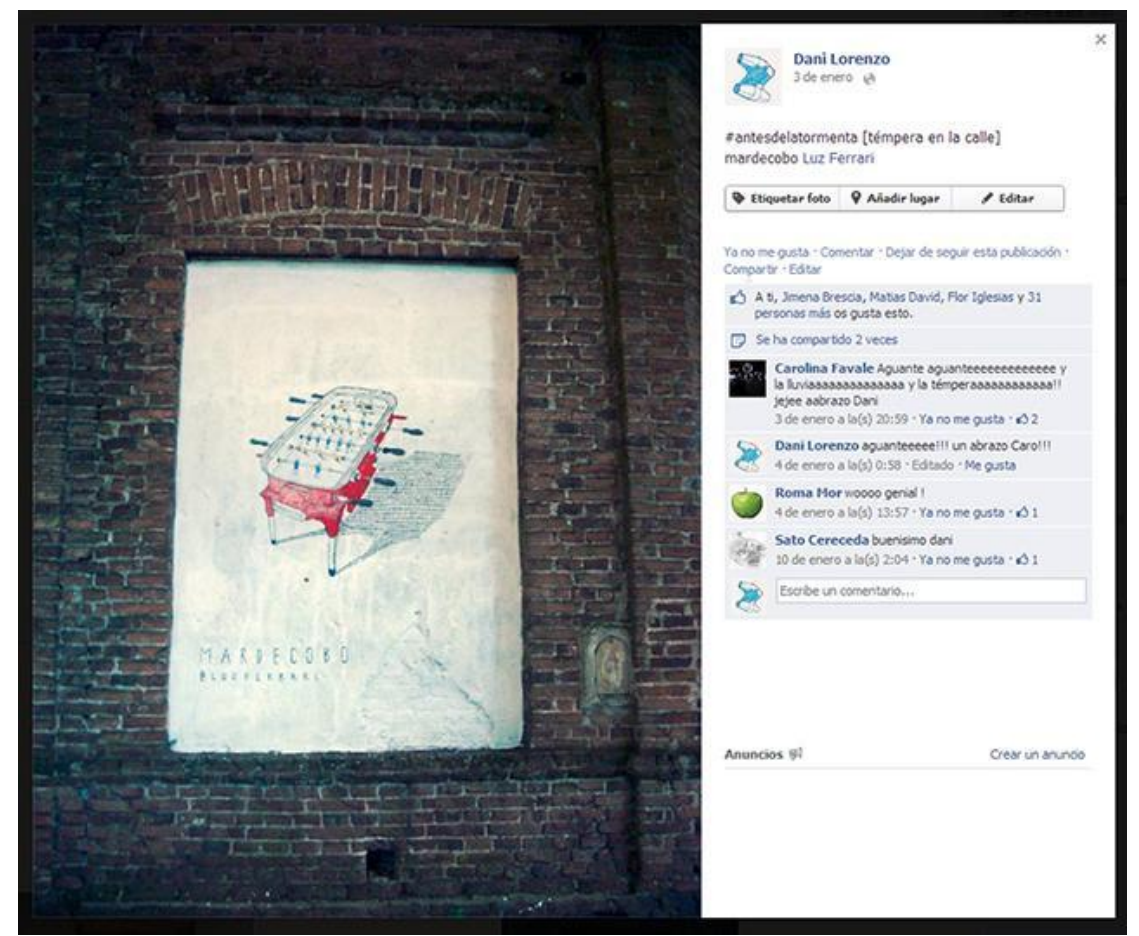

Imagen 26. "Paseo de Verano" muestra de cierre de la serie de dibujos "Amor de verano" de Dani Lorenzo. Imagen extraída del perfil de Facebook.

- "Volver a habitar"171. (2013-2014). Acción colectiva y de referencia. Se trató de intervenciones con murales, registro fotográficos y de entrevistas y la producción de micro-

\footnotetext{
${ }^{170}$ Reseña publicada en ramona web, cuenta con imágenes del recorrido y el texto de presentación del catálogo. Disponible en: http://www.ramona.org.ar/node/46732

171 Página en Facebook: https://www.facebook.com/volverahabitar y perfil en Youtube: https://www.youtube.com/user/volverahabitar
} 
documentales audiovisuales sobre barrios y vecinos afectados por la inundación del 2 de abril de 2013). Entre los organizadores y productores de esta acción estaban Luxor, los integrantes de Intervenir LP y el autor de esta investigación.

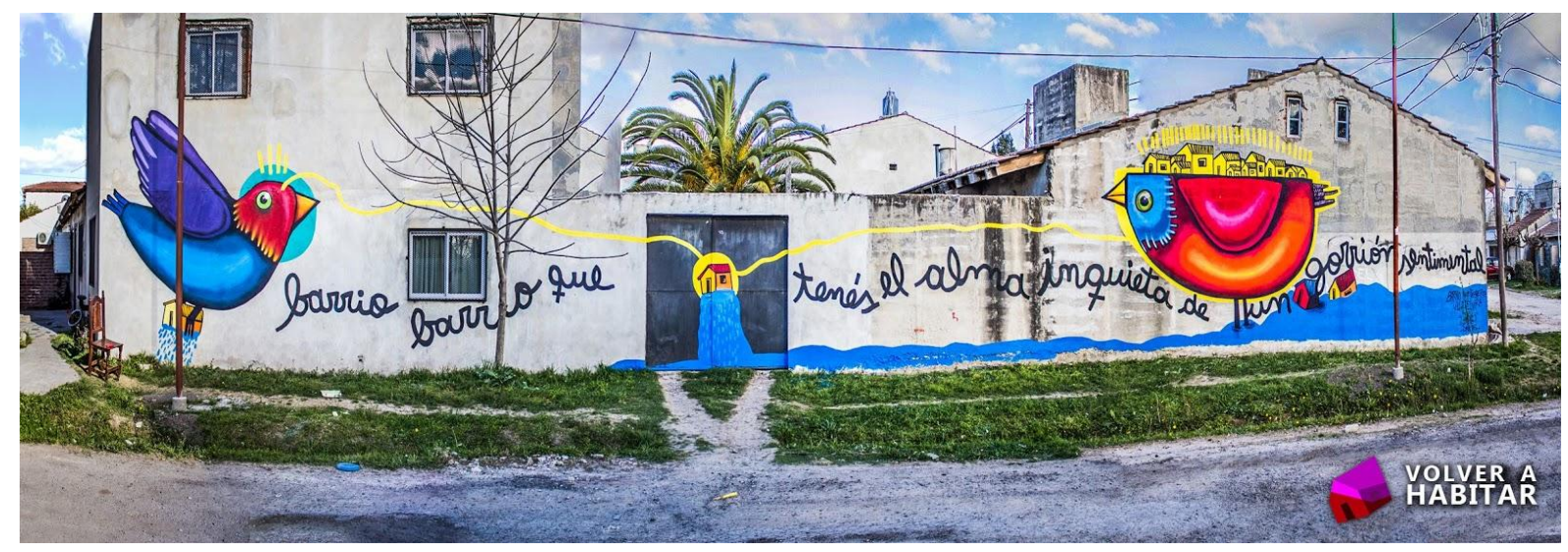

Imagen 27. "Volver a habitar", mural en el barrio 19 de noviembre (La Plata) con la leyenda "barrio, barrio que tenés el alma inquieta de un gorrión sentimental". Fecha: Septiembre de 2013. Imagen de Danpeople Fotografía, extraída de la página de Facebook del colectivo.

- Festival "DanzaAfuera"172 (2013-2015). Es un festival de danza contemporánea que se ha realizado en los meses de noviembre o diciembre. En el 2016 se realizó la $4^{\circ}$ edición.

- "Desbordes" (2014-2015), un "punto de encuentro" de acciones culturales realizado el 2 de abril de 2014 y 2015 en Plaza Moreno a un año de las inundaciones. Acción colectiva y de referencia. Estuvo organizada por varios colectivos culturales: Síntoma Curadores, Volver a habitar, Club Hem editores, Pixel editora, Malisia, Estructura Mental a las estrellas, La Pulseada, Otro Viento, La Grieta, Arte al ataque, entre otros ${ }^{173}$.

\footnotetext{
$172 \mathrm{https}: / /$ es-la.facebook.com/DanzafueraFestival/ y http://danzafuera.wixsite.com/festival

173 https://www.facebook.com/Desbordes-Punto-de-encuentro-de-acciones-culturales-2A
} 


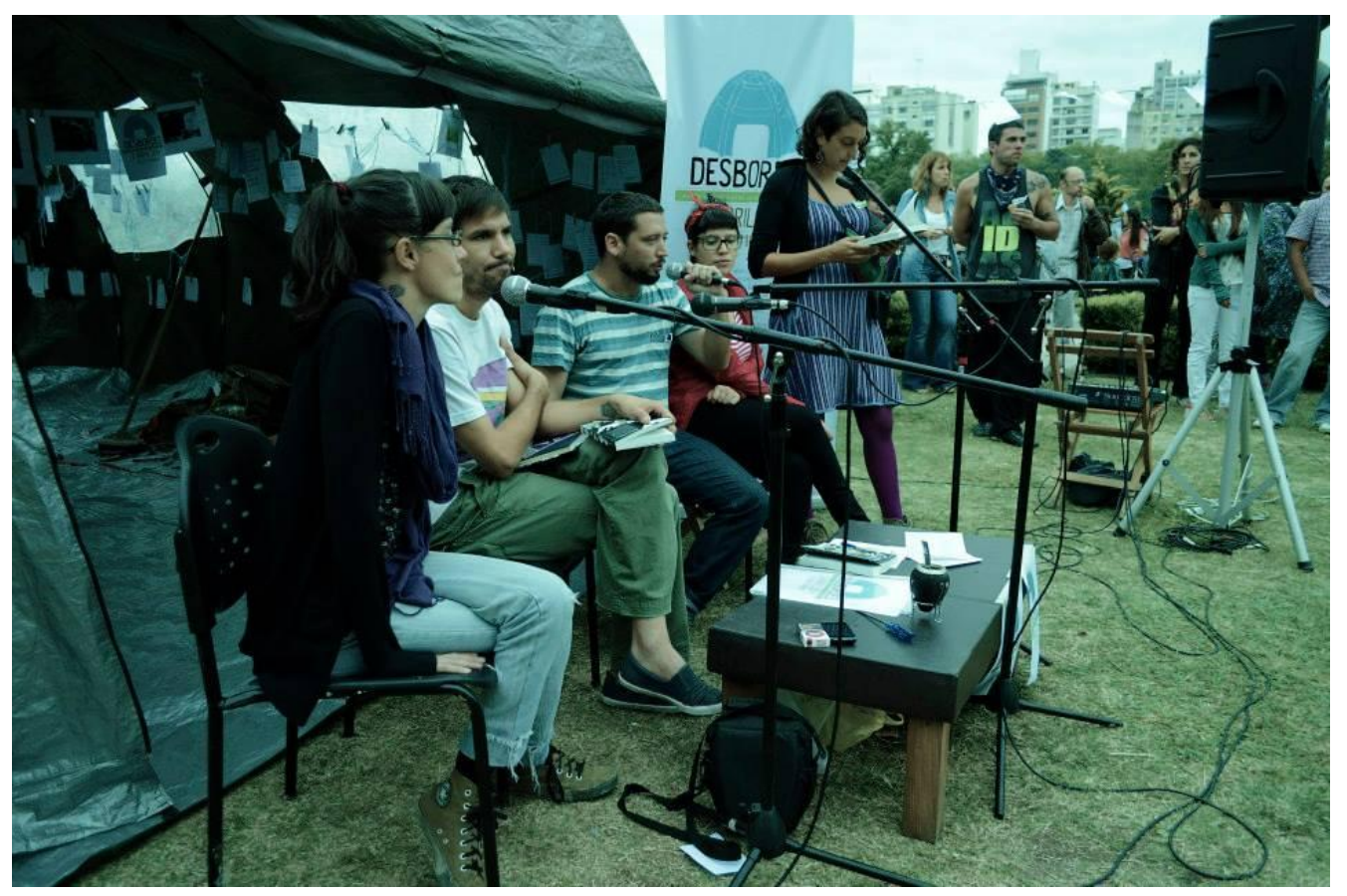

Imagen 28. "Desbordes, punto de encuentro de acciones culturales", 2 de abril de 2014, Plaza Moreno. Imagen extraída de la página de Desbordes en la red social Facebook.

- La Joda teatro y Volver a habitar, performance callejera por la ciudad al cumplirse un año de la inundación (2 de abril de 2014) más producción audiovisual de un corto.

- Muestra colectiva "Inundación y Después" en el Museo Arte y Memoria (de abril a junio de 2014). Participaron en la organización, montaje y curaduría, Síntoma, Club Hem, Pixel, Puchero, Volver a habitar, Ala Plástica, entre otros colectivos.

- Renovación de la pintada “¿A qué te podés acostumbrar?” (Septiembre de 2013 y 2014) en el edificio de la "Tres Facultades" (7 y 48). Al cumplirse siete años de la segunda desaparición de Julio López. Fue coordinado por las agrupaciones Surcos y Praxis. 


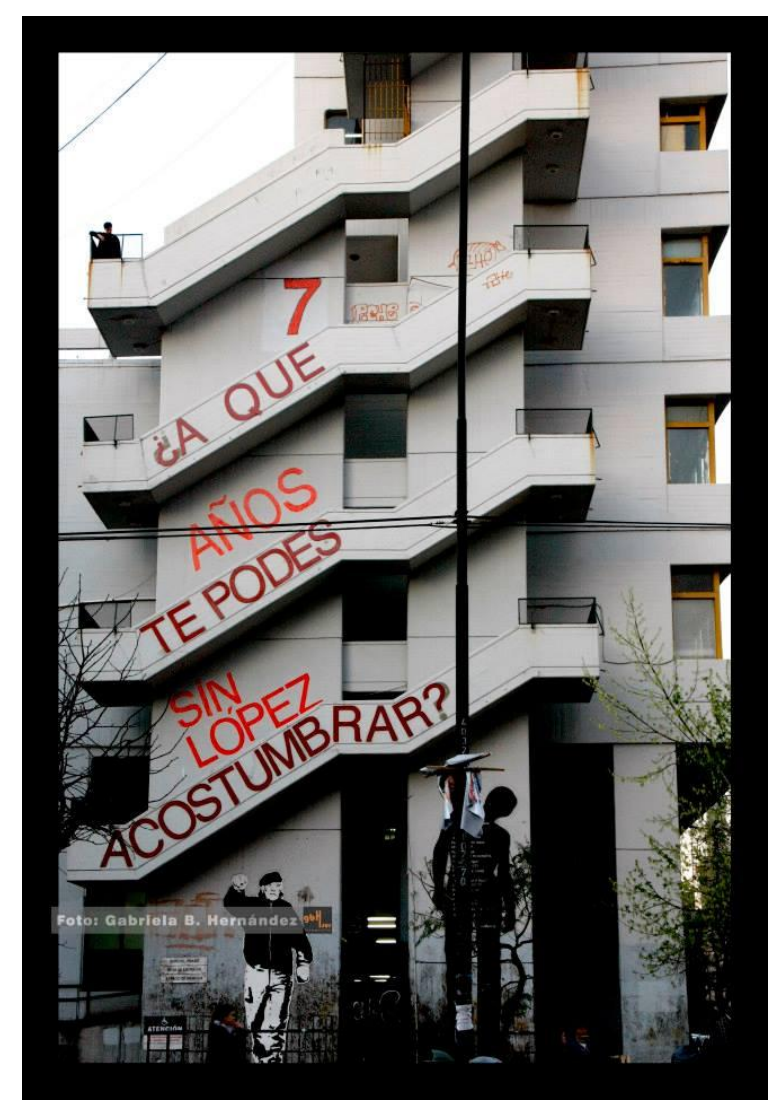

Imagen 29. “:A qué te podés acostumbrar? 7 años sin López”. Agrupaciones Surcos, Praxis y otros interventores. 18 de septiembre de 2013. Imagen: Gabriela B. Hernández.

- "Balada para otro loco" (septiembre de 2013) Mural a 7 años de la segunda desaparición de Julio López. Actividad en la que participaron varios productores visuales, se realizó en el paredón de 14 y 64 .

- "Concreto. Museo de la calle" (agosto y octubre de 2014) Se trató de encuentros de pintadas de graffiteros, pintores e interventores llevados adelante en dos escuelas públicas de la "periferia" de la ciudad. Luxor y Acra estaban entre sus organizadores.

- Repintada del rostro de Julio López (13 de septiembre de 2014) en el centro de Plaza Moreno. Actividad organizada por HIJOS La Plata, participaron además militantes e interventores visuales.

- "Desencuentros. Un safari por el patio del arte" (octubre 2014), organizado por Síntoma Curadores en el marco de la III Bienal de Arte y Cultura de la UNLP ${ }^{174}$. Las propuestas de este colectivo, que reflexiona sobre la emergencia y potencialidades de una "escena local de las artes visuales", se indagan en el capítulo 8.

\footnotetext{
174 Reseña del recorrido "Desencuentros" por Síntoma curadores para ramona web. Link: http://www.ramona.org.ar/node/54228
} 


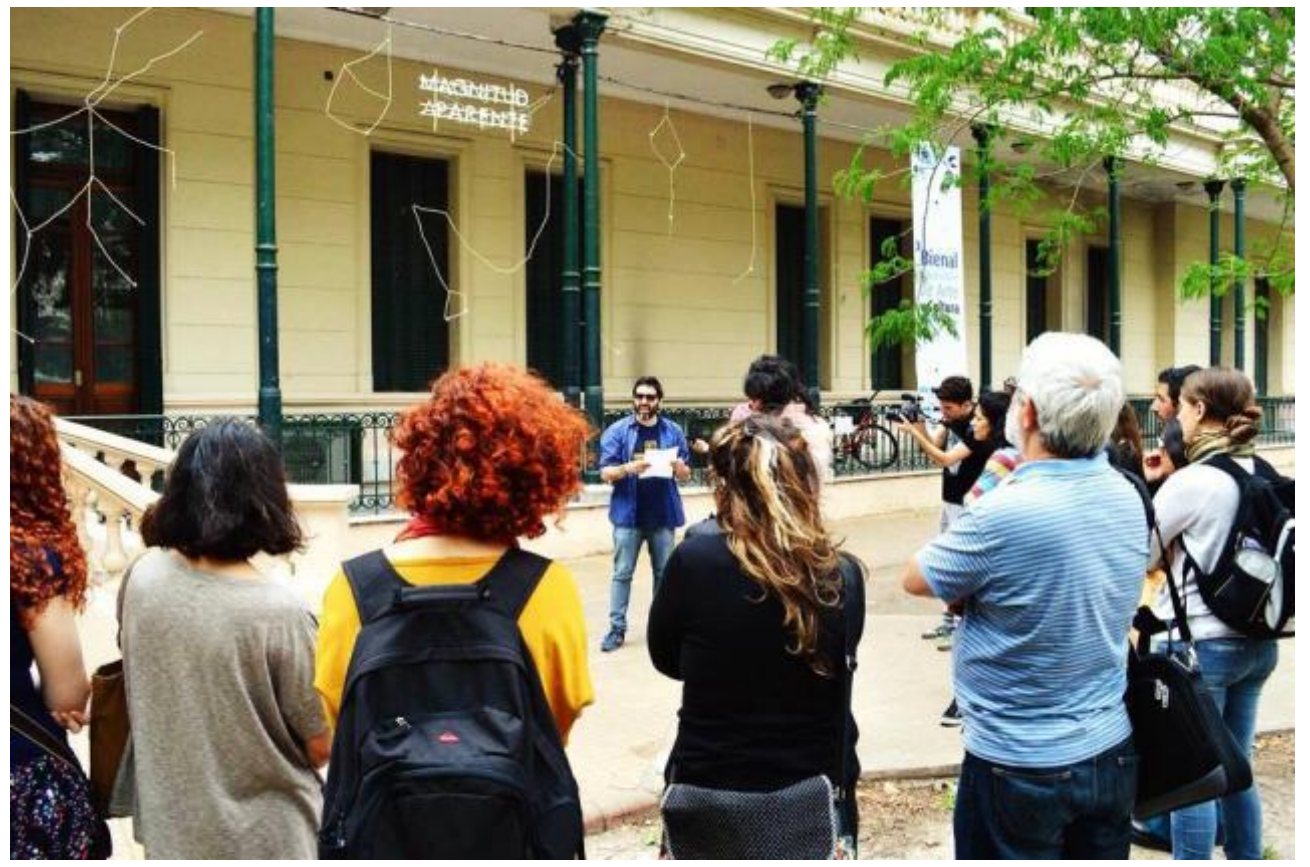

Imagen 30. "Desencuentros, un safari por el patio del arte". Uno de los puntos del recorrido propuesto, aquí en la entrada de la Facultad de Ingeniería de la UNLP frente a la obra "magnitud aparente" de Mariela Vita (1 y 47). Fecha: noviembre de 2014 Imagen: extraída de la página de Facebook de Síntoma curadores.

- "Pintó inundar lo nuestro" / "Pintó ocultar los muertos" (octubre de 2014 - abril de 2015). Contracampaña que consistió en stencils y en la pegatina de pequeños flyers con dichas frases, así como la circulación por las redes sociales, tanto del flyers como de la intervención. Estuvo organizada por Pólvora y planteada una tergiversación de la campaña municipal "Pintó cuidar lo nuestro", que tenía como acción principal tapar murales, graffitis, pintadas y despegar afiches pegados en paredes del centro de la ciudad ${ }^{175}$.

- Muestras del proyecto "Fuera!. Fotogalería a Cielo Abierto" (2012-2015), en la cara externa del muro perimetral del colegio Liceo Víctor Mercante (47 e/ 4 y 5) ${ }^{176}$. Las muestras fueron: "Desapariciones" de Helen Zout; "Aguanegra", muestra colectiva (luego desde Fuera invitaron a productores visuales para una "intervención plástica" sobre la fotografias); "Zona sur" de Alfredo Srur; "Territorio" de Daniel Muchiut, "América!” de Santiago Hafford y “Artigas" de Martín Atme, "La calle” de Rafael Calviño (en el marco de la III Bienal de Arte y Cultura de la UNLP).

- Re-pintada del Mural "Ni esclavos del gobierno ni rehenes de los laboratorios: contra el SIDA" (abril de 2015), realizada por Luxor, Yapán y Chempes, en la fachada lateral del Centro Cultural "Daniel Favero" (40 y 117).

\footnotetext{
${ }^{175}$ El registro de la primera intervención estuvo a cargo de colectivo fotográfico SADO. Disponible en: https://www.facebook.com/SADO-813762045330669/photos/?tab=album\&album id=819850514721822

${ }^{176}$ Tumblr: http://fotogaleriafuera.tumblr.com/ y Facebook: https://www.facebook.com/fuera.fotografia
} 
- "Teatro Argentino sin rejas" (agosto-septiembre de 2015). Dos festivales culturales realizados en la plaza seca del Teatro (10 y 51), organizados desde la asamblea autoconvocada $^{177}$.

- Mural "Palestina Libre" (31 de octubre de 2015) como parte de la jornada "murales por Palestina" promovido por el Comité de solidaridad con el pueblo palestino, Embajada del Estado Palestino en Argentina y COB La Brecha. Participaron, entre otros, Yapán, Zapaz Flecha, Colectivo Sesentoso y Chempes, entre otros. Ubicado sobre avenida 72 esquina 10.

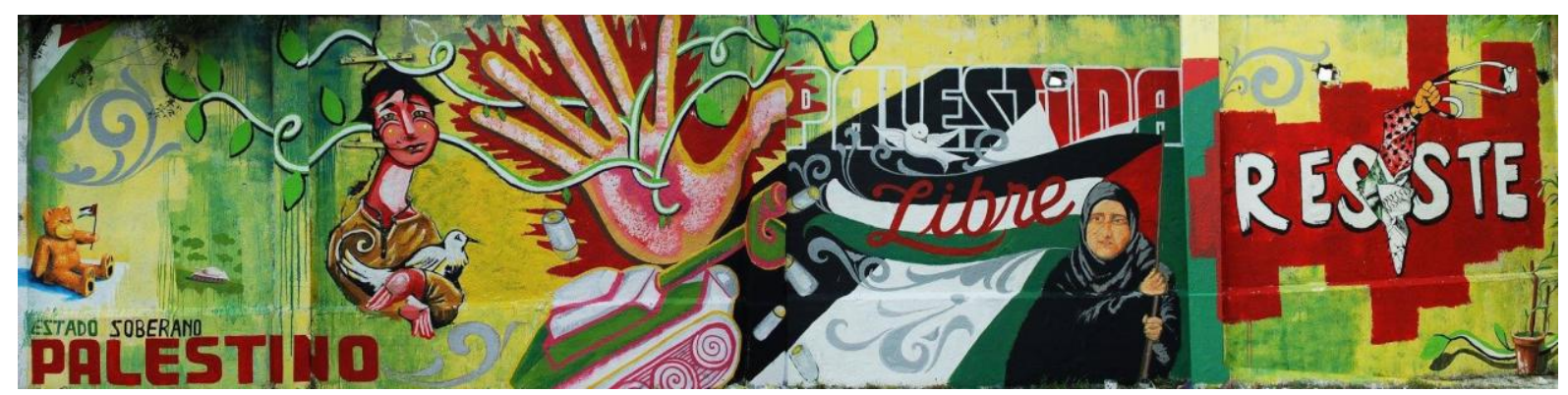

Imagen 31. Mural "Palestina Libre". Fecha: 31 de octubre de 2015. Ubicación: 72 y 10. Imagen de Chempes, extraída de Facebook.

- Mural por Omar Cigarán “Basta de gatillo fácil” (29 de noviembre de 2015). Organizada por Corriente de Organizaciones de Base - La Brecha y el Colectivo Contra el Gatillo Fácil. Ubicado en la plaza de Barrio Hipódromo (120 y 41). Participaron en la pintada del mural: Chempes, Martin Zinclair y Zapaz Fecha.

\section{Reflexiones sobre las intervenciones}

Del principal periodo relevado y cartografiado en la investigación se eligieron para analizar algunas de las intervenciones producidas por los colectivos e interventores seleccionados. La intención no es destacar a estas acciones como las más importantes de esos años, sino trabajar, a partir de ellas, algunas cuestiones referidas a las formas de apropiación del espacio urbano y la construcción de sentidos desde la producción cultural.

\section{II.a. Dispositivos de comunicación en la ciudad}

En sus intervenciones, el colectivo Sienvolando desplegó un repertorio rico y complejo de recursos visuales y comunicacionales. Así, los murales "Aparición con vida Julio López" (2006), “von Wernich genocida" (2007), “Trabajadores de Mafissa en Lucha”

${ }^{177}$ https://www.facebook.com/Teatro-Argentino-Sin-Rejas-817736588356074/ 
(2007), "Masacre de Magdalena" (2008), "Buscar Justicia" (2008) y "Ni esclavos del gobierno ni rehenes de los laboratorios: contra el SIDA" (2008) son algunos ejemplos de estas apuestas visuales y discursivas de este colectivo en donde primaban fondos con colores, el dibujo figurativo e icónico (un banco escolar, una mochila, pastillas, una pared en construcción) y un anclaje textual (una frase de denuncia, una frase poética, una frase referencial que aparecían arriba y en un zócalo demarcado con color por debajo). En todos los casos, dichos elementos forman, como composición, una metáfora. Esto es, no se trata de un discurso realista o literal sino metafórico donde se conjugan composición visual y enunciados escritos-textualizados.

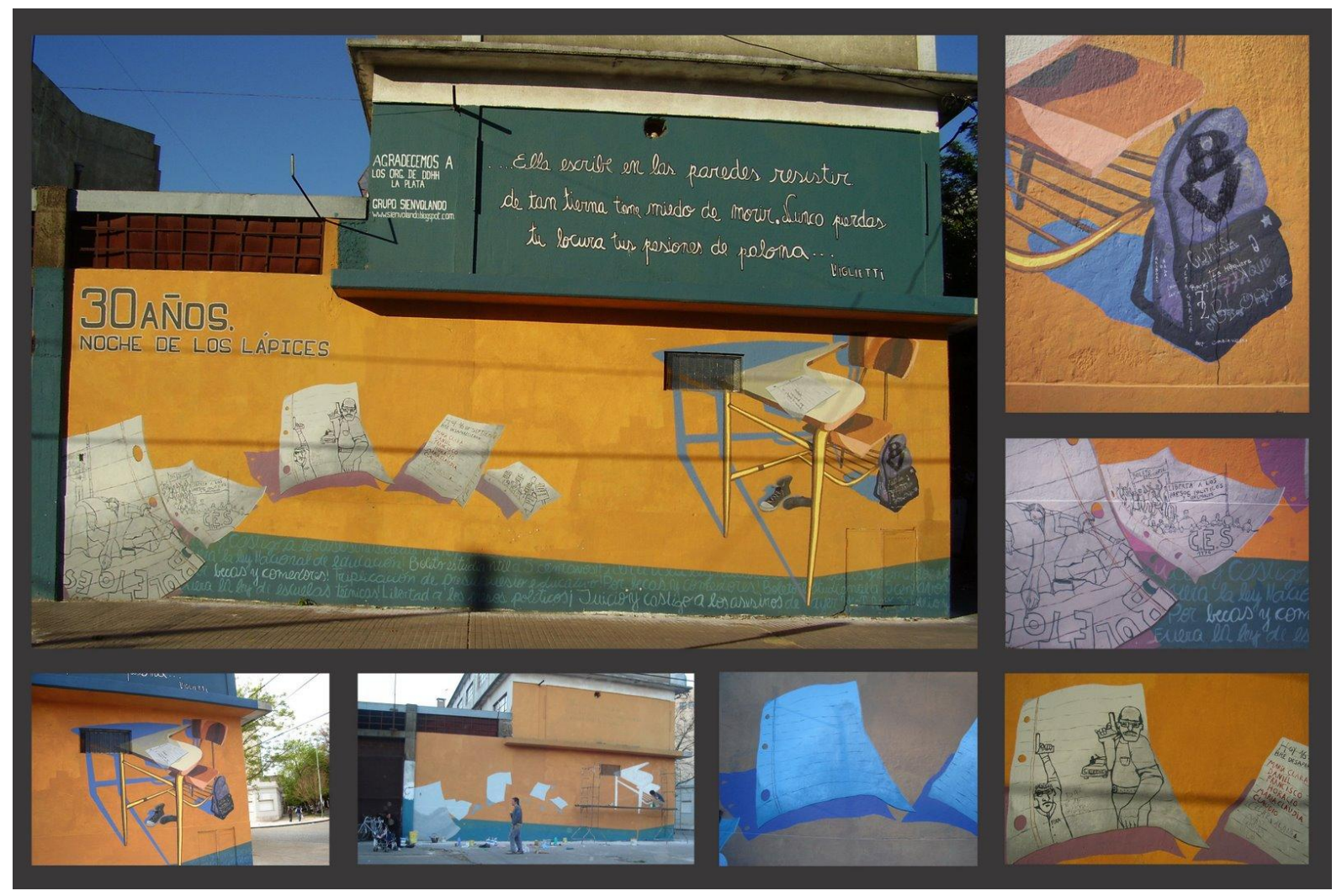

Imagen 32. Sienvolando, mural 30 años de la Noche de los lápices. Año: 2006.

Se puede pensar que el paso de un "mural" hacia el otro, de una acción a otra, configura una permanente complejización y ampliación de esos recursos gráficos y visuales. Una búsqueda permanente por la comunicabilidad de las acciones. Un punto importante de este constante desplazamiento de su estética fue representar la imagen de inicio de la página de Google y linkear desde una pared callejera a un sitio web apócrifo de una campaña que reclamaba justicia por los asesinatos de Darío Santillán y Maximiliano Kosteki (ver imagen 7). La otra fue a inicios de 2009 en las actividades organizadas en reclamo de justicia por el 
femicidio de Sandra Ayala Gamboa al cumplirse 2 años del hecho. En la propuesta de Sienvolando el mural cede su lugar completamente y se producen dispositivos de comunicación pública y vial (banner gigante, boleta apócrifa de impuesto de Arba) sin representación figurativa y sin búsqueda plástica. (Una descripción analítica de estas y otras acciones posteriores sobre el femicidio de Sandra Ayala se puede encontrar en Chempes, 2009 y Pérez Balbi, 2012b, sobre otras acciones de Sienvolando en Sager y López, 2009 y Capasso, 2011).

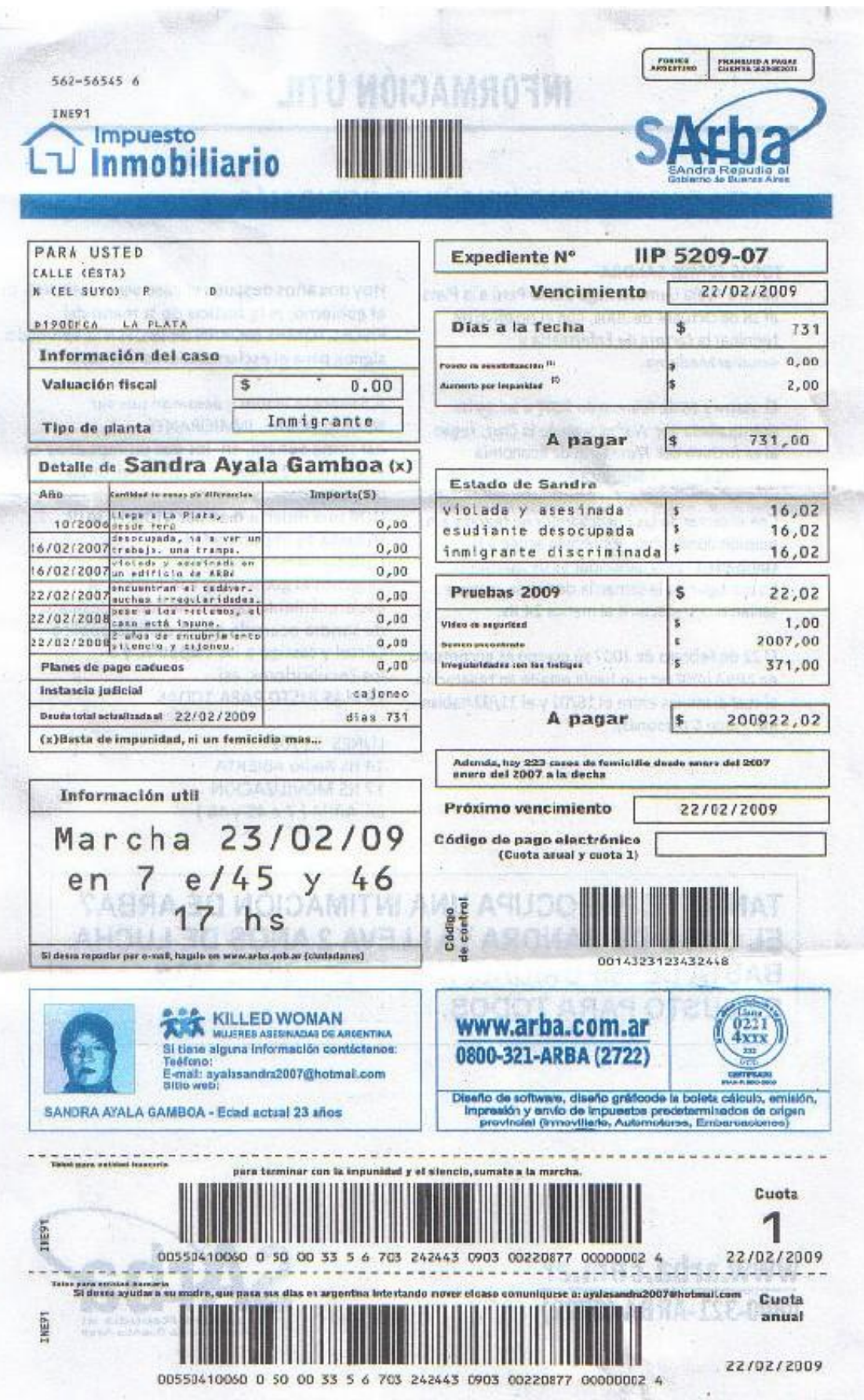


Imagen 33. Boleta tergiversada de ARBA, fue una propuesta de Sienvolando y otros interventores aunque se trató de una campaña anónima que se articuló con la asamblea "Justicia por Sandra". Fecha: febrero de 2009.

Una de las apuestas que estuvo presente en todas estas intervenciones de Sienvolando fue la de producir encuentros con otros (principalmente organizaciones sociales, y en algunos casos también vecinos). Un objetivo que, si bien en muy pocos momentos salió efectivamente del "cerco militante" como apunta el grupo, sirvió para plantear esa inquietud y buscar nuevas formas de comunicabilidad de las acciones.

En este sentido, como síntesis se puede plantear que el accionar de Sienvolando da cuenta del despliegue de un dispositivo crítico de enunciación; por lo que se puede hablar que no se trata solo de realizar murales -aunque gran parte de sus producciones estuvieron fuertemente ancladas en esa técnica y formato de trabajo con los recursos plásticos-. Desde su hacer discutió la perdurabilidad del muralismo tradicional (en una ciudad donde se recuperaba una carrera de muralismo), introdujo piezas que dialogan con la publicidad callejera y planteó algunas complejas estrategias de comunicación que tomaron la producción discursiva desde múltiples lugares. Se puede interpretar que estas últimas cuestiones, el diálogo con el diseño visual, la publicidad y con las estrategias de comunicación fue una intención aún más marcada -y que "estalló"- con las acciones de Luli.

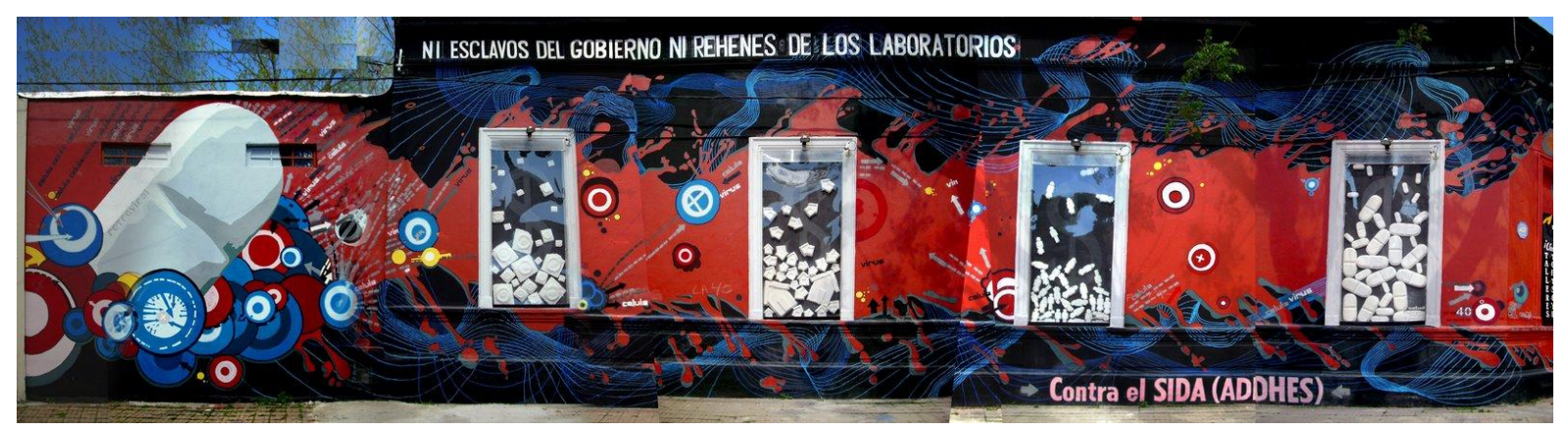

Imagen 34. Sienvolando, mural-instalación "Ni esclavos del gobierno ni rehenes de los laboratorios: contra el SIDA". La intervención contaba con relieves y acrílicos en las ventanas (que representaban frascos de pastillas) y un sistema de luces con fotocélulas que se encendían de modo invertido cuando un transeúnte pasaba por debajo de cada luminaria. Imagen extraída del blog del colectivo.

\section{II.b. Potencia performática de los cuerpos}

Con las acciones que podemos denominar "Rostros" (2007 y 2008) el colectivo Siempre experimentó una modalidad muy poco explotada en las intervenciones de ese momento: la puesta del cuerpo como propio campo de intervención. Al tiempo invitó a que 
esa presencia de los cuerpos fuera una acción y producción participativas ${ }^{178}$. Si bien la participación colectiva no es algo que puede ser del todo prevista de antemano, sin esos muchos otros que se involucren la acción puede perder efecto y contundencia. Las acciones fueron en total cuatro: tres en marchas por la desaparición de Julio López y la otra durante una jornada cultural convocada junto a otros colectivos en la plaza Islas Malvinas. Sobre la primera acción realizada en Plaza Moreno el 18 de marzo de 2007 Julia (E 16) comenta: "fue la más importante. El hecho de que hayan quedado las pancartas, para nosotras, era como que la intervención seguía andando":

“Creo que fue la más intensa. Veo las pancartas al día de hoy. Era algo que planteó una estética también. Esa intervención, analizándolo a la lejanía, tiene como una cosa así de esos momentos donde no sabes bien lo que estás haciendo o lo que está pasando. Y que hoy sigamos hablando de esa acción -lo visual o algo de esa acción-... como que uno en ese momento no dimensionaba el alcance de lo que estábamos haciendo: Pensar en una acción donde aparezca el cuerpo, justamente cuando estamos hablando de un cuerpo desaparecido" (E 16, Julia)

En cómo se desarrollaron las dos las últimas intervenciones en septiembre de 2007 y 2008 se encuentran parte de los motivos por lo que el colectivo decidió dejar de realizarlas. En tanto que sobre la acción del 18 de septiembre de 2007 Mariana e. y Diana comentan:

\footnotetext{
"la hicimos al año y ya intervino la Multisectorial. Me acuerdo que nos miraban como... éramos como las chicas torpes, éramos las bobas. Éramos como las chicas de la danza que 'van a hacer tal cosa'. Ellos sabían de qué hablar, nosotras no. Ahí hicimos 400 pancartas, mucha gente se la llevó y reapareció en distintos lugares. Mucha gente se la apropió y eso estuvo bueno. Empezó a aparecer. (...) Las pancartas las hizo la Multisectorial, no las hicimos todas nosotras, y ahí lo estético, el cuidado por el color... todo eso se fue perdiendo. Nosotras fuimos como muy prolijas en la primera intervención [de marzo de 2007]. En esa intervención de plaza Moreno había también una idea de un susurro que iba creciendo, que era decir nombres de militantes populares muertos o desaparecidos, como que eso era conmovedor, también. En la otra no, tenía un sentido de marcha, fue menos una acción estética, y fue más parte de la marcha.
}

\footnotetext{
${ }^{178}$ El medio principal que utilizó Siempre para la convocatoria de estas acciones fue a través de correos electrónicos, también realizó afiches que fueron pegados en lugares de la ciudad. En los mails se pedía que las personas concurrieran vestidas con colores particulares: negro y blanco. Para un análisis de estas acciones de Siempre ver Longoni 2010. Para una indagación de estas y otras intervenciones culturales, hasta el 2008, por la desaparición de López ver Chempes, 2008.
} 
Yo me acuerdo de eso. ponele que López aparecía medio deformado en la imagen, en azul... nos excedió, no podíamos controlar todas las pancartas." (E 15, Mariana e. y Diana)

El balance negativo de las últimas acciones -una realizada en los días previos y la otra en el acto por los dos años de la desaparición de López en 2008-, así como las discusiones internas y con otros grupos, fueron determinantes para que Siempre dejara de hacer intervenciones en las marchas por López. A su vez, comenzaron a pensar que estas movilizaciones estaban "perdiendo el sentido":

"La que hicimos que salió mal fue la del 'Silencio K', esa fue como... a los dos años de la desaparición.

Sí, dio discusiones y tampoco estuvo la propuesta estética muy clara, como que fue más confusa. Que es lo que también reflejaba un poco las confusiones que teníamos hacia adentro del colectivo. Quisimos trabajar con la idea del silencio. Entonces, en días previos habíamos empezamos a taparles la boca a las estatuas de las plazas, a poner fotos en el blog. Pero, bueno, estaba en ese momento ciudad limpia de Bruera $^{179}$. ¿Cómo era ese plan que limpiaba todo? La cuestión es que las cosas casi nadie las vio. No duraban mucho las estatuas con la boca tapada. Después, también se hizo como una acción en la plaza que no tuvo un buen cierre, no logramos darle... no funcionó. (...) La intervención era varias personas con la boca tapada, se repartía entre la gente que estaba ahí, y después supuestamente había en el final un grupo de percusión que eso falló. El final falló. Veníamos bien y se fue como diluyendo, la gente quedó con la boca tapada, nosotras también. Fue como... fue un garrón, falló. Hay fotos que funcionaron, no funcionaron las herramientas.

Un poco ahí nos empezó a hacer ruido (...) -y previamente- ya había discusiones que iban complicando un poco la fortaleza de la acción” (E 15, Mariana e. y Diana).

\footnotetext{
${ }^{179}$ La campaña "Ciudad limpia" como se indaga más adelante es parte de la gestión municipal de Julio Alak y terminó en diciembre de 2007. Aquí en verdad las integrantes de Siempre hacen referencia a otra campaña de limpieza urbana llevada adelante en ese momento por el bruerismo. Se trataba de acciones que tenían como objetivo limpiar paredes y el mobiliario urbano, y formaban parte del "plan de recuperación del espacio público". Sobre esta campaña se vuelve en el capítulo 6 .
} 


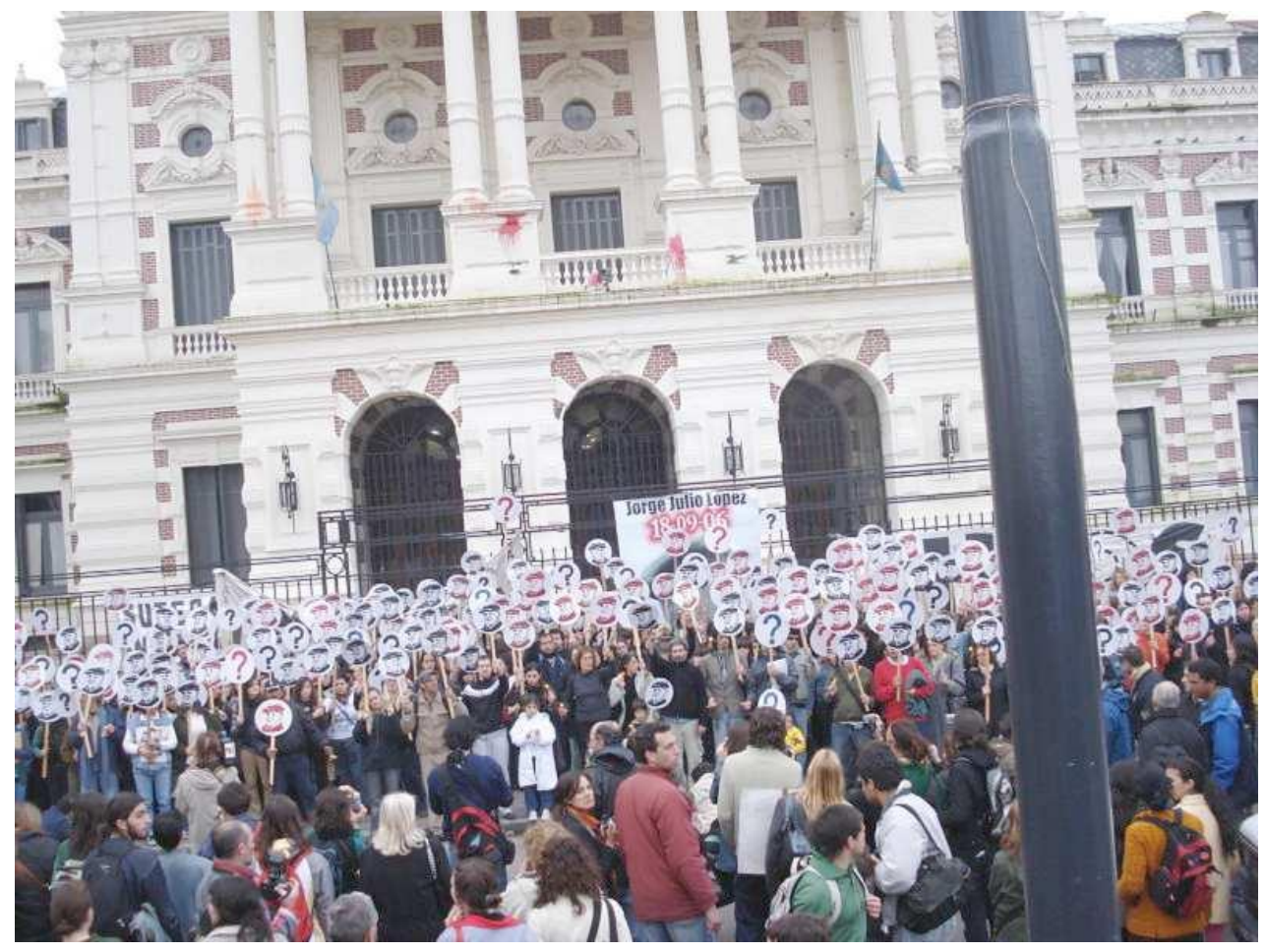

Imagen 35. Intervención propuesta por el Colectivo Siempre para la marcha por el $1^{\circ}$ año de la desaparición de Julio López coordinada junto con la Multisectorial. Lugar: Plaza San Martín frente a la gobernación provincial. Fecha: 18 de septiembre de 2007.

\section{II.c. Un espacio para la deriva}

Las Muestras Ambulantes (MA) se propusieron integrar el arte a la vida cotidiana -o por qué no, devolverle la vida cotidiana al arte-, transvasar las fronteras de lo público y lo privado -al tensionar los espacios propios con el "afuera"- y construir un espacio de visibilidad y diálogo entre artistas, productores culturales, vecinos y deambulantes por el barrio Meridiano V. Las tres últimas muestras (2006, 2007 y 2009) fueron en aumento tanto de propuestas como de personas que la recorrieron. Particularmente las últimas dos fueron eventos de una gran magnitud y masividad que sobrepasó incluso a las expectativas de los organizadores, de estas dos ediciones participó activamente el grupo de gestión cultural Medio Limón -en la última como grupo co-organizador de la muestra-. Durante los días de las muestras un barrio entero se "movia": sus calles, veredas, garages de casas particulares, comercios y espacios culturales se intervinieron con muestras, performances, obras de teatro, recitales, talleres de dibujo y tejido, recitado de literatura y espacios para la lectura. Se trató de de espacios de encuentro e itinerancia: recrear diálogos colectivos y apostar hacia el espacio público, junto a otra apuesta más: enfrentar la cultura al espectáculo (mediático y del ocio programado). 
En uno texto que funciona como una suerte de "manifiesto" de la MA 4 se plantea algunas ideas para pensar la condición "cotidiana" del arte, la situación de autoencierro que se vive en la ciudad y se lanzan algunas pistas para "apropiarse del paisaje" del barrio:

"Llevar el arte al barrio es recordarle su carácter cotidiano. El arte no es un oficio excepcional sino una práctica diaria que solemos interrumpir para ir al almacén de la esquina o a la panadería, todos aquellos lugares que suelen ser también su secreto mejor guardado, el insumo diario para ponerse a inventar. Pero el barrio no suele ser un lugar feliz. Es el lugar propicio para el chusmerío y, lo que es peor, para practicar la delación. Cuando los vecinos están asustados, apuntan sin preguntar. Los barrios se fueron enjaulando, amurallando. El temor cunde. Ya nadie juega en la vereda. Solo los más viejos sacan la silla a la vereda y comparten el mate. Todo el mundo anda apurado. Nadie vive al barrio. El barrio es un dormitorio gigante. Con la Muestra ambulante queremos irrumpir ese costado que define también al barrio. Recordarnos que estamos vivos. Que la risa todavía es posible. No hablamos de tomar el barrio sino de asediarlo. No se trata de hacer paracaidismo sino de habitarlo. Moverse desde su cotidiano contradictorio, a veces para celebrarlo, otras para despistarlo o interrogarlo, otras para lanzarle "un cross a la mandíbula", como le gustaba decir a Roberto Arlt. (...). Llamar la atención sobre los lugares comunes que desapercibimos."

Para Gabriela se trataba de una "gran construcción colectiva" (E 6). A su vez, Andrea (E 3) afirma lo mismo -"era una gran obra"- y agrega un interesante aporte sobre las lecturas que se hicieron de la MA:

"Fue una apuesta política nuestra, no solo artística. Luego, sucede que no todos lo leen así. (...) Quizás lo que no se dice ahí, que a nosotros nos interesa, es justamente ese material que no llega a ser narrativo, que quizás haya sido para muchos un no entender la Muestra Ambulante. Algunos la transitaron y no hicieron la lectura del sentido que nosotros le habíamos puesto, y me interesa pensarlo, porque muchos otros sí. Algunos pasaban como si fuera una feria de arte.” (E 3, Andrea). 


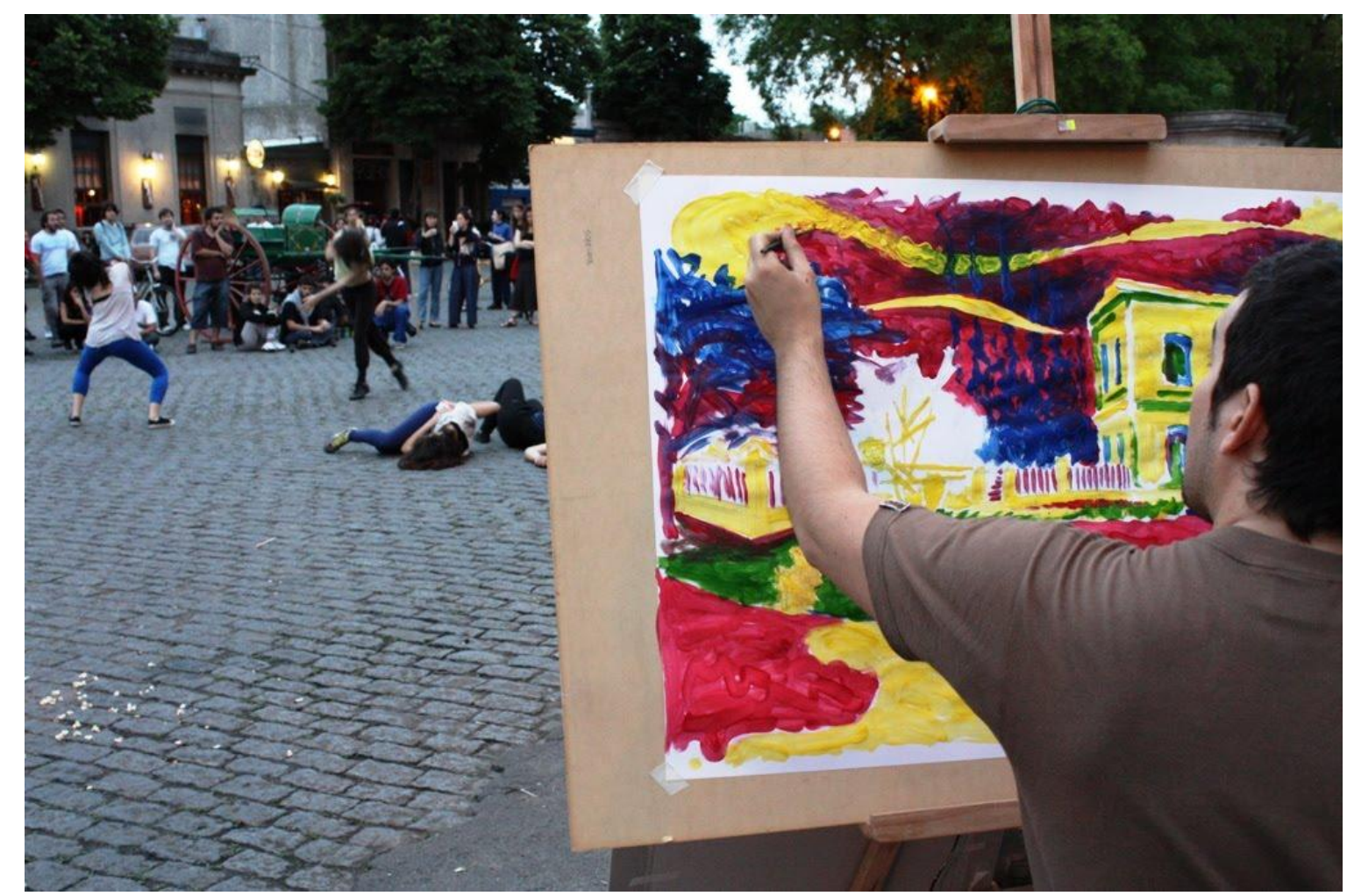

Imagen 36. Muestra Ambulante 5. Fecha: noviembre-diciembre de 2009. Lugar: barrio Meridiano V. Autor de la foto: Daniel Ayala, extraída de agencia NAN.

\section{II.d. El estallido del color, la insistencia del encuentro}

En 2010 el color magenta tomó gran parte de las paredes grises y blancas de la ciudad. Las pintadas de Luxor comenzaron a hacerse presente en diferentes muros desde inicios de ese año. El magenta con su pregnancia se destacaba en aquellas figuras y personajes creados por ese interventor. La figura que comenzó a predominar en sus pintadas fueron las "pajaritas" y el magenta el color que no faltaba. Pero también el magenta adquiere otra dimensión, desde mediados de aquel 2010 Luxor y otros interventores locales comenzaron a gestar un encuentro de grafiteros, pintores o interventores urbanos de la ciudad, la región y el país: "Intervención Magenta". Este evento, una suerte de gran convención visual donde la principal actividad fue la intervención en distintos muros de la ciudad, se convirtió en un espacio de encuentro que visibilizó a un movimiento heterogéneo de interventores visuales y referenció a Luxor como uno de los gestores-coordinadores de este tipo de movidas colectivas y al Club Alborada como espacio de nucleamiento de estas prácticas. Estas tres cuestiones se pueden interpretar, sobre todo, por lo acontecido en los años siguientes con eventos que continuaron y profundizaron algunas de las ideas propuestas por "Intervención Magenta": "Proyecto Kalle (2011), las "Pantufleta refrescante" (2011) y Encuentro "ZigZag” (2012), 
"Concreto" (2014). El 16 de octubre, durante una jornada de intervenciones, la ciudad de "lleno de color" a través de la participación de más de cien interventores visuales que pintaron, desde diferentes técnicas, sobre fondos color magenta.

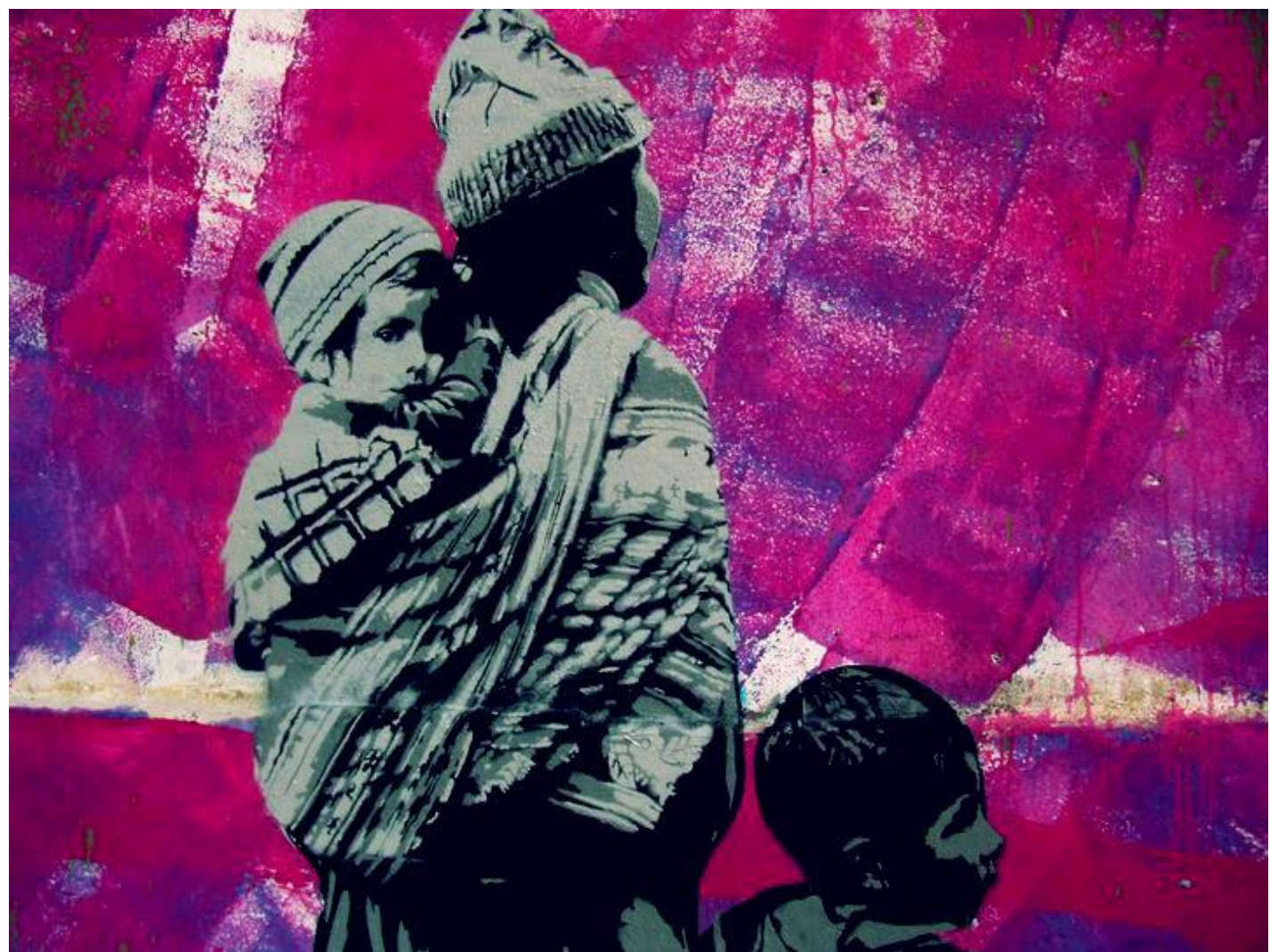

Imagen 37. Stencil de AdRian en "Intervención Magenta". Fecha: octubre de 2010. Imagen extraída de Los Towers Estudio.

\section{II.e. Figuras de una nueva esfera pública}

Algunas apuestas, proyectos y discusiones sobre una nueva configuración del espacio público "ampliado" por internet y las redes sociales se dieron de manera directa en algunas de las intervenciones culturales del período indagado. Se seleccionan aquí cuatro de ellas: “Buscar justicia” (2008), "Hace como José” (2009), "Esto no es una contravención” (dos momentos entre 2009-2010) y “Buscando a López” (tres ediciones entre 2010-2011).

"Buscar justicia" (2008) fue una acción coordinada en red entre Sienvolando y el espacio Cultural del FPDS -espacio del que derivará al poco tiempo Arte al Ataque- para exigir el castigo a los responsables de los asesinatos de los militantes piqueteros Maximiliano Kosteki y Darío Santillán en junio de 2002. La acción que se produjo a través de diferentes lenguajes fue una intervención multimedia que consistió en abrir un sitio web similar-apócrifo al portal de Google -ya en ese momento el buscador más famoso de Internet- donde se alteró 
su doodle de inicio, colocándose en sus letras "oo" del logo las caras de Darío y Maxi ${ }^{180}$. Paralelamente, se realizó de un mural en un paredón del estadio del Club Estudiantes de La Plata con la misma imagen del buscador. La acción se completó el 26 de junio -fecha del aniversario- en la Estación de trenes Avellaneda donde intervinieron el edificio, las paredes y las escaleras, con pintadas y calcos de la web referida, reemplazando en las carteleras el nombre de la estación por el de "Darío y Maxi” (Sager y López, 2009, López, 2014). La acción tenía también una suerte de manifiesto que se difundió en volantes serigrafiados y que también se plasmó en el mural. Sus palabras transmiten, con gran fuerza poética, el modo en que esta acción colectiva en red, al igual que muchos otros, definían las tareas pendientes que nos debemos como "pueblo". A su vez, colocaba en un plano de igualdad la importancia de todo tipo de reapropiaciones de los signos, el trabajo, la calle.

\footnotetext{
"Recuperar las herramientas de lucha, todas y cada una sin dejar ninguna regalada al prejuicio. Buscar la libertad desde el pueblo. Trabajar en la red de abrazos que permitan un intercambio justo. Resignificar la vida: su paisaje real y virtual, sus ejemplos y sus sentidos. Ocupar los símbolos, las fábricas y las calles: transformar la mirada. Maxi y Darío son un ejemplo de lucha, de nuevas conexiones, de poesía y práctica social. Por ellos y por quienes se atrevieron a imaginar un proyecto de vida sin explotación... con nuevos vínculos... ¡Buscar Justicia!”.
}

\footnotetext{
${ }^{180} \mathrm{El}$ sitio web -http://buscarjusticia.linefeed.org- debió ser dado de bajo por presiones judiciales de la empresa Google en Argentina que llegaron directamente a uno de los integrantes de Sienvolando por medio de correos electrónicos. En este sentido, podemos plantear -siguiendo a De Certeau (2000)- que en este hecho se expresa las tensiones entre "estrategias de producción y tácticas de los usuarios", así como las artes de hacer/ decir/ habitar en la cotidianeidad (en este caso, no sólo en la ciudad sino principalmente en la web que era el espacio que molestaba a Google) que constituyeron formas no previstas ni legitimadas -por la política, por el campo artístico, por los sectores que dominan la web-, conformando una discursividad que se "infiltró" en el espacio ocupado y dominado por otros.
} 


\title{
GR gle
}

Maxi y Dario dignidad piquetera!

\section{Cajoneo del gobierno Voy a buscar justicia!}

\begin{abstract}
Imagen 38. Acción en red "Buscar justicia!". La integró entre otras actividades la producción de un doodle de Google modificado para la web, stickers, mural e instalación que renombró la estación Avellaneda como "Darío y maxi" Fecha: junio-julio de 2008.
\end{abstract}

"Hace como José" (2009) fue una campaña que puso en cuestión el aumento del boleto de micros en la ciudad y pedía que se fijara la tarifa en $\$ 1$. Con la consigna “¡Basta de inseguridad! ¡El boleto a $\$ 1,90$ es un robo!” plasmó su demanda en afiches, mural, caravana, volanteadas, avión publicidad y encendido de velas, así como en spot radiales, blog, canciones, videos en Youtube y convocatorias vía e-mail y Facebook. Incluso con el mismísimo José -un personaje inventado para la campaña que jugó con los límites de lo real: se presentaba como un docente que vive en La Plata- interviniendo por la ciudad y realizando una conferencia de prensa. De este modo, la campaña produjo una compleja conjugación de intervención urbana con fuerte utilización de estrategias web y los recursos tecnológicos actuales. (López, 2009; Sager y López 2009). 


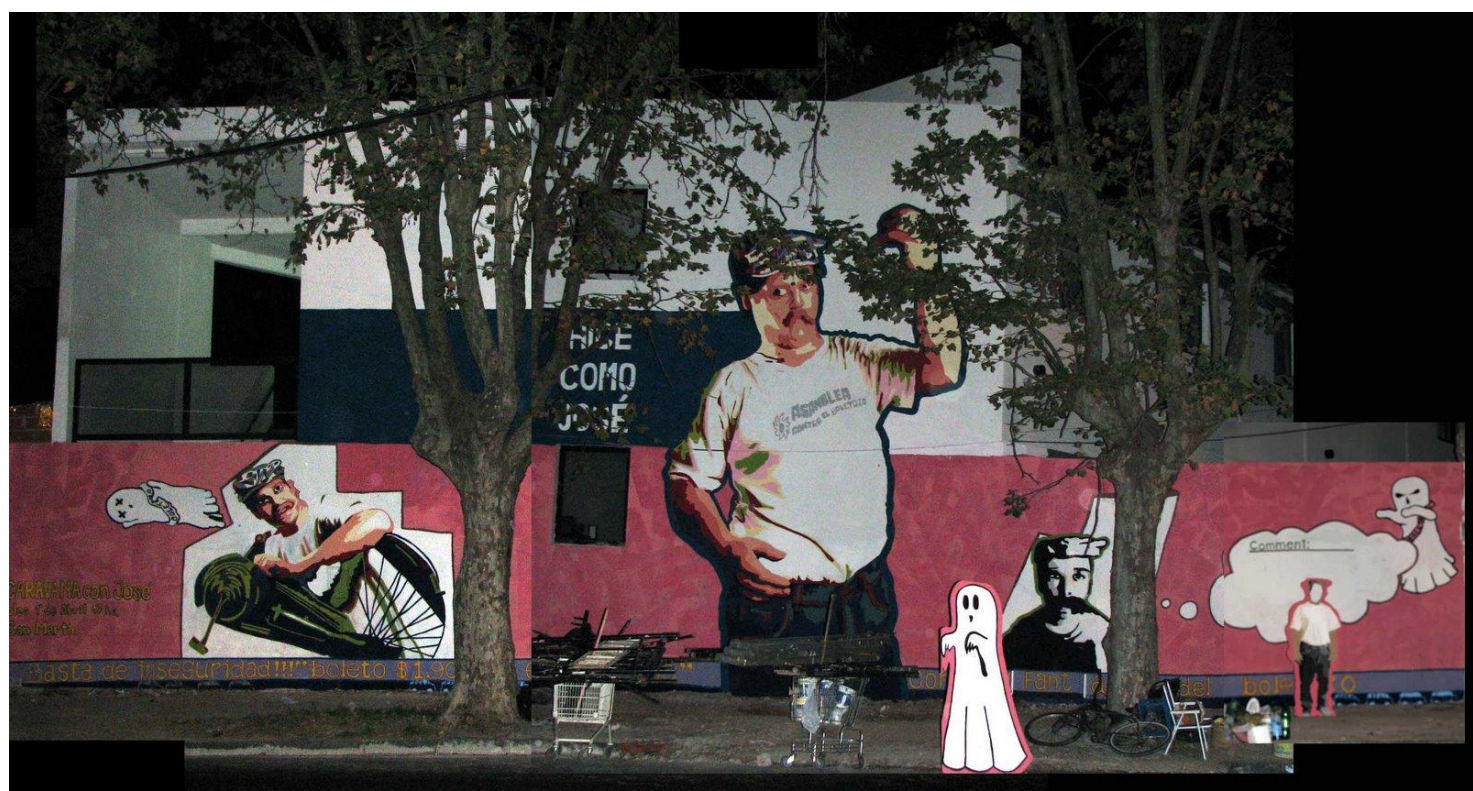

Imagen 39. Mural en el centro de la ciudad, una de las muchas acciones de la campaña "Hace como José". Fecha: febreroabril de 2009. Lugar: 9 y 62.

“Ceci n’est pas une contravención” / "Esto no es una contravención” (2009-2010). Al poco tiempo de que el gobierno provincial de Buenos Aires impulsó una reforma del "código contravencional", el colectivo Luli realizó la campaña que tuvo un primer desarrollo entre noviembre y diciembre de 2009. Se trataba de una acción web en la que se encontraba parte del articulado del nuevo código propuesto y una serie de representaciones visuales alusivas ${ }^{181}$. La discusión que se buscaba dar refería a que esas prácticas -como la venta ambulante, el graffiti, la situación de calle, el piquete y la movilización- no eran acciones de contravención que se debían prohibir o penalizar. En diciembre Luli fue invitado a participar en la Muestra "Calle tomada" -que se presentó en mayo de 2010-. Allí Luli siguió extendiendo y ampliando los sentidos de esta campaña web. Ahora, tanto fuera como dentro del museo, aquella afirmación se transformaba en pregunta: ¿Esto no es una contravención?. La acción, en sus dos superficies, era idéntica y producida desde la técnica de la tergiversación del discurso oficial: el propio Estado provincial era el enunciador. A su vez, en la web se proponía una imagen que enlazaba en $360^{\circ}$ a las dos acciones. En el museo, además, se linkeaba a la intervención “en calle” con una imagen del misma. (López, 2011, Pérez Balbi, 2012)

\footnotetext{
${ }^{181}$ Para la campaña Luli retomaba las discusiones y posicionamientos que abrieron diferentes organizaciones sociales sobre este asunto. Uno de los espacios multisectoriales que se generaron en torno a esta cuestión fue la "Asamblea contra el Código de Scioli".
} 


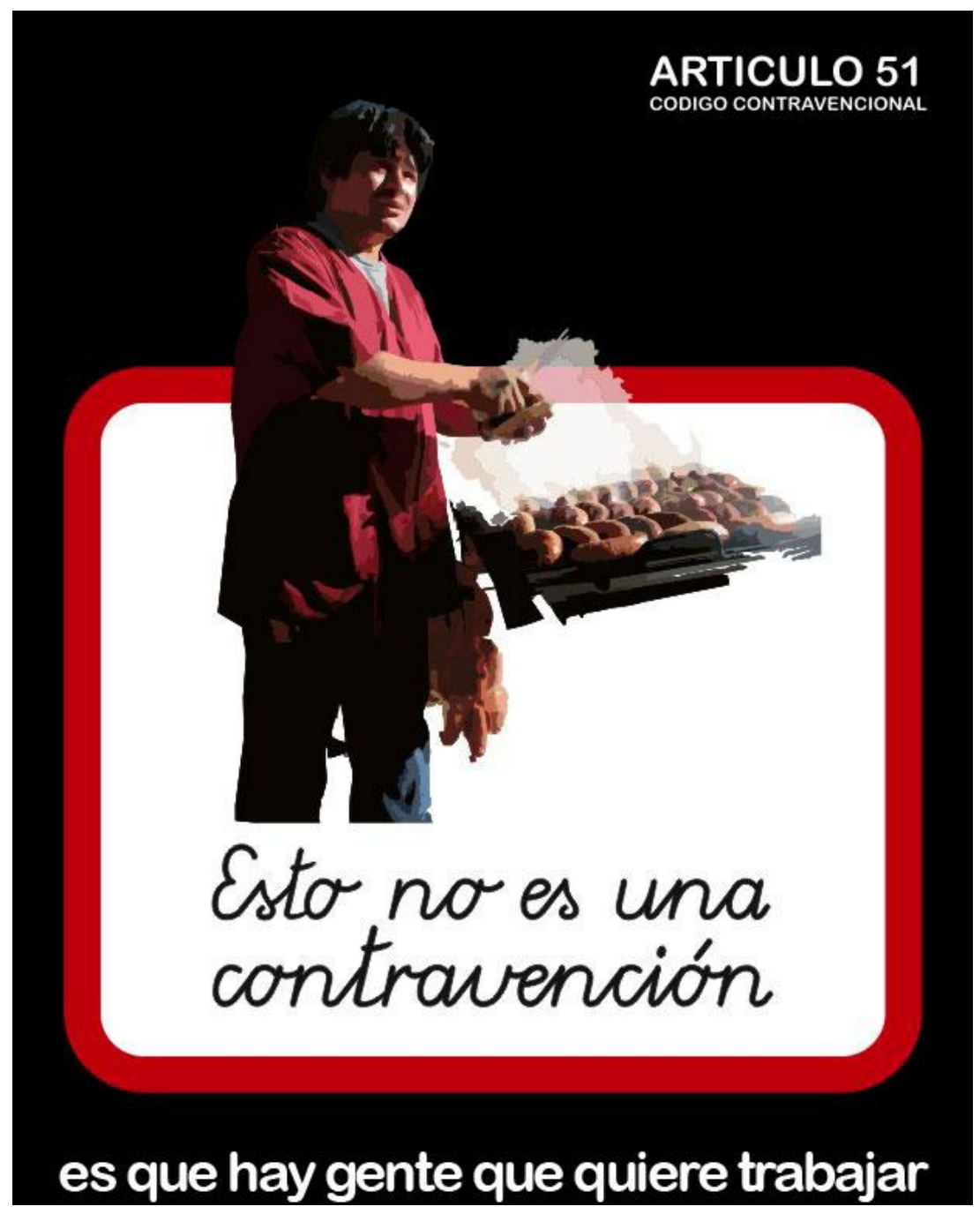

Imagen 40. Una de las placas de la campaña "Esto no es una contravención" realizada por Luli. Año: 2009. Imagen extraída del blog del colectivo.

"Buscando a López" fue una acción web que se desplegó en tres ediciones entre los años 2010 y 2011 realizada por Luli ${ }^{182}$. La versión 1.0 se presentó al cumplirse cuatro años de la desaparición de Jorge Julio López, testigo en el juicio a represor Miguel O. Etchecolatz. En otro cruce entre la web y el espacio urbano Luli propuso un juego virtual online y la promoción del mismo con un banner pintado sobre un mural realizado por el colectivo el año anterior ("Mucha tropa riendo en la calle"). En la página web de la aplicación, un recurso de Facebook donde se diseñó el juego, Luli se pregunta: “¿Se puede buscar justicia a través del juego y del color?". La acción se completaba en la participación de los usuarios de dicha red social, que al ingresar al enlace se re-diseccionaba y publicaba en los distintos "muros", lo que produjo que se replique en gran cantidad por la red. Las dos últimas versiones se

\footnotetext{
182 Link de la aplicación: http://apps.facebook.com/buscandoalopez/ y prezi que muestra cómo jugar: https://prezi.com/--nntheaz gk/como-jugar-a-buscando-a-lopez/ En 2016 al cumplirse 10 años de la segunda desaparición de López apareció una cuarta edición del juego, hasta diciembre de ese año estuvo disponible la nueva versión y se restablecieron las tres anteriores.
} 
presentaron entre septiembre y octubre de 2011 y ampliaba algunas referencias sobre la vida de López y sobre la causa judicial de su segunda desaparición. En ese cruce entre la web y la calle Luli producía uno de sus objetivos principales: "la construcción de la realidad”.

"Lo que te vamos a mostrar en la calle, en realidad, es para que vuelvas o vayas a la web a mirar esto, que tampoco aclaraba mucho lo que era, que se llamaba buscando a López. Ese es un cambio bien sustancial. (...) La interpelación para el activismo era clarísima." (E 19, Ernesto)

En referencia a los usos posibles de los recursos digitales y virtuales, en un contexto de reflujo de las experiencias políticas autónomas y también del reclamo de justicia por la desaparición de López, “la ética de 'Buscando a López' parece presentarse dentro de esa tensión, negando un carácter político inmanente de las herramientas digitales y proponiendo la necesidad de estudiar el dispositivo y desplegar otros usos.” (López, Badenes y Saurio, 2014: 14). Asimismo, en relación a algunas discusiones que generó la acción, que referían a una "banalización” de la lucha por los Derechos Humanos, Luli realizó una reflexión que hizo pública en su web. En ella buscó poner en tensión las formas en las que se construyen las figuras que se reivindican o enaltecen:

“Ahora, si la acción parece una DESACRALIZACIÓN, valga el término, de la figura de Julio, en ese caso es cierto. Nosotras estamos en contra de la "procerización", de poner a las personas como héroes inalcanzables completamente diferentes al resto"

Ante esta situación de encrucijada el grupo no buscó el repliegue, por el contrario la tensión se continuó manifestando en la participación activa de Luli en las movilizaciones por López, desplegando y ampliando el juego online, al menos hasta septiembre de 2011:

"Lo que intentamos, a contramano de nuestro propio mandato militante, es: a una imagen repetida mil veces (y que pensamos seguir repitiendo), a un nombre que a veces es reducido a una consigna (aunque pensamos seguir diciéndola) intentar sumarle información concreta de la causa."

\footnotetext{
${ }^{183}$ Estos dos fragmentos citados se encuentran en: "LULI'Kids: ¿es esto una banalización? - Buscando a Julio López", 20 septiembre de 2010. Disponible en: https://lulitieneblog.wordpress.com/2010/09/20/lulikids$\% \mathrm{C} 2 \% \mathrm{BFes}$-esto-una-banalizacion-buscando-a-julio-lopez/
} 
En las entrevistas realizadas para este trabajo se propuso pensar sobre estos años de intervenciones, donde la web fue un recurso muy utilizado. Al respecto, Dani -que integró Sienvolando y Luli- comentó: "la web fue haciéndose cada vez más próxima a todos." Así, ante la pregunta por qué tipo de discusiones tenían en Luli respecto de los recursos y usos de la web, puntualizó: "no recuerdo si había un tópico que manejáramos así fuerte. Me parece que iban siendo más pequeñas cosas que se iban barajando en cada momento" (E 22, Dani). Pili y Ernesto, en cambio, sí reconocen algunos debates e intencionalidades -principalmente en Luli y con algunas exploraciones previas en Sienvolando- al momento de llevar adelante estas acciones que cruzaban la web y el espacio urbano. Algo que se puede deducir, por ejemplo, de la discusión sobre la acción "Buscando a López". Algunos artículos que comentaron sobre esta acción: López, 2011; Pérez Balbi, 2012a, 2012b, Capasso, 2012; López, 2014; López, Badenes y Saurio, 2014.

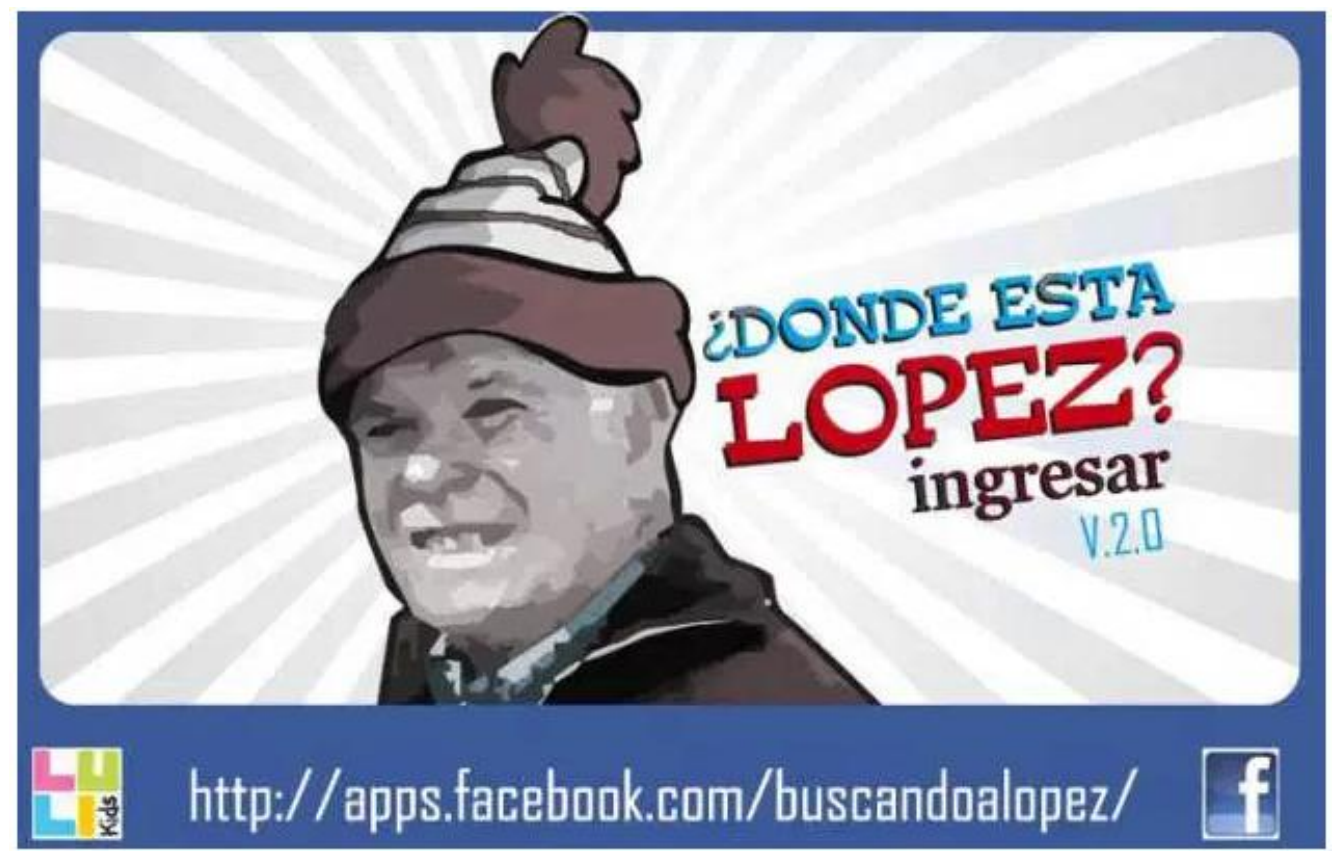

Imagen 41. "Buscando a López Vol. 2", juego-aplicación en Facebook del colectivo Luli. Año: septiembre de 2011.

De conjunto, se considera que estas y otras acciones llevadas adelante en este momento (2008-2011) marcaron y potenciaron la posibilidad de comprender a lo público más allá de algunos ámbitos más o menos delimitables de la ciudad y para pasar a comprender que el espacio público se configura de manera ampliada e interconectada con otras superficies, como la web y las redes sociales, en las que es importante intervenir desde la producción cultural. De este modo, podemos pensar que la web no sólo funciona como soporte para que la acción siga aconteciendo -o acontezca sólo ahí-, sino como un espacio de encuentro 
(virtual) que se vincula y potencia la acción (en el espacio urbano), es decir, una acción que se reterritorializa y que interviene en lo real articulando ambos espacios. Además la web y las redes virtuales también son un espacio afectivo de intercambio entre pares diferentes, conocidos de larga data o de vínculos circunstanciales que movilizan e interpelan a las intervenciones. Asimismo, se puede encontrar en estas acciones (y principalmente en las emprendidas por Luli) una interrogación y exploración permanente por los dispositivos -que enuncian, construyen realidad, se afectan-, sin una visión de exterioridad, sino todo lo contrario se trata de dispositivos en los que se participa.

\section{Reflexiones sobre las experiencias}

En este último apartado se continua la interpretación y comprensión de las diferentes propuestas llevadas adelantes por las experiencias de intervención culturales seleccionadas y que ya fueron presentándose a los largo de los capítulos 3 y 4 . Se propone aquí focalizar en tres aspectos importantes: los modos de producir la ciudad, las maneras en las que trabajan con lo político y la temporalidad de los cambios y reflujos en las experiencias. A su vez, estas cuestiones serán profundizadas en el próximo capítulo.

\section{III. a. Producir lo urbano}

En la mayoría de las experiencias de intervención cultural indagadas, las formas de pensar y habitar el espacio y la ciudad se encuentran como elementos destacados. En ellas el espacio y la ciudad se configuran como un "lugar practicado", allí la experiencia urbana se densifica desde los encuentros, las relaciones y los conflictos. A su modo y con sus herramientas, estas prácticas culturales se proponen ir más allá de de la dinámica hegemónica de la modernidad urbana, aquella que regula sitios y propone circulaciones/conexiones pero no construye lugares para ser habitados ni provoca encuentros entre los habitantes de la ciudad $^{184}$. En algunos casos se puede reconocer un énfasis en la apropiación del espacio

\footnotetext{
${ }^{184}$ Se reconoce aquí que tanto el espacio como el tiempo son productos sociales ligados tanto a la reproducción como a la producción de la vida social. A su vez, ambos se vinculan fuertemente entre sí. Entenderlos como dimensiones y elementos "socialmente construidos" no implica adherir a un determinismo -espacial o temporaly cobra relevancia para comprender las dinámicas sociales. En tal sentido, si se postula que estas prácticas culturales buscar construir otro tipo de espacio público y habitar la ciudad de otro modo, también es preciso entender que buscar construir "otra temporalidad", es decir saliera de los relatos y los tiempos hegemónicos sobre el presente. Ante una pregunta realizada por los coordinadores de la muestra "Calle Tomada", sobre qué los motiva a realizar intervenciones en el espacio público, Luli respondía: "La urgencia. Los forcejeos con el tiempo, una lucha en el tiempo. En esta avalancha de información, noticias, eventos, donde todo pierde la
} 
urbano desde una mayor conceptualización e indagación de sus formas, recursos y potencialidades (en La Grieta y Luli, y en parte también en Sienvolando y Luxor); en otros casos sobresale principalmente la idea de comprenderlo como el lugar-objeto de despliegue de las acciones colectivas, como un territorio donde las intervenciones pueden acontecer (podemos ubicar aquí a UMHT, Siempre y Arte al Ataque).

En la experiencia de La Grieta la ciudad se configura desde una geografía inquieta, movediza en la que se provocan encuentros con otros y se ponen en contrapunto -de diálogo y tensión- diferentes prácticas creativas: la literatura y el ensayo político, las artes visuales y la música, Esa forma itinerante de recorrer y habitar la ciudad también se ha anclado en una dimensión "barrial" -principalmente con la construcción del Galpón de Encomiendas y Equipajes- y el desarrollo de la mayoría de sus actividades en el barrio Meridiano V.

En Sienvolando se gestó una experiencia urbana con un ritmo acelerado y una presencia cotidiana en la ciudad. Pero se trataba de una presencia en la que, en gran medida, se diluía la visibilidad como grupo y ganaba peso tanto la situación colectiva de intervención y encuentro con otros -más allá del mural- como la construcción de relaciones que implicaba generar acuerdos y acciones colaborativas. En este aspecto de la presencia cotidiana y la no referencialidad propia también se puede encontrar un sentido bastante similar en las experiencias del colectivo Siempre y de la Muralista Hermanos Tello, aunque en este último caso se articulaba con una referencialidad más fuerte de lo político-ideológico bajado a consignas y definiciones ligadas el mundo libertario y a las luchas populares de la coyuntura.

En Luxor, su experiencia urbana también se construye desde una fuerte presencia cotidiana en la ciudad -"estar todo el tiempo en todos lados"-, con un dispositivo privilegiado: la "pintada callejera" en las paredes y los muros. Si bien esa continua e insistente presencia en la ciudad "tracciona" para una experiencia colectiva -ligada a la producción visual urbana en pequeños o grandes eventos y reuniones de interventores-, también jalona en la construcción de una figura y una trayectoria individual como productor visual.

conexión con su significado. En Luli vivimos en medio de esa marea y somos llevados de acá para allá, no somos inmunes. Muchas de las intervenciones, tratan de hacer un paréntesis en la indiferencia de los hechos y crear acontecimientos que puedan proponer otra temporalidad. Una mano fuera de la avalancha en que estamos. Cuando hacemos una acción, que puede ser un sitio web, un mural, un mail, un stencil, una calcomanía o simplemente una reunión nos motiva recuperar la especificidad y complejidad de esa situación, de transformarla, permitirnos opinar y no solo verla pasar delante, como algo inexorablemente empaquetado. Muchas veces nuestras opiniones son erradas, muchas veces ni lo sabemos. Pero nos parece fundamental trastocar la indiferencia propia del ritmo en que vivimos, y poblarla de intervenciones que intenten generar otros presentes, por más mínimos que resulten. Creo que eso es parte de lo que nos motiva. La urgencia." Disponible en: https://lulitieneblog.wordpress.com/2010/03/10/pregunta-de-calletomada-a-los-grupos-que-participaron-de-laexperiencia/ 
En Arte al Ataque una gran cantidad de las intervenciones que despliega en la ciudad también se constituyen desde la búsqueda de una referencialidad particular y una explicitación del lugar de enunciación, pero en este caso se trata de una identidad colectiva como grupo cultural y como organización social y política nacional-.

En el caso de Luli no hay un espacio único ni prioritario, ni a priori más importante que otro -la ciudad, el barrio, la calle, la web, el museo-. Aunque la discusión sobre el espacio es fundamental en este colectivo, se ajusta a lo que demandan de las acciones. Todos los espacios son potenciales territorios de intervención para desplegar dispositivos, "construir realidad" e "intervenir en la esfera pública". Allí la ciudad es reconocida como un ámbito habitado por múltiples dispositivos -los muros, las gigantografías, los banners, los recorridos, los eventos, las movilizaciones- desde los que se puede operar en aquella construcción de realidad.

\section{III.b. Las formas de lo político}

También la heterogeneidad se presenta en los modos en que lo político se configura en las experiencias de intervención cultural: un contenido, una temática, una modulación. Para algunas de estas prácticas es fundamental la utilización de recursos culturales y estéticos desde la explicitación de una posición política sobre la realidad. Se trata de una explicitación marcada por enunciados que delimitan un posicionamiento y por unas temáticas que se consideran políticas -la lucha por los derechos humanos, los recursos naturales, contra la precarización laboral, la defensa de la educación pública- esto se encuentra principalmente en UMHT y Arte al Ataque, y de algún modo también en Sienvolando, Luxor y Siempre aunque de un modo más "débil"185, con una retórica más metafórica y menos explicitadora de unos contenidos y posiciones. En otros casos, como en La Grieta y en Luli y en parte en Siempre, se configura desde otras situaciones, quizá más sutiles: lo político antes que una temática y una retórica es una modalidad, una interrogación por el cómo de la acción. En la experiencia de la MA impulsada por La Grieta lo político se encuentra en la intencionalidad de cruzar sujetos diferentes -artistas, vecinos y ambulantes, viejos, niños y jóvenes- y de tensionar el espacio privado y el espacio público -abrir garages, sacar parte de las casas particulares afuera, introducir producciones artísticas en la cotidianeidad de un barrio, brindarle vida cotidiana a la práctica artística-. En Luli lo político es un juego lleno de tensiones, se corre todo el tiempo de lugar y busca decididamente apartarse de las "retóricas militantes". Así, por

\footnotetext{
${ }^{185}$ La idea de "lo débil", la "debilidad" y del "pensamiento débil" es tomada de Sienvolando (ver E 7, Ernesto).
} 
ejemplo, se introduce en el mundo de la infancia y la niñez para construir su operación en lo real -la acciones emprendidas desde Luli Kids como "Coloreá tu ciudad" o "Buscando a López"- y en la interrogación y experimentación de los dispositivos de comunicación. El caso de Siempre es interesante porque atraviesa ambas modalidades: se explicita una temática fuerte -la luchas por los derechos humanos, los reclamos de justicia en el presente-, que es preponderante en casi todas sus acciones, pero se trabaja desde una modulación corporal, que plantea un hacer visible y decible diferente al de la enunciación verbalizada o escritural. En la experiencia de Luxor también se presentan tensiones, algunas veces se explicitan temáticas -la disidencia sexual, la vida en los barrios, el autocultivo- y cierto "contenido" general -pintar "relaciones de un mundo nuevo"- pero lo que muchas veces termina primando son sus figuras, formas y personajes que despliega en una pared o un lienzo, es decir, se presente un eje fuerte puesto en la producción visual -sus técnicas, sus modos de expresión, su composición visual-.

\section{III.c. Tiempo de cambios}

Cuando se eligió la temporalidad que va de 2006 al 2011 se hizo referencia a un momento de emergencia, alza y cierto repliegue de las experiencias de intervención cultural en la ciudad de La Plata. No se trata de entender aquí que en 2011 hubo un corte abrupto de las acciones. De hecho, como se documentó y describió unos apartados antes, se produjeron varias intervenciones culturales entre 2012 y 2015 (de carácter más temporario, y vinculadas a ciertas temáticas específicas). A su vez, no se encuentra por esos años la creación de colectivos nuevos y “más estables” de intervención.

Entonces, podemos entender que en ese momento -en el transcurso que va de finales de 2010 a finales de 2011- se comenzó a cerrar cierto ciclo de acciones y de grupos. Se puede plantear que el 2011 se convirtió en una suerte de año bisagra para gran parte estas experiencias culturales. Tanto Luli como Siempre y la Muralista Hermanos Tello se desactivaron. ${ }^{186}$ En algunos casos, sus integrantes emprendieron diversos proyectos que comenzaron a hacer andar unos años antes, en ese mismo año o en el siguiente (Proyecto Bruto, Aula 20, Síntoma curadores) o se sumaron a proyectos existentes (por ejemplo, una cuerda de tambores). En otros casos, hubo integrantes que -al menos inmediatamente- no

\footnotetext{
${ }^{186}$ Dice Ernesto de Luli con palabras críticas: "Hasta el momento que componemos el último post de Luli, nos quedamos prácticamente sin red. Se desarma el colectivo Siempre, Arte el ataque pierde casi toda su iniciativa, se desarman los muralistas Hermanos Tello, se desarma la Olla en Plaza San Martín, se desarman estos, se desarman otros, y te quedaste así. Si ni siquiera estás interpelando: cerremos, volemos esto, busquemos otra forma, porque ya ni siquiera haciendo lo más pulido y brillante que puedas hacer, va a tener mucha ida y vuelta..." (E 19, Ernesto).
} 
volvieron a retomar colectivos de intervención o prácticas culturales relacionadas y se concentran en proyectos individuales o emprendimientos productivos como forma de sustento económico (dictado de talleres, gestión de espacios de arte, impulso de proyectos productivos de estampados y diseño de ropa, encuadernación y diseño de cuadernos, por mencionar algunos ejemplos) ${ }^{187}$. Por su parte, para La Grieta fueron momentos de ciertos replanteos sobre el proyecto, los objetivos y el cotidiano en relación al sostenimiento del Galpón de "Encomiendas y Equipajes". En esta situación -que en La Grieta no se puede circunscribir solamente al año 2011- varios integrantes se retiran del día a día del proyecto y también se comienza a pensar en otras dinámicas y actividades para que se desarrollan en el galpón. Se toma la decisión de ir alejándose de los formatos de fiesta o actividad nocturna y potenciar aún más el desarrollo de los talleres que se realizan durante toda la semana y otros espacios formativos-creativos puntuales (seminarios, talleres de pocos encuentros); con el dictado de estos talleres varias de las integrantes de la Grieta encuentran una fuente de ingresos, que en algunos casos se convierte en el principal. Además, desde un tiempo antes -quizá desde el final de la última muestra- ya se había abandonado la idea de continuar con la experiencia de la Muestra Ambulante, lo cual puede haber contribuido a bajar la visibilidad del grupo en el barrio o al menos en las dinámicas del "circuito cultural" Meridiano V (volcado fuertemente a la programación del fin de semana y a los eventos nocturnos). Por contraste, Luxor y Arte al Ataque continuaron activos en ese 2011 y en los siguientes años, produciendo varias intervenciones en la ciudad. El primero acumulando gran cantidad de pintadas callejeras que le permitieron sostener y aumentar su visibilidad en La Plata y ampliar su intervención a otras ciudades y países. A la vez, Luxor también apostó a varias iniciativas colectivas junto con otros interventores y gestores locales -"Proyecto Kalle" (2011), "Pantufleta refrescante" (2011), “ZigZag" (2012), "Volver a habitar" (2013-2014), "Concreto" (2014)-. Al mismo tiempo, constituyó a la pintada callejera y a la venta de obra como (su) forma vida y sustento económico individual (varias muestras anuales con venta de obra, cobro por pintadas en casas particulares, pintadas en locales comerciales): a fuerza de creatividad, insistencia y riego fue construyendo su propio emprendimiento artístico-productivo ${ }^{188}$. Por su parte, en Arte al Ataque también algunos integrantes dejan el colectivo entre el 2011 y 2012 y en ese período concentra sus acciones en movidas, jornadas y eventos propios de la COMPA, el Frente Popular "Darío Santillán” y del centro social "Olga Vázquez". Aunque nunca deja de

\footnotetext{
${ }^{187}$ Por ejemplo, una integrante de Siempre comentó en el posteo de Facebook con el que el colectivo se despidió "de la clandestinidad salimos, para cada una emprender su kamino".

${ }^{188}$ Como parte de esa apuesta personal, a inicios de 2013 Luxor renunció a su empleo como trabajador nodocente en la UNLP.
} 
intervenir en el espacio urbano (principalmente en fechas clave: en febrero por el femicidio de Sandra Ayala Gamboa, 8 de marzo, 24 de marzo, 26 de junio, 22 de noviembre), hay cierto repliegue así el interior ${ }^{189}$. Quizá se puede entender que al ser parte de un agrupamiento colectivo mayor, esto sirvió a que la experiencia de Arte al Ataque se sostenga. Es así que queda como uno de los pocos grupos estables de intervención "visual", "callejera" y "política" en la ciudad, al menos si tenemos en cuenta a esa "camada" de experiencias como Sienvolando (desactivado en 2009), La Muralista Hermanos Tello, Siempre, Luli, Del último cajón. Arde Minga, CuerpoPuerco, Figurones y La Olla que, entre 2011 y 2013, dan por finalizada sus acciones.

En un sentido más global de lo que sucedía en la ciudad, se puede interpretar que la desactivación o reflujo de acciones colectivas también se produjo en otros grupos y experiencias colectivas que van perdiendo fuerza y visibilidad pública, por ejemplo, HIJOS La Plata, la Asamblea por los Derechos de la Niñez, Indymedia La Plata, la FLIA, la colectiva feminista Las Furiosas ${ }^{190}$. Algunos de estos grupos finalmente se disuelven o desactivarán por completo en los próximos años. Este reflujo de actividades y visualizaciones en el espacio urbano también se produjo con instancias de coordinación como la Multisectorial (La PlataBerisso-Ensenada), la Asamblea Justicia por Sandra o la Mesa de Escrache Popular, la baja intensidad que cobran los reclamos de justicia por la desaparición de Julio López es el hecho más sintomático -pero no el único- de esta situación ${ }^{191}$.

\footnotetext{
${ }^{189}$ Este repliegue tiene relación con el proceso de fuertes debates que entre 2011 y 2012 se dieron al interior del FPDS sobre la tareas que este espacio debía realizar en la etapa política, proceso que se desencadenó -en enero de 2013- con la ruptura de esta organización y la conformación de dos bloques: el FPDS y el FPDS Corriente Nacional (agrupamiento que integró Arte al Ataque). Este último espacio aclaraba que la ruptura se había dado por "diferencias sobre la disputa de la estatalidad mediante los mecanismos electorales" (comunicado del 13/01/2013). En las elecciones legislativas de 2013 el FPDS-CN se presentó a la contienda electoral: en la ciudad de la Plata, con el frente "Ciudad Nueva" junto con la Unión del Pueblo (Juventud Guevarista). Pero al poco tiempo se dió una nueva serie de discusiones con la conformación, a mediados de 2014, del "movimiento popular" Patria Grande -integrado por una fracción del FPDS-CN, Marea Popular, el Movimiento 15 de enero de Mar del Plata, Sudestada y Cutral Co de Córdoba, la Corriente Unidad Sur de la provincia de Buenos Aires, Podemos y Chico Mendes de la Ciudad de Buenos Aires y El Barro de San Juan- espacio que finalmente se presentó en las elecciones legislativas de 2015 en varios distritos y provincias. Esos debates llevaron a la ruptura del FPDS-CN y al alejamiento del sector que impulsó "Patria Grande", dos de las principales diferencias fueron -nuevamente- en relación cómo constituir una estrategia electoral y la caracterización política del gobierno kirchnerista.

${ }^{190}$ Cabe aclarar que si bien hay cierta desactivación de algunos grupos feministas o de género por esos años (Las Furiosas, Mariposas Mirabal, Comisión de género de periodismo, revista Baruyera), algunos continuaron (Malas como las arañas) y se crearon otros (Varones antipatriarcales). Asimismo los debates y las movilizaciones sobre los géneros, las identidades de género y las sexualidades disidentes fueron ganando mayor terreno en las organizaciones (sociales, políticas y sindicales), en los debates públicos y en las visualizaciones el espacio urbano de La Plata, a los que todos los colectivos mencionados con su presencia y activación previa o simultánea fueron destacados impulsores. Algunas de las acciones que continuaron en esos años: "Arte Closet", convocatorias locales a la marcha del orgullo, "Primavera lésbica", "Día de las mujeres", entre otras.

${ }^{191}$ Incluso, si se lleva esta situación a los de todos los grupos de intervención mencionados, se puede encontrar que únicamente Arte al Ataque produjo una acción en la movilización del 16 de septiembre de 2012.
} 


\title{
Capítulo 5
}

\section{“Mover todo de lugar”. Conceptos, saberes y prácticas de las experiencias}

\author{
"Para mí era como algo re nuevo. Salir de pintar en mi casa, o en la \\ facultad o de un taller. Salir a la calle me parecía emocionante. Algo \\ que estaba bueno, porque te juntabas con amigos. Caía mucha gente a \\ pasar ese momento con nosotros. Era toda una tarde de estar ahí \\ haciendo lo que me gustaba, y a la vez poniendo una opinión sobre \\ algo que me interesaba en el espacio público." \\ Entrevista a Pili de Sienvolando. \\ "Creo que esa mirada de muralista, de artista, viene cuando te \\ preguntan quién sos vos. Ahí recién viene la pregunta. En el momento \\ que vos estás haciendo la acción, lo estás haciendo como una acción \\ concreta. Una acción política de lucha." \\ Entrevista a Carlos de UMHT. \\ "Lo que buscamos es mover todas las cosas de lugar." \\ Entrevista a Gabriela de La Grieta. \\ "Una ciudad trashumante, o metafórica, se insinúa así en el texto vivo \\ de la ciudad planificada y legible." \\ Michel De Certeau, La invención de lo cotidiano, 1980.
}

\section{Las entrevistas: materiales para una trama}

En este capítulo se trabaja en la descripción densa e interpretativa de las voces de los testimoniantes: los/as interventores e integrantes de los colectivos de intervención cultural que fueron seleccionados. El objetivo de esta operación analítica es poder dar cuenta del modo en que los sujetos rememoran, re-piensan y re-procesan la experiencia de esas intervenciones, en el período en el que hace foco la tesis $(2006-2011)^{192}$. Esto, a su vez, pone en valor la importancia de revisar históricamente una experiencia del pasado: volver a la clave situada en la que esas experiencias se constituyeron y tuvieron lugar y, al mismo tiempo, actualizarla con los sentidos del presente -de la entrevista-.

\footnotetext{
${ }^{192}$ La idea rectora desde la que se parte es la capacidad de reflexión -abstracción, de construcción interrogantes y de nociones- que portan los propios actores de las prácticas indagadas. Se trata entonces de comprender que dichas actores y prácticas construyen saberes, ponen en circulación conceptos, abren debates, se pelean y discuten con otras nociones y prácticas.
} 
Para construir un modo de "leer" los testimonios y sentidos sobre la experiencia que están presentes en estos, algunos aportes de Raymond Williams (2000, 2009) colaboran con el entendimiento que la memoria no puede ser pensada como un registro transparente de lo ocurrido sino que se actualiza en el re-procesamiento y la puesta nuevamente en discurso de ese pasado, es parte así de un "proceso vivo"193. Por su parte, para E. P. Thompson (2012) la experiencia funciona como mediación entre el "ser social" y la "conciencia social", planteo que le otorga a dicho concepto un papel explicativo ${ }^{194}$; a su vez, y abre la distinción entre dos niveles: "experiencia vivida" y "experiencia percibida"195.

Plantear estas cuestiones en torno a las implicancias de los testimonios y las experiencias de los actores, no es ni un gesto de "demagogia académica" ni equivale a dejar liberado -o en estado de vacancia- el propio rol como investigador y productor de esta investigación doctoral. Aquí las prácticas no hablan por sí solas: los interrogantes y los ejes propuestos, las propias posturas e imposturas, así como los modos de mirar la densidad de lo social tamizan la investigación y la construcción de este capítulo. Entonces a partir de las voces de los sujetos que presentan, describen y re-piensan sus prácticas, se propone un descentramiento de la mirada del analista, para escuchar y comprender las voces protagónicas de los actores y sus sentidos construidos sobre su experiencia. A su vez, esto abre un espacio donde se tensa la experiencia pasada y la re-elaboración al momento de la conversación.

Las entrevistas en profundidad fueron parte importante de los materiales construidos en el trabajo de campo de la investigación para la indagación de las intervenciones culturales y son los materiales con los que se trabajan en este capítulo. Como se precisó en el apartado metodológico, fueron producidas teniendo presente un protocolo -principalmente para ordenar ejes y problemas-, pero de manera seminestructurada, es decir, dejando abierta la posibilidad de derivas en las conversaciones llevadas adelante con los actores involucrados en las prácticas. Como ya planteamos en el capítulo 2 sobre la perspectiva metodológica, en las

\footnotetext{
${ }^{193} \mathrm{Al}$ concluir la entrada sobre "experiencia" Williams plantea una tensión conceptual que ha estado presente tanto en las tradiciones filosóficas como en las ciencias sociales: "En un extremo, la experiencia (presente) se opone como fundamento (inmediato y auténtico) para todo razonamiento y análisis (subsiguientes). En el otro, la experiencia [...] se ve como el producto de condiciones sociales, sistemas de creencia o sistemas fundamentales de percepción y, por lo tanto, no como material de las verdades sino como evidencia de condiciones o sistemas que por definición ella no puede explicar por sí misma" (Williams, 2000: 140).

${ }^{194}$ Martin Jay (2009) sintetiza algunas de las controversias suscitadas el campo inglés de las izquierdas durante los años 70 a raíz de este concepto.

${ }^{195}$ Se puede entender que la experiencia vivida son aquellos conocimientos históricos y sociales que los sujetos y colectivos elaboran en el transcurso de su vida cotidiana, orientado por las cosmovisiones aprendidas en los contextos locales y desde las vivencias e interacciones que se construyen con otros sujetos. Mientras que la experiencia percibida es aquella proveniente del plano consciente: de los discursos elaborados y conocimientos formalizados que es incorporada por sujetos y grupos a través de los diferentes medios de comunicación y difusión cultural.
} 
ciencias sociales la entrevista es un tipo particular de conversación. "Refiere a una forma especial de encuentro: una conservación a la que se recurre con el fín de recolectar determinado tipo de informaciones en el marco de una investigación” (Marradi, Piovani y Archenti 2007: 215).

Sin embargo, también se planteó que en esta investigación se tomó a los entrevistados/as como "interlocutores"; esto es, entenderlos en tanto que sujetos que pueden aportar una mirada compleja sobre los procesos que fueron/son parte. En tal sentido, pueden afectar positivamente el curso de una investigación al abrir nuevas preguntas que no estaban presentes en el "formulario" de un proyecto, e "iluminar" ciertas zonas no exploradas hasta ese momento por el analista.

En los siguientes apartados se analizan 22 entrevistas en profundidad semiestructuradas. Los/as entrevistados/as son: integrantes La Grieta, integrantes del Sienvolando, y del colectivo Siempre, un integrante de la Unidad Muralista Hermanos Tello, los actuales integrantes de Arte al Ataque y el interventor Luxor. Las principales dimensiones para analizar las entrevistas fueron:

1) constitución de la práctica (cómo es o era, modos de participación y acción)

2) el espacio de lo público (definiciones, apropiaciones, formas y modos de estar y de habitar, usos, tensiones: espacio urbano, ciudad, espacio público, esfera pública)

3) articulaciones y acción colectiva (el cómo de la práctica, formas de participación e involucramiento, vínculos con otras prácticas y colectivos, etc.)

4) formas, recursos, usos y prácticas de la comunicación (formas de expresión, conceptos, enunciaciones colectivas, producción discursos, estrategias de comunicación)

5) desactivación o cambios en las prácticas.

\section{La constitución de las prácticas}

\section{La Grieta}

Según Esteban (E 2) La Grieta surge en 1993 en la confluencia de dos experiencias anteriores: la revista "filo libertaria" Adoquines, integrada por estudiantes de Derecho y personas del Taller de Teatro de la UNLP. La primera experiencia en Derecho -de la que él participaba- se diluyó porque había en su interior diferentes horizontes para el grupo: 
"había empezado a reflejarse alguna serie de diferencias sobre el horizonte del grupo que nos llevó a terminar en otras búsquedas. Era un grupo que se estaba planteando la pregunta si había que transformarse en agrupación estudiantil, y a otros no nos interesaba. Mi intención era más bien cultural. O sea, intervenir en los escenarios agregando preguntas, discusiones, ya sea con una charla, un cartel, una obra de teatro. (...) Veníamos trabajando algunas cosas con la gente del Taller de Teatro de la UNLP, porque de hecho ellos llevaron la obra El proceso de Kafka a la facultad, haciendo una puesta en escena ahí. Eso generó muchos vínculos, no con el Taller en sí, sino con gente que estaba trabajando ahí adentro" (E 2, Esteban)

Gabriela completa esta descripción sobre el momento de surgimiento del grupo, las inquietudes en común respecto "lo cultural" -las literaturas y el mundo editorial- y la permanente búsqueda del "contrapunto entre el ensayo y la poética" (E 6):

\begin{abstract}
“creo que a fines del 92, comienzos del 93 nos aglutinamos por vez primera en función de inquietudes que tenían netamente que ver con lo cultural. Estaban bien definidos nuestros intereses. Estaban ligados al universo de las literaturas. el contrapunto nació ahí. una manera contrapuntística de pensar entre el ensayo y la poética, entre las artes y la política permanentemente en el contrapunteo. y desde ese momento, motivados, esencialmente Esteban, yo por el universo de las revistas, que ya nos cautivaba a todos los que aglutinamos ahí, por diversas trayectorias que traíamos en relación al universo de las revistas" (E 6, Gabriela)
\end{abstract}

Luego de empezar a plantearse como un nuevo grupo que realizaría diferentes actividades, se terminaron centrando en la realización de una revista impresa, por ser un "producto más concreto" donde todos se podían expresar.

"Con ellos decidimos armar un grupo que no surgió como una revista, porque la idea era hacer justamente otras actividades. Pero, bueno... la revista empezó siendo una comodidad, porque era un formato que nos permitía también que cada uno pudiera decir lo suyo o acercar lo suyo a un producto más concreto. Era un lenguaje que te permitía adaptar a cada uno de los recorridos, porque en el grupo había gente que estudiaba abogacía, letras, trabajo social. Había otros que estaban en teatro, o que hacían poesías, también diseño industrial. Un grupo muy variado, entonces el lenguaje de la revista nos lleva un poco al nombre La Grieta" (E 2, Esteban).

Asimismo, puede destacarse, en la constitución y desarrollo de la práctica de La Grieta, la fuerte presencia de "un grupo de amigos" que buscaba construir una experiencia común -un hacer "con otros"-, a partir de la generación de pensamiento colectivo, la exploración y el diálogo entre lenguajes, formas y formatos -de las disciplinas artísticas al debate político y el ensayo; de lo editorial a lo eventual y viceversa, aunque la revista jugaría 
un papel importante como condensadora de todas esas inquietudes. En tal sentido para Fabiana:

“(...) es un grupo de amigos que se conocen de distintos lugares, que vienen de distintas experiencias (...) y tenían en común los libros, la música, las ganas de hacer algo con otros, y bueno se juntaron y el motivo fue hacer una revista (...) un poco el lugar donde se ponían en diálogo lenguajes diferentes. (...) un lugar donde se pretendía construir esos diálogos. (...) Si bien muchos de ellos estaban vinculados a la facultad (de Derecho) la revista no tenía un carácter académico ni disciplinar. (...) era como esa cuestión así más mixturada." (E 1, Fabiana) ${ }^{196}$

En esa constitución de la práctica es importante destacar el vínculo con el contexto social y político del país: una situación social y temporalidad -"los 90"'- de achicamiento de lo público, retraimiento de los espacios colectivos, despotilización y crisis -"no había espacios de discusión política, no había centros culturales en los que refugiarse" (E 1, Fabiana)-. Ahí la creación que pequeños espacios de encuentro puede leerse como ámbitos de oxigenación creativa, intelectual y afectiva; lugares vitales desde los cuales sostenerse y construir con otros.

“(...) Eran los años 90, además eran unos años tremendos donde no había espacios de discusión política, no había tantos centros culturales como ahora donde uno refugiarse, también tener un grupo que nos juntábamos en nuestras casas era una suerte de refugio en esos años.” (E 1, Fabiana)

Gabriela, a su vez, destaca otras cuestiones de ese momento en el que surge el grupo, ligadas a las movilizaciones de la vida estudiantil universitaria y a los recorridos que los integrantes del grupo realizaban por la ciudad:

\begin{abstract}
"ese momento es clave, y fueron años de vida estudiantil, pero muy intensos. al mismo tiempo que habitábamos la universidad, también habitábamos la ciudad. Entonces, ya también hay un contrapunto en nuestras prácticas y en nuestras circulaciones, no solamente en nuestras opciones teóricas para pensar una editorial o pensar criterios de imaginarios en la revista (...)" (E 6, Gabriela).
\end{abstract}

Como se comentó antes, la constitución y el sostenimiento del grupo en todos estos años se debe, en gran medida, a que se configuró como "un grupo de amigos". En tal sentido,

\footnotetext{
${ }^{196}$ Sobre otras particularidades de la publicación como "revista-objeto" y sobre sus intenciones del grupo, Gabriela comenta que: "era una revista objeto que hacía una especie de ruido para abrirse, y en la que teníamos una vocación muy muy grande para pensar. La revista salía lo más atractiva que podía serlo para nosotros en ese tiempo" (E 6, Gabriela).
} 
se puede observar que las incorporaciones de nuevos integrantes a La Grieta se va construyendo por afinidades, en el tejido de relaciones personales. Puede ser ilustrativo de esto los modos en los que Matías (E 5) y Daniel (E 4) se incorporan, ambos destacan cuáles fueron sus experiencias previas con el grupo:

"Los conozco a los chicos en el 95. Lo conozco a Esteban en la cátedra de Horacio González ${ }^{197}$. Comencé a ir invitado a los eventos y participar de esas discusiones más en relación a la cátedra de Horacio. Ya en el 96-97 fue que me invitaron a escribir, que me invitaron a alguna reunión. Y en el 98 tuve como la invitación oficial ceremoniosa y ahí empecé a ir todos los viernes a comer a lo de Gabi o a la de Fabi, y a charlar, a discutir, a debatir, a leer." (E 5, Matías)

"Tengo como distintas etapas con La Grieta, [a el grupo] lo conocí por el 2000. Yo empecé como allegado, como amigo, en algún momento como tallerista, (...) Entre los años 2001 a 2006 tengo relación de allegado a La Grieta, participo de algunas actividades. En algún momento me entero del galpón. (...) En el 2005 / 2006 me empiezo a relacionar más con Esteban. Empiezo a cruzármelo más en la universidad y demás. Y por esos años también voy al taller de literatura de Gabi y de Andre. Y además conozco si no me equivoco a Jose[fina] por laburar en el programa de "Jóvenes y Memoria". La cuestión es que a fines de 2006 soy amigo, o cercano de Gabi. De Esteban, por otro lado, de Jose por otro, de Matías por otro. Y así. Y ese verano en 2006/2007 empiezo a ir mucho al galpón. Un día voy a la tarde me quedo a tomar unos mates, termino pintando con ellos, y fue una cosa así que se fue dando. Un día me quedo a una reunión, charlamos. (...) Si lo pienso retrospectivamente, tengo la sensación de que me convierto en activo, permanente y muy militante de La Grieta después de la cuarta Muestra. Laburé bastante en esa muestra, en la barra y otras tareas pero no tuve un rol específico. Y ahí me sumé a La Grieta." (E 4, Daniel)

En relación a la Muestra Ambulante -en adelante MA-, algunas influencias previas fueron una muestra de Ralveroni en Buenos Aires, los textos ensayísticos de Christian Ferrer, la intervención del grupo Escombros en una cantera de La Plata ${ }^{198}$ y la influencia de Edgardo Antonio Vigo ${ }^{199}$. La decisión de llevarla adelante en Meridiano $\mathrm{V}$ tuvo varias

\footnotetext{
${ }^{197}$ Cátedra de "Sociología de la cultura" en la carrera de Sociología de la Facultad de Humanidades y Ciencias de la Educación de la UNLP.

${ }^{198}$ Esta es una influencia, si se puede definir así por la negativa, luego de sucedida la acción de Escombros en la cantera del barrio Ringuelet a las afueras de la ciudad. La Grieta se propuso discutirla y plantear que se podía desarrollar otra experiencia cultural en un barrio. En este sentido, el grupo produjo un texto crítico que circuló por espacios y ámbitos culturales de la ciudad en formato de panfleto o volante titulado: "Turismo cultural".

199 "Edgardo Antonio Vigo nace en 1928 en La Plata, ciudad en la que estudia, trabaja, forma su familia y desarrolla su actividad artística. Comienza de manera temprana su carrera laboral en el Poder Judicial, cosiendo expedientes. Su oficina es el "oasis de Tribunales". En paralelo, estudia en la Escuela Superior de Bellas Artes de la Universidad Nacional de La Plata, de la que egresa en 1953 con el título de Profesor de Dibujo." en "Un Tal Vigo..." ramona web, disponible en: http://www.ramona.org.ar/node/18175. Otros enlaces para conocer su obra, el Centro de Arte Experimental Vigo: http://www.caev.com.ar y la tesis doctoral de Bugnone (2013). A su vez, en 2016 se realizaron muestras retrospectivas de su obra y se publicaron varias reseñas en medios de comunicación sobre este artista, algunas se encuentran en: Diario La Nación: http://www.lanacion.com.ar/1905123-edgardo-antonio-vigo-la-otra-cara-de-la-vanguardia
} 
intencionalidades: porque los integrantes del grupo vivían allí y por la búsqueda de cuestionar la centralidad que tenía para el mundo arte y la cultura el centro de la ciudad.

\begin{abstract}
"Vivíamos en el barrio Meridiano V que en los 90 no se parecía en nada a lo que es hoy, un barrio así de viejos. (...) Y nos encantaba ese barrio (...) Entonces se nos ocurrió hacer ahí la primer Muestra Ambulante, en ese barrio. Esencialmente el motivo que tuvo fue poner en discusión la centralidad del mundo del arte, la centralidad en el sentido del centro de la ciudad. Todo lo que ocurría en relación al arte, las muestras, las muestras de artes visuales pero también el teatro, la música, también las letras. Todo circulaba por el centro de la ciudad. No pasaba nada en los barrios, como si el arte no perteneciera a esos territorios, como si no tuviera nada que ver con esa vida. Entonces dijimos, "bueno, vamos a hacer una muestra acá en un barrio”. Dijimos "¿dónde?" "Y que sea en los lugares que transitamos cotidianamente", o sea los comercios de barrio, las veredas, el playón de la estación, los bares que había para parroquianos (...) Poner en discusión donde habita el arte, lugares de exhibición y circulación del arte.” (E 1, Fabiana)
\end{abstract}

Entonces la MA -desde su primera edición en 1995- puede entenderse como una apuesta para poner en cuestión la hegemonía del "centro" de la ciudad para la producción, visualización, circulación y acceso de la cultura y las artes. A su vez, como un reposicionamiento del "barrio": de un lugar propio -cotidiano, vivencial, habitado- y territorio donde "no pasaba nada" a apostar a constituirlo como espacio posible -a construir y legitimar- para pensar desde ahí la producción cultural y el cruce entre artistas y no artistas, una búsqueda de otros "modos de pensar el arte, que no necesariamente tiene que ser un cuadro colgado en una galería o pensarlo en tanto mercancía" (E 1, Fabiana). Para Gabriela la MA "es una construcción colectiva":

\footnotetext{
"tiramos una vitalidad en formas de organización, conducimos los criterios de la muestra. Pero, los contenidos son provocados por todos, y ahí es donde la muestra ambulante para mí tiene sentido. (...) nosotros convocábamos además a otros a participar en esta experiencia, esta muestra, y el hecho de mover las cosas de lugar para nosotros era fundamental, queríamos mover todas las cosas de lugar, Pero incluidas las llamadas obras." (E 6, Gabriela)
}

Revista boba: http://www.boba.com.ar/quien-reivindica-a-vigo-eh/ http://www.boba.com.ar/un-terremoto-que-te-revolcaba-la-cabeza/

Dice Gabriela (E 6) sobre Vigo: "estamos ligados a mixturas que producen otros imaginarios. Digo, los materiales con los que estábamos trabajando, estábamos muy ligados a Vigo, año 92, 93, 94. 95, Vigo en el barrio, Vigo en la universidad, en Trabajo Social. Vigo en todos lados donde podíamos transitar con él. Un descolocado, una persona muy ávida de jóvenes, (...) de aquellos que tenían mucho fervor por las publicaciones sobre la poesía. Todos esos años son muy ligados a Vigo y a esa gran máquina que era Vigo, fue muy importante." En ese sentido, se puede marcar que el juego entre la escritura y la gráfica, la revista como objeto y el uso del objeto dentro de la revista que producía la publicación "Diagonal Cero", que editaba Vigo en los años 70 , es una importante referencia en la producción de la revista "La Grieta". 
"La silla en la vereda" se configuró como metáfora para pensar esos encuentros entre sujetos diferentes. Ese fue el eje de la MA 3 (2006) que llevó la discusión sobre las fronteras entre "lo público y lo privado" -se articularon en una misma propuesta los espacios privados, los garage de vecinos, con las producciones artísticas y los "deambulantes" de una muestrapara cuestionar el autoencierro, la vida entre rejas como configuración de vecindad y sociabilidad y habitar los espacios públicos que esta forma de vida lleva al replegarse. La Grieta propuso para la MA3 y la MA4 (2007) salirse de las dimensiones de la "obra" para plantear "los procesos de producción" del arte y de los oficios antes, después y más allá de la obra. Así en los garages y casas se instalaron dinámicas de talleres (abiertos algunos, participativos otros) para producir, compartir y exponer lo realizado.

\begin{abstract}
“En el 2006 (...) incorporamos otra cosa que tenía que ver un poco con las discusiones que uno empieza a darse con relación al arte y nosotros empezamos a discutir esta dimensión del arte por fuera de la obra, que también tenía que ver con lo que pasaba en las muestras, en la Muestra Ambulante del 2005 como no solamente de haber leído textos que nos ponían esa discusión en el cuerpo, sino de haber atravesado una experiencia concreta como había sido la de la Muestra." (E 1, Fabiana)

"Interpelábamos la versión de obra, por supuesto. Pero en definitiva, eso después lo hicimos en la $3^{\text {a }}$ Muestra Ambulante, ahí interpelamos con más elementos la idea de obra, y trabajamos más sobre nociones de proceso, de obra en construcción.” (E 6, Gabriela)
\end{abstract}

Esto amplió la dimensión experimental de la Muestra, no sólo construyendo una otra forma de circulación de obras y artistas, sino por mostrar y compartir el proceso de producción: "ahí empezaron a pasar otras cosas porque la Muestra no sólo incorporó una idea de circulación, una idea de romper los espacios convencionales de Muestra, sino que también empezó a proponer una instancia más participativa del público.” (E 1, Fabiana). La apuesta siguiente para la edición 2007 fue una apuesta porque "la casa salga a la calle": "apareció la imagen de esta casa que se le caen las paredes, toda la casa volcada hacia la vereda y la calle. Ya no es ir hacia el interior, si no ocupar la calle, ocupar el espacio público” (E 1). Sobre la última edición de la MA (2009) se encuentra desde La Grieta una mirada crítica de lo que ocurrió, incluso previamente. Por un lado, hubo un compromiso formal asumido con la Universidad Nacional de La Plata de hacer esa MA 5 -uno de los objetivos de un Proyecto de extensión- ${ }^{200}$. Pero sobre todo, leyendo las modificaciones que habían ocurrido y estaban

\footnotetext{
${ }^{200}$ El proyecto se llamaba "LA MUESTRA AMBULANTE: tejiendo lazos en el espacio público", y estaba radicado en la Facultad de Periodismo y Comunicación Social (UNLP). Anteriormente, para la MA 4 realizaron otro proyecto denominado "Arte vivo: intervenciones culturales con el barrio Meridiano V de la ciudad de La Plata" y estaba radicado en el Facultad de Bellas Artes (UNLP). Ambos estuvieron subsidios del Programa Nacional de Voluntariado Universitario (Ministerio de Educación) y por el Programa de Extensión Universitaria
} 
sucediendo en el barrio meridiano $\mathrm{V}$ y el pasaje al "circuito cultural" 201 , validado y promovido desde el Estado municipal y las lógicas comerciales que comenzaron a organizar las actividades, "lo que pasaba" en el barrio.

"La última Muestra fue complicada (...) había ya un territorio que no era el mismo. La Muestra ya había producido, la Muestra y otras experiencias: el teatro comunitario, con los chicos de la estación, los bares, todo ese proceso que fue transformando el barrio en términos comerciales, culturales, digamos y de gentrificación del barrio, pusieron al barrio en otro lugar donde todos los fines de semana pasaban cosas. (...) Nosotros ahí ya estábamos percibiendo que la Muestra se nos iba a ir de las manos en realidad, que iba a ser otra cosa, que iba a estar más en otra dimensión que tenía que ver con esta cosa más de la espectacularización de la cultura y del paseo cultural que de lo que nosotros habíamos pensado en sus orígenes, de construir lazos, de discutir lo público y o privado, lo que sea pero poner en discusión problemas.” (E 1, Fabiana)

Entonces, podemos reconocer que la última edición de la Muestra desbordó negativamente -para varios de sus integrantes- las posibilidades del grupo organizador, pero principalmente sus intenciones y sentidos de generar vínculos y complicidades. A su vez, podemos vincular e identificar esas mutaciones en Meridiano $\mathrm{V}$ con los procesos de gentrificación urbana contemporáneos, en los que luego de que algunos espacios de una ciudad fueran recuperados por iniciativas sociales y culturales -pensamos en la Asamblea barrial, en la recuperación de la Estación para construir un centro cultural de "gestión vecinal”, en el trabajo de La Grieta durante más de una década en el lugar- ciertos capitales reordenan las experiencias colectivas urbanas en función de las ganancias comerciales y la especulación inmobiliaria produciendo procesos de exclusión. En la conversación con Andrea (E 3), casi en modo de balance, ella comenta sobre las lecturas diferentes que se hicieron en los años posteriores de la última muestra y sobre repercusiones que pudo tener la MA en los cambios en el barrio Meridiano V, una situación que dice "sirve para pensar":

“- Muchos nos dicen 'este barrio que es hoy', hoy es un barrio que transitan infinidades
de personas, miles de personas los fines de semana, un barrio que está abierto durante
toda la semana, y los fines de semana estalla. Se han abierto infinidad de bares, negocios
para comer, para tomar, para escuchar música. Hay muchísimo movimiento, hay mucha
alegría, la calle está completamente poblada. Familias enteras van y vienen. Transitan el

(UNLP). Varios de los integrantes de La Grieta y de Medio Limón estaban en el equipo coordinador y extensionista. Dos artículos indagan sobre las experiencias de los proyectos y de las Muestras. El primero escrito por Fabiana y Esteban de La Grieta, se encuentra en la revista Nexo $\mathrm{N}^{\circ}$ 2, Secretaría de Extensión - FBA, 2008. El segundo escrito por Ana Negrete, integrante de Medio Limón, se encuentra en el $\mathrm{N}^{\mathrm{o}} 1$ de la revista Extensión en red, Secretaría de Extensión, FPyCS, 2010.

${ }^{201}$ http://www.meridianocultural.com.ar 
barrio permanentemente. Y algunos dicen: "bueno, esto lo hizo la Muestra Ambulante". Cuando nosotros hacíamos la muestra, no había bares, no había almacenes, las casas estaban cerradas, las calles no tenían ni un solo auto. Entonces, es una alegría ver el barrio con mucha vitalidad. Quizás, las muestras ambulantes abrieron, esa era la intención. Pero, bueno, no en este sentido, que está bárbaro también.

- Sí, quizás abrir con la mirada para pensar el barrio, habitarlo, recorrerlo.

Habitarlo con pensamiento de barrio.

- Claro, no solamente con la idea del consumo o del turismo cultural...

Claro, en eso se ha convertido ahora. En tanto apuesta, la Muestra a veces no fue leída en su pleno sentido. Sentido tan amplio que nosotros hacíamos." (E 3, Andrea).

\title{
Sienvolando
}

Para indagar en el surgimiento de la experiencia de Sienvolando, por el año 2002, se puede pensar en prácticas anteriores y simultáneas en las cuales buscar acciones similares y redes de afinidad: el movimiento de las murgas en la ciudad de La Plata y la producción de la "Marcha Carnavalera", que se realizaba -y se continúa realizando- a inicios de diciembre de cada año y que contaba con un despliegue importante de acciones de comunicación en las que algunos integrantes del grupo participaron.

\begin{abstract}
"Sienvolando viene de una práctica anterior, de los murales que se hacían en la Marcha Carnavalera, entre el año 2000 y 2002, 2003. Era todo muy intenso, era un mes que se pintaba en un solo día, pintando con ferrite que era lo más barato que había, una producción colectiva (...) para la protesta se recurría a un repertorio amplio, que iba desde mantener el sitio web de la marcha, que era un blog, hacer los regalos, los murales de un día, un momo gigante..." (E 7, Ernesto)
\end{abstract}

La primera acción del grupo es el mural en la fachada del Club Honor y Patria de Berisso que en 2002 estaba siendo recuperado y fueron convocados a pintarlo: "fue recuperado con gente del Frente [FPDS]. Fuimos con Dani, empezamos a pintar, una movida re colectiva. No éramos Sienvolando ahí, pero lo pusimos como hito fundacional." (E 7, Ernesto) Por su parte, para Dani (E 8) se hace “difícil” hablar de la práctica de Sienvolando, es una cuestión que se le dificulta poder de sistematizar y narrar, "fueron muchos años" dice.

"Es difícil... había muchas prácticas de Sienvolando. No sé si se puede definir como una práctica. Me decías que definiera la práctica de Sienvolando. Recién también hablabas de las diferentes etapas, me hablabas de una cuestión cronológica que no me voy a meter, pero también atravesó... no sé cuántos años estuvo Sienvolando. ¿Cuántos años estuvo?” (E 8, Dani). 
A aquel mural en el club de Berisso se le suman dos acciones más para configurar el surgimiento definitivo del colectivo: terminar el mural que se estaba "parado" en la Escuela de Trabajo Social y un mural con la Asamblea del barrio Autonomía (por la bajada de la Autopista Bs.As.-La Plata). Nacho y Lucía (E 12) encuentran el surgimiento del colectivo en ese momento.

\begin{abstract}
“- Vos Nacho estabas haciendo un mural en Trabajo Social. Yo era amiga de la Chola, la mujer de Ernesto de ese entonces... Ella me comentó: "Ernesto pinta murales, y no sé qué”. Y ahí lo conocí a Ernesto.

- Era un mural por el tema de la conquista de América, y el título que le habíamos puesto era: 'Anti-represión', viste. Una cosa bien de ultra. Había tenido una etapa que se había terminado, que era una cantidad de gente que se borró, no apareció más y después a los 2 años lo retomé. Primero cayó sólo Ernesto a Trabajo Social, me acuerdo, era tipo 9 de la mañana, yo dije: 'pobre tipo que al pedo que está, no debe saber nada'. Debe ser la única vez que le debo haber tirado una consigna y que la hizo. Me acuerdo que llegó él, así muy tímido, trabajamos y después bueno... ya se formó.” (E 12, Nacho y Lucía)
\end{abstract}

En ese momento -luego de esos dos murales- surge el nombre de Sienvolando, principalmente por la necesidad que tenían de realizar algunos eventos para juntar dinero, conseguir recursos y reconocerse de algún modo.

\footnotetext{
"Así salió el nombre, como un chiste, por la sien volando... y ahí en ese periplo se armó. (...) Ese fue para mí el armado, la experiencia de la marcha, chocarse con Nacho con una militancia más concreta -menos cultural y más ligado a lo político- y ese enganche de él hacia lo político que nos cerraba a todos y eso tiñó todo." (E 7, Ernesto)

"Creo que el nombre sale incluso porque en la "Rock and peña" teníamos que poner un nombre. No era que teníamos un planteo formal de: "somos un grupo que vamos a hacer", como que fluía la cosa, iba. en ese aspecto..." (E 12, Nacho)
}

Sin embargo, después de todas las acciones mencionadas -que se realizaron principalmente entre 2002 y 2004- hubo dos momentos importante en 2005 para pensar la constitución del grupo: el proyecto de mural para recordar a los desaparecidos en la Facultad de Ciencias Naturales, que luego de muchas discusiones con los organizadores no se llevó a cabo; y la llegada de George Bush a la Argentina -para asistir a la Cumbre de las Américas en Mar del Plata-. Allí se configuran algunos contornos y primeras apuestas políticas de Sienvolando en las que se empiezan a "desarrollar una poética" y pensar en términos de construir "dispositivos" de comunicación y relaciones, antes que solamente pintar un mural: 
"el grupo permaneció sin ningún tipo de definición hasta que se cayó el mural de Ciencias Naturales. (...) Y justo fue en el 2005 cuando vino Bush que hicimos el mural contra él y creo ahí fue el momento de quiebre, con un colectivo de otras características, mucho más apuntado a lo social, incluso me parece que a partir de ahí empezamos a desarrollar una poética. Antes, fines de 2002 a 2005, fue como de más transición, con ese mural, el de Bush, empezamos con una poética fuerte. Y se ve mismo en la materialidad de todo. Si lo ves, es un aparato, es un dispositivo y ahí como que se prendió la lamparita: que estamos construyendo dispositivos y no pintando paredes y además tuvo mucha repercusión, lo escracharon mil veces, después la municipalidad tapaba lo que escrachaban y la gente volvía a escrachar, había una respuesta..._decía 'escráchelo usted mismo', con un cosito de mousse, era como un antimural. Entonces al pensar dispositivos empezamos a pensar el colectivo." (E 7, Ernesto)

[Para el mural de Bush] hablábamos de cómo hacerlo, qué queríamos decir. no es que había enfrentamientos, era como que fluía. (...) Una vez por semana nos juntábamos. yo venía como de una línea más ortodoxa del mural, un cuento más común, y el Ernesto traía... esas discusiones más concentradas de la información. (E 12, Nacho)

Para Lucía, otro hecho importante fue la desaparición de Julio López y el mural que a los pocos días realizaron en una pared de la ciudad, acción que tuvo mucha repercusión:

“[el mural de] lo de López fue para mí como más consciente de lo que estábamos haciendo. El respeto a ese mural es zarpado, yo no lo puedo creer. Sigue estando todavía. Y bueno, después me acuerdo que ese día estábamos pintando y nos sacaron unas fotos. Salió un afiche, no sé si no fue la Comisión por la Memoria, un afiche que estamos de espalda pintando y está López" (E 12, Lucía).

Por su parte, Pili que ya conocía al grupo por Dani y los había visto en plena realización del mural en Trabajo Social, se sumó en el armado y la realización del mural sobre la desaparición de López en septiembre de 2006. Según cuenta ella las discusiones sobre la práctica del grupo llegaron un poco más adelante.

"No estaba definido como fue años después. No había un perfil de hacia dónde se quería ir. (...) Ese tipo de discusiones en ese momento... de poner algo en el espacio público como tal o en... no sé si las teníamos. Después sí, se fueron generando. Pero en ese momento era eso. Sí, ir a poner algo. Digamos, no como grupo. Sí, tal vez algunos sí, otros no. Yo en ese momento no sé si pensaba en... sí, me interesaba ir a poner algo en la calle y que el resto lo viera, y que se planteara una situación que al menos... no sé, que mi panadera supiera quién era López, o qué estaba pasando. Era como una necesidad de hacer justicia, de poner mi granito de arena en algún lado más que algo tan conceptualizado, como el rol del artista en la esfera del espacio público. Esas fueron discusiones posteriores". (E 9, Pili) 
Para Nacho otro momento también fundamental para la consolidación como colectivo son las intervenciones realizadas junto con los trabajadores despedidos de la fábrica textil MAFISSA a finales de 2007 y durante parte del 2008. Lo reconoce como un momento de quiebre de los "prejuicios" en el grupo: "yo creo que uno de los momentos más interesantes donde se rompen todos los prejuicios es cuando intervinimos en el conflicto de la fábrica que la dirigía el PTS, en Mafissa”. (E 12, Nacho)

En relación a las formas de participación en Sienvolando, Ernesto comenta que nunca se pensó "como un grupo cerrado, como "somos esto"”. Si bien no era un espacio enteramente abierto o asambleario, "quien quería sumarse al grupo se iba sumando" (E 7, Ernesto). El modo en el que tanto Lalo (E 13) como Mariano (E 10) relatan sus incorporaciones al colectivo -cuando éste hacía ya unos años que existía- da cuenta de su impronta particular en las formas organizarse, de cierta porosidad de su forma organizativa y en parte, de la poca relevancia que se le daba al manejo específico de los recursos plásticos y del muralismo al momento de incorporar a un nuevo integrante. Parecería que lo importante era compartir una experiencia colectiva que se desplegaba por la ciudad:

"arranca ahí en realidad (...) apoyando a los trabajadores de Mafissa, en la lucha. Y bueno, como sabían que yo pintaba, me invitaron. Me dijeron que al otro día iban a estar, entonces... encima algo re loco que pasara en Olmos... ponele, en mi barrio esa cosa ni en pedo. Al otro día a las 9 de la mañana, fui. Empezamos a tomar mates, Lucas había hecho un dibujo. Ahí me copó toda la movida que se estaba haciendo. Era todo muy suelto, y uno pensaba que era más estructurado. Se terminó el mural, después se hicieron unos grabados. Y bueno, ahí quedamos con los chicos buena onda, y me dijeron que me iban a avisar para la próxima. Al que le pareció interesante que yo entrara a Sienvolando era a Nacho, que también era de barrio a diferencia de los demás pibes que eran del centro. Me llamó Ernesto y me dice... "el sábado vamos a estar pintando en 3 y 44 con la CORREPI por lo de Magdalena. Si te querés acercar, nosotros vamos a estar ahí". Dije que sí. Laburaba de mañana y me fui con la ropa del laburo. Y pintamos todo el día como hasta las seis, siete de la tarde. Yo me di cuenta que eso era lo que me gustaba. Y ahí arrancó.” (E 13, Lalo).

"Yo ya los conocía a los chicos -a Lucas y Romina- y como grupo los conocía por circular en la ciudad. Vas caminando y vas viendo murales con una cierta retórica de lo que pasa a nivel social, de denuncia y con una estética determinada. Los conocía. (...) Yo llego de la mano de Lucas. Justo hacían un mural en la esquina de donde yo estaba viviendo, ahí en 3 y 44. Un mural acerca de la masacre de la cárcel de Magdalena. (...) Con él habíamos hecho muchas cosas... entre ellas capoeira. (...) [un día] me dice: "che, vamos a estar en la esquina de tu casa, pegate una vuelta". (...) De pasar a estar mirando cómo pintaban los demás, me dijeron de pintar, de empezar a hacer algo. Me dijeron: "en un par de días vamos a pintar en la cancha de Estudiantes". (...) Bueno, fui y empecé a incurrir en esas actividades. Capaz, primero desde un lugar más periférico, desde afuera, haciendo lo que te dije y después ya como que te vas metiendo un poquito más, ayudas en 
la organización, lo que es la logística, digamos. Y ya después empezás a ser parte del grupo. Pero sí, yo personalmente, estar relacionado a lo que sería el muralismo, el arte o el arte callejero, no. No estaba. Hasta ese momento que empecé ahí la experiencia." (E 10, Mariano)

Mariano y Lalo también comentan sobre sus incorporaciones "más activa" al colectivo de "ir a las acciones" a participar de las reuniones y el armado. Presentan así parte de la "cocina" cotidiana de la creación de las acciones de Sienvolando y las discusiones que se comenzaron a generar en el grupo cuando la "movida" comenzó a crecer. Mariano a su vez encuentra un desplazamiento en relación a las articulaciones con organizaciones -cuestión que se profundiza con mayor detalle más adelante-. Lalo destaca que lo interesante para él, la "filosofía" por la que había ingresado al grupo no era quiénes lo integran sino el "momento de la acción".

\footnotetext{
"Iba a las acciones o a los murales y un día me dijeron: "che, vení que vamos a planear tal mural". Bueno, vamos a la casa de uno de los chicos. Y ahí empieza la famosa lluvia de ideas y algunos lo encaraban más del lado artístico, estético, otros más desde la denuncia, lo comunicacional o lo discursivo. Se llegaba a una idea en común y después venían los bocetos. Es como un proceso bastante largo el armado de un mural. Y además también con la gente que te convocaba. Como que hubo... por lo que yo veo ahora... en el momento también te dabas cuenta pero ahora capaz más, como que hay una especie de evolución en esos años que fue de a hacer para, a hacer con. Como que se fue mutando y la idea era hacer con la gente que te invitaba." (E 10, Mariano)

“(...) Después empezaron ellos con las reuniones, me invitaron a algunas en la casa del Ernesto. Yo fui, me empecé a integrar. Pero siempre lo tomé como que estaba un poco más fuera de... porque había cuestiones políticas que en este momento si las puedo llegar a discutir, pero en ese momento era como que a mí me pasaba todo muy por arriba y era un montón de información. Fueron varios años con los chicos, ligué un bombazo de información. (...) Como que venía mucha gente a interesarse con la movida que estaba pasando y para mí era como re groso. Para Pili y Dani era medio preocupante la cuestión, porque había que pararse de otro lado, decían ellos. Como diciendo: "bueno, Sienvolando ya es un colectivo bastante importante que no se sabe quiénes son los integrantes, pero esto sigue funcionando". Podía ser cualquiera integrante. Esa era la filosofía que más o menos me habían inyectado a mí. (...) No importaba bien quién era Sienvolando. era el momento, la acción del momento lo que importaba. Entonces, todos los trabajadores de Mafissa podían ser Sienvolando. Eso era lo loco. Estabas como en un anonimato sí o sí, pero se sabía que había un grupo de gente que estaba dando vueltas que cuidaba todo esto." (E 13, Lalo)
}

El planteamiento de las intervenciones era colectivo; la mayoría de las veces a las acciones no se las pensaba como acciones "de" Sienvolando sino inscriptas en una trama de relaciones, en "una red", lo que da pie para pensar en la importancia de los diálogos y las 
articulaciones. Existían tres tipos de acciones: a) "murales de un día", propias del colectivo expresando una idea -“eran por motu propio, ir al error, no tomar las consignas de nadie, pintar lo que se nos parece" (E 7, Ernesto)-; b) "las acciones de estudio", que se hacían desde estas relaciones y articulaciones con otros y que llevaban tiempo (por ejemplo, el mural en el Centro Daniel Favero o en el local de Suteba) y por último, c) las "acciones de coyuntura", que coordinaban con otros grupos y que eran más propias de una "intervención” puntual; casi sin estudio previo, "íbamos con una caja de herramientas pero sin una idea cerrada" (E 7, Ernesto). En el momento y en el lugar se pensaba la acción y sus formas visuales (por ejemplo, el mural con Correpi).

\footnotetext{
"No pensábamos -ya después de 2005- que el mural o la acción la hacíamos nosotros, sino que era un gran colectivo que se extendía y participábamos. Y además, en verdad era así porque estábamos insertos en una trama re fuerte, sobre todo después de lo de López, hasta 2009. La autoría de las cosas nosotros la diluíamos, todo lo posible y se diluía también, porque nos cruzabamos en un montón de otros lugares, porque era más de una comunidad que metía dispositivos en la calle, más que nosotros.” (E 7, Ernesto)
}

Repensando los objetivos del colectivo Pili plantea que "se apuntaba a no repetir ciertos modelos estéticos o visuales del sector militante que hacía que, por ahí, ciertos reclamos no fueran tan visibles. Se trataba llamar la atención desde otro lado.” (E 9, Pili) Esta idea de discutir la discursividad militante, mientras al mismo tiempo se construían fuertes lazos con distintas organizaciones sociales de la ciudad, fue una de las características particulares de la experiencia del colectivo.

\section{Unidad Muralista Hermanos Tello}

La Muralista Hermanos Tello surge en 2006, en gran medida, por iniciativa de la OSL (Organización Socialismo Libertario) que realizó una actividad en su local en Constitución (CABA) y convocó a pintar un mural. Allí se comenzaron a gestar dos "unidades", una en La Plata y otra en Quilmes, con algunos integrantes de la organización y con otros allegados. Estas unidades muralistas seguiría una tendencia libertaria pero tendrían autonomía respecto de la OSL. Sus búsquedas serían construir una organización libertaria de base y brindarle una "estética propia" a dicha tendencia.

"Era el 2006. Se convocó a la actividad y ahí un compañero de la muralista de Concepción (Chile) fue y participó en el mural y pusieron el nombre de la muralista hermanos Tello. Nosotros en ese tiempo no conocíamos la historia. Recién habíamos llegado (a la Argentina provenientes de Chile), pero estábamos intentando rescatar el 
movimiento libertario que había surgido en el año 70 y rescatar un poco la experiencia de lucha que teníamos. Como que el primer nombre que apareció fue el de los hermanos Tello, y desde ahí nosotros dijimos: 'bueno, pongamos hermanos Tello'. De ahí fue todo cambiando (...) No había una cuestión orgánica hasta que se fueron dando los primeros grupos muralistas (...) era un pequeño grupo.” (E 17, Carlos)

A su vez, Carlos comenta sobre los intereses y objetivos de la Muralista ligados a la tendencia libertaria y a la búsqueda de una "estética propia", así como de la experiencia anterior en Chile:

\begin{abstract}
"apoyábamos el proyecto libertario. Ahora, dentro de los integrantes se fueron dando lecturas a lo largo del tiempo. Sobre qué es lo libertario y qué es el proyecto del anarquismo. Estaba atravesado por diferentes contradicciones, pero... al menos ese fue el enfoque principal, por darle una estética propia. Darle una renovación del espíritu libertario, dar una organización de base y darle una estética, también. Intentar entregarle herramientas, más que nada. (...) No hay una visión vanguardista de la organización de base, si bien había compañeros dentro de la militancia política, había un trabajo territorial, había un trabajo sindical, había toda una cuestión de querer manejar una línea en conjunto. (...) Nosotros veníamos de una corriente muralista que se estaba formando en Chile. La muralista Luchador Ernesto Miranda, que también había sido del OSL. Vinimos para acá, propusimos una estética muralística pero como una corriente latinoamericana." (E 17, Carlos)
\end{abstract}

En relación al vínculo entre organización política y organización de base, Carlos menciona que había una consideración por la autonomía de La Muralista: "Yo militaba en una organización política (OSL), pero no... La Muralista Hermanos Tello no perteneció a la organización política. Lo de la autonomía se manejó en claro desde el principio.” (E 17). A su vez, en cuanto a la visión sobre la estética y la propuesta particular de la Muralista comenta:

"En ese tiempo (...) éramos más cerrados, veíamos la cuestión estética, porque estábamos buscando una identidad, una firma propia. No necesitábamos tanto poner el nombre. Después, lo pusimos, pero ya no nos fue tan necesario. Sino que había otros mensajes para decir. Y empezamos a hacerlo al principio con rojo y negro, que ya venía con esa tradición. Pero después, lo rompimos también.” (E 17)

Esa cuestión fue modificada en la última etapa del grupo al incorporar otros colores y tonalidades. En relación a los diferentes momento que tuvo la Muralista, Carlos reflexiona:

"Se nos abrió también una variedad de paletas que fue también impresionante, porque jugar con un color y más tonalidades... como que medio cromático. (...) No veníamos con esa línea. Después, se fueron dando. Había una propuesta estética de Chile, pero 
también fuimos variando. Había una forma de hacer y después esa forma va mutando.” (E 17, Carlos).

En relación a los objetivos que La Muralista fue construyendo de sus intervenciones en La Plata, Carlos menciona la idea de intervenir sobre un "capital simbólico", aportando en la creación estética de imágenes y mensajes a las luchas de las organizaciones sociales:

\begin{abstract}
"Nosotros rescatábamos las consignas de la lucha. Rescatábamos la de la Multisectorial, la de HIJOS, se apoyaba también teniendo una lectura y respetábamos el mensaje, y nosotros lo íbamos transmitiendo de una manera. Como que esa es la cuestión, intentamos darle un lenguaje y una estética dentro de lo que sabíamos. Hubo mucho conocimiento de lo que fue el bombardeo comunicacional y cómo hacerlo. (...) Lo que intentábamos era entregar aporte discursivo a las organizaciones sociales. Porque ese aporte discursivo no tiene que ver con decir cómo hacerlo o que digan tal discurso, sino a la intencionalidad, la forma de construir ese discurso, y cómo se puede construir un capital simbólico. Lo que pasaba con Sandra Ayala Gamboa es que se necesitaba tener un capital simbólico, algo que se visibilizara. (...) Ahí uno aportó haciendo un análisis de cómo se puede hacer un fortalecimiento de capital simbólico en el espacio y de ahí la intervención. Entonces, en realidad intentábamos pensar eso. También nosotros pensábamos sobre la imagen de lo que fue Julio López. Nosotros estuvimos bastantes años luchando, y que llegue un proceso de que en toda la ciudad se hacía de López, que se había acumulado de la imagen de López. Se tuvo que borrar la imagen de López. (...) Es parte de la misma historia, la misma experiencia, la misma época. Entonces, como que justamente lo interesante de la cuestión es cómo nosotros alimentamos y cómo generamos material de comunicación social. Y ese material está ligado hacia la transformación, hacia la denuncia. Lo artístico viene después, porque viene la valorización de cómo se construye ese arte. Yo creo que aquí también había una intención del mensaje, pues. En esa intención de mensaje, en esa poesía de política que hay, ahí está la huevada artística y ahí está lo político. También, nosotros estábamos luchando sobre un capital simbólico.” (E 17, Carlos).
\end{abstract}

A su vez, la intención de la Muralista era reconocer y apoyar las luchas de las organizaciones sociales -como se puede deducir de sus intervenciones, fueron principalmente, organizaciones de derechos humanos y territoriales, pero también educativas y de trabajadores-, aportando a las formas de "construcción discursiva" de las mismas:

"lo que intentábamos era entregar aporte discursivo a las organizaciones sociales. Porque ese aporte discursivo no tiene que ver con decir cómo hacerlo o que digan tal discurso, sino a la intencionalidad, la forma de construir ese discurso, y cómo se puede construir un capital simbólico." (E 17, Carlos)

\title{
Colectivo Siempre
}


A partir de una convocatoria que surgió a inicios de 2006 en la Facultad de Bellas Artes de la UNLP por los 30 años del golpe cívico-militar, se comenzó a gestar una obra de danza y música titulada "Siempre", coordinada por Diana Montequin y Mariana Estévez ambas profesoras de la Facultad-. De esa obra fueron parte varias de las personas, de las mujeres, que luego serían integrantes del colectivo ${ }^{202}$. Se puede entender entonces que esta obra -su gestación y puesta en escena en esa facultad, y su recorrido por otros espacios de la UNLP- así como un hecho decisivo en septiembre de aquel 2006, la desaparición con Jorge Julio López-, fueron dos puntales para el surgimiento de este colectivo de danza. En ese contexto movilizador, apareció en el grupo la necesidad de "articular lo artístico con un accionar político".

\begin{abstract}
"Esa obra tuvo una mayor repercusión que la que nosotros pensábamos para ese momento. Todo ese año la hicimos como en distintos lugares. Una cosa que pasó en ese año... digo, fue justo el año de la segunda desaparición de López. Mientras estábamos haciendo la obra marcó un quiebre importante. Llevó a una reflexión hacia adentro del grupo, para mí un poco eso fue como el... digo, esta es una opinión personal que la estoy pensando ahora, habíamos definido muchas veces cómo surgió el colectivo y todo, pero uno lo vuelve a pensar y repensar. Para mí ese hecho nos llevó a reflexionar hacia adentro sobre qué queríamos decir, si se podía hablar de la misma manera cuando ese pasado había vuelto a estar más presente de nuevo. Empezó a aparecer la necesidad de tener un grupo que articule el arte con un accionar político más concreto." (E 15, Mariana e. y Diana)
\end{abstract}

Para Renée también la propuesta y realización de la obra "Siempre" fue decisiva en la posterior creación del grupo, ya que implicó una reflexión sobre el lugar de la memoria y que marca un posicionamiento de intervenir en lo político, así como una discusión con los espacios de la danza tradicional. Según ella, fue una experiencia "atravesadora":

"El colectivo, en realidad, empezó siendo una propuesta para una obra. No fue un colectivo de entrada, fue una propuesta para una obra que inicialmente la hicieron Diana y Mariana, que extendieron invitaciones para participar de esa obra. El comienzo fue bastante abierto, la gente que participaba éramos todas mujeres en

\footnotetext{
${ }^{202}$ Renée (E 13), al rememorar el momento que se creó y presentó la obra de danza "Siempre", encuentra fuertes lazos con el contexto político ligado al reconocimiento del campo de los Derechos Humanos realizado por el gobierno nacional: "En esas discusiones había pulsadores o dispositivos que nos unían de por qué teníamos... Me parece que ése es el camino que iniciamos con la obra 'Siempre', que es como ponerle unas palabras y unas acciones a una situación sobre los desaparecidos, la memoria y lo que se venía en ese tiempo, poner en evidencia, hacerlo ver. No me parece que haya sido casual en el momento que sucede lo de Néstor bajando los cuadros de Videla, de los represores. Como que hay un contexto que nos permite, o que todos estábamos, más o menos, en camino. Y también, fundamentalmente trabajar en acciones artísticas. Una herramienta para una manifestación política, o está pensado desde un lugar."
} 
ese momento ${ }^{203}$. No sé si por elección, o porque fue sucediendo de esa manera. Quizás también tiene un poco que ver con la época, porque después se empezaron a ver más varones bailando o en ese período, empezó a verse más el hombre en la danza contemporánea. (...) Y entonces, bueno... fue muy fuerte, muy atravesadora, atravesante, esa experiencia con la obra. No era casual que todas las que participamos teníamos una fuerte motivación en el hecho de que se cumplían 30 años del golpe de Estado y queríamos participar de esa especie de manifestación artística. Manifestación que implicaba una reflexión política en relación a la memoria y sobre todo a cómo se pensaba, cómo se ponía en valor ese tipo de reflexión" (E 13, Renée)

Por su parte, para Mariana s. la idea de conformar un colectivo surgió en ese contexto movilizador al poco tiempo de la desaparición de López y mientras se filmaba el video-danza "Siempre":

"Previo al colectivo una gran parte de la misma gente estaba trabajando en un video danza que se llama 'Siempre'. (...) cuando sucedió esto (la desaparición de Julio López), como toda la gente estaba aglutinada en el video, se decidió hacer algo y surgió como una primera acción en marcha que se hizo por López. Y a partir de eso, como de empezar a trabajar juntos porque se dio origen al colectivo." (E 14, Mariana s.)

En las reuniones y encuentros del colectivo se producía una constante discusión sobre lo artístico y lo político ${ }^{204}$. A la vez esas discusiones y definiciones se reformulaban al momento de pasar a la acción, principalmente a las dinámicas de ejecución en las que algunas integrantes tomaban la posta, en tal sentido Julia (E 16) comenta:

“Todo eso ahí (en las reuniones) en tensión. Cada una opinando desde los códigos y el lenguaje que manejaba, y cómo eso lo vinculaba con lo otro. esos cruces están en el grupo y también en cada una. cuándo el objetivo primero es lo político y cuándo es lo artístico. ese ida y vuelta siempre estuvo en tensión. (...) A la vez cada acción que hicimos... esas definiciones fueron diferentes, no todas las acciones tuvieron eso tan claro. Pero también porque al ser coordinadas por diferentes personas, digamos. en cada acción alguna que se ponía un poco al hombro. también eso modifica los objetivos, todo. estaba buena esa dinámica de trabajo." (E 16, Julia).

En tal sentido, sobre las definiciones sobre si Siempre era un colectivo de danza, Mariana plantea que "esa fue toda una discusión":

\footnotetext{
${ }^{203} \mathrm{Al}$ contrastar varios de los testimonios y algunos registros visuales se encontró que sí participaron hombres en la obra y en el video-danza, pero como parte del cuerpo músical y no en el cuerpo de baile.

${ }^{204}$ Por ejemplo, Julia encuentra que a partir de las discusiones en el grupo y de los encuentros con otros colectivos culturales, "empezamos a repensar los modos de creación, desde el lenguaje de la danza. Ahí surgió una segunda parte de la obra 'Cuerpo de baile' en donde encaramos un proyecto más horizontal.” (E 16, Julia).
} 
"Primero, porque no todos los que estaban en el colectivo provenían de la danza. Había, sobre todo, dos chicas que no venían del palo de la danza (...) Después, otras de las chicas bailaban, pero por ahí no lo sentían como una profesión o dentro de la danza se dedicaban a la expresión corporal, entonces por ahí había otras discusiones. Y como que nunca se terminó de definir como un colectivo de danza, o de danza y política, sino como un colectivo de arte y acción política. (...) Así lo pusimos en el blog. Cuando necesitas poner en algún lado qué es el colectivo Siempre. (...) como que todas esas discusiones ahora no me las acuerdo como para retomarlas. Pero sí que tuvimos muchas reuniones donde discutimos eso y llegamos a decir: "colectivo siempre, subtítulo: arte y acción política". Creo que eso también fue... en algún momento que definimos un logo, creo que ahí vino la discusión sobre cómo cerrar la idea." (E 14)

Mariana también recuerda que después de las primeras acciones por López el colectivo "empezó como a virar hacia llegar a otros sectores" y también "se fueron desprendiendo otras temáticas.” (E 14)

“empezamos como a discutir para quiénes lo estábamos haciendo en ese marco, si eso ampliaba algún tipo de visibilidad o solo era dialogar con los que ya estábamos convencidos... entonces, ahí empezamos a pensar otro tipo de acciones y a discutir eso. Para quién y qué herramientas teníamos que usar y de qué manera, y ahí surgieron distintas cosas. Y distintos temas.” (E 14, Mariana s.)

\section{Arte al Ataque}

Este colectivo surgió entre los años 2007 y 2008 primero por inquietudes que algunos militantes del Frente Popular Darío Santillán de La Plata. Luego se comienza a denominar “espacio cultural” de toda la regional (La Plata, Berisso y Ensenada), realizando sus primeras acciones desde inicios de 2008 con ese nombre. En ese momento surgió la idea de convocar a nuevas personas y buscar un nombre propio para el espacio.

"Surge de la inquietud que teníamos distintos militantes del Frente acá en La Plata, que veníamos militando en distintos espacios, distintos sectores de la organización. Pero que dentro de nuestro trabajo particular, siempre teníamos alguna relación con lo cultural. O estábamos en la comisión de cultura de una organización estudiantil o trabajábamos cultura en los territorios, y empezamos a juntarnos por esa inquietud. Primero para resolver problemas. En el 2007 llega la orden de desalojo del [Centro social y político] Olga [Vázquez] y una de las estrategias que nos dimos fue hacer el Cabildo Abierto [de Juegos]. Entonces, para resolver el problema de cómo hacer el cabildo, nos empezamos a juntar un par de compas. El Cabildo pasó (...) y a principios del 2008 empezamos a juntarnos un par de compas que veíamos que lo cultural... no tenía que ser nada más que dar respuestas a algunas cuestiones particulares de la organización como ponerle onda a las marchas, hacer las místicas. Como que siempre caíamos en eso de resolver problemas y que había toda una disputa para dar como organización en el ámbito cultural. Entonces 
con esas ganas de empezar a disputar como organización cultural, viéndolo también como parte fundamental de la política, del ser político del Frente, nos empezamos a juntar. Primero, se hizo una reunión de como treinta personas, luego fuimos dos y después ahí se empezó a armar el grupo" (E 18, Arte al Ataque)

En relación a las primeras acciones como espacio cultural del FPDS y la conformación de Arte al Ataque en La Plata rememoran:

"las primeras acciones que hicimos fueron una muestra en Humanidades que se llamaba 'Armar en movimiento', que era toda una muestra sobre el recorrido de las distintas luchas estudiantiles. Era un recorrido con un carrito de supermercado disfrazado de colectivo que era la lucha del boleto estudiantil, y empezaba con la reforma universitaria y terminaba con la lucha por la democratización de la universidad. Iba pasando por distintas partes. Había unas que eran medio instalaciones. La primera acción en la calle fue con Sienvolando, que coordinamos en conjunto el mural de 'Buscar justicia' de Google. el mural acá en La Plata y la instalación allá en la estación (Avellaneda). Y hasta ese momento éramos el espacio de cultura del Frente Popular Darío Santillán regional La Plata, Berisso y Ensenada. Firmábamos con todo eso. Como que nos damos ahí... empezamos a discutir que si la idea era empezar a llamar gente, no pegaba. Igual ahí se empezó a sumar gente con esas acciones, gente que o militaba en el Frente que se empezó a acercar directamente al espacio. $\mathrm{Y}$ ahí se decidió ponerle nombre como para que tenga un poco de punch, sea más atractivo. Y salió ponerle Arte al Ataque. Fue en agosto del 2008." (E 18, Arte al Ataque)

Sobre el modo en que piensan a sus prácticas se puede reconocer que Arte al Ataque no tiene un desarrollo "tan intelectualizado", sino más sus posiciones se acercan a las cuestiones que van surgiendo en el grupo y a los ámbitos en donde accionar, una práctica que va mutando.

"no nos hemos enroscado mucho en si es arte o no. Son propuestas estéticas que se van desarrollando en diferentes ámbitos, y en cada ámbito va cobrando diferentes formas, sea (la campaña y encuentros) "América late" o sean las intervenciones callejeras. Dentro de esa variabilidad, también tiene que ver con el grupo, con el colectivo, donde todos podamos desarrollar alguna tarea, y luego montamos otra tarea. Es permeable a esa mutabilidad. (...) Nunca nos enroscamos... sí, digamos como que hemos tenido: "bueno, todos somos artistas. Todos somos potencialmente artistas". Y eso nos ha generado muchas discusiones con otros grupos. (...) Digamos, muchas de esas definiciones las fuimos tomando también en el hacer práctico cotidiano nuestro. No es que nos sentamos a discutir: "bueno, ¿qué es el concepto del arte? ¿Qué es el concepto de artista?" son las herramientas que también construimos para poder ir a trabajar a donde queremos trabajar." (E 18, Arte al Ataque) 
El surgimiento de Luli se produce al poco tiempo que se disuelve Sienvolando en junio de 2009, por aquel entonces todas las integrantes de Luli habían formado parte de ese otro colectivo. Todas acuerdan en reconocer que en los inicios no hubo una idea fija de constituir un colectivo, sino que algunas situaciones las fueron juntando. En este sentido, según, Dani (E 22), Luli no surge primeramente como un colectivo definido sino por la necesidad de "hacer hago" y de "estar de nuevo juntos" que tenían algunos luego del cierre de Sienvolando. A su vez, era el momento de surgimiento de las primeras FLIA (Feria del Libro Independiente y Autogestionada) en La Plata donde aprovecharon para motorizar algunas acciones de tipo serigráfico con tacos con diferentes motivos, a partir de algunas producciones que ya tenían y la producción en taller de otras nuevas.

“para mi hubo un período de duelo y (...) un vacío que por eso también fue la necesidad de hacer algo. Creo que Sienvolando había sido muy intenso y como que se sintió mucho ese vacío. $Y$ en realidad, nació otro colectivo que no sé si tuvo... digo, no nació pensándose como otro colectivo. Estaba la FLIA y estaba arrancando, y fue con las cosas que teníamos a mano hacer algo para estar ahí, como personas también. Sienvolando había sido un colectivo para estar, un espacio para dialogar con otros. De ahí (con Luli) hicimos lo de los taquitos. Eso también es loco, porque tuvo mucho rato de taller. fue un laburo... fue como un proceso más interno todo eso, tuvo más de estar de vuelta medio juntos. Pero bueno ahí, ni asomaba que existía... que iba a ser como Luli, fue esa intervención en las primeras FLIA.” (E 22, Dani)

Por su parte, Pili (E 20) plantea una situación similar en la que se produce cierto devenir de la práctica a partir de algunas preguntas por cómo y con quién intervenir:

"Creo que nada de todas esas decisiones fueron (...) pensadas de antemano: "bueno, ahora vamos a ser tantos". Yo creo que siempre estuvo la posibilidad de abrirse a otros, a que existiese una red y trabajar con otros. Después, creo que también la coyuntura política de cada momento marcó bastante en cómo se trabajaba, con quién, a dónde y el nivel de participación.” (E 20, Pili)

Pili también encuentra importantes diferencias entre las propuestas de Sienvolando y las de Luli, no solo por otra situación política sino por intenciones e intensidades diferentes, así como la apertura de otros espacios de intervención:

"Creo que es distinto estar permanentemente en la calle haciendo murales o paredes, o haciendo gigantografias, donde el otro es convocado a participar de una cierta manera, en un cierto aspecto, -por ejemplo. donde puede ir y pintar un pedazo, o cebar unos mates, y está siendo parte de eso que está sucediendo ahí, más allá del mural, esa acción a después 
otro momento social-, que supongo que fue también lo que hizo a que Luli no fuera (eso)... Aunque tenía actividades en calle, estaba más volcada hacia otros espacios y hacia otro tipo de construcción, que tenía más que ver con repensar... como con un poco menos de urgencia. estábamos más en algunos detalles finos desde repensar un dispositivo web o un dispositivo de cómo encarar un seminario, (...) todo lo que fue el seminario de comunicación (popular) y el otro ("Cambiar el mundo con un Clik")". (E 20, Pili)

Ernesto (E 19) conceptualiza esa diferencias entre la propuesta de Sienvolando y la de Luli, allí encuentra una tensión entre un trabajo más "basista" ligado a los vínculos con las organizaciones sociales y otra más "foquista" en donde Luli "interpelaba" un poco más desde "afuera".

"Luli se potencia, si se quiere, al no estar tan en el movimiento real y puede generar cosas súper potentes. Toma una suerte de autonomía con preguntas hacia el lenguaje militante, hacia el lenguaje mismo, más allá del militante, más a cuestiones académicas, hacia una serie de planos de preguntas que se alejan de los planos mucho más organizativos que tenía Sienvolando.” (E 19, Ernesto)

Dani también encuentra una diferencia en cuanto a las producciones que se pretendía construir desde cada grupo: "la búsqueda más plástica en Sienvolando y la búsqueda de Luli es bien gráfica” (E 22). Y amplia sobre la propuesta de Luli: “creo que también era en ese momento, igual lo estoy diciendo ahora, era discutir no solo la discursividad militante -una discusión que ya estaba en Sienvolando-, sino también la discursividad del arte, del artista." (E 22), En ese sentido, en su relectura del grupo, Dani entiende que su búsqueda era "más artística" y en diálogo con cierto "circuito del arte":

“con un circuito que tal vez ya había puesto el ojo en ese tipo de cosas acá en La Plata. historiadores, investigadores que ya estaban atendiendo a esto más desde el lugar del arte. Además, desde lo estético es como vos decís, parece una continuación, los primeros murales, lo de "la galletita". (...) Creo que para Luli ya estaba más legitimada toda esta historia del arte activista, había un aire. En la época de Sienvolando todavía, acá en La Plata, no había llegado tanto." (E 22)

\section{Luxor}

Según Luxor, "siempre me gustó el graffiti". Pero en un viaje a San Pablo (Brasil) por un evento de capoeira, filmó graffitis pintados en los túneles, y al regreso, decidió salir a 
pintar por la ciudad a inicios de 2010. Si bien siempre estuvo interesado por las formas gráficas y los graffitis tradicionales ${ }^{205}$, esta experiencia fue movilizadora y determinante:

“La flashié y me volvió loco. (...) y dije 'cuando vuelva voy a pintar' (...) El graffiti que me conquistó fue el que conocí en Brasil, el 'graffiti personaje'. Es eso lo que me rompió la cabeza, mezclado con algo como figurones de esa época, ese impacto visual venía flasheando." (E 23, Luxor)

Entonces, comenzó a construir esa nueva práctica e identidad que se llamó "Luxor". Pero se trataba de una práctica que no estaba del todo definida, un hacer en el que "no tenía nada claro". Sin embargo, también la idea era tomar algunas propuestas de experiencias colectivas anteriores en las que había participado:

"la idea de seguir haciendo lo que hacíamos con Sienvolando, de tratar de llegar, de romper el círculo militante y llegar a otra gente... y ahí me hice el facebook, que era el "Loco Luxor", no "Luxor Magenta" que fue después... Ahora "soy Luxor". Pero como que no tenía nada claro. Arranqué por arrancar algo...” (E 23, Luxor)

A su vez, la propia propuesta de Luxor fue mutando y ampliando, principalmente lo estético -las formas, los personajes, las figuras y en los recursos empleados-. Pero también, en cierto sentido, hubo modificaciones en ejes-conceptos de lo político: de pensar en las "relaciones y sexualidades disidentes" a apostar por una retórica de lo popular-barrial y por "construir un mundo nuevo". Aunque cabe decir que ambas ideas tienen como eje fuerte las relaciones entre las personas.

“Con el tiempo lo fui cambiando eso. Y cuando conocí más el feminismo, encontré que hablar de disidencia era como hablar de contracultura. Para mí, hablando [sobre lo disidente], es como que legitimás el espacio que atacás. ¿Disidente a qué? Estás legitimándolo. Así que ahí salió todo de decir, una frase de Buenaventura Durruti que está cambiada, que siempre digo: 'construyamos un mundo nuevo, porque llevamos un nuevo mundo en nuestros corazones'. A partir de ahí, en vez de decir contracultura es construyendo un nuevo mundo, construyendo otra cosa. No es ni ésto ni lo otro: es otro mundo..." (E 23, Luxor)

\footnotetext{
${ }^{205}$ Antes de "salir a pintar" en la ciudad como Luxor y buscar construir su propia impronta y estética, participó (o seguía participando) de diversos colectivos y movidas culturales, que van desde la danza (capoeira) a la música (candombe) pasando por intervenciones culturales desde lo visual (por ejemplo en Sienvolando).
} 


\section{EI espacio de lo público}

Según Fabiana de La Grieta, en la primera MA lo que servía para pensar los espacios de la ciudad y preguntarse por el "cómo" de lo público era "poner en discusión dónde habita el arte, lugares de exhibición y circulación del arte” (E 1), buscando cuestionar la hegemonía del centro de la ciudad, proponiendo experiencias artísticas en un barrio, lejos y por fuera del centro, e interpelando a los vecinos y deambulantes. En las siguientes muestras en las ediciones que van del 2005 al 2009, una décadas después de la primera, los ejes-fuerza fueron otros. Se trataba de un momento social diferente, de "encerrarse en la propia casa" y de desconfianza hacia el otro, un momento marcado por las rejas en las casas, por el "Alerta! vecino vigilando". Para Fabiana "el barrio estaba cambiado, no era el mismo del 95, estaba peor en algún sentido. En términos de comunidad, en términos sociales, había pasado un proceso muy profundo de pasaje a la vida privada. Un barrio un poco paranoico con la inseguridad y muy vuelto a la vida privada." En ese contexto el grupo decidió darle un giro a la Muestra para discutir el espacio: "en ese contexto a nosotros nos pareció que era el momento ya no para decir 'bueno saquemos el arte del museo y pongámoslo en la verdulería' sino poner en discusión el uso de los espacios y esta cuestión del retiro a la vida privada" (E 1). Así se instalaron dos nuevos y potentes ejes para tensionar y poner en discusión: los "usos del espacio" de la ciudad y el barrio, y el "retiro a la vida privada", al autoencierro. La modalidad adoptada fue invitar a los vecinos a que prestaran parte de sus casas: "abrir el garage". Así, en la Muestra hubo una fuerte puesta en tensión de las fronteras entre "lo público y lo privado", articulando los espacios domésticos -sobre todo garages de vecinos, pero también los patios-, las producciones artísticas y los “deambulantes” de una Muestra. En la MA del 2005 hubo cinco garages abiertos, en la edición de 2009 más de 30. Esto da la pauta, por un lado, de la magnitud de la Muestra y a su vez, del interés creciente de los vecinos de Meridiano V en esta propuesta.

Según Ernesto, para Sienvolando "el espacio público era un lugar en el que construíamos relaciones" (E 7). Podemos interpretar que para este colectivo el espacio público se liga con la "experiencia urbana", por ahí pasaba una fuerte convicción e iniciativa para sus prácticas: construir lazos, fortalecer una "red de relaciones":

"la vereda era un lugar en el que te relacionabas. Ahí donde estábamos pintando era una forma de relacionarte y la web eran relaciones. (...) lo público como lugar que incluye 
otras cosas, pero desde el lugar de relacionarse, lo público como las relaciones, como cuidar eso..." (E 7, Ernesto)

En ese sentido, Pili de Sienvolando rescata el momento de estar compartiendo con otros, eso espacios de encuentro, más allá del mural: "estar con tus amigos haciendo algo, compartiendo algo, pasando toda una tarde", una situación "afectiva". También recuerda que "era un encuentro con gente que en otros momentos y en otras situaciones, en otros lugares, no veías." (E 9)

"Había gente que era la de los murales. Gente que iba para esos momentos que después yo no me cruzaba a tomar unos mates, pero ahí me tomaba tres termos. Charlaba horas, y después en otros momentos no me buscaba un lugar para ir a ver a esa gente.” (E 9, Pili)

Pili a su vez recuerda que en el grupo discutían muchos sobre el espacio, el lenguaje y las diferentes gramática que se validan en el espacio de la ciudad: "cómo nombrar, cómo presentarse, cómo intervenir en el espacio, hacia quiénes hablar.” (E 9)

"quiénes son los que sí tienen permitido hablar en el espacio público o en el espacio de la ciudad. En ese momento decíamos: 'Bueno, nosotros no queremos hablarle al afiche de otro partido. Vamos a hablar con la publicidad que es quien tiene ese lugar válido en el espacio público. Hablemos en esos términos, o por lo menos, empecemos a ver qué hacen ellos para poder hablar en el espacio público'. Y a la vez tratando de tomar terreno en la web como espacio válido también de intervenir, y generar como un cruce entre la calle y la web." (E 9, Pili)

En sentido similar, Dani considera que en el último período de Sienvolando se comenzó a entender que "la web era parte de lo público" (E 8). Parte importante de la construcción de su experiencia colectiva era la producción de un vocabulario "para recuperar la palabra", plantea Ernesto. En tal sentido, había una interesante discursividad en el grupo sobre la porosidad y mutabilidad de la ciudad: plantear como idea "la piel de la ciudad" va en esa dirección, discutiendo la eternización y perdurabilidad de las inscripciones en ese espacio -discutiendo así con cierto muralismo instituido-. Pero también, plantear que se salía a dialogar y disputar sentido con la publicidad callejera habla de en dónde y hacia quiénes se ponía el centro de una acción, su interlocución y disputa simbólica: "decíamos que nuestra disputa era con Coca Cola”. Pero además se planteaba el desplazamiento de los dispositivos de la web llevados a la calle (el buscador de Google con los rostros de Maxi y Darío en una pintada en el centro de la ciudad); y en otro nivel, al plantear las extensiones de una 
experiencia comunicativa -la del "espacio público ampliado"- por el desarrollo y uso de las tecnologías digitales (llevado adelante en la campaña "Hacé como José”): “(...) tenés en la superficie de la acción, de la materialidad de lo que se está haciendo, una discusión de cuál es el espacio público, qué tipo de espacio público y hasta dónde entra o sale.” (E 7, Ernesto).

Carlos destaca que en la Muralista Hermanos Tello "la calle" -casi como término intercambiable con la ciudad- era "un espacio completamente en disputa", lo que se buscaba con las intervenciones era "empoderar a la ciudadanía y al espacio" (E 17).

"Siempre estuvimos pensando en eso. Cuando nosotros veíamos la consigna de "Ciudad limpia"... veíamos "Ciudad limpia" por todos lados y los locos estaban ahí. Nosotros veíamos por todos lados la ciudad como un espacio de una batalla, como una disputa por una construcción de la memoria. Hay una memoria que está borrada y que fue dirigida desde el capital, desde el aparato del Estado. Nosotros en un principio dijimos: "bueno, aquí hay una intención de borrar un poco la memoria histórica". Pero, hay también una cuestión de la calle. Las paredes son el grito del pueblo. Entonces, hay una cuestión de reivindicación, porque tiene que ver a eso, al empoderamiento territorial.” (E 17, Carlos)

La ciudad entonces como un "campo de batalla simbólico", donde "se viven cotidianamente estos cambios culturales. Nosotros lo más cercano que teníamos fue la pintura y fue la muralla, y fue la pared." (E 17, Carlos).

Julia (E 16) reconoce que en Siempre no se dieron grandes discusiones sobre la ciudad y el espacio público, sino que la intervención en la ciudad se dió por algunas cuestiones concretas: la necesidad de conseguir un lugar para ensayar y por las cuestiones que estaban sucediendo en la coyuntura. A su vez, que esta acción en la calle emprendida por Siempre fue un gran aprendizaje para otras creaciones y proyectos:

"nosotras en realidad salimos a la calle, porque no teníamos espacio. Lo hicimos y porque teníamos que hacerlo, porque estaban pasando cosas... pero, bueno, coincidió con eso otro. Y ahora (en otros proyectos) seguimos en la calle, a partir de ahí seguimos en la calle y cada vez menos en teatros. nos gustó. (...) Más allá de la necesidad de salir a la calle y decir tal cosa... el proceso del colectivo, el tiempo del colectivo fue una instancia de aprendizaje. Yo al día de hoy siento que puedo resolver un montón de situaciones en la calle en relación a la creación, de crear algo en un espacio no convencional, porque transité esos años en el colectivo. Fue mi inicio en el arte callejero y hoy no, es que hago arte callejero, pero sí que puedo pensar el espacio público como un posible campo de acción. Me resulta cercano, algo a lo que le doy la misma importancia que un escenario tradicional." (E 16, Julia) 
En Arte al Ataque no encuentran "algo particular con la ciudad de La Plata", ya que a cada uno de los integrantes del grupo le tocó "estar acá por distintas circunstancias... muchos no somos de La Plata. La mayoría por venirse a estudiar nos tocó estar acá.” (E 18) Sin embargo, sí reconocen algo específico de su experiencia con "la calle" o el "espacio público". Lo entienden como un "escenario" lleno de potencialidades para la vida y para desarrollar la acción. Pero es preciso desnaturalizar los usos comunes -circular- y "disputar" a los diversos poderes -comercial, mediático, institucional:

"la calle, el espacio público, para nosotros siempre fue como nuestro escenario. Intentamos que no sea un lugar de paso y que las intervenciones rompan con ese circular cotidiano del espacio público. O sea, que tengas que frenar, pensar, asustarte. Por esto también fuimos modificando la forma de intervenir: usando pelucas, poniéndonos máscaras. Digamos, formas de que la gente esté obligada a vernos, de alguna forma. Una movilización hoy puede ser un hecho natural, tener que esperar más para poder cruzar por diagonal 74 porque hay una marcha, un esténcil es algo natural. Buscamos algunas formas de romper otra vez con eso, de desnaturalizar lo que se quiere naturalizar para poder generar algunas reflexiones. Y creemos que es un espacio que cada vez está menos público, más reglamentado, mediatizado, comercializado y que tiene una potencialidad que no tienen otros lugares. Lo que uno puede aprender, lo que uno puede vivir en la calle, no lo puede vivir en otros lados. El hecho de una murga ensayando y lo que implica eso, (...) lo que implica estar sentado tomando unos mates en la plaza, para nosotros son espacios que están en disputa. (...) Hay otros lugares que han tenido una pérdida o una normatización en el espacio público que no permite esas lógicas. De eso a tirar un pan y vender, digamos. Es el espacio que para nosotros nos forma como personas. Entonces, por eso siempre buscamos de intervenir en el espacio, pero también intervenir para el espacio, problematizando que el espacio tiene toda esa potencialidad."

En Luli hubo una ampliación de la idea de comprender a la web como parte de lo público, que estuvo presente en el último momento de Sienvolando -sobre todo con las acciones "Buscar justicia” y "Hacé como José"-. Ernesto comenta que "había todo esta cuestión del espacio público ampliado como idea, como cosa que te motoriza." (E 19). En este sentido, Pili (E 20) reconoce que en Luli se configuró una experiencia que partía de repensar muchas cuestiones, entre ellas, el replanteo "hacia adentro de la militancia, o hacia adentro de ciertos circuitos de la construcción del espacio público (...) pensar desde otro lugar ciertos dispositivos, o ciertas formas". Ella ejemplifica estas búsquedas y replanteos con lo cuestiones que desató la aplicación "Buscando a López":

"Creo que fue una acción que tuvo como una llegada hacia afuera y otra llegada hacia adentro, el circuito militante, digamos. Como que tenía distintas lecturas hacia adentro y 
hacia afuera. Después, pensar en el dispositivo web no solo como espacio de acción donde uno va y pone contenidos, sino que uno puede generar contenido a través de pensar ese dispositivo y su lógica interna: ¿cómo funciona una aplicación?, ¿cómo una aplicación, que puede ser un juego, te puede dar información acerca de un caso como el de López?. ¿cómo cruzar la web y la calle?... También empezar a pensar lógicas publicitarias, pensar formas de comunicar que teníamos al alcance y que por ahí otros utilizaban y nosotros no, en ciertos espacios se estaban utilizando medios para reproducir lo mismo que se producía en otro lugar. (...) Lo más común en grupos de intervención es usar la web para mostrar la acción que hicimos en otro lugar. Como que eso ya estaba demasiado utilizado como registro, y no como producción de contenidos. Incluso, me parece que 'Buscando a López', está más elaborado o más repensado ese espacio de la web más que en 'Buscar Justicia' (la de Darío y Maxi), que ahí hay un uso potente de la web. Pero me parece que en casi dos años después ya era otra situación. Creo que el impacto fue diferente, ahí no se dijo que se estaba banalizando la lucha de los compañeros, se lo utilizó como un recurso. Y acá -por 'Buscando a López'- pasó todo lo contrario. Incluso cuando está más discutida la mediación de: "bueno, estamos hablando de lo que estamos también discutiendo en la web" (...) como que las mediaciones: "bueno, vamos a pensar la web". está mucho más trabajada ahí." (E 20, Pili).

Por su parte, en la experiencia de Luxor, el espacio de la ciudad aparece como un lugar a intervenir y conquistar con las pintadas y graffitis. Estas inscripciones de figuras y colores son si están "en la calle”. De este modo, el graffiti es, tiene razón de ser en el espacio y en la temporalidad, permanencia y persistencia de la acción: "estar en todos lados" y "todo el tiempo estar en la calle".

“el graffiti para mí es estar todo el tiempo en la calle, eso es el graffiti. Lo que pasa es que no puse mi nombre básicamente, en vez de poner "Luxor" (...) puse personajes para que hablen de mí. (...) hasta que se vea que uno está en todos lados. Cuando me dicen "estás en todos lados", digo sí, "esa es mi conquista, estar en todos lados", "ese es mi objetivo". Antes había una pared gris, ahora está un graffiti (...) Se superó una instancia, logramos ganar un espacio más, más allá de lo que pueda opinar de esa pintura”. (E 23, Luxor)

Parecería que en las prácticas de Luxor el espacio público es principalmente reconocido como el espacio urbano sobre todo en algunas de sus dimensiones y formas: "la calle", "la pared" y "la vereda" (esta última para conversar). Es decir, una superficie y un recurso para ser intervenido y en el que desplegar determinada "poética" visual. Desde allí es que se puede comprender que Luxor toma la dinámica del graffiti de "estar todo el tiempo en la calle". Su acción es pintar la ciudad, pintar los barrios para marcar presencia -allí se pueden reconocer los comentarios del tono "Luxor está en todos lados"- y a la vez, inscribir 
sus formas estético-visuales (presencia de personajes, anclaje en una idea-fuerza, colores fuertes y pregnantes, juego con las líneas y trazos).

Se puede plantear que entre 2012 y 2013 Luxor ha comenzado a producir un desplazamiento en los espacios de la ciudad y los circuitos en los que pinta: de una fuerte presencia en el casco urbano en los primeros momentos de su acción a "pintar en los barrios", espacios en los que encuentra dinámicas diferentes. Según su mirada: "Mi intención es siempre pintar en barrios (...) todo lo contrario (es) el barrio al centro. Pero a mí me gusta más, no es tan anónimo, es más interesante: tenés que estar.” (E 23, Luxor)

\section{Articulaciones}

En la experiencia de La Grieta juntarse y compartir con otros es un eje fuerte de su hacer. La MA, en todas sus ediciones, involucró a muchos artistas -artistas plásticos, músicos, talleristas, grupos de danza- y productores culturales de la ciudad, pero también de Buenos Aires y la provincia-. Además, de un vínculo previo y constante con comerciantes, vecinos y grupos barriales -la asamblea barrial, los clubes, el Centro Estación Provincial-. En 2005, luego de haber tomado y recuperado un galpón abandonado de la estación de trenes de Meridiano V, desde La Grieta entendieron que más allá del convenio de "uso precario" que firmaron con la empresa Ferrobaires, tenían que construir un "lazo con el barrio, que es en definitiva lo que te sostiene, lo que te hace estar en un lugar, estar". Es así que para sostener y legitimar esa ocupación decidieron re-editar la MA a diez años de haber realizado la primera. En la MA se pueden encontrar algunos niveles diferenciados entre actores participantes (grupo organizador, amigos y compañeros que apoyaban, vecinos, artistas y público o "ambulantes"), sin embargo en la puesta en acto durante los momentos previos y sobre todo en el desarrollo de los días de la Muestra adquiere una complejidad en las formas de participación e involucramiento, lo que implica diferentes modos y tiempos de habla y escucha:

"Es complejo, hasta de elaborarlo en el tiempo también, porque uno no es tan autoconsciente cuando hace las cosas de lo que está sucediendo y la muestra tenía como especialmente ese carácter, de que excedía ampliamente cualquier capacidad de racionalización, de conceptualización in situ, ahí, de lo que sucedía. Pero en cuanto a estos niveles de cómo operaban estos distintos actores y qué lugar también ocupan en todo esto. No son ni tan compartimentados, se mezclan a veces un poco también y por otro lado se diferencian, porque una cosa éramos nosotros que nos desvariábamos, 
trasnochábamos hablando de estas discusiones de lecturas, políticas y teóricas. Otro momento es cuando a todo eso había que traducirlo a una convocatoria al artista; otra instancia es cuando todo eso uno quería conversarlo con el vecino, que es otra escucha, es otra habla." (E 1, Fabiana)

A su vez, se encuentra una articulación de todos los días en el hacer del grupo y particularmente en el hacer en el galpón, que se relaciona con los "cruces" entre generaciones y edades diferentes, en el trabajo con la infancia y con los adultos. Dice Andrea:

"las diferentes capas etarias, hacer ya ese cruce, pone a las relaciones como todas mezcladas. Esto que decís que siempre hay grandes con chicos, y damos talleres para grandes, y cuando los damos, todos esos grandes que vienen, saben que acá estamos dando talleres para chicos, y estamos todo el tiempo incentivando a que vengan los grandes a las muestras de los chicos, y los chicos vengan a las muestras de los grandes. Y que las familias empiecen a cruzarse, que estén de un modo también. Que sean parte del espacio y de las producciones y del hacer." (E 3, Andrea)

Como ya se mencionó, en la trayectoria de Sienvolando el encuentro con otros, las articulaciones para realizar las acciones son parte fundamental de su experiencia de intervención en la ciudad. Tanto con movimientos y organizaciones sociales, políticas, sindicales, territoriales y de derechos humanos ${ }^{206}$, como otros grupos de intervención (Espacio cultural del FPDS, Arte al Ataque, Unidad Muralista Hermanos Tello, Siempre, HIJOS La Plata, entre otros): "no pensábamos que la acción la hacíamos nosotros, sino que era un gran colectivo que se extendía y participábamos" (E 7, Ernesto) No era Sienvolando sino "una red", un movimiento colectivo que realizaba "la ciudad", la propia ciudad se activaba para movilizar discursos, para decir y hablar.

"tiene que ver con una red, no fue algo que hiciera Sienvolando. Creo que era un montón de actividad que hacía la ciudad. Es una ciudad, me parece, que tiene una actividad desbordante, entonces vos estabas dentro de una articulación donde una cosa llamaba a otra. Había montones de poéticas que nos sirvan para poder llevar adelante toda esa actividad. Pero esta actividad venía por demanda, muchísima, y por iniciativa propia, muchísima. (...) Estabas en una red y todo el tiempo estabas haciendo cosas." (E 7, Ernesto).

De este modo, el colectivo realizaba un "construcción" más "orgánica" y "cotidiana" con el movimiento social plantea Ernesto (E 19).

\footnotetext{
206 Trabajadores de Mafissa, Suteba La Plata, Multisectorial La Plata-Berisso-Ensenada, Asamblea por los Derechos de la Niñez, Frente Popular Darío Santillán, Autoconvocados contra el SIDA, Correpi, HIJOS La Plata, Agrupación Surcos, Asamblea por Sandra Ayala Gamboa, Asamblea contra el aumento del boleto.
} 
"En Sienvolando había más una articulación entre... vamos y pintamos el mural, una de las últimas acciones, allá en Villa Argüello, es de un carácter claramente de acompañamiento, de ese estilo. (...) Tenía como mucho más en mente la relación, si se quiere, con el movimiento social y político de La Plata (...) Sienvolando tenía mucho más una construcción orgánica. Tenía ese chiste que estuvo muy interesante, el de ser la construcción orgánica al movimiento sin serlo, sin pertenecer a ningún partido ni nada. Sienvolando iba a las reuniones del espacio por Sandra, iba mucho con el Frente, hacía esto con la gente de PTS y Mafissa, y estaba ahí en Mafissa, con la gente de SUTEBA y estaba ahí con la Multisectorial, estaba con el Favero y estaba un mes adentro. Como que tenía una articulación mucho más intensa de valoración.” (E 19, Ernesto)

Por su parte, en la Muralista Hermanos Tello existió una permanente intención de articular con las luchas y organizaciones sociales, pensado en la construcción de una herramienta o soporte artístico y comunicacional para éstas, pero sin una mirada vanguardista. Por lo tanto tampoco se buscó una actividad muralista en sí misma, desvinculada de contextos, grupos o coordinaciones.

"No era una actividad muralista, no tenía solución a los problemas. O sea, (...) una organización artística que está codo a codo con organizaciones sociales, que se plantea desde ese lado. Una organización artística dentro de un espacio político como herramienta era la intención." (E 17, Carlos)

Algunas de las organizaciones y colectivos con los que la Muralista articuló fueron: HIJOS La Plata, la Multisectorial, centros culturales como el Olga Vázquez, Hermanos Zaragoza y el Galpón de Tolosa, la FLIA La Plata, y otros colectivos de intervención como Sienvolando, Siempre, y Arte al Ataque, con los que coordinaron muchas de sus acciones.

En cuanto al colectivo Siempre, Renée reconoce que la primera acción por López "fue muy importante", y habilitó las relaciones y encuentros con otros grupos culturales que activaban en La Plata:

"Ahí nos une a varios grupos de la ciudad. Nos encontramos pensando las maneras de evidenciar lo sucedido. Ahí trabajamos con el rostro de López. Lo hicimos, lo presentamos, lo compartimos con otros grupos. Participamos de esas reuniones tanto en el (Centro) Olga (Vázquez) como en distintos espacios." (E 13, Renée)

Diana y Mariana amplían esta caracterización sobre sus vínculos con otros grupos locales: "un poco de todo. Empezamos a movernos en un circuito en donde te cruzabas con otros... con otra gente que estaba como en la misma situación o en lo mismo... se empezaron a dar 
intercambios." (E 15, Mariana e. y Diana). Desde Siempre articularon algunas actividades puntuales con Sienvolando, HIJOS La Plata, Tinta Roja, Surcos. También fueron parte de algunas actividades que se armaron en el Centro social "Olga Vázquez (FPDS), participaron de la "Muestra Ambulante" en sus dos últimas ediciones y de jornadas como "Arde Closet" y sobre el feminicidio de Sandra Ayala Gamboa.

Uno de los integrantes de Arte al Ataque plantea que el colectivo "siempre tuvo la decisión de coordinar y de compartir experiencias, de nutrirse”. En este sentido, destacan sobre todo los espacios de encuentros con otros colectivos y organizaciones como "La Calle es nuestra" (2010) y la participación en los ENECA (Encuentro Nacional de Espacios Culturales y Autónomos). Por su parte a nivel local recuerdan que han "trabajado distintos ejes con Sienvolando, con Los Tello, con la Olla. Después, Luli.” (E 18) Como una suerte de balance sobre la proliferación de colectivos culturales en la ciudad plantean que : "son más o menos los mismos grupos con distintos nombres":

"distintas personas o ya personas que antes eran grupo, Ahora quedaron individuos, pero hay una... es más o menos ese mismo espacio que se fue manteniendo. Un espacio de la cultura independiente de La Plata. Eso está muy bueno. Creció en los últimos años. El fenómeno que se dio en La Plata, yo no conozco que esté en otros lados. Permite que aparezcan nuevos espacios, que crezcan las articulaciones. Antes, tal vez era más sencillo porque éramos cuatro, cinco grupos, dos o tres centros culturales, y nos manejábamos con eso.” (E 18)

Para Ernesto (E 19), Luli "si bien tenía muy buenas relaciones" y "dialogaba fuerte con todo el movimiento" social de la ciudad, producía una interpelación "más desde afuera" sin esa impronta "orgánica" de Sienvolando-, lo que se daba ventajas y desventajas a su hacer. "Ventaja por concentrar la energía de una forma más intensa de hacer interpelaciones mucho más pulidas. La desventaja perderse la riqueza de una relación con mucho más termómetro de coyuntura, de algo mucho más real." (E 19, Ernesto). ${ }^{207}$ Un ejemplo que puede servir para comprender esta relación menos "orgánica" con el "movimiento" fue la construcción visual que Luli armó para una de las jornadas por el feminicidio de Sandra Ayala Gamboa realizada en agosto de 2011. El grupo aportó construyendo la gráfica para la intervención pero su participación / involucramiento terminó con el envío por mail de estos materiales. Ernesto lo ilustra del siguiente modo, tensionándolo con el tipo de relaciones que construía Sienvolando:

207 Dani aporta algo más para entender esto: “eso que buscábamos en Sienvolando de saltar el cerco militante, fue profundizándolo Luli, como que fue una búsqueda más fuerte.” (E 22). 
"Cuando (con Sienvolando) se pintó lo de Google, se pintó con la gente del Frente Popular Darío Santillán pintándolo. Todo era con una vinculación poética. Ahora, nosotros en Luli, el punto más alto que nos pareció, fue cuando mandamos por mail la gráfica, que las chicas que hicieron la intervención en lo de Sandra, pusieron.” (E 19) ${ }^{208}$

Dani también repiensa esta cuestión sobre las formas de articulación de menos implicación con las organización: "el lugar de articulación. era la web, era la red de contactos, la red de militantes cercana." (“E22) A su vez, plantea que Luli ejerció más de un diálogo con un "microclima cultural" de clase media de la ciudad y brinda otras ejemplos:

"por eso digo también que... quizás más clase media lo de Luli. Aunque Sienvolando fue re clase media, pero me parece que se embarraba un poco más que Luli. También éramos menos, era otro momento de las organizaciones. Me parece que estábamos más hablando de un microclima cultural que de un conflicto. Porque con lo de "Mafissa" de Sienvolando. eso fue ir, estar, hablar, laburar con la gente. Y lo de "Terrabusi", fue ir a pintar la pared y nos fuimos. En Luli había menos coordinación y había más autonomía, menos mediación con la organización. Lo de López con el gorrito fue re discutido, creo que hubiese sido muy difícil llevar a discusión lo de López con el gorrito adentro de la multisectorial" (E 22, Dani).

Pili destaca que lo sostuvo la experiencia de Luli -como también antes la de Sienvolando- fue una "red afectiva".

"que era la que nos permitía ser Luli, y hacer ciertas acciones, que por ahí en un ambiente militante... digamos, ya teníamos un recorrido donde: "bueno, sí. son estos pibes". como que algunos nos criticarían un poco más, otros un poco menos, o aceptarían un poco lo que hacíamos. Pero esas redes estaban conformadas por gente que queríamos." (E 20, Pili)

En la experiencia de Luxor las articulaciones cobran la forma de eventos, encuentros y proyectos colectivos puntuales desde "la independencia". Estos eventos-articulaciones fueron "Intervención Magenta" (2010), "Proyecto Kalle” (2011), "La pantufleta refrescante" (2011), “Encuentro ZigZag” (2012), "Volver a habitar” (2013 y 2014), “Concreto, museo de la calle" (2014), el proyecto-libro "Que cada día sea mágico y lleno de sueños" junto con la

\footnotetext{
${ }^{208}$ Sobre esta participación puntal de Luli en esa jornada, Dani comenta "hicimos el diseño, ni siquiera armar los banners, los mandamos a imprimir y les dijimos que los vayan a buscar. (...) Esa fue una especie de primera retirada. También lo que pasaba era eso... situaciones particulares que nos estaban llevando a que era cada vez más difícil salir, pero sí había un montón de gente queriendo hacer cosas. Me acuerdo que fue una prueba que nos re gustó. (...) Estuvo bueno para mí. Fue una discusión interesante eso de pensar el lugar del colectivo que interviene, y por ahí, el lugar era el que te ayudaba a diseñar una intervención. (...) Lo que necesitaban las organizaciones feministas era volver a volcar en esa casa de Sandra una intervención fuerte sobre Sandra. A mí me re-gustó esa experiencia. Pero también se puede leer como un síntoma de cómo estábamos.” (E 22, Dani).
} 
biblioteca infantil Del otro lado del árbol (2014), “2 PI” junto a Acra, otro interventor gráfico. La gestión del espacio cultural de Club "Alborada" (2010-2013) y de "Obrador 45" (desde inicios de 2016). También las muestras individuales y colectivas que ha producido en espacios culturales alternativos de la ciudad pueden interpretarse como articulaciones con otros -no sólo por la implicación de otros productores gráficos, sino por la participación de bandas musicales, DJ's para ambientar, fotógrafos para registrar los eventos, etc-. Sobre todo en las acciones que involucran a otros productores visuales se construye cierta grupalidad "sindical" que se reúne para hacer ("pintar"), abre diálogos para ampliar las acciones y "tomar partido de una situación":

"para mí es como un espacio de "lo sindical". como si decís, ¿de qué manera implementas tu teoría? lo demostrás construyéndola. La pintura callejera o gráfica es eso, es tomar partido de una situación y decir "¿qué hago con ésto?", que lo puede hacer cualquiera. quiero hacer pintura o me interesa ésto y los eventos es como materializar eso... tu teoría política" (E 23, Luxor)

\section{Usos y prácticas de comunicación}

La MA de 1995 tuvo un trabajo de difusión "precario" -principalmente afiches por el barrio Meridiano V y por Facultades-, fue "todo muy casero, no había redes sociales ni mail". Pero, a diferencia de las siguientes muestras, salió en la tapa del diario El Día. La Muestra contó con poco registro y desorganizado: desde La Grieta lo calificaron como "muy malo". La MA 3 contó con registro pero no sistematizado. En las dos últimas ediciones hubo un grupo encargado de la comunicación y el registro de la Muestra -en esa acción de pensar estratégicamente la comunicación tuvo importancia la presencia del grupo de gestión cultural Medio Limón-: "ya había algunos criterios, eso aparece recién en la de 2007, esa cabeza de registro, de registremos para". Esta tarea se entendió como importante previamente, "se organizó y socializó ese trabajo, no de hacerlo entre nosotros, así como se invita a un artista se invita a un fotógrafo para que registre y esa persona es tan importante como el artista que expone”. Antes de la $5^{\text {a }}$ Muestra la Grieta editó -en mayo de 2009- junto con la Facultad de Bellas Artes el "Catálogo de la $4^{\mathrm{a}}$ Muestra Ambulante" en el marco de un Proyecto de Extensión de la UNLP titulado "Arte vivo". De la producción artesanal de afiches y con pocas personas en la organización de la muestra se pasó a contar -sobre todo en las ediciones 2007 y 2009- con personas con tareas específicas de comunicación y más recursos 
financieros para solventar afiches a color y de mayor calidad, catálogos, señaléticas, stickers, etc. $^{209}$ A su vez, hubo una intensa construcción discursiva de la MA en la que había una fuerte interpelación al destinatario a "salir afuera", "al encuentro", a ocupar la calle y los espacios del barrio. ${ }^{210}$

En Sienvolando las formas de comunicación estuvieron asociadas, por un lado a su blog a través de imágenes, breves descripciones escritas y algunos videos cortos. En esta plataforma hay un pormenorizado registro de todas las acciones e intervenciones del grupo divididas por fecha, categorías y etiquetas: "el registro siempre estuvo pensado. Era una parte fundamental de la práctica”. Además cobró fuerza la utilización de pegatinas y figurones para promocionar sus eventos -sobre todo fiestas que las entendían como otra acción más. No hubo utilización de redes sociales y algo de registro audiovisual. Hubo una sola aparición en medios gráficos tradicionales -una nota por el mural realizado junto a Adhes- y sí hubo notas en medios alternativos: Indymedia, La Pulseada y Prensa de Frente, así como algunas notas en radios comunitarias. La principal forma de comunicación de Sienvolando eran las propias acciones en las que se "construían relaciones", ese era el objetivo del Colectivo.

En Siempre las cuestiones de la comunicación, el registro y la documentación de las acciones no fueron sistemáticas. Su blog funcionó casi como única plataforma en ese sentido, luego también el perfil de Facebook: "siempre había alguna que lo hacía, una agarraba y lo subía, Por eso es medio caótico.” (E 16, Julia). Para Mariana (E 14) el blog: “empezó a ser como un lugar para difundir lo que hacíamos."

"Por otro lado como el lugar de poner lo que estábamos pensando, poner en circulación lo que estábamos haciendo como posibilidad de interactuar con otra gente. Que de hecho funcionaba, porque a raíz del blog recibíamos correos, comentarios. Fue un poco eso. Como una cuestión más de dar visibilidad y de poner en circulación y en discusión algunas cosas." (e 14, Mariana s.)

\footnotetext{
${ }^{209}$ En la edición de 2009 el grupo responsable de la comunicación produjo un perfil de Facebook y dos blogs: uno como bitácora previa y diaria sobre la MA y otra como fotogalería. Además, existieron notas y entrevistas referenciando a la MA en medios alternativos de la ciudad: Indymedia La Plata, Prensa de frente, La Pulseada, Radio Futura, entre otros y en radios estatales: Radio Universidad y Radio Provincia.

${ }^{210}$ Entre esas discursividades construidas se pueden destacar: "(...) que la calle deje de ser un espacio de circulación para que vuelva a ser un espacio de encuentro (...) una muestra, muchas muestras!” (edición 2006); "otra vez la silla en la vereda" y "arte en las veredas, los comercios y los garages" (estos dos últimos, ejesslogan de la edición 2007); "La ciudad se mueve, los vecinos salen a la calle se encuentran. El arte está vivo. La cultura en las veredas" (programa de la edición, 2007); "propuesta cultural para encontrarse, compartir y crear en las calles, casas, comercios y veredas" (folleto "Noticias ambulantes", edición 2009). Hay en esta construcción una fuerte interpelación al destinatario a "salir afuera", "al encuentro", a ocupar la calle y los espacios del barrio.
} 
Desde Arte al Ataque plantean que "La web siempre nos pareció una pata... como que desde arrancó Facebook, estamos en Facebook." En relación a su blog, que es otras de sus plataformas muy utilizada mencionan: "Tenemos un blog que es el más actualizado en la historia de los blogs, porque cada vez que queres buscar algo, sabes que está. Eso es muy zarpado, porque hubo compañeras que tuvieron mucha constancia manteniendo eso." (E 18). ${ }^{211}$ A su vez, en cuanto al registro de las acciones, desde el colectivo dicen que "no lo pensamos mucho".

"Está, pero la idea no es compartir tres millones de fotos, sino un álbum que sea más fácil de ver. La idea no es que se busque una persona específicamente, sino la acción y... registrar la acción. No lo hemos discutido mucho. (...) Tuvimos una cosa de querer registrar. Hay muchos videos. Está la cuestión de la firma, y eso es una discusión de si es colectivo o es individual." (E 18, Arte al Ataque)

Sobre los usos creativos y astutos en la web y las redes desde Arte al Ataque mencionan la complejidad del momento actual que está poblado de flyer y memes.

“por ahí en su momento hacíamos imágenes a lo que nosotros le llamábamos 'molotov', imágenes que sabíamos que iban a tener repercusión, como una especie de flyer como gracioso, pero medio duro. Pero hoy son los millones de memes, hoy ya es moneda corriente las millones de páginas que hacen eso. Pero para ese momento era medio picante, y era picante dentro de nuestra organización, incluso. Sentíamos que también había que revolucionar desde ese lado. Eso es algo que dentro de la organización se valora muchísimo." (E 18)

Para Dani en Luli había una búsqueda más clara y permanente de los recursos de la gráfica, la web y la comunicación. A diferencia de Sienvolando, “creo que ya estábamos más aburridos de lo plástico (...) había mucho diálogo con la publicidad. La búsqueda de Luli es bien gráfica". Con esto Dani elabora una clave de lectura para pensar las diferentes acciones de Luli, la intervención en "la web era mucho más militante que la intervención en la calle, que era mucho más abierta." (E 22) Se puede reconocer en Luli no tanto la idea de usar la comunicación y la web como "medio de difusión" de las acciones, sino como la acción misma desde un posicionamiento particular y crítico, reconociendo el lugar destacado que

\footnotetext{
${ }^{211}$ También agregan una característica importante del blog como archivo de la experiencia del grupo: "Es un archivero muy zarpado. Por ahí uno que entra y lo administra, ve la interacción que hay o no, si comentan. Entonces, no es algo que se mueve mucho, sí hay gente que es más... existen todavía los blogueros que están más metidos en ese mundo, pero es un buen archivo. Está bueno tenerlo. Y más con lo que nos pasó que nos cerraron como tres o cuatro veces el Facebook." (E 18, Arte al Ataque)
} 
tienen en la contemporaneidad. Se puede encontrar así un uso táctico de las herramientas y recursos de la web, las redes sociales y la comunicación para ampliar los modos de la intervención cultural e intentar salir efectivamente del "cerco militante"

"esto de saltar el cerco militante (...) nos interesaba dar esa discusión. Sobre todo era esto como de tratar de interferir un poco más en Facebook, estar un poco más en esos lugares donde las cosas se replicaban por lugares que uno perdía el contacto y realmente saltaba al círculo militante. más que un mural también.” (E 22, Dani).

Pili agrega una definición de lo que pensaban sobre esto: "la web era una herramienta y un dispositivo para repreguntarse, para accionar, para modificar, para comunicar como lo era la pared.” (E 20)

"En un momento tuvo más trascendencia, porque estábamos empapados de eso. estábamos viviéndolo, nos atravesaba en lo cotidiano. Pero, no había una intención de ser 'net-artistas' o 'artivistas', para nada. Era más dónde poner una discusión simbólica, dónde poner el sentido, y bueno, en ese momento, era más potente ahí.” (E 20, Pili)

En la experiencia de Luxor hay un fuerte uso de la red social Facebook para comunicarse y mostrar sus producciones y recorridos. Cuenta que ni bien comenzó a pintar “armé el Facebook". Allí sube diaria o semanalmente el registro de sus producciones y obras, muchas veces en juego con breves textos poéticos o descriptivos. Una marcada intención de tomar las posibilidades de esa red social como herramienta: "lo pensaba como una herramienta más, es como salir en el diario todos los días; una estrategia." También se adentra en la producción de cortos y microdocumentales audiovisuales publicados en su perfil en Youtube. Además de una fuerte presencia en esa red social -principalmente a través del propio perfil de Facebook y actualmente página-, muchos medios locales, nacionales e internacionales relevaron su experiencia a través de notas y entrevistas. ${ }^{212}$

\footnotetext{
${ }^{212}$ Entre los medios comerciales -los diarios El Día y Diagonales-; entre los medios estatales -las radios Universidad y Provincia-; así como en medios alternativos: revistas La Pulseada, Sudestada y El pasajero, radios populares como Estación Sur, Futura, RadioNauta, agencias como ANRed y NaN; así como portales dedicados al graffiti y el street art (streetartmap.com.ar; buenosairesstreetart.com; escritosenlacalle.com; graficamestiza.com; Murales La Plata) y plataformas audiovisuales y virtuales (Pura vida TV y TEDx). Algunas de estas notas, entrevistas e intervenciones:

Pura Vida TV (2010): https://www.youtube.com/watch?v=zICJmSF7yss

La Pulseada (2013): http://www.lapulseada.com.ar/site/?p=4537

Intervención en TEDx (2014): https://www.youtube.com/watch? $\mathrm{v}=\mathrm{R} 8 \mathrm{Tdfq} X \mathrm{~A} 7 \mathrm{zc}$

El Pasajero (No 94, sep-oct. 2015): https://issuu.com/revistaelpasajero/docs/el pasajero $94 \quad 1 / 1$
} 


\section{Desactivaciones y cambios}

La Grieta ha continuado ininterrumpidamente su práctica desde 1993 a pesar de que hubo muchos cambios en la conformación del grupo -de aquel colectivo que tomó impulso en los años 90’ con la publicación de la revista y el inicio de talleres de creación, actualmente hay tres integrantes que permanecen: Gabriela, Fabiana y Andrea-. Sin embargo, desde 2004 con la recuperación del galpón ferroviario abandonado se comenzó a consolidar una parte importante de su proyecto, vinculado a lo educativo-creativo y a lo territorial, que es hoy el principal motor de la experiencia del grupo. A su vez, en aquel año el grupo editó el último número impreso de la revista. En relación a algunas particularidades de la experiencia del Grupo en todos estos años Daniel (E 4) destaca que:

"La Grieta fue un grupo que para mí, mirándolo retrospectivamente estos 22 años, tiene el mérito de que es un grupo que nunca se partió. Todo aquel que se fue, sigue orbitando, mirando con respeto y acompañando muchas cosas que hace La Grieta.” (E 4, Daniel)

Para Gabriela (E 6) aquellos cambios que implicaron nuevas dimensiones de la experiencia del grupo -pasar a tener un lugar propio, dejar de editar la revista, reeditar la MA en Meridiano $\mathrm{V}^{\mathrm{o}}$ - fueron evaluados colectivamente e involucraron muchas preguntas por los tipos de lazo a entablar con el "afuera" del galpón y de qué modo pensar la ciudad:

"Esa fue una evaluación que hicimos... muy atinada, porque al estar aquí, qué significaba visibilizarnos en un espacio, que es un espacio público. Además, qué tipo de lazo y construcción íbamos a establecer con el espacio que nos circunda, no solo esto, nosotros aquí haciendo los talleres que queríamos hacer. Sí, todo muy lindo, pero qué tipo de relación vamos a establecer, qué tipo de lazos vamos a tejer. En ese sentido, sí fue muy atractivo volver a pensar que la Muestra Ambulante, que podía ser el gran aglutinador de muchas sonoridades, de muchas imágenes, de muchas formas de pensar lo urbano, de pensar la ciudad. Esa pregunta fue conductora de la MA." (E 6, Gabriela)

En relación con esto, también Gabriela, una de las principales hacedoras del día a día de los talleres y las actividades que suceden en el "Galpón de Encomiendas y equipajes", prefiere poner en tensión el reconocer al proyecto del grupo como un proyecto ligado con "lo barrial" y propone vincular el accionar del grupo con la "composición” de la ciudad:

"lo barrial lo pongo en discusión. (...) No hablamos con mis compañeros mucho de esto. Pero estoy convencida de que cada uno pone en discusión algunas cuestiones de lo barrial. (...) Lo nuestro es una apuesta a imaginar la ciudad, a componerla, a generar una 
composición de la ciudad desde una mirada activa. En ese sentido, por más que estuvimos poniendo ladrillo tras ladrillo (en el galpón), no es que no estábamos pensando en qué ciudad deseamos, en qué ciudad necesitamos." (E 6)

En relación a su salida del grupo y al proyecto de La Grieta que se consolidó en los últimos años, el propio Daniel destaca positivamente este cambio en la dinámica y la proyección del grupo:

"para mí, es el grupo más real y lo que es el proyecto de La Grieta que se consolidó, que es ese grupo con un trabajo muy vinculado a lo educativo y territorial, a la traducción de lenguajes y al laburo con pibes. En el momento que me fui, teníamos una serie de discusiones, yo decía que había que pensar cuál era el proyecto de La Grieta, y yo creo que el proyecto es ese, que no me incluye, yo quiero hacer otras cosas. Pero no tengo dudas que el proyecto es el que encarnan ese trabajo en el galpón, pero un galpón mirándose hacia Altos de San Lorenzo y no hacia el centro, con los talleres. No el galpón abriendo los sábados a la noche como un boliche.” (E 4, Daniel)

Como ya se mencionó antes, luego de la última MA el colectivo cerró la posibilidad de organizar una nueva edición de la muestra en Meridiano V. En parte por lo que ya se refirió sobre los cambios urbanos y culturales ocurridos en ese barrio -cambios que abrieron balances distintos dentro de La Grieta-. Pero también por las actuales dinámicas e intereses en los que el grupo está enfocado, ligadas a los espacios de formación y creación con jóvenes y adultos, ámbitos que implican un trabajo cotidiano y, a veces, "invisible" de construcción.

Para Lalo (E 9) Sienvolando comenzó a disolverse por discusiones y problemas internos, sobre todo por la carta documento que envió Google, intimándolos por haber utilizado su logo en la web de la campaña "Buscar justicia"213.

“cuando se arma ese quilombo, que Google manda la carta documento, ahí está, para mí, el quiebre de todo, digamos. o te cura o te mata. (....) En un momento hay que tomar la decisión el grupo de cómo seguir y si vamos a seguir, si levantamos la página o si no.” (E 11)

Pili a su vez repiensa ese momento cuando sucedió la cuestión de la carta: “internamente era un momento en el que Sienvolando estaba débil.” (E 9)

\footnotetext{
${ }^{213}$ En esa carta, enviada por mail desde un un estudio de abogados de CABA asociados a la empresa, intimaban a que den de baja la página web por estar usando la imagen de Google. Pili recuerda el enunciado general de la misma: "Esa imagen tiene copyright, nos la están robando. No queremos hacernos cargo de lo que ustedes digan"”. (E 9)
} 
"En el momento en que llegó la carta, ya habíamos tenido... ya estábamos como en conflicto... En realidad fue a raíz de la carta, pero... entre nosotros estábamos decidiendo bien qué hacíamos cada uno con el grupo, hasta si seguíamos o no. Ninguno podía desde lo personal bancarse un juicio con Google. Ni siquiera como a nivel emocional. (...) Ellos no se dirigen a Sienvolando, se dirigen a uno de nosotros por mail. Entran otras cosas en juego y en las que sí tenés que tener un plafón un poquito más grande como para responder. No éramos León Ferrari. Más allá de que nos conocía un montón de gente, pero era de cierto circuito. Para muchísima otra gente, tal vez, éramos vandalistas. En ese momento, la situación no era la misma que cuando todo el mundo estaba enterado, o por lo menos estaba circulando la acción.” (E 9, Pili).

En ese contexto, según Pili en el grupo "hubo desencuentros entre varios"214 lo que fue llevando a que sucedieron algunas decisiones individuales de dejar el grupo que se fueron sumando. Alguien armó una imagen del "Game Over" del juego PacMan que circuló por mail entre los integrantes del grupo y se decidió que sea la forma de visibilizar hacia afuera el cierre del colectivo. Luego -recuerda Pili- “entre quienes fluíamos más en el hacer, surgió Luli pero no fue: 'Bueno, nos vamos, formamos otros grupo'. O sea, fue: 'Bueno, juntémonos. Qué bajón, ¿qué vamos a hacer ahora?'. Algo natural, porque también teníamos una relación de amistad y de encuentro más allá del colectivo.” (E 9).

Carlos de la UMHT realiza una aguda caracterización sobre la situación de la desactivación de muchas de las experiencias de intervención en la ciudad -entre ellas "Los Tello"-. Lo reconoce como el cierre de "toda una movida artística" y también como una "derrota simbólica" para la militancia que tiene que ver "con nuevos tiempos de lectura", un contexto en el que se pierde una "lectura política" en las organizaciones y los colectivos culturales “dejan de hacer cosas críticas" (E 17).

“- creo que tiene que ver con un proceso de culminación de toda una movida artística. Yo creo que antes había ya... se estaba generando mucha movida, pero culminó con la muestra de "Calle tomada", y después del encuentro de arte y política "La calle es nuestra". Pero todos los grupos que conocimos, todos los grupos que vos nombraste fueron parte de "Calle tomada", y después de "La calle es nuestra", desaparecieron todos. ¿Cómo te explicas eso?

- ¿Vos cómo lo explicarías?

Tiene que ver con el capital simbólico. Hay una huevada en el capital simbólico que nos derrotó. O sea, no es una derrota militante, sino simbólica. Tiene que ver con nuevos

\footnotetext{
${ }^{214}$ Pili recuerda que esos desencuentros no eran porque se llevasen mal entre los integrantes -"nos requerìamos, eramos amigos"-, sino sobre "el hacer colectivo": "en la forma de manejarse en un colectivo, en la forma de hablar como colectivo o de hacer hacia afuera. En la forma de trabajo colectivo. Era una cuestión personal que hacía al trabajo colectivo." (E 9)
} 
tiempos de lectura. Donde no hay una lectura política, que sí o sí las organizaciones culturales tenían que desaparecer o reestructurarse o recontextualizarse, no sé si La Muralista, para mí, le faltaron más militantes. No sé si la lectura es Muralista. Pero sí al contexto de todas las organizaciones. Digo, no muralista, porque en realidad yo creo que otros podrían haber seguido.

- Fue tal vez un faltante de fuerzas militantes... combinado con un discurso cultural que se estaba...

Sí, pero fue un tiempo bastante extraño. Fue incluso extraño para los movimientos sociales, para la misma izquierda. De que mucho núcleo de la militancia se fue para el kirchnerismo y también tiene que ver que fue la muerte de (Néstor) Kirchner. Es otra lectura que tiene que ver al contexto país. Muchos grupos se hicieron kirchneristas y dejaron de ser críticos.

- ¿Y vos crees que eso repercutió directamente a los grupos de intervención de acá de La Plata?

- Indirectamente. Porque dejaron de hacer cosas críticas. Era otro tiempo de lectura. Había que pasar a otro tiempo de ofensiva, también en lo artístico. Los que quedaron sobrevivieron a pura gota, haciendo un 24 (de marzo) y haciendo un 18 (de septiembre). Eso era lo que hacían los colectivos artísticos en todo el año. No hacían nada más. Eso no es vivir. No funciona, no son colectivos. Yo he hablado con colectivos y con organizaciones que funcionan y que están activando lo que fue un tiempo Sienvolando, Luli, La muralista. Que fue activando organizaciones, fue activando militancia, fue haciendo cosas. Vos no encontras a esos colectivos. No sé, me cuesta. Ojalá encontrar un colectivo que activara eso. Porque son colectivos pensados desde una cuestión... incluso de la parte artística, no hay una profundización de qué es lo artístico. Y tiene que ver con la parte de la esencia de la vida. Cuando vos construís arte, construís una belleza. Tiene que ver con cómo interpretas la vida, cómo te interpretas la lucha. Si no eres parte de la solución, te haces parte del problema, querés contar las cosas de colores o querés mostrar... tengo contradicciones. (...) No estoy planteando que ciertos grupos que adhirieron al kirchnerismo, cagaron la vena. Lo que digo es que fue más difícil tener una postura crítica. Entonces, los grupos no fueron críticos. Fueron neutros. Ni fu ni fa. Tanto así que Sienvolando tuvo que romperse, y tuvieron que formar Luli. La Muralista intentó durar un año más, pero no pudo más. Y después... siguió Dani con Ernesto, siguieron los dos juntos armando Síntoma. Armando toda una cuestión más íntima.” ( E 17, Carlos)

Según Mariana en Siempre se dieron "otras discusiones" por las que muchas integrantes no se sintieran "cómodas en el colectivo", debates que empezaron a "tener más que ver con el contexto", discusiones "sobre cómo pararnos en ese lugar y qué transmitir, o qué postura tomar en esa coyuntura"

"Me acuerdo, por ejemplo, que en una de las marchas... como que no me acuerdo exactamente la consigna de la Multisectorial, pero apuntaba directamente al gobierno nacional como que lo responsabilizaba por la desaparición de López. Y eso... como que fue algo que muchas de las integrantes del colectivo no toleraban. Entonces, ahí hubo un 
montón de discusiones en relación a eso. Sobre quién era el culpable de la desaparición de López, y más allá del culpable, a quién queríamos señalar y a quién no, por qué no lo queríamos señalar. Cuál era el enemigo que se quería construir y cuál no. $\mathrm{Y}$ esas fueron las discusiones que fueron ganando cada vez más en el último tiempo.” (E 14, Mariana s.)

Para Julia de Siempre esas diferentes lecturas sobre el kirchnerismo -tanto dentro del propio colectivo como en la coordinación con otras organizaciones-, fue uno de los detonantes de la disolución del grupo. Uno de los sucesos puntuales de ese proceso fueron las diferentes posturas en relación a las acciones y consignas de la movilización del 18 de septiembre de 2008, a 2 años de la segunda depuración de Julio López.

"ese fue como el quiebre. A partir de ahí empezaron las discusiones. Con la llegada del kirchnerismo sobre todo, se empezaron a notar esas divisiones en el grupo. Por un lado, estaban las que empezaron a confiar en el nuevo proyecto, desde el comienzo casi diría y después, había compañeras que no y que defendían la consigna está de la Multisectorial ("silencio $\mathrm{K}=$ impunidad"). A partir de ahí, surgieron estas discusiones, y creo que no sé si volvimos a producir, me parece que todo se fue disolviendo." (E 16, Julia)

Mariana entonces plantea que las principales discusiones que detonaron el cierre del grupo fue lo "coyuntural", que configuró posiciones diferentes -antagónicas e intermediasque no fue posible conciliar:

"muchas discusiones más de tipo políticas, como de la coyuntura, entre 'kirchneristas' y 'trotskistas', fue lo que hizo que sea muy difícil consensuar acciones o estar de acuerdo en hacia dónde apuntar algunas cosas. Y gente en el medio, la mayoría. Pero como que esas posturas más claras o más definidas, hacia un lado o hacia otro, generaban un montón de ruido y como que fue haciendo que el colectivo pierda su potencia. (...) Para mí fue como un proceso de kirchnerización de la sociedad. Ese proceso de algún modo se fue viendo al interior del colectivo. Había quienes ya eran kirchneristas de antes, quienes se mantuvieron en una posición más de izquierda dura, y quienes dábamos vueltas por ahí desorientadas. Pero, como que todo eso nos atravesó un montón. (...) Personalmente, como que todo el fenómeno del kirchnerismo hace que me pregunte un montón de cosas desde donde estoy parada. Y creo que eso nos pasó a un montón de personas. Como ciertas certezas más esquemáticas que una tenía de algunas cosas, se empezaron como a resquebrajar un poco." (E 14, Mariana s.)

Julia también recuerda que el cierre del colectivo "fue un proceso largo el de la disolución, porque todo el tiempo estaba cruzado lo afectivo (...) pasó un tiempo y el grupo se iba desgastando. era como un final a cuentagotas." (E 16) Además menciona la llegada de los hijos y que varias fueron madres a la vez, lo que modificó el tiempo y el espacio que se le 
podía brindar al colectivo. Luego de esa final "a cuentagotas", las integrantes de Siempre decidieron juntarse en un último encuentro para darle un cierre definitivo a la experiencia:

"nos empezamos a juntar cada vez menos y necesitamos como ponerle una fecha de cierre. Nos juntamos a despedirnos, para no dejar que muera, que quede en la nada. Pasó un montón de tiempo sin nada y necesitamos como cerrarlo y no dejar que desaparezca sin nosotras haber decidido el fin de una etapa. Me parece que eso es algo importante como grupo. También, eso hizo que se sigan manteniendo los vínculos de afecto entre nosotras, yo a algunas no las vi más, me las cruzo en las marchas o en lugares así, algunas de las chicas desaparecieron de mi cotidiano, Sin embargo, nos cruzamos y sigue intacto ese afecto. Después, con otras sí, seguimos laburando en diferentes grupos, colectivos, con otros proyectos." (E 16, Julia)

Renée también reconoce que en todo el proceso de Siempre fue de mucho aprendizaje en el contacto como otros colectivos y también encuentra algunas discusiones que no cuajaron en el grupo:

“en ese período entre la primera acción por López hasta que nos empezamos a separar, pasamos un proceso de mucho enriquecimiento con los demás grupos adonde íbamos a discutir. Y ahí, por supuesto que dentro del grupo ya había grandes diferencias. Por ejemplo, a mí personalmente siempre me interesó estar en la lucha de género, y en ese momento también fue el momento donde empezamos a pensarlo cómo nos comprometíamos en esos espacios. Y mis compañeras no estaban tan involucradas, algunas otras sí, pero éramos dos o tres apoyando esa moción.” (E 13, Reéne)

En Luli se "perdió la coyuntura y el cotidiano", plantea Dani (E 22), sumando a algunas adhesiones que se empezaron a notar hacia el kirchnerismo y a la apertura de un "período de normalización” a nivel más general en el país.

“para el final de Luli... no estábamos teniendo coyuntura, se perdió, Entró un periodo de normalización, ese final más kirchnerista, más con Néstor. y me parece que hubo algo ahí, ya se empezó a dividir un poco el agua ahí adentro. También empezamos a perder el cotidiano. (...) La muerte de Néstor también influyó un montón. Para adentro y también para afuera. Fue un momento en que (un integrante del grupo) se alineó más con el kirchnerismo, también. Entonces, ahí las discusiones y agites que se daban, se empezaron a dejar de dar y ya no era la misma coyuntura para todos. También fue un período donde se apagaron muchas cosas en general, fue como el momento de bienestar... para mí fue bien externo, como que nos quedamos sin ideas. (...) me cuesta igual echarle la culpa a algo externo. (...) sí, había pasado algo en la realidad. y creo que todos estábamos 
mirando qué estaba pasando. Algo cambió y nosotros seguimos haciendo lo mismo." (E 22, Dani) $)^{215}$

Ernesto (E 19) realiza una evaluación global y también encuentra un fuerte cambio en la "coyuntura", lo que implica varias replanteos en el movimiento social de la ciudad y el "agotamiento de un ciclo". Estos cambios los reconoce desde el 2009 con la desactivación de los reclamos y las movilizaciones callejeras por la desaparición forzada de Julio López y luego acentuado con la muerte de Néstor Kirchner al año siguiente:

"para mí, en general, las cosas se dan principalmente por coyunturas. (...) Cuando llegas al 2009, vos tenes marchas por López todos los meses y acciones todos los meses hasta el 2009. A partir del 2009, dejas de tener, la primera vez a partir de septiembre, que dejas de tener cada mes una actividad por López. Si lo rastreas, vas a ver que es así. Eso no solamente es por el devenir de toda la cuestión de las rupturas por lo del campo ${ }^{216}$, si no por el agotamiento de un ciclo. Ese ciclo terminó de agotarse, si se quiere, a mi humilde ver, con la muerte de Néstor y la reconfiguración simbólica que significó acá en La Plata, que fue muy fuerte e interpeló mucho.” (E 19, Ernesto).

Esta nueva coyuntura también interpeló de un modo particular a las experiencias de los colectivos culturales que se creaban y activaban en esos años en La Plata, que devino al poco tiempo en la disolución de la mayorías de los grupos:

"Entre el 2009 y el 2010, y después el 2011, cuando se cierra la experiencia de Luli, hay una diferencia que coincide, si se quiere, con el movimiento de creaciones de grupos (de intervención). Se crean catorce grupos, que se organizan idas acá, allá, mucho diálogo interno, que después se va perdiendo y se va quedando sin eso. Hasta queda más cantidad de grupos organizados, que sociedad civil movilizada u organizada. Cuando hacemos el encuentro que organiza Mandy (muestra "Calle Tomada"), tenés un montón de grupos, y sin embargo ya estaba habiendo un desfasaje que se notó más fuerte, ya en 2010.” (E 19, Ernesto).

\footnotetext{
${ }^{215}$ Dani se pregunta algunas cuestiones y realiza un elocuente análisis de los repliegues en el espectro militante, los cambios en relación a la subjetividad política en el país, así como sobre las mutaciones culturales en la ciudad y en el uso de las redes sociales: “¿qué pasó con toda esa gente que estaba ahí? igual siguieron, la gente del feminismo siguió arengando un montón, creo que fue la que más creció ahí. Calculo que habrá muchos que estaban por ahí que se alinearon más con el kirchnerismo. En La Plata se empezaron a dar otros flujos... es raro, ahora la gente va toda a las cervecerías, tienen demasiado público, me pregunto ¿dónde estaba toda esa gente antes?, esa gente que ahora va a tomar cerveza. qué hacían. Bueno, la gente se puso a postear más cosas en Facebook, también. Era distinto el Facebook de antes, creo que tirar una cosa política en ese momento, era raro, alguna imagen de López... ahora te la pones de avatar. porque además el Facebook se tornó al lugar político donde compartir la noticia política." (E 22).

${ }^{216}$ Hace referencia a la fuerte disputa entre el gobierno nacional liderado de Cristina Fernández y las entidades patronal-agropecuarias por la resolución 125 (de marzo de 2008) en relación a las retenciones móviles.
} 
Por su parte, Pili no encuentra discusiones internas en el grupo que hayan motoriza la disolución. Por el contrario, reconoce que "había ganas de seguir haciendo cosas juntos", cuestión que se viabilizó casi en simultáneo con la propuesta de armar Síntoma. Al reflexionar sobre la última acción y cierre del grupo dice: "darle un fin era darle fin a un sentido. Ese sentido y esta construcción llegó hasta acá y para no seguir repitiendo lo mismo, empezamos con otra cosa." (E20, Pili).

En relación a Arte al Ataque, sobre el final del capítulo 4 se hizo amplia referencia a los importantes cambios que atravesó este colectivo como integrante del FPDS y luego del FPDS-CN, hasta mencionar su más reciente fractura con el espacio político local que hoy conforma "Patria Grande". Actualmente Arte al Ataque centra sus acciones como espacio artístico-cultural de la organización social y territorial a la que pertenece. También se puede mencionar que en el intento por generar diálogos con otros sujetos, desde el 2012 en Arte Al Ataque comenzaron a pensarse como "trabajadorxs de la cultura" y a construir algunas acciones y proyectos productivos desde esa idea.

“Además se fue dando por una realidad del colectivo mismo que todos de una u otra forma buscábamos vivir de lo que hacíamos. A veces de manera individual, a veces de manera colectiva, a veces de manera orgánica. En lo particular éramos trabajadores de la cultura de distinta forma, y nos ayuda y nos ayudó en su momento a intentar organizar eso. Organizar nuestras vidas en términos de cómo nos ayudamos, cómo tenemos la solidaridad de clase de trabajador de la cultura y vemos qué es lo que podemos hacer nosotros para bancarnos en un ámbito que es más difícil que otros, de más restricciones." (E 18, Arte al Ataque).

Como se planteó antes, Luxor fue produciendo cambios y desplazamientos en relación a lo estético-visual y en lo retórico-discursivo, modificaciones que continuamente se encuentra ensayando. Pero hay en la experiencia de Luxor otra modificación -seguramente menos visible pero también de importancia-: vivir de su producción. Desde 2013 Luxor vive únicamente de hacer pintadas callejeras en paredes externas y en interiores (de casas y comercios) y de la venta de obras -grabados, pinturas en mediano y gran formato, reproducciones en pequeño formato- en su taller o en muestras. En relación a esto último, realiza muestras en pequeñas galerías y espacios culturales de la ciudad, que son importantes para la circulación de las obras y gestiona un espacio de taller y eventos de arte, "Obrador $45^{, 217}$ : "se fue modificando mucho todo desde que arranqué. Nunca pensé que iba a vivir del

${ }^{217}$ En el capítulo 8 se profundiza sobre esta cuestión. 
graffiti. Yo no empecé nunca con esa idea. (...)” (E 23, Luxor) Además, en esos cambios que produjo en su experiencia planteó "correrse del graffiti" para no quedar encasillado en un lugar asignado, definido en un espacio. Así en Luxor la "pintada callejera” reemplaza a la categoría de "graffiti". Actualmente hay un nuevo desplazamiento hacia la "pintura gráfica".

\begin{abstract}
"Es que también por eso me corrí. No sé si quiero ser un grafitero, pero en el hecho que agarrás y siempre tenés que estar en un lugar, el sistema te dice que tenés que tener un lugar asignado: 'el tuyo es el de graffitero'. Es bastante patético que te toque el lugar que el sistema quiere. Lo más fácil para anular a alguien es saber qué es.” (E 23, Luxor)
\end{abstract}

\title{
VII. Repensar el espacio de lo público desde las intervenciones culturales
}

Luego de desplegar, en la introducción de este trabajo, una amplia zona de argumentos y conceptualizaciones sobre lo público -retomando en particular los aportes de autores como De Certeau, Martín-Barbero, Delgado y Rabotnikof- y después de presentar la indagación sobre las intervenciones culturales -con las herramientas del cartografiado cultural y la entrevista en profundidad- podemos hacer algunas observaciones y ajustes a estas caracterizaciones y nociones.

De este modo, a partir de las observaciones cartográficas y análisis sobre los materiales y las prácticas de intervención cultural que utilizan tanto recursos del espacio urbano como recursos de la web (Luli principalmente, pero también Sienvolando, Arte al Ataque y Luxor), sostenemos como propuesta interpretativa que se fue gestando un nuevo espacio público donde lo virtual y lo espacial-urbano son reconfigurados $\mathrm{y}$, en sus cruces, los espacios de lo público, en plural, son ampliados y renovados. Podríamos pensar así en una cuarta propiedad para pensar la "semántica de lo público" (sumando una más a las tres planteadas por Rabotnikof): lo virtual-red-online. Podemos reconocer que varias de estas experiencias de intervención sirven para repensar al espacio de lo público a partir de los cruces de acciones, recursos, dispositivos y saberes en diferentes espacios. Podemos pensar así que en esa confluencia y entramado de espacios y tiempos, territorios y medios, formas, dispositivos y saberes se tramó una nueva configuración de la esfera pública; donde la web y sus recursos son importantes para el despliegue de la intervención pero sin renunciar a la acción en/sobre el espacio urbano.

En este sentido, si bien acordamos con Martín-Barbero (2001) en reconocer la importancia de las redes virtuales en la configuración de imaginarios y nuevos usos que le 
dan ciertos colectivos sociales para sus prácticas, parece desplazar demasiado la experiencia urbana al uso y potencialidades de las redes. Por el contrario, podemos pensar que, en relación con el corpus material de esta tesis, el "actuar en red" no se debe sólo a las posibilidades e influencias que las redes virtuales brindan y ejercen en el espacio social en general, y en prácticas sociales y culturales en particular (entre ellas las intervenciones culturales). Consideramos que estas formas red de actuar ya se encontraban (y encuentran) presentes en muchas prácticas -sociales, políticas y culturales- y se conectan con "lo virtual" con la "nube", la web y el teclado, la www- a través de formas novedosas y productivas; por lo que habría que pensar este proceso en acciones colectivas también a la inversa: cómo desde el territorio y el encuentro se pasa a lo virtual y a la conexión. En esta complejidad es desde donde se pueden comprender las coordenadas de la "experiencia urbana" contemporánea -atravesada por los consumos, las apropiaciones tecnológicas, las políticas espaciales y los accesos diferenciales de la ciudad- y las reconfiguraciones del espacio público -tanto en sus semánticas configurativas: lo abierto, lo común, lo visible, como en sus dimensiones políticas: los achicamientos y ensanchamientos, las disputas y tensiones, las agonías y las potencialidades-.

Por otro lado, también como propuesta analítica, podemos pensar cierto núcleo problemático con la idea decerteauciana de tácticas y estrategias, ya que muchas de estas acciones y prácticas culturales analizadas se pueden inscribir no sólo como tácticas (utilitarias, débiles y tenues, de desvío) sino que en sus cuestionamientos y discordancias enuncian una recuperación de la palabra que se conecta con/se inserta en estrategias políticas de cambio social. Es decir, que podemos vincularlas con nuevas formas de "protagonismo social" y de activación política-cultural que surgieron en Argentina desde finales de la década del '90 e inicios de los 2000 en diversos movimientos, colectivos y prácticas y con diferentes intensidades y fuerzas. Así, a partir de un "repertorio" diverso de recursos, se proponen la construcción de nuevas gramáticas disidentes, afirman cierto empoderamiento y performatividad de las acciones y los sujetos, antes que solamente la manifestación de una posición de denuncia respecto del poder estratégico dominante y el uso táctico de sus recursos simbólicos que se encuentra en el espacio cuadriculado. Podemos sostener que no solo utilizan el espacio de un modo táctico y astuto; sino que además imaginan otro mundo e intentan "pre-figurarlo", junto a otros/as sujetos, produciendo otras relaciones, imaginarios y realidades.

Es aquí que, con ciertos reparos y teniendo presente las "ambivalencias" de las prácticas sociales contemporáneas, podemos entender que algunas de las acciones e 
intervenciones culturales que sucedieron en la ciudad de La Plata jugaron, en la dimensión política, no sólo en el nivel de la politicidad (de una práctica cotidiana y cultural) sino en el nivel de la acción colectiva, jugando decididamente en el terreno de lo político y pasando de un espacio y posición de alteridad a otro oposicional a las políticas y discursos hegemónicos, siendo parte de una disputa hegemónica. Saliendo de algunos momentos y situaciones específicas, se puede interpretar que la mayoría de estas intervenciones culturales analizadas formaron parte de prácticas alternativas o de alteridad, desde la producción cultural. Allí, se puede comprender que sus aportes decisivos fueron potenciar el cruce de lenguajes y de dispositivos, deconstruir los modos de habitar la ciudad, ampliar los sentidos de lo público. Por lo tanto, si bien los modos de articulación política han sido mayormente "momentáneos", "temporarios", "precarios" y "débiles", se han configurado como "prácticas de disenso" posicionadas desde una mirada abierta, dinámica y conflictiva de lo social. 


\section{Capítulo 6}

\section{Sobre las políticas urbanas y culturales}

\begin{abstract}
"La presente Ordenanza rige la función pública local de ordenamiento y uso del espacio público.

Define las intervenciones urbanísticas autorizadas en el Partido de La Plata sobre las componentes del espacio público.

Constituye la expresión normativa de las directrices generales de ordenamiento y uso y del espacio público establecidas con carácter de instrumento regulatorio, bajo el principio general de sujeción de la actuación urbanística sobre el espacio público al interés general, urbano y ambiental de la comunidad."

Artículo $1^{\circ}$. "Código del Espacio público", ordenanza municipal 9880, 2004.
\end{abstract}

“... no se cuestiona aquí la necesidad y hasta la urgencia de planificar las ciudades. Las ciudades pueden y deben ser planificadas. Lo urbano, no. Lo urbano es lo que no puede ser planificado en una ciudad, ni se deja. Es la maquinaria social por excelencia, un colosal artefacto de hacer y deshacer nudos humanos que no pueden detener su interminable labor. En cambio, en todo el mundo se pueden constatar las evidencias de que el proceso que se sigue es exactamente el contrario. Se planifica lo urbano - la calle y la vida que se despliega en y por ella-, pero no la ciudad, que es vendida para que el más feroz de los liberalismos la deprede y haga de ella un negocio. Se estimula la propiedad, pero se restringe la apropiación. En realidad, una cosa es consecuencia de la otra: la renuncia de la administración pública a planificar la ciudad, para entregar al desorden especulador y a su conversión en producto de y para el consumo, solo es posible manteniendo rigurosamente vigilados los espacios por los que transcurre una vitalidad urbana contemplada siempre como obstáculo para el buen marketing urbano y como fuente de desasosiego para cualquier forma de poder político."

Manuel Delgado, Sociedades movedizas, 2007.

\section{La ciudad desde el Estado}

En este capítulo se plantean algunos sentidos, imaginarios e imágenes sobre la ciudad a partir de la indagación de las políticas culturales y urbanas desarrolladas por el Municipio de La Plata en el periodo amplio de análisis (2006-2015). El análisis se detiene principalmente en la campaña "La Plata, ciudad limpia" llevada a cabo en el último año de gestión de Julio Alak, el plan de "recuperación del espacio público", la aprobación del COUT 
y las campañas "0810" y "Pintó cuidar lo nuestro" impulsadas durante los gobiernos de Pablo Bruera. Se sostiene que este tipo de políticas estatales fomentan, en una dimensión comunicacional, el problema de la homogeneización del discurso público que se pone de manifiesto en la ciudad y, fundamentalmente, sobre las narraciones que habitan las tramas de lo urbano. A su vez, se las puede reconocer como intentos de clausura hacia la producción cultural diversa y heterogénea que se construye en la "ciudad practicada", en la vitalidad urbana cotidiana. Por lo tanto colaboran con el despliegue de las formas de una "ciudad excluyente" al conectarse con las iniciativas privadas de construcción y planificación urbana. Los principales materiales utilizados para esta indagación son notas periodísticas, discursos oficiales (que incluyen tanto la comunicación institucional del municipio como las declaraciones de los funcionarios) y el Digesto Municipal (las ordenanzas vigentes en período indagado).

Cuando se habla de politicas culturales y urbanas hacemos referencia a acciones deliberadas que buscan modificar una situación. Al mismo tiempo se reconoce que, si bien es el Estado en sus diferentes estamentos y niveles un actor importante en la promoción y el despliegue de estos tipos de políticas, no es el único. Las empresas privadas y muchas instituciones no-estatales (ONGs, fundaciones, asociaciones civiles, etc.), como así también otras diversas organizaciones de la sociedad civil (movimientos sociales, partidos políticos, organizaciones comunitarias, etc.) son actores que impulsan diferentes políticas culturales y urbanas (Urresti, Margulis, Lewin, 2014). Para este análisis se hace foco en parte de las políticas que se plantearon y llevaron adelante desde el Estado municipal de La Plata, aunque sobre el final del capítulo se explora también en algunas iniciativas surgidas desde otros actores de la ciudad.

\section{I.a. Acciones municipales}

En lo que sigue nos concentraremos en la legislación, políticas públicas y programas de gobierno de los dos intendentes que tuvo la ciudad de La Plata durante el período ampliado que se toma en la investigación (2006-2015): Julio Alak ${ }^{218}$ y Pablo Bruera ${ }^{219}$. Se

\footnotetext{
${ }^{218}$ Julio Alak fue intendente de la ciudad durante cuatro períodos consecutivos, entre los años 1991 y 2007 , por el Partido Justicialista (en las elecciones generales de 2007 se presentó como uno de los candidatos del Frente para la Victoria) Luego de perder la contienda electoral local a manos de Pablo Bruera, y al poco tiempo de terminar su último mandato al frente del municipio, fue convocado por la presidenta Cristina Fernández para ser representante del Estado argentino en la dirección de Aerolíneas Argentinas -cuando esa empresa pasó definitivamente a manos del estado, Alak fue nombrado Gerente General-. En julio de 2009 fue designado Ministro de Justicia y Derechos Humanos de la Nación cargo que ocupó hasta diciembre de 2015.

219 Pablo Bruera fue intendente de la ciudad durante dos períodos consecutivos entre diciembre de 2007 y diciembre de 2015, por un sector del peronismo local denominado Partido Progreso Social (como Julio Alak en
} 
entiende aquí que ningún gobierno, ni ninguna instancia institucional-estatal de control y ejecución de políticas, ni tampoco ninguna fuerza política puede ser reducida a personas individuales -sean estos líderes de masas, destacados estadistas, hábiles operadores o burócratas de turno-. Se menciona a estos dos políticos locales a los efectos prácticos del análisis y para poder delimitar tendencias y reconocer posicionamientos. Pero también se comprende el hecho insoslayable que ocuparon la intendencia de la comuna, es decir, la posición de gobierno más importante y visible de la ciudad en términos de política de estado local.

El siguiente cuadro lista algunas de las acciones claves impulsadas por el Municipio, durantes estos gobiernos locales, en materia de regulación cultural y urbana de la ciudad asociada a las intervenciones objeto de esta tesis:

\begin{tabular}{|c|}
\hline Gestión Julio Alak ${ }^{220}$ \\
\hline $\begin{array}{l}\text { 2007. Prohibición de venta de aerosoles en el casco urbano (mediante acuerdo con comercios } \\
\text { que vendían este producto). }\end{array}$ \\
\hline 2007. Desarrollo de la campaña "La Plata, Ciudad Limpia". \\
\hline Gestión Pablo Bruera \\
\hline $\begin{array}{l}\text { 2008-2015. Plan de "recuperación del espacio público", se implementó principalmente para el } \\
\text { mejorado de espacios verdes (plazas, parques, ramblas, etc.) tanto en la colocación de } \\
\text { luminarias como de equipamiento urbano (juegos para niños, espacios y módulos de } \\
\text { ejercitación, corredores y veredas). El slogan más utilizado durante la gestión de Bruera fue } \\
\text { "La Plata, ciudad de todos" / "La Plata, ciudad para todos" que se relaciona directamente con } \\
\text { este Plan. }\end{array}$ \\
\hline $\begin{array}{l}\text { 2008. Creación del MoPU (Monitoreo Público Urbano) } \\
\text { Prevención Ciudadana (desde el } 2014 \text { denendiente de la Sec }\end{array}$ \\
\hline
\end{tabular}

las elecciones generales de 2007 también fue candidato por el Frente para la Victoria). Bruera fue primero aliado y luego rival de Alak. Se presentó por primera vez como candidato a intendente en 2003 -por fuera del PJ vía el Frente Renovador Platense- para competir contra Alak con una campaña politica-electoral que tenía la leyenda "Bruera es agosto", frase que se reprodujo por miles de pintadas en las paredes de la ciudad. En esa elección la perdió con el entonces intendente.

${ }^{220}$ Cabe mencionar que, si bien es anterior a la temporalidad que se analiza en la tesis, entre diciembre de 2004 y abril de 2005 se aprobó en el Concejo Deliberante una nueva ordenanza sobre el espacio público ( $\mathrm{N}^{\circ}$ 9880) y se reglamentó a través del Decreto $\mathrm{N}^{\mathrm{j}}$ 553. Sobre esa reglamentación Mariana Chaves plantea: "la ordenanza se ocupa de las actividades realizadas en el espacio público (...) ¿Estas actividades -como las murgas, que son su caso de estudio- podrán seguir siendo realizadas libremente? La apropiación pública del espacio urbano no podrá realizarse sin autorización del 'organismo competente', según la norma, que para el caso es la Dirección de Control Urbano. La aprobación del nuevo Código de espacio Público cambia las reglas legales de ocupación del espacio público." (Chaves, 2010: 253) 
2008. Aprobación en el Concejo Deliberante del Régimen de Fomento Municipal para espacios Culturales Alternativos -promovido por la Red de Centros Culturales-.

2009. Impulso y creación del "Circuito Cultural Meridiano V", junto con la Asamblea barrial (integradas por centros culturales, comerciantes y vecinos).

2008-2015. Programa Presupuesto Participativo, fue una política pública donde diferentes proyectos se propusieron, votaron y ejecutaron en todos los barrios de la ciudad. Principalmente se trató de proyectos de obras de mejorado de la vía pública (asfalto, garitas de micros, semáforos, señalizaciones, mejorado de plazas y ramblas, etc.).

2010. Aprobación del nuevo Código de Ordenamiento Urbano y Territorial (COUT), ordenanza que habilitó una mayor construcción en altura en el centro de la ciudad. La modificación de esta normativa recibió muchas críticas y denuncias judiciales desde diversos sectores por degradar el patrimonio urbano e histórico de la ciudad y favorecer el negocio inmobiliario.

2014. Programa "Pintó cuidar lo nuestro" que realizó, a través de una serie de cuadrillas, la limpieza y blanqueo de paredes, columnas, mobiliarios urbanos, paradas de micros, cartelería urbana, etc. Fue parte de la política cultural y urbana, así como de una imagen renovada del municipio luego de las inundaciones del 2 de abril de 2013, que se tituló "Vamos La Plata".

2014. Impulso y aprobación de la Ordenanza No 11237 , la normativa buscaba crear un Registro de Inmuebles y Espacios ofrecidos para el muralismo en la vía pública ${ }^{222}$.

2015. Aprobación en el Concejo Deliberante de la Ordenanza $\mathrm{N}^{\circ} 11301$ de Espacios Culturales Alternativos, acordada por diferentes nucleamientos de espacios culturales de la ciudad ${ }^{223}$.

Cuadro 2. Políticas urbanas y culturales del Municipio de La Plata (período 2006-2015). Elaboración propia.

\section{I.b. Una ciudad "bella, limpia e iluminada"}

Una interesante entrada al análisis de los sentidos sobre la ciudad y la cultura que se producen desde el Estado local la representan las medidas impulsadas durante ambas gestiones de Pablo Bruera. Para ese objetivo se reproducen dos fragmentos del discurso pronunciado por dicho intendente al inaugurar las sesiones ordinarias del Concejo Deliberante local en 2011 y algunos materiales gráficos oficiales publicados durante sus

${ }^{221}$ Este sistema de monitoreo local se presenta como "una Herramienta tecnológica aplicada a contribuir con la
Prevención del delito y actuar como Medio de Prueba. Está compuesto por tres pilares fundamentales:1-
Cámaras de seguridad de última generación, para la visualización remota, tanto diurna como nocturna, ubicadas
en puntos estratégicos de la ciudad. 2- Red de Transmisión de datos. 3- Centro Integrador de Monitoreo.
Disponible en: http://www.mopu.laplata.gov.ar/ Una reciente tesis de Licenciatura en Sociología de la UNLP
analiza, de modo etnográfico, al Mopu local. Una de sus hipótesis principales es que esta acción de monitoreo
tuvo un lugar destacado en el proceso de municipalización de la seguridad en La Plata. Urtasun, Martín (2016)
Vigilancia detrás de cámara: Acercamiento etnográfico a un sistema de videovigilancia. Tesis de Licenciatura,
FaHCE (UNLP). Disponible en: http://www.memoria.fahce.unlp.edu.ar/tesis/te.1245/te.1245.pdf
222 http://www.concejodeliberante.laplata.gov.ar/digesto/or11500/or11237.asp. Una nota periodística interesante sobre este asunto: "Pintó controlar el arte urbano", Diario Contexto, 8 de julio de 2015. Disponible en: http://www.diariocontexto.com.ar/2015/07/08/pinto-controlar-el-arte-urbano

223 El texto de la ordenanza municipal se encuentra disponible en: http://www.concejodeliberante.laplata.gov.ar/digesto/or11500/or11301.asp 
gestiones ilustran de modo elocuente los sentidos tradicionales -y también los lugares comunes- que se configuran sobre la ciudad desde la política formal local.

En ambas textualidades se puede reconocer una mirada en la que el espacio público es un espacio delimitable a plazas, espacios verdes y calles. Por lo tanto un espacio -acotado"para que los habitantes lo pueden vivir y disfrutar"; en tal sentido, la acción del Estado local se traducía únicamente en "ponerlo en condiciones": iluminar, limpiar y embellecer ${ }^{224}$. En relación al discurso con el que Bruera inauguró el año legislativo en la ciudad, en todo momento plantea estar hablando desde un cabal conocimiento del presente contemporáneo cuyas preocupaciones centrales sintetiza en los problemas de energía, alimentación y espacio en el mundo-. Allí vuelve a reforzar una mirada pulcra y limpia de la ciudad y sobre lo que ésta no tiene que dejar de ser para frenar y enfrentar localmente esos desafíos/problemas globales.

“(...) sabemos perfectamente hacia dónde va el planeta, y que conocemos más que acabadamente lo que piensa y desea nuestro ciudadano, es la plataforma sobre la que se ha constituido la acción de gobierno municipal iniciada en diciembre 2007.

Cuando nos concentramos en recuperar el espacio público, cuidando, iluminando y embelleciendo plazas, cuando abrimos avenidas que sirven de vínculo y articulación del casco con nuestra periferia; cuando ponemos toda la capacidad negociadora del municipio en la consecución de una planta termoeléctrica regional que nos proveerá energía por más de tres décadas; cuando nos ponemos estrictos con la limitación a la construcción de grandes torres o edificios; cuando defendemos de todas las formas posibles nuestro cordón agrícola, límite natural a la conurbanización; cuando racionalizamos el estacionamiento en el centro de la ciudad; cuando impulsamos la construcción de cocheras subterráneas en la ciudad de mayor cantidad de automóviles por habitante del país; cuando reordenamos el sistema lumínico extendiendo su influencia territorial y eficacia; cuando trabajamos junto al gobierno nacional y provincial para modernizar nuestra red subterránea de agua corriente y construir las cloacas faltantes; cuando apostamos a un sistema de transporte público más moderno eficiente que garantice prestación cierta a todos nuestros barrios; cuando clasificamos la basura reciclando ya más de 80 mil kilos diarios de los residuos, proveyendo además trabajo digno y legal a nuestros desocupados de ayer; cuando constituimos cooperativas en las que trabajan en el mantenimiento de la ciudad quienes hasta hace

\footnotetext{
224 "Ciudad para Todos", diciembre de 2009, publicación impresa municipal. Este producto comunicacional del Estado local se repartía masivamente de manera gratuita casa por casa, tenía una periodicidad mensual y representó la voz del municipio durante la primer gestión de gobierno de Bruera.
} 
pocos años eran excluidos del sistema, estamos pensando en el mañana. Estamos conciliando la ciudad de hoy con la que se necesitará en un par de décadas, para que pueda seguir siendo un lugar agradable al volver." (Pablo Bruera, discurso ante el Concejo Deliberante, 2011).

A partir de lo que el funcionario entiende como diálogo directo con los vecinos, así caracteriza al imaginario urbano de La Plata y al supuesto anhelo de continuidad de un perfil “amigable" y próximo por parte de sus habitantes:

“(...) en muchas de las conversaciones que he mantenido con nuestros vecinos durante los últimos tres años y medio, los hombres y mujeres más simples, aquellos que nunca pretendieron ser estadistas, e incluso aquellos que inician sus conversaciones señalando que no entienden nada de política, me han advertido reiteradamente sobre este tema. Me lo han dicho en sus palabras, sin términos académicos, sin rebusques verbales. Tienen temor de que el futuro los asalte. Tienen temor de que lo que intuyen que se viene altere o deteriore su modo de vida actual y el de sus barrios. Muchos me dicen que disfrutan de la ciudad de Buenos Aires, siempre y cuando esté a cierta distancia. Que quieren seguir viviendo en lugares donde se conozca al vecino, en barrios donde sus hijos y nietos tengan vereda para sus juegos, donde existan nuestras tradicionales plazas, limpias e iluminadas. El platense, señores, bien lo saben los concejales, no quiere que su ciudad se transforme en una urbe impersonal, ni quiere locuras de tránsito, ni aglomeraciones. Nuestro ciudadano disfruta el espacio generoso, el verde, el saludo de reconocimiento en la calle, la limpieza, la belleza y la luz."225

Sin embargo, a los efectos de lo que dejaron muchas de las políticas que Bruera impulsó para la ciudad, esta posición encargada de asegurar y resguardar el espacio común de los platenses puede ser desmentida y refutada. Esa visión sobre una ciudad bella, apacible, limpia, con luz y "agradable al volver", sin aglomeraciones ni "locuras" de tránsito, se revela trágica. Algunos puntos centrales para discutir esta posición son el descuido y degradación del patrimonio urbano, histórico y cultural -y las posibilidades limitadas de tener luz solar en un cielo cada vez más recortado producto de la construcción en altura-, denunciada por organizaciones civiles como "Defendamos La Plata" y "SOS La Plata" (La Pulseada № 80, 2010). Las políticas hacia la niñez con la figura del Agente de Control Urbano a la cabeza que no opera desde la hospitalidad y el cuidado de la infancia sino desde intentar encontrar la

\footnotetext{
${ }^{225}$ El discurso completo de Pablo Bruera se encuentra transcripto en la siguiente nota del portal Realpolitik: http://www.realpolitik.com.ar/nota.asp?n=unica\&id=3706\&id_tiponota=2
} 
consumación de una contravención o un delito, políticas cuestionadas, entre otras organizaciones, por la "Asamblea Permanente por los Derechos de la Niñez" y una gran cantidad de especialistas y entidades dedicadas a la promoción y protección de los Derechos Humanos (La Pulseada N 63, 2008; Badenes, 2009; Calligo, 2016). También el aliento de la especulación inmobiliaria y el deterioro del acceso al suelo urbano que golpea a los sectores más vulnerables y los priva de una vivienda digna. Los servicios públicos municipales básicos deficientes que se brindan (electricidad, cloacas, transporte público urbano). Las propuestas culturales municipales ligadas a la espectacularización y los mega-eventos ${ }^{226}$. Además, durante esos años estas fueron políticas locales ampliamente cuestionadas por diferentes organizaciones de la sociedad civil, cuerpos profesionales, asambleas barriales, organizaciones culturales y movimientos sociales.

Luego de un 2013 atravesado por la inundación del 2 de abril, el Municipio decidió renovar lo referido al discurso institucional y a la imagen pública visual. Así el eslogan principal de gestión pasó de "Ciudad para todos" a "Compartamos la ciudad". En relación a la publicación impresa periódica se renombró "La capital. Un medio para compartir nuestra ciudad". A su vez, se creó una plataforma virtual con agenda de eventos, notas, entrevistas e información sobre iniciativas culturales y artísticas (oficiales, privadas y alternativas) titulada "Vamos La Plata" (esa web actualmente no está disponible). La retórica del nuevo discurso municipal procuró ser más pro-activo hacia la ciudadanía y hacia las iniciativas creativas que en ella suceden: "la ciudad se junta, la ciudad te invita", "La Plata es una gran usina creativa", "la ciudad se expresa, la ciudad te invita", "compartamos la alegría", "Ciudad saludable" (se trató de un programa de actividad física al aire libre en plaza y parques), "Yo reciclo" (programa de separación y clasificación de residuos secos), "nueva policía local: estamos más cerca". Se podría plantear, como hipótesis a seguir, que la gestión Bruera produjo un desplazamiento en la estrategia comunicación institucional sobre cómo pensar la ciudad: de una ciudad entendida como "cosa", es decir en tanto espacios físicos y materiales delimitados (a cuidar, limpiar, embellecer, iluminar, etc.), se pasó a una ciudad reconocida desde a las cualidades creativas, emprendedoras y culturales de sus habitantes (sobre esto se volverá más adelante cuando se analice la gentrificación urbana en La Plata). Sin embargo, más allá de esta modificación del discurso público oficial y de la renovación de algunas políticas de gobierno para entender que la ciudad se activa desde las iniciativas de sus ciudadanos, las cartas que ampliaron las características de La Plata como una "ciudad

\footnotetext{
${ }^{226}$ Para una completa radiografía de las políticas culturales durante parte de la gestión municipal de Bruera ver el informe periodístico "El malestar en la cultura", revista La Pulseada, No 109, mayo de 2013.
} 
excluyente" ya estaban echadas: un aumento del $1361 \%$ en la cantidad de metros habilitados para la construcción en altura en el casco urbano y del $372 \%$ en el resto de la ciudad ${ }^{227}$, la problemática del "hábitat informal" y la competencia entre sectores de altos y bajos recursos por espacios de tierra vacantes, los continuos conflictos en las periferias de la ciudad por la especulación de las inmobiliarias sobre el suelo que golpea a los sectores más vulnerables y produce fragmentación urbana (Frediani, 2013; La Pulseada No 130, 2015; Segura, 2014) N $^{228}$.

En los siguientes apartados se profundiza en la caracterización sobre la ciudad.

\section{La búsqueda de controlar lo urbano}

La cuestión que se viene sosteniendo en la tesis es que en las ciudades contemporáneas priman los proyectos que buscan limitar, planificar y controlar a lo urbano. Esto ocurre no tanto como una consecuencia inevitable de la globalización (y de la neoliberalización económica) sino como aporte fundamental para sostener y expandir ese tipo de proyectos liberales desde los gobiernos locales -en la bibliografía sobre las ciudades

\footnotetext{
227 "El casco urbano fue creado en 1882 con un diseño pensado para servir como capital de la provincia, pero desde allí su fisonomía ha debido adaptar las necesidades del siglo XXI a una estructura del XIX. Este proceso ha sido marcado por la política, que ha establecido normas específicas para el uso del suelo y la construcción. Todas las reformas han fomentado el desarrollo edilicio dentro del casco.". "La Plata, ciudad capital", agencia Marcha, abril de 2013. Disponible en: http://www.lapulseada.com.ar/site/?p=4577. Para una aproximación de las consecuencias que para la economía regional tiene el aumento del área urbana de La Plata -amparado en las normativas y verificado en los indicadores que marcan la intensificación de la construcción y el uso del suelover Losano, 2011.

${ }^{228}$ La expansión urbana que atraviesa el partido de La Plata en las últimas décadas "ha sido acompañada por la ocupación de nuevas superficies en la frontera entre los ámbitos urbanos y no urbanos. En este heterogéneo y dinámico espacio periurbano los sectores de bajos y altos ingresos compiten por los espacios vacantes, constituyendo la toma de tierra la modalidad predominante de acceso al suelo por parte de los sectores de menores ingresos." (Frediani, 2013: 46). "En las localidades que rodean al casco urbano platense hay casi 19.000 viviendas precarias, en 118 villas y asentamientos. 20 surgieron en los últimos cinco años. 80 están expuestos a riesgos ambientales o urbanos. Y sólo 20 comenzaron o terminaron algún proceso de regularización.". "Tierra y vivienda fuera del cuadrado", La Pulseada, $\mathrm{N}^{\circ} 130$, junio de 2015. Disponible en: http://www.lapulseada.com.ar/site/?p=9709. En el trabajo de campo etnográfico realizado en la periferia de La Plata -entre la reconstrucción histórica y la descripción de la cotidianeidad de los habitantes de esas zonas-, Ramiro Segura reconoce una situación paradójica: "la existencia de una experiencia común relacionada con los sentidos y las prácticas asociadas con habitar la periferia entre los pobladores de ese espacio residencial quienes, a la vez, se perciben como formando parte de grupos diferentes. Sostendremos aquí que la posición espacial y social de los residentes de la periferia respecto de "la ciudad", por un lado, y las temporalidades diferenciales en el arribo a la periferia y su cristalización en distintos "barrios" con organizaciones e historias particulares, por el otro, constituyen los procesos sociales y territoriales que nos ayudan a comprender la paradoja." (Segura, 2014: 250). Por otro lado, en el ámbito de las normativas vigentes, la provincia de Buenos Aires cuenta que una interesante Ley de Acceso Justo al Hábitat ( $\left.\mathrm{N}^{\circ} 14449\right)$ aprobada en 2012 y que el ejecutivo al mando de Daniel Scioli se resistió a promulgar y a aplicar, cuestiones que se vió obligado a realizar luego de movilizaciones de organizaciones sociales, denuncias y fallos judiciales. Esta ley define, entre otras cuestiones, la función social y ambiental de la propiedad; el reparto equitativo de cargos y beneficios que genera el crecimiento de las urbes; y la participación ciudadana como un bien indispensable a la hora de pensar ciudad. Texto completo de la ley disponible en: http://www.gob.gba.gov.ar/legislacion/legislacion/l-14449.html
} 
existen convergencias sobre esta cuestión incluso en miradas diferentes como pueden ser las de Delgado y Harvey-. A su vez se reconoce que, para el caso de La Plata, este tipo de políticas se volvieron recurrentes en los gobiernos locales de Alak y Bruera. A continuación se analizan algunas de las políticas urbanas y culturales que fueron mencionadas en el primer apartado, con la intención de observar recurrencias y sentidos construidos sobre la ciudad y la cultura desde las políticas públicas municipales.

\section{II.a. "Ciudad limpia"}

La campaña "La Plata, Ciudad limpia” se llevó adelante durante casi todo el 2007, el último año de mandato de Alak, que en octubre se presentaría nuevamente como candidato a intendente de la ciudad ${ }^{229}$. Algunas fuentes creen que en el desarrollo de esta campaña se blanquearon y pintaron más de 400 paredes de la ciudad con esa consigna ${ }^{230}$. Por medio de una veintena de cuadrillas de agentes municipales, la campaña consistía en blanquear muros y paredes de la ciudad en los que había distintas inscripciones gráficas y luego pintar con letras mayúsculas el nombre de la campaña. Esto era acompañado con la "firma" del municipio sobre alguno de los costados del mural. Con esta acción se generaba un hecho paradójico: para tapar diversas inscripciones visuales -personales, grupales, políticas, etc.- se debían pintar murales municipales, pintar para no pintar: "pintadas que estaban para recordarnos que no había que pintar, pintadas que prohibían pintar" (Rodríguez, 2007). Lo que quedaba claro era que el Municipio se anotaba como uno de los actores relevantes en la disputa por el espacio de la ciudad desde los discursos públicos en los muros; en un año de contienda electoral fuerte y también en un año muy activo para las intervenciones culturales que se

\footnotetext{
229 Quizá también esta campaña fue, en un año electoral como el 2007, uno de los últimos intentos del alakismo por retener el gobierno local. Es preciso recordar que una de las consignas de Pablo Bruera como opositor/candidato era posicionarse contra la "reelección indefinida" en la ciudad. Desde esa posición es que construyó su perfil para competir por el gobierno. Esto creaba un fuerte elemento diferencial -por ejemplo, renovador de la figura del político y del mandatario- sobre Alak que era intendente desde 1991, sobre todo porque en otros aspectos políticos no se podían diferenciar -por ejemplo, en apoyar y compartir boleta con Cristina Fernández en las elecciones generales-. Asimismo, "Ciudad limpia" puede ser, en parte, una respuesta a la campaña comunicacional (masiva, sostenida, intensa, sencilla, con economía discursiva y de recursos) emprendida por el espacio político de Bruera desde el 2003: "Bruera es agosto".

${ }^{230}$ En una nota del 1 de abril de 2007 de la Agencia Nova, a raíz del lanzamiento de esta campaña, se brinda información sobre el desarrollo de esta propuesta de "limpieza urbana" y se recogen algunos comentarios de Julio Alak: "se prevé concientizar a la población sobre las cuestiones básicas para mantener una ciudad en buenas condiciones de limpieza. 'La veintena de cuadrillas comenzarán a trabajar hoy mismo con la limpieza de las paredes para retirar los graffitis, además se comenzará a educar a los vecinos para que la basura se saque en horario, para que no se tiren papeles en la vía pública y para que cada quien mantenga su vereda limpia', explicó el mandatario comunal. (...) Alak reconoció el esfuerzo de las pinturerías platenses al decir que estamos muy contentos porque las pinturerías de la ciudad se comprometieron a no vender más aerosoles como una contribución al programa' (...) A modo de conclusión, Alak remarcó que durante los primeros 60 días se desarrollará una tarea educativa, pero tras culminar la misma se aplicarán multas a quienes no cumplan con las normas pautadas." Disponible en: http://www.poderlocal.net/leer_noticias.asp?ID=32037
} 
indagan en la tesis. En un breve ensayo de intervención publicado ese año en su blog, Esteban Rodríguez plantea que se trata de un caso que lesiona la libertad de expresión de la ciudadanía, y en particular de los "sectores desaventajados" que no cuentan con recursos para costear otras formas de comunicación. Asimismo, daña la "vida colectiva" que se despliega en la ciudad al obstaculizar los encuentros:

"Esta prohibición, entonces, constituye una claro perjuicio para la libertad de expresión. No sólo menoscaba el derecho de petición a las autoridades sino el derecho a la identidad propia. Y, lo que es más importante, daña la vida colectiva cuando dificulta los encuentros, y entorpece la construcción de lazos sociales, es decir, la creación y recreación de la vida comunitaria en un marco pluralista o multicultural. (...) "La Plata ciudad limpia" funciona, por un lado, clausurando el espacio público para aquellos sectores desaventajados que no cuentan con recursos para financiar la puesta de manifiesto de sus experiencias o reclamos a través de la comunicación pública privatizada. Por el otro, funciona como un mecanismo de censura previa puesto que les impide expresar libremente las ideas.” (Rodríguez, 2007)

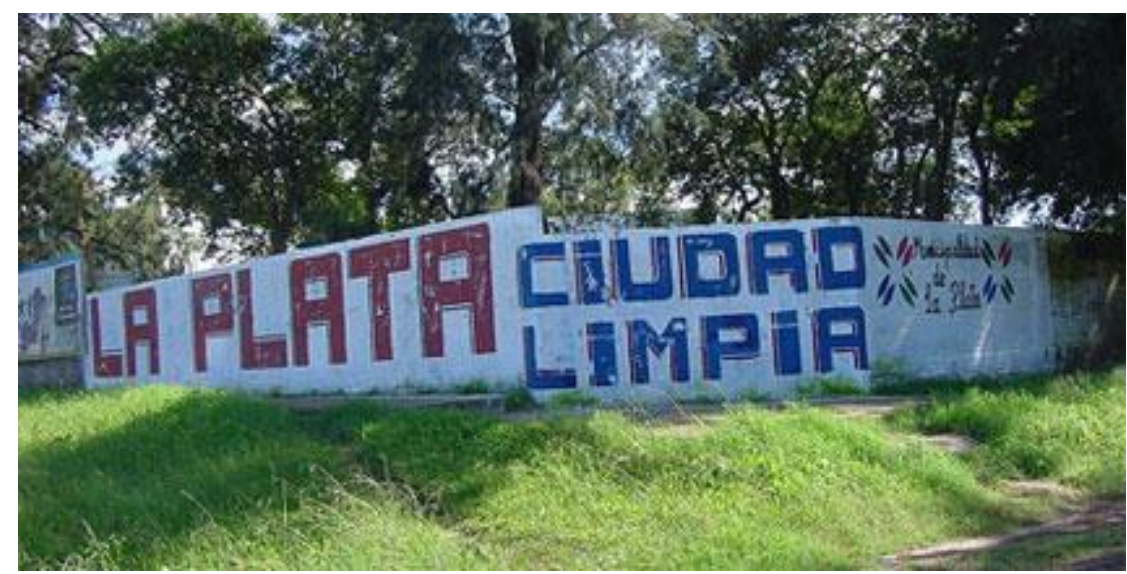

Imagen 42. Uno de los tantos murales realizados por la campaña municipal "La Plata, Ciudad Limpia". Año: 2007. Imagen extraída del sitio web de $I N F U$.

Para Pili de Sienvolando esta campaña municipal "generaba discusiones. De hecho en un momento era el interlocutor. Pintabas vos y tenías que ver si lo borraban o no.” (E 9). Por su parte, Ernesto comenta un episodio puntual que el grupo tuvo con esa campaña y el intento de tapar el mural que el colectivo había realizado sobre la desaparición de Julio López (mural que al día de hoy se mantiene y fue recuperado por otras personas):

"Nosotros lo detestábamos [a Alak], incluso con esa campaña empezaron a tapar el mural de López de la diagonal. Alguien lo vió y llamó a una radio (...) De la radio 
pidieron que vaya gente de derechos humanos. Ahí Alak dijo que no lo iban a tapar, ni a ningún mural nuestro. Se habían mandado el moco del siglo. Nosotros, imagínate, hicimos el mural diez días después de la desaparición, ya lo dábamos como desaparecido. (...) Ese episodio nos llegó para cuando ya estábamos híper radicalizados en el espacio público como un espacio de disputa simbólica.” (E 7, Ernesto)

Nacho, también de Sienvolando, agrega algunos sentidos de cómo interpretaban desde el colectivo a esa campaña: "Alak tenía esa campaña, y nosotros luchamos contra esa línea. Éramos conscientes de que había que salir a dar esa discusión.” (E 12)

Durante los primeros días de la MA 4, el colectivo Indymedia La Plata ensayó una contra-campaña nombrada “¿te animás a limpiarme?”. Se trataba de la utilización de recursos gráficos sencillos: una serie de carteles amarillos y planillas para stencils con los rostros de Julio López y Carlos Fuentealba y el nombre de la acción debajo. La intervención luego se replicó en otros espacios de la ciudad al año siguiente, aunque solamente con el formato de stencil sobre las paredes y el suelo.

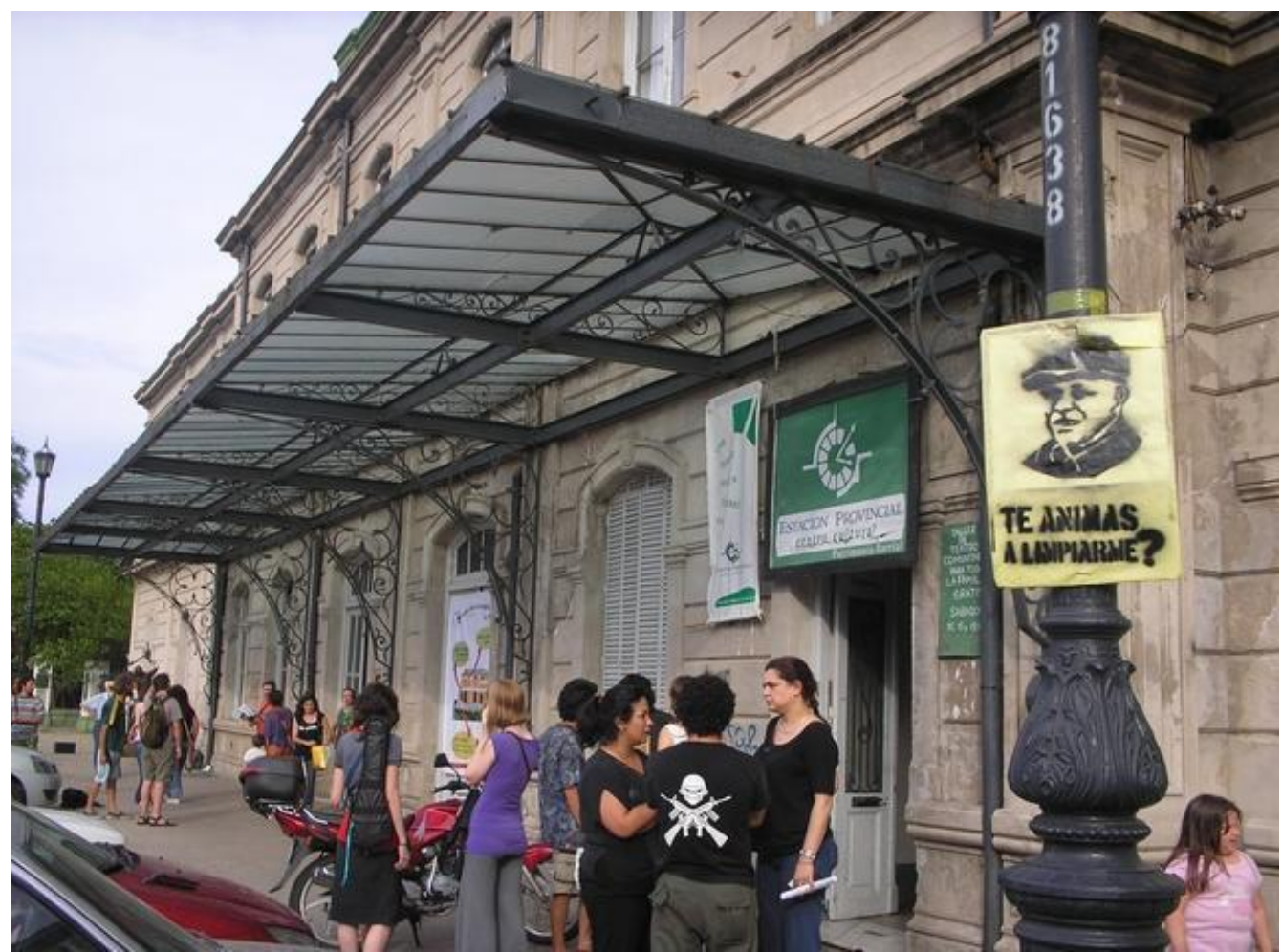

Imagen 43. Acción “¿te animás a limpiarme?” de Indymedia La Plata. Lugar: Meridiano V. Fecha: noviembre de 2007. Imagen de Federico Sager extraída del sitio del colectivo.

\section{II.b. Campaña 0810 del Servicio municipal}


Como parte del "Plan de recuperación del espacio público", desde inicios de 2012 la gestión de Bruera llevó adelante un "servicio municipal" que consistía en el arreglo de luminarias públicas y, fundamentalmente, en la limpieza y recolección de escombros de obras particulares y pastizales que los propios vecinos producían en sus casas -elementos que no entran en la recolección de residuos tradicional-. La propuesta era que los vecinos sacaran a la vereda esos elementos y avisaran al ente municipal correspondiente. Esta política pública de limpieza urbana se articulaba con una campaña de murales "informativos" que avisaban sobre el "servicio público de 72 horas" y difundían el teléfono al que los vecinos debían llamar. Tuvo algunas características similares a la la campaña de murales sobre la historia de los barrios La Plata -desarrollada en los primeros años de la gestión de Bruera- y también a la campaña "Ciudad Limpia".

\section{II.c. El nuevo COU}

La aprobación del nuevo COUT (Código de Ordenamiento Urbano y Territorial) en abril de 2010 marca otra importante política estatal que se produjo en La Plata promovida por el oficialismo. Entre otras cuestiones, la nueva ordenanza habilitaba la construcción en altura (de hasta 14 pisos) en zonas del casco urbano donde, hasta ese momento, no estaba permitido. Como ya se refirió antes, varias organizaciones no gubernamentales y colegios profesionales se opusieron a la nueva normativa y alertaron sobre sus consecuencias negativas sobre el patrimonio histórico y arquitectónico, así como sobre el funcionamiento de los servicios públicos (desagües, agua corriente). Lo definieron como un código "desregulador" y que consolidaba un "reparto urbano excluyente",231.

Como parte de las acciones que se realizaron denunciando el nuevo COU se produjo una campaña comunicacional -luego reivindicada por el colectivo Luli- que puso en juego múltiples dispositivos (un blog, una pegatina de stickers, una canción producida por la banda Les Minon, spots radiales producidos por radio Estación Sur). Entre todas las intervenciones de esta campaña, la más impresionante seguramente sea un gran dispositivo gráfíco "plantado" en una esquina céntrica de la ciudad. Una lona-gigantografía -ubicada en un mobiliario publicitario que en ese momento se encontraba vacío- que se preguntaba: “¿Y si en vez de plantar edificios, plantamos flores?" y mostraba la imagen de un "culo" masculino con una flor plantada. La otra pregunta que se abría con esta acción era por los cuerpos que

${ }^{231}$ Informe periodístico titulado "La ciudad desregulada", revista La Pulseada, No 80, junio de 2010. 
son mostrados en las imágenes publicitarias. El cuerpo que proponía esta campaña no seguía los cánones de belleza y delgadez.

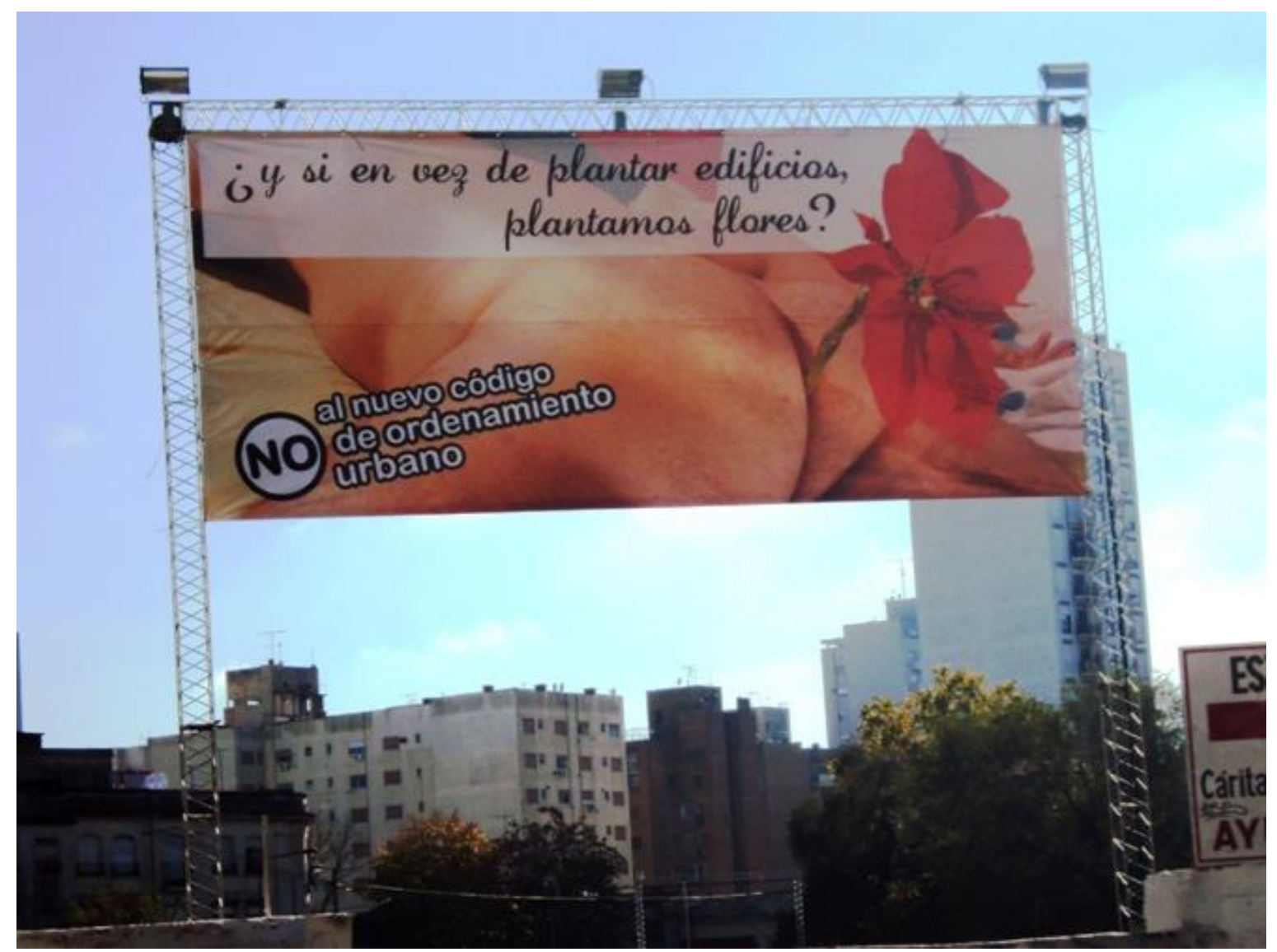

Imagen 44. Gigantografía sobre la reforma del COU. Acción anónima, luego reivindicada por Luli en su blog. Lugar: 4 y 49. Fecha: mayo de 2010. Imagen del autor.

\section{II.d. "Pintó cuidar lo nuestro"}

La campaña "Pintó cuidar lo nuestro" (2014-2015) promovida por Bruera tenía, llamativamente o no, un slogan / bajada casi idéntico al título de la campaña "La Plata, Ciudad Limpia" (2007) impulsada por la gestión Alak seis años antes: "por una ciudad más limpia". Esto no solo puede hablar de similitudes retóricas al momento de construir un discurso institucional (por demás elocuentemente obvias y sencillas). También da cuenta de ciertas convergencias ideológicas-políticas para pensar la ciudad y la gestión de gobierno (¿adhesión a un paradigma de la limpieza urbana, social, cultural?). A su vez, muestra lo poco original que fueron los planteos de estos gobiernos locales en materia de planificación urbana y al momento de pensar el desarrollo de una política pública -al mismo tiempo urbana y cultural- que abra y ponga en discusión los usos y sentidos sobre la ciudad, desde el 
discurso público-institucional. En este sentido, una de las cuestiones más preocupantes es que, mientras se impulsaba este tipo de políticas que planteaba "para recuperar la belleza de nuestra ciudad, una toma de conciencia y un plan de acciones para el cuidado y restauración de los espacios públicos" ${ }^{\text {,232, }}$, se habilitaba el espacio para la destrucción del patrimonio histórico, arquitectónico y urbanístico de la ciudad por medio de los negocios constructivos e inmobiliarios (por ejemplo, a través de la aprobación e implementación del COUT).

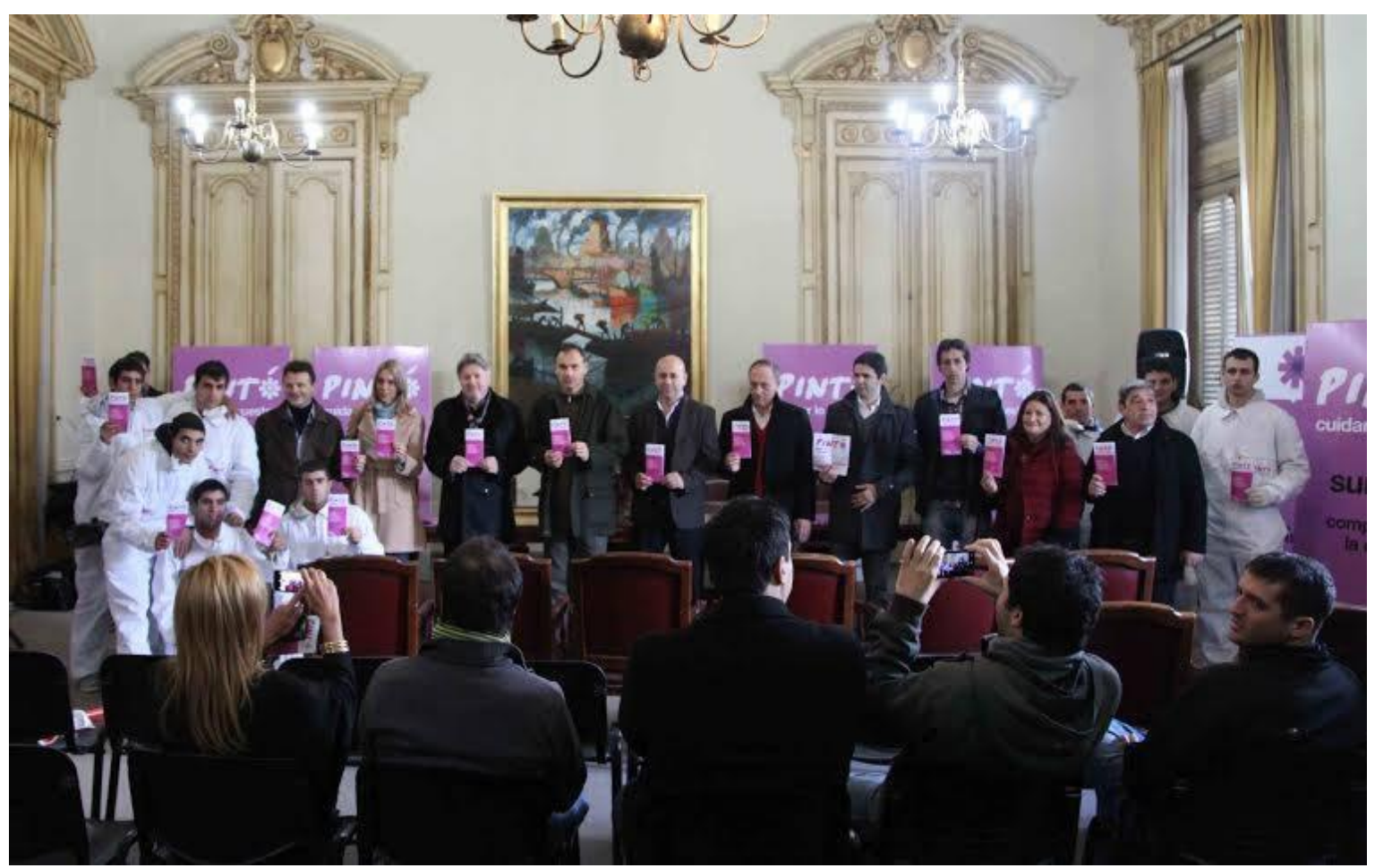

Imagen 45. Lanzamiento del programa "Pintó cuidar lo nuestro" en 2014. Extraída de Plus Información Agencia de Noticias Institucionales.

Entre 2014 y 2015 el grupo Pólvora produjo una contra-campaña de tergiversación en el espacio urbano a través de stencils y en la web por medios de un flyer digital para replicar en muros y perfiles de redes sociales. "Pintó inundar lo nuestro" y "Pintó ocultar las/as muertas/muertos" eran las frases directas de la campaña que cuestionaban no sólo al programa "Pintó" sino a su accionar durante y luego a la deficiente previsión y respuesta estatal ante el flagelo de las inundaciones de abril de 2013.

\footnotetext{
${ }^{232}$ La nota de la Agencia Plus Información solamente enuncia estas palabras (que resuenan a discurso institucional) como bajada del título de la noticia y presenta la imágenes que reprodujimos antes, lo que da cuenta de un limitado ejercicio del periodismo. Disponible en: http://plusinformacion.com/nota.php? Id=40374
} 


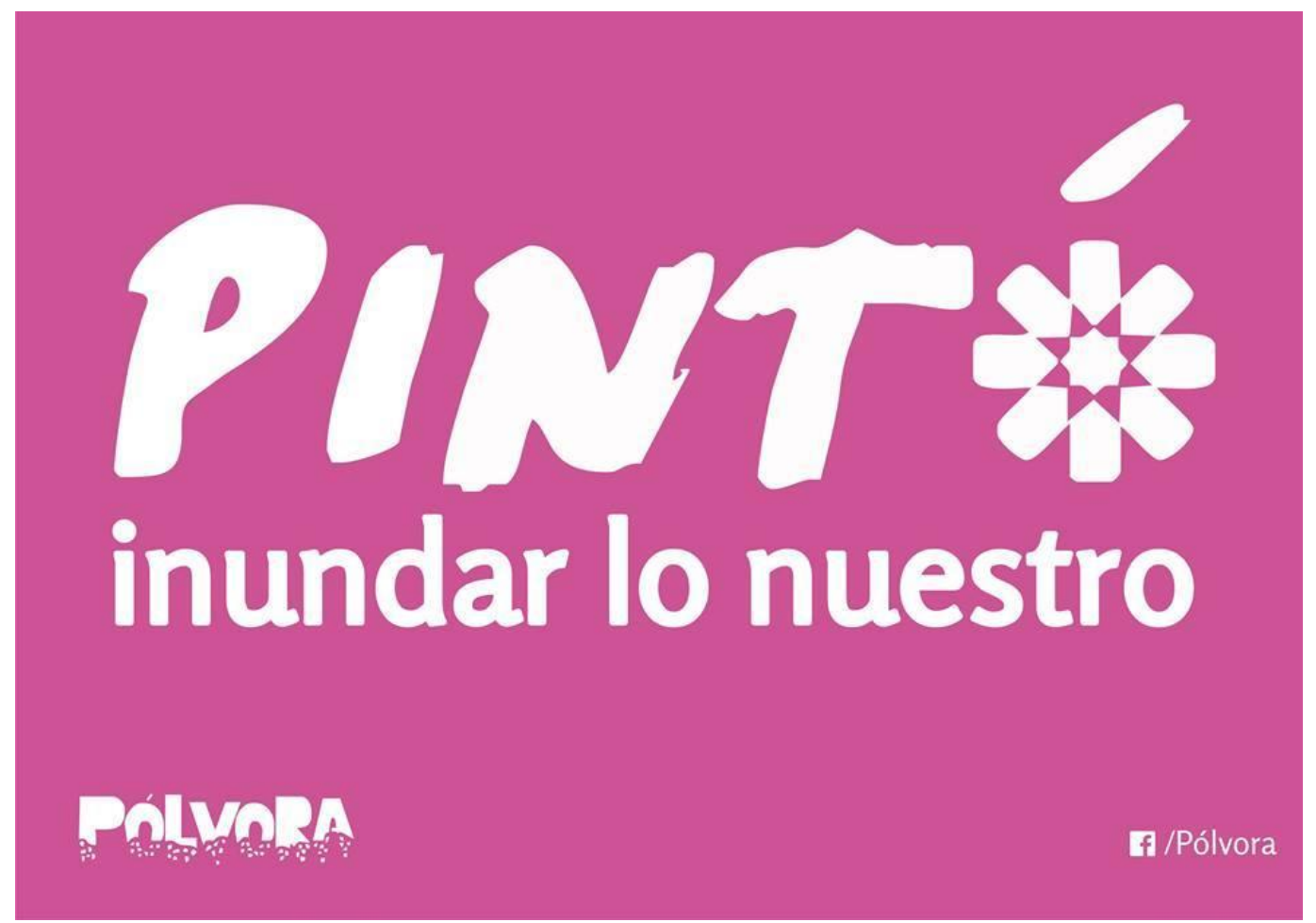

Imagen 46. Flyer digital realizado por el colectivo Pólvora (2014-2015), fue parte de su campaña que contaba además con stencils y pegatina de stickers por el centro de la ciudad.

El 7 de mayo de 2015, a un año de la implementación de "Pintó", desde el gobierno local llevaron adelante una jornada de presentación de un informe de lo realizado por el programa. Al momento que le tocó hablar, el por entonces intendente, comentó que "se busca una toma de conciencia frente al vandalismo, con un plan de acciones para el cuidado y restauración de los espacios públicos" ${ }^{, 233}$. Pero también el mandatario amplió el espectro de esta política pública al realizar una invitación a los "artistas urbanos" de la ciudad. Según Bruera:

"Todos los artistas urbanos que tiene la ciudad de La Plata ciudad, que son muchos y muy buenos, van a tener espacios realmente muy importantes para poder mostrar todo lo que tiene que ver con pinturas, con murales. (...) Nos va a gustar mucho mirar y disfrutar de todo lo que hacen los muralistas y artistas callejeros. Pero también, al mismo tiempo, lo que estamos trabajando acá es en tratar de terminar con el vandalismo. Esto no tiene nada que ver con lo anterior. Es decir, pintar una camiseta en una estatua que tiene alrededor de 120, 130 años o agredirla o romperla. Y para eso también necesitamos a toda la comunidad. Por eso queremos pedirles a todos que nos ayuden, estamos cumpliendo un año con este programa. Creo que le vamos a dar otra

233 "Habilitan paredones para desplegar el arte callejero en la Ciudad", diario El Día, 8/05/2015. 
vuelta de tuerca, en el sentido que vamos a intervenir más espacios públicos, más plazas, más parques, más barrios". 234

Esta campaña -así como antes lo fue "La Plata, ciudad limpia"- dan cuenta de las preocupaciones de los gobiernos locales por controlar las prácticas urbanas. A su modo, puede interpretarse que actualizan en la contemporaneidad un paradigma higienista de la ciudad: inhibir o tapar lo que no sería propio del paisaje urbano, lo que hace ruido, lo que lo distorsiona o molesta, lo que "afea" la ciudad. En tal sentido, no desarrollan solamente una acción de "blanqueamiento de las paredes dañadas", sino que, en un nivel ideológico, implican una política de segregación y de regulación de unas "otredades impuras". Esta mirada sobre la ciudad además se conecta con las políticas que refuerzan las dinámicas de fragmentación territorial, de exclusión hacia las periferias y las zonas periurbanas. Para Manuel Delgado:

"las mismas instancias políticas que se muestran sumisas o inexistentes ante el liberalismo urbanístico y sus desmanes pueden aparecer obsesionadas en asegurar el control sobre unas calles y plazas -ahora obligadas a convertirse en 'espacios públicos de calidad'- concebidas como mera guarnición de acompañamiento para grandes operaciones inmobiliarias." (Delgado, 2011: 11)

Podemos interpretar que en el caso de La Plata no hay paradoja sino complementariedad entre los discursos y las políticas urbanas del Estado local y los proyectos privados de "reconversión urbana" (que llevan adelante grandes construcciones y la instalación de nuevas zonas comerciales). Para ambos actores -autoridades locales y planificadores/emprendedores urbanos- la noción de "espacio público" se puso de moda: "a partir de las grandes iniciativas de reconversión urbana, como una forma de hacerlas apetecibles para la especulación, el turismo y las demandas institucionales en materia de legitimidad.” (Delgado, 2011: 9). De este modo, se puede reconocer que mientras se pretende una "ciudad limpia" -de graffitis y de grafiteros, de pibes pobres de las periferias- por medio de regular y controlar la vida urbana -las paredes, calles, espacios y las relaciones y prácticas, se deja librada la acción de la especulación privada.

\footnotetext{
${ }^{234}$ Nota con audio de Cool radio "Se presentó el informe sobre el Programa 'Pintó Cuidar lo Nuestro"”. Disponible en: http://coolradiohd.com/2015/05/07/se-presento-el-informe-sobre-el-programa-pinto-cuidar-lo$\underline{\text { nuestro/ }}$
} 


\section{II.e. Registro de murales y artistas}

En ese mismo acto de gestión en el que participó el intendente se dieron a conocer públicamente los lineamientos de un nuevo programa. Desde allí se plantearon los primeros pasos de la creación de un "registro único de murales" y artistas que habilitaría, por parte del municipio, muros y paredones "en desuso" de la ciudad. Sin embargo, no tuvo una repercusión positiva en la mayoría de los interventores visuales de la ciudad, que no se sintieron interpelados por la propuesta y que continuaron produciendo a su modo. Cabe indicar, por otra parte, que con el cambio de gobierno municipal, a finales de 2015, este programa y la ordenanza respectiva, permanecen paralizados-.

Esta estrategia de convocar -e invocar- al muralismo y el arte callejero para hacer de la ciudad un lienzo de arte ("para mirar y disfrutar"), pero también como método para hacerle frente al "vandalismo", es una propuesta similar de la que se desprende de las publicaciones del diario El Día -que se analizan en el siguiente capítulo-; lo que marca una convergencia entre el discurso político y el discurso mediático sobre algunas cuestiones sensibles de la ciudad.

De este modo, se puede concluir que la construcción de las políticas urbanas y culturales que se implementan en la ciudad en el periodo analizado estuvieron pendientes de "gestionar lo urbano" -es decir, ocupados en delimitar los recorridos y usos movedizos de los habitantes, allí el "arte" aparece como un recursos valido para enfrentarlos y ordenarlos-. Mientras que al mismo tiempo estas políticas estatales -ordenanzas, controles, aplicación de sanciones, cuidados del patrimonio, etc.- se liberalizaron para el desarrollo del negocio constructivo e inmobiliario a gran escala. Se buscó el control de lo urbano -restringir las apropiaciones de lo público y del espacio- para dejar hacer a la especulación inmobiliaria y constructiva -incentivar la propiedad-.

\section{Una ciudad que se gentrifica}

Como venimos sosteniendo, la ciudad de La Plata viene experimentando mutaciones urbanas y culturales que han ido transforman su morfología y su fisonomía visual, pero también sus tiempos y formas de relación. En tal sentido, las políticas, normativas y situaciones descriptas precedentemente dan cuenta de profundos cambios urbanos en este enclave local en los últimos quince años. Tres elementos fundamentales de este proceso se han mencionado: a) los constantes planes y programas de "recuperación del espacio público" 
-que van desde arreglar una plaza hasta buscar regular la práctica del "arte urbano", desde la instalación de las "cámaras de seguridad" hasta un mega festival en la vía pública-; b) la construcción en altura en el casco urbano -habilitada por la el COUT que eleva a 45 metros la altura permitida en el centro de la ciudad-, y c) la "conquista de las periferias" por parte de la especulación inmobiliaria y la búsqueda de acceso a la vivienda propia por parte de sectores de clase media -dinámicas todas ellas que llevan al encarecimiento del suelo urbano y al desplazamiento y/o segregación de los sectores más vulnerables a zonas más precarias-. Pero también hay que conectar en este proceso un cuarto elemento: la (re)valorización y reestructuración de ciertas zonas de la ciudad, en las cuales las circulaciones y los intercambios comienzan a estar marcados fuertemente por la lógica del consumo, cuestión que podemos reconocer como una de las características -pero no la única- de los procesos de "gentrificación” urbana o "ennoblecimiento" de algunas zonas de la ciudad ${ }^{235}$. En todas estas situaciones se pueden observar que el Estado local no es el único actor que entra en juego en este proceso de mutación de la ciudad.

En este sentido, los cambios que han sucedido en el barrio Meridiano V -que lo han transformado sustancialmente- pueden ser la referencia más clara al momento de ejemplificar estos procesos de reconversión urbana en La Plata, en los que la cualificación cultural e histórica cobra especial valor para el desarrollo del comercio y el turismo. Así es que en ese barrio se pueden observar modificaciones en los ritmos vecinales, una lógica comercial como uno de los elementos más destacados de los intercambios (expresado en la emergencia de bares y cervecerías artesanales, pizzerías, restaurantes, fiestas nocturnas), la explosión de ofertas y actividades culturales de esparcimiento y de espectáculos nocturnos. Asimismo, en esta nueva situación también se puede indagar sobre qué sectores de la sociedad platense son los usuarios-espectadores-consumidores-habitués de este tipo de propuestas y quiénes quedarán por fuera de estas iniciativas, cuestión que no solo tiene relación con contar o no con el capital económico necesario para su acceso, sino con el grado de interpelación que dichas propuestas logran generar en distintos sectores sociales ${ }^{236}$.

\footnotetext{
235 ' $O$ ' Connor y Wynne (1997: 189 y 204, citado en Carman, 2006: 140 y 25) definen el proceso de ennoblecimiento urbano como una especie de inversión del movimiento centrífugo para afuera desde el centro de la ciudad, por parte de las clases acomodadas, que deviene en un recentramiento de áreas de la ciudad anteriormente consideradas marginales (...) El neologismo -gentrificación-, formado a partir de gentry (nobleza), pretende significar el proceso de reestructuración de algunas zonas urbanas, acompañado de un efecto de atracción sobre grupos de recursos económicos y culturales medios y superiores que allí establecen residencia o comercio."

${ }^{236}$ Algunas situaciones cotidianas de los últimos cinco años son sintomáticas de esta cuestión: la proliferación de alarmas en las casas, la colocación de algunas cámaras de seguridad -incluso una cámara y un botón de pánico fueron colocados a inicios de 2015 por Control Urbano en el playón de la esquina de 17 y 71 , que luego
} 
En abril de 2009 comenzó a rodar el proyecto de "Circuito cultural" en Meridiano V con la Secretaría de Cultura del Municipio, algunos vecinos y comerciantes y los centros culturales -Estación Provincial, La Grieta y Viejo Almacén El Obrero- a la cabeza de esa iniciativa. En esa situación y ante el "desembarco" como centro cultural del partido político de Francisco De Narváez, Daniel Badenes -en ese momento integrante de La Grieta- escribió algunas reflexiones en un breve texto de intervención publicado en su blog. Allí problematizaba sobre las transformaciones que estaban sucediendo en el barrio a partir del vínculo con el dinero y los procesos de gentrificación urbana:

"Algunos queriendo, algunos temiendo, algunos sabiendo lo que dicen y otros repitiendo, anuncian que Meridiano V se está convirtiendo en el San Telmo platense. (...) Pero aún cuando los unidos por (y con) la plata se retiren, habrá que seguir pensando algunas cosas. Pensar el barrio. Discutirlo, como siempre. Asediarlo con preguntas.

¿Queremos un San Telmo platense?

¿Queremos la lógica del espectáculo masivo?

¿Queremos una circulación regulada en espacios previsibles?

Puede que sí; es el imaginario de más de uno. Pero también puede que no. Puede que no todos estén conformes con el modo en que crece la criatura.

Quizás la tarea cada vez más urgente sea sembrar esos interrogantes y empezar a producir, también, algunos corto-circuitos." 237

Más recientemente Matías Manuele, otro amigo/ex-integrante de La Grieta, propuso un balance crítico sobre el vínculo de los proyectos culturales que movilizaron y movilizan a Meridiano $\mathrm{V}$ con los procesos de gentrificación. También reconoció tensiones en las maneras de entender al "circuito cultural" y vislumbrar nuevas proyectos que se están amando por lo bajo y en el cotidiano del barrio:

"El territorio del Meridiano es hoy el campo de batalla de una nueva guerra mundial. La Plata se ha vuelto el Marte a colonizar por las nuevas formas del capitalismo que, de manera astuta, larvada, y simulada se infiltran en nuestro cotidiano. Y esas fuerzas se

fueron retirados-, la presencia policial y de agentes municipales cada vez más permanente y la aparición en el barrio, desde aproximadamente el año 2010, de chicos y chicas "cuidacoches" y "trapitos" en los horarios de la tarde y noche, cuando están abiertos los bares y restaurantes.

${ }^{237}$ Badenes, Daniel (2009). "Cortocircuitos", blog El oficio de blasfemar, 28 de abril de 2009. Disponible en: http://oficiodeblasfemar.blogspot.com.ar/2009/04/cortocircuitos.html 
metieron por la misma puerta que supimos abrir. El proceso se llama gentrificación, y es la colonización a través de la Indian Pale Ale (David Harvey dixit).

(...) Barrios ferroviarios, zonas portuarias, periferias semirurales, humedales, se transforman así en espacios codiciados de un capital ávido de mercancías baratas para su puesta en valor. Porque como bien nos explica Harvey, esa ha sido siempre la lógica del capital, la realización de sus excedentes a través de la urbanización colonizante. Cada crisis del capital está signada por una expansión urbana (...)

Y las fuerzas de choque, la vanguardia larvada de ese capitalismo, somos nosotros. La astucia de la razón es su capacidad de infiltrarse en nuestras propias estrategias. La Muestra Ambulante, y mucho del movimiento cultural del Meridiano V debe reconocer esa consecuencia no deseada que hizo de la recuperación de un espacio de vida, una mercancía de la especulación urbana. Como sostiene Mora González, una rápida mirada por los clasificados inmobiliarios de la ciudad, mostrará que las ofertas de casas antiguas por la zona llevan leyendas como "ideal para bares o restaurantes" o "barrio jerarquizado por la Estación Cultural Meridiano Vo". Así, el barrio se va transformando en una escenografía para el comercio y el Municipio, donde los habitantes -los pibes de la escuela, los habitantes de pensiones, mecánicos roñosos, putas y merqueros, jubilados quinieleros- pasan a ser figuras molestas.

(...) Frente a estos sentidos, una experiencia se fue larvando. Porque así como el efecto de las Muestras (Ambulantes) puede leerse como gentrificación, también hay un legado en el trabajo que actualmente se despliega en los talleres de El Galpón y en la Asamblea de la Estación Provincial. Experiencias que fueron acompañadas por un proceso que en la última década visibilizó y dio un lugar a los que antes estaban de paso por la avenida 72. El barrio se amplió y empezó a contener lo que antes no tenía representación. Así varias experiencias se fueron construyendo a la par que el barrio se iba gentrificando. El Galpón se cerró sobre sí. Pero solo aparentemente. Ya no es el polo de mega eventos que daban luz sobre un territorio olvidado. La luz interna del galpón está hoy iluminando otras experiencias (...) donde niños, adolescentes y jóvenes sostienen y reinventan ese espíritu autogestivo y rebelde de las derivas pasadas, tensando todo el tiempo el Circuito Cultural entendido como mercancía y un Circuito Cultural concebido como resistencia. $" 238$

Pero Meridiano V no es el único espacio de la ciudad que está involucrado en estos procesos. Con ciertas características similares, aunque de escala más pequeña, una zona de barrio Hipódromo experimenta desde hace unos años algunos cambios a través del impulso

${ }^{238}$ Manuele, Matías. (2016) “Amartizar en el barrio”. La Plata, revista boba, № 3, diciembre de 2016, pp. 19-20. 
de ofertas gastronómicas y culturales que toman la posta en las circulaciones e intercambios. En este sentido, en noviembre de 2014 fue lanzado el "circuito barrio Hipódromo, barrio de los studs". Así, de la mano de los "agentes culturales" que se encuentran presentes en el barrio desde hace un tiempo, esta iniciativa buscó replicar la construcción del circuito de Meridiano V, atendiendo a las improntas e identidades de Hipódromo ${ }^{239}$. Carla, integrante de La Bicicletería Creación Colectiva, planteó su opinión al respecto: "Es el principio de algo que va a estar bueno, esto recién comienza. (...) Creo que está bueno que los espacios que producen, se encuentren. Y a partir de ahora, quizás, encontrar una forma nueva de producir, como más amplia y colectivamente." 240 Por su parte, Rosana Lofeudo, integrante del taller "Buena Madera", otro de los colectivos que conforman el circuito cultural, lamentaba la virtual destrucción del perfil de Hipódromo como barrio de casas bajas:

"Esperamos que el COU, el Código de Ordenamiento Urbano, no nos afecte a nosotros. Esperemos que la gente no quiera vender sus terrenos para hacer edificios (...) que no suceda, que no nos derrumben las casas y queden atrapadas casitas pequeñas entre edificios altos. (...) Estamos en coordinación con Defendamos La Plata, un poco custodiando ésto y haciendo charlas de concientización y proyecciones."241

Pese a los cuestionamientos y las reacciones contrarias de una parte de los vecinos y organizaciones civiles, la reconversión y cualificación urbana de la ciudad está creciendo de forma acelerada desde hace unos años de la mano, también, de proyectos más "sólidos" o "pesados", que implican demoliciones, remodelaciones de locales, construcciones y grandes inversiones en la puesta a punto de espacios para tiendas comerciales. De este modo, sin el desarrollo de actividades culturales y creativas ni de "iniciativas comerciales de impronta cultural" como las de Meridiano $\mathrm{V}^{242}$ e Hipódromo y además sin los procesos de participación ciudadana de estos han tenido y tienen, otras zonas dentro del centro

\footnotetext{
${ }^{239}$ En noviembre de 2014, en el marco de las actividades coordinadas por el municipio por el aniversario 132 de La Plata, se lanzó el Circuito Cultural Barrio Hipódromo. El circuito está integrado por la cervecería Hermanos and Brothers, Centro Cultural Daniel Favero, espacio de arte Dionisia, Romania cerveza artesanal, El Sócalo, el espacio cultural Tita Merello, Taller de Buena Madera, radio Estación Sur y La Bicicletería. Nota disponible en: http://turismo.laplata.gov.ar/noticias_abierta.php?id=37

${ }^{240}$ Entrevista de radio Estación Sur. Disponible en: http://archivo.radioestacionsur.org/?p=11257

${ }^{241}$ Entrevista realizada en el programa "De mañana es mejor", FM Radionauta. Disponible en: https://radionauta.com.ar/2014/11/13/lanzamiento-del-circuito-cultural-barrio-hipodromobarrio-de-los-studs/

${ }^{242}$ La idea de "impronta cultural" está referida en el actual proyecto de ordenanza del "Circuito Cultural Meridiano V", presentado en 2016. A su vez, en ese proyecto se destaca como fundamento, como cualidad destacada, que la organización barrial ha producido un "polo de atracción" sin equivalencias en la región: "nucleados en la Asamblea Barrial Meridiano V, alumbraron durante las últimas dos décadas un polo de atracción turístico, gastronómico, histórico y artístico cuya configuración, en la actualidad, no reconoce equivalencias regionales."
} 
"neurálgico" de la ciudad transitan actualmente varias transformaciones. Entre ellas, la zona de diagonal 74 desde 19 y 60 hasta 47 y 8 y, más recientemente, la zona que abarca de calle 50 a 53 y de calle 6 a calle 4 . El rubro más preponderante que se puede reconocer en ambas zonas "renovadas" es el gastronómico: bares, cervecerías, pizzerías, restaurantes, hamburgueserías y casas de té. Los otros rubros destacados de comercios son: regalerías y bazares, decenas de tiendas de ropa para mujeres y para hombres de primeras marcas, así como de indumentaria deportiva, etc.

Lo que se puede concluir es que el espacio urbano de La Plata como una totalidad, aunque con desniveles y diferentes intensidades en su interior, está atravesado por un proceso de importantes cambios que implican modificaciones en las maneras de circular y consumir, en las formas de habitar la cotidianeidad barrial, en los modos de usar y apropiarse de los espacios y el modo de entender y experimentar lo público. Dicho proceso no está únicamente impulsado desde las políticas urbanas y culturales del Estado local. Como intentamos remarcar aquí, en él participan también los medianos y grandes emprendimientos privados (inmobiliarios y comerciales), así como también distintas iniciativas culturales y comunitarias ligadas a territorios específicos de la ciudad. Como todo proceso abierto, este se presenta lleno de tensiones y disparidades.

\section{IV. ¿Qué ciudad?}

Cuando se abordan las cuestiones y problemáticas que incumben a la ciudad -no solo al territorio en el que se la suele limitar sino a la vez a la cultura urbana que se busca practicar, habitar y sentir como propias- surge como riesgo el plantear idealizaciones y descontextualizaciones.

Pero si el análisis se posiciona en un punto de reflexión crítica, se vuelve preciso a su vez renegar de las ideas irreversibles de que nada se puede cambiar y así como de las que entienden que la ciudad es un "paisaje" para "contemplar". Como insistimos, aquí se considera que se puede hacer y vivir de otro modo la experiencia urbana, en parte, al entender a la ciudad como un espacio de lo transformable y lo posible en donde las prácticas cotidianas tienen un valor fundamental. Al comprender las tendencias hegemónicas en las ciudades contemporáneas (fragmentación, gentrificación, des-planificación, liberalización, formas de estado de excepción, etc.), se torna urgente sostener ese impulso que cuestiona y buscar transformar lo dado. Es por esto mismo que, al realizar la pregunta con la que cierra 
este capítulo (¿qué ciudad?), se la liga indefectiblemente con la de ¿qué sociedad? Las respuestas pueden ser muchas, y no es nuestra intención circunscribirnos a un manojo de ellas. Más bien interesa poner de relieve la importancia de tomar ambos interrogantes como necesariamente imbricados. Sea en las discusiones sobre lo local-global (o su síntesis, lo "glocal") donde los espacios territoriales y localizables se vuelven porosos frente a nuevas formas de conexión que reconfiguran las distancias y las proximidades; sea abordando los múltiples condicionantes y factores que producen ciudad y producen sociedad (es decir, el retomar un cierto productivismo).

En este sentido, parece oportuno pensar en un lugar y principalmente una trama de relaciones instituyentes donde lo urbano, es decir la "ciudad practicada", insista y persista frente a las lógicas instituidas de la política formal. Pero también, frente a las lógicas especulativas y a la desidia. Una trama en la que la cultura urbana -que como se indagó, se intenta restringir y acotar por la especulación del capital- se desarrolle junto a la necesaria planificación urbanística de la ciudad. Esto es: no negar la proyección -urbanística, territorial, productiva- de la ciudad si no discutir los fuertes intentos de regulación/constricción (vía la planificación, el ordenamiento y el control de lo urbano) de esas prácticas que lo producen cotidianamente, y que hoy son fuertemente impulsados desde las políticas estatales.

Frente a algunos aspectos de este proceso de mutación urbana de la ciudad -y en discusión con los políticas emprendidas desde el Estado local y las iniciativas privadascorporativas "pesadas"-243, las experiencias de intervención cultural indagadas reivindicaron, principalmente, los espacios de lo público a partir de una constante acción en el territorio urbano. Buscaron recuperar y generar espacio público, momentos de encuentro y apertura, instancias de retener lo común. Es decir, no solo se han posicionado desde la negatividad (rechazo a determinadas medidas, oposición a tales políticas y situaciones) sino desde la afirmación y la respuesta: aquí y ahora hacemos espacio público y buscamos habitar la ciudad de otro modo. Se puede interpretar que este es uno de los sentidos más fuertes que se retienen de los repertorios de la acción colectiva que se construyeron en la crisis y los acontecimientos de 2001 en el país.

A su vez, esta situación de cambios en la urbanidad de la ciudad opera como un escenario de interpelación y uso para las experiencias culturales que reclaman para sí en lugar

\footnotetext{
${ }^{243}$ Cabe mencionar que las situaciones y los elementos aportados por los circuitos culturales (impulsados con centros culturales y vecinos) a la re-cualificación y gentrificación urbana, han sido los menos discutidos y tensionados en la ciudad por parte de las intervenciones culturales seleccionadas. Una lectura posible de esto podría ser cierta proximidad y afinidad de entre algunas de estas experiencias culturales, que las hace compartir algunos horizontes comunes de inquietudes e intereses sobre la ciudad.
} 
en ella e intervienen desde una multiplicidad de dispositivos visuales y retóricos -la contingencia de un mural, una gigantografía o una pintada callejera, la fugacidad de un stencil, la presencia corporal de unos muchos, la invitación al encuentro en los recorridos de un barrio, el diálogo entre un banner en una pared y la web-. Ese escenario es una "piel" a intervenir en la cual estas prácticas buscaron plantear discusiones, generar tensiones, movilizar dispositivos, apropiarse del espacio urbano y dar disputas de sentido sobre los contornos de la ciudad y la experiencia urbana: activar una "vitalidad micropolítica" que mueva a la ciudad y trastoque los recorridos y sentidos instituidos. Entonces, activar la crítica y la respuesta, la negación de lo dado y la afirmación de un otro posible. Pero estas acciones de apropiación y disputa urbana y cultural no son únicamente motorizadas por los colectivos e interventores culturales. Muy por el contrario, estos actores participan de una heterogénea red de prácticas sociales que a veces alternativizan y otras antagonizan con las políticas culturales y urbanas oficiales y con los proyectos hegemónicos de reconversión urbana. 


\title{
Capítulo 7
}

\section{Artistas vs. vándalos: construcciones binarias desde la prensa comercial}

\author{
"Las paredes no hablan, lloran" \\ Diario El Día, 10/11/2012 \\ "La ciudad es una mugre gracias a estos atorrantes que la van \\ de "artistas". Deberían pagar por los daños a la propiedad, ya \\ sea pública o privada." \\ horacio_01, comentarios de los lectores. Diario El Día, 2013
}

\section{La ciudad en los medios, los medios en la trama urbana}

Una gran cantidad de autores han destacado la importancia de investigar a los medios de comunicación. Omar Rincón (2003: 245) sintetiza esto en cuatro puntos:

1. Para el campo de estudios de la comunicación, son un objeto irrenunciable. Se vuelve un imperativo investigar en los procesos y las lógicas mediáticas.

2. Constituyen los ejes centrales de la vida social contemporánea ya que su acción es significativa en las agendas de conversación, la toma de decisiones y la construcción de identidades comunes.

3. Tienen un papel estratégico en la construcción de una cultura popular mundializada, en la visibilidad estratégica que le otorga a las identidades locales y en la mediación y negociación que realizan entre lo local y lo mundial.

4. Tienen una historia de dispositivos, modos y estrategias de construir el mundo simbólico.

Pero ¿por qué indagar en los medios de comunicación para reflexionar sobre la ciudad y las intervenciones culturales que en ella se producen? En un artículo, publicado hace casi dos décadas, Néstor García Canclini comprendía que las dinámicas de la vida urbana tienen que ser también reconocidas en los discursos e imaginarios que sobre las ciudades -y las personas que las habitan- realizan los medios. "La caracterización sociodemográfica del 
espacio urbano no alcanza a dar cuenta de sus nuevos significados si no incluye también la recomposición que les imprime la acción massmediática" (García Canclini, 1997: 10). Para este autor, tanto los estudios urbanos y como los comunicacionales abrían "la tendencia a entender la ciudad en relación con los procesos de comunicación y a éstos vinculados con la trama urbana." De este modo, la ciudad "no es vista ya sólo como escenario para habitar y trabajar, y por tanto como simple organización espacial" (1997: 9). Por el contrario, la ciudad -como se viene sosteniendo a lo largo de la tesis- se constituye en una trama de sentidos, representaciones sociales y modos de habitar, que son diferenciales, desiguales y que, muchas veces, colisionan.

Es así que aquí se tiene en consideración a los medios de comunicación como constructores de sentido sobre las ciudades. Pero, más globalmente, se los entiende como actores que proponen "marcos interpretativos de la experiencia colectiva a través de la construcción de acontecimientos, casos, testimonios y series, y a la focalización en ciertas prácticas y sujetos" (Elizalde, 2005: 25), que de este modo operan en y disputan las significaciones sociales ${ }^{244}$. En el presente capítulo se indaga en el discurso mediático de la prensa escrita local, centrando el análisis en el diario El Día. En parte, la decisión de atender a la prensa escrita se debe a que esta "se ha considerado el lugar privilegiado donde una sociedad se piensa" (Rincón, 2003: 246), por sobre otras plataformas y lenguajes. Se indaga así en las construcciones de sentidos que produjo este medio sobre diversas intervenciones culturales en la ciudad.

La propuesta de tomar solamente a la prensa escrita de la ciudad puede resultar limitante si lo comparamos con la diversificación y gran cantidad de otros medios que existen actualmente, e incluso que se desarrollan en La Plata (agencias de noticias, medios electrónicos, radios públicas y privadas-comerciales, comunitarias, señales de televisión de aire y por cable, etc.). Una razón es por la accesibilidad de la muestra y los materiales (los diarios y publicaciones impresas suelen ordenar y archivar sus producciones y las hemerotecas catalogan estos materiales). Otra razón, más importante aún, es el lugar privilegiado que siguen ocupando los medios impresos en La Plata. Principalmente el diario El Día en tanto tradicional matutino y como medio de comunicación en el que la ciudad "se informa", "se expresa" y "se piensa", aunque queda claro que en esa construcción mediática -

\footnotetext{
${ }^{244}$ Una gran cantidad de trabajos académicos en el campo de la comunicación y cultura estudian la construcción de significaciones mediáticas, las intencionalidades editoriales de los medios, el tratamiento mediático de diversas situaciones sociales y las regulaciones culturales que operan los medios. Para algunos estudios sobre la "condición juvenil femenina" en los medios (Elizalde, 2005; 2015), sobre la "estigmatización de chicos en situación de calle" (Badenes, 2009; Calligo, 2016) y sobre las estrategias de "visibilidad" de los movimientos sociales en los medios (Reguillo, 2000b).
} 
que se presenta como abierta y democrática- existen muchas voces y formas de la ciudad que quedan por fuera ${ }^{245}$.

\section{El caso del diario EI Día}

\section{II.a. ¿Por qué El Día?}

Como se planteó recién y en el capítulo 2 al describir las herramientas metodológicas, la elección del diario El Día correspondió al supuesto de que ese medio de comunicación es un "actor político" (Borrat, 1989) ${ }^{246}$ de importancia en la construcción los discursos y sentidos que se configuran sobre y en la ciudad de La Plata. Es el principal medio que define agenda de discusión en la ciudad. Al mismo tiempo, en el acopio de materiales periodísticos y su cuantificación, fue este medio el que más publicaciones realizó sobre las cuestiones que interesan para este análisis, planteando no sólo "preocupaciones sentidas" por los vecinos de la ciudad, sino sobre todo una posición fuerte y contraria a ciertos tipos de intervenciones gráfico-visuales.

El Día fue fundado en 1884 y es considerado unos de los primeros medios de prensa de la ciudad. En 1955 con la dictadura autodenominada "Revolución Libertadora" David Kraiselburd -que era cronista del matutino desde 1928- integró el grupo empresario que se hizo del medio. En 1961 se transformó en su director y el principal accionista ${ }^{247}$. Su hijo Raúl

\footnotetext{
${ }^{245}$ El lugar que ocupa El Día en las narraciones sobre la ciudad no puede soslayarse, más allá de la posición contraria que se puede tener en relación a la política editorial de dicho diario y su posicionamiento sobre diferentes problemáticas que suceden y hacen a la ciudad. Por ejemplo, pensemos en la posición que asume $E l$ Día frente a los conflictos de trabajadores, las tomas de tierra que se producen en reclamo de viviendas, los reclamos estudiantiles o -como ya se refirió anteriormente en la tesis- su discurso sobre los jóvenes pobres de sectores populares.

${ }^{246}$ Este autor se propone "estudio de las actuaciones públicas del periódico independiente de información general y perioricidad diaria o semanal en tanto que actor del sistema político. (...) Su ámbito de actuación es el de la influencia, no el de la conquista del poder institucional o la permanencia en él. El periódico pone en acción su capacidad para afectar el comportamiento de ciertos actores en un sentido favorable a sus propios intereses: influye sobre el gobierno, pero también sobre los partidos políticos, los grupos de interés, los movimientos sociales, los componentes de su audiencia. $\mathrm{Y}$ al mismo tiempo que ejerce su influencia, es objeto de la influencia de los otros, que alcanza una carga de coerción decisiva cuando esos otros son los titulares del poder político" (Borrat, 1989: 67).

${ }^{247}$ Sobre el modo en el Kraiselburd y otros se hicieron con la dirección del medio puede ser ilustrativo el siguiente testimonio producido en la tesis de Badenes (2012: 50): "David Kraiselburd (...) asumió la dirección de El Día en 1961 tras ser una pieza clave en la ruptura de un conflicto laboral cuyos detalles aún no han sido historizados. Según Ricardo Soler, "los empleados hicieron una huelga feroz... Kraiselburd se juntó con los amigos y sacó un diarito chiquitito, un día, otro día, otro día, hasta que les rompió la huelga. Y se hizo cargo del diario. La anécdota célebre dice que Stunz, que es el propietario, que era un tipo que andaba en yate por el mundo, un dandy, le pregunta ¿cuánto me va a cobrar por todo esto que hizo?. 'Nada, doctor ', le dijo. Y entonces le dio no sé cuántas acciones. Y ahí él y Stunz coparon el diario hasta el día de hoy" (entrevista a Ricardo Soler, agosto de 2008)."
} 
Kraiselburd asumió la dirección del diario desde 1974, luego de que David Kraiselburd fuera secuestrado y asesinado por la organización Montoneros. Como tendencia de su línea e intencionalidad editorial se puede decir que El Día ha mantenido una mirada conservadora y que ha brindado su apoyo a los oficialismos locales en el poder. También desde sus páginas ha dado respaldo a la última dictadura cívico-militar ${ }^{248}$ en el país. Según Badenes "la relación con la dictadura fue de colaboración y apoyo, si bien no pertenece al grupo de empresas periodísticas con mayor compromiso, asociada al negocio de Papel Prensa" (2012: 51) ${ }^{249}$.

Según datos del Instituto Verificador de Circulaciones (IVC), en noviembre de 2016 El Día tenía una circulación neta pagada de casi 26.000 ejemplares diarios y es la edición paga más vendida de la ciudad ${ }^{250}$. En los últimos años se puede observar que El Día comenzó a modificar sus estrategias periodística y de negocios, en parte, con el rediseño su sitio web en el que ha incorporado varias actualizaciones diarias de noticias, ha realizado una ampliación de publicaciones producidas para la web, ha asignado importantes espacios para las publicidades pagas en la cabecera y los laterales de su sitio y ha generado perfiles en varias redes sociales (Facebook, Twitter, Instagram, Google+, Youtube) enlazadas con su web. Según el sitio Alexa -especializado en estadísticas web- la página www.eldia.com ocupa, a diciembre de 2016 el puesto 235 entre los sitios web más vistos de la Argentina. Pero lidera el ranking de las web más visitadas en La Plata, por sobre la página del diario Hoy

\footnotetext{
${ }^{248}$ El editorial "La prevista consecuencia" publicado el 26 de marzo de 1976 plantea que "Pocos desenlaces en la vida institucional argentina han sido tan inevitables y previsibles como el proceso desencadenado en las últimas horas de la jornada del martes pasado y que culminó con la caída definitiva del gobierno que había asumido el poder el 25 de mayo de 1973. (...) En el país se inicia una nueva etapa, por cierto nada fácil, para todos los argentinos. El reordenamiento del aparato productivo de la Nación y el aniquilamiento definitivo de la guerrilla - todo en un marco de libertad dentro del orden jurídico y los principios republicanos de la Constitución- parecen las prioridades indispensables para que los habitantes de este suelo recuperen la paz, tranquilidad y seguridad que les permitan sumar su esfuerzo creador a la tarea del conjunto". Fragmentos citados en el portal Diario sobre diarios. Disponible en: http://www.diariosobrediarios.com.ar/dsd/notas/4/38-el-golpedel-76-y-el-respaldo-de-los-diarios-la-voz-del-interior-y-el-dia.php

249 "La mañana del 28 de marzo de 1976, cuando asumió la intendencia local el capitán de navío Oscar Macellari, el diario lo saludó con una columna firmada por José del Río: "Tiempo de gobernar". Más tarde llegaría al cargo de intendente Abel Blas Román, abogado de la familia Kraiselburd y padre de un periodista que se desempeñó como secretario de redacción de El Día durante años.

Por otra parte, El Día sostuvo su membresía plena en Asociación de Entidades Periodísticas Argentinas (ADEPA) y la Sociedad Interamericana de Prensa (SIP). Cuando en la reunión anual de esta última realizada en 1980 el director de La Opinión Jacobo Timerman denunció las persecuciones de la dictadura argentina y la existencia de desaparecidos, tanto Kraiselburd como Máximo Gainza -de La Prensa-y Claudio Escribano -de La Nación- "replicaron que en la Argentina no había antisemitismo y que el ex director de La Opinión estaba cegado por el rencor personal...”. Más adelante, según publicó Escribano en 1981, Raúl Kraiselburd colaboró con la edición del libro del general Ramón Camps, quien fuera jefe de la Policía bonaerense y uno de los principales responsables del plan de secuestro, exterminio y desaparición de personas en la provincia. En 1982, tras la derrota en Malvinas, El Día acompañó todas las iniciativas gubernamentales para festejar el centenario de la ciudad." (Badenes, 2012: 51)

${ }^{250}$ Estos datos actualizados fueron provistos por dicha entidad a solicitud del autor. En marzo de 2012 El Día vendía poco más de 35.000 ejemplares diarios, en 2014 vendía cerca de 32.000 , lo que demuestra en cifras oficiales del propio diario y con dos años de diferencia, una constante caída en la venta de su versión impresa.
} 
-su competidor directo- y delante también de la página del municipio, la web de venta y alquiler de inmuebles SIOC y el portal de la UNLP ${ }^{251}$. De este modo, se puede inferir que si bien la versión impresa del medio fue perdiendo peso en el mercado de diarios y revistas -en volumen de ventas-, El Día se mantiene como principal medio de comunicación en la región. A su vez, El Día no es únicamente un diario y su web. Forma parte de un grupo empresario Kraiselburd dedicado a los medios que cuenta también con la agencia Noticias Argentinas, los diarios El Plata, Popular, las radios La Redonda y FM Diez y tres canales de televisión por cable.

\section{II.b. Los materiales y la propuesta de análisis}

Al perseguir como objetivo el análisis de los discursos y las representaciones mediáticas que se realizan sobre las intervenciones culturales en la ciudad, la primera acción consistió en la búsqueda aleatoria y el acopio de publicaciones aparecidas en diferentes medios de comunicación, la primera intención fue explorar la red de textualidades mediáticas. Dentro de lo que se puede denominar como prensa comercial, se encontraron publicaciones de El Día, Hoy, La Nación, Clarín y revista Ñ, tanto en sus soportes impresos como digitales. También se encontraron algunas publicaciones realizadas por medios alternativos de la ciudad (La Pulseada, Indymedia La Plata, Prensa de Frente) que puedan dar cuenta de otra intencionalidad e interés sobre las experiencias culturales. Luego se decidió seleccionar y sistematizar para el análisis el material publicado únicamente en El Día, por las razones que ya se expusieron: importancia local del medio y cantidad de publicaciones realizadas.

El corpus definitivo de análisis está compuesto por 44 textos periodísticos entre notas, notas breves, crónicas, entrevistas, editoriales y columnas de opinión, publicados entre los años 2007 y 2015 por el diario El Día ${ }^{252}$. La construcción de este universo es exhaustiva y tiene el objetivo que poder indagar en algunos materiales periodísticos concretos publicados durante parte la temporalidad que es objeto de la tesis.

El análisis fue realizado desde una propia adaptación de los criterios que propone Klaus Krippendorff (1990) para el análisis de contenido cualitativo. La utilización de esta técnica se inició con la sistematización del material recabado. Luego se realizó un cuadro descriptivo sobre esas publicaciones. De dichas publicaciones se tuvieron en cuenta e

251 Estas estadísticas y análisis están disponible en: http://www.alexa.com/siteinfo/eldia.com y http://www.alexa.com/topsites/category/World/Espa\%C3\%B1ol/Regional/Am\%C3\%A9rica/Argentina/Provinci as/Buenos_Aires/Partidos/La_Plata

${ }^{252}$ Las referencias a los materiales textuales se encuentran en el apartado de fuentes analizadas en la Bibliografía de la tesis. 
indagaron: titulares, volantas, bajadas, recuadros, titulares secundarios y fotografías. También el tipo de textualidad, las fuentes de información y los actores locales que relevan. El definitivo cuadro descriptivo de los materiales se organizó en orden cronológico ascendente con los siguientes ítems: fecha, tipo de texto, aspectos narrativos (título, cuerpo de texto, prácticas mencionadas, fuentes de información y aspectos visuales (uso de imágenes) (ver anexo 3).

Los objetivos del análisis se articulan entre sí. A efectos analíticos fueron separados en 1) poder marcar formas, recurrencias y énfasis en el discurso del medio (qué economía simbólica utiliza) y 2) realizar inferencias que den cuenta de las construcciones de sentido que realiza El Día sobre la ciudad y las intervenciones culturales (qué posicionamiento e intencionalidad editorial persigue, qué sentidos produce). A continuación se presenta el análisis pormenorizado.

\section{II.c. La guerra contra el vandalismo}

Se parte de entender que El Día ejerce un tipo de periodismo tradicional y, en muchos casos, presenta en su intencionalidad editorial una mirada conservadora y elitista sobre diversas situaciones y cuestiones de la realidad política y social de la ciudad, el país y el mundo. Esto produce desde el inicio un fuerte contraste con las prácticas que intervención cultural que se indagan en la investigación -que de modo simplificado se pueden entender como prácticas "alternativas", "no-institucionales" y "contestatarias"-. Desde la propia intencionalidad de la investigación, dicho contraste podía ser productivo para explorar y confrontar diferentes miradas sobre la ciudad y la cultura.

En tal sentido, las primeras inferencias que se tenían sobre la posición elitista y conservadora sobre la ciudad y la cultura de un medio de comunicación como el diario El Día se pudieron corroborar en las lecturas y descripciones de las publicaciones seleccionadas: las referencias al cuidado y la limpieza de la ciudad son recurrentes en su construcción discursiva. La Plata sería una ciudad que hay que cuidar y procurar que esté limpia (¿aséptica?) frente a las acciones que la atacan, la invaden y la contaminan.

Sin embargo, si bien sostiene un discurso que apela al cuidado y limpieza de la ciudad llamando a ejercitar políticas punitivas y de control que tendría que llevar adelante el Estado principalmente el Estado local-: "sancionar con el máximo rigor legal previsto a los transgresores"; también encuentra otra manera de pensar esas situaciones. A su vez, en relación a la cultura, en las publicaciones de este diario no se apela únicamente a una idea de las Bellas Artes, aunque siempre le reserva un lugar destacado. Estas dos cuestiones -la 
ciudad como limpieza y la cultura como las Bellas Artes- están presentes pero lo novedoso es que se encuentra algo más en la economía simbólica de sus publicaciones.

La operación de sentido que realiza El Día se complejiza cuando el medio recupera de manera positiva y toma para esa perspectiva conservadora a las prácticas tanto del "muralismo" como del "arte urbano" y el "street art". De este modo, para El Día estos conceptos y "prácticas artísticas" funcionan como sinónimo de "embellecimiento de la ciudad" y como acciones de combate al "vandalismo" y los "ataques" del graffiti y las pintadas, la "plaga de aerosoles" y el "escracho" ilegal. Como dice el diario en una de sus publicaciones: "el arte protege la pared". Esta operación discursiva implica a) limitar la acción de estas prácticas como productores de sentido; b) quitarles su potencial críticoconflictual para pensar y hacer la ciudad; y c) reforzar un binarismo conservador entre algo que sería artístico y estilizado frente a algo que sería ilegal y no-estilizado.

Para profundizar aún más lo dicho hasta aquí: según El Día aquellas acciones que serían ilegales y no-estilizadas solo buscan perjudicar a los "vecinos", causar un "daño" y hasta "atacar" o "despertar el temor" de los habitantes (identificados como "vecinos", "propietarios", "frentistas"). Por el contrario, el "muralismo" "embellece" instituciones de la ciudad y lleva adelante un "trabajo comunitario" en el que se encuentran artistas y vecinos generalmente alrededor de alguna causa o institución social. El "arte callejero"/ "arte urbano" por su parte "le pinta la cara a la ciudad": "embellece casas particulares" y se convierte en una "tendencia que crece" entre los "frentistas". También produce "coloridas galerías urbanas" con "figuras nacionales e internacionales" y "le cambia la cara" a los hospitales de la ciudad con un "mensaje de esperanza". Ambas "intervenciones artísticas" son, para el centenario diario platense, protagonistas de la "explosión de la imagen" y "el color" que se observa en las paredes de la ciudad y también herramientas válidas "frente al flagelo del graffiti" y el "avance del aerosol", utilizadas tanto por la ciudadanía como por las instituciones. Representan así una "defensa" de bienes y personas.

"Por cuestiones de estética urbana, para dotar a las fachadas de valor simbólico o simplemente como forma de contrarrestar el vandalismo que producen los grafitis, en muchas viviendas e instituciones se hacen los más diversos murales" (El Día, 7/12/2014).

“'La casa se destaca y el plus fue que me salvó de los graffitis' contó la dueña de la casa" (El Día, 24/08/2015). 
Esta operación que realiza del medio se completa con el tipo de fuentes de información que menciona en sus publicaciones. La principal fuente son aquellos que el medio denomina como "los vecinos" -y sus variantes: "propietarios", "dueños", "frentistas" y "comerciantes"-, lo que da cuenta de cierta pretensión de darle voz a los que el diario considera los afectados directos del "flagelo del graffiti" y el "avance del aerosol", como así también a los que ganan "belleza" en sus frentes. Otras importantes fuentes de información que menciona son las oficiales: "las autoridades", el Municipio -la administración de ese momento y el el Concejo deliberante- y la policía, entendidos como los ámbitos que tienen que velar y controlar que este tipo de acciones (el graffiti, el garabato, la pintada callejera) no sucedan, proteger a los edificios públicos y privados de los "ataques"253.

"El dibujo apareció en la madrugada (...), a unos cinco metros de altura, alarmó a los vecinos del lugar y reencendió el debate por las pintadas callejeras, que avanzan sin control en la Ciudad" (El Día, 14/08/2012).

"Los vecinos no vieron al graffitero, pero sí las huellas de sus zapatillas trepando por una pared lateral, lo cual les generó indignación por la pintada y temor" (El Día, 19/08/2012).

"Dañar el patrimonio público es un acto de vandalismo y desaprensión al que le cabe una efectiva sanción" (El Día, 31/08/2007).

"Según detallaron fuentes policiales en su reporte, en poder de los adolescentes secuestraron ' 10 aerosoles marca KWT de diferentes colores, 42 picos, un par de guantes, una tijera metálica y una mochila color gris"” (El Día, 3/07/2015).

"Cualquier frente de vivienda, comercio, institución o edificio público, monumento, señalética, y hasta el pavimento, se sabe, son objeto de pintadas, y el material que viene en aerosol es el más utilizado para esa clase de vandalismo. Hace muchos años que la modalidad "grafitera" se ensaña con los espacios limpios de la vía pública, y eso es así aunque ha habido más de un proyecto que buscó terminar con ese accionar" (El Día, 18/04/2015).

"Estos verdaderos atentados que afean el espacio público no sólo requieren de una mayor fiscalización municipal, en el sentido de aplicar las reglamentaciones vigentes a los autores de estas agresiones, sino que reclama asimismo la realización de campañas educativas -que puedan ser tan persistentes como persuasivas- destinadas a que se tome

\footnotetext{
${ }^{253}$ Se puede destacar que la retórica que utiliza El Día tiene una doble pertenencia: por un lado, una retórica belicosa ("avance", "ataque", "invasión", "defensa", "batalla", "combate", "freno") y también una retórica sobre el delito ("flagelo", "vandalismo", "miedo", "daño", "modalidad graffitera", "desastre”, "agresión"). Sin embargo, esta última contrasta fuertemente con su visión de la ciudad como un "paisaje" -es decir como un lugar fuera del conflicto- y no como un campo de fuerzas y batallas.
} 
conciencia de que los frentes de los edificios forman parte del patrimonio urbanístico y que éste pertenece a todos, no a quienes deciden, en base a un erróneo concepto de lo que debe ser la libertad, utilizarlos para hacer propaganda." (El Día, 5/09/2015)

Sin embargo, como se afirmó antes, también el diario se encarga de relevar algunas prácticas y actores que intervienen en la ciudad y los recupera como fuentes de información. De este modo, El Día recurre la voz de algunos "artistas callejeros" de la ciudad (Luxor y Lumpenbola principalmente, pero también refiere a las prácticas de otros productores como Acra, Bruno Sirota, el encuentro ZigZag).

Las respuestas de Luxor ante la insistencia del periodista para que realice algún comentario negativo sobre el graffiti y que lo asimile con un "daño", puede ser una interesante muestra de la operación de sentido de El Día y, a su vez, de la salida ¿juguetona?- que este productor visual propone para pensar las situaciones que se pueden vivenciar en la ciudad:

- Hay muchos vecinos que se quejan por los daños que les causan las pinturas en sus frentes... usted lo sabrá bien. Dicen que esos daños les originan costos económicos elevados, cuando quieren borrar esas pintadas.

- "A mí nunca nadie me dijo que lo que hago puede causarles un daño. De modo que no puedo hablar por lo que hacen los demás".

- En realidad, las mayores quejas son contra los grafiti. Hay gente disconforme con esto, gente que le desagrada...

- "Siempre me interesaron los grafitis, pero nunca los hice. Me parecen algo hermoso".

- Perdón por la insistencia, pero si un día ve que al frente de su casa lo embadurnaron con leyendas y pintadas... ¿no le molestaría?

- "No, para nada. No tengo apego a los bienes materiales". (El Día, 3/02/2013).

Sin embargo, son sobre todo a aquellos que le asigna el lugar de "los especialistas" con su variante en "las investigaciones", "los investigadores", "los profesores"- a los que este medio le asigna más espacio para enunciar sus discursos. En este último grupo es la figura de Cristina Terzaghi, docente de la Carrera de Muralismo y vicedecana de la Facultad de Bellas Artes de la Universidad Nacional de La Plata, la que en mayor cantidad de veces es repuesta 
su palabra (consultada en tanto "especialista") y su práctica muralista-educativa (como artista y docente) en las publicaciones del diario.

El discurso de Terzaghi -la pintura mural es dañada por el graffiti, el muralismo tienen que ser perdurable y monumental- funciona como un elemento destacado, legitimado y legitimador como especialista en la batalla contra el graffiti y todas las inscripciones visuales "no artísticas" que El Día emprende desde sus publicaciones. A su vez, Terzaghi se suma a las voces que reclaman que esta actividad en las paredes de domicilios particulares e instituciones sea regulada por el municipio.

"El incipiente muralismo platense también encuentra un obstáculo: la falta de conciencia de la población, que se puede constatar cada vez que una pintura mural aparece salpicada de grafittis." (Cristina Terzaghi, El Día, 19/09/2010).

"La artista y docente se mostró preocupada por la gran cantidad de firmas y escritos que no corresponden a expresiones artísticas y se observan en paredones. Aunque interpretó que son cuestiones generacionales que pueden obedecer a inseguridades, cree que estropean muchos edificios públicos y privados. 'Hay grafiteros que son buenísimos, pero pasa algo en esta Ciudad que no nos podemos explicar; hay vecinos que nos preguntan qué les enseñamos a nuestros alumnos', dijo la docente. En relación a la decisión de muchos vecinos de pintar murales en las fachadas de sus viviendas para desalentar las pintadas políticas u otro tipo de garabatos, Terzaghi evaluó que eso se hace más para prevenir el vandalismo que por amor al arte." (Cristina Terzaghi, El Día, 7/12/2014)

\section{II.d. Un paisaje para contemplar}

En las publicaciones analizadas de El Día el sentido de ciudad es acotado. Parecería que es principalmente el mobiliario urbano, las paredes, los muros y los frentes; en esas materializaciones urbanísticas parece quedar reducida la ciudad para este medio de comunicación, una “ciudad objeto". En relación con esto, se produce una mirada tradicional que entiende a la ciudad como un espacio para la contemplación: un "paisaje urbano", una "postal urbana", un "enorme lienzo". Así es que a este "paisaje-ciudad" solo se debe dar cuenta y mirar, una experiencia urbana limitada: la vida contemplativa. Pero esta mirada adquiere algunos matices: a) sin salir de ese paradigma objetual, considera a la ciudad como un objeto sensible: que "sufre”, llora", está “indefensa” y "pierde la batalla". b) Se actualiza (y se modifica en algún punto) al incorporar -como se planteó antes- a ciertas tendencias gráficas-visuales no tradicionales ni propias de las Bellas Artes: "muralismo", "arte callejero" 
o "arte urbano" están habilitados a "intervenir" en el paisaje siempre que se para "embellecer" y "frenar el vandalismo". De este modo, en la construcción de sentido que realiza El Día sobre la ciudad se introduce cierta praxis, algo de vida activa ${ }^{254}$. En varias de las publicaciones se considera positivamente estas prácticas y se excluye a aquellas otras expresiones que se identifican como negativas -principalmente, el graffiti, pero también las pintadas de todo tipo: políticas, personales, de hinchadas-. Esta mirada, a su vez, refuerza sentidos binarios sobre lo que sería legal o ilegal, legitimo o ilegitimo, bello o escracho visual, artístico o no-artístico, actividad con pedido de permiso o clandestina. Sobre lo que sería el cuidado o el vandalismo, lo propio de esta ciudad y lo que sería un flagelo-un cuerpo extraño-plaga que hay que sacarse de encima por todos los medios ${ }^{255}$. Para El Día cuando esas otras intervenciones actúan se produce un daño, la ciudad sufre y, aún con varias acciones para frenarlas, sigue "perdiendo la batalla frente a las pintadas y graffitis".

Por último, en cuanto a las prácticas de intervención que son analizadas en esta investigación, pocas han recibido cobertura en este medio. Se encontraron algunas excepciones: a) las intervenciones y obras de las acciones de Luxor, Lumpenbola, Acra (de los dos primeros productores visuales tuvieron varias notas en diferentes años); b) dos intervenciones disruptivas en el espacio urbano como fueron notificación tergiversada de ARBA en relación al femicidio de Sandra Ayala Gamboa y la campaña "Hacé como José" sobre el aumento del boleto (esta última con un tratamiento menor); c) dos eventos como la "Muestra Ambulante" y el encuentro "ZigZag" (este último fue una de las noticias de tapa y recibió una extensa nota).

De las primeras -como ya se refirió antes- son consideradas "prácticas artísticas" que con su explosión de color "embellecen la ciudad" y son tomadas -por los vecinos y las instituciones- como "recurso del arte para frenar el vandalismo" (El Día, 3/09/2015). Los interventores son identificados como "artistas" o "artistas urbanos".

Sobre las segundas intervenciones mencionadas, en las publicaciones de El Día se puede reconocer otro tratamiento, distinto entre ellas y en relación a otras acciones. Por un

\footnotetext{
${ }^{254} \mathrm{El}$ contrapunto entre "vida contemplativa" y "vida activa" para reconocer una condición urbana activa ligada a la segunda (como "lugar practicado", como praxis) se encuentra, entre otros, en el trabajo de Mongin (2006).

${ }^{255}$ Este binarismo también se puede encontrar en los aspectos visuales de las imágenes con las que El Día acompaña sus publicaciones escritas. En su mayoría, estas imágenes son de tipo referencial en anclaje al texto: ilustran el hecho mencionado en el escrito. Sin embargo, la principal diferencia es que en las notas que refieren al muralismo, el arte urbano y arte callejero se observa a las personas involucradas -los artistas, los organizadores- produciendo o contemplando la obra. Mientras que en las publicaciones que hablan sobre graffitis y otras pintadas esta únicamente la pintada, sin autor, sin responsable, como infiriendo un hecho negativo (un delito) consumado cuando nadie podía observar.
} 
lado, "Hacé como José" fue tomado con seriedad, se informa sobre la iniciativa de José María Martínez y de la asamblea "contra el tarifazo" y se recupera textualmente su voz que fue expresada en la conferencia de prensa que José montó en Plaza San Martín ante varios medios locales. Se puede decir que en este punto, si bien esa cobertura de El Día fue breve, se cumplió el objetivo de la campaña de visibilizar en los medios el reclamo sobre el aumento del boleto de colectivo. De este modo José, un docente de la ciudad que como otros trabajadores viaja en micro -pero también el personaje inventado, esa fábula para poder discutir sobre el "tarifazo"- adquirió mayor estado público por los medios. Por otro lado, se puede reconocer una carga negativa en el tratamiento mediático de El Día sobre las "notificaciones falsas" de ARBA -acción que no fue reivindicada o referida por ningún grupo o interventor pero que está articulada con los reclamos llevados adelante desde la "Asamblea Justicia por Sandra"-. Según la nota del diario:

"Los contribuyentes que se vieron involucrados en esta extraña "convocatoria" no comprenden si se trata de una burla grosera o si responde a una maniobra por parte de gente que de alguna manera está relacionada con el caso de Ayala Gamboa. Sea cual fuere el origen de estas comunicaciones "truchas" no se entiende cuál pudo haber sido el objetivo ni qué se gana molestando a la gente que concurrió, preocupada por la intimación, a la sede de 7 y 46." (El Día, 21/08/2009)

Sin embargo, también aquí se puede plantear que algunos de los objetivos de la acción -que El Día dice no entender- se cumplieron: visibilizar en los medios el reclamo por femicidio de Sandra Ayala Gamboa y que se trataba de un crimen impune. Cuestiones que el diario en su nota se hace eco. Lo que no se consiguió es vincular a ARBA en lo que sucedió con Sandra, en tanto encubrimiento.

"La intimación resultó falsa, según advirtió una vez que se lo indicaron en esas oficinas: no sólo no había salido del organismo sino que además en la nota se la invitaba a "esclarecer el caso" con Sandra Ayala Gamboa. Ese es el nombre de la joven que fue asesinada en 2007 en el edificio en el que ahora funciona ARBA y por quien su familia reclama justicia desde entonces.

(...) El cuerpo de Sandra Ayala Gamboa -de 21 años y peruana de origen- fue hallado en un baño de un edificio de la ex dirección de Rentas -hoy ARBA-. Antes de matarla, según las primeras pericias, abusaron sexualmente de ella. La familia de la joven demanda desde hace tiempo -con protestas incluidas- que el crimen no quede 
impune, ya que la investigación judicial no ha dado en dos años y medio señales de avance, a pesar de que el gobierno provincial ha ofrecido una recompensa de 70 mil pesos para quien aporte datos sobre el caso.

Igual que Ana, otros contribuyentes recibieron la "notificación" y en ARBA tuvieron que aclararles que "alguien está haciendo una broma de mal gusto", de acuerdo a las respuestas que aseguran haber obtenido quienes respondieron a la convocatoria que, creyeron, se había efectuado desde la agencia recaudadora de impuestos.

Voceros de ARBA indicaron que en el teléfono 0-800 de la repartición se atendieron numerosos llamados de vecinos que habían recibido esas notificaciones. "Son totalmente falsas", remarcaron, y comunicaron que instruyeron al personal para que informe a la gente que las recibió que no fueron emitidas desde esa dependencia." ( $E l$ Día, 21/08/2009).

Por último, sobre el tercer grupo de intervenciones culturales mencionadas en las publicaciones de El Día, la "Muestra Ambulante" (2009) y "Zig Zag" (2012) son identificados como eventos artísticos. De la Muestra Ambulante se reproducen fragmentos de lo que claramente son gacetillas de prensa (una invita a la presentación del libro-catálogo de la MA y la otra informa sobre algunas de las actividades de la Muestra de ese año), lo que da cuenta se se trabajó sobre gestión mediática de la comunicación desde la coordinación de la Muestra. Por su parte el encuentro "Zig Zag" fue una de las noticias de tapa acompañada incluso por una imagen referencial de graffiteros en plena acción. Fue presentado en la portada del diario en su versión impresa como "Cumbre internacional de graffitis: le pintan la cara a la Ciudad" (El Día, 14/10/2012) -aunque hacia el final de la nota interior se aclara que el espacio abarca además otras expresiones como el video, la fotografía, la danza, el teatro y la pintura de caballete-. En toda la nota se encuentra un tratamiento positivo del evento: "artistas de diversas partes del mundo", "maestros del graffiti artístico", "son verdaderas obras de arte". También se encuentran fragmentos de gacetillas de prensa (datos de referencia del evento y actividades) y se recupera la palabra de los involucrados.

““'La idea es organizar encuentros autogestivos donde se generen redes que nos permitan aprender de otras experiencias y pensar nuestras propias prácticas”, dijo ayer uno de los maestros del graffiti artístico sobre el encuentro que se desarrolla en La Plata. (...)

'Intervenimos en el espacio público porque es un lugar privilegiado para retomar la palabra", completó otro de los artistas." (El Día, 14/10/2012) 
La versión web de la nota sobre "Zig Zag”, a su vez, es acompañada por una galería de imágenes y suman en total 13 fotografías del evento, todas de pintadas en paredes y muros.

\section{Narrativas diferenciales sobre la ciudad}

Una de las conclusiones que deja el análisis de las publicaciones de El Día es que este medio no ha relevado a la gran mayoría de las prácticas de intervención culturales que se analizan en esta investigación. Parece que estas prácticas no están en la órbita de lo que este diario considera como noticiable. Pero existen, como se observó antes, algunas excepciones. Este diario que, como se planteó, ocupa una posición central en el sistema de medios privados de la ciudad, parece más (pre)ocupado en dar la batalla cotidiana contra el "graffiti vandálico". Para ello (o contra esta prácticas), como se analizó, El Día utiliza una economía discursiva estigmatizante, similar a las páginas asignadas a los hechos policiales y delictivos: realizan "ataques", producen daño a la propiedad, generan "alerta y miedo" entre los vecinos, "no se salva nadie" de su accionar. Así como una mirada estética de valoración negativa: no puede ser considerado arte, "las paredes lloran".

Asimismo, al comparar estos enunciado del medio con la construcción discursiva de las intervenciones culturales analizadas, se puede reconocer una fuerte tensión. Estos últimos producen cierto contra-discurso público sobre la ciudad y recuperar positivamente la dimensión conflictual de la realidad. Se trata de discursos diferentes y muchas veces opuestos a las construcciones discursivas hegemónicas -como las de un medio como El Día- y que buscan insertarse en la "gramática cultural" para producir otras miradas y sentidos. En este sentido, se considera que estos discursos de las intervenciones culturales comparten intenciones y posiciones con las experiencias de comunicación alternativa y popular que han existido y existen en La Plata (La Pulseada, Indymedia La Plata, Prensa de Frente, FM Futura, Radio Estación Sur, Radionauta entre los más destacados).

En tanto dimensión global, todos estos discursos contribuyen a comprender las disputas por el sentido de la ciudad. Así, mientras que para El Día la ciudad de La Plata es una "paisaje" a contemplar que se vuelve peligroso cuando es atacado por el graffitivandálico o intervenciones visuales similares desde las experiencias culturales la ciudad se configura desde otras cuestiones, se pone atención en otros propósitos y posibilidades. 
De este modo, para La Grieta frente a los circuitos de la ciudad que modelan la vida, se generan en ella -y en el barrio- propuestas culturales que producen encuentros inesperados entre desconocidos y tensionan los límites entre lo público y lo privado. Así es que la Muestra Ambulante es una "geografía inquieta" que busca tejer lazos, proponer derivas y habitar la cotidianeidad. Discutir el auto-encerramiento vecinal y proponer "la silla en la vereda". La Grieta realiza una descripción crítica de ciudad y despliega una poética que de cuenta de una ética del encuentro y la exploración:

"La ciudad, en alguna medida traduce el mundo. Este mundo que se viene complicando. Compliquémosnos entonces estos días con el ánimo de fiesta y de las luces encendidas. Vibran los colores sedientos, quieren más sed todavía, de otras voces nuevas, de canto, de goce y risa.

La Muestra Ambulante es una geografía inquieta; intervenir en el barrio impone otro tipo de lógicas, ya no se trata de pensar un gran festival con sus horarios, sus personalidades sino abrirse a un inventario donde la ruptura hable, diga sus cosas, fabule o nos 'salve' un poco de tanta capa caída y abrace, entonces, alguna expectativa." Folleto-catálogo de la MA 3 (2006).

"La ciudad se mueve, los vecinos salen a la calle, se encuentran. El arte está vivo. La cultura en las veredas.” Folleto-catálogo de la MA 4 (2007).

Para la poética de Sienvolando la ciudad es un "ser vivo" que va cambiando, no puede quedar inmutable en las visualidades y formas de decir, así es que existen múltiples miradas que se expresan en su piel, la intervienen y allí se genera un diálogo tenso. En tal sentido sostiene Ernesto que pensaban a la ciudad: "desde una radicalidad absoluta, de hecho hacíamos los murales esperando que los escrachen." Es por eso que dejaban en ellos zonas para que los intervengan otros, y agrega: “desde ese lugar lo pensábamos como un espacio de comunicación radical.” (Ernesto, E 7). A su vez lo público, se configuraba en Sienvolando como una "red de relaciones", en la vereda mientras se pintaba, en la web como espacio “ampliado", eran lugares para relacionarse (E 7).

Para Luxor la ciudad es principalmente la vida cotidiana y las historias de lucha, solidaridad y sensibilidad de las gentes que habitan en los barrios y que construyen disidencias. También se encuentra en Luxor una mirada respetuosa de las diversas 
inscripciones visuales que suceden en la ciudad ${ }^{256}$, a las que en muchas ocasiones se propuso articular y hacer confluir en diferentes eventos y proyectos colectivos. En cuanto a la insistencia permanente del graffiti/pintada por estar presente en la calle durante los últimos años, Luxor lo ve como una "espacio ganado" a la ciudad gris:

“Antes había una pared gris, ahora está un graffiti, te guste o no ese otro cantar, no estoy hablando de cosas estéticas. Cuando paso por una pared y no hay nada y después paso y hay una bomba o un graffiti, me pongo contento. Se superó una instancia, logramos ganar un espacio más, más allá de lo que pueda opinar de esa pintura.” (E 23, Luxor)

Para Luli la ciudad se configura en una multiplicidad de espacios que se cruzan: una gigantografía en la vía pública, un sticker, una movilización callejera, un cuaderno para colorear o un juego en Facebook. La ciudad es entonces, parte importante de esa red de discursos que intervienen en lo real.

Para Siempre, La Muralista y Arte al Ataque la ciudad es principalmente un espacio para desplegar la acción utilizando lenguajes y recursos diversos: gráfico-visuales, corporales, performáticos, lúdicos. Plantea Carlos de la UMHT que

"La calle es un espacio completamente en disputa. (...) Cuando uno toma un territorio, piensa en un mural con calidad, que sea lindo, que sea agradable para el vecino. Que lo acepte, con un mensaje político bien claro y bien concreto. Lo que hacemos es empoderar la ciudadanía, empoderar el espacio. Es una pequeña batalla ganada a nivel territorial. Entonces, la ciudad pasa a ser... es parte de una batalla cultural” (E 17, Carlos).

Para todas estas prácticas de intervención, la ciudad es un espacio en y de disputa material y simbólica que juega decididamente en la trama de sentidos y en las experiencias cotidianas que configuran lo público.

\footnotetext{
${ }^{256}$ En una de las primeras conversaciones mantenidas con Luxor durante el trabajo de campo (a mediados de 2012) me comentó -en relación a los graffitis, los tags y las pintadas políticas- "no le tapo las pintadas a los compañeros".
} 


\section{Capítulo 8}

\section{¿De la calle a la galería? Desplazamientos y derivas de las prácticas culturales}

Hasta aquí la tesis se ocupó centralmente de describir, cartografiar y analizar a las prácticas de intervención cultural realizadas por colectivos e interventores en un período específico (2006-2011), escenario también caracterizado. Pretendió ser un análisis pormenorizado, situado y relacional entre estas prácticas culturales, de sus inscripciones en los contextos de producción cultural contemporáneos y en los modos de habitar la ciudad. Pero, como parte del trabajo de campo que le continúo a dicho análisis, en este último capítulo -y a modo de epilogo- nos interesa plantear, con los casos de Luxor y de Síntoma, parte de las derivas de esas prácticas culturales, que sólo se comprenden con aquel "ciclo" e historia previa de acciones y sentidos construidos. Además, de ser dos prácticas que vienen de trayectorias previas, también existió un nuevo contexto social, político y cultural (entre 2011/2-2015) que configuró otras demandas e inquietudes ${ }^{257}$. Entre ellas se pueden destacar una mirada para pensar el campo del arte en sus formas contemporáneas y una cada vez más fuerte intensión de "vivir de la cultura y el arte".

\footnotetext{
${ }^{257}$ Dani de Luli lo indentificó como un período en el cual se "perdió la coyuntura", operó una "normalización” y se configuró cierto "bienestar social" (E 22). Para Carlos de la UMHT hubo una "construcción simbólica" que hizo perder la "lectura crítica" a las organizaciones sociales y políticas (E 17). En un sentido similar, Ernesto de Luli plantea que lo que sucedió fue el "agotamiento de un ciclo" y la "reconfiguración simbólica" a partir de la muerte de Kirchner que en La Plata "fue muy fuerte e interpeló mucho" (E 19). Podemos caracterizar que se abrió una nueva situación, por un lado, de cierta estabilidad en la que un sector de clase media de la sociedad platense -hasta no hace tanto empobrecida- se empoderó de recursos y comenzó a plantearse la posibilidad de vivir de sus propios emprendimientos y proyectos colectivos o individuales -por ejemplo, vivir de la producción y gestión de la cultura y las artes-, una situación sustancialmente diferente a los períodos previos que, en los años 90 y a las primeros años 2000, era imposible de pensar y proyectar. Por otro, respecto de las subjetividades políticas en la Argentina reciente, desde los colectivos culturales -y de modo más amplio en las organizaciones sociales populares- se realizaron diferentes lecturas de la experiencia política del kirchnerismo que tensó posiciones y se generaron adhesiones y afinidades a dicho proyecto. Consideramos que estas son algunas de las condiciones de posibilidad -en una dimensión local y nacional- que permiten comprender las disoluciones de algunas prácticas, así como los cambios en los modos intervención y la emergencia un nuevo campo de inquietudes en las prácticas culturales en la ciudad. En relación a otros elementos y procesos que entran en juego en un contexto epocal distinto, como la "reconversión urbana" y las dinámicas del "semio-capitalismo", ya nos detuvimos a caracterizarlos en la introducción y los capítulos 1, 3 y 6.
} 
Por lo tanto, esta suerte de coda final de la tesis, se detiene sobre algunos de los desplazamientos y las derivas actuales de las prácticas culturales platenses que fueron relevadas en el trabajo de campo de la investigación. Se intenta localizar en ese nuevo mapa a algunas de las propias derivas de las intervenciones culturales indagadas anteriormente. La sospecha es que hubo en varios casos un fortalecimiento o una nueva disposición -según el desarrollo particular de cada experiencia- hacia prácticas ligadas a las inquietudes, modalidades, procedimientos y espacios artísticos. Asimismo, en algunos sujetos, esto se combinó con el intento de "vivir de la cultura" a partir del desarrollo de pequeños emprendimientos productivos y autogestivos ${ }^{258}$. Al tener presente un contexto cambiante y más abarcativo de sentidos, prácticas y actores que activan en La Plata, este capítulo se interroga sobre la conformación de una "escena de las artes visuales" en la ciudad. Una escena -se insiste- en la que confluyen y dialogan diversas prácticas y actores, incluso anteriores y posteriores a las intervenciones culturales que fueron principal núcleo de interés en este trabajo.

La intención entonces es trabajar -de modo exploratorio y con un registro más ensayístico- estas cuestiones a partir de algunos de los diagnósticos y análisis de las experiencias culturales vinculadas a las artes visuales en la ciudad de La Plata ${ }^{259}$, en los que se viene reflexionando -junto a otros/as- en encuentros, publicaciones, conversaciones e

\footnotetext{
${ }^{258}$ Esto último se indagó en los capítulos 4 y 5 principalmente en los proyectos llevados adelante por La Grieta, Luxor y Arte al Ataque. Pero también este impulso de proyectos productivos ligados a la cultura y el arte se encuentra en productores y gestores individuales que formaron parte de otros colectivos culturales analizados por ejemplo, en Luli, Siempre y UMHT-.

${ }^{259}$ Existen en la ciudad una gran diversificación de prácticas culturales y artísticas que podemos definir como "escenas". Las artes visuales conforman una "escena" en la que podemos englobar actores y prácticas heterogéneas que van desde muestras de "artistas visuales" y galerías independientes a talleres de producción visual y de clínica de obra, desde prácticas curatoriales hasta la "movida" de grafiteros e interventores urbanos. Es decir, un gran número de prácticas vinculadas con el arte contemporáneo, la instalación, lo plástico, lo gráfico y lo fotográfico. Para la producción de la tesis y de otros trabajos académicos (López, 2013b, 2015a, 2015b) se ha realizado un mapeo de espacios de y para las artes visuales, Sobre otras escenas también se puede mencionar que existen en la ciudad: la escena de las artes performáticas, escénicas y de la danza, la escena musical (quizá la más visible y numerosa que va del rock indie al candombe, de los grupos de hip hop a los de folklore, de la electrónica al metal, por dar algunos ejemplos), la escena editorial y literaria (integrada por editoriales alternativas, espacios de talleres literarios y encuentros de lectura). Para el caso de La Plata, algunas de esas "escenas" y prácticas de producción cultural son indagadas en los trabajos de Ecart (2015), Saez (2015, 2016a, 2016b) y Boix $(2013,2016)$; a su vez, se trata de trabajos con interesantes reflexiones metodológicas para la investigación en ciencias sociales, y en particular sobre los usos y la reflexividad en la etnografía. Muchas veces se trata de escenas que se pueden delimitar pero también se pueden reconocer cruces, convites y, quizá, apuestas y proyectos en común. A su vez, analíticamente podemos identificar que cada escena cultural está compuesta por diferentes "circuitos" que tienen que ver principalmente con afinidades y estilos compartidos. Por ejemplo, en la escena musical local el rock indie y el candombe corresponden a dos circuitos diferentes. En la escena de las artes visuales el circuito de galerías, prácticas curatoriales y espacios y talleres de arte se diferencia del circuito del street art, sin embargo, en estos casos existen cruces y cuestiones compartidas, que podemos identificar en algunos lugares de circulación y apropiación en la ciudad.
} 
intervenciones públicas ${ }^{260}$. La idea es, a partir de trabajar unas hipótesis que juegan fundamentalmente en el nivel de la producción/circulación cultural local, poder esbozar propuestas "más generales" que contribuyan con el desarrollo uno de los objetivos de la tesis: constituir una analítica cultural de los procesos y experiencias culturales. Los casos particulares que se toman para indagar estas cuestiones son los de Luxor y Síntoma.

\section{Sobre las escenas culturales}

Junto con la noción de "escena", en este capítulo se invocan también otros conceptos productivos. Entre ellos, el de "campo cultural y artístico", presentado por la perspectiva sociológica de Pierre Bourdieu $(2002,2014)$ para analizar agentes, posiciones y estrategias dentro de un sub-espacio del campo intelectual ${ }^{261}$. Raymond Williams (2009) aporta asimismo algunos desarrollos conceptuales sugerentes sobre lo "emergente" y la "formación cultural". Con todo, la decisión es tomar con primacía la idea de "escena" por tratarse de un “concepto nativo" y porque es una noción flexible que puede alcanzar mayor operatividad y especificidad temática que las otras dos nociones mencionadas para el caso que se presenta y

\footnotetext{
${ }^{260}$ Algunos escritos propios sobre los temas de este capítulo: dos publicados en mi blog "La organización de la cultura (Notas a propósito de la muestra "Todavía no llegó el cocinero" Ruta 5)" y "Sospechas y conversas (sobre espacios culturales en La Plata)" y tres artículos académicos (López, 2013b, 2015a, 2015b). También entre el 2013 y el 2015 realicé una columna radial semanal sobre las artes visuales de la ciudad en el programa "La fábrica de manteca" de FM Provincia. Asimismo, la sección reseñas de Síntoma es un completo espacio de reflexiones sobre lo que ocurre en la ciudad en cuanto a la escena de las artes visuales. Disponible en http://issuu.com/sintoma. Desde el 2015 la revista boba realiza un intenso trabajo de reflexión sobre el arte contemporáneo -focalizando en las artes visuales- y en el relevamiento de las escenas locales de arte del país; esto se puede encontrar tanto en su versión impresa como en las actualizaciones de notas, entrevistas y reseñas en su web: www.boba.com.ar. Todas estas y otras contribuciones hacen al presente capítulo.

${ }^{261}$ Pierre Bourdieu retoma las ideas clásicas y canónicas para comprender el proceso de autonomización del campo intelectual y artístico respecto de otros poderes -sobre todo el político y el religioso-: en Europa surge en el siglo XV afirmando una legitimidad propiamente artística y, luego de una interrupción de dos siglos por la Contrarreforma, es con el Romanticismo y en el siglo XIX que se consolida la separación de un campo específico con "autonomía relativa" y sus propias reglas -por ejemplo, la primacía de la forma por sobre la función, las formas de consagración y legitimación de las producciones culturales, así como las competencias especiales para formar parte- e instituyendo una ruptura creciente con el "mundo ordinario", una configuración que podría considerarse vigente hasta la actualidad. Según este autor francés: "la constitución progresiva de un campo intelectual relativamente autónomo va a la par de la explicitación y la sistematización de los principios de legitimidad propiamente estética: afirmar la primacía de la manera de decir sobre la cosa dicha y, por ello, de la forma sobre la función; sacrificar el 'tema' (...), a la manera de tratarlo, al juego puro de los colores, los valores y las formas; constreñir el lenguaje para constreñir la atención al lenguaje y a las correspondencias esotéricas de los sonidos y del sentido; todo esto vuelve, en definitiva, a la especificidad y la insustituibilidad del productor poniendo el acento sobre el aspecto más específico y más irremplazable del acto de producción artística. (...) La conquista de la primacía de la forma sobre la función es la expresión más específica de la autonomía del artista y de su pretensión de detentar e imponer los principios de una legitimidad propiamente estética." (Bourdieu, 2014: 69-70)
} 
estudia aquí ${ }^{262}$. Por contrapartida, comporta como posible riesgo dar cierta idea de "puesta en escena", "teatralización" (o escenificación) de los procesos sociales y de las prácticas culturales en particular -es decir, abonar a una lógica representacional de la vida- que, claramente, no está en el foco de nuestro interés.

Con la intención de construir cierta definición conceptual primaria de la misma, se plantea que por "escena" se entenderá a una zona más o menos delimitable de circuitos, espacios, prácticas y actores que, aunque heterogéneos, comparten ciertas inquietudes a iniciativas. De este modo, por escena de artes / escena artística se hará referencia a un espacio específico y plural de prácticas artísticas que van tejiendo cuestiones en común. Dos parámetros para determinar una escena serán su localización geográfica -una ciudad- y su especificidad en la producción, el lenguaje de las artes y los procedimientos que utilizan (por ejemplo, artes visuales, la danza y las artes performáticas, la música folclórica, el rock indie). Pero se reconoce que una "escena" no se agota en estos elementos y parámetros. Es, por lo tanto, un campo a ser mapeado e interpretado constantemente en el trabajo de campo y en el ejercicio de reflexión, para lo que resulta fundamental relevar actores, dinámicas, circuitos, debates, discursos, sensibilidades, modos de hacer y de ser, concebir y significar. De esta manera, y entendiendo un sentido más amplio sobre la investigación de prácticas y procesos culturales, se hace necesario recuperar las preguntas, los saberes y relatos de los protagonistas que "des-centran" la mirada del investigador y reconocer así la "intemperie" como lugar desde el donde pensar (Martín-Barbero, 2004: 14-15).

En tal sentido, las inquietudes compartidas de una "escena local de artes visuales", pueden ser reconocidas a partir de espacios recurrentes y validados para la circulación de obras, proyectos y actores ${ }^{263}$, una red de discursos que hablan sobre tendencias de las artes

\footnotetext{
${ }^{262}$ Un concepto problemático de trabajar sería el de "vanguardia artística" que habría que reservarlo para pensar otros procesos culturales e históricos. Este es otro de los motivos por el cual se elige aquí la noción de "escena". Pero esta noción ¿abre la puerta para comprender los procesos culturales y artísticos contemporáneos desde la idea de nueva "clase creativa"? Sostenemos -a partir del trabajo de campo realizado en la ciudad de La Plataque en principio no hay una correspondencia directa, aunque no anula la posibilidad de cierta articulación. Algo de esto se trabajó en el capítulo 6 en relación a los "circuitos culturales" y su vínculo con las mutaciones urbanas y culturales que suceden en la ciudad. Se puede observar que existen una batería de nociones que pueden retener cierto interés así como potencial explicativo pero que deben ser trabajadas y confrontadas desde casos concretos y sus especificidades.

263 Actualmente se encuentran en la ciudad una veintena de espacios de exhibición y exposición, entre alternativos y estatales, ligados a las "artes visuales". En promedio se inauguran entre siete y diez muestras por año en cada uno de ellos. En casi todos se realizan muestras con venta de obra. Por mencionar algunos de esos espacios entre galerías, casas culturales, espacios de arte, centros culturales, salas y museos municipales y provinciales: Cösmiko, Trémula, Siberia, Residencia Corazón, Damme, Búm, Oro, La Salita (En eso estamos), Dionisia, Tormenta salvaje, Vincent, El hormiguero, La Grieta, Caleidoscopio, Victoria V, Obrador 45, C`est la vie, Club Alborada, Azul un Ala, Zule (entre los alternativos) y Microespacio (que integra el Museo Provincial de Bellas Artes), Centro Islas Malvinas, Mumart, Macla y Prosecretaría de Cultura de la UNLP (entre los estatales). También aparecieron otras iniciativas de visualización y articulación: Cama elástica, Cero Diagonal,
} 
visuales, y también de espacios y actores concretos (narraciones y discursos en los que se puede inferir una conversación y formas de conversar en común), dinámicas organizativas y estrategias de visibilidad, así como posicionamientos y vínculos diversos con lo institucional.

Sin embargo, la idea no es descartar a priori los conceptos de "campo cultural" y "formación cultural". Se puede plantear una tríada conceptual en la que adquieren utilidad descriptiva y analítica al presentar diferencias de escalas, dimensiones e intensidades. A grosso modo, se puede decir que de la "escena" (cierto nivel microsocial de prácticas culturales con similitudes que se conectan) se puede llegar analíticamente al un "campo cultural" (ciertos niveles de estructuración donde se pueden comprender dinámicas de relaciones -luchas por la legitimidad, conflictos de intereses, formaciones discursivas- en el tiempo y el espacio social) pasando por una "formación cultural" emergente (como tendencias renovadoras de la cultura en un momento específico), todas ellas atravesadas por ideas vinculadas a la creatividad y la producción cultural. En esta articulación se reconoce que no se trata de términos antagónicos ni superpuestos sino que se pueden complementar principalmente en términos de escala: una escena local de artes visuales que dialoga con otras escenas artísticas, que integra un campo cultural local, regional o nacional y que pueden ser parte de unas formaciones que movilizan "lo emergente". A su vez, como se mencionó, otra noción relacionada a la de escena será la de "circuitos": esta puede servir para poder detectar y especificar aún más diversos recorridos y circulaciones que realizan los actores participantes de una misma escena cultural o artística ${ }^{264}$.

A su vez, con el empleo de estas nociones se pretende distanciarse de cualquier perspectiva vinculada a las "bellas artes" y el canon artístico y estético (presente aún en las instituciones "promotoras" de la cultura y en las que pretender ser formadoras en artes, así como en ciertos discursos legitimados para hablar sobre "las cosas del arte"). Se busca dirigir el análisis en otro sentido, relevar apuestas y proyectos locales, relatos y discursos "menores" de la producción cultural y artística contemporánea. Pero con la necesidad de cruzarlos con

Agenda Zaz!, la muestra "F.D.A.C.M.A. Seccional La Plata", la intervención "La Multisectorial" y el "Encuentro Local de Espacios y Colectivos vinculados a las Artes Visuales" (realizado en 2013). Algunos espacios alternativos de galería dejaron de funcionar en los últimos años: Mal de Muchos (fines del 2014), club Alborada (ya no activa la galería de arte pero hace muestras de forma intermitente), Trémula y Tormenta Salvaje (diciembre de 2016).

${ }^{264} \mathrm{Al}$ continuar la construcción de un enunciado de implicación analítica con estas tres nociones, se entiende que se producen prácticas y saberes locales que activan y configuran "escenas" -en tanto espacios concretos de activación cultural que conectan prácticas, discursos y sensibilidades-, que se pueden (o no) articular en cierta "formación cultural" alternativa/emergente para disputar posiciones y definiciones en el "campo cultural" y en un campo social más general. 
situaciones y entramados estructurantes de la cultura, así como con las formaciones culturales alternativas o hegemónicas.

Para ampliar la noción de escena, y comenzar un primer acercamiento a su operacionalización para el caso de La Plata, se puede recurrir a los aportes de Nelly Richard cuando indaga la denominada "Escena de Avanzada"265. Para esta autora esa escena estuvo conformada por "micro-políticas del significante" que entre otras características, llevó adelante exploraciones en el lenguaje, los formatos y géneros y produjo a su vez una "espacialidad alternativa" (Richard, 2006, 2007). Si bien se trata de diferentes contextos sociopolíticos e históricos y situaciones divergentes respecto al arte (por ejemplo, actualmente no se reconoce que en la escena platense de las artes visuales sobresale una posición contraria a la institucionalización del arte), esta propuesta de Richard sirve para pensar de qué modo se renueva la utilización de los lenguajes y sus herramientas para desandar las prácticas artísticas y se dispersan las estéticas. A la vez, contribuye para pensar cómo se generan espacios alternativos de activación desde prácticas situadas. Por último, sirve para buscar comprender de qué manera en un momento determinado se puede generar una trama en la que se conectan y convergen prácticas y actores culturales. En La Plata, la cuestión los lenguajes y las estéticas, actualmente se presenta tensionada -entre otros elementos- por una insistencia con la pintura de caballete, la ilustración y el dibujo de pequeño y mediano formato -formatos más accesibles para la venta en esta ciudad y presentados en cuadros o láminas-, una vuelta a las formas de lo manual-artesanal y el trabajo de taller -el impreso, el grabado, la estampa, la serigrafía, el calado, la fotografía analógica-, y la instalación con utilización de los lenguajes sonoro y audiovisual y de tecnologías digitales atravesada fuertemente por lo conceptual y el trabajo de investigación. (Más adelante volveremos sobre esta cuestión, cuando se indague en las propuesta de Luxor y Síntoma).

\section{I.a. Las formas de gestión}

La palabra "gestión" no ha gozado de buena reputación entre los espacios culturales y los artistas de La Plata, a menos que se la piense como "autogestión", en cuyo caso ha funcionado como idea-fuerza potente que mueve a muchas de las experiencias culturales, aunque sus definiciones varias veces sean amplias, esquivas o incompletas: desde "valernos

\footnotetext{
${ }^{265}$ En el análisis de Richard, la "Escena de Avanzada" forma parte la resistencia cultural de finales de la década del 70 frente a la dictadura chilena y, a su vez, reformula el nexo entre "arte" y "política" alejándose y discutiendo el "repertorio ideológico de izquierda" (Richard, 2007).
} 
por nosotros mismos" hasta "conseguir y manejar nuestros propios recursos", pasando por utilizarla como sinónimo de autonomía y una definición de principios. Pero no hay duda que es un valor fundamental e identitario de muchos proyectos en la ciudad. En cuanto a la idea de "gestión" -a secas- comenzaron a aparecer algunas experiencias y situaciones novedosas que hacen repensarla más allá del aura tecnocrática que la rodea. Las sospechas y críticas muchas veces han sido fundadas: el peligro de desplazar los proyectos -es decir, las ideas que los impulsan, las prácticas casi siempre colaborativas que las activan, las producciones hechas desde la creatividad- hacia (solamente) la lógica comercial de "vender", "lucrar con la cultura". Es decir, caer en situaciones donde la potencia de los proyectos se podría anular por otras prioridades comerciales y recaudatorias. En las escenas culturales de la ciudad hay modos (en plural) de gestión. Prácticas de gestión diversas que, sobre todo cuando se trata de proyectos colectivos, priorizan las ideas de "autogestión", y en algunos casos despuntan desde ahí iniciativas para que sus integrantes puedan vivir de la producción y/o gestión cultural $^{266}$. Sin embargo, en esta nueva situación de nuevos debates y prácticas de gestión se puede afirmar -con algunas excepciones- que en las galerías y los espacios dedicados a las artes visuales son los lugares que menos trabajadas se presentan estas cuestiones.

De este modo, relevando de las situaciones y los fenómenos ligados a la escena local de artes visuales ${ }^{267}$, encontramos que las preguntas por la gestión comienzan a estar presentes sobre todo en 1) una incipiente mirada de profesionalización de las prácticas culturales -tanto en la producción como en la circulación y la gestión- y en 2) los intentos y esfuerzos que plantean "vivir del arte y la cultura", sea como productor-artista, y/o como gestor de espacios o de producciones de otros, como comunicador y divulgador cultural, como curador y/o comentarista de arte.

\footnotetext{
${ }^{266}$ En La Plata se puede reconocer que en los proyectos culturales que tienen "una cabeza" o un par de integrantes -sea "dueño/a" o "gestor/a" del espacio o del emprendimiento- esta cuestión de vivir de la producción, y principalmente, de la gestión del arte y la cultura queda mucho más claro que en los proyectos un poco más numerosos. En parte, por una ecuación simple: los recursos y el dinero que ingresan se divide entre un mayor número de personas.

${ }^{267}$ Algunas de las situaciones y prácticas cada vez más cotidianas y estables en esta escena son: la venta de obra a pequeña escala (de manera directa o con intermediarios como algunas galerías pero limitada aún en La Plata), la apertura de convocatorias abiertas para muestras en las galerías, el cada vez mayor caudal de artistas que se presenta a dichas convocatorias locales, la búsqueda de mayor visualización (tanto institucional como mediática) de productores, curadores y galeristas, la cada vez más sostenida participación en eventos artísticos y convocatorias estatales y privadas, y de escalas locales, provinciales, nacionales e internacionales (por ejemplo, ArteBA, Arte Jóven de la ciudad de Buenos Aires, subsidios y becas del Fondo Nacional de las Artes, Bienal Universitaria de Arte y Cultura, La Noche de los Museos, Microespacio dentro del Museo Provincial de Bellas Artes, premios del Salón Provincial de Arte Joven y de Artes Plásticas, participación en clínicas y residencias artísticas y en bienales y muestras en otros puntos del país como Buenos Aires, Córdoba, Rosario, Tucumán o Bahía Blanca) y la proliferación de diversos talleres de producción (de pintura, fotografía, arte urbano, arte gráfico e impreso, etc.) que se realizan en galerías, casas culturales, centros culturales y casas particulares.
} 
Sin embargo, estos intentos por desandar ideas y prácticas de profesionalización y de "vivir de la cultura y el arte", en el día a día, se mueven en acciones un tanto precarias para encarar muchos de los proyectos, tanto individuales como colectivos. Algunos de los siguientes puntos críticos pueden ser pensados para todas las escenas de la ciudad: por un lado, la poca sistematicidad de las acciones emprendidas, ya que se mueven principalmente por la fuerza de la voluntad individual o colectiva de los involucrados (por ejemplo, cuesta recuperar una memoria de lo construido). Por otro, se puede reconocer una ausencia de diálogos cruzados y sostenidos entre saberes y prácticas de las artes y la economía (por ejemplo, el saber académico y profesional sobre la gestión no tiene injerencia en los espacios y prácticas culturales). Distanciados como "mundos aparte" la cultura y la economía, la producción cultural y el desarrollo local no tienden lazos en la ciudad. Sólo se desarrolla principalmente -en las iniciativas privadas y autogestivas- una economía de subsistencia personal o grupal a pequeña escala de los productores y gestores de espacios. A su vez, esos proyectos e iniciativas tienen mucho impulso creativo y potencia colectiva pero varias veces terminan como cuerpo profesional o cuerpo de oficio tercerizado del Estado (sobre todo municipal, provincial y la universidad). Así, antes que un trabajo "con otros", mancomunado, muchas veces las prácticas que se activan (con recursos, ideas, tiempos propios) terminan siendo "para otros".

También se puede observar que falta visión política global y estratégica sobre las políticas culturales institucionales -sean estatales o privadas de mediana y gran escala-, problemática que atraviesa a todas las escenas culturales de la ciudad. En este sentido, es preciso comprender las transformaciones operadas por la globalización de la economía, las modificaciones en las políticas nacionales y locales y la "expansión y capitalización de lo simbólico debido a las innovaciones tecnológicas en las telecomunicaciones y en la industria del entretenimiento (que) han realzado el valor de la cultura como recurso." (Yúdice, 2008: 31)

Como síntesis de este punto se puede decir que del rechazo que habitaba en la cultura alternativa local a las ideas y prácticas de la "gestión", se pasó a intentos incipientes de tomarla desde una visión integral en varias de las experiencias locales: organizativa, política, económica y comunicacional. Actualmente en La Plata algunos actores locales comienzan a definirse como "gestores culturales" o "agentes culturales". De este modo, junto con las ya referidas nociones de "escena", "circuito" y "cultura emergente", aparecen estas denominaciones de "productor-gestor", "gestor" y "agente" cultural en sus propias retóricas así como otras nociones del universo de la "gestión cultural" y las "industrias culturales y 
creativas": "proyectos", "convocatorias" a las cuales "aplicar", así como también la "profesionalización" y el "mercado". Asimismo, se comienza a hablar de las problemáticas de la gestión y la autogestión en diferentes encuentros colectivos, espacios de formación y de debate y foros de articulación. Sobre esto último se trabaja en el siguiente apartado.

\section{I.b. Los modos de asociación: encuentro en la dispersión}

Algunas de las situaciones más potentes que se pueden encontrar en la ciudad son las formas dinámicas de asociación y articulación colectiva. La Plata es una ciudad en la que continuamente se construyen tramas de vínculos entre diversos actores, especialmente desde los itinerarios que cruzan el arte y la cultura (como se desarrolló en los capítulos 3, 4, 5 y parte del 6). Antes que "la ciudad" (como una cualidad "innata" o propia de su condición urbanística modernista), se considera que es su cultura urbana la que es un gran caldo de cultivo en ebullición de proyectos compartidos y encuentros colectivos.

Solo por dar algunos ejemplos que se producen desde la organización y coordinación independiente se puede mencionar al encuentro Ecart y DanzaAfuera, las FLIA (Feria del Libro Independiente y Autogestionada) hace unos años y, más recientes, las diversas "movidas" editoriales y literarias impulsadas por editores independientes y autores (muchos nucleados principalmente en El Espacio), las jornadas "Desbordes" (en las que confluyen diversas disciplinas y proyectos culturales), los tres ámbitos de confluencia de los centros y espacios culturales alternativos -RECA (Ronda de Espacios Culturales Autogestivos), Red de Espacios Culturales y UCECCA (Unión de Centros Culturales Alternativos y Artistas) y el " $1{ }^{\circ}$ Foro regional de espacios culturales autogestivos" organizado por esos tres reagrupamientos. En la música rock las masivas movidas en las que participaron bandas, músicos y rockeros en defensa del bar "Pura Vida" frente a los intentos de cierre por parte del Municipio. Dentro de la escena de las artes visuales, se destaca principalmente el "Encuentro local de espacios y colectivos vinculados a las artes visuales" (organizado por Cama elástica en 2013) y "TOC Artes visuales" (surgido a inicios de 2016). Sin embargo, se puede barajar que, en este aspecto de las articulaciones, en la escena de las artes visuales es donde las formas de encuentro son menos "públicas", menos volcadas a generar acciones colectivas y más ligadas a los entramados de relaciones personales que se bifurcan en los micro-circuitos y micro-comunidades. En comparación, la escena literaria-editorial y la escena de espacios culturales alternativos -en la que también están insertos actores de la escena de las artes visuales- generan, en mayor grado, visibilidades y discursos públicos "como escena" que se articulan y traducen en "movidas" colectivas, construcción de relatos afirmativos, producción 
de demandas al Estado -para generar normativas y fondos económicos de promoción cultural a sus actividades-, expresiones identitarias de cualidades, improntas, pareceres y, a veces, posicionamientos sobre la realidad.

Todos estos encuentros, y muchos más, que son planteados desde las diferentes escenas forman parte de esas tramas que forjan y movilizan a la "cultura emergente" de la ciudad. De este modo, se entiende que las formas de asociación y organización de las prácticas culturales crean un tejido de relaciones donde, en un grado importante, la amistad y el afecto son parte constitutiva de éstas y las sostienen. Asimismo, es en el encuentro sostenido en un trabajo de "hormiga" donde las prácticas culturales constituyen esa trama diversa y compleja de sentidos compartidos, afectividades y acuerdos. En ese día a día se crean y recrean esas diferentes escenas integradas por artistas y gestores, músicos y productores, amigos, personas inquietas y comunicadores, editores, escritores y poetas, curadores y productores vinculados a lo visual ${ }^{268}$.

\section{I.c. ¿Politicas estéticas en la escena local de artes visuales?}

Luego de desandar la caracterización de las escenas culturales de la ciudad, el objetivo de este apartado es ahondar aún más en los contornos que ya se fueron esbozando de la escena local de las artes visuales. Se retoma nuevamente a Nelly Richard (2014) cuando discute las figuras del arte y el artista "comprometido" que se constituyó en los años sesenta, y que son retóricas que actualmente han caído en desuso. Traer a este capítulo, que indaga sobre escenas culturales locales, y en particular a la escena de las artes visuales, esta reflexión crítica sobre el desplazamiento de la mirada en relación a las potencialidades transformadoras del arte en el contexto contemporáneo, no es azarosa. Sirve para ilustrar la época contemporánea del arte en sus últimas tres décadas, sus intencionalidades y propuestas, donde lo político es muchas veces re-elaborado, disuelto o negado en "los proyectos", las obras, las muestras, las formas colaborativas en red y las narraciones que se construyen alrededor de

\footnotetext{
${ }^{268}$ Si bien aquí no nos explayaremos especialmente, se pueden plantear algunas cuestiones críticas sobre las formas sutiles de exclusión en la escena de las artes visuales. Algunas prácticas artísticas, curatoriales y de gestión de espacios (tanto institucionales como alternativos) sostienen la "primacía del amor" como dato previo de cualquier iniciativa y proyecto a emprender, una "política del amor" que es selectiva (es decir, amor casi exclusivo para los amigos y afines) y, por lo tanto, obturadora de cualquier cuestionamiento. El "amor" es una noción recurrente en muchas obras y proyectos artísticos locales -cuestión que se relevó durante el trabajo de campo de esta investigación-. En la escena artística platense ha sido, sobre todo la experiencia de Síntoma la que propuso deconstruir y pensar esas "políticas del amor" (y del "amiguismo") en sus potencialidades y debilidades, principalmente en el espacio de las "reseñas" (más adelante volvemos sobre las propuestas de Síntoma). De un modo algo agresivo, Rodrigo Cañete emprende una querella contra lo que denomina "la mafia del amor" principalmente en la escena artística porteña. Links: https://www.loveartnotpeople.org/ y http://www.eldestapeweb.com/rodrigo-canete-el-caballero-infiel-del-arte-argentino-n17292
} 
dichas iniciativas (García Canclini, Cruces y Urteaga Castro Pozo, 2012). De este modo, aquí surge una pregunta: para la situación abierta desde los años 2011/2012 en adelante en La Plata ¿podemos hablar de una escena artística sin política?

Como un supuesto se puede pensar que si en los años 70 el énfasis de una obra artística estaba puesto en su contenido y en rol pedagógico que podía tener -direccionado por el pensamiento político esclarecedor-, se pasó en los años 80 a un momento histórico de "incertidumbres" que persiste hasta el presente. Desde allí muchas prácticas artísticas piensan en sus contextos locales de inserción y en el proceso de creación. En dicho proceso se observa que algunas prácticas artísticas buscan "desmaterializar" el arte y se trazan como objetivo generar una acción participativa con el público o dejar que éste re-elabore las propuestas a través de su "experiencia sensible" o también desarrollar procesos colaborativos y de co-producción con comunidades y territorios ${ }^{269}$-con matices y diferencias esto se trabaja en Bourriaud (2006), Ardenne (2006), García Canclini, (2010), Laddaga, (2006), Holmes (2008), Felshin (2001)- ${ }^{270}$.

Con los aportes de Rancière $(2010 b, 2011,2014)$, que han sido retomados en otros momentos de la tesis, sabemos que algo del arte siempre es político y viceversa: algo de lo político es estético. Nunca son dos esferas completas y totalmente separadas que luego entran en relación. También, a partir de sus cuestionamientos al "arte crítico" y sus legados, podemos comprender que las querellas en las que se debatían las vanguardias artísticas del siglo XX entre el reclamo de autonomía del arte y la primacía del vínculo con la política (o a veces, la subsunción del arte a la política) no son tales en la actualidad. Para Rancière no hay conflicto entre la búsqueda de autonomía del arte y la politización.

\footnotetext{
${ }^{269}$ En el Gran La Plata las propuestas artísticas sobre el diseño y desarrollo participativo de las comunidades y los territorios, han sido particularmente trabajadas por el grupo Ala Plástica desde hace 25 años. Link: http://www.alaplastica.org. En algún punto, La Grieta también se conecta con esta mirada del arte y la cultura, al proponerse cruzar edades y generaciones diferentes, lenguajes y formatos artísticos principalmente en las dinámicas de taller. Es este sentido, también se vincula al poner el acento no solo en la "obra" sino en la dimensión "procesual" del arte y al buscar una conección entre esos procesos creativo-colectivos y los contextos locales en los que se inserta.

${ }^{270}$ En esta propuesta igualmente se encuentran diferencias en los análisis, como ya se indagó antes: N. Bourriaud carga a la figura del "artista" como el que recrea y restituye el "lazo social" roto por los procesos de mercantilización y comunicación de la sociedad global. Otros autores privilegian los procesos colectivos donde esa figura del artista muchas veces se disuelve en la trama de mueve una acción. Por su parte, Rancière radicaliza los supuestos y plantea -en su definición que se ha vuelto moda- que la estética "es el pensamiento del sensorium paradójico que permite definir las cosas del arte" (2011:22). Volviendo sobre la figura del público, en la interesantísima propuesta de Rancière (2010a) hay que reexaminar el juego de las equivalencias (público y comunidad, mediación y simulacro) y las oposiciones (imagen y realidad, actividad y pasividad), así su hipótesis es que el hecho de espectar no implica ninguna debilidad. Para decirlo a grosso modo, para este autor no hay que molestar ni buscar activar al espectador, éste "ya tiene demasiado" con serlo.
} 
Teniendo presente esta propuesta podemos pensar de qué modo la escena local de artes visuales atraviesa "lo político". En este sentido -si analíticamente es adecuado hablar de "faltantes" y cuestiones pendientes- en la escena de artes visuales platense una de las cuestiones que escasean es conflictividad, hacer bulla, molestar ${ }^{271}$. Ese ruido y molestia no sólo en la forma de "reclamo ante el Estado". Tampoco en la forma más radical de rechazo o disputa directa contra las instituciones (algo que, en algunos momentos de la historia, emprendieron las vanguardias artísticas) ${ }^{272}$. Lo que "falta" en la escena de artes visuales es pensar preguntas y activar propuestas que desacomoden a la propia experiencia y a una escena creativa y heterogénea pero a veces algo previsible en su estética, en sus formas retóricas, de visualidad y de movilización. Faltan otras vibraciones y queda pendiente aún desarrollar lo productivo del conflicto, cuestiones que, como sostuvimos a lo largo de la tesis, se encontraron presentes en las experiencias de intervención cultural analizadas. En este sentido, la escena carece de estrategias de gestión y comunicación para desarrollar y visibilizar los proyectos: para construir narraciones sobre sus experiencias ${ }^{273}$. Es preciso pensar, pues, a los "públicos", a los que espectan muestras, los que compran obras, los que circulan por galerías y talleres. Y a todos los que lo podrían hacer. Es decir, no sólo enfocarse sobre el público afín y conocido que va a "las movidas", si no sobre aquellos sujetos que hoy no van, a fin de buscar formas para que sean parte.

\section{II. "Luxor te la muestra"}

La experiencia de Luxor puede ser ilustrativa y a la vez contrastante con algunas de las situaciones y tendencias mencionadas hasta aquí en relación a la escena de artes visuales. Es un productor que desde inicios de 2013 emprendió el camino por "vivir del arte", situación

\footnotetext{
${ }^{271}$ Una excepción sería la práctica del graffiti que en los últimos años está siendo criminalizada por gobernantes, algunas agencias estatales y medios comerciales de comunicación que fuerzan definiciones y buscan (no sin entredichos y ambivalencias) producir una distinción entre el graffiti (ilegal, vandálico, no-artístico) y el arte urbano (legal, colaborativo, artístico), estas cuestiones se trabajaron en los capítulos 6 y 7 . En 2015 hubo causas contravencionales abiertas por "daños" contra algunos interventores y se aprobó una nueva Ordenanza Municipal $\left(\mathrm{N}^{\circ} 11237\right)$ que busca regular y reprimir a las pintadas. Pero lamentablemente es una conflictividad por la negativa y defensiva. Se precisa conocer a la cultura de este movimiento y que el "arte urbano" hable y discuta más allá de sus creativos recursos plástico-visuales.

${ }^{272}$ Estas dos son maneras posibles y, a su modo, ambas son transformadoras para encarar lo político desde el arte: la primera podría ser una demanda que busca formalizarse en las instituciones -modificar o proponer una política pública específica-, la segunda es menos probable actualmente.

${ }^{273}$ Existen muchas limitaciones en las estrategias discursivas: por ejemplo, no alcanza con varios miles de "me gusta" en las páginas de Facebook. En relación a los modos de gestión de los proyectos, se puede plantear que es una de las escenas locales que menos desarrollo tiene en relación a esta cuestión: no es viable en el tiempo sostener los proyectos -y a las personas involucrada directamente- desde una economía de la subsistencia.
} 
novedosa para él ya que, como vimos, comenzó a intervenir en la ciudad sin ese objetivo ${ }^{274}$. Esto lo lleva a cabo por medio de muestras con venta de obra en La Plata ${ }^{275}$, la promoción de obras y acuerdos de ventas por Facebook, el espacio de venta permanente en su taller (actualmente "Obrador 45") y la realización de muchas de las pintadas callejeras por las que cobra. Es uno de los pocos productores visuales jóvenes de la ciudad que hoy vive de la circulación de su producción, lo que también da cuenta de un modo de vida autogestionado: de este modo el mismo es su propio hacedor y gestor. La mayoría de los productores de su generación, en cambio, sustentan su vida con otras actividades e ingresos, principalmente vinculadas a la docencia, el trabajo estatal y el dictado de talleres de producción o formación artística en espacios de arte, así la venta de obra pasa a ser un recurso secundario. En su hacer cotidiano Luxor combina las acciones en el espacio urbano y el espacio de muestras para la circulación de sus obras, aunque con un gesto de darle mayor importancia a las primeras intervenciones. Según este productor:

"Lo que pasa que se fue modificando mucho todo desde que arranqué. Nunca pensé que iba a vivir del graffiti. Yo no empecé nunca con esa idea. (...) Si ves bien, estoy produciendo con re poca guita, vivo con poco dinero. Pero vendo un par de obras y salgo a pintar, pintar, pintar...” (E 23, Luxor)

Asimismo, en contraste con lo que sucede con los artistas visuales de la ciudad, Luxor no suele presentarse a becas, subsidios y convocatorias institucionales y tampoco ha terminado una carrera académica vinculada a las artes, dos cuestiones que sí realiza la mayoría de los productores y actores de la escena de arte visuales de La Plata ${ }^{276}$. El gesto anti-académico y anti-las "Bellas Artes" de Luxor ya fue presentado en los capítulos 3 y 5 cuando mencionaba lo "estático" de las instituciones consagradas al saber y la circulación del $\operatorname{arte}^{277}$. A lo dicho se puede sumar su mirada sobre las vanguardias y su propuesta de estar con "la gente", ser parte de la "cultura popular":

"No me interesan nada las vanguardias. Yo me considero un pintor callejero. Las vanguardias se alejan de las masas y yo no quiero alejarme de la gente. Si

\footnotetext{
${ }^{274}$ Como ya mencionamos antes, Luxor renunció en 2013 a su empleo como trabajador no-docente de la UNLP.

${ }^{275}$ En el anexo se encuentra un cuadro descriptivo de las muestras realizadas por Luxor entre los años $2011 \mathrm{y}$ 2015 en La Plata (cuadro 3).

${ }^{276}$ Luxor estudió los primeros años de la carrera de Grabado y Arte impreso en la Facultad de Bellas Artes de la UNLP.

${ }^{277}$ Desde 2012 Luxor toma un taller de pintura y color dictado por Manuel Rubín. En varias conversaciones mantenidas con él manifestó que este espacio formativo y de producción es muy importante para su obra.
} 
me pusiera a intelectualizar como un vanguardista, perdería tiempo de acción.,278

Pero Luxor no está ajeno a las cuestiones del arte actual: como ya se indagó, se posiciona como gestor y coordinador de varias "movidas" colectivas ligadas a lo gráfico y lo visual ("Intervención magenta", "ZigZag”, galería de arte de Alborada, "Pantufleta refrescante", "Obrador 45", por mencionar algunas).

Otra cuestión contrastante de Luxor con las posturas e iniciativas actuales en el arte local es que no se reconoce dentro del "arte contemporáneo". Esto es algo que mencionó sobre todo en las últimas conversaciones que mantuvimos en 2015: "Lo que yo hago, mi producción, no es arte contemporáneo, no me muevo en ese circuito". Esta (in)postura de no sentirse dentro del espacio de lo contemporáneo en el arte puede ser leída como un intento de correrse de varias situaciones en boga que hoy activan y delimitan gran parte del campo artístico local y nacional, que van desde varias publicaciones hasta espacios formativos institucionales y no institucionales, de la explosión de espacios alternativos de exhibición a varias exposiciones masivas de "arte contemporáneo", sobre todo en CABA. En relación con esto también comentó: "No necesito curadores, mi obra no necesita ser curada"279. Aunque aquí se entiende que tanto en su producción como por su forma de moverse puede tener contactos con esas prácticas y discusiones contemporáneas. En tal sentido, la propia producción de Luxor fue mutando en estos años tanto en las temáticas que trabajó como en sus composiciones y en la ampliación de los formatos -grabados en láminas, estampas en remeras, reproducciones digitales en pequeño formato, obras originales en mediano y gran formato-. "Es que no podés pintar siempre lo mismo. Me gusta modificarlo. Ahora recién estoy encontrando de qué manera hablar.” (E 23). En relación al primer momento de sus creaciones sobre las "sexualdiades disidentes" y los desplazamientos en su mirada para pensar su producción y su propio lugar, Luxor dijo que modificó la idea de hablar de "disidencia" porque se emparentaba con la idea de "contracultura", lo que en su parecer terminaba legitimando su contrario: hablando desde y sobre lo disidente "es como que legitimás el espacio que atacás. ¿Disidente a qué? Estás legitimándolo” (E 23). Esta otra postura de Luxor puede pensarse, primero, como un giro decidido hacia la idea de práctica artística y la consecuente valorización de la "obra" y la "producción” que se realiza. Segundo, como un giro hacia lo contemporáneo en el arte: salirse de los lugares asignados, estar

\footnotetext{
278 "Hay paredes que piden que las pinte", diario El Día, 3/02/2013.

${ }^{279}$ Anotaciones de campo de conversaciones con Luxor en 2015.
} 
mutando y desplazándose todo el tiempo de lugar. En relación a la valorización de la obra / producción y las modos de su circulación recurrentemente ha comentado que busca producir "obras de calidad" tanto para la persona que solamente la puede pagar con una comida como para la persona que puede pagar miles de pesos por un "Luxor original".

\section{III. ¿Bourdieu o Rancière?}

Como se mencionó, algunas de las nociones que se vienen reflexionando en este capítulo -sobre todo las de "escena" y "campo"-, son parte de las categorías "nativas" utilizadas por los propios actores involucrados para narrar y caracterizar la situación de las artes visuales en La Plata. Es decir, que forman parte del repertorio discursivo disponible. A su vez, como se planteó en los primeros apartados, son nociones que resultan productivas y operativas para describir y analizar -desde una diferenciación de escala y relaciones- las prácticas emergentes que suceden en la ciudad en relación a la producción, la gestión y la circulación cultural. En este sentido, son particularmente útiles para reflexionar sobre las propias experiencias de Luxor y de Síntoma, sus propósitos y sus intervenciones dentro de esa trama de prácticas vinculadas a las artes visuales. También pueden ser categorías adecuadas para articular las apuestas de estas dos experiencias locales con las concepciones de división o "reparto de lo sensible", "política estética" y "escenas de disenso" aportadas por Rancière, que han sido invocadas anteriormente en esta tesis.

La noción de "campo cultural" -en sentido bourdiano- ${ }^{280}$ se entiende como un espacio de puesta de reglas y mecanismos de consagración, como ámbito de disputas de posiciones por la definición de los principios legítimos de división del campo -sistemas de relaciones de producción, circulación y consumo de bienes simbólicos-. En tanto que por "escena emergente" -en este caso, de las artes visuales- se entiende a la construcción de espacios concretos de activación, creación y circulación cultural, de actores, discursos y relaciones que se ponen en juego. Pero, al mismo tiempo que se tiene en cuenta esta propuesta que comprende la constitución de un campo cultural y artístico en tanto "dominio autónomo",

\footnotetext{
${ }^{280}$ En los términos genéricos propuestos por el propio Bourdieu un campo es un espacio social estructurado y estructurante en el que es necesario que exista algo en juego, agentes dispuestos a jugar y el conocimiento de reglas inmanentes al juego. Se trata de un espacio de luchas por la legitimidad y por el dominio de un campo específico. Es el resultante de relaciones de fuerza y de lucha entre agentes y/o instituciones que tienden a conservar o transformar formas específicas de poder. El concepto de campo intelectual -y allí el de campo cultural y artístico- ha servido para analizar los condicionamientos sociales que están presentes en el universo de la producción cultural y de los bienes simbólicos (Bourdieu 2002, 2014).
} 
como las reglas que van a demarcar lo que es propio del arte, es preciso destacar que algunas limitaciones y problemas de ese concepto. Entre las críticas que emprende Rancière se encuentra la perspectiva sociológica de Bourdieu -sobre todo en relación a la distinción cultural desde la que operan ciertos sectores para sostener su status y disimular la separación social-, cuando plantea que el pensamiento crítico antiestético encierra sobre sí mismo algo que sería "lo propio" de un orden o espacio ${ }^{281}$. Al tener presente estas observaciones críticas, el concepto de campo sirve si se (lo) abre y colabora a dilucidar confrontaciones y disputas desde una dimensión activa de las prácticas y no sólo clasifica, demarca y certifica unas ciertas posiciones -dominantes y dominadas- en ese espacio social ${ }^{282}$. A su vez, ambas perspectiva sirven para cuestionar las ideas -muy extendidas en los estudios sobre arte- de "creación pura" y "originalidad creadora" de los artistas y correrse así del énfasis puesto en el “creador" y la "creación” de obras propio del análisis esencialista del arte y la percepción estética.

La idea es aquí, apoyándose en estos aportes, pensar una "escena" artística en sus construcciones y sus relaciones. El campo -y la escena- "crean" y designan a los artistas, son los que inculcan la disposición y la competencia artística, y no el artista mismo. Es donde hay una estructura de distribución -desigual- de recursos, créditos y capitales y es el espacio en el que se ponen en juego las luchas por la acumulación de capital simbólico. Ahora bien, esta idea de "campo" artístico y cultural, y allí dentro una escena local de artes visuales, se inscriben en una situación contemporánea en la que según Rancière:

"la multiplicación de los discursos denunciando la crisis del arte o su captación fatal por el discurso, la generalización del espectáculo o la muerte de la imagen, indican suficientemente que el terreno estético es hoy aquel donde se continúa una batalla que

\footnotetext{
${ }^{281}$ Plantea Rancière: “El desprecio por la 'estética' le es consustancial. No hay duda que la sociología, en tiempos de Bourdieu, ha abandonado sus sueños originarios de reorganización social. Pero sigue queriendo, por el bien de la ciencia, lo que el orden representativo quería por el bien de las distinciones sociales y poéticas: que las clases separadas posean sentidos distintos" (Rancière, 2011: 23). Lo que refuerza es la separación y distinción que cuestiona. Así para Rancière sostener una perspectiva en la que su enclave son los condicionamientos sociales corre el riesgo de encerrarnos en el propio círculo de la dominación, llevando a la impotencia y sin la posibilidad de visualizar la emancipación política. Sin embargo, atendiendo estas observaciones críticas para no caer en el círculo de la dominación, consideramos que los aportes del "sociólogo anti-filosófico", sobre todo en la construcción de conceptos con un fuerte nivel de operatividad, son de utilidad para pensar desde una visión relacional a ciertas situaciones y fenómenos culturales. Así por ejemplo, la noción de "campo" -en nuestro caso, como campo cultural y artístico- puede servir a condición de no perpetuar las posiciones que allí se ocupan, ni sus especificidades, ni sus límites en relación a otros "campos"; y por lo tanto, pensar en la porosidad de los mismos y las movilidades posibles, atendiendo a las acciones intencionadas por generar cruces y reapropiaciones.

${ }^{282}$ Dos preguntas surgieron en el último período del trabajo de campo y continúan abiertas para próximas investigaciones: una es por la existencia de un "campo cultural" en La Plata y la otra por la pertinencia de ese término para el estudio de las prácticas locales.
} 
ayer remitía a las promesas de la emancipación y a las ilusiones y desilusiones de la historia." (Rancière, 2014: 13)

Desde esta perspectiva abierta por Rancière es que, además, podemos entender que se cargan a la cuenta del "terreno estético" muchas y diversas apuestas, librando en él batallas que buscan abrir campos de preguntas y ampliar los modos posibles de visibilidad y del hacer social. Así, resulta productivo construir una analítica cultural que exponga la centralidad contemporánea de la estética articulada con la política. Este autor también encuentra que mientras la opinión predominante en el pensamiento celebra el "retorno de la política", denuncia a la estética porque "se ha vuelto un discurso perverso que impide el cara a cara" con el acontecimiento, sometiendo a las obras y a las percepciones (Rancière, 2011: 10$11)^{283}$.

Sin embargo, Rancière se posiciona desde otro lugar, ya que no denuncia la distinción o la confusión estética sino que propone dar vuelta los razonamientos del discurso antiestético contemporáneo. Como ya se refirió antes, este autor propone entender a la estética no como una disciplina sino como configuración del mundo sensible común; como un "régimen de identificación específica del arte", es decir, de las cosas artísticas. Entonces, este "régimen estético del arte" entendido como un régimen general de identificación, visibilidad e inteligibilidad del arte y "un modo de discurso interpretativo que pertenece en sí a las formas de dicho régimen" (Rancière, 2011: 20).

En esta situación de tensiones, de re-elaboraciones conceptuales, de repensar posiciones, límites y alcances -del arte, de la política, de la estética de la política y de la política de la estética- podemos pensar que se inserta, justamente, la propuesta del colectivo Síntoma ${ }^{284}$. Ya que desde su hacer se pone a la orden del día de varias discusiones y polémicas contemporáneas en relación a "lo propio" y "lo impropio" del espacio del arte, la estética y su politicidad. Se inscribe en las "confusiones", "malestares", "síntomas" y "desencuentros" del presente. Podemos inferir que este grupo entiende, junto con Rancière, que un régimen estético visibiliza ciertas cosas a la misma vez que vuelve a otras invisibles,

\footnotetext{
${ }^{283}$ Para Rancière este diagnóstico se sustenta por teorías antagónicas que van de Schaeffer a Badiou y de Bourdieu a Lyotard; en estas reflexiones la estética sería "el discurso capcioso mediante el cual la filosofía -o cierta filosofía- desvía en provecho propio el sentido de las obras de arte y de los juicios de gusto" (Rancière, 2011: 9).

${ }^{284}$ Dentro las dos temporalidades que se marcaron en la tesis, para diferenciar dos momentos-contexto distintos y algunas mutaciones en las prácticas e inquietudes culturales, el colectivo Síntoma forma parte del segundo "período" que va de los años 2012 a 2015. Por su parte la experiencia de Luxor juega en ambos momentos. La idea aquí es interpretar que ambas prácticas forman parte de la emergencia de un nuevo ciclo y escenario de prácticas culturales.
} 
ocultas y que quedan afuera de ese régimen. Este será el itinerario analítico y los cruces prácticos y conceptuales de lo que sigue.

\section{IV. “Pensar y potenciar la escena local”: La experiencia de Síntoma ${ }^{285}$}

Con un breve enunciado en su página de Facebook Síntoma curadores -o solo Síntoma- presenta el propósito del grupo: "indaga sobre los dispositivos de exposición y comunicación de las producciones simbólicas". En sus objetivos se destaca una búsqueda por intervenir en los conceptos, dispositivos y espacios del campo cultural de la ciudad de La Plata y la escena local de las artes visuales -respecto de los recorridos anteriores y sus "trayectorias", los integrantes de Síntoma han participado en algunos de los colectivos y acciones grupales que se analizaron en la tesis-. Su presentación e instalación en esa escena local fue en 2012 con la organización de siete muestras y la participación en el armado del encuentro "ZigZag" junto con Luxor y otros productores y gestores de la ciudad $^{286}$. Esas muestras pueden pensarse como un ciclo bastante compacto -desde Síntoma lo llamaron “interlocutores"287_ y marcan su intención de "incidir" activamente en los circuitos alternativos de producción, circulación y validación de las artes visuales. ${ }^{288}$ Para ampliar una definición de lo que pretende y del modo en el que se presentó, desde el grupo plantean:

\footnotetext{
${ }^{285}$ Un trabajo de análisis pormenorizado sobre Síntoma se encuentra en López $2015 b$.

${ }^{286}$ En noviembre de 2011 este colectivo participó en la curaduría y el montaje de la muestra "Caminantes" de Luxor, su primera muestra individual. En aquel entonces esta actividad no estuvo mencionada como propia de Síntoma, pero puede ser interpretada como puntapié iniciático del quehacer del grupo. Para conocer las otras muestras curadas por Síntoma y otras de sus acciones, ver cuadro 4 en el anexo.

${ }^{287}$ Es interesante observar que la mayoría de los productores seleccionados por Síntoma para esas muestras Acra, RayMund, Pantera, Cons, Nelson y Luxor- son participantes activos del circuito local del "street art", el "graffiti" y la "pintada callejera", actores cuyos itinerarios de obras y acciones se dan "en la calle" y cuyo principal soporte es la pared -sea de espacios públicos o privados- y no los dispositivos del formato muestra y los espacios de galería. Ahí se puede encontrar una marcada intencionalidad de Síntoma para que esos productores se pongan a jugar en un terreno específico del campo artístico, en una escena local de las artes visuales. Desde allí en adelante, Luxor y Dani Lorenzo, con estilos diferentes, han sido dos de los productores que más han generado una intensidad de muestras y proyectos artísticos. En este sentido, es que podemos entender a estos productores locales, tomando las categorías de Bourdieu, como los agentes con menos "volumen de capital", quienes ocupan la posición de "recién llegados" al campo y deben generar sus estrategias para permanecer y consolidarse. Ver web: http://dlorenzo.com.ar y fanpage: www.facebook.com/soyluxor

288 Tomando la literatura disponible dedicada al "arte contemporáneo" y los circuitos de exposición y legitimación, resulta interesante el aporte de Raymonde Moulin, quien plantea -casi en oposición- las lógicas de diferentes tipos de galerías. Por un lado, "las galerías que se dedican al arte tradicional, en función de la selección de artistas que realizan, evitan la toma de riesgo que se asocia a la innovación" y supeditan la elección de artistas por el poder adquisitivo de su clientela y a la rotación rápida del stock; por el otro, las galerías que se dedican al arte contemporáneo ponen en práctica un "circuito de valoración cultural". La ecuación así es inversa: fabricación de la demanda contra sumisión a la demanda (Moulin, 2012: 32-33). Ampliando el concepto -ya que la autora se centra en analizar el "mercado del arte" en el que las galerías cumplen un rol importante-,
} 
"Síntoma básicamente es una cuestión de ethos, de una voluntad de incidir sobre el campo cultural, en el cual nosotros estamos vivos, estamos trabajando (...) el dispositivo mismo, toda la forma de abordar ese dispositivo es Síntoma. Es algo que en algún punto piensa la manifestación de algún tipo de estructura.

(...) Aterrizamos al campo, por A, B o $\mathrm{C}$, ya validados; en un cierto sector que estamos operando. La ausencia de otros competidores, si se quiere, nos da una facilidad total. Buscamos incidir en el campo. Esto [se refieren a la construcción de muestras] es el plan de mínima de todo lo que pasa en La Plata, no de máxima. La idea es que empecemos a discutir otros cosas.” (E 24, Síntoma)

En tal sentido, en los siguientes años, entre 2013 y 2015, sus prácticas se ligaron a la lectura, la crítica y la reflexión sobre muestras, ciertas situaciones y sobre la escena misma materializados en un espacio de reseñas, la curaduría de algunas muestras colectivas, algunas plagas virtuales, un conversatorio y la constitución de una agenda-. Sin ponerse en lugar de juez, Síntoma se desplazó para jugar en el plano de la reflexión, instalando ejes de debate y pensamientos sobre el contexto emergente y propuso activar la mirada sobre las exposiciones, tanto del circuito oficial como alternativo de galerías y espacios de arte en la ciudad.

"Hacíamos curaduría por una forma de pensar diferente la escena platense, lo que decíamos "no colgar los cuadritos", no era por la curaduría como montaje en sí mismo, sino que en realidad apuntábamos a lo mismo que apuntamos ahora. Incidir en lo que eran las prácticas, que veíamos como dominantes, que dejaban relegado para otro momento tomar en consideración todo lo que interviene en la producción simbólica, que no es solamente colgar un cuadro y ver cómo se lo presenta, sino tomar el circuito entero y pensarlo. (...) En eso lo primero era ponerlo en valor (...), un primer paso de conocimiento del campo, lo básico era una muestra. Una vez que vimos que ya era una preocupación paralela de otros espacios eso ya nos dejó de ser un paraguas.” (E 25, Síntoma)

Síntoma entiende que, en las muestras desarrolladas en la ciudad estos últimos años, hubo saltos cuantitativos y cualitativos, algo cambió y sirvió para cuestionar una visión más global. "Lo que uno monta no termina en la galería, sino que tiene mucha importancia en la escena donde uno lo monta" (E 25). Algunas de las acciones del grupo lograron brindaron espacios y actores que se implican en la presentación y circulación de las obras y prácticas artísticas. 
disparadores para la producción de muestras y reflexiones dentro de la escena y la apertura de conversaciones entre actores diferentes. En tal sentido apunta:

"Comenzamos a observar que había muestras que estaban proponiendo lo que nosotros ya veníamos planteado en esa primera etapa, podríamos decir. Entonces nos pareció que hacía falta mirar desde afuera esas muestras, hacer un análisis de lo que estaba sucediendo, de por qué se estaban haciendo y empezar un poco a poder ver, a cartografiar y a definir esas experiencias para definir una escena, para empezar a vernos como una escena. Lo que en un principio fue como un núcleo donde nosotros empezamos a hacer muestras, curando las muestras, terminó siendo todo un año de no hacer ninguna curaduría sino de estar mirando qué era lo que estaba sucediendo y plantear ya la curaduría no sólo de una muestra sino de una escena.” (E 25, Síntoma)

Para Síntoma, en la escena hay un "movimiento de autovaloración", de nuevas referencias, donde se amplían los espacios de exposición, se comienzan a visualizar en los medios locales e incluye un significativo número de investigadores del arte, junto a otros grupos que están también haciendo análisis sobre estos temas. A su vez, afirma -como caracterización- que la "estética platense" es que "una estética tensionada"289. Así acuñó la categoría "preciosismo conceptual" para pensar la escena local desde una visión global. Se trata de una categoría provisoria y para seguir trabajándola, que se tensiona entre un polo conceptual y un polo "preciosista", ligado al oficio ${ }^{290}$.

Otro elemento que hace a cierta "especificidad platense" de la escena artística local es la posibilidad de las conexiones que habilitan a "trabajar la red"291. lo que se relaciona con la propuesta de Síntoma ampliar los diálogos y el campo escuchas e intercambios. En este sentido, los productores y sus obras/producciones no son los únicos "interlocutores", por lo

\footnotetext{
${ }^{289}$ Según Síntoma, esta tensión está asociada a las "instituciones existentes" -ya sea la Facultad de Bellas Artes, los museos oficiales-, las gran cantidad de talleres de arte, las prácticas estéticas ligadas al espectro militante (las organizaciones sociales que trabajan en el campo del par arte y política), a la pintura, el grabado, el dibujo -por lo general de pequeño formato, en donde "lo técnico es llevado al extremo"-, a ciertas figuras del graffiti así como a las "promesas" del mercado del arte (E 25).

${ }^{290}$ Ante "un binomio de opuestos, que en cualquier discurso parecerían irreconciliables" Síntoma plantea que "lo interesante en La Plata es que no son opuestos e irreconciliables, es la escena la del "preciosismo conceptual"' (E 25). Existen tensiones fuertes hacia alguno de los polos "pero no se desconocen, se pelean, se encuentran, a veces tienen aciertos, a veces desaciertos. (...) No es una tensión intrínseca de actores que no se ven. Son actores que se ven, se tocan y generan una energía particular" (E 25). En tal sentido, estos movimientos se transforman en reajustes y acomodaciones dadas por los encuentros plenos de tensiones.

291 "Van apareciendo agentes nuevos en la ciudad, espacios (...) Nuestra idea sería poder seguir ampliando y seguir trabajando esa idea de 'trabajar la red' con nodos e ir tocando personas cercanas a nosotros pero para que toquen a otros, que vaya haciendo como una cadena, para no quedar acotados. Para no quedar en el amiguismo, o explotar el amiguismo, la potencialidad del amiguismo, un amiguismo que llame a otro amiguismo. Convocar a personas que convoquen a otras personas para no quedar en un círculo de conocidos.” (E 25)
} 
que en Síntoma buscaron "ir por el todo". Esto llevó a focalizarse en los espacios y los gestores que son los que aglutinan a los artistas y productores y se articula con una mirada del arte que discute la concepción moderna: "la obra no la hace ni la termina un artesano del arte. Se arma con un montón de sujetos, es un ensamble que lo hace la escena" (E 25). Pero, a su vez, la búsqueda no sólo es en relación con los actores propios del campo artístico, sino también con la reflexión sobre cómo desde "lo social" se interpela "al campo arte". Para Síntoma "fuera del campo del arte" existe una discursividad que puede enunciar interesantes preguntas, metáforas y posiciones. Esta propuesta generó diferentes tensiones y debates, respuestas y réplicas ${ }^{292}$.

"En la intención nuestra hay un cruce de cosas (...) empoderar la escena en un doble movimiento si se quiere: empoderar la escena propia a través de que los demás actores, periféricos, que se relacionan indirectamente, empiecen a tener derecho a hablar de esa escena, como a la inversa, que esa escena se deje hablar por cosas de otros campos.” (E 25, Síntoma).

No hay en Síntoma un programa definido. Hay sí intencionalidad de desvíos, un "estado de Beta permanente", como dicen. Un estado de mutación, escucha y creación, e incluso de incertidumbres. Sin embargo, en esa plasticidad de sus acciones hay una claridad de intervenir sobre lo real, activar en el propio presente, produciendo ajustes y apropiaciones: "hay pequeños estallidos y pequeñas cosas que van saliendo", "la idea es siempre estar probando, vas tirando muchas líneas en una dirección" (E 25).

Teniendo en cuenta la propuesta crítica de Rancière para pensar el hacer político y la estética $(2006,2007,2011)$, podemos interpretar que Síntoma se propone constituir una "estética del disenso"; poniendo en juego allí una dimensión ética y política. Ante el consenso estético que proponen las instituciones del arte, que clausura la posibilidad de crítica e instaura "la normalidad" (que luego se constituye en normalización de las prácticas artísticas), este colectivo se planta desde otro lado. Configura una intervención en la singularidad de un "momento" y a la vez, busca dibujar la cartografía de lo que este momento define y posibilita. Por todo ello, Síntoma entiende que el empoderamiento de una escena es

\footnotetext{
${ }^{292}$ En esos años (2013-2014) el espacio de las "reseñas" que el colectivo llevó adelante se transformó en, prácticamente, la única propuesta de "producción de textos" sobre muestras, obras y situaciones vinculadas a la escena en la ciudad. Además, se generaron en el mismo año dos columnas radiales semanales sobre la "escena emergente" de las artes visuales: la antes mencionada en FM Provincia y otra en el programa "El cubo mágico" de FM Universidad. Estos espacios radiales buscan trazar una cartografía de los espacios, las producciones y los productores de la escena local, compartiendo muchas veces los mismos materiales y hechos que se reseñan desde Síntoma.
} 
un elemento decisivo para que esta se reconozca como un actor generador de producciones, acciones y situaciones significativas ${ }^{293}$.

Como se indagó, Síntoma pone en escena la riqueza y complejidad de la producción cultural y artística local compuesta por actores y prácticas diversas, por entrecruzamientos de estéticas y discursos diferentes, por la construcción de redes afectivas y de afinidad y por las dislocaciones respecto de las políticas culturales institucionales. Este colectivo constituye una experiencia situada y renovadora que tensiona "lo propio" del campo del arte -de sus nociones, figuras, metáforas, modos y actores legitimados-. Esto lo hace al poner en entredicho esos sentidos y lugares asignados, al incorporar a "otros" para hablar del arte -y más que arte- $\mathrm{y}$ al buscar volver a repartir lo sensible -las formas de enunciar y mirar-.

Como cierre, se puede interpretar que las experiencias de Síntoma y de Luxor tienen vasos comunicantes, sobre todo al cuestionar los lugares comunes en los que se constituye el campo artístico, y en particular la escena de las artes visuales local. A su vez, tienen en común una mirada atenta a las tensiones y a los conflictos que son parte de lo social, y dentro de este del campo específico de la cultura y el arte. Sin embargo, como se pudo observar, la propuesta de Luxor es menos conceptual y conceptualizada que la de Síntoma; es una iniciativa que pretende acercar de un modo alternativo, las formas artísticas -composiciones, obras, miradas, procedimientos- a las dinámicas y los consumos “populares”, insertar o hacer parte a esas propuestas y producciones en la "cultura popular". Asimismo, Luxor se plantea construir autogestión no sólo como una cuestión de principios, sino también desde el plano más material: entender a la producción y circulación del arte como "forma de vivir", un aspecto que no ha sido trabajado en Síntoma.

Con todo lo expuesto hasta aquí sobre las derivas y desplazamientos en las prácticas culturales contemporáneas de la ciudad, sostenemos como supuesto, a continuar trabajando, que se está gestando -desde 2010/2011- una novedosa escena emergente de producción y circulación de las artes visuales que renueva el campo cultural por la introducción y constitución de nuevos actores -entre artistas o productores, gestores, curadores, investigadores, comunicadores y públicos- y por la apertura de nuevos espacios de arte y

\footnotetext{
293 También ese empoderamiento se ampliará cuando se reconozca vinculada a otras escenas y prácticas culturales que desandan sus apuestas en la ciudad: desde las editoriales autogestivas a los centros culturales independientes, de los productores y colectivos de intervenciones simbólica en el espacio urbano hasta las bandas y grupos musicales del circuito alternativo. En este sentido es que podemos pensar que en estas prácticas y activaciones de las escenas culturales de la ciudad se constituye ciertas "formaciones culturales" -en términos que ya definimos de Raymond Williams (2009)-, que se generan y potencian "por fuera" de las instituciones formales, constituyéndose en movimientos, tendencias y espacios efectivos de creación colectiva e incidencia local.
} 
galerías -para muestras, venta de obras, talleres, encuentros-. Por todo esto, se sugiere que se está configurando una formación "emergente", alejada de los espacios de decisiones de las instituciones culturales estatales (tanto a nivel municipal y provincial como en el universitario) y ligada a idearios de alternatividad, autogestión e independencia (López, 2013b). En esa escena local, Luxor interviene y se mueve como un productor visual que fortalece -principalmente- redes locales de contactos e intercambios por donde su producción circula y se renueva. Como se pudo observar -si bien mantiene algunas inquietudes sobre las maneras de habitar la ciudad y operar en ellas, propias de las intervenciones culturales analizadas anteriormente en la tesis- ha realizado algunos desplazamientos importantes respecto a cómo pensar y desarrollar el hacer de su práctica "artística", ligada a la construcción de una "poética" personal y al intento de autogestionar su vida desde al arte. Por su parte, Síntoma se puso a intervenir -a hablar y reflexionar- sobre la escena local de artes visuales para visibilizar un espacio emergente de prácticas, constituyéndose en actor "mirado", tenido en cuenta. Comenzó a entablar diálogos productivos y a invitar a hablar a actores de la escena y a otros que no son parte. Comenzó a "hacer ruido" y a relevar los "síntomas" de una escena que se encuentra en pleno proceso de formación y transformación.

20 un año pelopincho

iLlegaron los caramelos

(Llegaron los carame
(vender anto on la ciudad)

- IAlgo de sombra por favor!

3 Montados en un delfin

Hundido

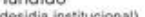

Molinete de noticias

(difusion de una escena en comón)

- Patitos que chiflan

- Parches Sintomáticos

Parches de la Universidad

Patitos feos

Pahunas muestras del anof

Echale cloro
(los Promios Vigo)

[El amor con critica salva vidas!

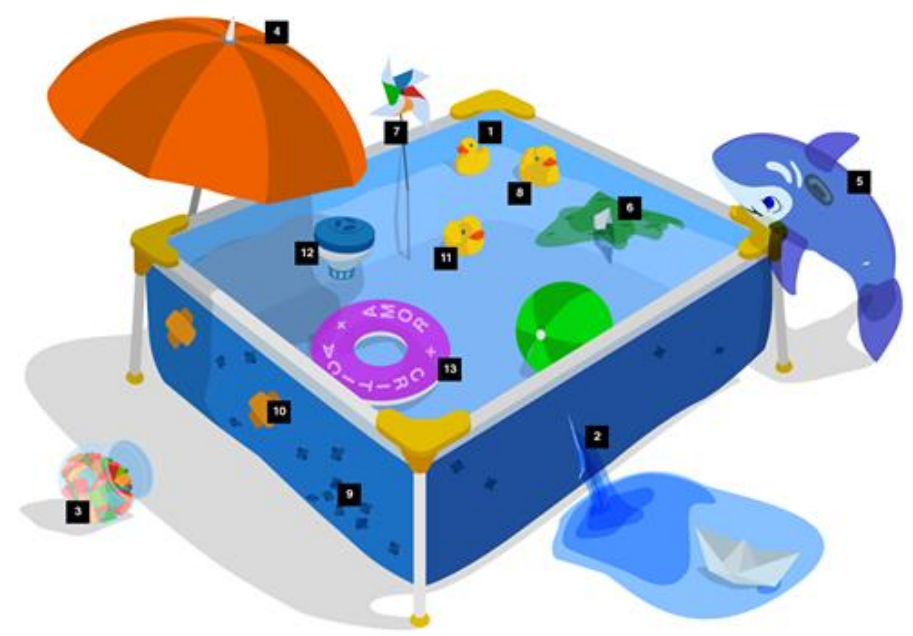

Imagen 47. Flyer virtual de la acción "Año Pelopincho" de Síntoma. Fecha: diciembre de 2013 /enero de 2014. 


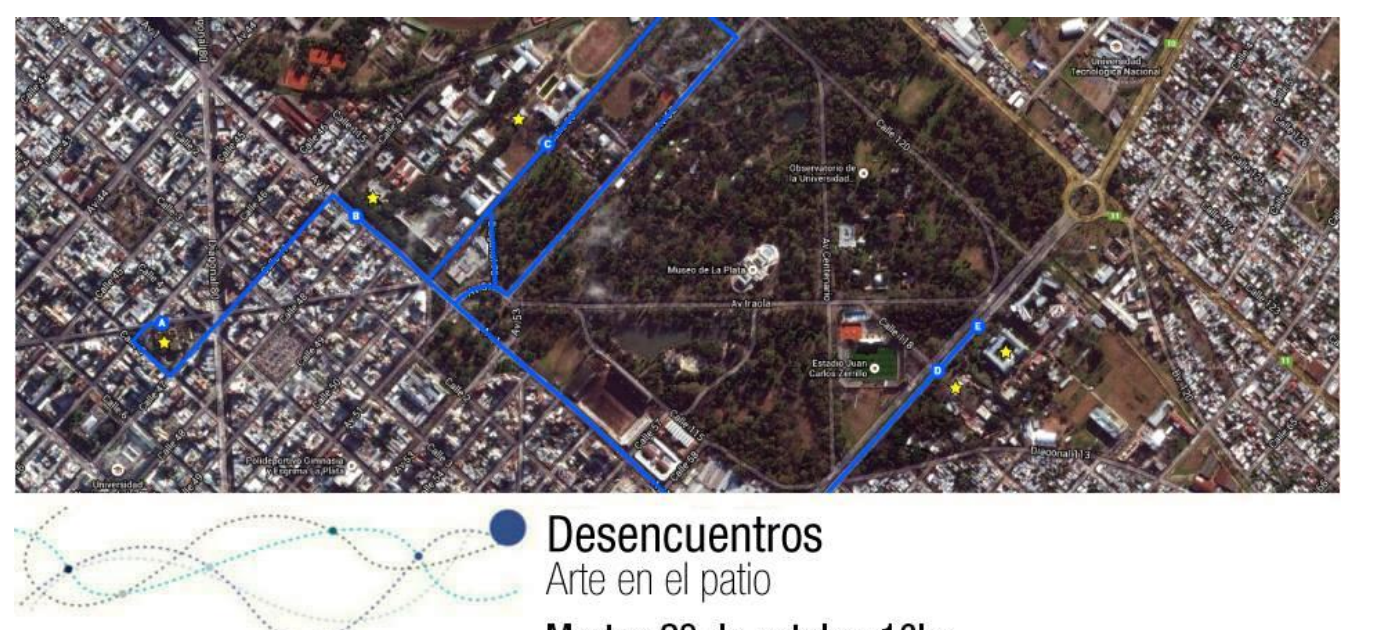

Martes 28 de octubre 16hs

partida, puerta del colegio Liceo Victor Mercante

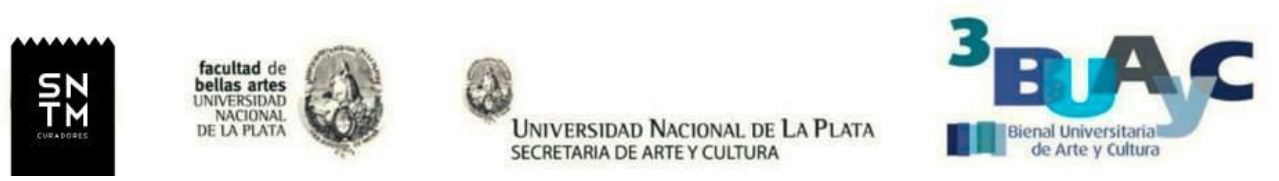

Imagen 48. "Desencuentros” organizado por Síntoma. Fecha: Octubre de 2014. Lugar: recorridos por distintos puntos de la ciudad. 


\section{Palabras finales}

\section{Preguntas}

A lo largo de la tesis se indagó sobre cuáles son los sentidos que asumen, para los sujetos involucrados, el llevar adelante intervenciones culturales que se apropian del espacio urbano. Ligado a este interrogante surgieron otros: ¿qué tipo de prácticas y saberes pusieron en juego? ¿Qué posicionamiento o postulados sostuvieron? En relación con esto otra pregunta central fue por los modos de habitar la ciudad contemporánea (de practicarla, de producir espacios y lugares). En el despliegue de esas prácticas y sentidos de las experiencias culturales ¿se puede entender que configuraron la emergencia de otro tipo de espacio público?

Estas fueron preguntas -se sostuvo- que situaron a la investigación a fin de reflexionar sobre los modos de apropiación contemporáneos del espacio urbano y sobre la configuración y las dimensiones del espacio de lo público que realizan dichas prácticas culturales. A su vez, fueron interrogantes sobre las narraciones y los sentidos sobre la ciudad en los que intervienen -disputando sentidos, postulando argumentos e instalando distintas lógicas de regulación- los medios de comunicación hegemónicos y las políticas culturales y urbanísticas locales. Por último, se procuró reflexionar sobre los modos en que distintos actores sociales y grupos intervinieron e intervienen en dichas políticas culturales y urbanas para expandirlas, generar posibles redefiniciones y/o discutirlas. En tal sentido, la pregunta por el espacio institucional y las tensiones con lo emergente integró asimismo el horizonte de exploración de la tesis.

\section{Tensiones}

Durante la primera Bienal Universitaria de Arte y Cultura -una inédita y renovadora iniciativa organizada por la UNLP-, diferentes interventores visuales y graffiteros locales 
fueron parte de la gran cantidad de actividades programadas durante los días del evento. Corría octubre de 2010 y todo un movimiento de arte público-urbano que se estaba generando alrededor de "Intervención Magenta" -coordinada por Luxor y Acra- tenía su lugar en ese evento institucional de arte y cultura. Decenas de estos productores visuales, que tienen al aerosol, la brocha y unos gruesos fibrones como elementos siempre listos en sus bolsos y mochilas, intervinieron los muros externos de la Facultad de Bellas en la zona de Plaza Rocha y también en el Parque Saavedra. Sucedía un hecho novedoso en la ciudad -aunque seguramente no relevado en la Historia del Arte local-, una institución ligada a la órbita de lo público-estatal incorporaba -al menos por un momento- a unas prácticas que las miradas tradicionales no dudarían en reconocer como no-artísticas y, más importante aún, como vandalismo. Con algo de la pintura y los aerosoles que sobró de esa intervención, algunos productores visuales siguieron la acción sobre la fachada de la Biblioteca de la misma universidad, a unas cuadras de la Facultad. Se mezclaron así con otras intervenciones visuales que ya estaban presentes en el lugar: tags, pintadas políticas, stencils y afiches varios. Con el tiempo otras inscripciones más se sumarían.

Sin embargo, a los pocos meses de aquella bienal universitaria, reapareció otra respuesta distinta. La misma universidad que había avalado y financiado -al menos los materiales- a las pintadas en la fachada de la Facultad de Bellas Artes desplegó más tarde una gran lona sobre la pared externa de la Biblioteca en la que podía leerse "cuidemos nuestro espacio", y anunciaba además que "estamos trabajando en la limpieza y pintura de la fachada". Esa lona vertical -¿una metáfora de una decisión desde arriba?- continuó varios meses ahí y solo se movió ocasionalmente por el viento. En cambio en la fachada de ese antiguo edificio a las distintas intervenciones que ya poblaban sus paredes se le sumaron otras que anunciaban nuevas cosas, en una sugerente metáfora de lo poroso y cambiante del espacio urbano. Por debajo de aquella lona la piel del edificio seguía transformándose, mutaba. En algún momento, ya en 2012, se consumó la "limpieza y pintura de fachada". Se borraron y quitaron afiches, tags, "escrachos" inentendibles, stencils con reclamos sociales varios y aquel stencil gigante de dos manos -que emulaban a las de la creación de Adán, pintadas por Miguel Ángel- que se convidaban una lata de aerosol. Creación y encuentro. Insistentes e interpeladoras, luego de la limpieza, vinieron otras pintadas y stencils, que continuaron la insolencia frente al espacio.

A finales de 2009, mientras el por entonces gobernador Daniel Scioli impulsaba una reforma del "código contravencional”, el colectivo Luli realizó la campaña “Ceci n’est pas une contravención" / "Esto no es una contravención”. Retomaba las discusiones que abrieron 
diferentes organizaciones sociales sobre este asunto y proponía -en un principio de manera anónima- una acción web en la que se encontraba parte del articulado del nuevo código propuesto y una serie de representaciones visuales alusivas. La discusión que se buscaba dar era que esas prácticas -venta ambulante, graffiti, situación de calle, piquete y movilización callejera- no eran acciones de contravención, en una clara confrontación con la regulación impulsada por el Ejecutivo provincial. Al poco tiempo Luli fue invitado a participar en la Muestra "Calle tomada", en el Museo Arte y Memoria de la Comisión Provincial por la Memoria. Luli decidió ser parte con una intervención que siguió extendiendo y ampliando los sentidos de la mencionada campaña web. En la nueva acción, tanto fuera como dentro del museo, aquella afirmación se presentó en clave de pregunta: ¿Esto no es una contravención?. La acción, en sus dos superficies, era idéntica y seguía la estrategia de la tergiversación del discurso oficial: el propio Estado provincial pasaba a ser el enunciador. Esa inscripción con fondo "rojísimo" y logo oficial, era acompañada por una bajada: "No dudes, nosotros lo decidimos por vos". A su vez, en la web se proponía una imagen que enlazaba en $360^{\circ}$ a las dos acciones. En el museo, además, se linkeaba a la intervención "en calle" con una imagen de la misma y un breve epígrafe: “calle / penalizado". Sobre un costado del mural del museo se reproducía un texto que también aparecía en el espacio urbano:

"Existe dualidad. Y existe contradicción.

La provincia de Buenos Aires, a partir de la entidad de sus secretarías, oficinas y museos, enmascara su incumplimiento de respeto y resguardo de los derechos humanos. La provincia de Buenos Aires, en un marco de exposiciones en espacios propios, paga este mural. Y además, sanciona este mismo mural y otras maneras de ocupar la vía pública.

La provincia de Buenos Aires, a través de su Código contravencional vigente, penaliza también a las personas en situación de calle: gente sin techo, gente que cuida coches, gente que se prostituye.

La provincia de Buenos Aires, a través de sus diputados y senadores, está en proceso de reforzar el poder y la discrecionalidad de la policía a partir de la sanción de un nuevo Código contravencional."

Lo que Luli estaba produciendo -además de generar algún aireado enojo entre los organizadores, la dirección del Museo y la Comisión Provincial- era una interesantísima discusión sobre la tensión entre lo que sería una producción artística legitimada (dentro del museo) y una producción estético-comunicacional contraventora (afuera, en el espacio 
urbano). Se trataba de algo más que una provocación "artística": diálogo tenso y posicionamiento ético.

\section{Nociones}

Este trabajo buscó intencionalmente no hablar de "identidades" (culturales, políticas, colectivas, de género). La reticencia vino por dos lados. El primero, de algunas recurrentes lecturas de autores/as que discuten esencialismos varios (Foucault, Deleuze, cierto marxismo y cierto deconstructivismo). Se trata de escritos que ayudan a conceptualizar cuestiones del presente. Pero que las lecturas/relecturas -compartidas con otros/as- que hacemos desde nuestro propio lugar, a veces, también pueden obstaculizar el pensamiento al construir cierto "sentido común pretendidamente crítico" que no confronta sus postulados, sino que los refuerza como verdades cerradas, como algo dado -¿los afirma como una identidad?-. El segundo, vinculado al anterior, viene de la sospecha hacia las modas académicas que últimamente- traducen todo fenómeno social en términos de identidad. La mirada, un poco cínica, podría ser enunciada del siguiente modo: despojados de poder transformar el mundo material y simbólico, solo nos queda jugar en y transformar nuestras identidades.

Sin embargo, en la tesis se habló de "experiencia/s" (Hall, 2010; Elizalde, 2008; Jay, 2009, Williams, 2009; Thompson, 2012); una noción muchas veces hermanada con la de “identidad" ${ }^{294}$. De modo genérico en este trabajo se la utilizó principalmente como sinónimo de "práctica" o "acción"; de un modo más conceptual en sintonía con los conceptos de "praxis" y "cultura" -este último en el sentido aportado por Williams-. Por último, se procuró articularla complejamente con las nociones de práctica cultural, acción colectiva y hacer político, evitando caer en una perspectiva de análisis sostenida en elementos invariables -por ejemplo, una perspectiva que no encuentra sujetos, estilos de vida, sentidos y actividad creadora sino que únicamente halla efectos, síntomas, estructuras y reproducción-. La idea de experiencia giró así cercana a lo que Raymond Williams (2009) entendía como "formas de vivir" y "experiencia vivida". Un concepto que permite reponer las prácticas y vivencias de

\footnotetext{
${ }^{294}$ La discusión en el pensamiento contemporáneo en torno al estatuto de la experiencia y su lugar en el conocimiento, está atravesada por una fuerte impugnación que se realizó a esa noción desde el denominado "giro lingüístico" y el análisis postestructuralista del discurso sobre todo en las décadas de 1980 y 1990 (Jay, 2009). A lo largo de la tesis, se buscó construir una perspectiva de análisis cultural que se nutra de otros "giros": el "acontecimental" y el "experiencial", que podemos identificar -pero no acotar- en los aportes tomados aquí de Guattari y Lazzarato de un lado y de Williams y los Estudios culturales del otro.
} 
los sujetos en los procesos sociales que los atraviesan y de los cuales son parte ${ }^{295}$. De este modo, con la noción de experiencia se intentó referir a un proceso vivido, vivencial y vivo, aún abierto, en el que una multiplicidad de prácticas gestan una "cultura (en) común” y viva. Una cultura plural ligada a lo afectivo, al encuentro y el convite, a la autogestión y la organización horizontal, a la alegría y a la crítica del presente, a la "producción" desde la cultura. A su vez, en el hacer de esa "experiencia compartida" de intervención cultural dichas prácticas pusieron a andar un "repertorio" amplio y diverso de recursos y dispositivos desde el cual intervinieron en aquello que consideran lo "real" y lo "común" -la calle, el barrio, la ciudad, el espacio público, el lenguaje y la gramática cultural, el capital simbólico, las redes virtuales y la web-. Justamente en eso "común" y "real" -desbordado de prácticas y de sentidos- fue lo que esta tesis intentó focalizar, a partir de una trama conceptual que incluyó, también, otras nociones claves para pensar estos procesos, como las de espacio público, ciudad, espacio urbano, cultura -producción cultural- y política -politicidad de las prácticas-. Para articular a las prácticas culturales específicas con la dimensión conceptual, se entendió que sería apropiado deconstruir, analizar, reponer y complejizar esas nociones comunes desde una perspectiva plural de análisis cultural que tuviera en cuenta los aportes de diferentes campos de saber y construyera una estrategia metodológica abierta.

De este modo, se volvió a mirar y a intentar comprender las experiencias "platenses" y se reconoció que éstas también intervienen de una manera situada, con los pies en la tierra y, algunas veces, “dentro del teclado". En este sentido, se postuló que estas experiencias de intervención cultural "hacen" ciudad -se apropian del espacio urbano, proponen modos de habitar, construyen espacios y lugares-; emprenden acción colectiva -se juntan con intenciones comunes pero, a la vez, tejen redes de intercambio y relaciones-; y participan en la reconfiguración del espacio de lo público -lo amplían, lo extienden, lo expanden, lo tensionan- más allá de los límites formales y tradicionales en los que se entiende a dicho

\footnotetext{
${ }^{295}$ Martín Jay afirma que la izquierda británica -con la influencia de los Cultural Studies donde se destacaban las figuras de Hoggart, Thompson, Williams y Berger, a quienes denomina "marxistas humanistas británicos""encontraron en el concepto de experiencia -tanto como en su hipotético empobrecimiento- una valiosa herramienta para sus críticas a la sociedad moderna" En Williams particularmente el registro de esa experiencia “era evidente en una 'estructura del sentimiento'. (...) Era la misión de la crítica radical rescatar la experiencia vital del pasado, con todas sus contradicciones y anhelos no realizados, a fin de poder utilizarla en favor de los propósitos emancipadores contemporáneos. Por muy reprimida y soterrada, por muy resistente que fuese a la articulación directa, tales experiencias podían ser la materia prima de una potencial contra-historia a la narrativa dominante del triunfalismo burgués" (Jay, 2009: 209 y 228). Asimismo, este autor alerta sobre la posibilidad de caer en el fetiche de la experiencia, una cuestión latente, no sólo en los Cultural Studies, sino en todo el pensamiento social y político que reivindica la "acción" y la "experiencia". Nuevamente, la misma observación crítica se puede realizar a las contemporáneas "políticas de identidad" o "políticas identitarias", por ejemplo, al desprender la "creencia (...) de que las experiencias grupales compartidas conducen inexorablemente a tomar una posición política" (Jay, 2009: 213).
} 
espacio -convivencial y consensual, ágora de civilidad, ámbito en el que la opinión pública se manifiesta y es informada y sintetizada por los medios de comunicación-. Con todo esto, se abría así el espacio de las pistas y algunas certezas.

\section{Pistas}

En relación a las intervenciones culturales se trabajó con la intención de no comprenderlas a priori como auxiliares de luchas específicas, expresión o máscara simbólica de una práctica política o representación estética de una acción que otros manifiestan o llevan adelante. Lo que se buscó es tensionar esa forma convencional de abordar las prácticas culturales -como subsidiarias-, para pensar que las intervenciones practican también un "hacer político", es decir que despliegan una politicidad emergente que se escapa de los lugares asignados de la política tradicional, y que al mismo tiempo portan una ética potente de los afectos y la amistad, de la crítica del presente como detonador de la acción y la reflexión-. En tal sentido, se postuló que no son tanto una "práctica artística" como el despliegue a una politicidad -construida por elementos heterogéneos: artísticos, estéticos, comunicacionales, culturales, políticos-, que a veces conecta/hace puente con otras prácticas (políticas, territoriales, colectivas, etc.). En tal sentido, se observó que ponen en juego un repertorio diverso y yuxtapuesto de prácticas y saberes del arte, de la militancia política no tradicional, de la comunicación social, de la publicidad y el diseño visual, de las redes sociales y de los usos de internet.

Con todo esto se comprendió que los interrogantes y las maneras de habitar la ciudad y producir lo público son diversas en esas prácticas culturales analizadas: incidir en la vida cotidiana de un territorio e interpelar al mundo del arte, producir marcas (no permanentes) en la "piel" de la ciudad para abrir preguntas y diálogos, repensar los modos de creación y visibilizar reclamos y cuestiones pendientes, ser parte de las luchas sociales aportando capital simbólico. La ciudad fue y es entendida como "ser vivo que va mutando", "espacio donde construir relaciones", “campo de acción”, y "escenario de la batalla cultural y simbólica". 


\section{Certezas y cierre}

La ciudad moderna ha entrado en una "crisis terminal", ahora es tiempo de la "ciudad virtual" dominada por -el desorden de- los "flujos" de intercambio.

La ciudad abierta, la de la calle y los lugares ha muerto, "ya no existe".

La calle es el lugar "más inseguro" para la percepción de los ciudadanos.

El espacio público se ha "perdido", "desvanecido" y con él la posibilidad de encuentro.

Estos son algunos de los enunciados que se escuchan -resonantes y desde hace algunos años- por diferentes lados y que evidenciarían el debilitamiento de los proyectos colectivos, el declive de lo compartido, la imposibilidad de lo común y la agonía de lo público. Algunos de estos discursos incluso se conectan, tengan la intención o no, con las miradas que alientan un mundo "post-político"296.

Sin embargo, aún reconociendo las profundas transformaciones contemporáneas ocurridas en las últimas décadas, en las que las ciudades y el espacio público experimentaron importantes cambios y reveses, esta investigación buscó desandar una propuesta analítica basada en una doble asunción de partida: a) en las formas de habitar la ciudad se concentran las tensiones y los dilemas de la sociedad contemporánea. Desde esa posición se asume que el habitar la ciudad no significa tanto circular y contemplar como ocuparla y apropiarla, de allí que se produzca una significativa renovación de la experiencia urbana. Es decir, un "hacer" la ciudad desde las prácticas cotidianas que la ponen a "andar", pero también desde la construcción de acontecimientos que interrumpen esa cotidianeidad, la descolocan y hacen vibrar al movilizar lo sensible y producir conflictos y otras temporalidades. b) En el cruce de lenguajes y dispositivos, recursos y estrategias heterogéneas de la producción cultural con las formas de habitar lo urbano anida la posibilidad de configurar otro espacio público constituido por escuchas y diálogos críticos, urgencias y construcciones pacientes, organizaciones horizontales y afectivas, conexiones virtuales y presenciales.

Lo que se trató de poner en juego, analizar y comprender fueron unas prácticas culturales situadas. Lo situado fue entendido no como un mero contexto, medio físico o ambiente por el cual se anclan, circulan o se emplazan unas acciones, sino en tanto territorio poroso y movedizo de una "trama sociocultural" particular y cambiante: el espacio urbano de la ciudad de La Plata en los últimos diez años (2006-2015). De este modo, se planteó el

\footnotetext{
${ }^{296}$ Para Slavoj Žižek (2008) este mundo post-político busca impedir la "universalización metafórica de las reivindicaciones particulares", la posmoderna post-política es una forma de negación de lo político.
} 
interrogante por la emergencia de un otro espacio público en el cual las intervenciones culturales pudieran comprenderse como configuradoras de modos diferentes de habitar la ciudad, de producir lo urbano y de construir lo público. Así, frente a las propuestas de circular, contemplar y regular preponderantes en las políticas estatales, pero también en los discursos que refuerza la prensa tradicional de la ciudad, el habitar se demostró productivo, una apropiación y un hacer inquietos desde la crítica, la creatividad y la exploración de lenguajes, dispositivos y formas comunicacionales y estéticas. Un mural que propone desde su concepción ser escrachado durante el recorrido de una movilización, es decir, un "antimural" -o un "más allá del mural"- que no tiene la intención de perdurar como representación pictórica y plástica para ser contemplado por los transeúntes apresurados. Aquí lo perdurable y lo efímero no fueron parte de la discusión central. Sí lo fue, en cambio, la ocupación del espacio urbano y su apropiación por, para y en una acción colectiva y, a su vez, una concepción de intervención cultural como algo mucho más allá de su "mera" materialidad "literal".

Un banner en una pared con el rostro de Julio López -que lleva puesto un gorrito "a lo" Dónde está Wally? - e invita a linkear en la red social más famosa y a ponerse a jugar para encontrarlo (o al menos para conocer por qué desapareció y por qué el Estado no lo ha encontrado): la discusión puede ser en torno de una posible banalización de la lucha por los Derechos Humanos en el país y por los límites de los recursos estéticos a utilizar. O, más relevante aquí, por los modos de proponer otras estrategias comunicacionales frente a las visualidades construidas anteriormente y frente a la invisibilización cada vez más cotidiana de la segunda desaparición de López. O por la conexión entre la ciudad y la web, dos territorios desde donde se configura lo público contemporáneo.

En la misma línea, una Muestra itinerante busca convidar experiencias y proponer encuentros entre diferentes y desconocidos, en un barrio y una ciudad cada vez más marcados por la desconfianza en el otro (y que se puebla de cámaras de seguridad, rejas, alertas vecinales). Ante ella es factible abrir una discusión por la circulación del arte y por la idea del centro-periferia que refuerzan los discursos institucionales, o complejizar el planteo y reparar en la tensión que se instala sobre las formas en las que se produce, no sólo la práctica artística, sino el propio encuentro, aunque sea momentáneo y más allá de la grilla de espectáculos para el fin de semana, al proponer aventuras y derivas.

Unos cuerpos que invitan a muchos otros cuerpos, cuerpos múltiples que se amontonan, que hacen ruido y hacen pregunta al desplazarse por la ciudad, llevan dos pancartas, una con el rostro de Julio López, la otra con un signo de interrogación: no es tanto 
un ejercicio de destreza masiva como un ejercicio de memoria colectiva y reclamo común en el cual "poner el cuerpo" no es una metáfora cuanto una toma de posición corporal y ética, un acto político frente a los espacios de poder institucional.

Unos murales y "figurones" que presentan personajes con colores rojos, negros y grises y con el puño en alto: imágenes construidas con sencillez y simplicidad con el propósito poder llevar esas formas visuales a un plano accesible y popular y poder integrar a quien desee participar durante su realización.

Unas pintadas callejeras con colores saturados y plenos -realizadas en aerosol y látex que aparecen por decenas en la ciudad-, que presentan unas pajaritas, travestis, mujeres, putos, lesbianas, voladoras, protectores. ¿Solo embellecen la ciudad con su estallido de color? Más bien se transforman en mito, en fuerza vital, en energía "piola" para luchar en los días y alentar a las complicidades. Sus personajes se activan e invitan a activar con un abrazo, una frase, una pregunta, una afirmación.

Las intervenciones culturales aquí analizadas fueron realizadas por diferentes colectivos e individuos, que en muchos casos compartían vínculos y prácticas (anteriores y presentes al momento del trabajo de campo): tramaron en común, tejieron una red amplia de discursos, recursos, sentidos y relaciones. Como propuesta interpretativa se las pensó como conformando una "formación cultural" que propuso, al menos por un espacio-tiempo específico, nuevas visibilidades y otros modos de habitar la ciudad desde la producción cultural. Discutieron así las "divisiones" establecidas y abrieron un campo de preguntas y acciones sobre las maneras de hacer, ver y decir. Propusieron -se comprendió aquí- un nuevo "reparto de lo sensible" más allá de las formas instituidas de circular por el espacio urbano y controlarlo, más allá de las maneras de narrar la experiencia de la ciudad en los medios comerciales, más allá de las formas de promover "cultura emergente" desde las políticas oficiales y, en muchos casos, a espaldas de las "reglas", los "canones" y "circuitos" del mundo artístico.

No se trató de un "laboratorio" aséptico en el que tuvieron lugar prácticas novedosas para catalogar hacia el campo del arte o hacia el campo de las políticas y los proyectos culturales, sino de un campo de experiencias múltiples en las que las tensiones, los debates y reajustes estuvieron siempre presentes, propuestos e incentivados -cuestiones abiertas que, en parte, llevaron luego a la desactivación de algunas prácticas-. En muchos casos las preguntas principales que guiaron las acciones estudiadas no fueron si lo que se hacía era o no arte, un "hecho artístico" y/o la consumación de una "experiencia estética" para un público. Las preguntas principales giraron en torno a cómo colaboraban en la configuración de una 
experiencia vivida y colectiva que hiciera vibrar a los sujetos, detonar preguntas y explorar formas y nuevos sentidos críticos sobre el presente.

Por todo esto, las prácticas que se relevaron y se buscó comprender se inscriben en discusiones, apuestas y propuestas sobre lo político, lo comunicacional, lo estético, lo urbano y lo local y lo público. En la producción de la tesis se fue construyendo (en los diálogos, en las búsquedas por la web, en el análisis de documentos, en el diseño de la cartografía y de nuevo en las conversaciones con los actores) una trama intensa de prácticas, recorridos, sentidos, repertorios conceptuales y de acción.

En tal sentido, otra de las apuestas analíticas (y políticas) de la tesis fue reconocer y comprender en estas experiencias culturales su capacidad de "agencia" social, de producir lo urbano en sus insistencias por ocupar, apropiar y habitar la ciudad (¿puede la ciudad ser algo más que un escenario, un paisaje o un enorme lienzo? $)^{297}$. Prácticas que intervinieron en la gramática cultural al buscar dislocar -con preguntas, tergiversaciones, campañas, contradiscursos y poéticas- a la red de discursos y sentidos "comunes" (que habitan en todo el cuerpo social) y "hegemónicos" (oficiales, institucionales, mediáticos). Acciones prestas a disputar y configurar los espacios de lo "público", en algunos casos ensanchando sus límites contemporáneos y explorando "otros territorios" más allá de lo urbano y del espacio físico tangible.

Como una ajustada síntesis del análisis crítico de cada experiencia indagada podemos señalar un conjunto de conclusiones arribadas:

-En Sienvolando es posible reconocer una apuesta por la exploración de los recursos y dispositivos visuales -los murales, las estampas, los stickers, las campañas comunicacionales, un sitio web- en estrecha articulación con organizaciones sociales de base. Una insistencia por construir desde ese lugar enunciados y retóricas que interpelen a la ciudad, que modifiquen su piel, y por tejer una "red de relaciones" con otros.

-En Siempre la danza y el cuerpo fueron puestos como espacios de exploración crítica y colectiva ligada a los dramas del pasado presente. Lo artístico y lo político en tensión y diálogo.

-En La Muralista Hermanos Tello se constata una insistencia por ligarse y ser parte de las luchas actuales -de la ciudad y de otros lugares- y por aportar allí con recursos y

\footnotetext{
${ }^{297}$ La respuesta a esta pregunta puede ser contestada de maneras diversas en la experiencia y el discurso de cada una de las prácticas de intervención indagadas. Esas formas, si se quiere, más tradicionales de comprender el fenómeno urbano (escenario, paisaje, lienzo) son parte de los enunciados de algunas de las experiencias.
} 
herramientas gráficas y visuales para producir contra-discurso público en la "lucha simbólica".

-También en Arte al Ataque se lee una iniciativa fuerte por fundirse en las luchas populares de la ciudad, el país y la región, desplegando recursos y dispositivos diversos para desnaturalizar y disputar usos y sentidos; intervenir "en y para el espacio público", como escenario de potencialidades.

-En Luli, por su parte, se advierte un juego constante (y explosivo) con los dispositivos y lenguajes de la comunicación y los recursos de la web (producción de sitios web, intervención en redes sociales, juegos online), el diseño visual (banner, gigantografías, producción y uso permanente de imágenes) y la gráfica artesanal (serigrafía, stencil, mural). Su interrogación principal ha sido sobre "cómo producir esfera pública".

-En La Grieta -y particularmente en la propuesta de la MA- su apuesta fuerte fue tensionar el lugar de lo artístico (que saliera de los lugares comúnmente confinados y de los actores preponderantes para convidar prácticas y cruzar sujetos diferentes), y su fórmula se cifró en la mezcla -de lenguajes y personas- y en el contrapunto -de sentidos y posicionespara provocar encuentros. También se observa allí una búsqueda por poner en tensión lo local: una insistencia por pensar y actuar en la ciudad como un espacio en el que siempre hay algo por deconstruir y descubrir, una experiencia que se ancla en estar y habitar el territorio.

-Finalmente, en la propuesta de Luxor también se encuentra un sentido fuerte por estar presente en la ciudad/calle "todo el tiempo": la cotidianeidad de los barrios, algunas luchas populares y las complicidades y sensibilidades disidentes son el motor de su poética. Su recurso predilecto: la pintura callejera. Su soporte: la pared. Pero también una deriva en los formatos de la pintura y la gráfica: cuadros en mediano y gran formato, reproducciones visuales, serigrafías, láminas, estampas, etc. En esas presencias y recorridos cotidianos en los que "la gente piola se junta" fue donde Luxor configuró y configura aun su experiencia del habitar la ciudad.

Los modos organizativos y las maneras de hacer fueron en la tesis otro punto de interés. La autoorganización y autogestión aparecieron como principios y puestas en acto de las experiencias indagadas, también el compartir y el co-producir con otros (entre vecinos y artistas, con las organizaciones sociales y colectivos, etc.) En tal sentido, además, se pudo reconocer la importancia de la dimensión sensible y afectiva en la configuración y en el hacer de estas prácticas culturales: "nuestro objetivo es construir una red de relaciones", "pinto sobre las complicidades y las relaciones disidentes de un mundo nuevo", "se trata de un mínimo sismo que genere otro tipo de frecuencia en las relaciones", el colectivo "era esas 
redes afectivas". De este modo, se precuró demostrar que todas esas cuestiones daban cuenta de una politicidad emergente (¿particular?, ¿singular?) de las prácticas culturales en La Plata en el periodo analizado: organización colectiva y horizontal, retóricas positivas y críticas, del afecto y el encuentro, modos de hacer/producir colaborativos y miradas renovadas y dinámicas sobre de la ciudad y lo público.

Asimismo, también fueron importantes en la indagación los modos de decir y narrativizar el presente. Así es que en dichas experiencias se pudo reconocer unas retóricaspoéticas y construcciones discursivas ricas en los sentidos que despliegan y en formas de leer la realidad, productivas asimismo para reflexionar sobre la ciudad y la cultura: "la piel de la ciudad", "la silla en la vereda", "la gente piola se junta", "pintar belleza", "relaciones del mundo nuevo", "disputar belleza".

Sin embargo, también se reconoció cierta ambivalencia en esa formación cultural. Ambivalencia que no habla tanto de una debilidad (de sus formas de interpelación política) o de una inconsistencia (conceptual y estratégica para leer el presente) como de cuestiones abiertas, debates latentes y asuntos pendientes que condicionaron y afectaron las formas de acción colectiva de estas experiencias y la construcción de esa "red de relaciones", -no está de más decir que esas cuestiones y debates han estado presentes en las distintas formas de organización colectiva contemporáneas-. En este sentido, la configuración de lo estatal no fue leída del mismo modo en los distintos colectivos y hacia su interior, e incluso, esos modos fueron asumiendo matices diferenciales: rechazo de lo estatal, disputa y diálogo en lo estatal. De hecho esas lecturas diferenciales se agudizaron con la fuerte interpelación política producida por el kirchnerismo -que generó algunas nuevas expectativas en la política formal y la apertura a diálogos con la forma-estado-. Aquí se interpretó que esa interpelación repercutió en las experiencias culturales de La Plata con mayor fuerza sobre todo hacia finales de 2010, que -con el fallecimiento de Néstor Kirchner mediante- movilizó en la escena pública una fuerte subjetivación político-cultural: valorización de ciertas políticas de Estado y de la presencia estatal en la organización social, reconocimiento de ciertos liderazgos, apertura de oportunidades políticas para las organizaciones populares, etc. No por casualidad algunas de las prácticas culturales analizadas se desactivaron o mutaron en otras entre finales de 2010 y 2011. Esto no implica plantear que las experiencias de intervención cultural de La Plata desaparecieron como consecuencia la subjetividad política que proponía el kirchnerismo -de hecho, como se pudo reconocer en el cartografiado elaborado ad hoc, si bien varias experiencias dejaron de existir surgieron otras quizá más esporádicas y puntuales entre los años 2012 y 2015-, sino que esa propuesta política puede ser leída como una de las 
situaciones importantes que desataron los debates, quiebres, reajustes y desactivaciones de varias prácticas colectivas que se estaban produciendo hasta el momento. Así es que simultáneamente comenzaron a perder potencia algunos reclamos (por ejemplo, la exigencia al Estado por de la aparición con vida de Julio López como el caso más notorio en La Plata) y algunas organizaciones -principalmente las ligadas a las perspectivas de izquierda independiente e izquierda nacional- iniciaron procesos de debates internos, fracturas, reagrupamientos y reacomodamientos en el mapa de las organizaciones sociales y populares.

Asimismo, como procuramos desarrollar en la tesis, la cuestión de la ambivalencia también puede ser rastreada en la dimensión de la "producción" de la ciudad. Si pensamos en las derivas y las luchas que se desatan en y por la ciudad contemporánea, el signo característico de la trama urbana es la "ambivalencia": interpelación de las diferencias (ambiente tolerante, aire de libertad, estímulo a la singularidad cultural) e interpelación del orden y la seguridad ("tolerancia cero", monitoreo, criminalización de la pobreza, entre otras), apertura a la creación/recuperación de lo público y la captura de las innovaciones (Mezzadra, 2008). La ambivalencia, se puede conjeturar, como condición y resultado de época del presente, la dinámica en la que se desenvuelve la sociedad contemporánea. La ciudad es así uno de los espacios donde esta condición se produce, se desarrolla y se profundiza. Pero la ambivalencia es, además, donde se juega la potencialidad de una nueva imaginación y acción política radical en la contemporaneidad, sin grandes fundamentos para su consumación y sin garantías de victoria.

La perspectiva analítica que se buscó llevar adelante, tuvo la pretensión de no solamente producir una investigación empírica sobre objetos delimitados del campo social -al cartografiar y describir prácticas de intervención cultural en La Plata-, sino de plantear relaciones y articulaciones de dichas prácticas con los procesos sociales, políticos y culturales contemporáneos. De allí la intención de reconocer las configuraciones de los "espacios de lo público", las diferencias y tensiones entre la ciudad y lo urbano, las transformaciones en los proyectos urbanísticos y en las maneras de habitar la ciudad, las retóricas de las políticas públicas locales destinadas a la cultura y a la "recuperación del espacio público" y la economía discursiva de los medios de información para pensar las prácticas culturales y la ciudad. De allí también surgió la reflexión sobre la distinción entre la política y lo político y interrogación por las formas de politicidad emergente que acontecen en la vida contemporánea.

En este punto una de las cuestiones que se buscó reflexionar y desandar, cuando se analizaron las prácticas culturales y las perspectivas sobre lo urbano, fue cómo sostener la 
idea de la ciudad como lugar practicado o espacio de lo practicado (De Certeau, 2000; Delgado, 2007a; Lefebvre, 1970) y comprender al mismo tiempo que lo público es más que un espacio, es decir, que es preciso des-anclar-lo de su condición espacial para comprender su compleja configuración contemporánea. Una sospecha para indagar esto -a distancia de varios de los estudios en ciencias sociales que los asimilan- fue que la ciudad no es sinónimo de lo público, aunque desde luego haya -o pueda haber- espacio público en lo urbano (de forma normativa, consolidada, emergente, situacional, inestable, fugaz). La idea fue entonces plantear analíticamente que el espacio público no es un dato previo localizable en lo urbano y en la ciudad, sino algo que es configurado en las prácticas (y en los discursos, narraciones y sentidos que se disputan y se tensionan) y que pueden suceder -o no- en la ciudad.

Sin embargo, la idea principal de la tesis fue también reponer de qué modo las prácticas culturales situadas y que se apropian del espacio urbano son parte de la configuración un otro espacio público, otra esfera pública que tensiona las características tradicionales y normativas. Es decir que fue preciso, luego de de-construir lo público, volver a espacializarlo en una de sus dimensiones, aunque se reconozca que no se pueda limitarlo o determinarlo en un espacio localizado. Allí es donde el trabajo cartográfico fue clave: reterritorializar y fijar las intervenciones culturales en un mapa de la ciudad, pero con otro objetivo. En simultáneo, desplegar discursos y sentidos, saberes y prácticas, conocer sensibilidades y comprender proyectos colectivos que desde la producción cultural "hacen" ciudad, "practican" lo urbano y reconfiguran "lo público" en sus tres semánticas: lo común, lo manifiesto y lo abierto (Rabotnikof, 2005), y en su dimensión comunicacional (MartínBarbero, 2001). Lo que se pudo reconocer allí es que las intervenciones culturales indagadas han producido, principalmente, cierta "espacialidad alternativa" (Richard, 2007) que discutió con aquellos recorridos normados e instituidos por el Estado (o más genéricamente las instituciones) y por los sentidos tradicionales que narran la ciudad -a esta ciudad en particular-. Y lo hicieron mediante acciones fuertemente situadas -en el espacio urbano pero sobre todo en su contexto socio-cultural, que supieron "leer" y cuestionar- en las que recrearon microrrelatos, microterritorios y microconflictos con los que pusieron a "andar" una "vitalidad micropolítica" (Guattari, 2013).

Se entiende que todo esto se introduce en un camino de indagación de sumo interés. Un camino para la investigación social que cobra potencia mientras el espacio, el territorio, la ciudad, el espacio urbano y el espacio público, pero también las prácticas culturales y la producción cultural, no sean considerados sólo objetos de la disección disciplinar. Si no que, por el contrario, ganen vigor explicativo y valor heurístico en los cruces que pueden producir 
las perspectivas y miradas transversales y plurales que recuperan saberes y prácticas heterogéneas.

Esta investigación, con sus limitaciones y sus aciertos, pretende ser un aporte en este sentido. 


\section{Bibliografía}

Bibliografía contextual: globalización, postfordismo, urbanización

AGAMBEN, Giorgio. (2005) Estado de excepción. Buenos Aires, Adriana Hidalgo.

BECK, Ulrich. (2001) ¿Qué es la globalización? Falacias del globalismo, respuestas a la globalización. Barcelona, Paidós.

BERARDI, Franco. (2007) Generación PostAlfa. Buenos Aires, Tinta Limón.

CASTELLS, Manuel. (1976 [1972]) La Cuestión urbana. México, Siglo XXI.

- (1974) Movimiento sociales urbanos. México, Siglo XXI.

(1995 [1989]) La ciudad informacional. Tecnologías de la información, reestructuración económica y el proceso urbano-regional. Madrid, Alianza.

(2001 [1998]) La era de la información. Vol. 3. Madrid, Alianza

(2009) "Nueva economía y política urbana". Venecia, Proyecto La comunidad inconfesable. Disponible en: http://blogs.llull.cat/venezia2009/

(2012) Redes de indignación y esperanza: los movimientos sociales en la era de Internet. Madrid, Alianza.

CONTESTED CITIES. (2016) Módulo 1. Ciudades en disputa: Gentrificación. Propuesta de abordaje didáctico. Disponible en: http://contested-cities.net/wp-content/uploads/2016/09/CCMODULO-1-web.pdf

CORBOZ, André. (2016) Orden disperso. Ensayos sobre arte, método, ciudad y territorio. Bernal, Universidad Nacional de Quilmes.

ESPOSITO, Roberto. (2012 [1998]) Communitas: origen y destino de la comunidad. Buenos Aires, Amorrortu.

FOUCAULT, Michel. (1979) "Nuevo orden interior y control social" en Saber y Verdad. Madrid, La Piqueta, pp. 163-166.

FREDIANI, Julieta C. (2013) "La problemática del hábitat informal en áreas periurbanas del partido de La Plata", Revista Universitaria de Geografía, N²2, pp. 43-67

GIDDENS, Anthony. (2000) Un mundo desbocado. Los efectos de la globalización en nuestras vidas. México, Taurus.

GUATTARI, Félix. (2003) "Prácticas ecosóficas y restauración de la ciudad subjetiva", Catalunya, Quaderns d'arquitectura i urbanisme, № 238. Col-legi d'Arquitectes de Catalunya.

(2004) Plan sobre el planeta. Capitalismo mundial integrado y revoluciones moleculares. Madrid, Traficantes de Sueños.

(2015) ¿Qué es la ecosofía?. Buenos Aires, Cactus.

GUATTARI, Félix y Suely Rolnik. (2013 [2005]) Micropolítica. Cartografias del deseo. Buenos Aires, Tinta Limón. 
HARDT, Michael y Antonio Negri. (2002 [2000]) Imperio. Buenos Aires, Paidós.

HARVEY, David. (1977 [1973]) Urbanismo y desigualdad social. Madrid, Siglo XXI.

(1998 [1990]) La condición de la posmodernidad. Investigación sobre los orígenes

del cambio cultural. Buenos Aires, Amorrortu.

(2005) "El arte de la renta: la globalización y la mercantilización de la cultura”. En

Harvey, D. y N. Smith. Capital financiero, propiedad inmobiliaria y cultura. Barcelona, Museu d'Art Contemporani de Barcelona.

(2013) Ciudades rebeldes. Del derecho de la ciudad a la revolución urbana.

Madrid, Akal.

HIDALGO, Rodrigo y Michael Janoschka (eds) (2014). La Ciudad Neoliberal. Gentrificación y exclusión en Santiago de Chile, Buenos Aires, Ciudad de México y Madrid. Santiago de Chile / Madrid, Instituto de Geografía, Pontificia Universidad Católica de Chile / Departamento de Ciencia Política y Relaciones Internacionales, Universidad Autónoma de Madrid.

JAMESON, Fredric. (2012 [1984]) Posmodernismo o la lógica cultural del capitalismo tardío. Vol. 1. Buenos Aires, La Marca.

KOOLHAAS, Rem. (1995) "La ciudad genérica". Versión en castellano extraída de internet.

Disponible en: https://urbanismodos.files.wordpress.com/2015/05/la-ciudad-generica-rem-

koolhaas.pdf

LEFEBVRE, Henri. (1970 [1968]) El derecho a la ciudad. México, Siglo XXI.

(1974) "La producción del espacio", Barcelona, Papers. Revista de Sociología.

Disponible en: http://papers.uab.cat/article/view/v3-lefebvre/pdf-es

LOSANO, Gabriel (2011) "Código de ordenamiento urbano y economía urbana. Análisis de una problemática concreta en la ciudad de La Plata", revista Quid, N 16, FCS (UBA), pp. 74-91.

MATTELART, Armand. (2001) Historia de la sociedad de la información. Buenos Aires, Paidós.

MEZZADRA, Sandro. (2005) Derecho de fuga. Migraciones, ciudadanía y globalización. Madrid / Buenos Aires, Traficantes de Sueños y Tinta Limón.

(2008) "Las migraciones van configurando otro espacio latinoamericano" (entrevista), revista La Biblioteca, $\mathrm{N}^{\circ}$ 7, primavera de 2008. Biblioteca Nacional, pp. 40-51.

MONGIN, Olivier (2006) La condición urbana. La ciudad a la hora de la mundialización. Buenos Aires, Paidós.

ORTIZ, Renato. (1998 [1996]) Otro territorio. Ensayos sobre el mundo contemporáneo. Santafé de Bogotá, Convenio Andrés Bello.

RODRIGUEZ, Esteban. (2014) Temor y control. La gestión de la inseguridad como forma de gobierno Buenos Aires, Futuro Anterior.

(2016) La máquina de la inseguridad. La Plata, EME.

RODRÍGUEZ, Esteban, Julián Axat, Jerónimo Pinedo, Sofía Caravelos y otros. (2003) La criminalización de los protesta social. La Plata, Ed. Grupo La Grieta / HIJOS La Plata. 
SASSEN, Saskia. (1999 [1991]) La ciudad global: Nueva York, Londres, Tokio. Buenos Aires, Eudeba. -- (2012 [2007]) Una sociología de la globalización. Buenos Aires, Katz.

SOJA, Edward W. (2008 [2000]) Postmetropolis. Estudios críticos sobre las ciudades y las regiones. Madrid, Traficantes de sueños.

THEODORE, Nik, Jamie Peck y Neil Brenner (2009) "Urbanismo neoliberal: la ciudad y el imperio de los mercados". Santiago de Chile. Temas Sociales, $\mathrm{N}^{\mathrm{o}} 66$. Disponible en: http://www.sitiosur.cl/publicacionescatalogodetalle.php?PID $=3532$

VIRNO, Paolo (2003). Gramática de la multitud. Para un análisis de las formas de vida contemporáneas Madrid, Traficantes de Sueños.

WALLERSTEIN, Immanuel. (2002) “¿Globalización o era de transición?. Una perspectiva de larga duración de la trayectoria del sistema-mundo”. México, Revista Eseconomía, №1, otoño 2002, Escuela Superior de Economía-IPN.

WACQUANT, Loïc. (2007) Los condenados de la ciudad. Gueto, periferias y estado. Buenos Aires, Siglo XXI.

Cultura, producción cultural y prácticas culturales:

ALONSO, Rodrigo. (Cur.) (1999) "En torno a la acción" en Arte de acción 1960-1990 (cat. exp.), Buenos Aires: Museo de Arte Moderno. Disponible en: http://www.roalonso.net/es/arte_cont/accion.php (2011) “Arte de acción”. (Dossier en línea). Buenos Aires: Centro Virtual de Arte Argentino (Centro Cultural Recoleta). Disponible en: http://cvaa.com.ar/02dossiers/accion/2 intro.php

ARDENNE, Paul. (2006) Un arte contextual. Creación artística en medio urbano, en situación de intervención, de participación. Murcia, Cendeac.

BENJAMIN, Walter. (2015) Estética de la imagen. Buenos Aires, La Marca.

BENZECRY, Claudio. (Comp.) (2012) Hacia una nueva sociología cultural. Bernal, Universidad Nacional de Quilmes.

BLANCO, Paloma, Jesús Carrillo, Jordi Claramonte, Marcelo Expósito. (Eds.) (2001) Modos de hacer: arte crítico, esfera pública y acción directa. Salamanca, Universidad de Salamanca.

BOURDIEU, Pierre. (2002) Campo de poder, campo intelectual. Buenos Aires, Ed. Montressor. (2014 [2003]) El sentido social del gusto. Elementos para una sociología de la cultura. Buenos Aires, Ed. Siglo XXI (Especial) Biblioteca esencial del pensamiento contemporáneo. BOURRIAUD, Nicolás. (2006 [1998]) Estética relacional. Buenos Aires, Adriana Hidalgo. (2009a [2001]) Postproducción. La cultura como escenario. Buenos Aires, Adriana Hidalgo. (2009b) El radicante. Buenos Aires, Adriana Hidalgo. 
BOIX, Ornela. (2016) "Una socióloga en un mundo de la música: usos de la investigación etnográfica en la profesionalización de un sello musical emergente de la ciudad de La Plata" En: Arias, Ana Carolina y Matías David López. Indisciplinas. Reflexiones sobre prácticas metodológicas en Ciencias Sociales. La Plata, Club Hem / IICom (FPyCS-UNLP).

BREA, José Luis. (2004) El Tercer Umbral. Estatuto de las prácticas artísticas en la era del capitalismo cultural. Murcia, CENDEAC.

BUCK-MORSS, Susan (2014 [2005]) Walter Benjamin, escritor revolucionario. Buenos Aires, La Marca.

CAPASSO, Verónica. (2012) “Arte en el espacio público y nuevas estrategias para hacer memoria”. I Encuentro de Jóvenes Investigadores en Arte - Centro Argentino de Investigadores de Arte y Universidad Nacional de Luján. Disponible https://www.academia.edu/4927140/Arte_en_el_espacio_publico_y_nuevas_estrategias_para_hacer_ $\underline{\text { memoria }}$

(2013) "Prácticas artístico-militantes platenses como formas de acción política.

El caso de Luli y Luxor Magenta”. X Jornadas de Sociología, FCS (UBA).

CHEMPES. (2008) "El recurso a la cultura en las marchas por Julio López en la ciudad de La Plata.

Período 2006 - 2008". Disponible en:

http://argentina.indymedia.org/images/24mesesDeMarchasPorLopez_chempes.pdf (2009) "Potencia fragmentaria. Reclamos por el femicidio de Sandra Mercedes Ayala

Gamboa." Disponible en: http://argentina.indymedia.org/news/2009/11/706887.php

CUELLO, Nicolás. (2014) "Flujos, roces y derrames del activismo artístico en Argentina (20032013): Políticas sexuales y comunidades de resistencia sexoafectiva", revista Errata \#12, Bogotá, Fundación Gilberto Alzate Avendaño.

DE RUEDA, María de los Ángeles. (2003) Arte y utopía. La ciudad desde las artes visuales, La Plata, Asunto Impreso.

(Comp.) (2014) Arte y medios: entre la cultura de masas a la cultura de redes. La Plata. Proyecto de investigación "Arte y Medios", FBA (UNLP). Web del proyecto: https://arteymediosunlp.wordpress.com

DI FILIPPO, Marilé (2011).”Walter Benjamin y Jacques Rancière: arte y política. Una lectura en clave epistemológica”. Rosario, Revista de Epistemología y Ciencias Humanas, № 3, p. 257 - 288.

ELIZALDE, Silvia. (2005) "Salir en los diarios. Juventud, regulaciones culturales e (in)visibilidad de género". Buenos Aires, Cuadernos Críticos de Comunicación y Cultura, pp. 25-32.

(2008) "Debates sobre la experiencia. Un recorrido por la teoría y la praxis feminista”, La Plata, Oficios Terrestres, N²3, FPyCS (UNLP), pp. 18-30.

- (2015) Tiempo de chicas. Identidad, cultura y poder. Buenos Aires, Grupo Editor

Universitario / CLACSO. 
EXPÓSITO, Marcelo. (ed.) (2010) Los nuevos productivismos. Barcelona, Museu d'Art Contemporani de Barcelona (MACBA) / Universitat Autònoma de Barcelona.

EXPÓSITO, Marcelo y Jaime Vindel. (2014) "Activismo artístico" en AA.VV. Perder la forma humana. Una imagen sísmica de los años ochenta en América Latina Madrid, Museo Nacional Centro de Arte Reina Sofía.

FELSHIN, Nina. (2001) “¿Pero esto es arte?: el espíritu del arte como activismo”. En Blanco, Paloma y otros (Eds). Modos de hacer: arte crítico, esfera pública y acción directa. Salamanca, Universidad de Salamanca.

FLUSSER, Vilém (2015) El universo de las imágenes técnicas. Elogio de la superficialidad. Buenos Aires, Caja Negra.

FOLLARI, Roberto A. (2003) "Adorno y Benjamin sobre la cultura: acerca de un equívoco persistente". Mendoza, revista Confluencia, № 3, FCPyS (UNCuyo).

FOSTER, Hal. (2001a) "Recodificaciones: hacia una noción de los político en el arte contemporáneo". En Blanco, Paloma, y otros (Eds). Modos de hacer: arte crítico, esfera pública y acción directa. Salamanca, Universidad de Salamanca.

(2001b [1996]) El retorno de lo real. La vanguardia a finales de siglo. Madrid, Akal.

GARCÍA CANCLINI, Néstor. (2008 [1990]) Culturas híbridas. Estrategias para entrar y salir de la modernidad. Buenos Aires, Paidós.

(2010) La sociedad sin relato. Antropología y estética de la inminencia. Buenos Aires, Katz.

GARCÍA CANCLINI, Néstor, Francisco Cruces y Maritza Urteaga Castro Pozo. (2012) Jóvenes, Culturas urbanas y redes digitales. Prácticas emergentes en las artes, las editoriales y la música. Madrid / Barcelona, Ariel / Fundación Telefónica / UAM.

GIUNTA, Andrea. (2009) Poscrisis: Arte argentino después del 2001. Buenos Aires, Paidós. (2008 [2001]) Vanguardia, internacionalismo y política. Arte argentino en los años sesenta. Buenos Aires, Siglo XXI.

GONZÁLEZ CANOSA, Mora. (2010) "Nuevas prácticas y apropiaciones del espacio urbano. El caso

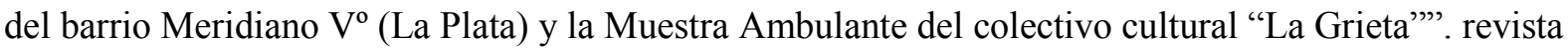
Afuera, $\mathrm{N}^{\mathrm{o}}$ 8. Disponible en: http://www.revistaafuera.com/articulo.php?id=157\&nro=8

GROYS, Boris. (2014) Volverse público. Las transformaciones del arte en el ágora contemporánea. Buenos Aires, Caja Negra.

(2016) Arte en flujo. Ensayos sobre la evanescencia del presente. Buenos Aires,

Caja Negra

GRUPO AUTÓNOMO a.f.r.i.k.a., Luther Blisset, Sonja Brünzels. (2000) Manual de la guerrilla de la comunicación. Madrid, Virus. 
HALL, Stuart. (2010). Sin garantias. Trayectorias y problemáticas en estudios culturales. Quito, Instituto de estudios sociales y culturales Pensar (Universidad Javeriana), Instituto de Estudios Peruanos (Universidad Andina Simón Bolívar - sede Ecuador), Envión Editores.

HOLMES, Brian. (2002/2003) "El póker mentiroso. Representaciones de la Política / Política de la Representación", Madrid, revista Brumaria, №2. Versión online disponible en: https://brianholmes.wordpress.com/el-poker-mentiroso/

(2008) "Investigaciones extradisciplinares". Madrid, revista Brumaria, No 8.

Versión oline disponible en: http://eipcp.net/transversal/0106/holmes/es

HUYSSEN, Andreas. (2006) Después de la gran división. Modernismo, Posmodernismo y cultura de masas. Buenos Aires, Adriana Hidalgo.

INDIJ, Guido (Ed.) (2011 [2004]). Hasta la victoria, stencil! , Buenos Aires, La Marca. (2011b [2007]) 1000 stencil. Argentina graffiti, Buenos Aires, La Marca.

INDIJ, Guido y Gonzalo Dobleg (2011) Buenos Aires Street art. Buenos Aires, La Marca.

INFANTINO, Julieta. (2013) "El Circo de Buenos Aires y sus Prácticas: definiciones en disputa" Florianópolis, lha. Revista de Antropología, vol. 15, p. 277-309

(2014) Circo en Buenos Aires. Cultura, jóvenes y políticas en disputa. Buenos Aires, Editorial del Instituto Nacional del Teatro.

JAY, Martin (2009 [2005]) Cantos de experiencia. Variaciones modernas sobre un tema universal. Buenos Aires, Paidós.

KOZAK, Claudia. (2004) Contra la pared: sobre graffitis, pintadas y otras intervenciones urbanas. Buenos Aires, Libros del Rojas.

(2009) "No me resigno a ser pared. Graffitis y pintadas en la ciudad artefacto". Revista Artefacto, Buenos Aires, enero 2009.

(Ed.) (2012) Tecnopoéticas argentinas. Archivo blando de arte y tecnologías. Buenos Aires, Caja Negra.

LADDAGA, Reinaldo. (2006) Estética de la emergencia. La formación de otra cultura de las artes. Buenos Aires, Adriana Hidalgo.

LONGONI, Ana. (2005) “¿Tucumán sigue ardiendo?”, revista Sociedad, N 24, Buenos Aires, Facultad de Ciencias Sociales (UBA).

(2006) "La teoría de la vanguardia como corset", revista Pensamientos de los confines, $\mathrm{N}^{\circ} 18$. Buenos Aires, julio de 2006, FCE, pp. 61-79.

(2007) "Encrucijadas del arte activista", revista Ramona, № 74, Buenos Aires, pp. $31-43$.

(2009) “Activismo artístico en la última década en Argentina: algunas acciones en torno a la segunda desaparición de Jorge Julio López", revista Errata, Año 1, № 0, Bogotá, 2009, pp. $16-35$.

LONGONI, Ana y Bruzzone, Gustavo (Comp). (2008) El siluetazo. Buenos Aires, Adriana Hidalgo. 
LONGONI, Ana y Jaime Vindel. (2010) "Fuera de categoría: la política del arte en los márgenes de su historia", revista El río sin orillas, № 4, Buenos Aires, octubre de 2010.

LONGONI, Ana y Mestman, Mariano. (2010 [2000]). Del Di Tella a Tucumán Arde. Vanguardia artística y política en el 68' argentino. Buenos Aires, Eudeba.

MARGULIS, Mario, Marcelo Urresti, Hugo Lewin y otros (2014) Intervenir en la cultura. Más allá de las políticas culturales. Buenos Aires, Biblos.

MOULIN, Raymonde. (2012 [2003]) El mercado del arte. Globalización y nuevas tecnologías. Buenos Aires, La Marca.

OPITZ, Michael y Erdmut Wizisla (Ed). (2014) Conceptos de Walter Benjamín. Buenos Aires, Las Cuarenta.

PÉREZ BALBI, Magdalena. (2012a) "Desbordes y convergencias: la dimensión de lo público en el activismo artístico actual en la Argentina". La Plata, Revista Question № 35 (UNLP). Disponible en: http://perio.unlp.edu.ar/ojs/index.php/question/article/view/1582

(2012b). "Entre internet y la calle: activismo artístico en La Plata".

México, Revista Versión (edición digital), UAM. Disponible en: http://148.206.107.15/biblioteca_digital/estadistica.php?id_host=6\&tipo=ARTICULO\&id=8743\&arc hivo=7-608-8743jsh.pdf

(2013) "Imágenes disidentes. Dos producciones en torno a la segunda desaparición de Julio López”. La Plata, Boletín de Arte; año 13, no. 13 (FBA-UNLP) Disponible en: http://sedici.unlp.edu.ar/handle/10915/35200

RANCIÈRE, Jacques. (2005) Sobre políticas estéticas. Barcelona, Museu d'Art Contemporani de Barcelona.

(2010a [2008]) El espectador emancipado. Buenos Aires, Manantial.

(2011 [2004]) El malestar en la estética. Buenos Aires, Capital Intelectual.

(2014 [2000]) El reparto de lo sensible. Estética y politica. Buenos Aires,

Prometeo.

RICHARD, Nelly. (2004) “Lo político y lo crítico en el arte: ‘QQuién le teme a la neovanguardia?’”, Santiago de Chile, Revista de Crítica Cultural, N $^{\circ} 29 / 30$.

(2006) "La escena de Avanzada y su contexto histórico" en Mosquera, Gerardo (Ed.) Copiar el edén: Arte reciente en Chile, Santiago, Puro Chile.

(2007) Fracturas de la memoria. Arte y pensamiento crítico. Buenos Aires, Siglo XXI.

(2014) "Lo político en el arte: Arte, política e instituciones", E-Misferica, 6.2.

RODRIGUEZ, Esteban. (2007) "La Plata ciudad limpia: censura previa y clausura de los espacios públicos”. Blog Crudos. Disponible en: http://rodriguezesteban.blogspot.com.ar/2007/11/la-plataciudad-limpia.html 
(2010) "La pava en el fuego". En Artigas, Celina. La Plata, ciudad imaginada. La Plata, Primer Párrafo / MLP, pp. 30-37.

SARLO, Beatriz (2007 [2000]) Siete ensayos sobre Walter Benjamín. Buenos Aires, FCE.

SHOLETTE, Gregory. (2015) Materia oscura. Arte activista y la esfera pública de oposición. Archivos del Índice. Disponible en: http://www.archivosdelindice.com/Materia-oscura

SAEZ, Mariana (2015) "Ser/estar en el aire-Ser-estar en el suelo. Apuntes sobre la espacialización y el extrañamiento corporal en el proceso de investigación”. En: AA.VV. Hacer espacio. Circulaciones múltiples entre cuerpos y palabras. La Plata, Ecart y Club Hem

(2016a) “Potencia de la contradicción”. La Plata, revista boba, N 02, junio de 2016.

(2016b) "El cuerpo como punto de partida. Etnografía y extrañamiento corporal entre la danza y el circo." En: Arias, Ana Carolina y Matías David López. Indisciplinas. Reflexiones sobre prácticas metodológicas en Ciencias Sociales. La Plata, Club Hem / IICom (FPyCS-UNLP).

SILVA, Armando (2006 [1992]) Imaginarios urbanos. Bogotá, Arangos.

THOMPSON, Edward. P. (2012 [1963]) La formación de la clase obrera en Inglaterra. Madrid, Capitán Swing.

TRANSFORM (2008) Producción cultural y prácticas instituyentes. Líneas de ruptura en la crítica institucional. Madrid, Traficantes de Sueños.

VÁZQUEZ Cecilia. (2008) “Arte y protesta. Notas sobre prácticas artísticas de oposición” en: Alabarces, Pablo y Rodríguez, María Graciela (Comps.) Resistencias y Mediaciones. Estudios sobre cultura popular. Buenos Aires, Paidós.

VAZQUEZ, Mariano. (2013) "Primeras aproximaciones a la esfera pública virtual” En: Fernández, Mariano y Matías David López. Lo público en el umbral. Los espacios y los tiempos, los territorios y los medios. La Plata, IICom - EPC (FPyCS-UNLP).

(2015) "La visibilidad de lo público. Visibilidad y perspectiva política de la esfera pública virtual". La Plata, revista Question, No 45, FPyCS (UNLP). Disponible en: http://perio.unlp.edu.ar/ojs/index.php/question/article/view/2360/2109

VINDEL, Jaime. (2010) "Politizar la historia del arte, liberarse del origen absoluto: dos cuestiones pendientes", revista Re-Visiones. $\mathrm{N}^{\circ}$ 0. Disponible en: http://re-visiones.net/spip.php\%3Farticle2.html WILLIAMS, Raymond. (1994 [1980]). Sociología de la cultura. Buenos Aires, Paidós (1997 [1989]) La política del modernismo. Contra los nuevos conformismos.

Buenos Aires, Manantial.

(2000 [1976]) Palabras clave. Un vocabulario de la cultura y la sociedad.

Buenos Aires, Nueva Visión.

(2009 [1977]) Marxismo y literatura. Buenos Aires, Las Cuarenta.

YUDICE, George. (2002) El recurso de la cultura. Barcelona, Gedisa. 
(2008) "La globalización y la nueva división internacional del trabajo cultural" En Lacarrieu, Mónica y Marcelo Álvarez (comp.). La (indi)gestión cultural. Una cartografía de los procesos culturales contemporáneos. Buenos Aires, La Crujía.

\section{Ciudad y espacio urbano}

BADENES, Daniel. (2007) "Comunicación y ciudad: líneas de investigación y encuentros con la historia cultural urbana". La Plata, revista Question, $\mathrm{N}^{\circ}$ 14, FPyCS (UNLP). Disponible en: http://perio.unlp.edu.ar/ojs/index.php/question/article/view/354/286

(2009) "Un estigma con-sentido. Derecho a la ciudad y violencia mediática: el caso de "Los chicos de la glorieta"”. La Plata, revista Question, N²1, FPyCS (UNLP). Disponible en: http://perio.unlp.edu.ar/ojs/index.php/question/article/view/709/612

(2015) Un pasado para La Plata. Una historia de la historia local. La Plata,

EME.

CARMAN, María. (2006) Las trampas de la cultura: los intrusos y los nuevos usos del barrio de Gardel. Buenos Aires, Ed. Paidós.

CARMAN, María y Michael Janoschka. (2014) "Ciudades en disputa: estudios urbanos críticos sobre conflictos y resistencias", QUID 16, vol. 1, Área de Estudios Urbanos, Instituto Gino Germani - FCS (UBA), pp. 1-7.

CHAVES, Mariana. (2010) Jóvenes, territorios y complicidades. Una antropología de la juventud urbana. Buenos Aires, Espacio Editorial.

DELGADO, Manuel. (1999) El animal público. Barcelona, Anagrama.

(2007a) Sociedades movedizas: Pasos hacia una antropología de las calles.

Barcelona, Anagrama.

(2007b) "El rumor de la calle" (entrevista). Disponible en: http://www.circulobellasartes.com/revistaminerva/articulo.php?id=185

DE CERTEAU, Michel. (2000 [1980]) La invención de lo cotidiano 1: Artes de hacer. México, Universidad Iberoamericana/Iteso.

GARCÍA CANCLINI, Néstor. (1996) "Ciudades y ciudadanos imaginados por los medios". México, Perfiles Latinoamericanos. N 9, FLACSO, pp. 9- 24.

(1997) Imaginarios urbanos. Buenos Aires, Eudeba.

(Coord.) (2005) La antropología urbana en México. México, Conaculta / UAM

/ FCE.

(2008 [1990]) Culturas hibridas. Estrategias para entrar y salir de la modernidad. (Nueva edición). Buenos Aires, Paidós.

GONZÁLEZ, Jorge A. (1994) Más (+) cultura (s). Ensayos sobre realidades plurales. México. Consejo Nacional para la Cultura y las Artes. 
GORELIK, Adrián. (2004) Miradas sobre Buenos Aires, historia cultural y crítica urbana. Buenos Aires, Siglo XXI.

(2007) "Las metrópolis latinoamericanas, el arte y la vida. Arte y ciudad en tiempos de globalización". Santiago, Revista Aisthesis No 41, Instituto de Estética - Pontificia Universidad Católica de Chile.

(2010 [1998]) La grilla y el parque. Espacio público y cultura urbana en Buenos Aires, 1887-1936. Bernal, Universidad Nacional de Quilmes.

KOHAN, Martín (2004) Zona urbana. Ensayo de lectura sobre Walter Benjamín. Buenos Aires, Norma.

MARTÍN-BARBERO, Jesús. (2003 [1987]) De los medios a las mediaciones. Comunicación, cultura y hegemonía. Bogotá, Convenio Andrés Bello.

- (1996a) "De la ciudad mediada a la ciudad virtual", TELOS, $\mathrm{N}^{\circ} 44$,

Madrid.

(1996b) "Comunicación y ciudad: sensibilidades, paradigmas, escenarios”, en: Giraldo, F. y F. Viviescas (comps.) Pensar la ciudad, Bogotá, Tercer Mundo.

(2001) "Reconfiguraciones comunicativas de lo público". Barcelona, Revista Anàlisi. Quaderns de Comunicació i cultura, No 26, pp. 77-88. Facultad de Ciencias de la Información (Universidad Autónoma de Barcelona).

(2004) "Transformaciones de la experiencia urbana" en Oficio de cartógrafo. Buenos Aires, FCE.

(2009) "La nueva experiencia urbana: trayectos y desconciertos".

Andalucía, Ciudad Viva, № 1, enero de 2009. Junta de Andalucía.

PICCINI, Mabel. (1996) "Acerca de la comunicación en las grandes ciudades". México, revista Perfiles Latinoamericanos, № 9, Flacso, pp. 25-46.

REGUILLO, Rossana. (1991) En la calle otra vez. Las bandas: identidad urbana y usos de la comunicación. Guadalajara, Iteso.

(1997) “Ciudad y comunicación. Densidades, ejes y niveles". Lima, revista Diálogos de la comunicación, $\mathrm{N}^{\circ} 47$, FELAFACS.

(2000a) Emergencia de culturas juveniles: estrategias del desencanto.

Bogotá, Norma.

(2000b) "Identidades culturales y espacio público. Un mapa de los silencios".

Lima, Diálogos de la comunicación, № 59-60, FELAFACS.

(2005 [1996]) La construcción simbólica de la ciudad: Sociedad. Desastre y

Comunicación. México, Iteso / Universidad Iberoamericana.

(2012) "Espacio inmunitario en la metrópolis: Intimidades selectivas". Revista

Telos: Cuadernos de comunicación e innovación, $\mathrm{N}^{\mathrm{o}} 93$. 
SEGURA, Ramiro. (2013) "Lo público como lugar practicado. Regulaciones sociales, temporalidades colectivas y apropiación diferencial de la ciudad” en Fernández, Mariano y Matías D. López. (Eds.) Lo público en el umbral. Los espacios y los tiempos, los territorios y los medios. La Plata, IICom EPC (UNLP), p. 18 - 46.

(2014) "Vivir afuera. Experiencias comunes, temporalidades diferenciales y límites barriales en la periferia de la ciudad de La Plata (Argentina)" en Casas de infinitas privaciones ¿Germen de ciudades para todos?. Quito, Abya-Yala / Clacso. p. 249 - 283.

(2015) "Desigualdades socio-espaciales en ciudades latinoamericanas: segregación y fragmentación urbanas en un escenario paradojal" en Sehtman, Alejandro y Elizabeth Zenteno (Coords.) Continuidades, rupturas y emergencias. Las desigualdades urbanas en la América Latina. México, UNAM.

Acción colectiva y movimientos sociales

COLECTIVO SITUACIONES (2002). 19 y 20. Apuntes para el nuevo protagonismo social. Buenos Aires, Tinta Limón.

MODONESI, Massimo. (2008) “Crisis hegemónica y movimientos antagonistas en América Latina. Una lectura gramsciana del cambio de época". Revista Acontracorriente. $\mathrm{N}^{\circ}$ 2, pp. 115-140.

(2010) Subalternidad, antagonismo, autonomía. Marxismo y subjetividad política. Buenos Aires, Clacso / Prometeo.

SVAMPA, Maristella. (2008) Cambio de época. Buenos Aires, Siglo XXI.

(2012) "Movimientos sociales, gobiernos y nuevos escenarios en América

Latina" en: Moreira, Carlos y Dante Avaro (Coords). América Latina hoy. Buenos Aires, Teseo. p. 15 $-89$

Espacio público y esfera pública / política y acción política

ARENDT, Hannah. (2009 [1958]) "La esfera pública y la privada” en La condición humana. Buenos Aires, Paidós.

DELGADO, Manuel. (2011) El espacio público como ideología. Madrid, Catarata.

HABERMAS, Jürgen. (1981 [1962]) Historia y crítica de la opinión pública, Barcelona/México, Gustavo Gili.

LACLAU, Ernesto. (1990) Nueva reflexiones sobre la revolución de nuestro tiempo. Buenos Aires, Nueva Visión.

(2011 [2000]) "Identidad y hegemonía. El rol de la universalidad en la constitución de lógicas políticas" en: Butler, Judith, Ernesto Laclau y Slavoj Zizek. Contingencia, hegemonía, universalidad. Buenos Aires, FCE, pp. 51-94.

LAZZARATO, Mauricio. (2006) Pensar el acontecimiento. Buenos Aires, Tinta Limón MOUFFE, Chantal. (2009 [2005]) En torno a lo politico. Buenos Aires, FCE. 
OFFE, Claus. (1988) Partidos políticos y nuevos movimientos sociales, Madrid, Sistema.

RABOTNIKOF, Nora. (1997) El espacio público y la democracia moderna. México, Instituto Federal Electoral.

(2005) En busca de un lugar común. El espacio público en la teoría política contemporánea. México, IIF, UNAM.

(2013) "Presentación” en Fernández, Mariano y Matías D. López. (Ed.) Lo público en el umbral. Los espacios y los tiempos, los territorios y los medios. La Plata, IICom - EPC (UNLP).

RABOTNIKOF, Nora y Julio Aibar. (2012) "El lugar de lo público en lo nacional-popular ¿Una nueva experimentación democrática?". Buenos Aires, Nueva sociedad, No 240, julio-agosto de 2012, pp. 54-67. Disponible en: http://nuso.org/media/articles/downloads/3880_1.pdf RANCIÈRE, Jacques. (2006 [1998]) Politica, policía, democracia. Santiago de Chile, LOM. (2007 [1996]) El desacuerdo. Política y filosofia. Buenos Aires, Nueva Visión. (2010b) Momentos políticos. Buenos Aires, Capital Intelectual.

RETAMOZO, Martín. (2010) "Movimientos Sociales: Un mapa de la cuestión” En Villarreal Cantú, Eduardo y Víctor Hugo Martínez González (Eds) (Pre)Textos para el Análisis Político. Disciplinas, Actores y Procesos. México, Flacso, p. 233 - 256.

SCHMITT, Carl. (2006 [1932]) El concepto de lo político. Madrid, Alianza.

SENNETT, Richard. (2011 [1974]) El declive del hombre público. Barcelona, Anagrama.

THOMPSON, John B. (1996) “La teoría de la esfera pública”. Barcelona, Voces y culturas, № 10.

VIRNO, Paolo. (1993) "Virtuosismo y revolución: notas sobre el concepto de acción política". .Versión original publicada en la revista italiana Luogo Comune, $\mathrm{N}^{\circ} 4$. Versión en castellano extraida del sitio web: http://biblioweb.sindominio.net/pensamiento/virno.html

ŽIŽEK, Slavoj. (2008) En defensa de la intolerancia. Madrid, Sequitur.

Recientes Tesis de Licenciatura, Maestría y Doctorado:

BADENES, Daniel. (2012) Un pasado para La Plata: Producción editorial y disputa de sentidos sobre la historia de la ciudad en su centenario -1982- (Tesis de posgrado). - Facultad de $\begin{array}{llllll}\text { Humanidades } & \text { y Ciencias de la Educación (UNLP). Disponible }\end{array}$ en:http://www.memoria.fahce.unlp.edu.ar/tesis/te.880/te.880.pdf

BOIX, Ornela. (2013) Sellos emergentes en La Plata: Nuevas configuraciones en los mundos de la música. (Tesis de posgrado). - Facultad de Humanidades y Ciencias de la Educación (UNLP). Disponible en: http://www.memoria.fahce.unlp.edu.ar/tesis/te.1015/te.1015.pdf

BUGNONE, Ana Liza. (2013) Una articulación de arte y política: Dislocaciones y rupturas en la poética de Edgardo Antonio Vigo (1968-1975). (Tesis de posgrado). - Facultad de Humanidades y Ciencias de la Educación (UNLP). Disponible http://www.memoria.fahce.unlp.edu.ar/tesis/te.989/te.989.pdf 
CALLIGO, Rubén (2016) Te escriben, te escrachan y te ensucian. El estigma policial/mediático de la "banda de la frazada" en la voz de los sujetos criminalizados. Tesis de Licenciatura (FPyCS-UNLP). CAPASSO, Verónica. (2011) Muralismo en la ciudad de La Plata: La experiencia del colectivo de arte Sienvolando, un análisis de la activación de una esfera pública de oposición (Tesis de grado). Facultad de Humanidades y Ciencias de la Educación (UNLP). Disponible en: http://www.memoria.fahce.unlp.edu.ar/tesis/te.723/te.723.pdf

CHAVES, Mariana. (2005) Los espacios urbanos de jóvenes en la ciudad de La Plata. Tesis Doctoral. FCNyM (UNLP). Disponioble en: http://naturalis.fcnym.unlp.edu.ar/id/20120126000076 RACIOPPE, Bianca (2015) Cultura libre y Copyleft: Hacia una redefinición en la manera de entender la producción artística. Tesis Doctoral en Comunicación (UNLP). Diosponible en: http://sedici.unlp.edu.ar/handle/10915/44651

SEGURA, Ramiro. (2010) Representar. Habitar. Transitar. Una antropología de la experiencia urbana en la ciudad de La Plata. Tesis de Doctorado en Ciencias Sociales. Universidad Nacional de General Sarmiento (UNGS) - Instituto de Desarrollo Económico y Social (IDES). Mimeo.

VÁZQUEZ Cecilia. (2011) Prácticas artísticas de protesta y politica en la Ciudad de Buenos Aires (2003-2007), Tesis doctoral en Ciencias Sociales, Universidad de Buenos Aires. Mimeo.

\section{Publicaciones propias y en co-autoría}

LÓPEZ, Matías David. (2009) "La píldora roja. Apuntes sobre las tensiones entre tecnologías y comunicación alternativa". La Plata, revista Question Nº 22, FPyCS (UNLP), otoño 2009. Disponible en:

http://perio.unlp.edu.ar/question/numeros_anteriores/numero_anterior22/files/lopez_1 ensayos_22oto $\underline{\text { no2009.htm }}$

(2011) "Estrategias de intervención en la ciudad y en la web. Espacio público y acción política.” La Plata, revista Question, No 30, FPyCS (UNLP), primavera de 2011. Disponible en: http://perio.unlp.edu.ar/ojs/index.php/question/article/view/949/1036

(2013a) "Acciones y estrategias en lo público. Algunas reflexiones sobre (y en) la catástrofe", La Plata, revista Question, (Incidente 1). IICom (FPyCS-UNLP). pp. 38 - 57. Disponible en: http://perio.unlp.edu.ar/ojs/index.php/question/article/view/1853/1512

(2013b) "Lugares de vida. Nueva escena de espacios culturales emergentes de exhibición en la ciudad de La Plata” en Fernández, Mariano y Matías David López. Lo público en el umbral. Los espacios y los tiempos, los territorios y los medios. La Plata, IICom - EPC (FPyCSUNLP).

(2014) “¿El paisaje nos devora? Tecnologías, entre lo cotidiano y lo político". Rosario, revista La Trama de la Comunicación; vol. 18 pp. 313 - 327. Disponible en: http://www.latrama.fcpolit.unr.edu.ar/index.php/trama/article/view/481/391 
(2015a) "Gestionar espacios, asociar prácticas y apuestas, potenciar políticas estéticas. Apuntes para reflexionar sobre las escenas culturales" en AA.VV. Hacer espacio. Circulaciones múltiples entre cuerpos y palabras. La Plata, Ecart y Club Hem.

(2015b) "Breves viajes al país de Síntoma. Provocación, visibilización y régimen estético en la escena de artes visuales de La Plata”. La Coruña, Revista Latina de Sociología, $\mathrm{N}^{\circ}$ 5, Facultad de Sociología - Universidad de La Coruña. Disponible en: http://revistas.udc.es/index.php/RELASO/article/view/1518/pdf_2

(2016a) “Aproximación a la esfera pública contemporánea: habilitaciones desde la producción cultural”. Barranquilla, revista Encuentros, Vol. 14, n 2, Universidad del Caribe. Disponible en: http://ojs.uac.edu.co/index.php/encuentros/article/view/367/pdf 37 (2016b) "Nociones, articulaciones y debates sobre lo público en las reflexiones de Laclau, Mouffe y Rancière". Trabajo final - Seminario "Análisis de la Política Contemporánea”. Doctorado en Ciencias Sociales, FaHCE (UNLP). mimeo.

SAGER, Federico y Matías David López. (2009) "Hacia una esfera pública no estatal. Nuevas tecnologías, acción política y espacios sociales urbanos”. La Plata, revista Question, No 24, FPyCS (UNLP), primavera de 2009. Disponible en:

http://perio.unlp.edu.ar/question/numeros_anteriores/numero_anterior24/files/sageryotro_1_ensayos 24primavera2009.htm (2010) "La ciudad desregulada". La Plata, revista $L a$ Pulseada, No 80. Disponible en: http://www.lapulseada.com.ar/80/80_cou.html (2012) "Televisión alternativa: la experiencia de Papa Negra TV", La Plata, revista Question $\mathrm{N}^{\circ} 35$, pp. 168 - 187. Disponible en: http://perio.unlp.edu.ar/ojs/index.php/question/article/view/1544/1359

SÍNTOMA Curadores y Matías David López (2014) "La Plata a un año de la inundación, una performance colectiva - 14 postales". Buenos Aires, ramonaweb. Disponible en: http://www.ramona.org.ar/node/52050

LÓPEZ, Matías, Daniel Badenes y Chempes Saurio (2014) "Comunicación y acción colectiva en América Latina: intervenciones culturales en el espacio público". Lima, XII Congreso Alaic. Disponible en: http://congreso.pucp.edu.pe/alaic2014/wp-content/uploads/2013/09/GT11-LopezBadenes-Saurio.pdf

ARIAS, Ana Carolina y Matías David López (2016) Indisciplinas. Reflexiones sobre prácticas metodológicas en Ciencias Sociales. La Plata, Club Hem / IICom (FPyCS-UNLP)

\section{Analítica y perspectiva metodológica:}

BORRAT, Héctor (1989) "El periódico, actor del sistema político". Barcelona, revista Anàlisi. Quaderns de Comunicació i cultura, $\mathrm{N}^{\mathrm{o}}$ 12, pp. 67-80. Facultad de Ciencias de la Información (Universidad Autónoma de Barcelona). 
DELFINO, Silvia. (2009) "Investigación y activismo en el vínculo entre teorías de género, identidad de géneros y luchas políticas", La Plata, revista Tram[p] as de la Comunicación y la Cultura, N. ${ }^{\circ}$ 66, FPyCS (UNLP).

(2013) Programa del Seminario "Prácticas y saberes de la comunicación" (2013).

Doctorado en Comunicación (FPyCS-UNLP).

GIMÉNEZ, Gilberto. (1999) “La investigación cultural en México. Una aproximación”. México, revista Perfiles Latinoamericanos, No 15, FLACSO.

GONZÁLEZ, Jorge A. (1995) "Coordenadas del imaginario. Protocolo para el uso de cartografías culturales". Colima, Revista Estudios sobre las Culturas Contemporáneas, Época II, Vol. I, N² diciembre de 1995.

HINE, Christine. (2004 [2000]) Etnografia virtual. Barcelona, UOC.

MARRADI, Alberto; Nélida Archenti y Juan Ignacio Piovani. (2007) Metodología de las Ciencias Sociales. Buenos Aires, Emecé.

MARTÍN-BARBERO, Jesús. (2004). Oficio de cartógrafo. Travesías latinoamericanas de la comunicación en la cultura. Buenos Aires, FCE.

KRIPPENDORFF, Klaus (1990 [1980]) Metodología de Análisis de Contenido. Teoría y Práctica. Barcelona / Buenos Aires, Paidós.

RINCÓN, Omar. (2003) “Por qué investigar los medios?” en Pereira González, José Miguel y Mirla Villadiego Prins (Ed.) Comunicación, cultura y globalización. Bogotá, CEJA.

SOUZA, María Silvina; Carlos Giordano y Mario Migliorati (Ed.) (2012) Hacia la tesis. Itinerarios conceptuales y metodológicos para la investigación en comunicación. La Plata, IICom, UNLP.

WUTHNOW, Robert, J.D. Davison Hunter, A. Bergesen y E. Kurzweil (1988 [1984]) Análisis cultural. La obra de Peter L. Berger, Mary Douglas, Michel Foucault y Jürgen Habermas, Buenos Aires, Paidós.

\section{$\underline{\text { Revistas }}$}

boba, $\mathrm{N}^{\mathrm{o}}$ 02, La Plata, junio de 2016

boba, No 03, La Plata,diciembre de 2016.

La biblioteca, $\mathrm{N}^{\mathrm{o}}$ 7, primavera de 2008, Buenos Aires, Biblioteca Nacional.

La Pulseada $\mathrm{N}^{\circ}$ 55, noviembre de 2007, La Plata.

La Pulseada, No 80, mayo de 2010, La Plata. Disponible en: http://www.lapulseada.com.ar/80/80_cou.html

La Pulseada, $\mathrm{N}^{\mathrm{o}}$ 108, abril de 2013. Disponible en: http://www.lapulseada.com.ar/site/?p=4446 La Pulseada, No 109, mayo de 2013. Disponible en: http://www.lapulseada.com.ar/site/?p=5179 La Pulseada, № 112, agosto de 2013. Disponioble en: http://www.lapulseada.com.ar/site/?p=6289 La Pulseada, $\mathrm{N}^{\mathrm{o}}$ 130, julio de 2015. Disponible en: http://www.lapulseada.com.ar/site/?p=9709 
La Pulseada, $\quad \mathrm{N}^{\mathrm{o}}$ 133, septiembre de 2015. Disponible en: http://www.lapulseada.com.ar/site/?p=10037

"Paredes que hablan", La Pulseada, $\mathrm{N}^{\circ}$ 135, noviembre de 2015. Disponible en: http://www.lapulseada.com.ar/site/?p=10204

"Calle tomada: Una muestra mutante, un espacio de encuentro". La Pulseada, No 82, agosto de 2010.

Disponible en: http://www.lapulseada.com.ar/site/?p=1461

Pensamientos de los confines. $\mathrm{N}^{\mathrm{o}} 18$, junio de 2006. FCE.

ramona, $\mathrm{N}^{\circ} 74$, septiembre de 2007, Buenos Aires, Fundación Start

\section{Materiales relevados y fuentes periodísticas}

\section{La Grieta}

Revista La Grieta, № 0, 1993.

Colectivo La Grieta (2009) La Muestra Ambulante (catálogo), La Plata, Ediciones Grupo La Grieta / FBA (UNLP).

Folletería: Muestra Ambulante (1995), Muestra Ambulante 3 (2006), Muestra Ambulante 4 (2007), "Noticias Ambulantes" (Muestra Ambulante 5, noviembre de 2009).

Documentos y manifiesto de la MA 4.

Rodríguez, Esteban. (2008) "Habitar y derivar. 20 tesis sobre la Muestra Ambulante". La Plata, revista Oficios terrestres, $\mathrm{N}^{\circ} 23$ FPyCS (UNLP), pp. 68-74. Disponible en: http://sedici.unlp.edu.ar/handle/10915/45092

Di Luca, Fabiana y Esteban Rodríguez. (2009) "Pero se mueve! Arte vivo! y Muestra Ambulante, barrio Meridiano V". revista Nexo, Secretaria de extensión, FBA (UNLP) Disponible en: http://sedici.unlp.edu.ar/bitstream/handle/10915/51853/Documento completo.pdf?sequence=1

Negrete, Ana (2010) "La Muestra Ambulante: tejiendo lazos en el espacio público". revista "Extensión en red". FPyCS (UNLP). Disponible en: http://sedici.unlp.edu.ar/handle/10915/41279

Blogs: http://muestraambulante.blogspot.com.ar/ y http://fotosmuestraambulante5.blogspot.com.ar/ Nota "Muestra Ambulante: Una excusa para cuestionar la cultura del miedo". Agencia NAN, 25/1172009: http://lanan.com.ar/muestra-ambulante-una-excusa-para-cuestionar-la-cultura-del-miedo/

\section{Sienvolando}

Blog: http://sienvolando.blogspot.com.ar

“Tatuadores de la ciudad”, revista La Pulseada, No 55, noviembre de 2007.

\section{UMHT}

Blog: http://umht.blogspot.com.ar 
Fotolog: http://www.fotolog.com/umht/mosaic

Perfil de Facebook (actualmente no está disponible)

\section{Siempre}

Blog: http://colectivosiempre.blogspot.com.ar

Perfil de Facebook: https://es-la.facebook.com/colectivo.siempre

Video-danza Siempre (2009)

Nota en agencia NAN (16/12/2009): http://lanan.com.ar/colectivo-siempre-tratamos-de-poner-enescena-la-presencia-de-una-ausencia/

Entrevista a Diana del Colectivo Siempre en Indymedia La Plata (19/03/2007) : http://argentina.indymedia.org/news/2007/03/497732.php

\section{Arte al Ataque}

Blog: http://artealataque.blogspot.com.ar

Video: https://www.youtube.com/watch?v=TU2_u3TvZP8

\section{Luli}

Blog: http://lulitieneblog.wordpress.com

Perfil de Facebook: https://www.facebook.com/lulitienefb (actualmente no disponible)

Entrevista en Prensa de Frente, 21/12/2010. Disponible en:

https://lulitieneblog.wordpress.com/2010/12/21/nota-en-pdf

\section{Luxor}

Web: http://soyluxor.com.ar

Blog: https://soyluxor.wordpress.com

Página de Facebook: https://www.facebook.com/soyluxor

Flickr http://www.flickriver.com/photos/luxormagenta y https://www.flickr.com/photos/luxormagenta

Pura Vida TV. Video disponible en: https:/www.youtube.com/watch?v=zICJmSF7yss\&t=17s

Entrevista en agencia Nova

http://www.novalaplata.com/nota.asp?n=2011_7_14\&id=27083\&id_tiponota=11

Nota-entrevista en "Grafica mestiza" (enero de 2013):

http://www.graficamestiza.com/index.php/artistas/argentina/74-luxor/

\section{Otros materiales y sitios web}

http://argentina.indymedia.org/features/laplata/

https://papanegratv.wordpress.com/ 
http://calletomada.blogspot.com.ar

\section{Fuentes periodísticas analizadas (capítulo 7)}

\section{Diario El Día}

1) "El daño al patrimonio público es una conducta que debe ser sancionada". 31/08/2007. Disponible en: http://pasado.eldia.com/catalogo/20070831/opinion6.htm

2) "Expo de arte en garages del barrio Meridiano V". 02/12/2007: Disponible en: http://pasado.eldia.com/edis/20071203/laciudad35.htm

3) "Firmas por el boleto". 02/04/2009. Disponible en: http://pasado.eldia.com/edis/20090402/laciudad21.htm

4) "Se viene la 'Muestra Ambulante". 29705/2009. Disponible en: http://pasado.eldia.com/edis/20090529/espectaculos24.htm

5) "El stencil y sus diferencias con el graffiti". 02/08/2009. Disponible en: http://pasado.eldia.com/catalogo/20090802/revistadomingo3.htm

6) "Inquietud por falsas notificaciones de ARBA". 21/08/2009. Disponible en: http://pasado.eldia.com/edis/20090821/laciudad27.htm

7) “Muestra Ambulante". 20/11/2009.

8) "Los graffitis invaden escuelas, monumentos y edificios históricos". 18/04/2010. Disponible en: http://pasado.eldia.com/edis/20100418/laciudad15.htm

9) "La hora de los murales". 19/09/2010. Disponible en: http://pasado.eldia.com/edis/20100919/revistadomingo0.htm

10) "Los murales invaden las fachadas de los hospitales públicos". 25/01/2011. Disponible en: http://pasado.eldia.com/edis/20110125/educacion0.htm

11) "Cambia el paisaje urbano con murales en casas particulares" 11/04/2011. Disponible en: http://pasado.eldia.com/edis/20110410/cambia-paisaje-urbano-murales-casas-particulares$\underline{20110410111645 . h t m}$

12) "El Liceo muestra los bocetos del mural más grande de la Ciudad" 28/05/2011. Disponible en: http://pasado.eldia.com/catalogo/20110528/el-liceo-muestra-bocetos-del-mural-mas-grande-ciudadeducacion $0 . h t m$

13) "Un estallido de música y color copa el pasaje" 27/08/2011 Disponible en: http://pasado.eldia.com/catalogo/20110827/un-estallido-musica-color-copa-pasaje-laciudad9.htm

14) "Festival de graffiti en Ringuelet" 06/10/2011. Disponioble en: http://pasado.eldia.com/catalogo/20111006/breves-ciudad-laciudad15.htm

15) "El Liceo, nueva postal urbana". 26/05/2012. Disponible en: http://pasado.eldia.com/catalogo/20120526/el-liceo-nueva-postal-urbana-educacion9.htm 
16) "Experimento: palabra y formas" 27/06/2012. Disponible en: http://pasado.eldia.com/catalogo/20120617/septimodia3.htm

17) "Insólita aparición de graffiti en primer piso de edificio céntrico". 14/08/2012. Disponible en: http://pasado.eldia.com/edis/20120814/insolita-aparicion-graffiti-en-primer-piso-edificio-centrico$\underline{20120814214232 . h t m}$

18) “El aerosol ya se trepa a los edificios: no se salva nadie". 15/08/2012. Disponible en: http://pasado.eldia.com/catalogo/20120815/el-aerosol-ya-trepa-edificios-no-salva-nadie-tapa6.htm 19) "No se salva nadie: ahora también pintan en altura" 15/08/2012. Disponible en: http://pasado.eldia.com/catalogo/20120815/no-salva-nadie-ahora-tambien-pintan-alturalaciudad11.htm 20) "El aerosol ya avanza en las alturas y detrás de las rejas" 19/08/2012. Disponible en: http://pasado.eldia.com/catalogo/20120819/el-aerosol-ya-avanza-alturas-detras-rejas-laciudad3.htm 21) "El vandalismo, una agresión cotidiana a bienes privados y al patrimonio público" Disponible en: http://pasado.eldia.com/edis/20120822/el-vandalismo-agresion-cotidiana-bienes-privados-patrimoniopublico-opinion3.htm

22) "Artistas de varios países le pintan la cara a La Plata" / "Cumbre internacional" 14/10/2012. Disponible en: http://pasado.eldia.com/catalogo/20121014/laciudad0.htm

23) "No aflojan las pintadas vandálicas y hacen un desastre en otro barrio" 10/11/2012. Disponible en: http://pasado.eldia.com/edis/20121110/no-aflojan-pintadas-vandalicas-hacen-desastre-otro-barriolaciudad11.htm

24) "Hay paredes que piden que las pinte" 03/02/2013. Disponible en: http://pasado.eldia.com/edis/20130203/Hay-paredes-piden-pinte-septimodia0.htm

25) "Vigencia y singularidad del graffiti platense" 09/06/2013. Disponible en: http://pasado.eldia.com/catalogo/20130609/vigencia-singularidad-graffiti-platenserevistadomingo0.htm

26) "La calle, un lienzo vivo donde pintar un futuro en común" 16/09/2013. Disponible en: http://pasado.eldia.com/catalogo/20130916/la-calle-lienzo-vivo-donde-pintar-futuro-comuninformaciongeneral2.htm

27) "La Plata vive en una permanente tensión entre las ciencias y el arte..." 23/02/2014. Disponible en: http://pasado.eldia.com/edis/20140223/septimodia0.htm

28) "El hospital de niños luce dos nuevos murales", 23/07/2014. Disponible en: http://pasado.eldia.com/catalogo/20140723/el-hospital-ninos-luce-dos-nuevos-murales20140723165252.htm

29) "El arte urbano le cambia la cara a los hospitales públicos platenses". 27/07/2014. Disponible en: http://pasado.eldia.com/catalogo/20140727/laciudad8.htm 
30) "Murales en los frentes: debate sobre las reglas y condiciones". 07/12/2014. Dispnible en: http://pasado.eldia.com/edis/20141207/Murales-frentes-debate-sobre-reglas-condicioneslaciudad8.htm

31) "Avanzan con el proyecto de enrejar el Teatro Argentino". 10/02/2015. Disponible en: http://www.eldia.com/la-ciudad/avanzan-con-el-proyecto-de-enrejar-el-teatro-argentino-35454

32) "Un mural de Estrellas en Los Hornos". 14/02/2015. Disponible en: http://www.eldia.com/laciudad/un-mural-de-estrellas-en-los-hornos-36507

33) "En una esquina de La Plata se juntaron Elvis, Maradona, Favaloro, Chaplin y el Che". 15/02/2015. Disponible en: http://www.eldia.com/la-ciudad/en-una-esquina-de-la-plata-se-juntaronelvis-maradona-favaloro-chaplin-y-el-che-36544

34) "El "Paseo de la Fama"” 20/02/2015. Disponible en: http://www.eldia.com/oeste/el-paseo-de-lafama-37662

35) "Los Hornos tiene un mural del Papa Francisco". 6/04/2015. Disponivle en: http://www.eldia.com/la-ciudad/los-hornos-tiene-un-mural-del-papa-francisco-47416

36) "Contra los grafitis: prohibirían la venta de aerosol a los menores". 18/04/2015. Disponible en: http://www.eldia.com/la-ciudad/contra-los-grafitis-prohibirian-la-venta-de-aerosol-a-los-menores$\underline{50262}$

37) "Habilitan paredones para desplegar el arte callejero en la Ciudad". 8/05/2015. Disponible en: http://www.eldia.com/la-ciudad/habilitan-paredones-para-desplegar-el-arte-callejero-en-la-ciudad-

54665

38)" De Rito: "Después de un ataque, si el frentista pinta su pared, el grafitero no la vuelve a dibujar"”'. 8/06/2015. Disponible en: http://www.eldia.com/la-ciudad/de-rito-despues-de-un-ataque-siel-frentista-pinta-su-pared-el-grafitero-no-la-vuelve-a-dibujar-62093

39) "Pintaban grafitis en el Teatro Argentino: presos". 3/07/2015. Disponible en: http://www.eldia.com/policiales/pintaban-grafitis-en-el-teatro-argentino-presos-67513

40) "El artista de lo sensible". 11706/2015. Disponible en: http://www.eldia.com/espectaculos/elartista-de-lo-sensible-69420

41) "La Plata a todo color: cada vez más vecinos deciden ponerle arte al frente de sus casas". 24/08/2015. Disponible en: http://www.eldia.com/la-ciudad/la-plata-a-todo-color-cada-vez-masvecinos-deciden-ponerle-arte-al-frente-de-sus-casas-78573

42) "A los vecinos les cuesta desde 2.500 pesos limpiar los grafitis". 3/09/2015. Disponible en: http://www.eldia.com/la-ciudad/a-los-vecinos-les-cuesta-desde-2-500-pesos-limpiar-los-grafitis$\underline{80735}$

43) "El recurso del arte para frenar el vandalismo". 3/09/2015. Disponible en: http://www.eldia.com/la-ciudad/el-recurso-del-arte-para-frenar-el-vandalismo-80739 
44) "La Ciudad y los vecinos siguen perdiendo la batalla frente a las pintadas y grafitis". 5/09/2015. Disponible en: http://www.eldia.com/opinion/la-ciudad-y-los-vecinos-siguen-perdiendo-la-batallafrente-a-las-pintadas-y-grafitis-81176 